\title{
Instrumentos musicales
}

encontradós en excavaciones arqueologicas pertenecientes a los siglos XX XV

\section{en el territiorio andaluz}

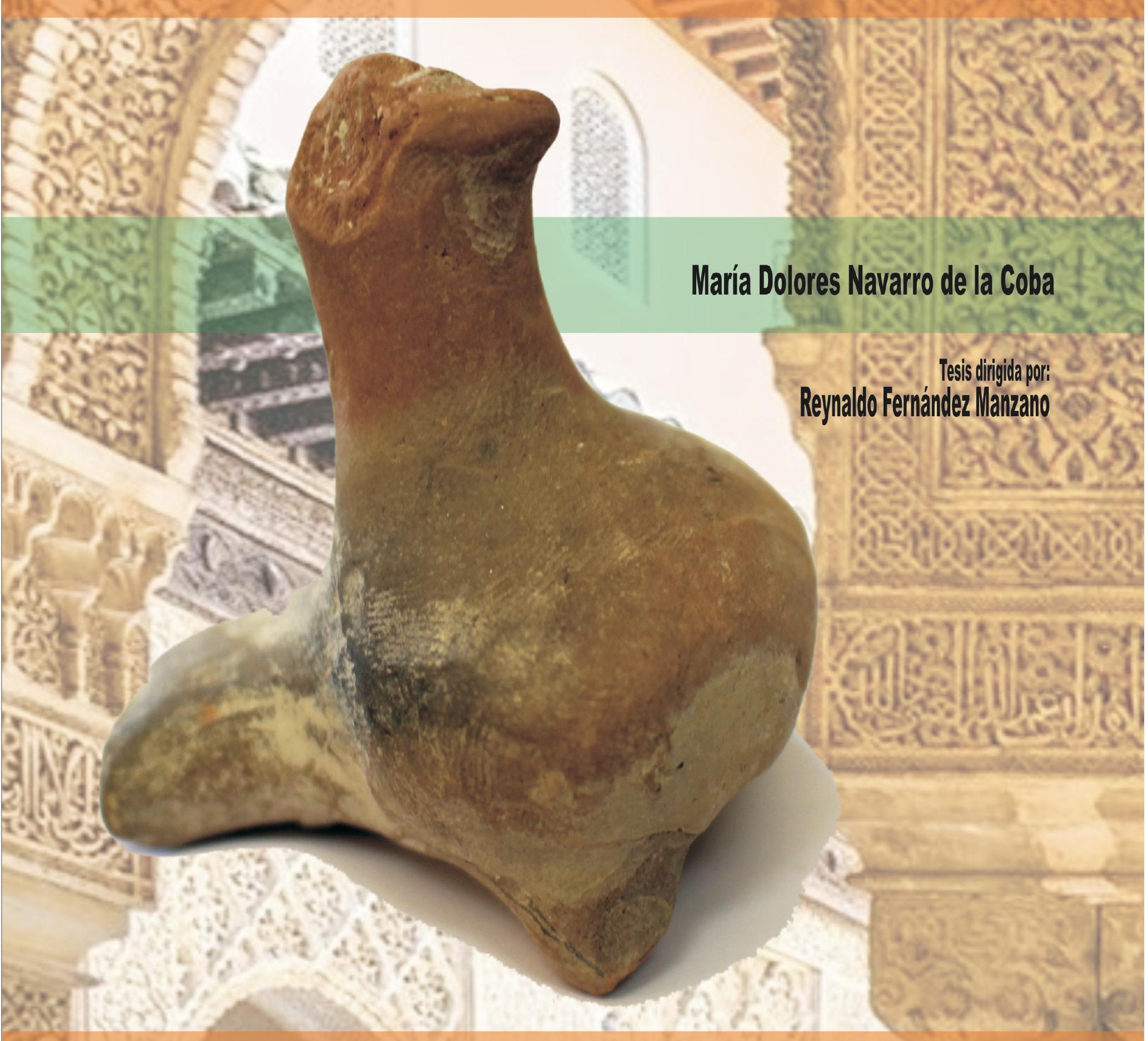


Editor: Universidad de Granada. Tesis Doctorales Autor: María Dolores Navarro de la Coba

ISBN: 978-84-1306-523-6

URI: http://hdl.handle.net/10481/62888 
A mis padres 


\section{Agradecimientos}

Son muchas las personas que han hecho posible la realización de esta investigación, es por ello por lo que me gustaría ponerlas en valor.

En primer lugar, quiero agradecerles a mis padres el haber sacrificado tanto para que yo llegase hasta aquí. El estar de forma incondicional siempre cerca, por sus consejos y preocupación, así como su inagotable paciencia y comprensión.

A Manuela Cortés, quien empezó dirigiendo esta tesis y ha realizado grandes aportaciones a la misma, tanto a través de las reuniones como con sus numerosas publicaciones. A Reynaldo Fernández Manzano, por su valentía al unirse a este proyecto a la altura en la que se encontraba, por los buenos consejos, grandes aportaciones y excelente trato.

A Dani, mi pareja, por alentarme, comprenderme y apoyarme. Por sus incansables revisiones y por su comprensión cuando esta investigación nos ha robado tiempo juntos.

A Rafael Martín, por estar siempre ahí, dispuesto a ayudar sacando hueco para mi en su apretadísima agenda. A Isabela de Aranzadi, por su constante ayuda, ánimo, cariño y buenos consejos. A Jorge por tan buenos momentos y esta preciosa portada. A Cristina Bordas, por su preocupación y cariño. A Instrumenta por la gran motivación.

A Koska y María Isabel por tanto apoyo y preocupación así como por los viajes, largar charlas y cariño.

A Susana Navarro por su predisposición y ayuda con el programa Word. A Andrés Armenteros por su maña para reproducir las "flautas". A Oscar por imprimirme a contrarreloj todos los papeles que me permitieron empezar esta aventura. A M $\mathrm{M}^{\mathrm{a}}$ Ángeles Zapata por su apoyo, consejo y largas conversaciones. A Josemi Lorenzo, Juan y Anuncia Carpio por allanarme el camino. A Encarna por las revisiones, preocupación y ánimo, y a Nacho por sus consejos. A Isabel Ferrera por su buen hacer con Mendeley y esa tarde de curso intensivo. A Fátima de Palma y Susana Gómez por darme la oportunidad de participar en una excavación arqueológica. A Andrea Pezzini por su generosa ayuda en italiano. A Carmen Íñiguez por su colaboración, cariño y consejo.

A Purificación Marinetto, Museo de la Alhambra, María Bárbara Jiménez Serrano del Archivo y Biblioteca del Patronato de la Alhambra y Generalife, Rafael 
Carmona del Museo de Priego, José Ángel Palomares del Museo de Málaga, Ildefonso Navarro del Museo de Estepona, Elena Aguilera del Museo de Huelva, Paqui Hornos del Museo de Jaén, Rosa María Morales de los Baños árabes de Jaén, Paqui Jiménez del Museo de Montemayor, Francisco Barrionuevo del Museo de Jerez, Juan José Delgado del Museo del Puerto de Santa María, Paqui López del Museo Arqueológico y Etnológico de Córdoba, Isidoro Toro del Museo Arqueológico de Granada, Encarnación Maldonado del Museo de Almería, Juan A. Paz del Museo de Zaragoza y al arqueólogo Pepe Suárez por su tiempo y por atenderme de la mejor manera posible.

A Hassan Marso, Consejero de Cultura de Tetuán, por su predisposición y amable trado, a Arbi Belehmar, director del Conservatorio de Música de Tetuán, Samira Kadiri, directora la Casa de la Cultura de Tetuán, Aziz Idrissi, jefe de colecciones de museos arqueológicos de Marruecos en Rabat, Medhi Zuak, director de la Escuela de Bellas artes de Tetuán y Farid Othman, gestor cultural, por sus colaboraciones y excelente trato.

A mi familia y amigos, por los buenos momentos y constante apoyo. 


\section{Índice}

1. Introducción

1.1. Presentación y justificación del proyecto …....................................................11

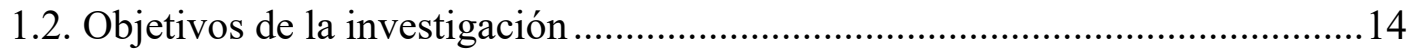

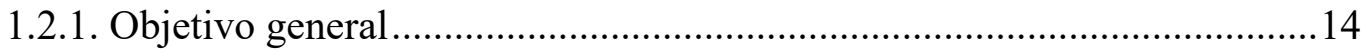

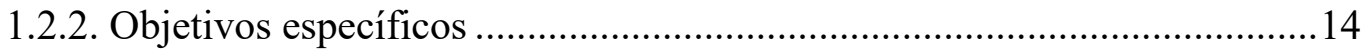

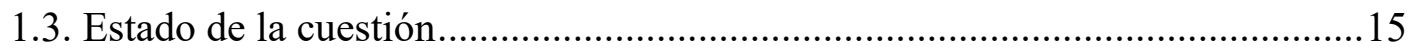

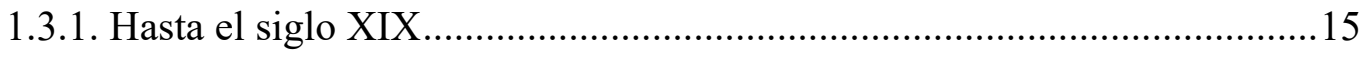

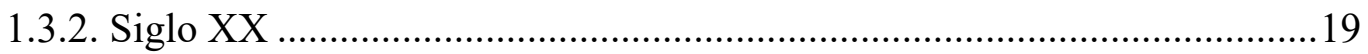

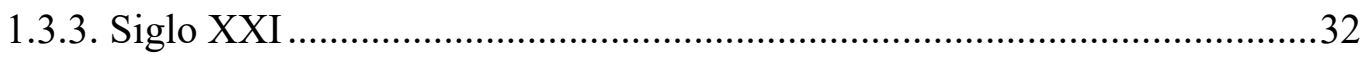

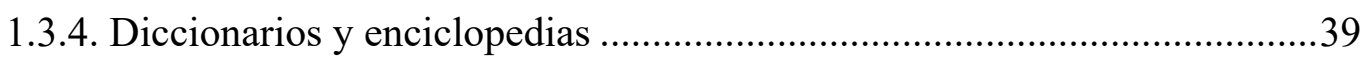

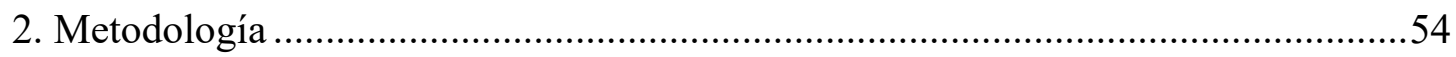

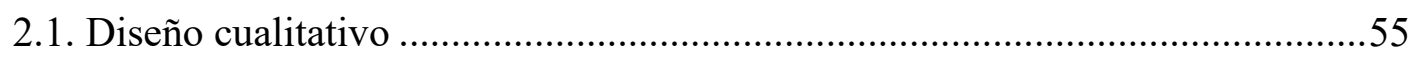

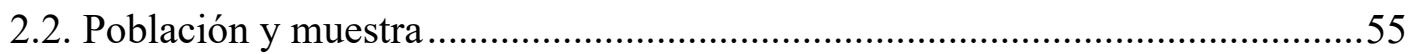

2.3. Herramientas, recogida de datos y materiales..............................................59

2.4. Dificultades encontradas durante la investigación.........................................65

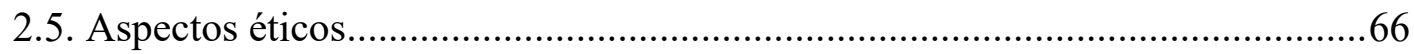

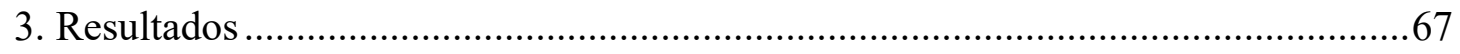

3.1. Los instrumentos musicales en los tratados de los sabios andalusíes ss. IX-XV

3.1.1. Ibn 'Abd Rabbihi, Abu 'Umar (Córdoba, 860- Córdoba, 940) ..................70

3.1.2. Ibn Sida, Abu 1-Hasan (Murcia, 1007-8- Denia, 1066) .............................73

3.1.3. Al-Turtusi, Abu Bakr (Tortosa, 1059 - Alejandría, 1120) ........................75

3.1.4. Abu L-Salt b. Umayya al-Dani (Denia, 1068- 1134)..............................76

3.1.5. Ibn Bayya, Abu Bark (Zaragoza, finales s.XI- Córdoba, 1139) ................77

3.1.6. Al-Saqundi, Abu-I-Walid (Córdoba, mediados del s. XII- Sevilla, 1231-2) 
3.1.7. Ibn Sab'in, Abd al-Haqq (Valle de Ricote [Murcia], 1216-7/ 1217-8 - La Meca, 1270/ 1271)

3.1.8. Ibn al-Darray al-Sabti, Abu 'Abd Allah (¿Sevilla? $1^{\circ}$ mitad s.XIII- Ceuta, $1293 / 4)$

3.1.9. Relación de instrumentos musicales citados por los tratadistas andalusíes

3.2. Muestra de la presencia de los instrumentos musicales en los poemas andalusíes

3.3. La iconografía musical andalusí

3.3.1. Piezas hispanomusulmanas con iconografía musical 100

Bote de al-Mughira (Museo del Louvre, París). Anexo $\mathrm{n}^{\circ} 1$. 100

Bote de Davillier (Museo del Louvre, París). Anexo 2. 100

Arqueta de Leyre (Museo de Navarra). Anexo 3 101

Arqueta del Museo Victoria \& Albert. Anexo 4. 102

Botella de los músicos. Anexo 5. 103

Capitel de los cuatro músicos. Anexo 6. 104

Tañedora de tamborcillo, Córdoba. Anexo 7. 105

Imágenes del códice "Hadith o Qissat Bayad wa Riyad" (Codex. Vat. Arabo 368). Anexo 8-11. 106

"Pintura de moros" en el Partal, s. XIV 108

Imagen caza sala Reyes de la Alhambra. S.XIV. Anexo 12-13 114

Aclaración iconográfica sobre la "Capa de Fermo" - "Casula di Thomas

Becket"

3.3.2. Relación de instrumentos musicales en la iconografía hispanomusulmana tratada.

Aerófonos

Cordófonos

Membranófonos

3.3.3. Iconografía musical en el territorio andalusí no andaluz.....

Tañedora de nai, s. XII, Palacio Pequeño de Ibn Mardanis (Murcia)

Tañedora de laúd, segundo cuarto s. XIII, Murcia

Fragmento de vaso con escena festiva, s. XIII, Murcia 
Pila de Játiva

Almohada de Berenguela de Castilla ...........................................................137

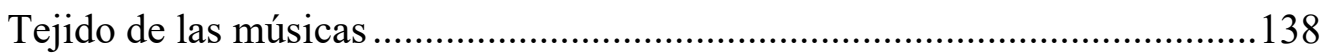

3.3.4. Algunos ejemplos de pervivencia árabe en la iconografía musical cristiana

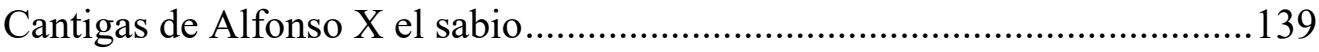

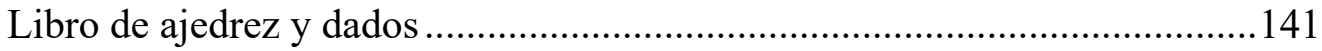

3.3.5. Iconografía musical fatimí .....................................................................143

3.4. Instrumentos musicales en excavaciones arqueológicas andaluzas................149

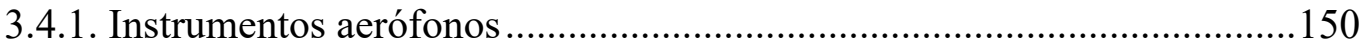

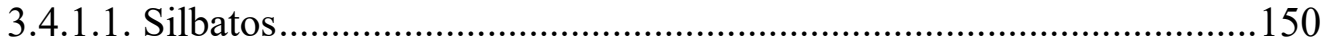

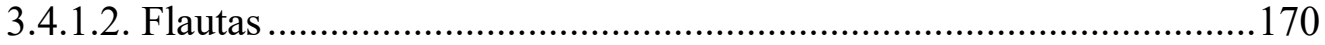

3.4.1.2.1. Réplicas de las piezas catalogadas como flautas ......................180

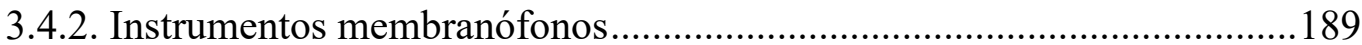

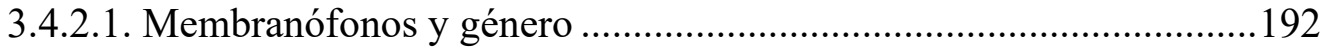

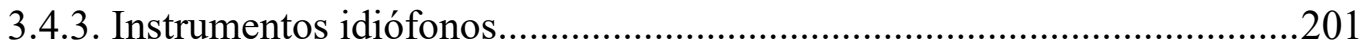

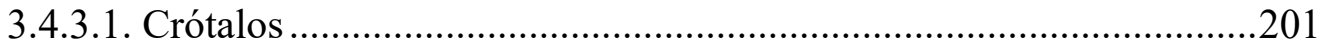

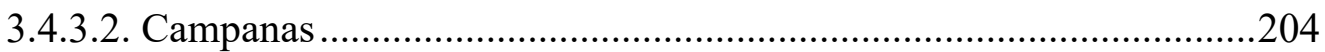

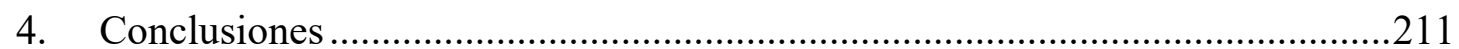

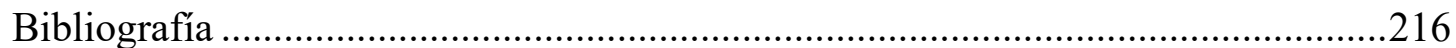

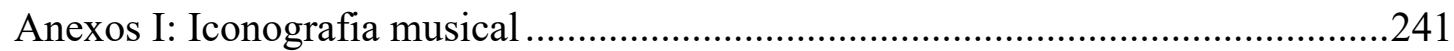

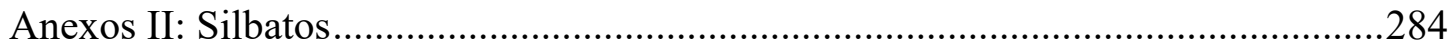

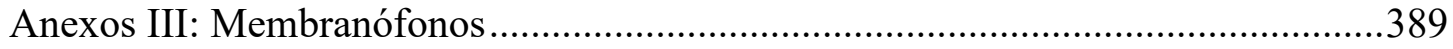

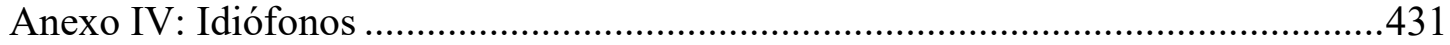

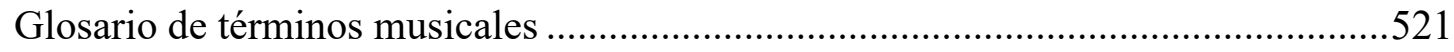

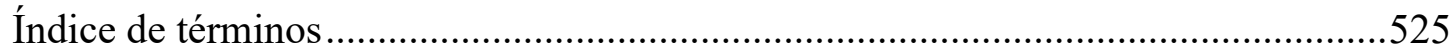

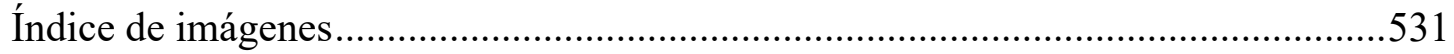




\section{Introducción}

\subsection{Presentación y justificación del proyecto}

La presente investigación versa sobre los instrumentos musicales árabes datados entre los siglos IX y XV, encontrados en excavaciones arqueológicas en el actual territorio andaluz. El estudio sobre el efímero arte de la música en las culturas antiguas constituye, desde hace años, un reto para muchos investigadores, teóricos y músicos. Mediante el análisis de fuentes conservadas hasta nuestros días, se intentan recomponer, o recrear la música de todas las épocas en la Península Ibérica. Habida cuenta de la importancia de los protagonistas tangibles, en esta investigación se compila y estudia en profundidad los instrumentos musicales que llegan hasta nuestros días a través de los yacimientos, desde un punto de vista organológico. Supone, por lo tanto, un complemento histórico a la reconstrucción de la música andalusí, la cual puede aportar nuevos datos y colaborar así en la composición de este puzle histórico andalusí.

A lo largo de la historia de al-Andalus fueron distintos los territorios, que dentro de la Península Ibérica, se conquistaron y perdieron en los distintos periodos acontecidos, siendo Andalucía, o parte de ésta, la que contó con la presencia de los árabes en convivencia con los cristianos de forma constante. Es por ello por lo que la cultura andalusí dejó una notoria huella en este territorio, dato que se tuvo en cuenta al trazar los límites temporales y geográficos para esta investigación. Con la finalidad de trabajar de forma exhaustiva se decidió tratar el actual territorio andaluz para contribuir a la reconstrucción histórica y la puesta en valor del patrimonio musical de esta Comunidad Autónoma. Asimismo, se considera importante destacar la considerable actividad arqueológica y la consecuente cantidad de museos existentes, exactamente noventa y nueve, de temática relacionada con la arqueología, que han salvaguardado de forma mayoritaria estas relevantes piezas. La delimitación geográfica realizada no descarta la esencial comparativa y contraste con los instrumentos musicales encontrados en lugares que estuvieron fuera de la Andalucía islámica, en las zonas bajo el dominio musulmán como fueron el Algarbe o el levante peninsular. También, se han tenido en cuenta las piezas correspondientes a la misma época encontradas en Marruecos, lugar de peregrinación y marcha de los árabes expulsados de la Península Ibérica. Hasta el momento, son escasos los trabajos sobre la compilación de objetos sonoros que abordase toda la variedad encontrada 
correspondiente a la época andalusí en estas actividades arqueológicas en España, por lo que investigar este campo donde se incluyen todo tipo de evidencias musicalessonoras constituía una tarea necesaria desde el planteamiento arqueomusicológico. La arqueomusicología, según explica Ellen Hickmann es:

\footnotetext{
"The application of the methods of archaeology to the study of music. Setting out from the analysis of archaeological findings, however acquired, archaeomusicology reconstructs the music and musical life of early cultures and ethnic groups that can often be dated very far back in time" 1 .
}

Siendo la arqueología musical una ciencia interdisciplinar, se nutre de distintas especialidades como son la organología, la iconografía, la historiografía, la etnología, la antropología, la acústica e incluso la zoología, entre otras. Todas ellas están presentes en esta investigación y abordadas en tres grandes bloques temáticos que forjarán el grueso de esta investigación: la historiografía, mediante la información aportada por los sabios andalusíes que hablan y contextualizan los instrumentos musicales, la organología y la iconografía.

A pesar de la creciente presencia de esta área de investigación en nuestro país, aún siguen siendo escasos los trabajos realizados. Es por ello por lo que resulta importante poner en valor todos los hallazgos musicales encontrados en excavaciones arqueológicas para poder completar la historia de la música que durante décadas se centró en los documentos escritos y la iconografía musical.

Esta investigación no pretende hacer un recorrido histórico sobre la música en al-Andalus ya que esta perspectiva está abundantemente tratada, sino que nace con el objetivo de crear un inventario de piezas que incluya un estudio profundo de los instrumentos musicales encontrados en excavaciones arqueológicas en la comunidad andaluza.

Llegados a este punto es necesario definir qué se entiende por "instrumento musical" y por lo tanto tendrán cabida en este trabajo. En palabras de la investigadora y organóloga Cristina Bordas, los instrumentos musicales son aquellos artefactos construidos para sonar ${ }^{2}$. Según el músico y musicólogo Jesús Salius la música es “todo aquel sonido o conjunto de sonidos producidos y organizados antrópicamente,

1 Ellen Hickmann, "Archaeomusicology", en Grove Music Online. Oxford University Press, 2001. http://www.oxfordmusiconline.com/subscriber/articl (Última consulta: 12/10/2019).

${ }^{2}$ Cristina Bordas Ibáñez, "Los instrumentos musicales y sus colecciones: nuevas perspectivas desde la organología y la museología" en La gestion del patrimonio musical. Situación actual y perspectivas de futuro. Madrid: Centro de Documentación de Música y Danza. INAEM, 2014, 83-90. 
es decir, creados con conciencia por las personas como un medio comunicativo y con un valor diferenciado del lenguaje"3.

Partiendo de ambas afirmaciones se incluyeron en este estudio instrumentos de membrana y silbatos junto a campanas, cascabeles y piezas catalogadas como aerófonos.

Es preciso aclarar que, a lo largo de este documento, cuando se emplea el término "instrumentos" se está aludiendo a "instrumentos musicales", una licencia lingüística que se toma con la finalidad de agilizar la lectura de esta. Entiéndase que cuando se mencionan los "instrumentos" estos son referidos a los "instrumentos musicales". Igualmente, éstos serán llamados piezas, objetos o sinónimos por la misma finalidad.

Por último, se emplean entrecomillados en "culta" o "tribus" habida cuenta de las connotaciones negativas que ambos términos conllevan, pero respetando al mismo tiempo a los investigadores que, correspondiendo a sus épocas, los utilizan.

\footnotetext{
${ }^{3}$ Jesús Salius, Etnoarqueomusicología. La producción de sonidos y la reproducción social en las sociedades cazadoras-recolectoras. Madrid: Consejo Superior de Investigaciones Científicas (CSIC), 2015, 12.
} 


\subsection{Objetivos de la investigación}

A continuación se detallarán los objetivos de esta investigación siendo uno el objetivo general y cuatro específicos.

\subsubsection{Objetivo general}

Conocer en profundidad las evidencias que llegan hasta nuestros días a través de excavaciones arqueológicas, los tratados y la iconografía musical sobre los instrumentos musicales, sus funciones y contexto histórico-cultural dentro de la sociedad de al-Andalus (ss. IX-XV) pertenecientes al ámbito geográfico de la actual Comunidad Autónoma de Andalucía.

\subsubsection{Objetivos específicos}

1. Contrastar la información recogida en los estudios realizados sobre manuscritos andalusíes que han sido la base documental de la historia musical de al-Andalus para establecer una comparativa con las piezas encontradas en los yacimientos arqueológicos.

2. Evaluar la tipología de instrumentos musicales utilizados en la época, a través de los localizados en las excavaciones arqueológicas.

3. Detallar su uso y funciones de los instrumentos musicales mediante el análisis puntual de cuanta información proporciona la iconografía musical y la organología, teniendo en cuenta la cronología, tipologías y características.

4. Inventariar los distintos instrumentos musicales existentes en el territorio andaluz, con el fin de clarificar su importancia en el marco del patrimonio cultural y musical de la comunidad andaluza. 


\subsection{Estado de la cuestión}

Seguidamente se realizará un recorrido a través de los principales trabajos que nutren las tres grandes especialidades de esta investigación: la historiografia, la organología y la iconografía musical, así como las investigaciones clave para este trabajo. Aunque el planteamiento de reflexión sobre los trabajos previos a esta investigación se aborde de forma cronológica algunas líneas de trabajos se trazarán de forma consecutiva sobre las épocas donde se inician para poder plasmar la continuidad y repercusión de los mismos, aunque esto suponga en un momento dado romper la línea cronológica general. Por otro lado, con la intención de aclarar qué campos aborda cada uno de los trabajos en estricto orden cronológico, concluyendo este recorrido se ha realizado un cuadro donde aparece el primer apellido del autor o autora y la fecha de publicación de cada uno de los trabajos presentados puntualizando a qué rama afecta: la arqueo-organológica, la iconográfica y la arabista, así como las zonas geográficas que abarcan. Con la intención de puntualizar en qué momentos la perspectiva arqueológica es incluida en las investigaciones organológicas y concretar cuáles de estos trabajos así la aplican, ambas especialidades se tratarán de forma separada.

\subsubsection{Hasta el siglo XIX}

Durante el siglo XIX se empieza a vislumbrar esta rama de mano del musicólogo Guillaume-André Villoteau (1759-1839), pionero en su enfoque metodológico y por su inquietud en la época grecorromana. Entre sus trabajos cuenta con un libro titulado Description historique, technique el littéraire des instruments de musiques des orientaux ${ }^{4}$, donde defiende el estudio de la organología como rama de la musicología y situando a los instrumentos musicales histórica y tecnológicamente contextualizados dentro de una cultura musical. Este trabajo defiende la inclusión de tres disciplinas que ayudan a su estudio, como son la arqueología, al traer a la luz el instrumento musical y las posibles representaciones figurativas, el análisis de los textos que los mencionan y la musicología, así como el análisis de las piezas y la fabricación y su función musical y social.

\footnotetext{
${ }^{4}$ Guillaume-André Villoteau, Description historique, technique et littéraire, des instrumens de musique des orientaux. París: Impre. impériale, 1812.
} 
Posteriormente, en 1848 Maurice Bourges (1812-1881) ${ }^{5}$ menciona la arqueología musical en el artículo: "L'archeologie musicale" en la Revue et gazette musicale de Paris $^{6}$. En este artículo el autor pone en valor la ardua tarea del musicólogo que cual arqueólogo se adentra en la biblioteca del conservatorio de música de París en búsqueda de partituras y documentos.

El compositor, director de orquesta y musicólogo belga François-Joseph Fétis $(1784-1871)^{7}$ en 1869 publica su trabajo inconcluso Histoire Générale de la Musique $^{8}$. Cuyo eje se forja a través del estudio de los instrumentos musicales en la antigüedad, además de comentar la importancia de "les recherches archéologiques" al afirmar que contribuye al conocimiento de las culturas antiguas.

Esencial sería el trabajo realizado por los musicólogos Curt Sachs (18811959) y Erich Moritz von Hornbostel (1877-1935) publicado en 1914 con el sistema de catalogación de los instrumentos musicales Systematik der Musikinstrumente ${ }^{9}$. Este trabajo será el resultado de varios pasos previos iniciados miles de años antes con la clasificación de instrumentos musicales que se utilizaba en la antigua china 4000 años antes de la actual era, donde los instrumentos eran clasificados por su material de construcción: metal, seda, piedra, bambú, calabaza, arcilla, cuero o madera, según traduce el ingeniero Édouard Biot en el trabajo No Le Tcheou-Li Ou Rites Des Tcheou $^{10}$. En 1529 se publicaría una clasificación de instrumentos musicales en Europa de la mano del músico Martin Agricola con Musica instrumentalis deudsch ${ }^{11}$, quien detalla, en en verso rimado, su clasificación de instrumentos musicales, además de aportar detalles sobre digitación, afinación y notación de los instrumentos musicales tratados. Posteriormente será el magistrado, bibliófilo y coleccionista de curiosidades, entre éstas instrumentos musicales, Pierre Trichet (1586/87-1644) con el Traité des instruments de musique (ca.1640) ${ }^{12}$, quien presentará su colección

\footnotetext{
5 “Maurice Bourges" https://data.bnf.fr/fr/14847453/maurice bourges/(Última consulta 12/10/2019).

${ }^{6}$ Maurice Bourges, "L'archeologie Musicale," Revue et Gazatte Musicale, 1848.

7 "François Joseph Fétis", https://www.biografiasyvidas.com/biografia/f/fetis.htm (Última consulta 1210-2019).

${ }^{8}$ François-Joseph Fétis, Histoire générale de la musique depuis les temps les plus anciens jusqu'a nos jours, Librairie. París: L'institut, 1869.

${ }^{9}$ Enrich M. Hornbostel y Curt Sachs, "Systematik Der Musikinstrumente," Zeitschrift Für Ethonologie 46 (1914), 553-90.

10 Édouard Biot, No le Tcheou-Li ou Rites des Tcheou, ed. L'Impremerie Nationale. Paris, 1803-1850.

${ }^{11}$ Martin Agricola, Musica Instrumentalis Deudsch. Wittenberg: Georg Rhaw, 1529.

12 Pierre Trichet, Traité des instruments de musique (vers 1640). Publié avec une introduction et des notes par François Lesure, ed. Société de musique D'autrefois. Genève: Minkoff Reprint, 1957.
} 
mediante descripciones y representaciones gráficas ${ }^{13}$. Siguiendo la cronología, será el padre Marin Mersenne el autor de Traité de l'harmonie universelle ${ }^{14}$ en 1627. Todos ellos crearán la base clasificatoria en cuatro posibilidades: cuerda, viento, percusión y "varios"15. A partir de 1880 Víctor Mahillon ${ }^{16}$ ideará un nuevo sistema de clasificación tras conocer la variada colección de instrumentos musicales procedentes de distintos lugares del mundo, en el Museo del Conservatorio de Bruselas que se basará en los siguientes puntos:

\begin{abstract}
"Mahillon toma como referencia la palabra griega "fono", que significa sonido. Sobre esta base denomina las divisiones como membranófonos (instrumentos en los cuales el material que entra en vibración es una membrana); cordófonos (cuando el material que entra en vibración es una cuerda); aerófonos (si lo que entra en vibración es el viento) y autófonos (aquellos instrumentos en los cuales el material que entra en vibración es el mismo que compone a la pieza). Las subdivisiones que plantea para continuar la clasificación están determinadas por la manera con la que el ejecutante hace vibrar el cuerpo del instrumento" ${ }^{\text {"17 }}$.
\end{abstract}

Será sobre este último trabajo donde Erich Hornbostel y Curt Sachs construyan la clasificación de instrumentos musicales que llega hasta nuestros días ${ }^{18}$. Este importante trabajo que supone un punto de referencia para investigadores, organólogos y museólogos que se encuentran con este tipo de colección es posteriormente traducida al inglés en el artículo publicado por la The Galpin Society Journal "Classification of Musical Instruments: Translated from the Original German by Anthony Baines and Klaus P. Wachsmann"19. Décadas después la investigadora $\mathrm{M}^{\mathrm{a}}$ Antonia Juan i Nebrot realizará: Versión castellana de la clasificación de instrumentos musicales según Erich von Hornbostel y Curt Sachs ${ }^{20}$, donde la autora unifica las traducciones de la misma que se habían producido hasta el momento. Pero

${ }^{13}$ Florence Gétreau, "Quelques Cabinets d'instruments de Musique au Temps des Rois Bourbons" Musique. Images. Instruments, Klincksieck 8, 2006, 27-28.

${ }^{14}$ Marin Mersenne, Traite de l'harmonie Universelle. Indiana: Indiana University, 1962.

15 José Pérez de Arce y Francisca Gili, "Clasificación Sachs-Hornbostel de Instrumentos Musicales: Una revisión y aplicación desde la perspectiva americana”, Revista Musical Chilena 219 enero-junio, 2013, 44.

16 Victor-Charles Mahillon, Catalogue Descriptif \& Analytique du Musée Instrumental Du Conservatoire Royal de Bruxelles. Bruselas: 1880.

17 José Pérez de Arce y Francisca Gili, "Clasificación Sachs-Hornbostel de Instrumentos Musicales: Una Revisión y Aplicación desde la Perspectiva Americana”, Revista Musical Chilena 219 enero-junio, 2013, 45 .

${ }^{18}$ Ibidem, 44.

${ }^{19}$ Erich Hornbostel y Curt Sachs, "Classification of Musical Instruments: Translated from the Original German by Anthony Baines and Klaus P. Wachsmann", The Galpin Society Journal 14, 1961, 3-29.

${ }^{20}$ M. Antonia Juan i Nebrot, "Versión Castellana de La Clasificación de Instrumentos Musicales Según Erich von Hornbostel y Curt Sachs (Galpin Society Journal XIV, 1961)", Nassarre: Revista Aragonesa de Musicología XIV, 1, 1998, 365-87. 
será la versión de Javier Serrano Godoy la más actual hasta la fecha, en esta revisará y ampliará la clasificación siguiendo las directrices del Comité international pour les musées et collections d'instruments et de musique (CIMCIM) y el Musical Instruments Museum Online (MIMO) ${ }^{21}$.

No será este trabajo la única gran aportación que realice al estudio organológico Curt Sachs, ya que en su publicación The history of musical instruments publicado en Nueva York en 1940 (cuya versión española no llegaría hasta 1947, Historia Universal de los Instrumentos Musicales editada en Buenos Aires ${ }^{22}$ ) pone en valor los instrumentos musicales encontrados en excavaciones arqueológicas, estudiándolos de forma detallada por sí mismos y dentro de un contexto cultural concreto. La siguiente investigación en esta línea de Curt Sachs será publicada en 1943, The rise of music in the Ancient World: East and West $t^{23}$ (1943), la finalidad de este no es puramente organológica pero sí aborda la iconografía musical para el estudio musical de las primeras civilizaciones.

En lo referente a la organología árabe, François-Joseph Fetís entre 1869 y 1876 publicaría su trabajo Histoire generale de la musique dépuis les temps les plus anciens jusqu'a nos jours publicada en París $^{24}$, cuyo segundo volumen La musique chez les arabes, les maures et les kabyles trata la historia de la música árabe oriental y del Magreb incluyendo los instrumentos musicales presentes en el momento. También Francisco Salvador Daniel (1831-1871), investigador y violinista publico varios trabajos acerca de la música árabe, siendo pionero en la investigación a ambas orillas del Mediterráneo. Sus trabajos fueron recopilados y publicados en la década de los 80 del siglo XX con el título Musiques et instruments de musique du Maghreb ${ }^{25}$, siendo este el resultado de los artículos realizados entre 1856-186726.

\footnotetext{
${ }^{21}$ Javier Serrano Godoy, Versión en español de la Clasificación de Instrumentos Musicales de Curt Sachs y Erich von Hornbostel, según la edición CIMCIM - MIMO 2011 / 2017. Madrid: Universidad Complutense de Madrid, 2018.

${ }^{22}$ Curt Sachs, Historia Universal de los Instrumentos Musicales, Ediciones Buenos Aires, 1947.

${ }^{23}$ Curt Sachs, La Música en el Mundo Antiguo. Oriente y Occidente, 1981.

${ }^{24}$ François-Joseph Fetís, Histoire generale de la musique dépuis les temps les plus anciens jusqu'a nos jours. París: Firmin Didot, 1876.

${ }^{25}$ Francisco Salvador Daniel, Musiques et Instruments de Musique du Maghreb, La Boîte à Documents. París, 1986.

${ }^{26}$ Manuela Cortés García, La música árabe y andalusí de las dos orillas en los estudios musicológicos (ss. XVIII-XXI). Málaga: Ediciones Genal, 2018, 48-49.
} 


\subsubsection{Siglo $X X$}

En 1901 el compositor y musicólogo Felipe Pedrell (1841- 1922) $)^{27}$ publicó su reconocido trabajo Emporio científico e histórico de organografía musical antigua española donde menciona a las "familias de instrumentos" siguiendo las pautas clasificatorias planteadas por Víctor Mahillon ${ }^{28}$. En esta obra Felipe Pedrell ofrece tres fuentes previas para el estudio de los instrumentos musicales, como son Declaración de instrumentos musicales de fray Juan Bermudo publicado en $1555^{29}$, Melopeo y Maestro ${ }^{30}$, de Pietro Cerone publicado en 1613 y Escuela de Música ${ }^{31}$, de fray Pablo Nassarre, $1724^{32}$. Estos trabajos referenciados por el mismo Pedrell ofrecen datos sobre el trato documental y estudio de los instrumentos musicales hasta el momento, reseñando la dificultad de estudiar instrumentos musicales medievales, entre otros, debido al gran número de terminologías utilizadas, incluso en varios idiomas como el árabe o latín ${ }^{33}$.

En cuanto a la iconográfica musical andalusí será en la década de los años 20 y de la mano del historiador José Ferrandis (1900-1948) quien presente piezas con iconografía musical con sus obras Marfiles y azabaches españoles ${ }^{34}$ y Marfiles árabes en Occidente vol. I y $I I^{35}$, obras que están planteadas sobre el patrimonio artístico hispanoárabe.

Una gran aportación al estudio de la música andalusí y sus instrumentos son los trabajos del investigador y arabista Henry Georges Farmer (1882-1965). Su obra se reparte entre libros y artículos, la mayoría de estos últimos ha sido compilada en

\footnotetext{
${ }^{27}$ Paulino Capdepón Verdú, "Felipe Pedrell Sabaté" http://dbe.rah.es/biografias/8205/felipe-pedrellsabate (Última consulta: 11/10/2019).

${ }^{28}$ Felipe Pedrell, Emporio científico e histórico de organografia musical antigua española. J. Gili, $1901,9$.

${ }^{29}$ Fray Juan Bermudo, Declaración de instrumentos musicales. Osuna: Juan de León, 1555.

${ }^{30}$ Pietro Cerone, El Melopeo y Maestro: Tractado de Musica Theorica y Pratica. Nápoles: Juan Bautista Gargano y Lucrecio Nucci, 1613.

${ }^{31}$ Pablo Nassarre, Escuela de Música. Zaragoza, 1723.

${ }^{32}$ Felipe Pedrell, Emporio cientifico e histórico de organografia musical antigua española. J. Gili, 1901,13

${ }^{33}$ Ibídem, 16.

${ }^{34}$ José Ferrandis, Marfiles y Azabaches Españoles. Barcelona-Buenos Aires: Editorial Labor, S.A., 1928, lám. XI, XIV, XVI.

35 José Ferrandis, Marfiles Árabes de Occidente. Tomo I. Madrid: Facultativo de Archiveros, Bibliotecarios y Arqueólogos, 1935, 69-71, 74-75, 78-80, 84-85; José Ferrandis, Marfiles Árabes de Occidente. Tomo II. Madrid: Facultativo de Archiveros, Bibliotecarios y Arqueólogos, 1940, 45-52, 131-133, 154-155, 209-210.
} 
libros posteriormente en Studies in oriental music vol. I y $I^{36}$. El primer volumen está organizado en cuatro puntos principales: Juglares y estudios generales, influencias musicales, manuscritos y tratados y la música árabe en la escena contemporánea. El segundo volumen está centrado en instrumentos musicales y música militar.

Del primer volumen, el artículo The arabic musical manuscripts in the Bodleian Library. A Descriptive catalogue with ilustrations of musical instruments ${ }^{37}$ resulta interesante desde el punto de vista documental e iconográfico para el estudio de la música oriental. En este segundo volumen aparecen artículos sobre instrumentos, de todas ellas las más relevantes por su concreción sobre la temática para esta investigación son Ninth century musical instruments ${ }^{38}$, A note on the mizmar and $n a y^{39}$, donde realiza un estudio intentando diferenciar los distintos instrumentos árabes que durante la Edad Media podían entrar dentro de esta terminología; The origin of the arabian lute and rebec ${ }^{40}$, en este artículo pone en valor la entrada de la mano de los árabes de estos importantes instrumentos a Europa durante la Edad Media y lo que supondrían los mismos para la evolución de la música; A maghribi work on musical instruments ${ }^{41}$, compila una treintena de instrumentos musicales mencionados por Ibn al-Darray de Ceuta, en su Libro sobre el gozo y aprovechamiento de la audición musical al-sama' aunque este trabajo fue atribuido erróneamente por Farmer al copista magrebí al-Salahi (s. XVIII) ${ }^{42}$. The musical instruments/Instruments of music on the Taq-i Bustan Bas-Reliefs ${ }^{43}$, donde realiza un estudio de los bajorrelieves que tanto se han reproducido y de los que tantas versiones, consecuentemente, se han creado; Thirteenth century arabian instruments/

\footnotetext{
${ }^{36}$ Henry George Farmer y E Neubauer, Studies in Oriental Music, Vol. 1. Frankfurt: Institute for the History of arabic-islamic Science at the Johann Wolfgang Goethe University, 1997; Henry George Farmer, Studies in Oriental Music Vol. 2. Frankfurt am Main, Institut fur geschicte der ArabischIslamichen wissenschaften an der Johann Wofgang Goethe Universitat, 1986.

${ }^{37}$ Henry George Farmer, The arabic musical manuscripts in the Bodleian Library: A descriptive catalogue with illustrations of musical instruments. W. Reeves, 1925.

${ }^{38}$ Henry George Farmer, "Ninth Century Musical Instruments", en Studies in Oriental Musical Instruments: First and Second Series. Boston: Longwood Press, 1978.

${ }^{39}$ Henry George Farmer, “A Note on the Mizmar and Nay”, Journal of the Royal Asiatic Society 61, 1 1929, 119-21.

${ }^{40}$ Henry George Farmer, "The Origin of the Arabian Lute and Rebec", The Journal of the Royal Asiatic Society of Great Britain and Ireland, No 4, 1930, 767-83.

${ }^{41}$ Henry George Farmer, "A Maghribi Work on Musical Instruments", en Studies in Oriental Musical Instruments. Glasgow: The civic press, 1939, 19-35.

42 Manuela Cortés García y Marcos González Berlanga, “Ibn Al-Darray” en Enciclopedia de la cultura Andalusí: Apéndice. Fundación Ibn Tufayl de estudios árabes, 2012.

${ }^{43}$ Henry George Farmer, "Instruments of Music on Taq-i Bustan Bas-Reliefs", en Studies in Oriental Musical Instruments. Glasgow: The civic press, 1939, 70-85.
} 
Arabian musical instruments on a Thirteenth century Bronze bowl ${ }^{44}$ en este artículo Farmer visibiliza la escasez de iconografía musical árabe al trabajar la imagen reflejada en un cuenco de bronce que normalmente no sería un referente documental por su modo de fabricación.

Por otro lado H. G. Farmer realizaría varias publicaciones concretamente sobre el laúd, que ayudaron a enriquecen el estudio de este instrumento como base de la teoría musical árabe. En ellos aborda el análisis del instrumento desde distintas perspectivas, tanto en comparación con otros instrumentos de similares características, como las versiones del mismo que se pueden dar en distintos lugares, sus técnicas de interpretación o afinación. Los trabajos de este musicólogo y arabista están basados y/o fundamentados en las traducciones de los tratados de la época que él mismo traduce o estudia. El listado, por lo tanto, de publicaciones afines al estudio organológico del laúd en la cultura andalusí sería el aplicado al laúd morisco: An old moorish lute tutor ${ }^{45}$, este estudio está compuesto por distintos artículos que realiza, entendidos como una investigación en varios fascículos que publicaba en The Journal of the Royal Asiatic Society of Great Britain and Ireland, en estas publicaciones vuelca las novedades en la investigación de este instrumento según los distintos tratados que consigue encontrar, tanto dándolos a conocer como trabajándolos $\mathrm{y}$ comentándolos si tenía acceso a los mismos. The lute scale of Avicenna ${ }^{46}$, en este trabajo defiende que la escala utilizada para este instrumento fue desarrollada entre los árabes y los persas. En este trabajo realiza un estudio sobre la escala propuesta por Avicena desde el punto de vista histórico, mientras que en Was the arabian and persian lute fretted ${ }^{47}$ Farmer se plantea la posibilidad de que existiesen trastes en el laúd árabe o persa durante la Edad Media y llegando a la conclusión de que, una vez revisadas las fuentes, no existen evidencias de los mismos. En la obra, The structure of the arabian and persian lute in the Middel Ages ${ }^{48}$, Farmer afirma que el laúd es un instrumento musical esencial en la cultura musical árabe muy presente y conocido

\footnotetext{
${ }^{44}$ Henry George Farmer, "Arabian Musical Instruments on a Thirteenth Century Bronze Bowl", Journal of the Royal Asiatic Society 82, 1950, 110-11.

${ }^{45}$ Henry George Farmer, “An Old Moorish Lute Tutor”, Journal of the Royal Asiatic Society of Great Britain \& Ireland, 64, 1932, 379-89.

${ }^{46}$ Henry George Farmer, "The Lute Scale of Avicenna," The Journal of the Royal Asiatic Society of Great Britain and Ireland, $N^{\circ} 2,1937,245-57$.

${ }^{47}$ Henry George Farmer, "Was the Arabian and Persian Lute Fretted?", Journal of the Royal Asiatic Society 69, 1937, 453-60.

${ }^{48}$ Henry George Farmer, "The Structure of the Arabian and Persian Lute in the Middel Ages", The Journal of the Royal Asiatic Society of Great Britain and Ireland, $N^{\circ} 1,1939,41-51$.
} 
pero que la interpretación del mismo se reservaba solo a los músicos profesionales a pesar de su fama, detallando, asimismo, características de su construcción y técnica de interpretación. An old moorish lute tutor: being four arabic texts from unique manuscripts in the Biblioteca Nacional, Madrid (No. 334) and the Staatsbibliothek, Berlin (Lbg. 516), en esta importante investigación realiza un análisis desde la teoría musical árabe sobre los citados manuscritos únicos.

Asimismo, Farmer cuenta con varios trabajos en los que se mencionan y contextualizan los instrumentos musicales andalusíes, aún no siendo tratados estos como protagonistas están presentes de forma continua: The arabian influence on musical theory $(1925)^{49}$, siempre partiendo de la importancia del laúd en la música y teoría musical en este trabajo menciona el uso de otros instrumentos musicales de forma contextualizada como pueden ser instrumentos de membrana o la guitarra. $A$ history of arabian music to the XIIIth century $(1929)^{50}$ este estudio se estructura de forma cronológica y especifica las circunstancias y leyes que regían el uso de instrumentos musicales. En Historical facts for the arabian musical influence (1930) $)^{51}$ Farmer defiende la influencia árabe en la teoría musical medieval señalando el efecto que tuvo en áreas cruciales como la armonía, polifonía, solmisación o tablaturas instrumentales. En este trabajo también incluye referencia a los manuscritos de música árabe que trataban el órgano antiguo. Con respecto a Ancient Arabian musical instruments $^{52}$ traduce el manuscrito de al-Muffadal ibn Salamah del Kitab al-malahi realizado por Yaqut al-Musta'simi (m. 1298), en él se comentan distintos instrumentos musicales desde un punto de vista organológico que será trabajado por investigadores como James Robson, obra que acompaña con ilustraciones de algunos instrumentos.

Será en 1937 cuando Francis William Galpin (1858-1945) ${ }^{53}$ publicará The music of the sumeriens and their inmediated succesors the Babilonyans and

\footnotetext{
${ }^{49}$ Henry Georges Farmer, The Arabian Influence on Musical Theory. Londes: 1925.

${ }^{50}$ Henry George Farmer, A History of Arabian Music to the XIIIth Century. Luzac: 1929.

${ }^{51}$ Henry George Farmer, Historical facts for the arabian musical influence. Londres: Villiam Reeves, 1930.

52 James Robson y Henry George Farmer, Ancient Arabian Musical Instruments: As Described by AlMufaddal Ibn Salama (Ninth Century) in the Unique Istanbul Manuscript If the Kitab Al-Malahf in the Handwriting of Yaqut Al-Musta'sima (d. 1298). Glasgow: Civic, 1938.

${ }^{53}$ Rosemary Williamson, "Galpin, Francis William" Grove Music Online, Oxford Music Online, https:/www.oxfordmusiconline.com/grovemusic/view/10.1093/gmo/9781561592630.001.0001/omo9781561592630-e-0000010591 (Última consulta: 12-10-2019).
} 
Assyrians $^{54}$, donde tratará las culturas musicales antiguas incluyendo información acerca de los instrumentos y la iconografía musical. También en esta misma década de los 30, Antoni Mulet i Comila publicará el artículo "Los recientes hallazgos de cerámica en Palma" donde empezarán a darse a conocer, entre los enseres de la cerámica árabe, unos silbatos islámicos ${ }^{55}$. Este mismo investigador posteriormente, durante los 40, publicará Pitos y cántaros en Mallorca ${ }^{56}$ donde hace referencia nuevamente a los siurell, los silbatos mallorquines. En esta línea de trabajo sobre los silbatos, durante la primera mitad de los 50, el historiador Cid Priego (1920-1998) ${ }^{57}$ publica un artículo sobre estos instrumentos explicando su proceso de fabricación y su relación con la mujer durante el mismo. En la segunda década de los 50, el arquitecto y restaurador de la Alhambra, Torres Balbás (1880-1960), en "Animales de juguete" pondrá en valor los juguetes andalusíes señalando la peculiaridad de que la mayoría fueron utilizados como silbatos ${ }^{58}$.

En 1938 Alexis Chottin (1891-1975) ${ }^{59}$ publicará Tableau de la musique marocaine $^{60}$ donde presenta y analiza instrumentos musicales, entre otras temáticas, representativos de la cultura andalusí y bereber en Marruecos.

Posteriormente el musicólogo alemán Hans Hickmann (1908-1968) conocido principalmente por sus trabajos sobre instrumentos musicales del antiguo Egipto, publicará en 1940 una importante obra titulada Catalogue general des antiquitées égyptiennes $d u$ Musée du Caire ${ }^{61}$ donde describirá instrumentos y fragmentos incluyendo cuestiones técnicas de interpretación. Asimismo, adjuntará dibujos de los detalles de construcción.

Focalizando la atención sobre la organología andalusí, el siguiente paso cronológico sería el dado por Jonh Brande Trend (1887-1958) del que se publicará en

\footnotetext{
${ }^{54}$ Francis William Galpin, The Music of the sumerians and their immediate successors the babylonians and assyrians, described and illustrated from original sources, 1936.

55 Antoni Mulet, "Los recientes hallazgos de cerámica en Palma", Boletín de la Sociedad Arqueológica Luliana 27, 1938, 169-80.

${ }^{56}$ Antoni Mulet, Pitos y Cántaros de Mallorca. Palma de Mallorca: Imprenta Sucesores de Amengual y Muntaner, 1949.

57 Francesc Fontbona, "Cid Priego, Carlos”, Diccionari d'historiadors de l'art català, valencià $i$ balear, https://dhac.iec.cat/dhac_mp.asp?id_personal=202 (Última consulta: 12-10-2019).

${ }^{58}$ Leopoldo Torres Balbás, “Animales de Juguete”, Crónica Arqueológica de la España Musulmana XXXIX, 1956, 373.

${ }^{59}$ Manuela Cortés García, La música árabe y andalusí de las dos orillas en los estudios musicológicos (ss. XVIII-XXI). Málaga: Ediciones Genal, 2018, 137.

60 Alexis Chottin, Tableau de La Musique Marocaine. París: P. Geuthner, 1939.

${ }^{61}$ Hans Hickmann, Catalogue Général Des Antiquités Égyptiennes Du Musée Du Caire. Nos. 6920169852. Instruments de Musique. El Cairo: 1'Institut Français d'Archéologie orientale, 1949.
} 
1965 las cartas intercambiadas con Manuel de Falla con quien compartió inquietudes sobre música ${ }^{62}$. En su trabajo The music in spanish history to $1600^{63}$ hará referencia a la influencia de la música árabe a la andalusí e incluirá información sobre los instrumentos musicales ${ }^{64}$.

El siguiente paso cronológico contextualizaría la arqueomusicología asentando sus bases de forma paralela a la etnomusicología, o la musicología comparada como así se denominaba a esta especialidad hasta $1950^{65}$, ya que ambas aparecen, evolucionan y comparten metodologías de trabajo desde sus inicios. Esta similitud será más evidente a partir de los años 60 , coincidiendo con la publicación de la obra de Alan Merriam The anthropology of music ${ }^{66} \mathrm{y}$ con la nueva perspectiva desde la arqueología a la antropología cultural ${ }^{67}$. Durante la primera mitad del siglo XX la arqueología priorizaba la especificación de la ubicación y cronología de la pieza. No será hasta la década de los 60 cuando las investigaciones arqueológicas den el giro antropológico que las hiciese plantearse nuevas metas anteriormente no estudiadas en profundidad, como era la vida ritual y musical de las sociedades en estudio. El hecho de que ciertos hallazgos arqueológicos fuesen catalogados como instrumentos musicales de uso directo o la posibilidad de los mismos, contribuyó a que esta temática se estudiara de forma exhaustiva. En 1947 Hickmann publicó Terminologie arabe des instruments de musique ${ }^{68}$ en este trabajo revisa los términos de raíz árabe relacionados con ciertos instrumentos musicales, así como se hace eco de los instrumentos occidentales que se utilizan en Egipto en esa actualidad.

Los primeros restos arqueológicos estudiados sobre las culturas antiguas se remontan a las tablillas con escritura cuneiforme, encontradas en Mesopotamia que recogían textos y notación musical. Es ahí cuando empezaron a tratarse estos

\footnotetext{
${ }^{62}$ Tess Knighton, “John Brande Trend (1887-1958) and His Musical 'Iter Hispanicum”", Music and Letters 95, no. 4, 2014, 550-83.

63 John Brande Trend, The Music of Spanish History to 1600. Nueva York: University Press: Humpherey Milford, 1965.

${ }^{64}$ Manuela Cortés García, La música árabe y andalusí de las dos orillas en los estudios musicológicos (ss. XVIII-XXI). Málaga: Ediciones Genal, 2018.

65 Primera denominación de la etnomusicología, pasando a llamarse así a partir de 1950; Enrique Cámara de Landa, Etnomusicología. Instituto Complutense de Ciencias Musicales, 2003, 27.

${ }^{66}$ Alan P. Merriam, The Anthropology of Music. Illinois: Northwestern University Press, 1964.

${ }^{67}$ Raquel Jiménez Pasalodos, "Arqueología Musical y Etnomusicología: Por una interpretación etnomusicológica de los materiales arqueológicos", Etno-Folk: Revista Galega de Etnomusicoloxía 14, 2009,639

${ }^{68}$ Hans Hickmann, Terminologie arabe des instruments de musique, ed. Verlang nicht Ermittelbar. El Cairo: 1947.
} 
importantes hallazgos que ofrecían información acerca de la presencia musical en esta cultura. Una de las grandes figuras en la investigación arqueomusicológica en España, Rosselló Bordoy, comenzará a finales de los 50 sus estudios sobre los silbatos, siruells $^{69}$. En los 60, Rosselló realizará un estudio completo arqueomusicológico recopilando las hipótesis trabajadas por Mulet y Torres Balbás ${ }^{70}$. Por las mismas fechas, el crítico de arte Gaya Nuño dedica un capítulo a los silbatos de Andújar y Mallorca en su trabajo Esculturas ibéricas ${ }^{71}$ donde fundamentará su origen en la cultura cretense o púnica destacando los silbatos con forma de toros como los más representativos de la cultura íbera. Con respecto a la iconografía, en 1967 se publicará el artículo "Caza en el recinto de la Alhambra"72 donde se hará mención a la escena de caza donde aparece un cuerno en la figura del ojeador. Sobre esta misma temática se volverá a publicar en 1982 "Las pinturas de la sala de los Reyes de la Alhambra: los asuntos, los trajes, la fecha"73.

Igualmente, en la década de los 70, se intensificaría el estudio de la presencia de la música en la Prehistoria y la Antigüedad, siendo diversas las revistas que dedicaron algunos números a esta temática.

En 1919 el musicólogo Nikolai Findeizen impartió un curso denominado “Arqueología Musical” aunque según Carlos Benítez el enfoque y fuentes del mismo estaba realizado principalmente desde la óptica de la historia y no desde la $\operatorname{arqueología~}^{74}$.

En 1974 Amnon Shiloah publicaría 'Un ancien traité sur le 'ud d'Abu Yuful alKindi” ${ }^{75}$ donde se hacía eco de la epístola de al-Kindi centrada en la importancia del laúd como instrumento donde se forja la teoría musical árabe. En este mismo año George Vindry publicará "Présentation de l'épave árabe du Batéguier (Baie de

\footnotetext{
69 Guillermo Rosselló Bordoy, "Silbatos Mallorquines”, al-Andalus 1, 1957, 196-98.

70 Guillermo Rosselló Bordoy, "Siurells", Boletín de la COCIN 636, 1964, 185-93.

71 Juan Antonio Gaya, Escultura Ibérica. Madrid: Aguilar, 1964.

72 Eduardo Molina Fajardo, "Caza en el recinto de la Alhambra”, Cuadernos de la Alhambra 3, 1967 , 31-53.

${ }^{73}$ Carmen Bernis Madrazo, "Las pinturas de la sala de los Reyes de la Alhambra: los asuntos, los trajes, la fecha", Cuadernos de la Alhambra 18, 1982, 21-50.

${ }^{74}$ Carlos García Benito, “Arqueología Musical Prehistórica: Aproximación a través de la arqueología Experimental Aplicada a la Arqueo-Organología, de la Arqueoacústica y de la Iconografía Musical Prehistórica". Tesis doctoral Universidad de Zaragoza, 2014.

75 Amnon Shiloah, "Un ancien traité sur le 'ud d'Abu Yuful al-Kindi", Israle Oriental Music IV, 1974, 179-205.
} 
Cannes, Provence Orientale)" ${ }^{976}$ donde se hace eco de las darboukas localizadas en la nave hundida en Batéguier. En 1975 J. Torres publicará "Los instrumentos de música en las miniaturas de las Cantigas"77. En 1976 se publicará Music and musical instruments in the world of islam $^{78}$ este importante trabajo los instrumentos musicales considerados "clásicos" y su influencia en otras culturas.

Posteriormente, en el año 1977 y en el marco del Congreso Internacional de la Musicological Society celebrado en Berkley es cuando se empezó a tratar la necesidad de unir la arqueología con la musicología/etnomusicología, despertando la inquietud en muchos de los asistentes que, posteriormente, se unieron para crear el primer grupo de trabajo sobre arqueología musical perteneciente al ICTM: Study Group for Music Archaeology, reconocido por el International Council of Tradicional Music en 1983. Asimismo, a través de la prestigiosa revista World Archaeology se empezaron a tratar las metodologías sistemáticas para el análisis de artefactos sonoros arqueológicos, dándole difusión a estas investigaciones y facilitando su estudio. Esta inquietud emergente despertaría la curiosidad de reconocidos arqueólogos que, en 1996, se acercarían a esta nueva línea, también de la mano del grupo de trabajo independiente International Study Group for Music Archaeology (ISGMA). Posteriormente, en 2003, el grupo del ICTM se reactivaría, liderado por Anthony Seeger y Julia Sánchez, siendo, en la actualidad, uno de los grupos más activos e influyentes dentro de este campo de investigación ${ }^{79}$.

En 1979 Amnon Shiloah publicará "The 'ud and the origin of music" ${ }^{80}$ donde recalcará la importancia del laúd para la teoría musical árabe.

A partir de 1980 será cuando aparezcan este tipo de estudios de forma más regular, contemplando la iconografía y arqueología desde una perspectiva musicológica. La revista Word Archaeology dedicará un número monográfico a la arqueomusicología bajo el título The archaeology of musical instruments. En este

\footnotetext{
76 Georges Vindry, "Présentation de L'épave árabe du Batéguier (Baie de Cannes, Provence Orientale)", Archéologie Médiévale. La Céramique Médiévale en Méditerranée Occidentale 584, 1976, $221-26$.

77 Jacinto Torres Mulas, "Los instrumentos de música en las miniaturas de las Cantigas de Santa María”, Bellas Artes 48, 1975, 25-29.

78 Jean Jenkins y Poul Rovsing Olsen, Music and musical instruments in the world of Islam. London: Horniman Museum, 1976.

79 Carlos García Benito y Raquel Jiménez Pasalodos, "La música enterrada: historiografía y metodología de la arqueología musical", Cuadernos de Etnomusicología, 2011.

${ }^{80}$ Amnon Shiloah, "The 'ud and the origin of music", Studia Orientalia, Memorae DH Baneth, 1979, 395-407.
} 
número publicado en 1981 participarán importantes investigadores, entre ellos Cajsa Lund con "The archaeomusicology of Scandinavia" 81 donde presenta su trabajo basado en la evidencia de música y sonido en la Escandinavia Prehistórica planteando métodos, problemas y ayudas metodológicas para desarrollar este tipo de investigaciones, o Tadeusz Malinowski con "Archaeology and musical instruments in Poland" 82 donde recalca la importante labor conjunta que deben llevar a cabo musicólogos y arqueólogos para estudiar la música de culturas antiguas.

En 1983 Rosselló Bordoy publicará "De nuevo los animales de juguete y otros aspectos de coroplastia andalusí" 83 donde presentará distintos instrumentos nazaríes que podrían ser interpretados como juguetes.

En 1984 se publica "Musical humour in the Kitab al-Aghani" 84 donde se estudia la Teoría del Ethos sobre el laúd oriental.

Posteriormente Rosario Álvarez trabajará con Rosselló Bordoy en un estudio sobre tres tambores andalusíes ${ }^{85}$, este artículo impulsaría la presencia de este tipo de investigaciones. No será la única en esta década de Rosario Álvarez, ya que también trabajará sobre la iconografía musical en los códices de Alfonso X El Sabio ${ }^{86}$ y la obra de los Beatos ${ }^{87}$. Reseñable también de Rosario Álvarez serán sus trabajos "Los instrumentos musicales de al-Andalus en la iconografía medieval cristiana” dentro del libro Música y Poesía al sur de al-Andalus ${ }^{88}$ e "Incidencias de una forma de trabajo en las representaciones de los instrumentos musicales: la copia de códices en la Edad Media"89. También durante los 80, el investigador marroquí Muhammad al-Tanyi y el arabista James T. Monroe editarán y traducirán dos capítulos del códice Tifashi bajo

\footnotetext{
81 Cajsa Lund, "The Archaeomusicology of Scandinavia", Word Archaeology 12, 3 (1981), 146-265.

82 Tadeusz Malinowski, “Archaeology and Musical Instruments in Poland”, World Archaeology 12, 3, 1981, 266-72.

${ }^{83}$ Guillermo Rosselló Bordoy, "De nuevo los animales de juguete y otros aspectos de coroplastia andalusí", Actas Del IV Coloquio Hispano-Tunecino. Palma de Mallorca: 1979, 205-12.

${ }^{84}$ George Dimitri Sawa, "Musical humour in the Kitab al-Aghani", Losod Islamikos: Studia Islamica in Honorem Georgii Michaelis Wickens, ed. Roger M. Savory and Dionisius Agius. Toronto: Pontificial Institute of Medieval Studies, 1984.

${ }^{85}$ Rosario Álvarez y Guillermo Rosselló Bordoy, "Hallazgo de tambores de la España islámica (Siglos IX-XIV)”, Revista de Musicología XII, n², 1989, 411-21.

86 Rosario Álvarez Martínez, "Los instrumentos musicales en los códices alfonsinos: su tipología, su uso y su origen. Algunos problemas iconográficos", Revista de Musicología X, n 1, 1987, 67-104.

${ }^{87}$ Rosario Álvarez Martínez, "La Iconografía Musical de los Beatos de los Siglos X y XI y su procedencia", Anuario del Departamento de Historia y Teoría Del Arte n 5, 1993, 201-18.

88 Rosario Álvarez Martínez, "Los instrumentos musicales de al-Andalus en la iconografía medieval cristiana”, en Música y Poesía del Sur de Al-Andalus. Granada-Sevilla: 1995, 93-124.

89 Rosario Álvarez Martínez, "Incidencia de una forma de trabajo en la representación de los instrumentos musicales: La copia de Códices en la Edad Media”, Nassarre XXIII, 1990, 53-70.
} 
la óptica histórica, literaria y musicológica. Gracias a estos trabajos salió a la luz la importancia de la taifa de Sevilla para la fabricación y exportación de instrumentos ${ }^{90}$. En 1980 Schéhérazade Qassim Hassan publicará Les instruments de musique en $I r a k^{91}$, donde la autora realiza una comparativa organológica e iconográfica con la antigua Mesopotamia.

En el año 1982 Reynaldo Fernández Manzano publicará "La música de alAndalus en su marco interdisciplinar: aspectos metodológicos" ${ }^{92}$ donde pondrá en valor el estudio sobre la música y los instrumentos musicales andalusíes a través de fuentes orales y escritas.

En el año 1985 Antonio Martín Moreno publicará un completo libro sobre la música en Andalucía titulado Historia de la Música Andaluza ${ }^{93}$. En este libro dedicará un capítulo a la música arábigo-andaluza donde realizará un análisis sobre lo trabajado hasta entonces por los investigadores sobre los tratadistas andalusíes.

Con el cambio de década, durante los 90, Mercedes Lillo realizará un artículo sobre la figura de los intérpretes musicales en los marfiles califales andalusíes ${ }^{94}$.

Faustino Porras dedicará un artículo a la Iconografia musical en la escultura hispanomusulmana ${ }^{95}$ donde realiza una breve descripción de las escenas con instrumentos musicales comentando sus orígenes y características, así como un estudio organológico. Manuela Cortés, asimismo, publicará Organología oriental de al-Andalus ${ }^{96}$, donde realizará un recorrido por los materiales iconográficos y arqueológicos. Por su parte Isabel Rubio de Miguel publicará un artículo sobre los instrumentos musicales en el Paleolítico y las técnicas para el estudio del

\footnotetext{
${ }^{90}$ Manuela Cortés García, La música árabe y andalusí de las dos orillas en los estudios musicológicos (ss. XVIII-XXI). Málaga: Ediciones Genal, 2018, 98.

91 Schéhérazade Qassim Hasan, Les instruments de musique en Irak et leur rôle dans la société traditionnelle. Editions de 1'Ecole des Hautes Etudes en Sciences Sociales, 1980.

92 Reynaldo Fernández Manzano, "La música de al-Andalus en su marco interdisciplinar. Aspectos metodológicos", Gazeta de Antropología 1, 1982.

93 Antonio Martín Moreno, Historia de la música andaluza. Granada: Biblioteca de la cultura andaluza. Vol. 13, 1985.

${ }^{94}$ Mercedes Lillo, "La figura del intérprete musical en los marfiles califales andalusíes", Cuadernos de Arte e Iconografía Tomo 6, nº, 1993, 143-50.

95 Faustino Porras Robles, "Iconografía Musical en la Escultura Hispanomusulmana", Nassarre: Revista Aragonesa de Musicología 25, no. 1, 2009, 39-56.

96 Manuela Cortés García, "Organología Oriental En Al-Andalus", Separata de: Boletín de La Asociación Española de Orientalistas, 1990, 303-32.
} 
correspondiente lenguaje musical ${ }^{97}$ dos años después de la publicación de este trabajo realizaría una ampliación del mismo ${ }^{98}$.

En 1993 el investigador Reynaldo Fernández Manzano publicará el artículo "Diversos aspectos sobre los cordófonos en al-Andalus y la etapa morisca" 99 no siendo el único que dedique durante su carrera a los instrumentos musicales ya que será uno de sus focos de atención a través de publicaciones como "Introducción al estudio de los instrumentos musicales de al-Andalus" 100 o "Instrumentos musicales en al-Andalus"101. De este mismo investigador es el libro Música de al-Andalus ${ }^{102}$, fruto de su tesis doctoral leída en 2012, donde dedica un capítulo a los instrumentos musicales.

Posteriormente, Reynaldo Fernández, Rosario Álvarez, Guillermo Rosselló y Manuela Cortes, en 1995 publicarán Música y poesía del sur de al-Andalus, catálogo de una exposición realizada en los Reales Alcázares de Sevilla ${ }^{103}$ con importantes trabajos que muestran las distintas perspectivas por las que se puede abordar la arqueomusicología.

Durante esta misma década, la revista Música Oral del Sur dedicaría un volumen monográfico a los instrumentos musicales populares en la península Ibérica, con artículos de Rosselló Bordoy104 "Instrumentos en barro cocido: una pervivencia medieval" donde trata campanas, silbatos y atabales; Espinar Moreno ${ }^{105}$ trabajará la distinta tipología y clasificación de silbatos estudiando su uso y presencia en las sociedades medievales y su evolución hasta la actualidad; $\mathrm{M}^{\mathrm{a}}$ Soledad Asensio e

\footnotetext{
${ }^{97}$ Isabel Rubio de Miguel, "Instrumentos musicales de la Prehistoria: El Paleolítico (I)", Boletín de la Asociación Española de Amigos de la Arqueología 29, 1990, 13-19.

98 Isabel Rubio de Miguel, "Instrumentos musicale de la Prehistoria: El Paleolítico (II)", Boletín de la Asociación Española de Amigos de la Arqueología 32, 1992, 2-11.

${ }^{99}$ Reynaldo Fernández Manzano, "Diversos aspectos sobre los cordófonos en al-Andalus y la etapa morisca", Revista de Musicología 16, 3, 1993, 1373-93.

100 Reynaldo Fernadez Manzano, "Introduccion al estudio de los instrumentos musicales de alAndalus", Cuadernos de Estudios Medievales y Ciencias y Técnicas Historiográficas 12.13, 1983, 4777.

${ }^{101}$ Reynaldo Fernández Manzano, "Instrumentos musicales en al-Andalus", El saber en al-Andalus Vol. 1, 1997, 101-36.

102 Reynaldo Fernández Manzano, Música de Al-Andalus. Granada: Universidad de Granada, 2016.

103 Reynaldo Fernández Manzano y Emilio de Santiago, Música y poesía del sur de al-Andalus. Granada: Fundación El Legado Andalusí, 1995.

104 Guillermo Rosselló Bordoy, "Instrumentos en barro cocido: una pervivencia medieval", Música Oral Del Sur 2, 1996, 28-51.

${ }^{105}$ Manuel Espinar Moreno, "Instrumentos Musicales de Barro: Silbatos Zoomorfos, Antropomorfos y Otros Vestigios Musicales”, Música Oral Del Sur: Revista Internacional 2, 1996, 63-84.
} 
Inmaculada Morales ${ }^{106}$, ambas investigadoras del Centro de Documentación Musical de Andalucía presentan el trabajo de campo realizado por distintos lugares de Andalucía desentrañando y mostrando la variedad y el actual uso y presencia de los silbatos. Este trabajo de campo realizado por Almería (Albox, Huebro Níjar y Topares), Cádiz (Conil y Jerez de la Frontera), Córdoba (Hinojosa del Duque y La Rambla), Granada (Cenes de la Vega, Cúllar, Guadix, Huéscar, Monachil, Nechite Válor-), Huelva (Rociana), Jaén (Andújar y Vilches), Málaga (Almáchar, Cómpeta y Tolox) y Sevilla (Lebrija y El Viso del Alcor), será publicado entre tres documentales de poco más de veinticinco minutos de duración cada uno de ellos: 1. El ritmo del barro $^{107}, 2$. Aire y Barro ${ }^{108}, 3$. Piel y Barro ${ }^{109}$.

En 1996 Manuela Cortés publicará el libro Pasado y presente de la música andalusi $^{110}$ en este trabajo dedicará un capítulo a los instrumentos musicales hispanomusulmanes a través de la iconografía musical y testimonios de algunos teóricos andalusíes.

En 1997 Javier Baena, Consolación Casarrubios e Isabel Rubio publicarán en la Revista de Musicología el artículo "Etnoarqueología y Música: Flautas y silbatos primitivos" $" 11$ donde defienden la importancia de los estudios arqueo-organológicos para "cubrir campos del pasado"112. En este mismo año Reynaldo Fernández publicará el artículo "Instrumentos musicales en al-Andalus"113. Este artículo aborda los cordófonos andalusíes prestando una especial atención al 'ud, asimismo trata la iconografía musical y los distintos instrumentos musicales, cercanos a la música académica por familias de instrumento. También Purificación Marinetto pondrá en valor los juguetes y silbatos infantiles de la época nazarí en un artículo que muestra

${ }^{106} \mathrm{M}^{\mathrm{a}}$ Soledad Asensio y Inmaculada Morales, "Instrumentos musicales de barro cocido en Andalucía (I). Aerófonos", Música Oral Del Sur 2, 1996, 85-186.

107 Reynaldo Fernández Manzano, Ma Soledad Asensión Cañadas e Inmaculada Morales Jiménez, Instrumentos musicales de barro en Andalucía. El Ritmo Del Barro (I). Andalucía, 1991-1993, https://www.youtube.com/watch?v=9sUwaWidDZY, (Última consulta: 12-10-2019).

${ }^{108}$ Reynaldo Fernández Manzano, Ma Soledad Asensión Cañadas e Inmaculada Morales Jiménez, Instrumentos musicales de barro en Andalucía. Aire y Barro (II). Andalucía, 1991-1993, https://www.youtube.com/watch?v=foBFc3XY-ak\&t=22s, (Última consulta: 12-10-2019).

109 Reynaldo Fernández Manzano, Ma Soledad Asensio Cañadas e Inmaculada Morales Jiménez, Instrumentos musicales de barro en Andalucía. Piel y Barro (III). Andalucía, 1991-1993, https://www.youtube.com/watch?v=jmVLybsC5zQ, (Última consulta: 12-10-2019).

${ }^{110}$ Manuela Cortés García, Pasado y presente de la música andalusí. Sevilla: El Monte, 1996, 59-69.

111 Javier Baena, Consolación Casarrubios e Isabel Rubio de Miguel, "Etnoarqueología y Música: Flautas y Silbatos Primitivos”, Separata de Revista de Musicología XX, 2, 1997, 867-74.

112 Ibidem, 867.

113 Reynaldo Fernández Manzano, "Instrumentos musicales en al-Andalus”, El saber en al-Andalus Vol. 1, 1997, 101-36. 
gran variedad encontrada hasta la fecha, 1997, incluyendo dibujos de los mismos ${ }^{114}$. En este mismo año Christian Poché publicará la segunda edición de su libro La música arábigo-española ${ }^{115}$, este interesante libro vendrá acompañado por un cd de música mostrando su enfoque pedagógico. Contará, asimismo, con dibujos de instrumentos musicales y fotografías de intérpretes. En este mismo año se dará lugar el IV Congreso de la Sociedad Española de Musicología en el que participará Rosario Álvarez con "Iconografía musical y organología: un estado de la cuestión"116, en este trabajo defiende la importancia de la interdisciplinariedad para abordar de forma satisfactoria este tipo de investigaciones. La arqueomusicología se ve recogida igualmente.

En 1998 Hassan Habib Touma publicará La música de los árabes ${ }^{117}$, en este trabajo se tratan los aspectos historiográficos de la música árabe oriental incluyendo un capítulo, el número seis, para el estudio de los instrumentos musicales.

Muy importante será el catálogo publicado por la organóloga Cristina Bordas sobre colecciones de instrumentos musicales en museos estatales donde además incluirá varios silbatos de la época ${ }^{118}$. Este libro será publicado en dos volúmenes saliendo el segundo en $2001^{119}$. Esta obra supone un gran avance en el conocimiento de colecciones de instrumentos musicales que no estaban al alcance del público, así como una gran aportación para la catalogación de este tipo de colección.

Al borde del cambio de siglo, Catherine Homo-Lechner y Christian Rault publican la obra Instruments de musique du Maroc et d'al-Andalus donde realizan una comparativa entre los instrumentos conservados en el Magreb y los dados en la

\footnotetext{
114 Purificación Marinetto Sánchez, "Juguetes y silbatos infantiles de época nazarí”, MEAH, Sección árabe-islam 46, 1997, 183-205.

115 Christian Poché, La música arábigo-andaluza. Ediciones Akal, 1997.

116 Rosario Álvarez Martínez, "Iconografía Musical y Organología: Un estado de la cuestión”, Revista de Musicología, ejemplar dedicado al IV Congreso de La Sociedad Española de Musicología. La Investigación Musical en España. Madrid: 1997, 767-82.

${ }^{117}$ Habib Hassan Touma, La música de los árabes. Junta de Andalucía: Editorial Alpuerto, 1998.

118 Cristina Bordas Ibáñez, Instrumentos musicales en colecciones españolas: museos de titularidad estatal, Ministerio de Educación y Cultura (Vol. 1). Madrid: Centro de Documentación de Música y Danza. INAEM, 1999, 68-77 y 87-88.

${ }^{119}$ Cristina Bordas Ibáñez, Instrumentos musicales en colecciones españolas: museos de titularidad estatal (Vol. II). Madrid: Centro de Documentación de Música y Danza. INAEM, 1999, 48-56 y 59-61.
} 
Península Ibérica ${ }^{120}$. Asimismo, el músico Omar Metiuio publica un artículo sobre instrumentos musicales andalusíes y magrebíes con numerosas imágenes ${ }^{121}$.

En 1999 será traducida una de las obras de Mahmud Guettat de la mano de Manuela Cortés García y $\mathrm{M}^{\mathrm{a}}$ del Mar Carrillo La música andalusí en el Magreb: Simbiosis musical entre las dos orillas del Mediterráneo ${ }^{122}$, donde dedica una parte de este trabajo a los instrumentos y la iconografía musicales. Realiza un cuadro donde compila todos los instrumentos musicales de forma clasificada ${ }^{123}$.

\subsubsection{Siglo XXI}

Con este cambio de siglo es notable la gran cantidad de trabajos referente a esta temática que se irán sucediendo gracias a la continua labor investigadora de mano de afianzados expertos como los hasta aquí mencionados, y la presencia de nuevas generaciones que se adhieren a esta inquietud.

Uno de los trabajos que más aportaciones ha realizado a la comprensión de un campo en español será el realizado por Rafael Pérez Arroyo bajo el título La música en la era de las pirámides ${ }^{124}$, sobre la arqueomusicología egipcia y la reconstrucción de la historia de la música. En él su autor profundiza en la cultura faraónica y las evidencias teórico-prácticas que han llegado hasta nuestros días, al mismo tiempo que comprueba la vigencia de un gran número de instrumentos egipcios que permanecen en las culturas actuales del área mediterránea. Rosselló Bordoy continuará poniendo en valor los instrumentos musicales medievales encontrados en excavaciones arqueológicas fundamentando su gran presencia en la vida cotidiana andalusí mediante la obra El ajuar de las casas andalusíes, donde dedicará un capítulo completo a los instrumentos musicales ${ }^{125}$. Laura Hortelano publicará en el año 2000 el artículo "Un pito procedente de Ibiza en el Museo de Prehistoria de Valencia"126,

\footnotetext{
${ }^{120}$ Catherine Homo-Lechner y Christian Rault, Instruments de musique du Maroc et d'al-Andalus. París: Fondation Royaumont-CERIMM, 1999.

121 Omar Metioui, "Historia y evolución del instrumentarium andalusí-magrebí", al-Andalus y el norte de Africa: Relaciones e Influencias, ed. Pablo Beneito y Fátima Roldán. Sevilla: Fundación El Monte, 2004, 111-51.

122 Mahmoud Guettat, La música andalusí en el Magreb. Simbiosis musical entre las dos orillas del Mediterráneo. Sevilla: Fundación El Monte, 1999.

123 Ibidem, 37.

${ }^{124}$ Rafael Pérez Arroyo, La música en la era de las pirámides. Centro de Estudios Egipcios, 2001.

125 Guillermo Rosselló Bordoy, El ajuar de las casas andalusíes. Málaga: Sarriá, 2002, 89-103.

${ }^{126}$ Laura Hortelano Piqueras, "Un pito procedente de Ibiza en el Museo de Prehistoria de Valencia", SAGVNTVM. Papeles del Laboratorio de Arqueología de Valencia 32, 2000, 191-94.
} 
siendo este parte de su posterior trabajo final del tercer grado titulado Arqueomusicología: bases para el estudio de los artefactos sonoros prehistóricos ${ }^{127}$, con el que realiza una gran aportación a este tipo de estudios desde el punto de vista metodológico. Del año 2001 será también el trabajo publicado por $\mathrm{M}^{\mathrm{a}}$ Carmen Gómez Muntané, La música medieval en España ${ }^{128}$ cuyo VII volumen está dedicado a la música en al-Andalus y los instrumentos musicales La música de al-Andalus.

También durante el 2001 Alberto García Porras publicará su estudio relazado sobre las piezas encontradas en "El Castillejo" de los Guájares, entre estas un tambor ${ }^{129}$.

En el año 2004 se realizará la primera publicación tras el hallazgo del "Vaso de Tavira", el primero de ellos fue $O$ vaso de Tavira: Uma proposta de interpretaçao ${ }^{130}$ realizado por Claudio Torres. El siguiente sobre esta misma pieza será el realizado por Campos Paulo en $2007^{131}$ ambos pondrán en valor la pieza visibilizando la perspectiva arqueomusicológica.

Artículos como "Musical vultures in the Iberian Peninsula: sounds through their wings" ${ }^{132}$, "Evidencias arqueológicas y etnográficas de instrumentos musicales elaborados en un hueso del ala de buitre" ${ }^{133} \mathrm{o}$ "Comentarios arqueo-zoológicos sobre el aerófono de la Necrópolis de Afligidos, Villa romana del Val (Alcalá de Henares, Madrid)"134, de Carlos Pimienta y Marta Moreno-García, junto con Mario Gros, en el caso del primer artículo citado, ponen en valor desde una perspectiva práctica la

${ }^{127}$ Laura Hortelano Piqueras, "Arqueomusicología: bases para el estudio de los artefactos sonoros Prehistóricos". Trabajo de investigación para tercer ciclo, Universitat de Valencia, 2003.

${ }_{128} \mathrm{M}^{\mathrm{a}}$ del Carmen Muntané, La música medieval en España (Edition Reichenberger, 2001).

129 Alberto García Porras, La cerámica del poblado fortificado medieval de "El Castillejo" (Los Guájares, Granada). Athos-Pérgamos, 2001.

130 Claudio Torres, "O Vaso de Tavira: uma roposta de interpretaçao", Campo Arqueológico de Mértola, 2004.

131 Luís Campos Paulo, "O simbolismo da purificaçao. O 'Vaso de Tavira': Iconografia e interpretaçao", Revista Portuguesa de Arqueología 10, 2007, 289-316.

132 Marta García Moreno, Carlos M. Pimienta y Mario Gros, "Musical vultures in the iberian peninsula: sounds through their wings", en Fathers, grit and symbolism. Birds and humans in the ancient old and new worlds. Proceedings of the 5th Meeting of the ICAZ Bird Working Group in Munich, Verlag Marie Leidorf, Rahden/Westf, ed. J. (eds.) Grupe G., Peters. Munich: Documenta Archaeobiologiae, 2005, 327-45.

${ }^{133}$ Marta Moreno y Carlos M. Pimienta, "Evidencias arqueológicas y etnográficas de instrumentos musicales elaborados en un hueso del ala de buitre", Revista de Estudios Mirobrigenses II, 2007, 237 54.

${ }^{134}$ Marta Moreno y Carlos M. Pimienta, "Comentarios arqueo-zoológicos sobre el aerófono de la necrópolis de Afligidos, Villa Romana del Val (Alcalá de Henares, Madrid)", La Investigación Arqueológica de la época Visigoda en la Comunidad de Madrid. III. La Cultura Material, 2006, 796803. 
importante inclusión arqueozoológica en este tipo de estudios ya que pueden arrojar mayor información acerca de las piezas origen y uso de las mismas llegando a contribuir al esclarecimiento sobre si un objeto pudo tener la función de instrumento musical.

En 2006, la iconografía hispanomusulmana y cristiana será estudiada por investigadores como Mauricio Molina, quien publicará Frame drums in the Medieval Iberian Peninsula ${ }^{135}$ y "Tympanistria nostra: la reconstrucción del contexto y la práctica musical de las pandereteras y aduferas medievales a través de sus representaciones en el arte románico español" ${ }^{136}$ reflejando el uso de estos instrumentos de percusión enlazados con el papel de la mujer en la música.

En diciembre del 2008 el British Museum realizó un congreso internacional titulado Near Easten Archaeomusicology. Este congreso parte del International Council of Middel Eastern Archaeomusicology (ICONEA) ${ }^{137}$, plataforma que sirve de contacto entre estudiantes e investigadores que pueden compartir libremente trabajos, videos, fotos o información acerca de esta temática arqueomusicológica. Siendo este su primer congreso se repetiría de forma anual de los que irán publicando las actas ${ }^{138}$.

Posteriormente, en 2009, se publicará un artículo con una innovadora metodología de estudio de piezas, los exámenes arqueométricos, realizados a una pieza catalogada como flauta almohade encontrada en Sevilla ${ }^{139}$. Este estudio intentaba saber si los orificios de esta pieza pudieron ser tapados con cera para su interpretación, por desgracia esta hipótesis no se consiguió resolver.

En el área de la iconografía musical, en el año 2008 y 2009 Faustino Porras realizará dos publicaciones de gran valor para el estudio de la cultura hispanomusulmana, el primero de ellos fue "Iconografía musical en la escultura hispano

\footnotetext{
135 Mauricio Molina, Frame drums in the medieval Iberian Peninsula. Nueva York: University of New York, 2006.

136 Mauricio Molina, “Tympanistria Nostra: La reconstrucción del contexto y la práctica musical de las pandereteras y aduferas medievales a través de sus representaciones en el arte románico español", Cuadernos de Investigación del Monasterio de Santa María La Real 26, 2010, 77-103.

137 “International Council of Middel Eastern Archaeomusicology (ICONEA)", http://www.iconea.org/ (Última consulta: 20-10-2019).

138 Richard Dumbrill y Irving Finkel, eds., Proceedings of the Internacional Conference of Near Easten Archaeomusicology. London: ICONEA publications, 2010.

139 Mark A Hunt Ortíz et al., "Examen arqueométrico de un objeto de hueso decorado de época Almohade (Siglo XIII d. C.) Procedente de la excavación arqueológica de la calle San Fernándo, Sevilla”, en VIII Congreso Ibérico de Arqueometría, 2009, 165-74.
} 
musulmana" ${ }^{140}$ y el segundo "Los instrumentos musicales en la poesía castellana medieval: Enumeración y descripción organológica"141. Siguiendo esta línea sobre iconografía musical, posteriormente serán los artículos de Manuela Cortés, “Tratados musicales andalusíes de la Escuela Levantina y aportaciones al marco interdisciplinar" ${ }^{142}$, un capítulo del libro La música en la Zaragoza islámica, titulado “Apuntes sobre iconografía y arqueología musical" ${ }^{143}$ y el artículo "Estatus de la mujer en la cultura islámica: las esclavas cantoras (ss. XI-XIX)"144 los que trabajen y contextualicen la iconografía musical andalusí. No centrando la atención solo por la parte iconográfica en los dos últimos trabajos mencionados realizados por Manuela Cortés, resultan una gran fuente de información el primero, La música en la Zaragoza islámica, excepcional para conocimiento de los tratadistas y escuelas de músicas andalusíes y el segundo "Estatus de la mujer en la cultura islámica" por el valioso estudio de la mujer en la música. En 2009 Raquel Jiménez publicará el artículo “Arqueología musical y etnomusicología por una interpretación etnomusicológica de los materiales arqueológicos"145 en el que relaciona la evolución de la arqueología y la etnomusicología hasta llegar a unificarse con la arqueología musical.

En 2009 se publicará "Fretagge du 'ud (luth arabe) dans la théorie musicale árabe et influence sur la practique" ${ }^{146}$ donde Amine Beyhom y Hamdi Makhlouf realizarán un análisis comparativo sobre este instrumento en los tratados de al-Kindi, Alfarabi, Ibn Tahhan, Avicena, al-Urmawi, Ibn Zayla, al-Ladhiqi y al-Shirwani (ss.IX-XV) e incluye iconografía del instrumento ${ }^{147}$.

\footnotetext{
140 Faustino Porras Robles, "Iconografía musical en la escultura hispanomusulmana", Nassarre: Revista aragonesa de musicología, 25, 2009, 39-56.

141 Faustino Porras Robles, "Los instrumentos musicales en la poesía castellana medieval: enumeración y descripción organológica", Lemir: Revista de Literatura Española Medieval y del Renacimiento 12, 2008, 113-36.

142 Manuela Cortés García, "Tratados Musicales Andalusíes de la Escuela Levantina y Aportaciones al Marco Interdisciplinar (ss. XI-XIII)", ITAMAR. Revista de Investigación Musical: Territorios para el Arte 1, no. Facultad de Filosofía y Ciencias de la Educación. Universitat de València, 2008, 178-202.

${ }^{143}$ Manuela Cortés García, La música en la Zaragoza islámica. Zaragoza: Instituto de Estudios Islámicos y del Oriente Próximo, 2009.

${ }^{144}$ Manuela Cortés García, "Estatus de la mujer en la cultura islámica. Las esclavas-cantoras (ss.IXXIX)", Mujer versus Música. Colección Feminismo Musical. Editorial Rivera Mota, 2011, 139-98.

145 Raquel Jiménez Pasalodos, "Arqueología musical y etnomusicología: por una interpretación etnomusicológica de los materiales arqueológicos", Etno-Folk: revista galega de etnomusicoloxía, $\mathrm{n}^{\circ}$. 14-15, 2009, 637-654.

146 Amine Beyhom y Hamdi Makhlouf, "Frettage du 'ud (luth arabe) dans la théorie musicale árabe et influence sur la pratique", Congres Interdisciplinaire de Musique (CIM). París: 2009.

147 Manuela Cortés García, La música árabe y andalusí de las dos orillas en los estudios musicológicos (ss. XVIII-XXI). Málaga: Ediciones Genal, 2018, 155.
} 
En 2011, Francisco de Asís Escudero en su artículo "Los tambores musulmanes del alfar de la Calle San Pablo" se hará eco del importante hallazgo de alrededor de medio centenar de tambores junto a sus alfares de producción en Zaragoza $^{148}$. En este mismo año Juan Gallardo, $\mathrm{M}^{\mathrm{a}}$ Dolores Párraga, Ana Llorach y Pedro Pérez publicarán el artículo "Un conjunto de silbatos y figurillas de época moderna del alfar de avenida Santa Clara (Lorca, Murcia)"149 dando a conocer unos silbatos, mediante una detallada descripción de cada uno de ellos, aparecidos en dicha dirección pertenecientes a los siglos XVII-XIX. Incluido en este 2011, Raquel Jiménez y Carlos García publicarán el interesante y novedoso artículo, ya que escasamente se había tratado la temática en castellano, "La música enterrada: Historiografía y Metodología de la Arqueología Musical"150. Este artículo pretende dar a conocer la arqueomusicología así como mostrar su interdisciplinariedad y su correspondiente metodología de trabajo. Esta misma temática fue tratada por ambos investigadores en las IV Jornadas de Jovens em Investigação Arqueológica de las cuales se publicaron las actas siendo la aportación de éstos titulada "Archaeoacoustics, Experimental Archaeology and Music: Theoretical and Methodological Challenges In Music Archaeological Research" ${ }^{151}$. En este mismo encuentro Raquel Jiménez, esta vez en solitario presentará “A "phenomenology of soundscape": archaeoacoustics, landscapes and environment in Music Archaeology"152 donde relacionará el enfoque fenomenológico de la arqueología de la música con nuevas teorías etnomusicológicas como la "Etnomusicología Ambiental", la "Eco Musicología" o las teorías propuestas por Martin Clayton.

Otro avance metodológico dará esta nueva rama de la mano del investigador Jesús Salius, quien realizará y publicará posteriormente su tesis doctoral sobre la

\footnotetext{
148 Francisco Escudero, "Los tambores musulmanes del alfar de la Calle San Pablo", Saldvie: Estudios de Prehistoria y Arqueología, no. 11, 2012, 147-74.

149 Juan Gallardo Carrillo et al., "Un conjunto de silbatos y figurillas de época moderna del alfar de Avenida Santa Clara (Lorca, Murcia)", Alberca 9, 2011, 135-61.

150 Carlos García Benito y Raquel Jiménez Pasalodos, "La música enterrada: historiografía y metodología de la arqueología musical”, 2011, 80-108.

${ }^{151}$ Carlos García Benito y Raquel Jiménez Pasalodos, "Archaeoacoustics, experimental archaeology and music: theoretical and methodological challenges in music archaeological research", IV Jornadas de Jovens Em Investigação Arqueológica, 2011, 409-10.

152 Raquel Jiménez Pasalodos, “A 'Phenomenology of Soundscape': archaeoacoustics, landscapes and environment in music archaeology", IV Jornadas de jovens en investigaçao arqueológica, ed. J. Cascalheira y C. Gonçalves. Promotoria Monografica, 2011, 443-46.
} 
etnoarqueomusicología ${ }^{153}$, en este trabajo procura seguir poniendo en valor, como años antes ya habían propuesto otros investigadores más cercanos a la óptica antropológica, la perspectiva etnomusicológica para un completo estudio de una cultura antigua.

En cuanto a la catalogación de las piezas localizadas en el área peninsular, existen trabajos previos que sirven de guía para el estudio de los instrumentos musicales en los museos españoles. Entre ellos, los ya mencionados de Cristina Bordas Ibáñez sobre Instrumentos musicales en colecciones españolas o el trabajo coordinado por Guillermo Rosselló y Ana Dolores Navarro Ortega titulado Del Rito al Juego: Juguetes y silbatos de cerámica desde el Islam hasta la actualidad ${ }^{154} \mathrm{y}$ el último trabajo publicado por el Centro de Documentación de Música y Danza Colecciones de instrumentos musicales. Recomendaciones para su gestión ${ }^{155}$, este libro blanco supone un gran avance tanto para la catalogación, como para el estudio y conservación de los instrumentos musicales.

En 2012 serán dos los artículos que se publicarán sobre la arqueomusicología en al-Andalus, en este caso los protagonistas serán los membranófonos. El primer artículo realizado por Raquel Jiménez y Alexandra Bill se realizará un listado de tambores encontrados en la Península Ibérica perteneciente a esta época, serán unos cincuenta los mencionados en esta publicación ${ }^{156}$. El segundo artículo lo realizarán Carlos García Benito, Raquel Jiménez Pasadolos y Alexandra Bill los cuales realizarán una interesante clasificación de tambores según la forma de las copas ${ }^{157}$.

De un año posterior se encontrarán en la página web de Basilio Pavón Maldonado artículos inéditos realizados por este doctor en arte y arqueología musulmana. Perteneciente a 2013 y titulado Iconografía hispanomusulma (matizaciones y connotaciones): Naturalismo, fauna y árbol de la vida, este trabajo compila una gran cantidad de menciones a distinta iconografía incluyendo el estudio

\footnotetext{
153 Jesús Salius, Etnoarqueomusicología. La producción de sonidos y la reproducción social en las sociedades cazadoras-recolectoras. Consejo Superior de Investigaciones Científicas (CSIC), 2015.

${ }^{154}$ Guillermo Rosselló Bordoy, Navarro Ortega, A., Flores Escobosa, Del rito al juego: juguetes y silbatos de cerámica desde el islam hasta la actualidad. Junta de Andalucía: 2006.

${ }^{155}$ Cristina Bordas y Elena Vázquez, Colecciones de instrumentos musicales. Recomendaciones para su gestión. Madrid: Centro de Documentación de las Artes Escénicas y la Música. INAEM, 2019.

${ }^{156}$ Raquel Jiménez Pasalodos y Alexandra Hill, "Los tambores de cerámica de al-Andalus (ss. VIIIXIV): Una aproximación desde la arqueología musical”, Nassarre, 2012.

157 Alexandra Bill, Raquel Jiménez Pasalodos y Carlos García Benito, "A Clasiffication of Clay Drums from Al-Andalus (9th-14th Centuries AD)", en Proceedings of the 16th Symposium on Mediterranean Archaeology, vol. II, 2012, 893-94.
} 
de la botella de los músicos o la arqueta de Leyre, entre otros ${ }^{158}$. Durante este 2013, el Study Group on Music Archaeology del ICTM publicará el libro Music and Ritual ${ }^{159}$ en el que participarán los investigadores más reconocidos e internacionales que trabajan la arqueomusicología. Como representante española participa la arqueóloga y musicóloga Raquel Jiménez quien realiza la introducción del libro con el capítulo "Ritual music and archaeology: problems and perspectives" ${ }^{160}$, en él trata la importancia de la música para la identidad cultural individual o colectiva. Este mismo año, 2013, Juan Jesús Padilla, Raquel Jiménez, Carlos García y Linda Chapon publicarán "La cadena técnico-operativa del Alarde las Cogotas (Cardeñosa, Ávila): la construcción experimental de un horno cerámico de la II Edad del Hierro"161, en esta investigación realizan un estudio de la función social del propio alfarero, un área especializada de trescientos metros cuadrados, de época prerromana. Asimismo, realizan una reproducción experimental de este horno en Bailén, Jaén. En este mismo año publicaron las cocciones experimentales para reproducir trompas numantinas ${ }^{162}$.

En el año 2014 John Schofiel publicará "The archaeology of sound and music"163 este trabajo da por hecho la importancia de la organología para el estudio de las músicas en culturas pasadas, pero plantea un paso más en este tipo de investigaciones al preguntarse por la idoneidad de los espacios donde podrían ser interpretados los instrumentos musicales, evaluando su contexto y el sonido final esperado. Este artículo se encuentra directamente relacionado por el proyecto internacional llevado a cabo por Raquel Jiménez y Carlos García European Music Archaeology Project (EMAP) el cual se plantea estudiar las antiguas raíces de la

\footnotetext{
158 Basilio Pavón Maldonado, "Iconografia hispanomusulmana: naturalismo, fauna y árbol de la vida" http://www.basiliopavonmaldonado.es/Documentos/icohispa.pdf (Última consulta: 29-07-2019).

${ }^{159}$ Raquel Jiménez Pasalodos, Rupert Till y Mark Howell, eds., Music and Ritual. Bridging Material And Living Cultures. Publications of the ICTM Study Group on Music Archaeology Vol. 1, 2013.

${ }^{160}$ Raquel Jimenez Pasalodos, "Introduction to the Volume. Ritual Music and Archaeology: Problems and Perspectives", en Music and Ritual. Bridging Material and Living Cultures, ed. Ekho Verlag. Berlín: Publications of the ICTM Study Group on Music Archaeology Vol. 1, 2013, 17-23.

161 Juan Jesús Padilla et al., "La cadena técnico-operativa del Alarde las Cogotas (Cardeñosa, Ávila): La construcción experimental de un horno cerámico de la II Edad del Hierro", Sèrie Monogràfica del MAC-Girona 25, 2, 2013, 467-75.

162 Raquel Jiménez Pasalodos y Juan Jesús Padilla, "Las trompas numantinas: aproximación a su estudio acústico en una cocción experimental con una reproducción de un horno de la Edad del Hierro", 3er Congreso Internacional de Arqueología Experimental. Girona: 2013, 387-95; Carlos García Benito, Raquel Jiménez Pasalodos y Juan Jesús Padilla Fernández, "The clay rattles of the Numantine Museum of Soria (Spain). An approach from experimental archaeology", 8th Symposium of the International Study Group on Music Archaeology in Suzhou and Beijing. China: 2012, 47-63.

${ }^{163}$ Raquel Jimenez Pasalodos, "Introduction to the Volume. Ritual Music and Archaeology: Problems and Perspectives", en Music and Ritual. Bridging Material and Living Cultures, ed. Ekho Verlag. Berlín: Publications of the ICTM Study Group on Music Archaeology Vol. 1, 2013, 17-23.
} 
cultura europea desde un punto de vista musical, científico y sensorial ${ }^{164}$. Este interesante proyecto concluirá con la realización de una exposición itinerante titulada “ArqueoMúsica. ¡Así sonaba la Europa Antigua!” expuesta en Valladolid en el Museo de la Ciencia del 7 de febrero al 21 de mayo de 2017. No será esta la única exposición itinerante que llegue a España sobre arqueomusicología ya que del 9 de junio al 16 de septiembre de 2018 CaixaForum de Madrid ofrecerá la exposición "Música en la Antigüedad" donde se reunirán 373 piezas de distintos lugares como son el Musée $d u$ Louvre, unas veinte instituciones internacionales, entre ellas el Metropolitan Museum de Nueva York, los Musei Capitolini de Roma y el Museo Nacional de Atenas ${ }^{165}$.

Durante el 2018 Raquel Jiménez y Carlos García publicarán el artículo "Modelando Sonidos: instrumentos musicales de barro en los museos españoles. Una aproximación desde la Etnoarqueología, Etnomusicología y la Arqueología Experimental"166 dentro de un monográfico que realiza la revista Menga, Revista de Prehistoria de Andalucía a la cerámica titulado Algo más que galbos y cacharros. Etnoarqueología y experimentación cerámica. En este artículo presentan la Asociación para el Estudio Experimental de la Cerámica Arqueológica (AEECA) donde realizan reproducciones de instrumentos musicales con el fin de su estudio completo. Asimismo comentan que hasta ahora han sido 569 los restos arqueomusicales recopilados de barro y los presentan de forma cronológica y catalogados según sus características.

En 2019 Manuela Cortés publicará el artículo Músicas en la Andalucía islámica $^{167}$ donde pondrá en valor la perspectiva arqueomusicológica para la documentación histórica.

\subsubsection{Diccionarios y enciclopedias}

Aparte de las fuentes comentadas hasta este punto existen varios diccionarios claves para esta investigación, los cuales a continuación serán presentados

\footnotetext{
164 John Schofield, "The Archaeology of Sound and Music", World Archaeology 46, 3 (2014), 289-91.

165 Aa.vv, Músicas en la Antigüedad. Madrid: Obra Social "la Caixa", 2018.

166 Raquel Jimenez Pasalodos, Carlos García Benito y Juan Jesús Padilla Fernández, "Modelando sonidos: instrumentos musicales de Barro en los museos españoles. Una aproximación desde la etnoarqueología, etnomusicología y la arqueología experimental”, MENGA. Revista de Prehistoria de Andalucia, 2018, 615-34.

${ }^{167}$ Manuela Cortés García, "La Música en la Andalucía Islámica," Andalucia en la Historia, 2019, 8 12.
} 
apareciendo de forma cronológica. En los casos en los que las fechas de publicación coincidan serán organizados alfabéticamente según sus títulos:

Encyclopaedia of Islam (EI), 1913-1935 168

Esta enciclopedia de estudios islámicos, que ya va por la tercera edición, se publicó por primera vez entre 1913 y 1938. Este trabajo incluye artículos sobre musulmanes reconocidos de distintas edades y lugares, así como "tribus" y dinastías. También abarca temas políticos y religiosos o de artesanía y ciencia, así como geografía, etnografía, flora y fauna. Los territorios que incluye son los araboislámicos, países islámicos de Irán, Asia Central y subcontinente indio e Indonesia junto al Imperio Otomano, entre otros. Todos ellos son tratados desde el punto de vista histórico, topográfico y a través de sus monumentos, pueblos y ciudades. Igualmente, incluye sabios y personajes históricos relevantes. En esta enciclopedia se pueden consultar términos musicales y organológicos organizados de forma alfabética. Cuenta con una entrada sobre la "Música Andalusí" realizada por Jonathan H. Shannon donde menciona instrumentos como el ud, duff, rebab, buq, nafir o nai. La definición de terminología específica de instrumentos musicales viene explicada por reconocidos investigadores como Anne H. van Oostrum con el barbat, Henry George Farmer en el caso del duff y el mi'zaf, J.-Cl. Chabrier con el 'ud, Christian Poché presentando al músico Munir Bachir (1930-1997), Miriam Rovsing Olsen con la "Música Bereber" o George Dimitri Sawa con la "Música Abasí". Actualmente existe una versión online ${ }^{169}$ que resume los conceptos explicados en la publicación en papel. En este recurso web, basado en la tercera edición de la enciclopedia, aparecen nuevas referencias a instrumentos musicales que no se veían en versiones anteriores como es el caso del barbat, cuya entrada remitía a la explicación del 'ud en la primera edición.

Los instrumentos musicales en el mundo, 1980 (edición 2008) ${ }^{170}$

Este referente para el estudio organológico resulta una de las fuentes esenciales de consulta para este fin. Partiendo de términos genéricos aborda el estudio de los

\footnotetext{
168 M. Th Houtsma et al., eds., Encyclopaedia of Islam (Rowman \& Littlefield, 1913-1935).

169 “Encyclopaedia of Islam" https://referenceworks.brillonline.com/browse/encyclopaedia-of-islam-3 (Última consulta 26-01-2020).

${ }^{170}$ François-René Tranchefort, Los Instrumentos Musicales en el Mundo. Madrid: Alianza Musical, 2008.
} 
instrumentos sin barreras geográficas o temporales. El índice analítico detalla la gran cantidad de términos tratados que pueden encontrarse a lo largo del libro organizados por su clasificación, la cual es explicada mostrando las peculiaridades de cada una y su evolución. Los epígrafes que utiliza, por lo tanto, para abordar el estudio de los instrumentos son: percusión, cuerda, viento, eléctricos y electrónicos e instrumentos mecánicos y automáticos. Como último capítulo incluye las principales formaciones instrumentales en todo el mundo y como anexo, la inclusión de colecciones discográficas, así como bibliográficas de referencia. A lo largo del trabajo, Tranchefort parte de nombres genéricos de instrumentos musicales, como por ejemplo "Flauta" y va presentando la variedad existente en los distintos puntos geográficos y su evolución a través del tiempo. Con esta perspectiva, permite ver la relación entre los mismos y sus características particulares.

Para esta investigación resultó especialmente importante los epígrafes de los instrumentos árabes que este autor muestra, en ellos se pueden encontrar referencias al recorrido de los mismos desde Oriente a al-Andalus. Este autor recoge tanto anécdotas de los orígenes de los instrumentos, así como descripciones, dibujos de algunos de ellos, y modos de interpretación. Entre los tratados se encuentran: alghaita, bendir, daff, darabukka, nai, naqqara, qanun, rabab, riq, tabl, ud y zorna.

\section{An annotated Glossary of Arabian Musical Terms, $1981^{171}$}

Este libro recoge términos musicales que organiza de forma alfabética acompañados por una definición y aclaración sobre los numerosos vocablos que se utilizan para denominar, en este caso, un instrumento musical. Este libro enfocado para estudiantes e investigadores del campo de la música resulta especialmente aclaratorio al relacionar directamente los términos árabes con los académicos incluyendo una breve explicación sobre los mismos. Sobre organología cuenta con una amplia variedad de definiciones de términos, así como entradas genéricas como Aerophone, Bowed Chordophones, Chordophones, Woodwind instrumet, Drum, Flutes, Kettledrum u Oboe.

\footnotetext{
${ }^{171}$ Lois Ibsen Faruqi, An Annotated Glossary of Arabic Musical Term. United States of America: Greenwood Press, 1981.
} 
Encyclopédie berbère, 1984

Enciclopedia publicada con la asistencia del Consejo Internacional de Filosofía y Ciencias Humanas (UNESCO) y editada por Edisud en Francia. Su primer editor fue Gabriel Camps quien fue relevado tras su muerte por Salem Chaker en 2002. La enciclopedia cuenta con 1283 registros repartidos en varios volúmenes que se suceden por orden alfabético. Contiene tanto definiciones de términos específicos como la definición de objetos, así como conceptos generales, como la contextualización de una época o cultura o amplios conceptos como por ejemplo la alimentación. Actualmente la enciclopedia puede consultarse de forma online a través de su página oficial ${ }^{172}$. La búsqueda de conceptos se puede realizar a través de los autores que lo han escrito o mediante palabras clave, contando con los epígrafes como "música" y "musicología". Asimismo se encuentra en proceso de ampliación ya que aún no cuenta con las palabras que empiezan por las letras: "Q", "U”, "W", "X" e "Y". En este trabajo puede hallarse referencias a al-Andalus, realizada por J. Taieb y sobre términos como darbuka, escrito por C. El Briga con una explicación, dibujo y bibliografía sobre el instrumento. Toda esta documentación está disponible para libre descarga.

New Grove Dictionary of music an musicians, $2001^{173}$

La primera edición de este reconocido trabajo se publicó en 1980. Este diccionario de referencia para cualquier investigación musical existe en versión papel y se puede consultar de forma online. Incluye las épocas, compositores con sus obras, géneros musicales, instrumentos y músicos. Los autores de cada una de las entradas son especialistas reconocidos en la temática tratada. La recopilación de todos los instrumentos musicales incluidos en estos volúmenes se compila formando, en 1984, The Grove Dictionary of Musical Instruments ${ }^{174}$. Esta versión resulta un referente internacional en el campo de la organología donde se encuentra un estudio sistemático en la historia, diseño, tecnología y funciones de los instrumentos musicales sin barreras cronológicas o geográficas. Esta enciclopedia, asimismo, realiza una imagen completa del papel cultural de los instrumentos musicales. En ambas fuentes citadas,

\footnotetext{
172 "Encyclopedie Berbere” https://journals.openedition.org/encyclopedieberbere/ (Última consulta 2601-2020).

${ }^{173}$ Stanley Sadie y John Tyrrell, eds., The New Grove Dictionary of Music an Musicians, 2o. Nueva York: Macmillan Publishers, 2001.

${ }^{174}$ Stanley Sadie, The Grove Dictionary of Musical Instruments. Londres: Macmillan Press, 1984.
} 
la información mostrada sobre los instrumentos es la misma, lo que aporta esta segunda versión es la focalización sobre la organología. Entre los instrumentos definidos en este trabajo se encuentran duff cuya descripción la hacen R.Conway Morris, Cvjetko Rihtman, Christian Poché y Verónica Doubleday, 'ud realizada de forma individual por Christian Poché, nai presentada por Scheherazade Qassim Hassan y Jean During o rabab por Alastair Dick, Christian Poché, Jack Percival Baker Dobbs, Margaret J. Kartomi, Jean During y John Baily.

\section{Enciclopedia de la Música Española e Hispanoamericana, $2002^{175}$}

Esta enciclopedia cuenta con investigadores internacionales que tras dos décadas de trabajo llegan a compilar todo lo recogido en diez volúmenes con más de 26.000 artículos. Esta enciclopedia resultó todo un avance para la investigación musicológica en castellano, ya que fue la pionera en tratar historias, biografías, instrumentos y terminologías técnicas de distintos lugares e instituciones musicales dentro del ámbito hispano. El trabajo de esta enciclopedia se inició en 1988 llegando a publicarse finalmente en 2002. En el primer volumen se puede encontrar una entrada titulada "Árabe, música" realizada por el investigador Reynaldo Fernández Manzano, quien realiza un completo recorrido a través de los sabios andalusíes y sus trabajos enlazados a la música, iconografía musical e instrumentos musicales, entre otros conceptos. Los instrumentos son presentados siguiendo los epígrafes: "Cordófonos: familia del laúd", contando con una breve aclaración sobre la qitara, 'ud (el cual será ampliamente presentado por Pepe Rey en la entrada "Laúd"), tunbur o tar; "Cordófono: familia de las vielas" con el rabab (el cual será tratado de forma más ampliada junto a su posterior versión española en la entrada "Rabel" realizada por Gemma Salas Villar); “Cordófonos: familia de las cítaras” con el qanun; “Aerófono: familia de las flautas" con el nay o sabbaba; "Aerófono de lengüeta doble" con mizmar, buq у zurna; "Aerófonos de lengüeta simple" con zammara; "Aerófono: familia de las trompas" con albogue; "Instrumentos de percusión" dividido entre membranófonos con riqq, tar, duff, darbuka, naqqara y tabl e idiófonos con sany, jalajil y safaq.

\footnotetext{
${ }^{175}$ Emilio Casares Rodicio, Ismael Fernández de la Cuesta y José López-Calo. Diccionario de la Música Española e Hispanoamericana. Fundación Autor. Sociedad Genral de Autores y Editores, 2002.
} 
DAOA. Diccionario de autores y obras andalusies, $2002^{176}$

Este trabajo resulta un primer paso en lo que será la posterior Enciclopedia andalusí que a continuación también será presentada. Se trata de un directorio biográfico y bibliográfico sobre los académicos andalusíes entre 711 y 1492 que realizaron obras originales, quedando excluidos de este volumen los que han sido documentados como meros transmisores ${ }^{177}$. En el momento de su publicación resulta una novedad absoluta y una gran herramienta para los investigadores. Este primer volumen contiene de las letras "A" a "Ibn B", recopilando biografías de cada personaje, suponiendo para muchos de ellos, la primera que se realiza sobre su figura. De los sabios andalusíes incluidos en esta investigación incluye a Ibn Abd Rabbihi ${ }^{178}$ documentado por M. Guillén Monje, el filósofo, músico y poeta Ibn -Bayya, Avempace $^{179}$, escrito por Joaquín Lomba y M. Puerta Vílchez, Ibn Abi 1-Salt al-Dani, Albuzale $^{180}$, expuesto por M. Comes, o el recopilador y transmisor de la música andalusí-magrebí al-Ha'ik (s.XII-XIII) ${ }^{181}$, presentado por Manuela Cortés García. Asimismo, cuenta con una entrada sobre el manuscrito Bayad wa-Risad, Hadit/ Qissat $^{182}$ donde C. Robinson explica los detalles de los restos documentales de este cuento de posible procedencia andalusí, así como relata la historia que cuenta.

Garland Encyclopedia or world music. Volumen 6: The Middle East, $2002^{183}$

Este reconocido trabajo académico, en su sexto volumen, es el que mayor aportación realiza a esta investigación al centrarse en el Medio Oriente. En este tomo se aborda la música en el norte de África, Oriente Medio y Asia Central. La primera sección está dedicada al norte de África, El Magreb, incluyendo las mezclas culturales y buscando la raíz de las tradiciones musicales. Se introducen testimonios de artistas, compositores y maestros que relatan en primera persona sus vivencias, actuaciones y

\footnotetext{
176 Jorge Lirola Delgado y José Miguel Puerta Vílchez, Enciclopedia de Al-Andalus. Diccionario de Autores y Obras Andalusíes. Granada: El Legado Andalusí, 2002.

177 Ibidem, 13.

178 Ibidem, 306.

179 Ibidem, 624.

180 Ibídem, 373.

181 Ibídem, 233.

182 Ibidem, 111.

183 Virginia Danielson, Dwight Reynolds y Scott Marcus, "The Middle East" The Garland Encyclopedia of Word Music, 2002.
} 
eventos musicales. En este trabajo se contextualiza la presencia de instrumentos musicales así como se aclaran algunos términos referidos a ellos.

Dictionnaire des musiquees et danses traditionnelles de la Méditerranée, $2009^{184}$

Siendo Christian Poché un gran referente dentro del campo de la música árabe, en este libro trabaja sobre las tradiciones musicales de diez islas del mediterráneo: las Islas Baleares, Córcega, Creta, Chipre, las Islas Jónicas, la isla Krk en la costa istriana, Malta, Cerdeña y Sicilia. También ha incluido un país continental, Albania, ya que considera, este arabista, que se ha mantenido aislado durante mucho tiempo lo que propicia pocos cambios musicales. Todos estos lugares comparten la peculiaridad de que sus propios estilos poco tiene que ver los lugares colindantes ${ }^{185}$.

Una de las aportaciones más interesantes que tiene este diccionario es que cada término que define viene acompañado por una bibliografía y una discografía, lo que enriquece enormemente la explicación y contextualización de cada explicación.

La constante presencia de este investigador en importantes trabajos enciclopédicos donde se presentan los distintos instrumentos musicales hace que este diccionario parezca algo más superficial de lo que puede encontrarse en otras fuentes, la gran aportación que supone, por lo tanto, es la variedad tratada y la concisa aclaración de cada término.

Diccionario de instrumentos musicales. Desde la Antigüedad a J.S. Bach, $2009^{186}$

Este diccionario muestra las raíces de cada uno de los términos musicales referentes a músicos, épocas, géneros o instrumentos musicales a través de las evidencias documentales de cada uno de ellos. En ciertos términos el autor muestra las líneas comunes entre artes como música, pintura y literatura. De este libro es también importante recalcar la rica referencia bibliográfica que detalla de forma general o más concreta en instrumentos cordófonos (con y sin mango, arco y tecla), instrumentos aerófonos (tipo flauta, de lengüeta, con depósito de aire, trompa y trompeta y tecla) e instrumentos de percusión (idiófonos y membranófonos). Cuenta con entrada "rabé morisco" siendo de las escasas menciones andalusíes ya que este

\footnotetext{
${ }^{184}$ Christian Poché, Dictionnaire des Musiques et Danses Traditionnelles de la Méditerranée. Éditions Fayard, 2005.

185 Ibidem, 9.

${ }^{186}$ Ramón Andrés, Diccionario de instrumentos musicales. Desde la Antigüedad a J.S. Bach. Barcelona: Ediciones Península, 2009.
} 
diccionario muestra principalmente la perspectiva occidental de los instrumentos que aborda como ya el título, mencionando a J.S. Bach, advierte.

Diccionario de música, mitología, magia y religiosidad, $2012^{187}$

En este diccionario Ramón Andrés estudia cada término desde la perspectiva mitológica. Pretende acercar al investigador al análisis de la naturaleza y los sonidos, así como su simbología o posibles lazos de unión entre hombres y dioses. Este peculiar diccionario ofrece una curiosa perspectiva que puede ayudar en la completa contextualización de, en este caso, los instrumentos musicales. Son 1715 el total de términos definidos en este trabajo, incluyendo instrumentos musicales documentado desde fuentes de la época y llevados hasta la actualidad. Los términos incluyen aclaraciones etimológicas y observaciones gramaticales y de usos. Exceptuando las entradas: "barbat", "daff" "mizhar", "rabab" y "tanbur", el resto de los instrumentos andalusíes que tienen cabida se estudian desde la perspectiva y documentación europea, aunque sin omitir la óptica andalusí. Asimismo, también aparece la leyenda de Lamak y el laúd ${ }^{188}$ y una definición de "Instrumentos musicales" que aborda la importancia de la arqueología, así como la relación de éstos con la mitología cuando se tratan sus orígenes.

ECA. Enciclopedia de la Cultura Andalusí. Biblioteca de al-Andalus, $2012^{189}$

Esta enciclopedia numera de forma alfabética los distintos tratadistas andalusíes, 2465 en total entre los años 711 y 1492, de los que recoge la biografía y obra, sumando un total de 7790 trabajos abordados. Está compuesta por diez tomos, siendo siete de ellos referidos a los tratadistas andalusíes y tres a la ampliación referente a la temática. Esta enciclopedia unifica denominaciones de estos sabios compartiendo su nombre completo, raíces familiares, vida personal y profesional terminando con un detallado listado de obras escritas que llegan o no hasta nuestros días. Este listado de obras viene brevemente presentado pudiendo conocer el contenido de cada uno de estos y el lugar donde se conservan, así como en las traducciones y análisis de las obras que se han realizado hasta el momento. La única

\footnotetext{
187 Ramón Andrés, Diccionario de música, mitología, magia y religión. Barcelona: Acantilado, 2012.

188 Ibidem, 929.

189 Jorge Lirola Delgado y José Miguel Puerta Vílchez. Biblioteca de Al-Andalus. El Legado Andalusí. Almería: Fundación Ibn Tufayl de estudios árabes, 2012.
} 
crítica, desde la óptica musical, es la omisión de ciertos detalles musicológicos relevantes que son humildemente mencionados o incluso omitidos. Interesante asimismo resulta el volumen dedicado al balance de resultados e índices donde pueden verse los datos estadísticos abordando los lugares de residencia de estos sabios, así como sus edades cuando se publicaron sus trabajos, épocas en las que vivieron o los campos de saber que abordaron. Igualmente, en este volumen existe un índice de los reconocidos redactores de las entradas. 


\begin{tabular}{|c|c|c|c|c|c|}
\hline Trabajos & Organología & Iconografía & Arqueología & Arabista & Zona geográfica \\
\hline Cerone, 1613 & $\mathrm{X}$ & & & & Transversal (España) \\
\hline Trichet, 1640 & & & & & Transversal \\
\hline Nassarre, 1723 & $\mathrm{X}$ & & & & Transversal (España) \\
\hline Biot, 1803-1850 & $\mathrm{X}$ & & & & China \\
\hline Fétis, 1869 & $\mathrm{X}$ & & $\mathrm{X}$ & & General \\
\hline Fetís, 1876 & $\mathrm{X}$ & & & & Oriente \\
\hline Mahillon, 1880 & $\mathrm{X}$ & & & & Transversal (Bruselas) \\
\hline Pedrel, 1901 & $\mathrm{X}$ & & & & España \\
\hline Houtsma, 1913-1935 & & & & $\mathrm{X}$ & Área islámica \\
\hline Lavignac y Laurencie, 1913 & & & & $\mathrm{X}$ & Internacional \\
\hline Farmer, 1929 & $\mathrm{X}$ & & & & Oriente \\
\hline Farmer, 1930 & $\mathrm{X}$ & & & & Oriente \\
\hline Farmer, 1930 & $\mathrm{X}$ & & & $\mathrm{X}$ & Oriente y Occidente árabe \\
\hline Farmer, 1932 & $\mathrm{X}$ & & & & Occidente árabe \\
\hline Ferrandis, 1935 & & $\mathrm{X}$ & & & Occidente (árabe) \\
\hline Menéndez, 1935 & & & & $\mathrm{X}$ & España \\
\hline Farmer, 1937 & $\mathrm{X}$ & & & & Occidente árabe \\
\hline
\end{tabular}




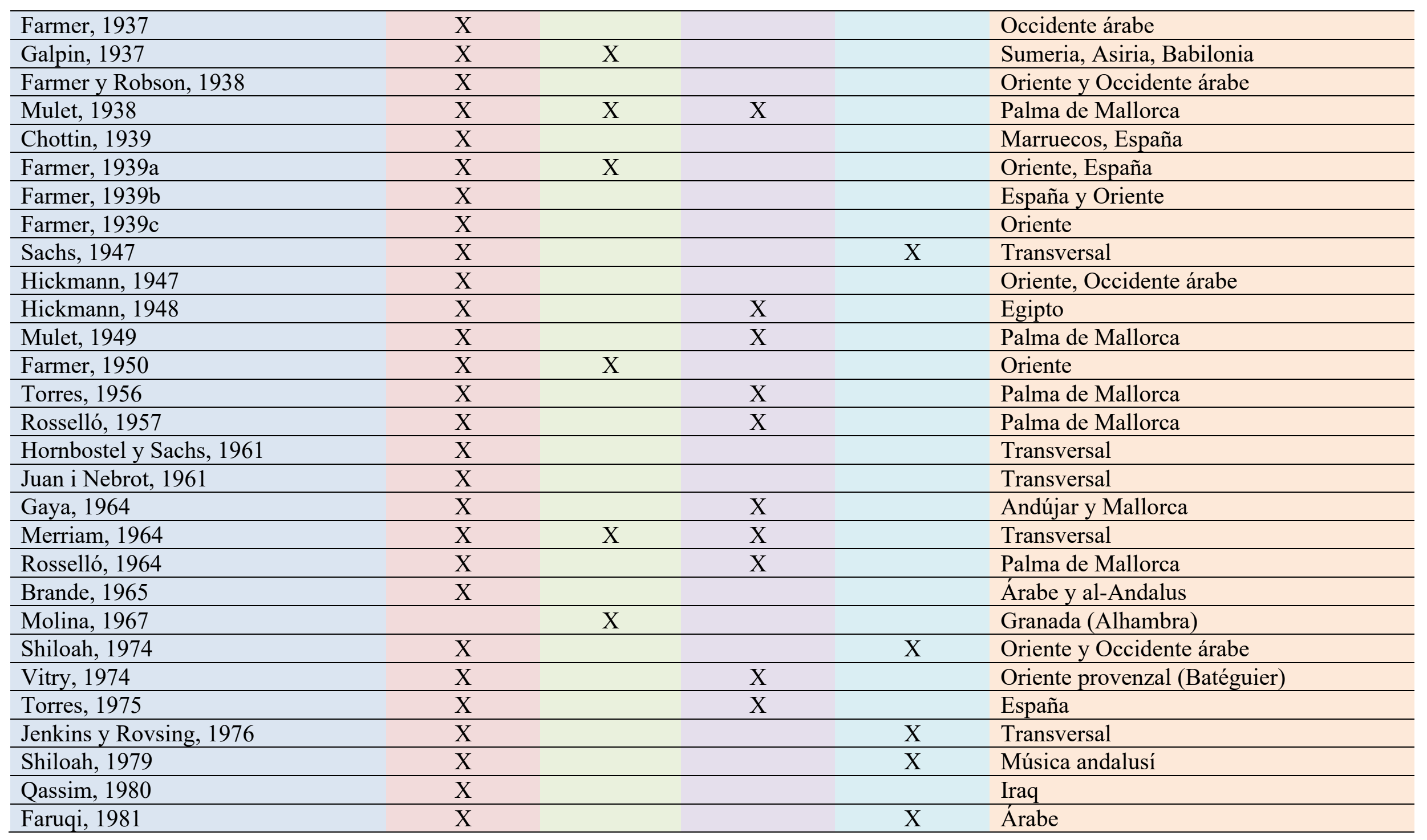




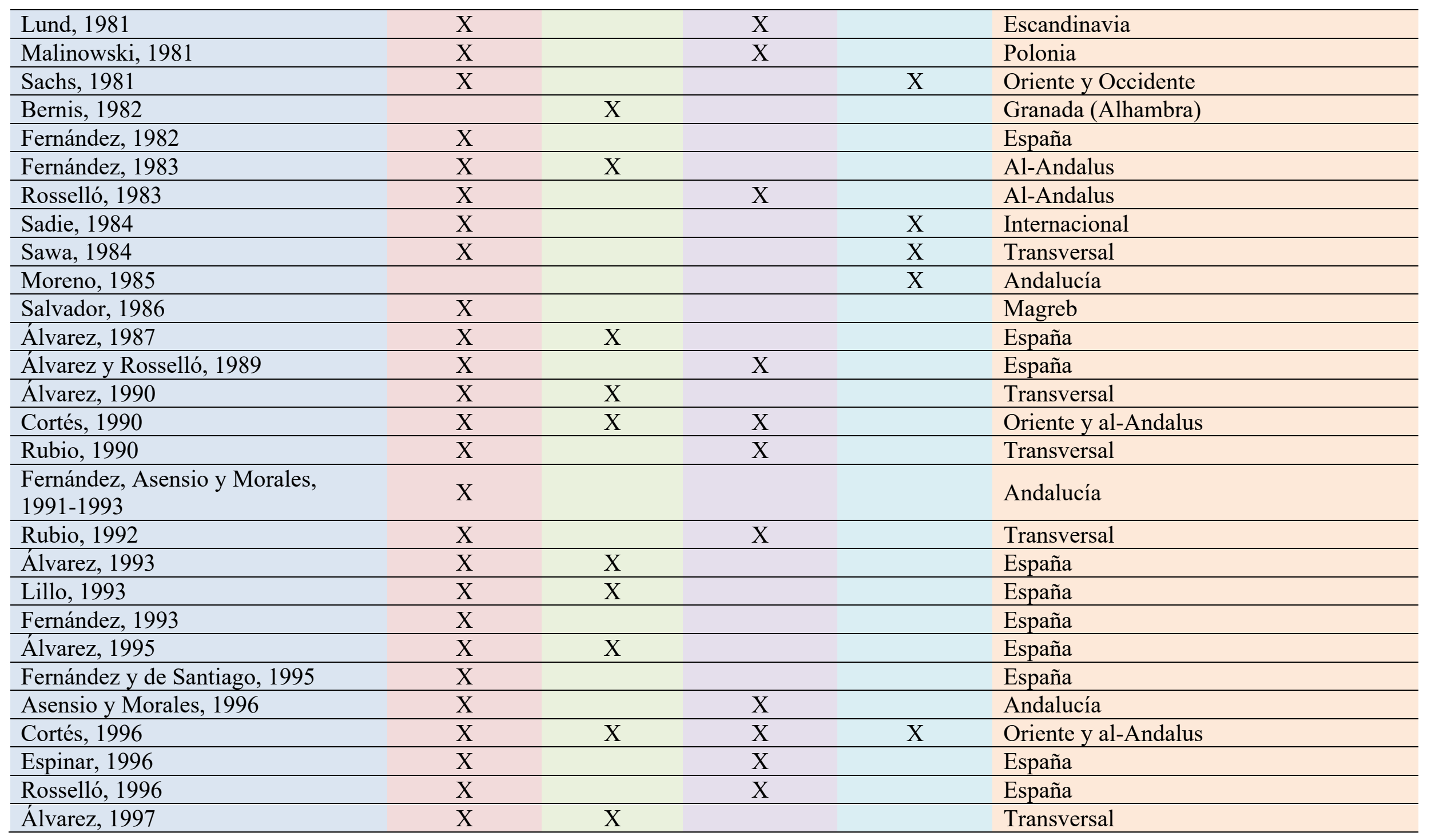




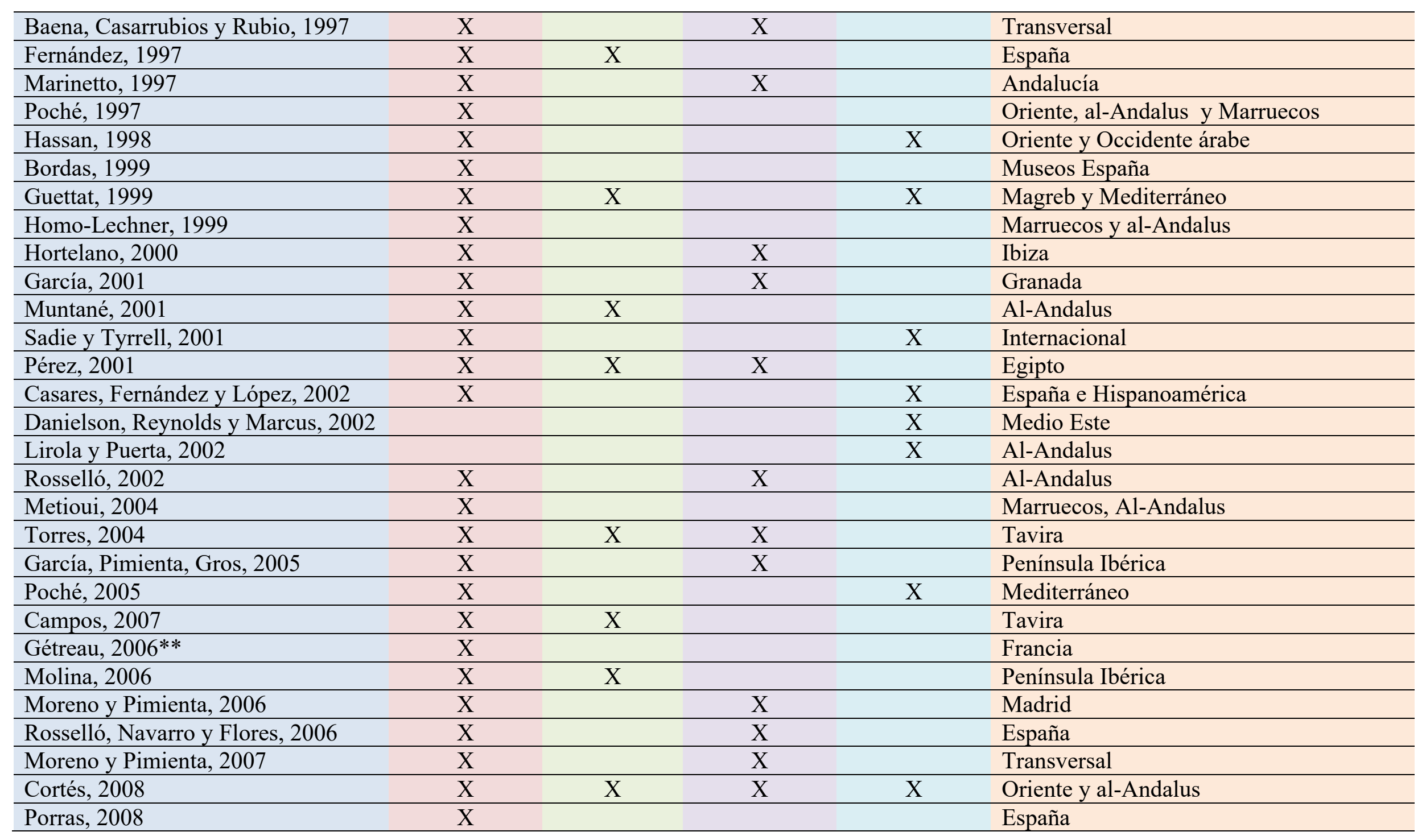




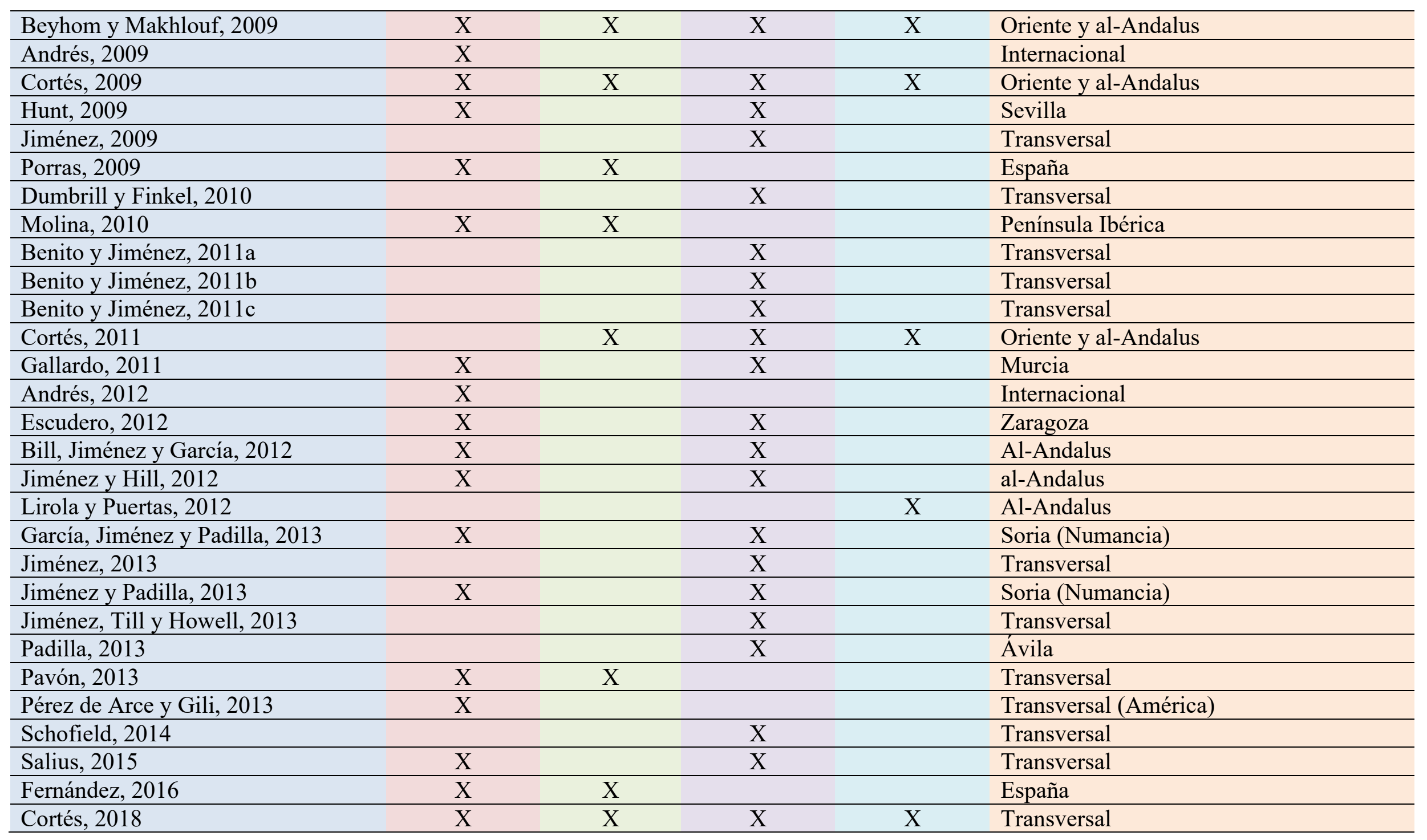




\begin{tabular}{|c|c|c|c|c|}
\hline Jiménez, García y Padilla, 2018 & $\mathrm{X}$ & & $\mathrm{X}$ & España \\
\hline Serrano, 2018 & $\mathrm{X}$ & & & Transversal \\
\hline Bordas y Vázquez, 2019 & $\mathrm{X}$ & & & Transversal \\
\hline
\end{tabular}

*Puesta en valor de la investigación

**Año de publicación

Tras este recorrido que tiene prácticamente como eje guía el campo organológico, se puede comprobar cómo la arqueología, a pesar de contar con trabajos puntuales previos, con el paso del tiempo tiende a estar más presente en este tipo de investigaciones. 


\section{Metodología}

Esta investigación tiene principalmente un enfoque cualitativo ya que se trata de un estudio analítico-descriptivo en el que se combinan procedimientos de estudio de contenido a través de la revisión bibliográfica, con los etnográficos a través de entrevistas y observación arqueológica.

Para realizar esta investigación se han acudido a museos, arqueólogos y arqueólogas ligados a yacimientos medievales en el actual territorio andaluz con la intención de conocer las posibles piezas catalogadas, o con posible interpretación, como instrumento musical. De forma paralela se ha realizado una recopilación y estudio de trabajos afines a esta investigación. Al mismo tiempo, se han revisado fuentes documentales de la época, a través de los trabajos de traducción de los códices de los sabios andalusíes, para una posible contextualización organológica.

Una vez asentada la base documental y halladas las piezas, o la información de las mismas, se procedió a aplicar las metodologías de trabajo correspondiente a la arqueomusicología. Siguiendo las indicaciones de la investigadora Ellen Hickmann sobre esta una rama interdisciplinar, se cuenta con metodologías arqueológicas y etnomusicológicas ${ }^{190}$ ya que, como se mencionó anteriormente, ambas ciencias comparten su evolución y enfoque durante su desarrollo. Remontándonos a su evolución e historia, a finales de los años 20 del siglo XX la Escuela de Annales creada en torno a la revista Annales, dirigida por Marc Bloch y Lucien Febvre trataba las metodologías de los distintos parámetros por los que se debía estudiar las distintas culturas. Esta escuela lideró el cambio de enfoque de los investigadores pasando de ser historicista, siendo la prioridad documental la ubicación y la cronología ${ }^{191}$, a adaptarse a los nuevos campos surgidos en el área de la iconografía, la organología, la antropología y la etnomusicología. El desarrollo de la antropología cultural repercutió directamente en la antropología musical y su relación con la etnomusicología, o musicología comparada como se denominaba en esas fechas ${ }^{192}$, a finales del siglo XIX. Ello permitió abrir nuevos horizontes en las investigaciones orientales y

\footnotetext{
${ }^{190}$ Ellen Hickmann, “Archaeomusicology”, en Grove Music Online. Oxford University Press, 2001, http://www.oxfordmusiconline.com/subscriber/articl (Última consulta: 27-07-2019).

191 Carlos García Benito y Raquel Jiménez Pasalodos, "La música enterrada: historiografía y metodología de la arqueología musical”, Cuadernos de Etnomusicología, (2011), 80-108.

192 Enrique Cámara de Landa, Etnomusicología. Madrid: Instituto Complutense de Ciencias Musicales. ICCMU, 2003.
} 
magrebíes de transmisión oral, llegando a perfilar el estudio de las mismas contemplando su simbolismo. En los años 70 de la mano del etnomusicólogo Alan Merriam, las investigaciones se tornan y cuentan con un enfoque más antropológico, nueva perspectiva que es liderada por especialistas en este campo como Clifford Geertz contemplando los fenómenos sociales y culturales que satisfacían las necesidades de la sociedad. En la vertiente arqueológica aparece la Nueva arqueología o Arqueología procesual ${ }^{193}$, que intenta reconstruir elementos de la cultura material del pasado para responder a preguntas determinadas. Con esto se llegaría a la Antropología Transcultural y a la Etnoarqueología ya a finales de los años 70. Esta forma de documentar y estudiar cada una de las piezas de forma contextualizada es lo que se propone este trabajo en la medida de lo posible, ya que en gran mayoría de casos los datos documentales resultan escasos o nulos por las condiciones y casuísticas de recogida de material en las que se ven envueltas y/o llegan las piezas a los museos o almacenes.

Finalmente los resultados de la investigación se forjan de forma acumulativa, ya que se compilan y clasifican mediante familias de instrumentos todas las piezas recopiladas con la finalidad de realizar un sondeo y poner en valor el patrimonio cultural que llega hasta nuestros días.

\subsection{Diseño cualitativo}

Al ser una investigación cualitativa no cuenta con un diseño estructurado ya que fue adquiriendo su forma a medida que se avanzaba sobre la misma.

Teniendo asimismo este estudio histórico un carácter observacional, el enfoque se realiza de forma descriptivo-exploratoria ya que se centra en la consulta de fuentes documentales.

\subsection{Población y muestra}

Con la finalidad de concretar la temática de la investigación, las fuentes documentales en las que se ha procurado exhaustividad en la consulta y análisis han sido las musulmanas, utilizando las cristianas de forma puntual para contextualización, pero sin pretensión de incluir una completa visión desde ambas

193 Raquel Jiménez Pasalodos, “Arqueología musical y etnomusicología : por una interpretación etnomusicológica de los materiales arqueológicos", Etno-Folk: revista galega de etnomusicoloxía, Vol. $14,2009,640$. 
perspectivas. Esta intención se ha aplicado, igualmente, en los restantes campos por lo ambicioso que podría resultar este trabajo perdiendo concreción y linealidad.

Con respecto a la selección de tratadistas incluidos en esta investigación, los parámetros aplicados han sido el tratamiento del marco histórico, y no solo la mención, de los instrumentos musicales. Existen sabios andalusíes que realizaron tratados musicales, como Ibn Hayyan (Córdoba, s. XI) o Ibn Saba'in (Valle del Ricote-Murcia-La Meca, s. XIII), así como otros que en sus poemas mencionan de forma más o menos documentada el uso de instrumentos musicales en distintos lugares y momentos. Pero esta amplia variedad de referencias se considera una futura línea de investigación tras este paso previo donde pueden empezar a situarse desde una perspectiva técnica ofrecida por estos especialistas andalusíes, los instrumentos en relación con la sociedad. Por lo tanto se muestra a continuación el listado de los siete tratadistas sobre los que se ha realizado esta parte del estudio:

- Ibn 'Abd Rabbihi (Córdoba, 860- Córdoba 940)

- Ibn Sida (Murcia, 1007 - Denia, 1066)

- al-Turtusi (Tortosa, 1059 - Alejandría, 1120)

- Abu L-Salt (Denia, 1068-Burgía, 1134)

- Ibn Bayya (Avempace) (Zaragoza, finales s.XI - Fez, 1139)

- Al-Saqundi (Secunda [Córdoba], mediados del s. XII- Sevilla, 1231/2).

- Ibn al-Darray (¿Sevilla? $1^{\circ}$ mitad s.XIII - Ceuta, 1293/4)

Igualmente, se ha querido dar una muestra de las posibilidades que ofrecen los trabajos de estos autores andalusíes que nombran la presencia de instrumentos en los distintos escenarios que sus poemas recrean, realizando una breve ejemplificación sobre lo que la poesía puede aportar a este tipo de investigaciones. Para este fin se ha contado con ejemplos de los trabajos de cinco tratadistas:

- Ibn Hazm (Córdoba, 933-Monitija [Huelva], 1064)

- al- Ramadi (Córdoba ¿? - Córdoba, 1013)

- Ibn Ezra' (Granada 1055- 1135)

- Ibn Quzman (m. 1170)

- Ibn al-Jatib (Loja, 1313-Fez, 1374- 1375)

En cuanto a la iconografía musical se han incluido, como ya se ha mencionado, las fuentes musulmanas, nombrándose en ocasiones puntuales ciertas 
evidencias cristianas con rasgos musulmanes pero sin la pretensión de exhaustividad y más como muestra anecdótica dejando abierta, igualmente, una futura línea de investigación. Asimismo se ha mencionado de forma contextualizada cierta iconografía referente a la danza como muestra del valor documental de las mismas pero no se han tratado de forma tan detallada por la ausencia de instrumentos musicales.

Respecto a la localización de las piezas, los museos consultados se han seleccionado según la afinidad de sus colecciones, así como por el equipo profesional con el que cuentan, con la finalidad de poder contactar y entrevistar a arqueólogos y arqueólogas que hayan podido tener relación con yacimientos medievales. Tras un exhaustivo análisis han sido 99 los museos consultados, siendo 16 los que cuentan con instrumentos musicales. Por otro lado, el Laboratorio de Arqueología de la Universidad de Granada cuenta con una pieza, el tambor de los Guájares, otras tres piezas se encuentran custodiadas por particulares, y de otros cuatro instrumentos incluidos solo se conservan sus dibujos o imágenes, ya que se desconoce su paradero.

A continuación se realizará un listado con los museos que tienen piezas incluidas en esta investigación y se detallará de qué tipo de piezas se trata. Los nombres que se han escogido para mencionar los museos son con los que se inscribieron dentro de la Red de Museos de Andalucía, ya que a algunos de ellos es posible encontrarlos bajo otras referencias:

\begin{tabular}{|l|c|c|c|c|c|}
\hline \multicolumn{1}{|c|}{ Centro } & Silbatos & Tambores & Campanas & Cascabeles & Platillos \\
\hline $\begin{array}{l}\text { Conjunto } \\
\text { Monumental } \\
\text { Alcazaba de } \\
\text { Almería }\end{array}$ & 3 & 0 & 0 & 0 & 0 \\
\hline $\begin{array}{l}\text { Museo de } \\
\text { Almería }\end{array}$ & 5 & 3 & 0 & 0 & 0 \\
\hline $\begin{array}{l}\text { Museo } \\
\text { Arqueológico } \\
\text { de Jerez }\end{array}$ & 5 & 3 & 0 & 0 & 0 \\
\hline $\begin{array}{l}\text { Museo } \\
\text { Arqueológico }\end{array}$ & 3 & 6 & 1 & 0 & 0 \\
\hline
\end{tabular}




\begin{tabular}{|c|c|c|c|c|c|}
\hline $\begin{array}{l}\text { y Etnológico } \\
\text { de Córdoba }\end{array}$ & & & & & \\
\hline $\begin{array}{l}\text { Museo de } \\
\text { Bellas Artes } \\
\text { de Córdoba }\end{array}$ & 1 & 0 & 0 & 0 & 0 \\
\hline $\begin{array}{l}\text { Museo } \\
\text { Histórico } \\
\text { Municipal de } \\
\text { Priego }\end{array}$ & 0 & 1 & 1 & 0 & 0 \\
\hline $\begin{array}{l}\text { Museo } \\
\text { Histórico } \\
\text { Municipal de } \\
\text { Villamartín }\end{array}$ & 0 & 1 & 0 & 0 & 0 \\
\hline $\begin{array}{l}\text { Museo de la } \\
\text { Alhambra }\end{array}$ & 11 & 0 & 11 & 22 & 2 \\
\hline $\begin{array}{l}\text { Museo } \\
\text { Arqueológico } \\
\text { y Etnológico } \\
\text { de Granada }\end{array}$ & 6 & 0 & 0 & 0 & 0 \\
\hline $\begin{array}{l}\text { Laboratorio } \\
\text { de } \\
\text { Arqueología } \\
\text { de la } \\
\text { Universidad } \\
\text { de Granada }\end{array}$ & 0 & 1 & 0 & 0 & 0 \\
\hline $\begin{array}{ll}\text { Museo de } \\
\text { Huelva }\end{array}$ & 1 & 0 & 1 & 0 & 0 \\
\hline $\begin{array}{l}\text { Museo de } \\
\text { Jaén }\end{array}$ & 7 & 0 & 1 & 0 & 0 \\
\hline $\begin{array}{l}\text { Baños } \\
\text { Árabes de } \\
\text { Jaén }\end{array}$ & 2 & 0 & 0 & 0 & 0 \\
\hline Museo & 1 & 0 & 0 & 0 & 0 \\
\hline
\end{tabular}




\begin{tabular}{|l|c|c|c|c|c|}
\hline $\begin{array}{l}\text { Arqueológico } \\
\text { de Estepona }\end{array}$ & & & & \\
\hline $\begin{array}{l}\text { Museo de } \\
\text { Málaga }\end{array}$ & 0 & 2 & 0 & 0 & 0 \\
\hline $\begin{array}{l}\text { Museo } \\
\text { Histórico }\end{array}$ & 0 & 0 & 3 & 1 & 0 \\
$\begin{array}{l}\text { Municipal de } \\
\text { Teba }\end{array}$ & 0 & 1 & 1 & 0 & 0 \\
\hline $\begin{array}{l}\text { Museo } \\
\text { Arqueológico } \\
\text { de Sevilla }\end{array}$ & & & & & \\
\hline
\end{tabular}

De las 142 piezas recopiladas, 56 son inéditas, 131 se encuentran en museos mientras que el resto están en paradero desconocido o custodiadas por particulares. Entre las piezas inéditas hay 10 silbatos, 6 tambores, la fotografía de un tambor que se consideraba perdido y del que solo se tenía un dibujo, y 40 idiófonos: 15 campanas y 23 cascabeles y 2 platillos. Además, se han recopilado 24 piezas catalogadas por sus respectivos museos, en Andalucía y Marruecos, como aerófonos o mástil de cordófono y 13 imágenes.

\subsection{Herramientas, recogida de datos y materiales}

Se llevó a cabo un sondeo exhaustivo de datos mediante la búsqueda en distintas plataformas digitales $\mathrm{y}$ en bibliotecas públicas sobre los trabajos desarrollados hasta la fecha en el territorio andaluz en torno a la temática arqueomusicología, así como sobre los llevados a cabo en otras zonas, principalmente del área peninsular y mediterránea. Ello ha permitido establecer una considerable base de datos en el plano bibliográfico. La primera toma de contacto se realiza de forma general a través de plataformas como Google Scholar ${ }^{194}$, Questia ${ }^{195}$, iSeek ${ }^{196}$, Jurn ${ }^{197}$ o Academia.edu ${ }^{198}$ donde a través de palabras clave se pueden llegar a referencias o

\footnotetext{
194 “Google Scholar”, https://scholar.google.es/ (Última consulta: 18-10-2019).

195 “Questia”, https://www.questia.com/ (Última consulta: 18-10-2019).

196 “iSeek", education.iseek.com/iseek/home.page (Úlima consulta: 18-10-2019).

197 “Jurn”, jurn.org/\#gsc.tab=0 (Última consulta: 18-10-2019).

198 “Academia.edu”, academia.edu (Última consulta: 18-10-2019).
} 
trabajos sobre la temática especificada. Conforme la investigación avanza y se empieza a concretar más la temática y estudios específicos, se acuden a plataformas más especializadas como Scopus ${ }^{199}$, Abes ${ }^{200}$, Jstor ${ }^{201}$, ProQuest Central ${ }^{202}$ o Recolecta $^{203}$, Biblioteca Digital Musical ${ }^{204}$, International Music Score Library Project (IMSLP) ${ }^{205}$ y la Red de revistas científicas de acceso abierto Redalyc ${ }^{206} \mathrm{o}$ Latindex ${ }^{207}$ plataformas que recopilan repositorios científicos a nivel nacional e internacional. Con la finalidad de localizar trabajos que no estuviesen online y por lo tanto deben encontrarse en bibliotecas físicas se ha consultado WorldCat ${ }^{208}$, plataforma que centraliza una gran red de bibliotecas internacionales.

Asimismo, con la finalidad de conocer estudios que pueden no haber sido publicados se acudió a webs de libre acceso para la consulta y lectura de tesis doctorales como Teseo ${ }^{209}$, el apartado específico de tesis de ProQuest ${ }^{210}$, Dialnet ${ }^{211}$ y la asociación de bibliotecas de investigación cuya finalidad es la visibilidad de tesis Europeas: Dart Europe ${ }^{212}$. Finalmente, para la gestión de referencias bibliográficas en esta tesis se elige el gestor Mendeley ${ }^{213}$ por su facilidad en el uso y amplia base de datos.

Una vez realizada la búsqueda online y localizadas las publicaciones relevantes para esta investigación se realizó una búsqueda sistemática en distintas bibliotecas como la de la Facultad de Filosofía y Letras de Universidad de Granada, Biblioteca de la Facultad de Filosofía y Letras de la Universidad de Málaga,

\footnotetext{
199 "Scopus", https://www.scopus.com/search/form.uri?display=basic (Última consulta: 18-10-2019).

200 “Abes. Agence Bibliographique de l'Enseignement Supérieur", http://es.abes.fr/Sudoc/Sudoccatalogo (Última consulta: 18-10-2019).

201 “Jstor", https://www.jstor.org/ (Última consulta: 18-10-2019).

202 "ProQuest Central", e-libro.com/boletin/PQ/Proquestcentral/PQcentral.html (Última consulta: 1810-2019).

203 "Recolecta", https://www.recolecta.fecyt.es/ (Última consulta: 18-10-2019).

204 "Biblioteca Digital Musical", http://biblioteca-musical.weebly.com/ (Última consulta: 18-10-2019).

205 "International Music Score Library Project (IMSLP)", https://imslp.org/wiki/Main Page (Última consulta: 18-10-2019).

206 "Redalyc", http://www.redalyc.org/home.oa (Última consulta: 18-10-2019).

207 "Latindex", http://www.latindex.org/latindex/inicio (Última consulta: 18-10-2019).

208 "WorldCat", worldcat.org (Última consulta: 18-10-2019).

209 "Teseo",

https://www.educacion.gob.es/teseo/irGestionarConsulta.do;jsessionid=826320BF472FE502438852FA 282EFC0F (Última consulta 18-10-2019).

210 "ProQuest Dissertations \& Theses Global", https://www.proquest.com/productsservices/pqdtglobal.html (Última consulta: 18-10-2019).

211 "Dialnet", https://dialnet.unirioja.es/ (Última consulta: 18-10-2019).

212 "Dart-Europe", http://www.dart-europe.eu/basic-search.php (Última consulta: 18-10-2019).

213 "Mendeley", https://www.mendeley.com/newsfeed (Última consulta: 18-10-2019).
} 
Biblioteca de la Facultad de Filosofía y Letras de la Universidad de Cádiz, Biblioteca de la Facultad de Arquitectura y Bellas Artes de la Universidad de Málaga, Biblioteca de Humanidades de la Universitat Autònoma de Barcelona, Biblioteca de la Facultad de Filosofía y Letras de la Universidad Complutense de Madrid, Biblioteca Islámica de la Agencia Española de Cooperación Internacional para el Desarrollo (AECID) y las distintas bibliotecas pertenecientes a los museos a los que se ha accedido y cuentan con ella, como la del Museo Arqueológico de Granada, Jaén o Córdoba.

Para la recopilación de instrumentos musicales pertenecientes a excavaciones arqueológicas que se adhieren a esta investigación se acudió a todos los museos arqueológicos de Andalucía y a los propios arqueólogos relacionados con estas excavaciones. Igualmente, se localización de las piezas a través de los catálogos públicos de los museos, ya sean de forma privada en sus webs o en los respectivos catálogos comunes y públicos en plataformas como la Red Digital de Colecciones de Museos de España (CERES $)^{214}$ o el Sistema Integrado de Documentación y Gestión Museográfica (DOMUS) ${ }^{215}$. Asimismo, gran parte de las excavaciones arqueológicas andaluzas realizadas se recogen en unos Anuarios $^{216}$ que se hacen eco de las piezas más relevantes y/o curiosas, por lo que en ciertas ocasiones los investigadores mencionan este tipo de colecciones de forma más o menos documentada. El total de museos consultados en toda Andalucía suma un total de noventa y nueve entre todas las capitales y provincias de esta Comunidad Autónoma. Esta selección de museos entre todos los existentes se realizó basándose en el tipo de colecciones que acogen o la cercanía a esta época andalusí, como en el caso de "Baños árabes" que no siempre cuentan con piezas expuestas en sus propias instalaciones o museos municipales los cuales suelen contar con una colección muy variada, muchas veces incluso recopiladas por el mismo pueblo como en el caso del Museo Municipal de Montemayor, Córdoba.

\footnotetext{
214 "Red Digital de Colecciones de Museos de Epaña (CERES)", http://ceres.mcu.es/pages/SimpleSearch?index=true (Última consulta: 18-10-2019).

215 "Sistema Integrado de Documentación y Gestión Museográfica (DOMUS)", http://www.juntadeandalucia.es/cultura/WEBDomus/buscador.do?lng=es (Última consulta: 18-102019).

${ }^{216}$ Publicaciones de la Secretaría General de Cultura que publica todas las actividades arqueológicas que se realizan en Andalucía. "Anuario Arqueológico de Andalucía" https://www.juntadeandalucia.es/organismos/cultura (Última consulta 15-06-2019).
} 
Por otro lado, con la finalidad de contextualizar los instrumentos protagonistas de esta investigación así como de contrastarlos con su posible uso actual y los encontrados en las mismas fechas en otros lugares involucrados en la mezcla cultural, se visitaron diversas instituciones en Marruecos. Allí se entrevistó a investigadores y profesionales del mundo de la música y la arqueología tales como el Consejero de Cultura de Tetuán, Hassan Marso, quien nos mostró el Museo de Tetuán donde se exhiben varias piezas sobre las que recae la duda de si serán instrumentos musicales pertenecientes a las mismas fechas que las de esta investigación. El director del Conservatorio de Música de Tetuán Arbi Belehmar, cuya familia es de origen andalusí. La directora la Casa de la Cultura Samira Kadiri, cantante y conocedora de la cultura andalusí. El jefe de colecciones de museos arqueológicos de Marruecos en Rabat, Aziz Idrissi. El director de la Escuela de Bellas artes y anteriormente jefe de colecciones arqueológicas en Marruecos y arqueólogo Medhi Zuak, y el gestor cultural tangerino Farid Othman. Estas entrevistas proporcionaron una información adicional considerable que enriquecieron la investigación y ofrecieron la oportunidad de entablar líneas de comunicación y trabajo entre ambas orillas.

Con el fin de conocer la parte documental y práctica de la arqueología in situ en el verano de 2017 tuvimos la oportunidad de trabajar como parte de los trabajadores voluntarios en una excavación arqueológica en Mértola, gracias a lo cual se pudo conocer de primera mano todo el proceso de búsqueda, documentación y tratamiento de piezas, lo que ha facilitado el conocimiento del lenguaje y la información necesaria que hay que dejar reflejada en fichas para su posterior estudio. Esta perspectiva, junto a los cursos específicos sobre arqueología realizados como "La documentación gráfica en arqueología" en la Universidad de Burgos o "La imagen científica y proyectada de la arquitectura, la ciudad y el patrimonio" en la Universidad de Granada han ayudado considerablemente a este fin documental.

Una vez ajustado el enfoque de estudio que se debe realizar a las piezas teniendo todo lo anteriormente mencionado en cuenta, se diseñó la ficha de catalogación utilizada para este estudio y que se presentará a continuación. Para ello se tuvieron en cuenta las plataformas genéricas ya mencionadas DOMUS o CERES utilizadas por los propios museos, pero se le realizó una adaptación al tipo de colección e investigación que se ha llevado a cabo. Asimismo, se acudió a trabajos de referencia de catalogaciones de instrumentos musicales como el realizado por Cristina Bordas, Instrumentos musicales en colecciones españolas: Museos de titularidad 
estatal (Vol. I y II) ${ }^{217}$, el trabajo de Rosselló Bordoy, Navarro Ortega y Flores Escobosa Del rito al juego: juguetes y silbatos de cerámica desde el Islam hasta la actualidad $^{218}$, así como la plataforma que recoge reconocidas colecciones de instrumentos musicales a nivel internacional y que da como resultado el museo virtual Musical Instruments Museum Online (MIMO) ${ }^{219}$. Contemplando asimismo las necesidades específicas de catalogación de este tipo de colección gracias a estos trabajos previos junto a publicaciones específicas como la publicada por el Centro de Documentación de Música y Danza del INAEM ${ }^{220}$ Las colecciones de instrumentos musicales y su valor patrimonial. España en el contexto internacional en colecciones de instrumentos musicales. Recomendaciones para su gestión, así como por experiencia propia al catalogar como museóloga la colección de instrumentos musicales para el Museo Interactivo de la Música, se procedió a realizar una plantilla que contemple todas estas casuísticas, así como que esté preparada para el público que puede sentirse interesado por esta investigación.

Al ser un estudio pluridisciplinar la investigación y ficha de catalogación debe estar adaptada para la consulta de distintos especialistas, por lo que se le dio un formato intuitivo y musical pero incluyendo datos de referencia necesarios para arqueólogos e historiadores. Como afirma Laura Hortelano tras el estudio de Catherine Homo-Lechner sobre la arqueomusicología, esta especialidad se encuentra en un campo parcial de la musicología, a mayor concreción la musicología histórica donde se encuentran las áreas de la organología, la iconografía, la acústica, psicología de la audición, fisiología del oído y la voz y la ejecución instrumental. Siendo así, las ciencias auxiliares por lo tanto de esta disciplina serían la arqueología, filología y lingüística, para la base documental histórica, la historia del arte para la iconografía y

\footnotetext{
217 Cristina Bordas Ibáñez, Instrumentos musicales en colecciones españolas: museos de titularidad estatal, Ministerio de Educación y Cultura (Vol. 1). Madrid: Centro de Documentación de Música y Danza. INAEM, 1999); Cristina Bordas Ibáñez, Instrumentos musicales en colecciones españolas: Museos de Titularidad Estatal (Vol. II) Centro de Documentación de Música y Danza. INAEM, 2001.

${ }^{218}$ Guillermo Rosselló Bordoy, Navarro Ortega, A., Flores Escobosa, Del rito al juego: juguetes y silbatos de cerámica desde el Islam hasta la actualidad. Junta de Andalucía: 2006.

219 "Musical Instrument Museums Online (MIMO)", http://www.mimo-international.com/MIMO/ (Última consulta: 18-10-2019).

220 Cristina Bordas Ibáñez y Elena Vázquez García, Las colecciones de instrumentos musicales y su valor patrimonial. España en el contexto internacional en colecciones de instrumentos musicales. Recomendaciones para su gestión. Centro de Documentación de Música y Danza. INAEM, 2019.
} 
la física y medicina para acústica y fisionomía ${ }^{221}$. Por las características de esta investigación el estudio acústico se quedaría como una futura línea de investigación.

Por lo tanto, la plantilla de catalogación que se incluye en los anexos de este trabajo aborda los siguientes puntos:

\section{$\mathrm{N}^{\mathrm{n}} 1$}

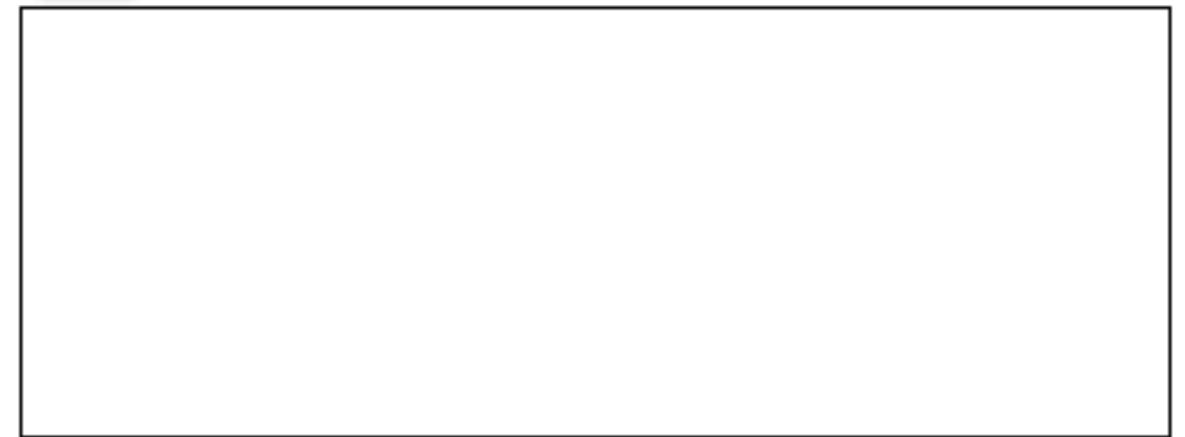

\section{Datos generales}

\begin{tabular}{|l|l|}
\hline Nombre & \\
\hline N*de inventario $^{*}$ & \\
\hline Ubicación aetual & \\
\hline Dimensiones & \\
\hline Cludad & \\
\hline Cronedogia & \\
\hline Caracteristicas merfológicas & \\
\hline Materiales & \\
\hline Conservacióm & \\
\hline
\end{tabular}

\section{Datos organológicos}

\begin{tabular}{|l|l|}
\hline Tipo de instrumento & \\
\hline Subdivisilin & \\
\hline Funcióm & \\
\hline Fabricación & \\
\hline Caracteristicas musicales & \\
\hline Posible relación iconogrifica & \\
\hline
\end{tabular}

\section{Datos arqueológicos}

\begin{tabular}{|l|l|}
\hline Procedencin & \\
\hline Yaciniento & \\
\hline Unidad Estratigrifica & \\
\hline $\begin{array}{l}\text { Contexto arquecológico } \\
\text { asociado }\end{array}$ & \\
\hline
\end{tabular}

\section{Bibliografia}

${ }^{221}$ Laura Hortelano Piqueras, “Arqueomusicología: bases para el estudio de los artefactos sonoros Prehistóricos”. Investigación de tercer ciclo de Universitat de Valencia, 2003, 18-19. 
Asimismo, no siendo la finalidad de esta investigación la catalogación de las piezas, sino un medio para un completo estudio de las mismas, éstas fueron igualmente estudiadas en el respectivo capítulo de la investigación desde los posibles orígenes de este instrumento y su recorrido histórico, así como clasificadas por su tipología y características físicas y musicales. Posteriormente se presentan por ciudades y lugares donde se han encontrado para la puesta en valor desde la perspectiva histórica y museológica, donde se habla de forma más específica de cada una de ellas según la información registrada sobre cada pieza.

Por último, con la intención de obtener formación sobre la lengua árabe básica y poder descifrar de forma muy humilde alguna palabra o texto concreto se comenzó el estudio de este idioma en la Escuela Oficial de Idiomas de Málaga.

\subsection{Dificultades encontradas durante la investigación}

Han sido varias las dificultades encontradas durante la recopilación de piezas que deben quedarse reflejadas:

- Pérdida de piezas: Tras una exhaustiva revisión de los Anuarios arqueológicos de Andalucía, más la revisión de trabajos sobre la temática y entrevistas con distintos arqueólogos y arqueólogas, se podrían encontrar referencias de ciertas piezas que no han podido ser halladas.

- Piezas particulares: El que las piezas no estén custodiadas por entidades de referencia, públicas o privadas, dificulta enormemente el estudio de las mismas, ya que resulta complejo el contacto con estos propietarios privados así como se depende de su disponibilidad y voluntaria colaboración.

- Información sesgada sobre las piezas: Por diversos motivos como puede ser pérdida de documentos, jubilaciones, cambios de sedes de trabajos, escaso personal, etc., hay ciertas piezas que se encuentran con carencias informativas.

- Dataciones ambiguas: la dificultad de la actividad arqueológica y las concretas casuísticas que se dan en los yacimientos hace que en ciertos casos se encuentren piezas que no pueden ser datadas o las circunstancias donde se ven envueltas pueden conducir al error, esto ocurre cuando se hallan piezas en vertederos o similares.

- Anuarios arqueológicos no públicos: A partir de 2008 los anuarios arqueológicos dejan de publicarse, pasando a tener que solicitarse la consulta de expedientes concretos, pudiendo tomar nota de los mismos sin fotografiarlos. Esto además de conllevar mayor inversión de tiempo imposibilita un sondeo de posibles piezas 
encontradas ya que el investigador o investigadora debe ir tras un dato concreto. Han sido varias las piezas halladas por la lectura general de Anuarios. Esto no quiere decir que en estas publicaciones se volcase toda la información de las excavaciones, pero al menos daba nociones de las mismas y ofrecía los nombres de los responsables.

\subsection{Aspectos éticos}

Para la consulta de materiales arqueológicos se han pedido permisos a los responsables de las respectivas colecciones. Prácticamente todos los museos están dentro de la Red de Museos de Andalucía, por lo que la petición de consulta y fotografiado de piezas se puede realizar de forma telemática a través de la página web de la Junta de Andalucía, aunque la mayoría cuenta con solicitudes propias que suelen gestionar de forma más ágil. Este aparente sencillo trámite resulta, en ciertas ocasiones, un eslabón más para la persona interesada en acceder a ellas ya que puede retrasar varios años el encuentro con la pieza. 


\section{Resultados}

\subsection{Los instrumentos musicales en los tratados de los sabios andalusíes ss. IX-} XV

Importantes testimonios sobre al-Andalus han llegado hasta nuestros días gracias a la conservación de distintos manuscritos realizados por cronistas e historiadores andalusíes permitiendonos conocer las raíces de la historia. Los sabios andalusíes dominaron las humanidades, las ciencias y artes, lo que llevo a mostrar en sus tratados una amplia perspectiva sobre la vida cultural de al-Andalus.

Los analistas han traducido importantes trabajos, que posibilitan el estudio de los mismos y permiten superar, en parte, las barreras idiomáticas a investigadores en los distintos campos como el de la musicología. A pesar de la pérdida de numerosos códices como resultado de las confrontaciones políticas que se han ido sucediendo a lo largo de la historia, la información que llega hasta nuestros días gracias a la tradición oral y a través de los documentos escritos, permiten acercarnos al conocimiento sobre la música en al-Andalus ${ }^{222}$.

Para realizar una reconstrucción histórica de la música en al-Andalus, se cuenta con tres importantes fuentes de documentación. Por un lado, estarían los tratados, más o menos específicos sobre música, por otro la poesía, la cual refleja la gran presencia de la música en la vida andalusí, y por último la jurisprudencia, donde se puede observar el peso que la música tenía en al-Andalus a través de la legislación específica.

Cortés García en su libro La música árabe y andalusí de las dos orillas en los estudios musicológicos (ss. XVIII-XXI) ${ }^{223}$, realiza un recorrido por los primeros pasos que se dieron en este tipo de investigaciones situando el inicio de las mismas en investigadores como el historiador y antólogo al-Maqqari (1578-1632) con Nafh altibb en The History of Mohammedan Dynasties in Spain y el orientalista holandés Reinhart Dozy (1820-1883) en Analectes sur l'histoire et la littérature des Arabes d'Espagne, así como la obra traducida por P. Gayangos del erudito Ibn al-Abbar

\footnotetext{
222 Manuela Cortés García, "Fuentes escritas para el estudio de la música en al-Andalus (Siglos XIIIXVI)", en Fuentes musicales en la Península Ibérica, ed. Maricarmen Gómez y Màrius Bernadó. Lleida, 2002, 289-304.

223 Manuela Cortés García, La música árabe y andalusí de las dos orillas en los estudios musicológicos (ss. XVIII-XXI). Málaga: Ediciones del Genal, 2018.
} 
(1199-1240) Kitab al-Takmila (Suplemento biográfico de los sabios andalusíes) ${ }^{224}$, entre otros. Todos estos trabajos formarían la raíz inicial de un importante camino que más tarde recorrerían investigadores como Julián Ribera y Tarragó, Henri Pérès, Henry George Farmer, Mahmoud Gettat, Amnon Shiloah, Emilio García Gómez, Christian Poché y Manuela Cortés.

Inicialmente Amnon Shiloah (1928-2014), es quien, entre sus numerosas publicaciones realiza la catalogación de algunos de los manuscritos musicales andalusíes en un compendio en dos volúmenes: The Theory of arabic writing (c.9001900) ${ }^{225}$ y su segundo volumen The Theory of Music in Arabic Writings (c.9001900). Descriptive Catalogue of Manuscripts in Libraries of Egypt, Israel, Morocco, Russia, Tunisia, Uzbekistan, and Supplement to $B X^{226}$. Estos trabajos resultan una herramienta fundamental para musicólogos investigadores de esta temática, siendo el resultado de previos pasos realizados por investigadores como el franco-alemán Joseph Derembourg (1811-1895) quien realizó la catalogación Les manuscrits árabes de l'Escorial ${ }^{227}$, el realizado por Miguel Lafuente y Alcántara (1817-1850) en Catálogo de códices arábigos adquiridos en Tetuán ${ }^{228}$ y Francisco Guillén Robles (1846-1926) con Catálogo de manuscritos árabes existentes en la Biblioteca Nacional de Madrid ${ }^{229}$, donde englobaba los códices de la Biblioteca General y Archivos de Tetuán ${ }^{230}$.

Julián Ribera y Tarragó (1858-1934) ${ }^{231}$ será una pieza clave en el estudio de los manuscritos musicales andalusíes. Sus primeros trabajos sobre los tratados en bibliotecas emirales y la relevancia de los instrumentos musicales de origen árabe será una continuación de trabajos anteriores como el desarrollado por el orientalista

224 Ibidem, 43.

225 Amnon Shiloah, The Theory of Music in Arabic Writing (c. 900-1900). Munich: International Musicological Society and the International Association of Music Libraries, 1979.

226 Amnon Shiloah, The Theory of Music in Arabic Writings (c.900-1900). Descriptive Catalogue of Manuscripts in Libraries of Egypt, Israel, Morocco, Russia, Tunisia, Uzbekistan, and Supplement to B X. Munich: G. Henle Verlag München, 2003.

227 Hartwig Derenbourg. Les manuscrits arabes de l'Escurial. E. Leroux, 1884.

228 Emilio Lafuente y José Maria de Eguren. Catálogo de los códices arábigos adquiridos en Tetuán. Imprenta nacional, 1859.

${ }^{229}$ Francisco Guillén Robles, Catálogo de los manuscritos árabes existentes en la Biblioteca Nacional de Madrid. Imprenta y Fundación de M. Tello, 1889.

${ }^{230}$ Todos estos trabajos aparecen citados en el libro de Manuela Cortés García, La música árabe y andalusí de las dos orillas en los estudios musicológicos (ss. XVIII-XXI). Málaga: Ediciones Genal, 2018, 46.

231 "Julián Ribera y Tarragó", http://dbe.rah.es/biografias/4193/julian-ribera-y-tarrago (Última consulta: 21-10-2019). 
europeo R.G. Kiesewetter y G.A. Villoteau ${ }^{232}$. Este arabista asienta las bases de la música oriental a través de el Kitab al-Agani (Libro de las Canciones) de al-Isfahani $(\mathrm{s} . \mathrm{IX})^{233}$. De él se han tenido presente para esta investigación los trabajos La música en las Cantigas, estudio sobre su origen y naturaleza ${ }^{234}$ y La música árabe y su influencia en la española ${ }^{235}$.

De Henry George Farmer (1882-1965) se ha hablado ampliamente anteriormente en esta investigación de su faceta como arabista cercano a los instrumentos musicales y se han mencionado algunas de sus principales obras genéricas que incluían la presencia de instrumentos.

Henri Pérès (1890-1983) ${ }^{236}$ orientalistas enfocado a la poesía andalusí, realizará una gran aportación a este campo de los sabios andalusíes cercanos al arte y la música mediante su trabajo Esplendor de al-Andalus ${ }^{237}$. En él realiza una recopilación de poesías andalusíes por temáticas sociales reflejando la gran presencia de este arte, y por lo tanto colateralmente en la mayoría de los casos la música, en la vida hispano-musulmana medieval.

Emilio García Gómez (1905-1995) dedica gran parte de su labor investigadora al tratamiento de los textos andalusíes. Entre sus trabajos se encuentra la traducción de la epístola de al-Saqundi publicada como El elogio al islam ${ }^{238}$.

Mahmoud Guettat (1945) cuenta, asimismo, con distintos trabajos de gran relevancia para esta temática de estudio; entre ellas estaría La musique andalouse et ses prolonguements contemporains au Magreb ${ }^{239}$ y su mencionado trabajo La música andalusí en el Magreb: Simbiosis musical entre las dos orillas del Mediterráneo ${ }^{240}$.

Igualmente, Christian Poché (1938-2010) cuenta con distintos trabajos relevantes para el estudio de los tratadistas andalusíes, entre ellos su libro traducido al

\footnotetext{
232 Ibidem, 58 -59.

233 Manuela Cortés García, La música árabe y andalusí de las dos orillas en los estudios musicológicos (ss. XVIII-XXI). Málaga: Ediciones del Genal, 2018, 77-78.

234 Julián Ribera y Tarragó, La música de las cantigas, estudio sobre su origen y naturaleza. Madrid: Real Academia Española de la Historia, 1922.

235 Julián Ribera y Tarragó, La música árabe y su influencia en la española. Valencia: Pre-Textos (Música "la Huella Sonora"), 2000.

236 “Henri Pérès”, https://data.bnf.fr/fr/11919115/henri peres/ (Última consulta 21-10-2019).

237 Henri Pérès, Esplendor de al-Andalus. Madrid: Libros Hiperión, 1983.

238 Emilio García Gomez, Elogio al Islam español. Valladolid: Publicaciones de las Escuelas de Estudios Árabes de Madrid y Granada: Serie B. Núm. 2, 2005.

239 Mahmoud Gettat, La musique andalouse et ses prolonguements contemporains au Magreb, 1977.

240 Mahmoud Gettat, María del Mar Carrillo y Manuela Cortés García, La música andalusí en el Magreb: Simbiosis musical entre las dos orillas del Mediterráneo. Fundación El Monte, 1999.
} 
español por la editorial Akal La música arábigo-andaluza ${ }^{241}$ y su artículo "Un nouveau regard sur la musique d'al-Andalus" ${ }^{242}$.

Cortés García, asimismo, cuenta con numerosas publicaciones acerca de los tratados andalusíes relacionados con la música. Concretamente es una de las grandes figuras a nivel internacional sobre temas de organología, arqueomusicología y sabios andalusíes en relación con esta temática. Los trabajos de esta arabista están basados en el estudio y análisis de los manuscritos árabes y el estudio de la música en su relación con las distintas disciplinas. Entre sus numerosas obras, cabe reseñar Pasado y presente de la música andalusi $i^{243}$, Música y poesía en el esplendor omeya ${ }^{244}$ y La música en la Zaragoza islámica ${ }^{245}$.

A continuación se presentará un estudio sobre los sabios andalusíes que aportarán noticias sobre los instrumentos musicales en al-Andalus, siguiendo un orden cronológico.

\subsubsection{Ibn 'Abd Rabbihi, Abu 'Umar (Córdoba, 860- Córdoba, 940) ${ }^{246}$}

Reconocido poeta y antólogo, fue un hombre apasionado por la música y el canto $^{247}$. Este sabio andalusí fue autor de la primera antología sobre temáticas diversas basadas en obras orientales anteriores ${ }^{248}$, el Kitab al- 'Iqd al-farid (El collar único), siendo la única obra íntegramente conservada de Ibn Abd Rabbihi ${ }^{249}$. Según sus biógrafos, en un principio el nombre de este trabajo era al-'Iqd (El collar) pero fue tal la impresión de los copistas al conocerlo que le añadieron el calificativo al-farid (único, sin par o incomparable $)^{250}$. Mediante esta obra Ibn abd Rabbihi se propuso compilar todos los conocimientos que debería poseer el hombre culto de la época, de

\footnotetext{
${ }^{241}$ Christian Poché, La música arábigo-andaluza (con CD). Ediciones Akal, 1997.

${ }^{242}$ Christian Poché, "Un nouveau regard sur la musique d'al-Andalus: le manuscrit d'al Tifashi" Revista de musicología, 16, 1, 1993, 367-379.

${ }^{243}$ Manuela Cortés García, Pasado y presente de la música andalusí. Sevilla: El Monte, 1996.

${ }^{244}$ Manuela Cortés García, Música y poesía en el esplendor Omeya. Córdoba: Ayuntamiento y Fundación Foros de Córdoba, 2001.

245 Manuela Cortés García, La música en la Zaragoza Islámica. Zaragoza: Instituto de Estudios Islámicos y del Oriente Próximo, 2009.

246 Julia Haremska, "Ibn 'Abd Rabbihi, Abu 'Umar", en Enciclopedia de la cultura andalusí, Vol. 1. Fundación Ibn Tufayl de estudios árabes, 2012, 621-629.

247 Ibidem, 620.

248 Manuela Cortés García, "Sobre la música y sus efectos terapéuticos en la epístola sobre las Melodías de Ibn Bayya”, en Separata de La Revista de Musicología XIX, no. 12, 1996, 12.

249 Julia Haremska, "Ibn 'Abd Rabbihi, Abu 'Umar", en Enciclopedia de la cultura andalusí, Vol. 1. Fundación Ibn Tufayl de estudios árabes, 2012, 620.

${ }^{250}$ Josefina Veglison, El Collar Único de Ibn Abd Rabbihi. Madrid: Editorial Síntesis, 2007, 19.
} 
ahí que escriba con un enfoque enciclopédico, según se comprueba en la breve introducción que antecede a cada obra donde el autor resume los contenidos ${ }^{251}$. Asimismo incluirá actitudes, dichos, palabras de Mahoma y sus familiares, así como información histórica del Islam incluyendo antecedentes, con anécdotas y juicios que muestran una mirada crítica sobre las temáticas que cada parte de esta obra magna aborda $^{252}$. Según Haremska, la antología cuenta con veinticinco volúmenes de aproximadamente 150 páginas $^{253}$. Cada una las sitúa bajo el título de una piedra preciosa o perla hasta el libro número trece, el cual sirve de broche. A partir del mismo se repetirá la misma serie de gemas en orden inverso y acompañadas por el calificativo de "segundo" ${ }^{254}$. El orden de la enciclopedia corresponde a la escala jerárquica de valores que les otorga su autor, perteneciendo el volumen dedicado a la música al último escalafón social "costumbres, gustos, distracciones, vida familiar y cotidiana del hombre y la mujer"255. Ibn Abd Rabbihi, defiende un enfoque didáctico y formativo en su obra, resaltando que el lector podrá ver el saber como "un árbol de ramas extendidas, que crece en tierras ricas y puras, dando tiernos frutos maduros" 256 .

En lo concerniente a la música y el canto, Ibn Abd Rabbihi dedica el volumen veinte titulado Kitab al-Yaquta al-taniya (El libro del segundo zafiro) a la música oriental. En él lleva a cabo un recopilatorio sobre la historia de dicha música, además de explicar los distintos tipos de canto y las virtudes de una buena voz. Cortés García puntualiza que al analizarlo se puede percibir que fue escrito con anterioridad a la obra de al-Isfahani, lo que revela que conocía tratados orientales anteriores, considerados perdidos ${ }^{257}$. Asimismo, el autor incluye anécdotas sobre cantores reconocidos, el efecto que la buena voz puede tener sobre las personas; también incluye poemas sobre los instrumentos musicales y su evolución, como el laúd y los

\footnotetext{
251 Julia Haremska, "Ibn 'Abd Rabbihi, Abu 'Umar", en Enciclopedia de la cultura andalusí, Vol. 1. Fundación Ibn Tufayl de estudios árabes, 2012, 625.

252 Josefina Veglison, El Collar Único de Ibn Abd Rabbihi. Madrid: Editorial Síntesis, 2007, 22-23.

253 Ibídem, 24.

254 Ibídem, 20.

255 Ibidem, 21.

256 Julia Haremska, "Ibn 'Abd Rabbihi, Abu 'Umar", en Enciclopedia de la cultura andalusí, Vol. 1. Fundación Ibn Tufayl de estudios árabes, 2012, 625.

257 Manuela Cortés García, "Estatus de la Mujer en la Cultura Islámica. Las Esclavas-Cantoras (ss.IXXIX)", en Mujer versus Música. Colección Feminismo Musical. Editorial Rivera Mota, 2011, 156.
} 
diferentes tipos de composiciones ${ }^{258}$ (aunque no comenta sobre su ejecución), el sonido y las cantoras orientales ${ }^{259}$.

Una parte de esta obra fue traducida y publicada por H. G. Farmer en "Music: The priceless jewel", Collection of oriental writers on music, Bearsdem, $1942^{260}$. Igualmente, la arabista Josefina Veglison publica un breve resumen sobre esta antología. Veglison, en el fragmento de esta publicación dedicado a la música, indica la importante escuela de canto del músico Ziryab, donde formaba a famosas cantoras que actuaban, acompañándose del 'ud (laúd), en "tertulias de mecenas y poderosos". Asimismo, puntualiza que este libro también trata de la evolución de los instrumentos musicales $^{261}$. Del laúd comenta que fue inventado por Lamek, hijo de Caín, e incluye otra versión con Tolomeo como inventor, además de detallar otros nombres que se aplicaban a este instrumento, como kiran, mizhar y barbat ${ }^{262}$. Josefina Veglison refleja también el poder que Ibn Abd Rabbihi le daba a la música a través de la pregunta que este sabio realiza a un hombre que se encontraba tallando un laúd: “¿para quién afilas esa espada?” equiparando, por lo tanto, el poder de este instrumento musical con un arma mortífera ${ }^{263}$.

Constatando la importancia del laúd, Ibn Abd al-Rabbihi incluye en este manuscrito, un poema sobre el laúd y sus cuerdas:

\footnotetext{
"Las cuerdas muthana (segundas) y muthalat (terceras) del laúd laten al alba cuando los pájaros alegran con sus trinos, mientras las sonajas (al-hayarat) marcan los ritmos y al hablar les responde la guitarra (al-kitarat) al pulsarla el músico. El laúd $(a l-u d)$ se erige en rey caminando lento, precedido de su guarnición, orgullosos junto a sus cuerdas (al-awtar), cual Cosroes hijo de Hormuz precedido del cortejo de sus jinetes"264
}

258 Julia Haremska, "Ibn 'Abd Rabbihi, Abu 'Umar", en Enciclopedia de la cultura andalusí, Vol. 1. Fundación Ibn Tufayl de estudios árabes, 2012, 627.

${ }^{259}$ Manuela Cortés García, "La música, los instrumentos y las danzas andalusíes y moriscas en las fuentes árabes y cristianas (ss. IX-XVII)", Cuadernos del CEMYR, 25, 2017, 150; Manuela Cortés García, "Escuelas musicales andalusíes y magrebíes: perfiles y sistemas pedagógicos”, en Revista del Centro de Estudios Históricos de Granada y su Reino, no. 23, 2012, 47.

260 También en JRAS, 1941, 22-30 y 127-44.

261 Josefina Veglison, El Collar Único de Ibn Abd Rabbihi (Madrid: Editorial Síntesis, 2007), 54.

262 Amnon Shiloah, The Theory of Music in Arabic Writings (c.900-1900). Descriptive Catalogue of Manuscripts in Libraries of Europe and the U.S.A. Munich: G. Henle Verlag München, 1979, 139.

263 Josefina Veglison, El Collar Único de Ibn Abd Rabbihi. Madrid: Editorial Síntesis, 2007, 56.

264 Manuela Cortés García, La música en la Zaragoza Islámica. Zaragoza: Instituto de Estudios Islámicos y del Oriente Próximo, 2009, 35. 
Cortés García en la traducción del capítulo al-Sawt al-Hasan (La buena voz), se reflejan los efectos que le otorgaban a ésta producir en los oyentes: "gran parte de los médicos mantienen la teoría de que la voz hermosa corre por el cuerpo y por las venas, purifica la sangre, eleva el alma, alivia el corazón y se estremecen los miembros" 265 .

Ibn Adb Rabbihi, asimismo, llega a equiparar la voz de David, personaje bíblico, con el mizmar, aerófono de lengüeta doble, mostrando así su valoración hacia el sonido de este instrumento ${ }^{266}$. Igualmente, contextualiza la presencia de la mi'zafa, cítara, en manos del Profeta David mientras recita salmos que unen a hombres y pájaros junto a él ${ }^{267}$. No serán éstos los únicos instrumentos que el sabio andalusí mencionará ya que incluye breves descripciones sobre cordófonos o sobre el nai, flauta de caña ${ }^{268}$. En cuanto a la licitud de la música y el uso de los instrumentos según la escuela teológica y jurídica dominante, Ibn Abd Rabbihi se posicionaría en defensa del uso de instrumentos musicales frente a los que no querían ${ }^{269}$.

\subsubsection{Ibn Sida, Abu l-Hasan (Murcia, 1007-8- Denia, 1066) ${ }^{270}$}

Ibn Sida conocido como El ciego de Murcia ${ }^{271}$, fue historiador, médico, lexicógrafo, filósofo, astrónomo, poeta, músico y compositor, experto en astronomía, matemáticas y óptica ${ }^{272}$. Como sabio fue valorado por el emir de la Taifa de Denia, quien le alentó a escribir un diccionario en tres volúmenes de términos árabes. Entre ellos, el Kitab

265 Manuela Cortés García, "Sobre la música y sus efectos terapéuticos en la epístola sobre las Melodías de Ibn Bayya”, en Separata de La Revista de Musicología XIX, no. 12, 1996, 12.

266 Traducción propia de "you have been given a reed-pipe (mizmar) from the reed-pipes of David". Henry George Farmer, "Music: The Priceless Jewel. From the Kitab Al-'iqd Al-Farid of Ibn 'Abd Rabbihi (d. 940). Edited and Translated", en Studies in Oriental Music. Frankfurt: Institut für Geschichte der Arabisch-Islamischen Wissenschaften, 1986, 6.

267 Traducción propia: "David Prophet (Upon him be peace) had a cithara (mi'zafa) on which he would play when he read the psalms, in order that the jinn ${ }^{267}$, and men, and birds might gather to him". Ibídem, 14.

${ }^{268}$ Henry George Farmer, "Music: The Priceless Jewel. From the Kitab Al-'iqd Al-Farid of Ibn 'Abd Rabbihi (d. 940). Edited and Translated" Vol. 1, en Studies in Oriental Music. Frankfurt: Institut für Geschichte der Arabisch-Islamischen Wissenschaften, 1986.

269 Reynaldo Fernadez Manzano, "Introduccion al estudio de los instrumentos musicales de alAndalus", en Cuadernos de Estudios Medievales y Ciencias y Técnicas Historiográficas 12.13, 1983, 55.

270 Dolores Serrano-Niza, "Ibn Sida, Abu 1-Hasan”, en Enciclopedia de La Cultura Andalusí, Vol. 5. Fundación Ibn Tufayl de estudios árabes, 2012, 352-363.

${ }^{271}$ Manuela Cortés García, La música en la Zaragoza Islámica. Zaragoza: Instituto de Estudios Islámicos y del Oriente Próximo, 2009, 30.

272 Manuela Cortés García, "Escuelas musicales andalusíes y magrebíes: perfiles y sistemas pedagógicos", Revista del Centro de Estudios Históricos de Granada y su Reino, 23, 2012, 40. 
al-Mujassas (Diccionario de términos especializados), obra que resulta especialmente importante desde el punto de vista organológico ya que los volúmenes II y XI recogen términos musicales, así como algunos cordófonos demostrando la importante variedad existente en el siglo $\mathrm{XI}^{273}$.

El musicólogo Amnon Shiloah indica que este diccionario estaba dividido en setenta obras subdivididas en capítulos y dedicadas cada una a la terminología correspondiente a temas concretos como la mujer, la comida o los caballos. En el libro XIII hay un capítulo titulado "sobre el canto y los instrumentos musicales", donde cita varios tipos de laúdes de mango corto como son: 'ud, mizhar, kiran, barbat, 'artaba y urtuba, términos relativos al 'ud y su técnica, laúdes de mango largo: tunbur, tinbar, dirridj, clarinetes dobles como mizmar, zammara, zamkhara, kussab, flautas: nay, yara, iran, hayra'a, un cuerno: buk, y los atabales: tabl, kabar, kuba, duff, daffata ${ }^{274}$.

Cortés García aclara que los instrumentos musicales abordados por Ibn Sida son diecisiete, siendo cuatro los cordófonos clásicos tipo laúd de mango corto: al-kiran, instrumento preislámico, al-ud, al-barbat, de origen persa y al-artaba, variante del anterior. De mango largo nombra al-tunbur (o al-tinbar) de dos o tres cuerdas, y aldirriy, instrumento variante del anterior. Como último cordófono nombra al-mi'zaf, familia de las arpas y cítaras cuyo origen se remonta al periodo mesopotámico y faraónico. Dentro de los aerófonos distingue dos tipos, al-nai, de caña o hueso y alya-ra', pastoril o popular. En cuanto a los de doble lengüeta nombra al-mizmar, aliran y al-zammara, las cuales son relacionadas con la música popular. Por último, mencionará al-buq, el albogue, relacionado con escenas militares. En cuanto a los instrumentos de membrana, hará referencia al-daff, pandero, al-tabl, tamborcillo cilíndrico, al-kabar de barro o cerámica, al-kassaba, tipo darbuka de madera y alhayra'a, relacionado normalmente con crótalos o castañuelas ${ }^{275}$.

Asimismo, el académico y arabista Julián Ribera y Tarrago, en La Música de las Cantigas se hace eco del contenido de este diccionario, siendo el primer investigador que deja constancia de los primeros tratados descubiertos en su época.

\footnotetext{
273 Manuela Cortés García, La música en la Zaragoza Islámica. Zaragoza: Instituto de Estudios Islámicos y del Oriente Próximo, 2009, 30-31.

${ }^{274}$ Amnon Shiloah, The Theory of Music in Arabic Writings (c.900-1900). Descriptive Catalogue of Manuscripts in Libraries of Europe and the U.S.A. Munich: G. Henle Verlag München, 1979, 210.

275 Manuela Cortés García, La música en la Zaragoza Islámica. Zaragoza: Instituto de Estudios Islámicos y del Oriente Próximo, 2009, 31-33.
} 


\subsubsection{Al-Turtusi, Abu Bakr (Tortosa, 1059 - Alejandría, 1120) ${ }^{276}$}

Afamado jurista, fue autor del Kitab Tahrim al-gina' wa-l-lahw 'alà l-sufiya fi raqsi-him wa-sama'i-him (Libro de la prohibición del canto y de las danzas sufíes y sus ceremonias de $a l$ - $\operatorname{sam}^{\prime} a^{277}$.

En este códice al-Turtusi muestra el carácter rigorista de la escuela jurídica malikí dominante en al-Andalus y Oriente, y como jurista, se posiciona en contra de la música, la audición, el canto y la danza, con especial rechazo al comercio de las esclavas cantoras ${ }^{278}$. Justificando su posición, se basa en las citas de tradicionalistas, ulemas y representantes de escuelas jurídicas orientales, andalusíes y magrebíes ${ }^{279}$. Asimismo, mantiene su postura de ilegalidad con respecto a los músicos remunerados y al uso de instrumentos como el laúd de mango corto, el tunbur y el mizmar, al considerar que atraían las fuerzas del mal y llegando a equipararlos a los efectos del consumo abusivo del vino o alucinógenos ${ }^{280}$.

Cortés García se hace eco del contenido de este manuscrito al mostrar las controversias entre la ortodoxia islámica, con respecto a la música y sus intérpretes, haciendo diferenciación entre hombre y mujeres ${ }^{281}$. Asimismo, retoma la información de la analista experta en jurisprudencia islámica Arcas Campoy, quien recalca al analizar una segunda obra de al- Turtusi, el Kitab al-hawadith wa-l-bidda; la consideración del autor sobre la imposibilidad de la correcta práctica de la religión por parte del pueblo si no seguían las leyes de los ulemas, algo que no contemplaban, añade, los sufíes al incluir prácticas de danza y éxtasis en las mezquitas y lugares públicos. En el Kitab tahrim al-sama' (Tratado sobre la prohibición de al-sama) Arcas Campoy subraya la postura del mufti y jurisconsulto, Abu Ishaq al-Shatibi (Granada, 1320-1388), quien se muestra más moderado en sus críticas hacia estas

\footnotetext{
276 Maribel Fierro, “Al-Turtusi, Abu Bakr”, en Enciclopedia de la Cultura Andalusí, Vol. 7. Fundación Ibn Tufayl de estudios árabes, 2012, 500-531.

277 Ibídem, 500.

278 Manuela Cortés García, "Estatus de la Mujer en la Cultura Islámica. Las Esclavas-Cantoras (Ss.IXXIX)”, en Mujer versus Música. Colección Feminismo Musical. Editorial Rivera Mota, 2011, 160.

279 Manuela Cortés García, La música árabe y andalusi de las dos orillas en los estudios musicológicos (ss. XVIII-XXI). Málaga: Ediciones Genal, 2018, 94.

${ }^{280}$ Manuela Cortés García, La música en la Zaragoza Islámica. Zaragoza: Instituto de Estudios Islámicos y del Oriente Próximo, 2009, 77.

${ }^{281}$ Manuela Cortés García, "La música, los instrumentos y las danzas andalusíes y moriscas en las fuentes árabes y cristianas (Ss. IX-XVII)", Revista del Centro de Estudios Históricos de Granada y su Reino, 23, 2012, 157; Manuela Cortés García, "Escuelas musicales andalusíes y magrebíes: perfiles y sistemas pedagógicos", Revista del Centro de Estudios Históricos de Granada y su Reino, 23, 2012, 53
} 
prácticas $^{282}$.

Con respecto a este último tratado, Amnon Shiloah subraya los aspectos legales sobre escuchar e interpretar música afirmando que, según al- Turtusi, la doctrina malikí prohíbe la música y su escucha. Según el musicólogo este códice está dividido en nueve partes y trata, entre otros temas sobre los instrumentos como el ' $u d$, tunbur, ma'azif, kitara, mizmar, hadib y duff prohibiendo el uso de estos, al mismo tiempo que condena el dinero ganado al interpretarlos en público ${ }^{283}$. Asimismo, en el segundo volumen de The Theory of Music in Arabic Writings (c.900-1900), centrado en Egipto, Israel, Marruecos, Rusia, Túnez y Uzbekistan, habla de otro tratado de este sabio andalusí titulado Kitab tahrim al-ghina' wa'l-sama donde perfilando los temas anteriormente vistos en su trabajo puntualiza de forma más concreta sobre ellos. Este segundo trabajo cuenta con una introducción y diecisiete capítulos compuestos por alrededor de ciento setenta y dos párrafos de diferentes longitudes. Del capítulo 1 al 4 trata la prohibición de la música en general y a partir del mismo hasta el final aborda el sama' sufí. En el primer capítulo titulado, según la traducción de Amnon Shiloah: "Evidencias que demuestran que escuchar música es censurable para los hombres y prohibido para las mujeres" 284 menciona los instrumentos musicales que no deben ser interpretados en público, como son: 'ud, tunbur, mizmar, qitar, zammara, tabl y qadib $^{285}$.

\subsubsection{Abu L-Salt b. Umayya al-Dani (Denia, 1068- 1134)}

Conocido en las fuentes cristianas como Abusale, en su formación contó con reconocidos preceptores, por lo que posteriormente buscaría un reconocimiento que al no conseguír le haría emigrar a Oriente (1096), viviendo en El Cairo y Alejandría y visitando Siria e Iraq. Posteriormente se asentaría en Mahdiyya (Túnez) donde enseñaría la música andalusí, maluf, y logrando la fama como laudista y compositor

\footnotetext{
${ }^{282}$ Manuela Córtés García, "Aproximación al universo musical sufi de al-Andalus en las cofradías, los tratados y la impronta de sus poetas en las nawbas magrebíes (Ss. XVIII-XX)", en Música Oral del Sur $\mathrm{n}^{\mathrm{o}} 13,2016,23$.

${ }^{283}$ Amnon Shiloah, The Theory of Music in Arabic Writings (c.900-1900). Descriptive Catalogue of Manuscripts in Libraries of Europe and the U.S.A. Munich: G. Henle Verlag München, 1979, 351.

284 Traducción propia de "evidence showing that the listening to music is reprehensible for men and forbidden for women".

285 Amnon Shiloah, The Theory of Music in Arabic Writings (c.900-1900). Descriptive Catalogue of Manuscripts in Libraries of Egypt, Israel, Morocco, Russia, Tunisia, Uzbekistan, and Supplement to B $X$. Munich: G. Henle Verlag München, 2003, 187.
} 
de moaxajas musicalizadas ${ }^{286}$. Será en esta última época cuando escribirá el tratado Risalat fi l-musiqa (Epístola sobre la música) donde dedica un capítulo a los cordófonos y aportando interesantes datos sobre al-ud (laúd) y tunbur (bandola) y rebab (rabel). El musicólogo Hanoch Averany realizó una traducción inglesa de esta epístola basándose en una copia hebrea de un copista del siglo XIII judeo-sefardí emigrado a Provenza donde según Cortés García el copista tuvo que realizar un lenguaje especial tomados del árabe y la propia inventiva, lo que dificulta la traducción de los términos específicos, como pueden ser los musicales ${ }^{287}$. Asimismo, según la investigadora, este tratado se encuentra articulado en tres grandes apartados: I. Introducción a la ciencia musical; II. Teoría de la música (materias y formas); III. Práctica de la música: materia y su forma. Este último, trata sobre los instrumentos musicales ${ }^{288}$. En este último capítulo el autor diferencia los sonidos naturales, realizados por la garganta o manos del hombre, de los artificiales, realizado por instrumentos como "el laúd (al-ud) y al-barbat, al-kanun (la cítara), al-rabab (el rabel), al-tunbur en sus dos variantes: al-bagdadi (de la Escuela de Bagdad) y aljurasani (Escuela persal del Jurasán), junto con el mizmar como aerófono, diferenciación que establecen los autores clásicos griegos"289.

Según el musicólogo Hanoch Avenary (1948-1965) ${ }^{290}$, el tratado resulta actual en su forma de abordar los instrumentos musicales.

\subsubsection{Ibn Bayya, Abu Bark (Zaragoza, finales s.XI- Córdoba, 1139) ${ }^{291}$}

Conocido en los textos latinos como Avempace, fue un excelente tañedor de instrumentos $^{292}$. Al- Saqundi en su Risala fi Fadl al-Andalus ensalzando al-Andalus realiza la siguiente pregunta retórica “¿Tenéis en música y filosofía alguien

\footnotetext{
286 Manuela Cortés García, La música en la Zaragoza Islámica. Zaragoza: Instituto de Estudios Islámicos y del Oriente Próximo, 2009, 37.

${ }^{287}$ Ibídem, 36.

${ }^{288}$ Ibidem, 103.

289 Ídem.

290 “Hanoch Avenary" https://jewish-music.huji.ac.il/content/hanoch-avenary (Última consulta: 10-012020).

291 Joaquín Lomba Fuentes y José Miguel Puertas Vílchez, "Ibn Bayya, Abu Bark”, en Enciclopedia de la Cultura Andalusí, Vol. 2. Fundación Ibn Tufayl de estudios árabes, 2012, 624-661.

292 Manuela Cortés García, "Tratados musicales andalusíes de la Escuela Levantina y aportaciones al marco interdisciplinar (Ss. XI-XIII)", ITAMAR. Revista de investigación musical: territorios para el arte, 2008, 171.
} 
comparable a Ibn Bayya?" ${ }^{293}$ reflejando así los saberes de este tratadista entre sus coetáneos.

Avempace fue autor de una obra perdida Sobre las melodías musicales (Fi lAlhan $)^{294}$, a través de trabajos que le hacen referencia a esta obra se sabe que defiende las correlaciones entre las melodías y el temperamento humano "planteando así un pensamiento orientado tanto hacia la teoría y estética musicales como a su valor educativo, ideas que, además de al-Farabi, pudo aprenderlas en las célebres Rasa'il Ijwan al-safa' wa-jullan al-wafa' (Epístola de los Hermanos de la Pureza y Amigos de la Fidelidad)".

Según sus biógrafos, con las siguientes palabras expresa Ibn Bayya la relación entre sonidos y temperamento: "Si se produce una afinidad (taskul) y concordancia (tawafuq) de caracteres (tiba), el alma siente un anhelo y, entonces, actúa y expansiona su incorporeidad espiritual (ruhaniya) y se regocija (inbasatat) emanando afabilidad (unsa) de su materia incorpórea" ${ }^{295}$.

Posteriormente comenta la capacidad de las melodías para influir en el alma donde expresa que a través de un músico "hábil" que sea conocedor de la técnica de los sabios relacionado con los temperamentos humanos puede tocar cuerdas, acordes e intensidades que pueden conducir a los fines psicológicos perseguidos. Ibn Bayya relaciona los cuatro "tipos humanos": colérico, sanguíneo, flemático y melancólico con las cuerdas nombradas respectivamente: zir, que conduce a la alegría, matnà, relacionada con el regocijo, hamm, la cual suscita tristeza, y mitlat, capaz de provocar miedo o terror ${ }^{296}$.

Sobre este sabio andalusí, Reynaldo Fenrández Manzano ha realizado dos publicaciones "Ibn Baya: músico, teórico y filósofo de Zaragoza, en la segunda mitad del s. XI y primer tercio del siglo XII"297 y otra perteneciente al Diccionario de la Música Española e Hispanoamericana bajo el nombre de "Avempace (Abu Bakr

${ }^{293}$ Emilio García Gomez, Elogio al Islam Español. Valladolid: Publicaciones de las Escuelas de Estudios Árabes de Madrid y Granada: Serie B. Núm. 2, 2005, 55.

294 Joaquín Lomba Fuentes y José Miguel Puertas Vílchez, "Ibn Bayya, Abu Bark", en Enciclopedia de la Cultura Andalusí, Vol. 2. Fundación Ibn Tufayl de estudios árabes, 2012, 631.

295 Ibidem, 632.

296 Ídem.

${ }^{297}$ Reynaldo Fernández Manzano. "Ibn Baya: músico, teórico y filósofo de Zaragoza, en la segunda mitad del s. XI y primer tercio del siglo XII". Nassarre: Revista aragonesa de musicología 3.2, 1987, $19-25$. 
Muhammad Ibn Yayà Ibn al-Sa'ig Ibn Baya)" ${ }^{298}$ poniendo en valor la figura de este tratadista. A su vez, Cortés García dedica al sabio zaragozano un capítulo de su obra, La música en la Zaragoza islámica además de hacer la traducción parcial y el análisis de la epístola sobre las melodías ${ }^{299}$ donde analiza la relación de las cuerdas con los temperamentos humanos y los efectos terapéuticos de la música:

\begin{abstract}
"Si un hombre padece de una enfermedad hepática, debe pulsar la cuerda zir, es decir, la cuerda teñida de color amarillo que simboliza la bilis y el fuego, pues al tañerla con fuerza provocará la dulzura y desaparecerá la dolencia. Contra las enfermedades relacionadas con la sangre aconseja frotar la cuerda matnà o segunda del laúd, de color rojo, símbolo de la sangre y el aire; con ella se fomenta la alegría y el corazón se llena de gozo. Contra la atrabilis sugiere tañer la cuerda tercera, es decir, la matlat de color negro, símbolo de la tierra; al pulsarla el oyente se siente invadido por el miedo y la melancolía. En cambio, si quiere combatir la flema, pulsará la cuerda bamm, símbolo del agua. Su color blanco y su naturaleza provoca la tristeza y el llanto"300.
\end{abstract}

Comparando este fragmento de Avempace con las ideas defendidas por Ibn Bayya puede verse una clara relación entre ambas coincidiendo dolencias y remedios. En esta misma línea, en el Cancionero de al-Ha'ik, cancionero escrito en el siglo XVIII por un posible morisco, el autor recoge el siguiente poema sobre las cuatro cuerdas del laúd y los efectos terapéuticos que produce su audición:

"Mira cómo las cuerdas han adoptado un carácter como la naturaleza humana.

La zir es la primera porque su sollozo es la queja del enamorado y la embriaguez del ebrio.

La matnà ríe y juega con reproche, cuando juguetean con ella los dedos.

La matlat es la triste porque está acostumbrada al llanto y vibra con el movimiento del indeciso.

La bamm baja su voz como si estuviese fatigada, llorando el enamorado por el dolo del abandono"301.

La epístola Risalat Fi l-Nafs (Sobre el alma), traducida por Joaquín Lomba, dedica el quinto capítulo al estudio del oído, donde realiza definiciones físicas del

298 Reynaldo Fernández Manzano. "Avempace (Abu Bakr Muhammad Ibn Yayà Ibn al-Sa'ig Ibn Baya). En Diccionario de la Música Española e Hispanoamericana, V.1. Madrid: 1999, 880-881.

${ }^{299}$ Publicado en el artículo "Sobre la música y sus efectos terapéuticos en la epístola sobre las melodías de Ibn Bayya" de Cortés García.

${ }^{300}$ Manuela Cortés García, "Sobre la música y sus efectos terapéuticos en la epístola sobre las melodías de Ibn Bayya", Separata de la Revista de Musicología, 1996, 15.

${ }^{301}$ Ibidem, 13. 
fenómeno de la audición añadiendo conclusiones que ayudan a conocer su teoría musical $^{302}$.

Manuela Cortés en la traducción y estudio sobre la Risalat al-alham (Epístola sobre las melodías) puntualiza que se trata de la primera obra andalusí conservada sobre el laúd y la forma de tañerlo: "cuando el hombre escucha las notas de una melodía, coge el instrumento y las interpreta acompanándose de la poesía, y además, se esfuerza en comprenderla, la música llega a lo más profundo del ser y lo purifica" ${ }^{303}$.

En el estudio y análisis de la risalat que Ibn Bayya dedicada al laúd, las cuatro cuerdas de este cordófono, la forma de tañerlo, sus efectos terapéuticos y las características que ha de reunir un buen laudista, llevan a Cortés García al contenido con los trabajos desarrollados sobre el laúd por los tratadistas orientales al-Kidi, los Ijwa al-Safa, al-Farabi, Ibn Sina, al-Safadi, Safi al-Din al-Hilli y al-Kadiri entre otros autores que relacionan las cuatro cuerdas del laúd con los cuatro elementos de la naturaleza, las cuatro estaciones del año y las cuatro edades del hombre ${ }^{304}$.

Con respecto a las características que debe reunir un buen laudista para "interpretar las notas correctas que proporcionen el estado idóneo al alma" ${ }^{305}$, debe fijarse en pecho [cuerda bamm], garganta [matlat], frente [matnà] y cabeza [zir]. Esta normativa dadas por Ibn Bayya en opinión de Cortés García parecen tomadas del tratado de Ibn Abd al-Rabbihi cuando habla sobre "la voz hermosa" (al-sawt alhasan) donde afirma que "mediante el proceso del canto, la voz surge del corazón, para pasar a la garganta y ascender hasta llegar al entendimiento"306. Con respecto a la posición de los dedos comenta que de ello dependerá conseguir los efectos esperados, por lo que el índice debe colorase sobre la bamm, el corazón sobre la matlat, el anular sobre la matnà y el meñique sobre la $z i r^{307}$.

\footnotetext{
302 Joaquín Lomba Fuentes y José Miguel Puertas Vílchez, "Ibn Bayya, Abu Bark", en Enciclopedia de la Cultura Andalusí, Vol. 2. Fundación Ibn Tufayl de estudios árabes, 2012, 643.

${ }^{303}$ Manuela Cortés García, La música en la Zaragoza Islámica. Instituto de Estudios Islámicos y del Oriente Próximo, 2009, 67.

304 Manuela Cortés García, "Sobre la música y sus efectos terapéuticos en la epístola sobre las melodías de Ibn Bayya", Separata de la Revista de Musicología, 1996, 14.

305 Ídem.

306 Manuela Cortés García, La música en la Zaragoza Islámica. Instituto de Estudios Islámicos y del Oriente Próximo, 2009, 68.

307 Manuela Cortés García, "Sobre la música y sus efectos terapéuticos en la epístola sobre las melodías de Ibn Bayya", Separata de la Revista de Musicología, 1996, 16.
} 
En la Risala ittisal al- 'aql bi-l-insan, (Tratado de la unión del intelecto con el hombre), traducido por Miguel Asín Palacios ${ }^{308}$ y basado en los manuscritos, de Berlín y Oxford, Ibn Bayya habla sobre los motores específicos que mueven al hombre: "Porque el primer motor específicamente en el hombre mueve con dos tipos de instrumentos: unos corporales y otros espirituales. De los corporales unos son artificiales y otros naturales, como son la mano, el pie, el pulmón, los cuales mueven la flauta" 309 .

Posteriormente afirmará que "en efecto la mano es exigida por los instrumentos para ser usada por ellos, como el azote y la flauta" ${ }^{310}$. Por otro lado, Ibn Bayya relaciona los movimientos de los astros con los humores del cuerpo explicando que "cuando el hombre escucha las notas de una melodía, coge el instrumento y las interpreta acompañándose de la poesía, y hace el esfuerzo de entenderlas, la música llega a los más profundo del ser y lo purifica"311.

En cuanto a los acordes del laúd andalusí, el primer testimonio se remonta al siglo XIII con al-Tifasi. Según indica el tunecino Guettat en La música andalusí en el Magreb, los músicos tomaban como referencia para afinar el instrumento la cuerda matna, a partir de esta con el dedo meñique tañían la cuerda zir. Una vez afinadas cambiaban de posición y hacían sonar la cuerda hamm, según la referencia marcada por el dedo índice en la cuerda matna y el anular en la matla ${ }^{312}$.

Sin embargo, no todo fueron reconocimientos a la figura de Avempace, Ribera y Tarragó se hace eco de una crítica hecha por Ibn Jaqan sobre los conocimientos del zaragozano donde afirmaba que Avempace perdió el tiempo con la música:

"Pasó la vida cantando y tocando; hizo de la música un comercio, y su pasión desaforada por ella era tal, que se iba tras de cualquier gañán a quien oyera cantar llevando las bestias al abrevadero; gastaba el tiempo entreteniéndose en oír piezas musicales, sin dedicar a otras ocupaciones momento alguno; ése ha sido el fundamento de su fama y renombre" 313 .

\footnotetext{
${ }^{308}$ Miguel Asín Palacios, "Tratado de Avempace sobre la unión del intelecto con el hombre", en $\mathrm{Al}$ Andalus: Revista de las Escuelas de Estudios Árabes de Madrid y Granada VII, 1942, 1-47.

${ }^{309}$ Joaquín Lomba, “Avempace. Tratado de la unión del intelecto con el hombre”, en Anaquel de Estudios Árabes VII, 2000, 375.

310 Ibidem, 376.

311 Manuela Cortés García, "Sobre la música y sus efectos terapéuticos en la epístola sobre las melodías de Ibn Bayya", Separata de la Revista de Musicología, 1996, 15.

312 Mahmoud Guettat, La música andalusí en el Magreb. Simbiosis musical entre las dos orillas del Mediterráneo. Sevilla: Fundación El Monte, 1999, 53.

313 Julián Ribera y Tarragó, La música árabe y su influencia en la española. Pre-Textos (Música "la Huella Sonora"), 2000, 150.
} 


\title{
3.1.6. Al-Saqundi, Abu-I-Walid (Córdoba, mediados del s. XII- Sevilla, 1231-2)
}

Este reconocido poeta y antólogo fue autor de la Risala fi Tafdil al-Andalus wa$s u^{\prime} a^{\prime} a^{\prime} i-h a$ (Epístola en loor de al-Andalus y sus poetas), conocida con el título de Risala fi Fadl al-Andalus (Epístola en elogio de al-Andalus). Esta obra fue traducida por el arabista y académico García Gómez y publicada bajo el nombre Elogio del Islam español ${ }^{315}$. En ella nombra alrededor de quince instrumentos musicales como son: 'ud, rota, rabab, qanun, kithara, zulami, al-shaqra y al-nura y buq. En el segundo grupo de términos incluye el daff, yara, abu qrun, dabdabat al-Sudan y hamaq al-barabir ${ }^{316}$. En el capítulo dedicado a Sevilla elogia las excelencias de esta ciudad y la fama de la música ${ }^{317}$. La traducción que hace este arabista del fragmento donde menciona los instrumentos musicales, acompañado de la siguiente aclaración a pie de página:

\begin{abstract}
"El jayal se ignora lo que es; el karriy es el carrizo (Simonet, Glosario, 107); el 'ud es el laúd; la ruta es la rota (Dozy, Suppl., I, 571 a); el rabab es el rabel; el qanun es un salterio o arpa (Dozy, Suppl., II, 408 a); el munis se ignora lo que es; la kanira es una especie de cítara; el qitar (leo así, en vez de ginar) es la guitarra; la suqra y la nura van explicadas en el texto [flautas, una barítona y otra triple]; el buq es el albogue; el duff es el adufe; el aqwal es una especie de tambor (Dozy, Suppl., I, 30 a); el yara', es una cítola, fístula o caramillo (Dozy, Suppl., II 850 b); el abu qarun se ignora lo que es (bocina?); la dabdaba y el hamaqi se ignora lo que son"318.
\end{abstract}

En opinión de Cortés García, al-Saqundi hace una diferenciación entre los membranófonos utilizados en las fiestas populares bereberes frente a los usados en la música "culta" andalusíin'.

Sobre los instrumentos que desconocía García Gómez, Farmer afirma que el abu qarun es un cuerno de grandes dimensiones, dabdaba es un membranófono con

\footnotetext{
314 Ángel Custodio López y López, "Al-Saqundi, Abu-I-Walid", en Enciclopedia de la Cultura Andalusí, Vol. 7. Fundación Ibn Tufayl de estudios árabes, 2012, 295-302.

315 Emilio García Gomez, Elogio al Islam español. Valladolid: Publicaciones de las Escuelas de Estudios Árabes de Madrid y Granada: Serie B. Núm. 2, 2005.

${ }^{316}$ Amnon Shiloah, The Theory of Music in Arabic Writings (c.900-1900). Descriptive Catalogue of Manuscripts in Libraries of Egypt, Israel, Morocco, Russia, Tunisia, Uzbekistan, and Supplement to B $X$. Munich: G. Henle Verlag München, 1979, 169.

317 Emilio García Gomez, Elogio al Islam español. Valladolid: Publicaciones de las Escuelas de Estudios Árabes de Madrid y Granada: Serie B. Núm. 2, 2005, 98.

318 Ídem.

${ }^{319}$ Manuela Cortés García, "Fuentes escritas para el estudio de la música en al-Andalus (siglos XIIIXVI)", en Fuentes musicales en la península Ibérica (ca. 1250-ca. 1550): actas del Coloquio Internacional, Lleida, 1-3 abril 1996. Edicions de la Universitat de Lleida, 2002, 293.
} 
sonido intenso y yara es una flauta $\operatorname{corta}^{320}$, el karriy es una flauta de caña, mientras que el munis sigue siendo hoy en día un misterio ${ }^{321}$.

Complementando la aportación musical de al-Saqundi, García Gómez traduce un fragmento dedicado a las bailarinas de Úbeda ensalzando su habilidad con las espadas, dados, cubiletes y juegos de $\operatorname{manos}^{322}$.

\subsubsection{Ibn Sab'in, Abd al-Haqq (Valle de Ricote [Murcia], 1216-7/ 1217-8 - La Meca, 1270/ 1271)}

Conocido como Ibn Sab'in, fue un afamado sufí, filósofo y teórico musical ${ }^{323}$. Según Cortés García, se trata del tercer códice sobre música que se conserva de la escuela levantina ${ }^{324}$. Ibn Sab'in cuenta con 64 obras donde muestra su inquietud por las heterodoxias, la geomancia y el mensaje críptico encerrado en el significado y las combinaciones de las letras y los números. En cuanto a la música escribió el Kitab aladwar fi hall al-awtar (Tratado sobre los modos y su relación con las cuerdas) manuscrito marcado por la impronta oriental ${ }^{325}$, citado por H.G. Farmer en Studies in oriental music ${ }^{326}$ como documento desaparecido. Cortés García descubrió hace dos décadas el lugar donde se encontraba una copia de este tratado. Aunque Farmer indica que formaba parte de la biblioteca privada del mecenas egipcio Ahmad Taymur Bachá, la investigadora nos informa que actualmente forma parte de los fondos manuscritos del Museo Islámico del Cairo (Dar al-Kutub). Este códice trata la teoría musical centrada en el laúd de cinco cuerdas y la relación de estas con los modos, humores, elementos y astros. Siguiendo los precedentes de los teóricos orientales

\footnotetext{
${ }^{320}$ Henry George Farmer, "Early References to Music in Western Sudan”, en Oriental Studies: Mainly Musical. Londres: Stephen Austin and Sons, 1953, 4-5.

${ }^{321}$ Henry Georges Farmer, "The Mediaeval Psaltery in the Orient", en Studies in Oriental Musical Instruments. Londres: Longwood Press, 1931, 18.

322 Emilio García Gomez, Elogio al Islam español. Valladolid: Publicaciones de las Escuelas de Estudios Árabes de Madrid y Granada: Serie B. Núm. 2, 2005, 107.

323 Anna Akasoy, "Ibn Sab'in", en Enciclopedia de la Cultura Andalusí, Vol. 5. Fundación Ibn Tufayl de estudios árabes, 2004, 29-38.

324 Manuela Cortés García, "Tratados musicales andalusíes de la Escuela Levantina y aportaciones al marco interdisciplinar (ss. XI-XIII)”, Itamar. Revista de investigación musical: territorios para el arte, 2019, 170.

325 Manuela Cortés García, "Escuelas musicales andalusíes y magrebíes: perfiles y sistemas pedagógicos", Revista del Centro de Estudios Históricos de Granada y su Reino, 23, $2011,54$.

326 Ibidem, 51.
} 
sobre los sistemas de pulsación del laúd, utiliza la notación alfabético-numérica propia de la época ${ }^{327}$.

\subsubsection{Ibn al-Darray al-Sabti, Abu 'Abd Allah (¿Sevilla? $1^{\circ}$ mitad s.XIII- Ceuta,} 1293/4)

Conocido como Ibn al-Darray al Ansari al-Sabti fue alfaquí, poeta, gramático y hombre de gran cultura ${ }^{328}$ autor del Kitab al-imta'wa-l-intifa'fi masálat sama'alsama (Libro de la alegría y beneficio de escuchar música). Este manuscrito suscitó gran controversia ya que no se conserva el original, sino una copia que fue hecha para el sultán Abu Ya'qub (m.1307) de la mano del copista Muhammad b. Ibrahim alSalahi a quien se le atribuyó su autoría por la rúbrica y resumen en latín realizado por Miguel Casiri (1710-1791) titulada Kitab al-imta'wa-l-intifa'fi masálat sama'al-sama (Libro de la alegría y beneficio de escuchar música). La copia del mismo que se conservaba entre los fondos de la Biblioteca de El Escorial (Ms. 1530), aunque actualmente está depositada en la Biblioteca Nacional de Madrid (Ms. Res. No 246). Según sus biógrafos Cortés García y González Berlanga, este manuscrito fue escrito para el sultán almorávide abu Ya'qub b.'abd-1-Haqq, quien reinó del 1206 al 1307. Se compone por una introducción y tres capítulos subdivididos en secciones, contando con una sección en el primer capítulo especialmente importante al enumerar y comentar 31 instrumentos musicales pertenecientes al instrumentarium andalusí ${ }^{329}$.

Entre los arabistas que han trabajado este manuscrito se encuentra Rosario Mazuela quien tradujo en 1982 el capítulo sobre los instrumentos musicales en su trabajo Libro de los instrumentos musicales incluidos en el Kitab al-imta'wa-lintifa'fi masálat sama'al-sama'de al-Salahi ${ }^{330}$, cuando aún se pensaba que su autor

\footnotetext{
${ }^{327}$ Manuela Cortés García, "La música, los instrumentos y las danzas andalusíes y moriscas en las fuentes árabes y cristianas (ss. IX-XVII)", Cuadernos del CEMYR, 25, 2017, 155.

328 Manuela Cortés García y Marcos González Berlanga, "Ibn Al-Darray", en Enciclopedia de la Cultura Andalusí: Apéndice. Fundación Ibn Tufayl de estudios árabes, 2012, 169-172.

${ }^{329}$ Amnon Shiloah, The Theory of Music in Arabic Writings (c.900-1900). Descriptive Catalogue of Manuscripts in Libraries of Egypt, Israel, Morocco, Russia, Tunisia, Uzbekistan and Supplement to B X. Munich: G. Henle Verlag München, 1979, 97.

330 Rosario Mazuela Coll, "Edición, traducción y comentario del 'Libro de los Instrumentos Musicales' incluido en el 'Kitab Al-Inta Wa Al-Imtifa Fi Mas'alat Sama' Al-Sama' de Al-Salahi”. Instituto hispano árabe de cultura, 1988.
} 
era al-Salahi ${ }^{331}$. Este error fue descubierto por el musicólogo libanés Bachir Odeimi $^{332}$.

Los instrumentos citados por Ibn al-Darray según Mazuela son: duff, girbal, masafiq, kabar, 'asaf, mizhar, 'ud, rabab, kiran, sany, kaytar, mi'zaf, 'azf, mizmar, nay, qussaba, buq, tabl, kus, kuba, 'ayr, tunbur, barbat, qadib, sahin, safaqis, sizan, kinnara, 'artaba, saffara y sabbaba ${ }^{333}$, acompañados por una pequeña aclaración y descripción de cada uno de ellos.

Este libro trata la licitud del canto y la audición musical sufí, e incluye un apartado donde Cortés García y González Berlanga añaden que ibn al-Darray describe 31 instrumentos musicales utilizados en el Masriq y el Magrib.

"Entre ellos describe las características principales de 13 instrumentos de cuerda (alat al-awtar), 7 aerófonos (al-alat al-hawa'iya) y 9 membranófonos (al-alat al-gisa'iya), junto a dos instrumentos de difícil identificación aunque parecen pertenecer a la familia de los idiófonos, instrumentos que, en general, encontraremos formando parte de la música clásica, popular y sufí del oriente y el occidente islámico",334.

El autor plantea, además, la polémica entre los alfaquíes respecto a la música y las retribuciones a los músicos, el rechazo hacia las esclavas cantoras y su compraventa. Igualmente ligaba la interpretación de música sufí solo para los hombres y a mujeres y hombres la interpretación de la música profana ${ }^{335}$.

\footnotetext{
331 Manuela Cortés García y Marcos González Berlanga, "Ibn Al-Darray”, en Enciclopedia de la Cultura Andalusí: Apéndice. Fundación Ibn Tufayl de estudios árabes, 2012, 169-182.

332 Ibidem, 171.

333 Rosario Mazuela Coll, "Edición, traducción y comentario del 'Libro de los Instrumentos Musicales' incluido en el 'Kitab Al-Inta Wa Al-Imtifa Fi Mas'alat Sama' Al-Sama' de Al-Salahi”. Instituto hispano árabe de cultura, 1988, 54.

${ }^{334}$ Manuela Cortés García y Marcos González Berlanga, "Ibn Al-Darray”, en Enciclopedia de la Cultura Andalusi: Apéndice. Fundación Ibn Tufayl de estudios árabes, 2012, 170.

${ }^{335}$ Manuela Cortés García, "Estatus de la mujer en la cultura Islámica. Las esclavas-cantoras (ss.IXXIX)", en Mujer versus Música: itinerancias, incertidumbres y lunas, 2011, 160-161.
} 
3.1.9. Relación de instrumentos musicales citados por los tratadistas andalusíes

\begin{tabular}{|l|}
\hline Nombre: Ibn 'Abd Rabbihi, Abu 'Umar \\
\hline Fecha: (Córdoba, 860- 940) \\
\hline Obra: Kitab al- 'Iqd al-farid (El collar único) \\
\hline Lugar donde se conserva: \\
- Biblioteca Islámica de El Cairo. \\
- Versión de la obra de la Hégira 1898-1899 digitalizada por a Biblioteca de Estudios \\
Islámicos: http://bibliotecadigital.aecid.es/bibliodig/es/consulta/registro.cmd?id=1511 \\
[última visita: 24/09/2019]. \\
\hline Traducción apartado/capítulo organológico: \\
- Farmer, Henry George. "Music: The Priceless Jewel. From the Kitab Al-'iqd Al- \\
Farid of Ibn 'Abd Rabbihi (d. 940). Edited and Translated.” In Studies in Oriental \\
Music, 1-27. Frankfurt: Institut für Geschichte der Arabisch-Islamischen \\
Wissenschaften, 1986. \\
- Veglison, Josefina. El Collar Único de Ibn Abd Rabbihi. Madrid: Editorial Síntesis, \\
2007. \\
- Shiloah, Amnon. The Theory of Music in Arabic Writings (c.900-1900). Descriptive \\
Catalogue of Manuscripts in Libraries of Europe and the U.S.A. Munich: G. Henle \\
Verlag München, 1979. \\
Instrumentos musicales: \\
- Idiófonos: hayarat (sonajas) \\
- Membranófonos: - \\
- Cordófonos: 'ud (laúd), kitarat (guitarra), mi'zafa (arpa-cítara), kiran (laúd de \\
mango corto), mizhar (laúd de mango corto), barbat (laúd de mango corto) \\
- Aerófonos: mizmar (tipo oboe), nai (flauta de caña). \\
\hline
\end{tabular}




\begin{tabular}{|c|}
\hline $180 m 0$ \\
\hline \\
\hline XI \\
\hline $\begin{array}{l}\text { Lugar donde se conserva: } \\
\begin{array}{l}\text { - } \\
\text { - }\end{array} \text { Miblioteca Islámica de El Cairo }{ }^{336} \\
\text { Manuscrito incompleto en la Biblioteca del Escorial }\left(n^{0} 575\right)^{337} .\end{array}$ \\
\hline $\begin{array}{l}\text { Traducción apartado/capítulo organológico: } \\
\text { - Ribera y Tarragó, Julián. La Música de Las Cantigas, Estudio Sobre Su Origen y } \\
\text { Naturaleza. Madrid: Real Academia Española de la Historia, } 1922 . \\
\text { - Shiloah, Amnon. The Theory of Music in Arabic Writings (c.900-1900). Descriptive } \\
\text { Catalogue of Manuscripts in Libraries of Europe and the U.S.A. Munich: G. Henle } \\
\text { Verlag München, } 1979 .\end{array}$ \\
\hline $\begin{array}{l}\text { Instrumentos musicales: } \\
\text { - Idiófonos: hayra'a (Karkaba) } \\
\text { - Membranófonos: daff (adufe), tabl (atabal), kuba (tambor pequeño cilíndrico), kabar } \\
\text { (tipo darbuka¿?), kassaba (tipo darbuka¿?), daffata (tambor). } \\
\text { - Cordófonos: kiran (laúd de mango corto), 'ud (laúd), barbat (laúd persa de mango } \\
\text { corto), tunbur o tinbar (laúd de mango largo), dirriy (variante tunbur), mi'zaf (arpa- } \\
\text { cítara), qanun (cítara), sandj (arpa), shahrud (lira-arpa), rabab (rabel), sandj djini o } \\
\text { sini (tipo salterio), 'artaba (laúd mango corto), urtuba (laúd mango corto). } \\
\text { - Aerófonos: nai (flauta de caña), ya-ra' (flauta pastoril), mizmar (tipo oboe), } \\
\text { zammara (tipo oboe), zamkhara (tipo oboe), kussab (tipo oboe), iran (aerófono), buq } \\
\text { (albogue), urghun (órgano), surnay (tipo clarinete), mizmar al-djarab (cornamusa). }\end{array}$ \\
\hline
\end{tabular}

\footnotetext{
336 Dolores Serrano-Niza, Glosario árabe español de indumentaria según el "Kitab Al-Mujassas" de Ibn Sidah. Madrid: Editorial CSIC-CSIC Press, 2005, 13.

${ }^{337}$ Dolores Serrano-Niza, "Ibn Sida, Abu 1-Hasan”, en Enciclopedia de la Cultura Andalusí, Vol. 5. Fundación Ibn Tufayl de estudios árabes, 2012, 357.
} 


\begin{tabular}{|l|}
\hline Nombre: Al-Turtusi, Abu Bakr \\
\hline Fecha: (Tortosa, 1059 - Alejandría, 1120) \\
\hline Obra: Kitab Tahrim al-gina' wa-l-lahw 'alà l-sufiya fi raqsi-him wa-sama'i-him \\
(Libro de la prohibición del canto y de la diversión a los sufíes en sus danzas y \\
audiciones). \\
\hline Lugar donde se conserva: Biblioteca Islámica de El Cairo. \\
\hline Traducción: \\
No está traducido solo existen análisis sobre esta obra en árabe realizados por: \\
- Arcas Campoy \\
- Ibn al-Hayy (m. 737=1336), Madjal al-sar al-sarif, 4 volúmenes, El Cairo, \\
1380=1960 \\
Instrumentos musicales: \\
- Idiófonos: ma'azif(palmeo) \\
- Membranófonos: duff (adufe), tabl (atabal) \\
- Cordófonos: 'ud (laúd), tunbur (laúd de mango largo), kitara (guitarra), qitar \\
(guitarra) \\
- Aerófonos: mizmar (tipo oboe), zammara (tipo oboe) \\
- Sin determinar: hadib, qadib. \\
\hline
\end{tabular}

\begin{tabular}{|l|}
\hline Nombre: Abu L-Salt b. Umayya al-Dani \\
\hline Fecha: (Denia, 1068-Burgía, 1134) \\
\hline Obra: \\
- Risalat al-Musiqà (Epístola sobre la Música). \\
\hline Traducción: Hanoch Avenary, “The Hebrew versión of Abu 1-Salt's Treatise on \\
Music”. Yuval, vol. 3 (1974), pp. 7-82. \\
\hline Instrumentos musicales: \\
- Idiófonos: - \\
- Membranófonos: - \\
- Cordófonos: 'ud (laúd), barbat (laúd persa), kanun (cítara), rabab (rabel), tunbur \\
(laúd de mango largo) tunbur al-bagdadi (de la Escuela de Bagdad), tunbur \\
jurasani (Escuela persal del Jurasán). \\
- Aerófonos: mizmar (tipo oboe).
\end{tabular}




\begin{tabular}{|l|}
\hline Nombre: Ibn Bayya, Abu Bark \\
\hline Fecha: (Zaragoza, finales s.XI- Fez, 1139) \\
\hline Obra: \\
- Risalat al-alham (Epístola sobre las melodías). \\
- Fi l-Nafs (Epístola sobre el alma). \\
\hline Lugar donde se conserva: \\
- Epístola sobre las melodías: Oxford. \\
- Sobre el Alma: Oxford. \\
\hline Traducción: \\
- Manuela Cortés García. "Sobre la música y sus efectos terapéuticos en la Epístola \\
sobre las melodías de Ibn Bayya” Revista de Musicología XIX, 1-2, 1996, 11-23. \\
- Joaquín Lomba Fuentes, "La ciencia del alma en Ibn Bayya (Avempace)”. Revista \\
de Filosofía da PUCRS, 52, n³, 2007, 79- 90. \\
\hline Instrumentos musicales: \\
- Idiófonos: - \\
- Membranófonos: - \\
- Cordófonos: 'ud (laúd) \\
- Aerófonos: -
\end{tabular}

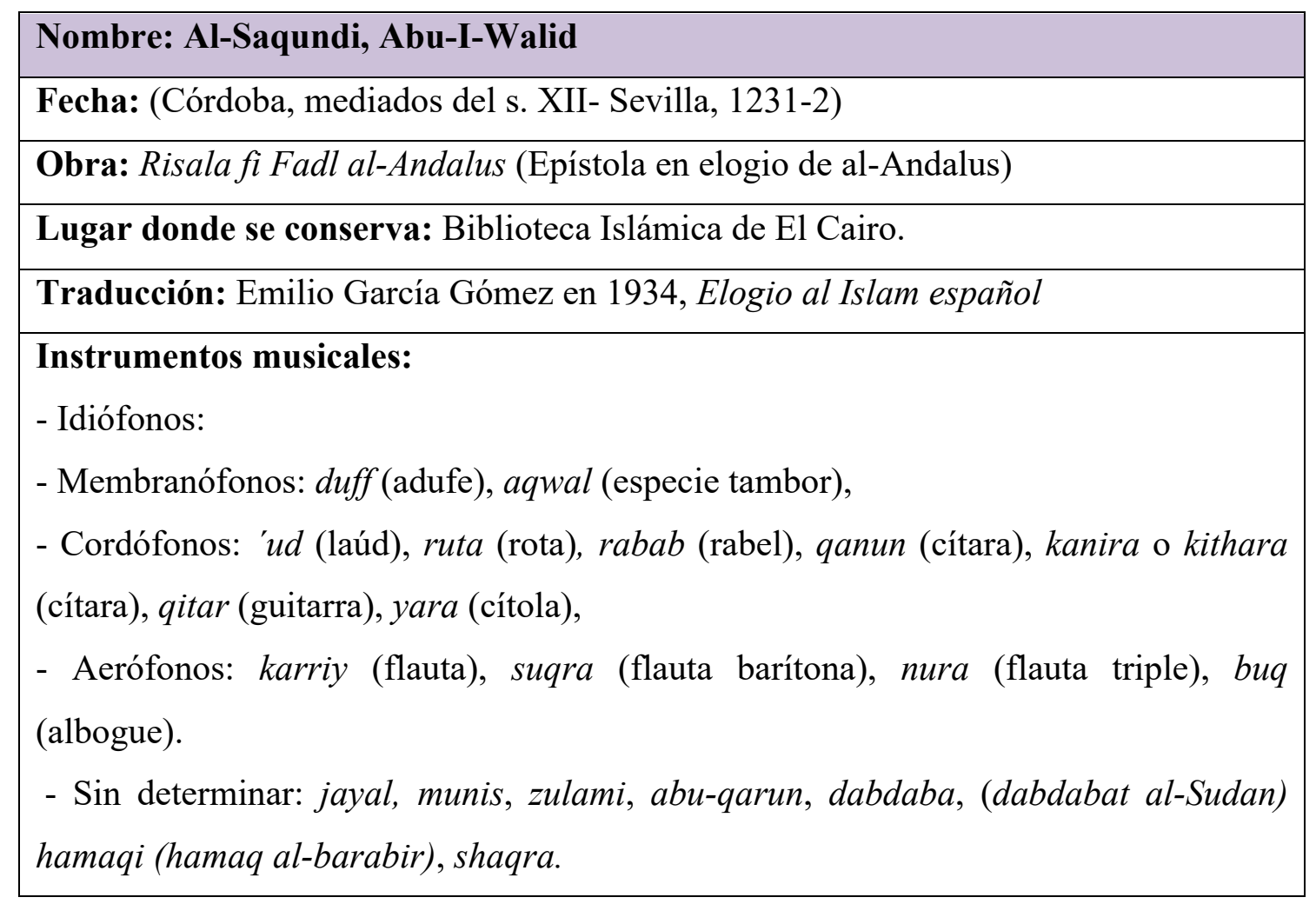




\begin{tabular}{|l|}
\hline Nombre: Ibn Sab'in, Abd al-Haqq \\
\hline Fecha: (Valle de Ricote [Murcia], 1216-7/ 1217-8 - La Meca, 1270/ 1271) \\
\hline Obra: Kitab al-adwar fi hall al-awtar (Tratado sobre los modos y su relación con las \\
cuerdas) \\
\hline Lugar donde se conserva: Biblioteca Islámica de El Cairo \\
\hline Traducción: \\
No existen traducciones. \\
\hline Instrumentos musicales: \\
- Idiófonos: - \\
- Membranófonos: - \\
- Cordófonos: 'ud (modos, humores, elementos y astros) \\
- Aerófonos: - \\
\hline
\end{tabular}

\begin{tabular}{|l|}
\hline Nombre: Ibn al-Darray al-Sabti, Abu 'Abd Allah \\
\hline Fecha: (¿Sevilla? $1^{\circ}$ mitad s.XIII-Ceuta, 1293/4) \\
\hline Obra: Kitab al-imta'wa-l-intifa'fi masálat sama'li-istitara bi-l-kifaya wa-l-gina'fi \\
ahkam ahl al-gina'wa-l-radd 'alà man naqas 'alà l-muslimin bi tahrir ma ubiha la- \\
hum min-hu fi mizan al-masra wa-hana' (Libro del goce y el provecho).
\end{tabular}

Lugar donde se conserva: Biblioteca Nacional de Madrid (Ms. Res. No 246) ${ }^{338}$.

\section{Traducción:}

- Capítulo sobre los instrumentos musicales ha sido traducido por Rosario Mazuela en "Libro de los instrumentos musicales incluidos en el Kitab al-imta'wa-l-intifa'fi masálat sama'al-sama'de al-Salahi"

- Editado en Casablanca en árabe.

\section{Instrumentos musicales:}

- Idiófonos: masafiq (palmeo).

- Membranófonos: duff (adufe), girbal (tipo adufe), tabl, kuba, kabar (especie darbuka de barro o cerámica), 'asaf (tambor una sola membrana), kus (tipo tabl), 'ayr (tipo tabl), kinnara (tipo duff).

- Cordófonos: 'ud, rabab, kiran, tunbur, barbat, mizhar (laúd de mango corto), mi'zaf

\footnotetext{
338 Manuela Cortés García y Marcos González Berlanga, "Ibn Al-Darray”, en Enciclopedia de la Cultura Andalusí: Apéndice. Fundación Ibn Tufayl de estudios árabes, 2012.
} 
(arpa-cítara), sany, kaytar, 'artaba (tipo laúd).

- Aerófonos: mizmar, nai, buq, 'azf, qussaba (tipo mizmar), saffara (silbato), sabbaba (silbato).

- Sin determinar: Qadib, sahin, safaqis, sizan.

Quedando clasificados por familias de instrumentos genéricas:

\begin{tabular}{|l|l|}
\hline Aerófonos & Cordófonos \\
abu qarun (cuerno grande) & barbat (laúd persa) \\
buq (albogue) & dirriy (variante del tunbur) \\
iran (tipo mizmar) & kamanya \\
karriy (flauta carrizo) & kiran (laúd mango corto) \\
mizmar (aerófono tipo dulzaina) & mi'zafa (cítara) \\
nai (flauta de caña) & qanun (cítara) \\
nayruz o nawruz (silbato) & rabab (rabel) \\
nura (flauta) & ruta (rota) \\
sabbaba (axabeba) & tunbur (o al-tinbar) (laúd de mango \\
suqra (flauta barítona) & largo): bagdadi (de la Escuela de \\
ya-ra' (flauta pastoril) & Bagdad) y jurasani (Escuela persal del \\
zammara (aerófono pastoril) & Jurasán) \\
'ud (laúd) & yank (arpa) \\
& yara' (cítola, fístula o caramillo) \\
& Membranófonos \\
Idiófono & aqwal (especie de tambor) \\
hayra'a (crótalos) & daff (adufe) \\
kabar (tipo darbuka de barro o cerámica) \\
kassaba (tipo darbuka) \\
kuba (tambor cilíndrico) \\
tabl (atabal) \\
\end{tabular}

3.2. Muestra de la presencia de los instrumentos musicales en los poemas andalusíes

Como muestra de la presencia de los instrumentos musicales en otras fuentes documentales se mencionarán brevemente algunos casos en los que se ven reflejados en la poesía andalusí. Este punto, por lo tanto, pretende plantear un futuro camino a transitar ya que la revisión y análisis de estas numerosas menciones sería digna de una investigación propia. 
El arte, ligado al ocio y el esparcimiento, ha creado gran controversia a lo largo de los tiempos. Historiadores y antólogos magrebíes como al-Tífasi, Ibn Jaldun o al-Maqqari, entre otros, nombran a historiadores y juristas como Ibn Hazm o alTurtusi en textos de jurisprudencia donde tratan la licitud e ilicitud de la música y los instrumentos musicales ${ }^{339}$. Sin embargo, la música fue considerada en al-Andalus, como una ciencia integrante del trivium y el cuadrivium, además de formar parte de las fiestas cortesanas y populares.

Poetas como al- Ramadi (Córdoba ¿? 1013) ${ }^{340}$ hacen referencia al laúd en este poema:

\footnotetext{
"Sus dedos besan las cuerdas cual boca, más les falta la saliva. Su reveladora melodía se adelanta a la voz mientras el estribillo parecía desbocarse como párpado palpitante de emoción o relámpago rasgando la nube ${ }^{\text {341. }}$.
}

Citas más explícitas se encuentran en la obra del filósofo y poeta hispanojudío Ibn Ezra' (Granada 1055- 1135) 342 $^{34}$ autor del Kitab al-Zuhd (Libro de la abstinencia), tratado que incluye un listado de instrumentos musicales como la flauta de caña (alnai), la dulzaina (al-mizmar), el laúd (al- 'ud), la bandola (al-tunbur) y el arpa (alyank) ${ }^{343}$.

Asimismo, estos y otros versos del poeta cordobés Ibn Quzman (m. 1170) recoge numerosos instrumentos presentes en la vida andalusí en este poema:

\footnotetext{
“¡Recibid saludos! Pronto iré a vosotros. Aprestad el plectro y empuñad adufes. ¡Con las castañuelas nadie ha de pasarse! Si un pandero hubiese, bueno es añadirlo. ¡Y la flauta, amigos! Vida os da la flauta. Taparéis la Zuhra con flotante velo.
}

\footnotetext{
${ }^{339}$ Manuela Cortés García, "Nuevos datos para el estudio de la música en al-Andalus de dos autores granadinos: As-Sustárí e Ibn Al-Jatíb", en Música Oral del Sur: Revista Internacional, 1995, 177.

340 Estela Navarro i Ortiz, "Al-Ramadi, Yusuf", en Enciclopedia de la Cultura Andalusí, Vol. 7. Fundación Ibn Tufayl de estudios árabes, 2012, 155.

${ }^{341}$ Ídem, 25.

${ }^{342}$ Manuela Cortés García, La música en la Zaragoza Islámica. Zaragoza: Instituto de Estudios Islámicos y del Oriente Próximo, 2009, 92.

${ }^{343}$ Manuela Córtés García, "La música andalusí en el Reino de Granada", en La música andalusí en el Reino de Granada. Fundación Pública Andaluza Centro de Estudios andaluces. Consejería de la Presidencia e Igualdad. Junta de Andalucía, 2012, 14.
} 
Tafetán se vista con completa franja...,344

Otro tipo de datos sobre instrumentos musicales serán proporcionados por tratadistas como Ibn al-Jatib (Loja, 1313-Fez, 1374- 1375) 345 teórico, historiador, poeta y polígrafo que en su trabajo Fi l-taba'i 'wa-l-tubu' wa usulu-hum (Sobre los humores, los modos, orígenes y relaciones). Cortés García se hace eco de las reuniones que realizaban en la cofradía sab iniyya fundada por Ibn Saba'in de Murcia (m. 1271) de la que Ibn al-Jatib fue adepto, y afirma que era habitual escuchar zéjeles precedidos por el canto de los discípulos que se acompañaban con laudes, rabeles, flautas y adufes ${ }^{346}$.

La figura y poesía de este sabio andalusí ha sido trabajada, asimismo, por el profesor alemán Wilhelm Hoenerbach quien recopiló y tradujo una serie de fragmentos de este sabio andalusí ${ }^{347}$, en su libro Dichterische Vergleiche Der Andalus-Araber I Und II recoge poemas referidos a instrumentos musicales como estos ejemplos sobre el 'ud o el rabab:

"Ibn Hudail sobre el laúd (mizhar) [sari']: 1. (El laúd) está parado allí a la izquierda como un altavoz, /expresando alguna melodía, 2. como si explicara un temor sincero/ en una primera clave de su juego silencioso. 3. como si fuera una amante, / para su horror, abandonada por su amado. 4. como si las cuerdas (autar) en su cuello/canales en un cuenco de oro" $" 348$.

Donde el laúd es reflejado como un orador que recita melodías donde sus cuerdas vocales se hacen pasar por las del laúd acelerando el pulso en añoranza al amante perdido.

\footnotetext{
${ }^{344}$ Reynaldo Fernández Manzano, "La música de al-Andalus en su marco interdisciplinar. Aspectos metodológicos", en Gazeta de Antropología 1, 1982.

345 Joaquín Lirola Delgado, "Ibn al-Jatib al-Salmani, Lisan al-Din”, en Enciclopedia de la Cultura Andalusí, Vol. 3. Fundación Ibn Tufayl de estudios árabes, 2012, 643.

${ }^{346}$ Manuela Cortés García, "Aproximación al universo musical Sufi de al-Andalus en las cofradías, los tratados y la impronta de sus poetas en las nawbas magrebíes (ss. XVII-XX)", en Música Oral del Sur: Revista Internacional, 2016, 21.

${ }^{347}$ Celia del Moral, "Contribución a la historia de la mujer a partir de las fuentes literarias andalusíes", en La Sociedad Medieval a través de la literatura Hispanojudía. VI Curso de Cultura Hispano-Judía y Sefardi de la Universidad de Castilla-La Mancha, 1998, 110.

${ }^{348}$ Traducción propia de: "Ibn Hudail über die Laute (mizhar) [sari']: 1. (Die Laute) steht links als Redner daselbst, /vortragend manche Melodie, 2. Als erkläre sie eine Herzensangst/ bei einer ersten Tonart ihres leisen Spiels. 3. Als wäre sie, wenn sie sich so vehält, eine Liebende, /zu ihrem Schrecken verlassen vom Liebsten. 4. Als wären die Saiten (autar) an ihrem Halse/ Rinnen in einer goldnen Schale" Wilhelm Hoenerbach, Dichterische Vergleiche Der Andalus-Araber I Und II. Bonn: Selbstverlag des Orientalischen Seminars del Universität Bonn, 1973, 101.
} 
"Lo mismo ocurre con el violín de palo (rabab) [munsarih]: 1. se diferencia del laúd en la forma en que se usa / y es de una forma diferente, aunque menos: 2. imita las canciones / de las artes persas tan pronto como está a mano; en las manos de su violinista / mi corazón y lo que siente parece despertar a través de él; 4. cuando lo despierta, David / ve salmos y versos cantando sobre él!",349

O sobre el uso del rabab (rabel), donde es presentado como un laúd de pequeño tamaño cercano a la música persa, que permite a los intérpretes conmover al corazón del oyente e inspirar versos y salmos de David.

Sirvan estos poetas mencionados como representantes y ejemplo de otros muchos ${ }^{350}$ que igualmente fueron reflejando en sus versos esa cercanía entre la música y la poesía, que, en palabras de Henri Pérès, proporcionan datos "sobre los instrumentos musicales en uso" 351 .

En cuanto a la relación de la música y la poesía, Rubiera Mata lo relaciona con los primeros pasos del amor cortés árabe, del amor 'udri, "ya no se entonan con la monótona melopea beduina sino con las notas del laúd y de la música persa, ya no entona la casida el rapsoda con aires épicos sino que la cantan las bellas esclavas, elegidas y educadas para ser cantoras" ${ }^{" 352}$. Según Ribera y Tarragó, la unión de estas artes se da por la intención del elemento rítmico que se inicia con la figura del poeta Tuéis, quien se acompañaba con el adufe por no saber tañer el laúd ${ }^{353}$. Con esta última referencia se comprueba cómo las fuentes literarias y musicales de los siglos IX al XIV muestran igualmente la relación entre el Oriente islámico y al-Andalus, debido al la constante relación entre ambos lugares, entre otros motivos, por los viajes de los sabios andalusíes para acudir a La Meca. Estas travesías supondrán un idílico momento de intercambio cultural y proporcionarán las copias de tratados orientales

\footnotetext{
349 Traducción propia de: "Derselbe über die Stockgeige (rabab) [munsarih]: 1. Sie unterscheidet sich von der Laute nach Art ihrer Verwendung / und ist von ihrer Form, wenn auch leiner: 2. Sie imitiert Lieder /von den Künsten der Perser, sobald sie zur Hand; in den Händen ihres Fiedlers scheint / mein Herz und was es fühlt durch sie zu erwachen; 4. Wenn er sie weckt, seheint David / Psalmen und Verse auf ihr zu singen!" Ídem.

${ }^{350}$ Manuela Córtés García, "La música andalusí en el Reino de Granada”, Seminario: La música Andalusi en el Reino de Granada, 2012, 15.

${ }^{351}$ Henri Pérès, Esplendor de al-Andalus. Madrid: Libros Hiperión, 1983, 382.

${ }^{352}$ María Jesús Rubiera Mata, "Cuando los andaluces cantaban en árabe: la poesía andalusí en época Omeya (Siglos VIII-IX)", Música y poesía del sur de al-Andalus, Granada-Sevilla: Lunwerg Ed., 1995, 125 .

${ }^{353}$ Julián Ribera y Tarragó, La música árabe y su influencia en la española. Valencia: Pre-Textos (Música "la Huella Sonora"), 2000, 61.
} 
que llegarán a al-Andalus con la intención de completar bibliotecas de eruditos andalusíes ${ }^{354}$.

Ibn Hazm (Córdoba, 933-Monitija [Huelva], 1064) 355 tradicionista, genealogista, teólogo, filósofo, teórico del zahirismo, poeta y humanista en la Risalat fi l-gina' al-mulhi (Epístola sobre el canto con música instrumental), muestra las opiniones de las escuelas de jurisprudencia islámica con respecto a la música ${ }^{356}$. En esta misma línea jurídica, Ibn Rusd (Córdoba, 1126- Marraquech, 1198), apodado alHafid (el nieto), más conocido en las fuentes latinas como Averroes ${ }^{357}$, con su perfil de filósofo, teólogo, médico y jurista aporta información acerca de los silbatos. Esta cita del arqueólogo Rosselló Bordoy indica el uso y contexto que pudo tener este instrumento musical:

"Ellas [las mujeres] vestían telas, frecuentemente realzadas con dibujos de seres animados, Ibn Rusd, sin embargo, toleraba tales telas, pues decía que estos dibujos al no ser en relieve, no podían proyectar sombra. Sí condenaba los juguetes en forma de animales, como las jirafas que había por costumbre fabricar en al-Andalus con motivo del Año Nuevo (la fiesta de Nayruz), Al-'Uqbani, en este sentido, recordaba que igual costumbre existía en Tlemcen, a lo largo del mes de enero, añadiendo que, de manera general, se fabricaban juguetes semejantes en ocasión de todas las fiestas, costumbre a su entender que denotaba un origen cristiano" 358

Ibn Rusd ofrece en esta cita la gran presencia de instrumentos musicales en Sevilla mediante esta afirmación que realizó durante una disputa. Estas palabras le reportaron numerosos detractores ${ }^{359}$ :

"No sé lo que dices, pero sí que cuando muere un sabio en Sevilla y quiere vender sus libros, éstos son llevados a Córdoba para ser vendidos allí, mientras que si muere un músico en Córdoba y se quiere vender sus instrumentos, éstos son llevados a Sevilla. Córdoba, pues, es la ciudad de Dios en la que hay más libros"360.

354 Manuela Cortés García, La música árabe y andalusí de las dos orillas en los estudios musicológicos (ss. XVIII-XXI). Málaga: Ediciones del Genal, 2018, 99-100.

355 José Miguel Puertas Vílchez, "Ibn Hazm, Abu Muhammad", en Enciclopedia de la Cultura Andalusí. Fundación Ibn Tufayl de estudios árabes, 2012, 392.

${ }^{356}$ Manuela Cortés García, "La música, los instrumentos y las danzas andalusíes y moriscas en las fuentes árabes y cristianas (ss. IX-XVII)", en Cuadernos Del CEMYR 25, 2017, 157.

357 Jorge Lirola Delgado, "Ibn Rusd", en Enciclopedia de la Cultura Andalusí, Vol. 4. Fundación Ibn Tufayl de estudios árabes, 2012, 517.

358 Rosselló Bordoy, Guillermo, Navarro Ortega, A., Flores Escobosa, Del rito al juego: juguetes y silbatos de cerámica desde el Islam hasta la actualidad. Junta de Andalucía: 2006, 24-25; Leopoldo Torres Balbás, “Animales de juguete”, en Crónica Arqueológica de la España Musulmana XXXIX, 1956, 374.

Jorge Lirola Delgado, "Ibn Rusd", en Enciclopedia de la Cultura Andalusí, Vol. 4. Fundación Ibn Tufayl de estudios árabes, 2012, 529.

${ }^{360}$ Ídem. 


\subsection{La iconografía musical andalusí}

A pesar de las conocidas reticencia de la religión musulmana a la representación figurativa, menos restrictivas de lo que se planteaba como se verá a continuación, llegan hasta el presente importantes referentes que cuentan con representaciones musicales. Este hecho aporta gran información al estudio de los instrumentos musicales ya que éstos son representados en contextos concretos. Como afirmaban Rosario Álvarez y Rosselló Bordoy, "la fuente primordial para el estudio de los instrumentos musicales en el Medioevo hispano es, sin lugar a duda, la iconografía, debido a la carencia casi total de instrumentos de ese período"361, lo que hace esencial este capítulo para poder encuadrar los instrumentos encontrados en excavaciones arqueológicas, así como tratar otros que por estar hechos con materiales perecederos no han llegado hasta la actualidad.

La representación humana siempre es un tema que ha creado gran controversia en la cultura islámica ya que existen pasajes del Corán que condenan este tipo de hechos. La arqueóloga Susana Gómez aclara que este rechazo incide en la idolatría y el peligro del politeísmo ya que "Dios es creador de todo y vela por todo" (Corán: XXXIX, 62 $)^{362}$. Asimismo, Gómez Martínes explica que, en contraste con esta idea, existen otros muchos argumentos retirados del Corán que valoran las representaciones como una forma de glorificar la obra del creador, lo que favorece que lleguen hasta nuestros días representaciones artísticas de animales y personas ${ }^{363}$.

En esta línea, Gómez Moreno contextualiza que la inquietud iconográfica llega a Oriente a través de Mesopotamia desde donde parten los pintores formados en las primeras escuelas creadas por artistas griegos en este territorio ${ }^{364}$. Señala, asimismo, que en España fue introducida la moda de pintar en las pareces de las casa y palacios, retratos e imágenes, por la cultura islámica basando esta opinión en las declaraciones de Aben Jaldún ${ }^{365}$.

Las primeras representaciones andalusíes se dan en la época califal; se desconoce si no fueron hasta ese momento cuando se dieron o si simplemente no se

\footnotetext{
${ }^{361}$ Rosario Álvarez y Guillermo Rosselló Bordoy, "Hallazgo de Tambores de la España Islámica (Siglos IX-XIV)”, Revista de Musicología XII, n², 1989, 411.

${ }^{362}$ Susana Gómez Martínes, "Imágenes del cuerpo en el día a día de al-Andalus”, DigitAR 2, 2015, 11. 363 Ídem.

${ }^{364}$ Manuel Gómez Moreno, "Pinturas de Moros en El Partal (Alhambra)", Textos de Gómez-Moreno sobre la Alhambra Musulmana, 1912, 156.

${ }^{365}$ Ídem.
} 
han conservado ${ }^{366}$. Según Faustino Porras, es muy probable que durante la etapa omeya y de las taifas se realizasen en al-Andalus numerosas obras con figuras humanas, pero seguramente éstas fueron destruidas tras la llegada de los almorávides y los almohades ${ }^{367}$.

Asimismo, las arqueólogas Laura Aparicio Sánchez y Encarnación Cano Montoro puntualizan igualmente que las escasas representaciones antropomorfas solían estar restringidas al ámbito privado y que será el marfil el material más utilizado para reflejar escenas cortesanas, cacerías, luchas u ocio ${ }^{368}$.

El hecho de restringir las piezas solo a lugares privados sería uno más de los hándicaps que explicarían la escasa iconografía que llega hasta nuestros días. En esta línea Reynaldo Fernández Manzano afirma que siendo así, el acceso a este tipo de piezas quedaría, además, reservado para las autoridades: "Su significado entrará dentro de la iconografía de la autoridad, de la soberanía sobre la tierra y el dominio político de la misma, siendo en ocasiones atributo exclusivo del gobernante, extendiéndose a los grandes personajes cortesanos y clánicos del mundo musulmán"369.

En lo concerniente a la presencia musical en estas piezas, el arqueólogo Julián Navarro realiza la siguiente reflexión:

\begin{abstract}
"Los músicos, flautistas y tañedores de laúd son un motivo iconográfico muy frecuente en el arte islámico en general y, sobre todo, en las representaciones de lo que se ha dado en llamar "ciclo cortesano". Son abundantes las imágenes de músicos en la Capilla Palatina de Palermo, junto con bailarinas y pájaros, que han sido interpretados como una imitación de la armonía musical que, según la tradición pitagórica y platónica, determina el movimiento de los planetas y las esferas celestes. Se trata, en cualquier caso, de un tema frecuente en los ciclos reales del Creciente Fértil y que, al parecer, penetró en el repertorio islámico desde la Persia sasánida. Ya en las pinturas del palacio omeya de Qasr al-Hayr al-Garbi aparece el flautista junto con el tañedor de laúd y en la propia Murcia se halló la representación pintada de un flautista en un fragmento de adaraja perteneciente a una cúpula de mocárabes descubierta en las ruinas del palacio antiguo de Santa Clara (tercer cuarto del siglo XII) ${ }^{\text {,370. }}$.
\end{abstract}

\footnotetext{
366 Ibídem, 12.

${ }^{367}$ Faustino Porras Robles, "Iconografía musical en la escultura hispanomusulmana”, Nassarre: Revista Aragonesa de Musicología 25, no. 1, 2009, 42.

368 Laura Aparicio Sánchez y Encarnación Cano Montoro, "Fragmento cerámico con decoración antropomorfa en verde y manganeso hallado en el arrabal de 'El Fontanar' (Córdoba)", Antiquitas 22, 2010, 195.

369 Reynaldo Fernández Manzano, Música de al-Andalus. Granada: Universidad de Granada, 2016, 167.

370 Julio Navarro Palazón y Pedro Jimenez del Castillo, "La cerámica andalusí de Murcia a la llegada de Alfonso X", en Alfonso X y su época. Catalogo de la exposición celebrada en Murcia, 2009, 704.
} 
Estando, por lo tanto, este capítulo dedicado a la iconografía musical musulmana se podrá comprobar que, dentro de esta, los instrumentos musicales que se encontrarán serán cordófonos, esencialmente laúdes y rebabs, aerófonos, con flautas, instrumentos de lengüeta y silbatos, y membranófonos, con distintos ejemplos de tambores y panderos. Esta fuente documental que, a priori, puede parecer escasa al abordar un reducido número de instrumentos dentro de la gran riqueza organológica de la época, resulta un gran complemento con las piezas arqueológicas musicales econtradas que integran esta investigación, ya que la mayoría de estos instrumentos reflejados en la iconografía no llegan a nuestros días al estar fabriados con materiales perecederos como es, en este caso y principalmente, la madera. La conexión que, por lo tanto, se puede trazar entre estas fuentes se complementan igualmente con los códices de los sabios andalusíes en el caso de los los silbatos y tamborcillos, ya que a día de hoy no existen evidencias iconográficas, y es escasa en los tratados, de instrumentos como campanas, cascabeles o crótalos que son las otras piezas encontradas en excavaciones arqueológicas.

Una curiosa iconografía musical que tanto aportará a la documentación del instrumento será la encontrada en el techo de la Sala de los Reyes de la Alhambra, donde se verá a un joven montado en un árbol soplando un silbato que parece utilizar a modo de reclamo. Hasta el momento la escasa documentación de este instrumento contractaba con su gran presencia en yacimientos ya que los tratadistas solo reflejaban de estos instrumentos el arduo debate en la época sobre la supuesta procedencia cristiana. Igualmente, especial relevancia tendrá la tañedora de tamborcillo del Museo Arqueológico y Etnológico de Córdoba, que pondrá rostro y ejemplo de quiénes y cómo podían tocar este instrumento, corroborando las hipótesis que se llevaban años barajando sobre la cercanía de estos pequeños membranófonos a la figura de la mujer. Importante, igualmente, para el estudio de este último tipo de instrumentos mencionados serán las fuentes cristianas, de las que se mencionarán las dos esenciales en el estudio iconográfico musical de la época, Las Cantigas de Alfonso X el Sabio y El Libro de Ajedrez y dados, donde se muestra la presencia de instrumentos musulmanes en fuentes cristianas. Esta ejemplificación de fuentes cristianas reflejando instrumentos musulmanes no pretende abarcar el gran número de iconografía sino simplemente puntualizar lo que puede enriquecer unas fuentes a otras demostrando, asimismo, lo cercana que fueron ambas culturas, como tantos años 
llevan recalcando investigadores como Rosario Álvarez García o Reynaldo Fernández Manzano, entre otros.

Como se ha mencionado, la iconografía musical recopilada se encuentra en distintas piezas y contextos, tanto dentro de una rica colección de marfiles en botes y arquetas, como en piezas más inesperadas como un capitel, "El capitel de los músicos", una redoma, "La botella de los músicos" o figuritas, manuscritos y telares, e incluso en miniaturas y esculturas cristianas que reflejan la influencia árabe.

Al ser el territorio andaluz el protagonista de esta investigación, sus piezas serán las que se tratarán más ampliamente de forma general en los distintos epígrafes y de forma concreta y técnica en los anexos, donde se contará con una ficha a modo de catalogación de estas y se contextualizarán con la imagen junto con una explicación organológica. Asimismo, se incluirán de forma más superficial, el resto de las piezas pertenecientes a la misma época que se encuentran en el resto de la Península Ibérica. Por lo tanto, se incluirá una breve presentación de las piezas más relevantes que guarden relación con la temática o piezas protagonistas.

A modo aclaratorio desde el punto de vista documental en la ficha de catalogación, al tratarse la mayoría de las fuentes iconográficas de piezas arqueológicas, se intentó guardar un lugar para este tipo de información, pero debido a las dificultades documentales de las mismas, ya que la mayoría fueron encontradas de forma fortuita $\mathrm{o} / \mathrm{y}$ compradas a colecciones privadas, esta idea terminó desechándose. Igualmente, la ficha de catalogación que se ha desarrollado está basada en la realizada por el "Grupo Complutense de Iconografía Musical"371, ésta a su vez ampliada sobre la plantilla realizada por el Répertoire International d'Iconographie Musicale (RIdIM) ${ }^{372}$, con la finalidad de unificar este tipo de documentación, así como por la calidad documental de la misma.

371 “Grupo Complutense de Iconografía Musical”, http://www.imagenesmusica.es/ (Última consulta: 17-11-2019).

372 Répertoire International d'Iconographie Musicale (RIdIM). https://ridim.org/ridim-database/ (Última consulta: 17-02-2020). 


\subsubsection{Piezas hispanomusulmanas con iconografía musical}

\section{Bote de al-Mughira (Museo del Louvre, París). Anexo no 1.}

Este bote perteneció al coleccionista granadino José Facundo Riaño quien lo vendió al Museo del Louvre en $1898^{373}$. Se trata de una escena de un maqama y es una de las imágenes andalusíes más conocidas y difundidas. En ella se observa a una laudista, por el contexto seguramente una esclava cantora, que tañe el laúd acompañando a una reunión solemne entre dos combatientes, posicionándose el autor a favor de los omeyas. La figura de la intérprete llama la atención al estar en el centro de la representación y en pie, en contraste con las otras figuras que permanecen sentadas. Fernández Manzano recalca el hecho de que los jóvenes tienen el pelo corto y liso, con la cabeza al descubierto sin contar con el tocado que suele asociarse a las personas de alto rango ${ }^{374}$. Esta pieza está fechada, ya en la propia tapa del bote, en 968 y fue dedicada al príncipe al-Mughira, de ahí su nombre.

\section{Bote de Davillier (Museo del Louvre, París). Anexo 2.}

Una de las piezas donde se refleja iconografía musical que más ha pasado desapercibida es el Bote de Davillier. Esta pieza custodiada por el Museo del Louvre llegó a formar parte de estos fondos de la mano de Jean-Charles Davillier (18271883), el barón Charles Davillier, un hispanista, anticuario y viajero francés que realizó una travesía por "su admirada España" que le llevó a recopilar todo tipo de piezas que tras su muerte en París el 1 de marzo de 1883 fueron donadas al Museo ${ }^{375}$. Esta pieza pudo adquirirla en Córdoba hacia el $1860^{376}$. En la misma, se puede observar lo que parece una figura femenina interpretando un laúd mientras acompaña a una figura masculina que sostiene un vaso. De esta pieza no se conserva la tapa, por lo que no puede conocerse la fecha exacta de su fabricación, ya que suele ser en ese lugar donde habitualmente se reflejaba este tipo de información ${ }^{377}$. Galán y Galindo se hace eco de una carta intercambiada entre Davilliers y el pintor Fortuny a este

\footnotetext{
373 Ángel Galán y Galindo, "Las Arquetas de Trovadores, Canciones, Música y Amor. Desde Bagdad, a Los Trovadores Medievales, Pasando Por Córdoba", Arte, Arqueología e Historia 18, 2011, 88.

374 Reynaldo Fernández Manzano, Música de al-Andalus. Granada: Universidad de Granada, 2016, 167.

${ }^{375}$ Luis Sazatornil Ruiz, "El Barón Davillier: Hispanista, Anticuario y Viajero Por España”, en El Arte y El Viaje, A. López-Yarto Elizalde y W. Rincón García, M. Cabañas Bravo (eds.). Madrid: Colección Biblioteca de Historia del Arte, CSIC, 2011, 353-68.

376 Ángel Galán y Galindo, "Las Arquetas de Trovadores, Canciones, Música y Amor. Desde Bagdad, a Los Trovadores Medievales, Pasando Por Córdoba", Arte, Arqueología e Historia 18, 2011, 88.

377 Ídem.
} 
respecto: “...si queréis restaurar la tapa de vuestro bote, tengo un dibujo exacto del que ha sido vendido en Córdoba..." refiriéndose sin duda al que hoy alberga la Hispanic Society" 378 .

La pieza a la que hacen referencia es la catalogada por el museo de la Hispanic Society of America con la referencia D752 datada en el 966 perteneciente al palacio Madinat al-Zahra. Esta píxide no cuenta con iconografía ${ }^{379}$.

Estos botes no serán los únicos de esta época y lugar ya que existen otros como el Bote Ziyad (969-970), probablemente de Madinat al-Zahra, Córdoba que actualmente se encuentra en el museo Victoria \& Albert de Londres bajo el número de referencia 368-1880 380 ; el bote de Mutárrif (999) cuya tapa fue posteriormente encontrada y por lo tanto revalorizó la pieza ya que se llegó a pensar que ésta podía ser del escultor valenciano Francisco Pallás i Puig lo que le hizo al Metropolian Museum de Nueva York vender la pieza que actualmente se encuentra en paradero desconocido $^{381}$; el Bote de Zamora (964), procedente de Córdoba, actualmente en el Museo Arqueológico Nacional ${ }^{382}$. Ninguno de ellos cuenta con iconografía musical.

\section{Arqueta de Leyre (Museo de Navarra). Anexo 3.}

Esta arqueta es una de las piezas más icónicas del arte andalusí. Perteneciente a Madinat al-Zahra se conoce bien la historia de la construcción gracias a los grabados externos e internos. Ésta fue realizada en el taller de un artista artesano llamado Faray el cual contó con cinco discípulos que le ayudaron en su construcción. Reflejo del trabajo de cada uno de ellos queda una placa distintiva en su interior con sus nombres ${ }^{383}$ : Cubierta: Maestro Faray; Lateral izquierdo: Rasid; Frente posterior: Jair; Lateral derecho: Sa Abada; Frente anterior: Misbah ${ }^{384}$. 
Lo que supone una incógnita es el momento en el que llegó al Monasterio de Leyre ya que se desconoce si pudo ser un botín de guerra o un pago para prolongar la paz. Una vez en el monasterio esta arqueta sirvió para salvaguardar reliquias de las santas mozárabes oscenses Nunilo y Alodia. En 1865 pasó a formar parte del Tesoro de la catedral de Pamplona siendo robada el 10 de agosto de 1935 y encontrada días más tarde, el 8 de septiembre en Berrioplano ${ }^{385}$.

Esta pieza cuenta con la representación de tres mujeres que tañen un laúd de mango corto, una flauta doble y un albogue. La disposición de estas conduce a pensar en una interpretación común como agrupación. En el centro de la escena se encuentra la laudista, a su derecha la intérprete de flauta doble y a su izquierda la intérprete de albogue. Esta distribución ensalza la importancia del laúd ya que además lo reproduce de frente mientras que los otros dos aparecen de perfil.

\section{Arqueta del Museo Victoria \& Albert. Anexo 4.}

Arqueta de marfil con monturas plateadas probablemente añadidas en los siglos XVII o XVIII. La fecha original de la pieza no se conserva ya que fue eliminada en fechas posteriores a su fabricación. A pesar de no contar con la información se piensa que puede ser de procedencia cordobesa, aunque la venta de esta se realizase desde Cuenca. Tras la caída del califato omeya el centro principal para la talla de marfil se trasladó a esta ciudad ${ }^{386}$.

Esta arqueta guarda diversas similitudes, por los animales representados, con

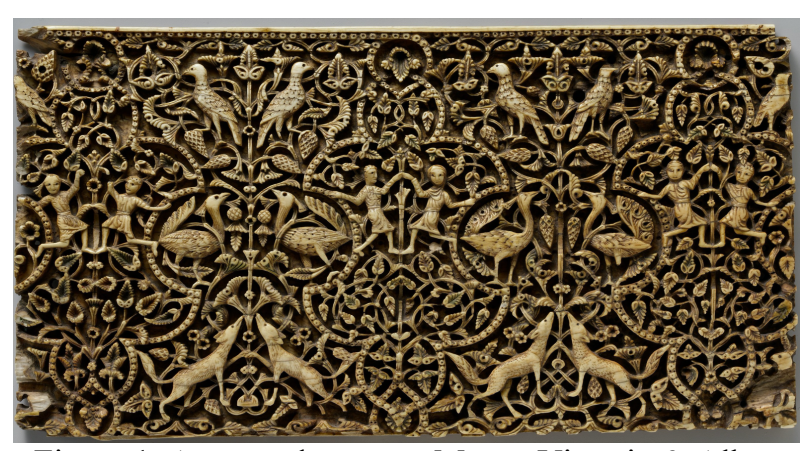

Figura 1. Arqueta danzantes Museo Victoria \& Albert (extraída de la web del museo). la de Leyre, del Museo de Navarra. Fue John Charles Robinson quien compró esta arqueta en León, en 1866. Durante este viaje adquirió otra arqueta más pequeña realizada en el año 962 para la hija del difunto califa Abd al-Rahman III $^{387}$.

Leire \&simpleSearch=0\&hipertextSearch=1\&search=simpleGroup\&MuseumsSearch=MNANA\%7C\& MuseumsRolSearch=1\& (Última consulta: 07-11-2019).

385 Ídem.

386 “Arqueta Museo Victoria \& Albert”, http://collections.vam.ac.uk/item/O70461/casket-unknown/ (Úlitima consulta: 07-11-2019).

387 Ídem. 
Por otro lado, existe un friso de posible procedencia cordobesa, de Madinat alZahara, tallado en una sola pieza de marfil entre los siglos X y XI, actualmente ubicada en el Metropolitan Museum de Nueva York ${ }^{388}$, donde pueden observarse tres parejas de danzantes de ambos sexos, llevando ellas la cabeza cubierta con el hiyab. Los ojos de las personas y animales representados fueron perforados y rellenados con unas piedras de cuarzo. Este friso carente de inscripción posiblemente podría formar parte de una arqueta desaparecida. Esta pieza fue adquirida por el museo en $1913^{389}$. Al estar la iconografía centrada en la danza sin que aparezca ningún instrumento musical no se realizará una ficha de catalogación de esta.

\section{Botella de los músicos. Anexo 5.}

Esta icónica botella fue encontrada en 1950 por un trabajador durante unas obras para mejorar el alcantarillado de la calle Alfonso X el Sabio de Córdoba. Al hallarse en una zona privada tuvo que ser comprada al dueño de la finca para así pasar a formar parte de la colección del Museo Arqueológico y etnológico de Córdoba ${ }^{390}$.

La iconografía de esta botella recrea una zambra protagonizada por seis figuras masculinas, la mayoría de ellas barbadas, que danzan y tocan instrumentos musicales. Los que se observan en esta botella son: albogue, adufe y un instrumento de viento (pieza recuperada tras la limpieza de 2004) indeterminado por el momento. Fernández Manzano se pregunta si el intérprete de este podría ser un chambelán ${ }^{391}$.

Susana Gómez parafraseando a Rosselló Bordoy afirma que esta botella recrea: "Escena palatina que reproduce el modo de vida de la corte omeya, semejante a las que aparecen, repetidamente, en los marfiles de los siglos X y XI y también en las piezas en mármol de Córdoba y Játiva" ${ }^{\text {392 }}$.

\footnotetext{
388 "Friso de los Danzantes" https://www.metmuseum.org/art/collection/search/446285? searchField=All\&amp;sortBy=Relevance\& amp; $\mathrm{ft}=\mathrm{al}$-andalus\&amp;offset $=0$ \&amp;rpp=20\&amp;pos $=3$ (Última consulta: 07-11-2019). Ángel Galán y Galindo, "Las Arquetas de Trovadores, Canciones, Música y Amor. Desde Bagdad, a los Trovadores Medievales, pasando por Córdoba", Arte, Arqueología e Historia 18 (2011), 99.

390 "Botella de los Músicos"

http://ceres.mcu.es/pages/ResultSearch?txtSimpleSearch=C/\%20Alfonso $\% 20 \mathrm{X} \% 20 \mathrm{el} \% 20$ Sabio\&simpl eSearch=0\&hipertextSearch=1\&search=simpleSelection\&MuseumsSearch=MAECO \%7C\&Museums RolSearch=2\&listaMuseos=[Museo\%20Arqueol\%F3gico\%20y\%20Etnol\%F3gico\%20de\%20C\%F3rd oba] (Última consulta: 08-11-2019).

${ }^{391}$ Reynaldo Fernández Manzano, Música de al-Andalus. Granada: Universidad de Granada, 2016, 171.

392 Susana Gómez Martínes, "Imágenes del cuerpo en el día a día de al-Andalus", digitAR-Revista Digital de Arqueologia, Arquitectura e Artes, 2, 2015, 13.
} 
Esta afirmación concuerda con la de Fernández Manzano, quien la cataloga como "escena lúdica"393.

La pieza muestra similitud con la conocida como Redoma de las liebres, encontrada en Medina Elvira, Granada. La botella granadina no cuenta con el cuello, pero su contorno conserva un colorido adorno que enmarca la figura de una liebre. Actualmente esta pieza se conserva en el Museo Arqueológico y Etnológico de Granada ${ }^{394}$.

\section{Capitel de los cuatro músicos. Anexo 6.}

Susana Gómez afirma que la presencia de personas en la decoración arquitectónica en al-Andalus es muy rara reseñando como una "notable excepción" esta pieza ${ }^{395}$. Realizada en mármol blanco, este capitel pertenece a la época califal (s. X). Según Faustino Porras, el uso de figuras humanas como decoración hace pensar que esta pieza pudo estar destinada para ser exhibida en un espacio privado no religioso, como podría ser una almunia en las proximidades de la capital cordobesa ${ }^{396}$. La cara de los intérpretes se encuentra desfigurada, algo que Faustino Porras concluye que fue llevado a cabo durante las posteriores invasiones cordobesas ${ }^{397}$. Coincidiendo con esta información, la ficha de la pieza ofrecida por el Museo Arqueológico y Etnológico de Córdoba corrobora esta teoría puntualizando que la deformación de estas parece haberse realizado a propósito ${ }^{398}$.

Asimismo, Faustino Porras asemeja esta pieza al capitel conocido como "de los Evangelistas" perteneciente al siglo VII. Éste no cuenta con iconografía musical pero sí con cuatro figuras de disposición similar. Esta pieza se encuentra en la iglesia

393 Reynaldo Fernández Manzano, Música de al-Andalus. Granada: Universidad de Granada, 2016, 171.

394 "Redoma de las Liebres",

http://ceres.mcu.es/pages/Main?idt=127790\&inventary=CE00677\&table=FMUS\&museum=MAEGR (Última consulta: 08-11-2019).

395 Susana Gómez Martínes, "Imágenes del cuerpo en el día a día de al-Andalus", digitAR-Revista Digital de Arqueologia, Arquitectura e Artes, no 2, 2015, 12.

396 Faustino Porras Robles, "Iconografía musical en la escultura hispanomusulmana", Nassarre: Revista aragonesa de musicología, 25, 2009, 42.

397 Ibidem.

398 “Capitel de Los Músicos”,

http://ceres.mcu.es/pages/ResultSearch?txtSimpleSearch=Capitel\%20de\%201os\%20M\%FAsicos\&simp leSearch $=0$ \&hipertextSearch=1\&search=simpleSelection\&MuseumsSearch=MAECO $\% 7 \mathrm{C} \&$ Museums RolSearch=2\&listaMuseos $=[$ Museo $\% 20$ Arqueol $\% \mathrm{~F} 3$ gico $\% 20 \mathrm{y} \% 20 \mathrm{Etnol} \% \mathrm{~F} 3$ gico $\% 20 \mathrm{de} \% 20 \mathrm{C} \% \mathrm{~F} 3 \mathrm{rd}$ oba] (Última consulta: 09-11-2019). 
visigótica de Quintanilla de las Viñas (Burgos) ${ }^{399}$. Las representaciones humanas de este capitel curiosamente también fueron deformadas de forma intencionada ${ }^{400}$. Ciertamente la disposición de las figuras puede llevar a comparar un capitel con otro, pero las representaciones de los evangelistas, San Lucas, San Mateo, San Marcos y San Juan ${ }^{401}$, resultan mucho más discretas en comparación con los músicos del capitel ya que no cuentan con la presencia y el relieve de éstos.

\section{Tañedora de tamborcillo, Córdoba. Anexo 7.}

Fruto de una actividad arqueológica preventiva llevada a cabo entre el 26 de septiembre y el 18 de octubre de 2005 en la Avenida de las Ollerías no $16^{402}$ aparece la figura de una tañedora de tamborcillo.

Esta escultura antropomorfa perfectamente definida de una pieza redonda completa se encuentra muy bien conservada. Sus rasgos faciales son claros, ojos, nariz, boca, orejas y pómulos. Cuenta con abalorios como collar y pendientes, así como turbante con broche. Su postura evidencia el estar golpeando un pequeño tambor de forma cilíndrica. Los dedos de sus manos están perfectamente definidos y quedan apoyados en lo que sería la membrana del instrumento mientras que el otro extremo de este quedaría apoyado sobre el pecho.

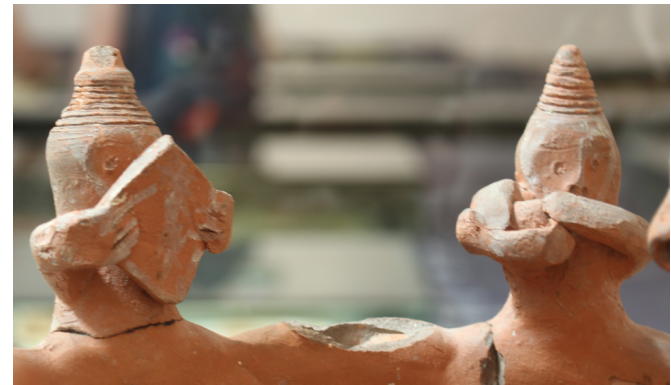

Figura 2. Vaso de Tavira (archivo personal)

Observando la figura se percibe en la parte inferior izquierda un pequeño orificio. La iconografía de esta representación se asemeja al conocido Vaso de Tavira, donde se observa muy bien definidos dos músicos, entre ellos uno interpretando un adufe y otro un tambor. En este caso, el tambor de forma casi tubular con una leve tendencia en la zona del parche a terminar en forma de copa, es colocado por el músico bajo su brazo derecho para ser percutido de forma directa con la mano izquierda. El adufe de forma cuadrada parece tratarse de un tambor de marco bimembranófono que el o la

\footnotetext{
${ }^{399}$ Faustino Porras Robles, "Iconografía musical en la escultura hispanomusulmana", Nassarre: Revista aragonesa de musicología, 25, 2009, 43.

400 Ibídem.

401 Ibídem.

402 Francisco Javier Ariza Rodríguez, “A.A.P. en la Avd. de Las Ollerías, No16, de Córdoba”, Anuario Arqueológico de Andalucía 1, 2004, 521-31.
} 
intérprete sujeta sobre su pecho pudiendo golpearlo con ambas manos a la vez que lo sostiene.

\section{Imágenes del códice "Hadith o Qissat Bayad wa Riyad" (Codex. Vat. Arabo}

\section{8). Anexo 8-11.}

Son varios los investigadores que se han acercado a este especial y atípico manuscrito con la intención de conocerlo en profundidad y sobre todo contextualizarlo, quedando aún el debate abierto sobre su origen. El arabista Giorgio Levi della Vida en su trabajo Elenco dei manoscritti arabi islamici ${ }^{403}$ sostiene que su procedencia es árabe-magrebí y que pudo ser parte del botín de Túnez de $1535^{404}$. Por otro lado, Kurt Holter Die islamischen miniaturhandschriften vor $1350^{405}$, Monnerett de Villard en su trabajo Un códice arabo-spagnolo con miniature $e^{406}$ junto a Alois Richard Kykl en Historia de los amores de Bayad y Rijad ${ }^{407}$ y C. Robinson en The lover, his lady, her lady, and a Thirteenth-Century Celestina: A Récipe for love sickness from al-Andalus ${ }^{408}$ defienden su origen andalusí. Una de las investigadoras más activas en este campo, Arianna D'Ottone, en su libro La storia di Bayad e Riyad 409 y en el artículo "Il manoscritto Vaticano arabo 368 Hadit Bayad wa Riyad" 410 sostiene que las ilustraciones pueden proceder del oeste árabe concretamente sitúa los paisajes en la zona centro-norte de Irak en un afluente del Tigris $^{411}$.

Ante tal confusión y por su genuinidad será incluido en esta investigación con las fichas de catalogación respectivas a las imágenes con iconografía musical según el

\footnotetext{
403 Giorgio Levi della Vida, Elenco Dei Manoscritti Arabi Islamici Della Biblioteca Vaticana. Città del Vaticano, 1935.

404 Arianna D'Ottone, "Il Manoscritto Vaticano Arabo 368, Hadit Bayad Wa Riyad. Il Codice, Il Testo, Le Immagini”, Rivista Di Storia Della Miniatura 14, 2010, 55.

${ }^{405}$ Kurt Holter, Die Islamischen Miniaturhandschriften Vor 1350. Otto Harrassowitz, 1937.

${ }^{406}$ Ugo Monneret de Villard, "Un Codice Arabo-Spagnolo Con Miniature”, La Bibliofilía, 43 n. 10/12, 1941, 209-23.

407 Alois Richard Kykl, Historia de los amores de Bayad y Rijad, 1941.

${ }^{408}$ Cynthia Robinson, "The Lover, His Lady, Her Lady, and a Thirteenth-Century Celestina: A Recipe for Love Sickness from Al-Andalus", en Islamic Art and Literature, 2001, 79-115.

409 Arianna D'Ottone, La Storia Di Bayad e Riyad (Vat. Ar. 368): Una Nuova Edizione e Traduzione, 2013.

410 Arianna D'Ottone, "Il Manoscritto Vaticano Arabo 368, Hadit Bayad Wa Riyad. Il Codice, il Testo, le Immagini”, Rivista di storia della miniatura, 14, 2010, 55-70.

${ }^{411}$ Ibidem, 61.
} 
orden actual del manuscrito ya que los treinta folios y las catorce imágenes se han numerado varias veces a lo largo del tiempo ${ }^{412}$.

Este códice se encuentra en la Biblioteca del Vaticano, pero se desconoce en qué momento pudo llegar a este lugar. Se conserva incompleto y es anónimo y está datado a principios del siglo XI, aunque recientes investigaciones lo situan en el siglo XIII. Al no contar con el manuscrito al completo no se conoce el inicio ni el final del cuento.

Esta narración relata la historia de amor entre Bayad, hijo de un rico mercader de Damasco y Riyad, una esclava cantora que contaba con el especial aprecio del oficial de la corte o chambelán, hayib. Bayad, enamorado de Riyad pretende reunirse con ella para mostrarle sus sentimientos, pero gestionar un encuentro entre ambos resulta harto difícil, por lo que éste acude a una anciana que le hospeda para que medie entre ambos aprovechando que está invitada a una velada musical en palacio, donde podrá encontrarse con ella. Durante esta, la anciana se acerca a Riyad para mostrarle el interés de Bayad y que parece corresponder la esclava cantora accediendo a un encuentro. A pesar del positivo resultado de la conversación entre ambas, la anciana, asustada ante la situación de que el hayib pueda enterarse, intenta desalentar a Bayad tras la velada. Desoyendo los consejos de la mujer, Bayad le pide que consiga invitarle a la siguiente velada musical que tendrá lugar el siguiente viernes. La anciana utiliza toda su habilidad para conseguir que éste sea invitado. Cuando acuden a la velada se encuentran con que el hayib no ha podido asistir y en su lugar recibe a los invitados su hija, la Sayyida, la señora. Durante la fiesta, Bayad interpreta versos acompañado por el laúd levantando las pasiones y el agrado de todos los asistentes. Esta idílica velada se ve truncada cuando Riyad en plena exaltación hace público su amor por Bayad entre versos. La Sayyida se deja llevar por su gran enfado y concluye la velada ordenando encerrar a Riyad. El repentino desenlace entre los enamorados hace que estos caigan enfermos de melancolía, a pesar de la ayuda prestada por el resto de las esclavas del palacio, la anciana y un pariente de esta celestina que consiguen que al menos intercambien cartas entre ellos. Ante esta situación, la anciana habla con la Sayyida para que perdone a Riyad y la deje en libertad para que los enamorados puedan encontrarse. Después de mucho sopesarlo la Sayyida decide dejarla libre, no sin temor a lo que pueda decir su padre.

\footnotetext{
412 Ídem.
} 
Con la reconciliación de la Sayyida y Riyad este manuscrito deja al lector intrigado ante el impedimento de saber el final de esta historia.

\section{"Pintura de moros" en el Partal, s. XIV}

En 1907, al levantar los enlucidos de las paredes de la habitación contigua a la torre llamada de las Damas en el Partal en la Alhambra, se descubrieron unas imágenes en alarmante estado de conservación por el "desgaste natural del color, al roce, limpiaduras y humo de la hornilla, cuando la habitación estuvo convertida en cocina, y muy particularmente por los efectos desastrosos del picado de las paredes al enlucirlas"413. Gómez Moreno relaciona estas pinturas con las iluminaciones de los manuscritos árabes del siglo XIII "procedentes de la Mesopotamia, si bien más imperfectas que estas y sin sus notorias influencias bizantinas" ${ }^{414}$.

Las pinturas se encuentran en dos zonas de la habitación, siendo una de ellas un mural en una de las paredes y otra sirviendo de adorno como contorno de una de las ventanas de este espacio. La primera imagen está dividida en tres zonas horizontales, la central y más grande representa la llegada de las tropas al campamento. Las figuras representadas miden entre 11 y 13 centímetros y entre 18 y 19 centímetros cuando van montadas sobre animales ${ }^{415}$. En la parte izquierda de esta se observan seis tiendas de campaña donde se recrean escenas de llegada de mensajeros o reunión del consejo, por la calidad de los ropajes pueden distinguirse los distintos cargos de las figuras representadas. La segunda imagen mencionada está en otro lado de la sala y también quedan divididas en tres franjas horizontales cruzando la primera el mural entero y quedando las otras dos divididas por la presencia de la ventana en medio. La escena superior recrea batallas y momentos de caza, la imagen central parece recrear la vuelta al campamento tras apresar animales vivos y la imagen inferior muestra la vida en palacio.

Estas pinturas resultaron todo un hallazgo en la época, por lo que intentaron documentarlas de la mejor manera posible ya que el estado de conservación era muy delicado, como se ha comentado, por lo que optaron por realizar una recreación con acuarela. Este encargo se le confió a Isidoro Marín, quien realizó en 1909 una

\footnotetext{
413 Manuel Gómez Moreno, "Pinturas de Moros en El Partal (Alhambra)", en Textos de GómezMoreno sobre la Alhambra musulmana, 1912, 155.

414 Ídem.

415 Ibidem, 157.
} 
recreación que se encuentra actualmente custodiada por el Instituto Gómez Moreno y publicada en el libro "Obra dispersa e inédita" de Manuel Gómez-Moreno González ${ }^{416}$. Posteriormente a esta, entre 1921 y 1922, se le volvió a encargar otra recreación al mismo autor, ya que la primera se consideraba perdida, ambas recreaciones resulta idénticas. Actualmente para el estudio de estas pinturas realizadas en el Partal, el investigador debe partir de estos trabajos realizados previamente por Torres Balbás e Isidoro Marín, ya que las imágenes hoy en día se encuentran gravemente deterioradas, lo que complica un estudio exhaustivo sobre ellas. Posteriormente a estas recreaciones, han sido dos los artistas que han intentado realizar una nueva versión más detallada, completando, en la medida de lo posible, las pinturas de esta sala, pero al no contar con una imagen de base clara es mucho lo que dejan abierto a la imaginación, por lo que estas imágenes realizadas por el pintor Manuel López Reche, bajo el encargo de Antonio Fernández Puertas y las del pintor Manuel López Vázquez resultan una versión artística y no científica-documental de estos murales. Debido a esta casuística las imágenes musicales serán presentadas en el grueso del texto y no como anexo.

En la pintura que se encuentra en la parte central de la sala, aparece representada la llegada de los guerreros montados en camello al campamento. Algunos de ellos se ven ya instalados en tiendas de campaña mientras que otros traen

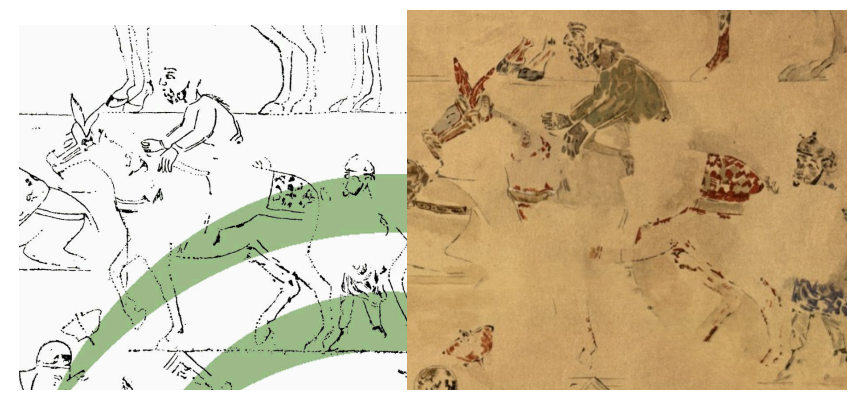

Figura 4. Detalle mural del Partal (extraída del artículo de Torres Balbás)

Figura 5. Detalle del mural del Partal de Isidoro Marín 1921-1922 (cedida por la Alhambra)

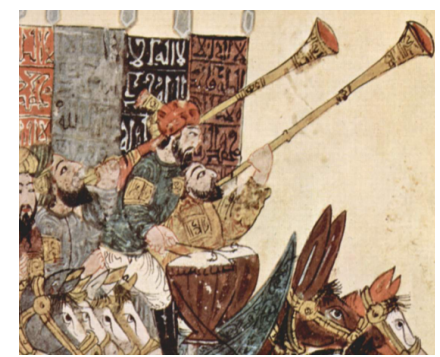

Figura 3. Detalle de Naqqarat del manuscrito Maqamat al

416 Javier Moya Morales, Obra Dispersa e Inédita. Manuel Gómez-Moreno González, 2004, 204.

enseres o simplemente vuelven a este lugar. Centrado en este mural se encuentra un hombre sobre un camello con una postura que podría parecer que interpreta un instrumento musical. Éste ya llamó la atención de Gómez Moreno, quien decía de él: "hay un hombre cuya 
posición indica que debía estar tocando un timbal, y podría ser el atabalero que formara parte de la expedición" ${ }^{417}$. Como puede observarse en las figuras 4 y 5 , las manos de este personaje quedan en el aire por lo que se podría interpretar que estuviese golpeando dos tambores que quedarían entre la cresta y la cruz del caballo. Por el contexto, el instrumento musical que podría estar interpretando esta figura sería un naqqara ya que este membranófono solía tener uso militar, pero resulta extraño el hecho de que se interprete con las manos ya que, si la función de este instrumento era la de intimidar al enemigo, se tendría que conseguir un sonido intenso que así lo hiciese y para ello se recurría a baquetas para percutir el instrumento. Ejemplo de este instrumento y de su interpretación mediante la percusión indirecta se encuentra reflejado en el manuscrito Maqamat al Hariri del pintor y calígrafo iraquí Yahya ibn Mahmud al-Wasiti (s. XIII), donde puede observarse en la miniatura un intérprete de naqqarat que interpreta el instrumento con una especie de mazas y es acompañado por dos músicos que tocan añafiles.

Otro de los estudios desarrollados sobre esta pintura es el realizado por el historiador y filólogo Antonio Fernández-Puertas quien fue conservador y director del

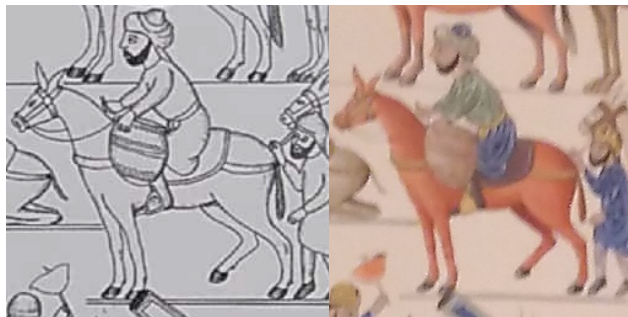

Figura 6. Detalle mural del Partal de Manuel López Vázquez.

Figura 7. Detalle mural del Partal de Manuel López Reche- Antonio Fernández Puertas.
Museo de la Alhambra, del que se publica a título póstumo el trabajo Alhambra. Muhammad V. El mawlid de 764/ 1362, gran obra que realiza otra hipotética recreación sobre las figuras de este mural. En este caso, la figura que Gómez Moreno interpretaba como unos posibles membranófonos, Fernández-Puertas lo interpreta como unas alforjas, al igual que hace Manuel López Vázquez, como pueden verse en las figuras 7 y 8 . Esta segunda hipótesis se considera más acertada.

\footnotetext{
417 Manuel Gómez Moreno, "Pinturas de Moros en El Partal (Alhambra)", en Textos de Gómez-
} Moreno sobre la Alhambra musulmana, 1912, 159. 
Por otro lado, en la pintura que rodeaba la ventana musulmana, que fue sustituida por una cristiana ${ }^{418}$, existen dos escenas musicales. En la primera de ellas, según lo escasamente observable se podría interpretar como una reunión de seis figuras masculinas descifrables por los turbantes, en la que, frente a uno de ellos, el primero de la parte derecha hay un objeto con forma cilíndrica-cónica, lo que podría ser interpretado como un membranófono como hacen las posteriores recreaciones, pero quedando abierta a otro tipo de hipótesis como un objeto tipo cáliz. Sobre el

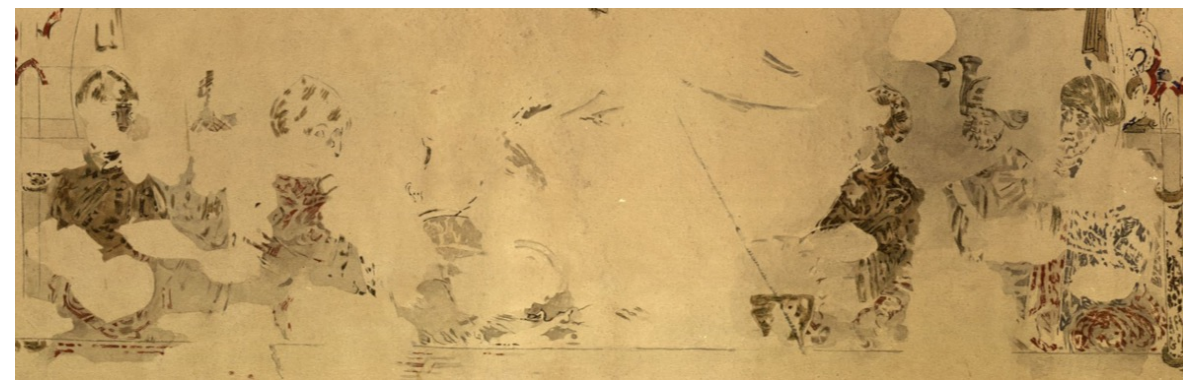

Figura 8. Detalle del mural del Partal de Isidoro Marín.

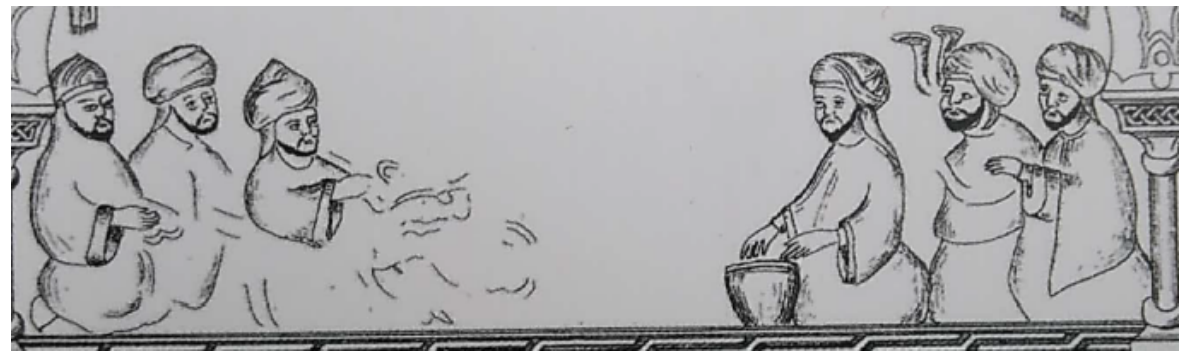

Figura 9. Detalle del mural del Partal de Manuel López Reche- Antonio Fernández Puertas.

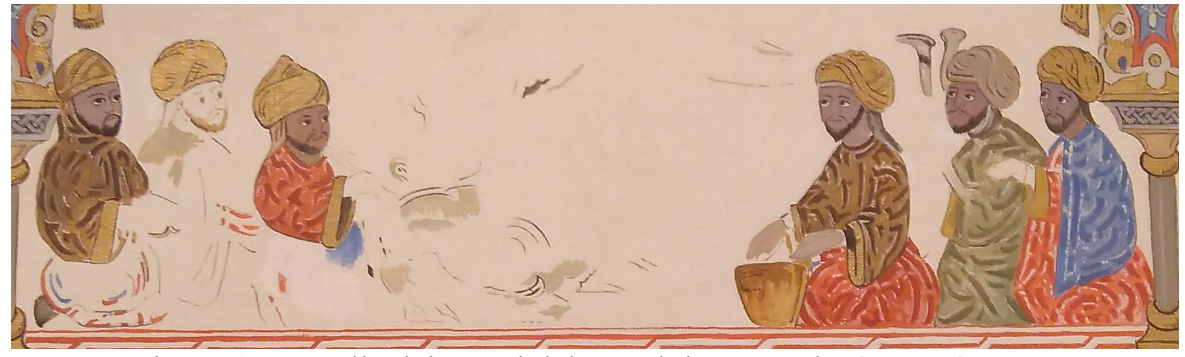

Figura 10. Detalle del mural del Partal de Manuel López Vázquez.

hombro de la figura que se encuentra tras la mencionada se ven unos objetos con forma acampanada que no llegan a ser del todo definidas en ninguna de las recreaciones. Del resto de figuras poco se puede vislumbrar por su estado de conservación.

\footnotetext{
418 Antonio Fernández Puertas, Alhambra. Muhammad V. El Mawlid de 764/ 1362. Granada: Almed, 2018,142 .
} 
En la parte derecha de este mural aparece la segunda escena musical la cual es ya visible desde la versión realizada por Isidoro Marín, mientras que las otras quedan demasiado difusas como para poder plantear una hipótesis de las escenas por lo que queda abierta a las interpretaciones de los artistas. En el caso de Manuel López Vázquez éste hace extensible la

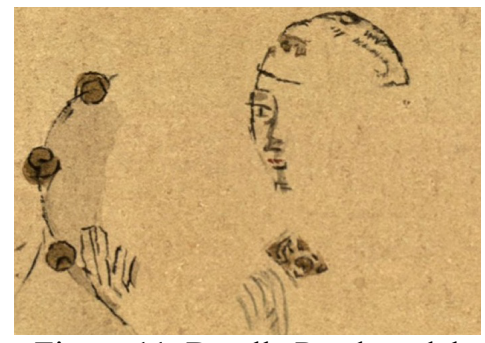

Figura 11. Detalle Pandero del mural del Partal, Isidoro Marín. escena musical a toda la franja del mural. Centrando la atención en la parte central, ésta tiene cinco figuras con las cabezas cubiertas donde se pueden intuir dos rostros femeninos a la derecha y dos masculinos a la izquierda, del personaje central solo se puede observar parte del turbante o velo, que no se asemeja a los que visten el resto de los integrantes de la escena. Antonio Fernández Puertas en su versión ha considerado que todas las figuras eran femeninas, pero al ampliar y ver los detalles con detenimiento la segunda figura empezando por la izquierda del arco central cuenta con facciones masculinas y la de su lado izquierdo se asemeja en el ropaje. Los instrumentos que le son atribuidos a esta imagen aparecen ya reflejados en la versión de Isidoro Marín, viéndose parte de la caja de resonancia del instrumento y el mástil con la mano izquierda del intérprete apoyada. Por el estado de conservación de la imagen no se puede definir claramente qué forma exacta es la que tiene el cordófono de la imagen, de ahí las recreaciones totalmente descontextualizadas que realizan del mismo. Como afirma Rosario Álvarez el artista tiende a "escoger modelos, es decir, a imitar obras tradicionales" ${ }^{419}$. El otro instrumento representado es un tar, el cual contaría con seis pares de crótalos cuando normalmente cuenta con un máximo de

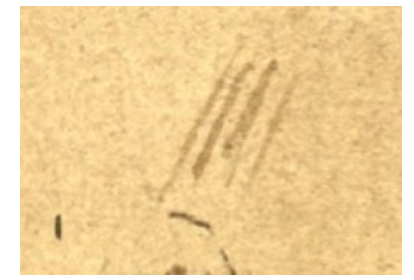

Figura 12. Detalle posible cordófono mural del Partal, Isidoro Marín. cinco. De estos seis, que tanto Antonio Fernández como Manuel López le otorga a este instrumento, Isidoro Marín solo define tres, pero siguiendo la progresión que marca la distancia entre estos crótalos sumaría un total de seis como ambos artistas defienden.

\footnotetext{
${ }^{419}$ Rosario Álvarez Martínez, "Incidencias de una Forma de Trabajo en las representaciones de los Instrumentos Musicales: La Copia de Códices en la Edad Media", Nassarre: Revista Aragonesa de Musicología 23, 1, 2007, 54.
} 
Por otro lado, los restos que quedan de la imagen de la derecha son tan difusos que cualquier hipótesis que se plantee depende de la imaginación del artista ya que

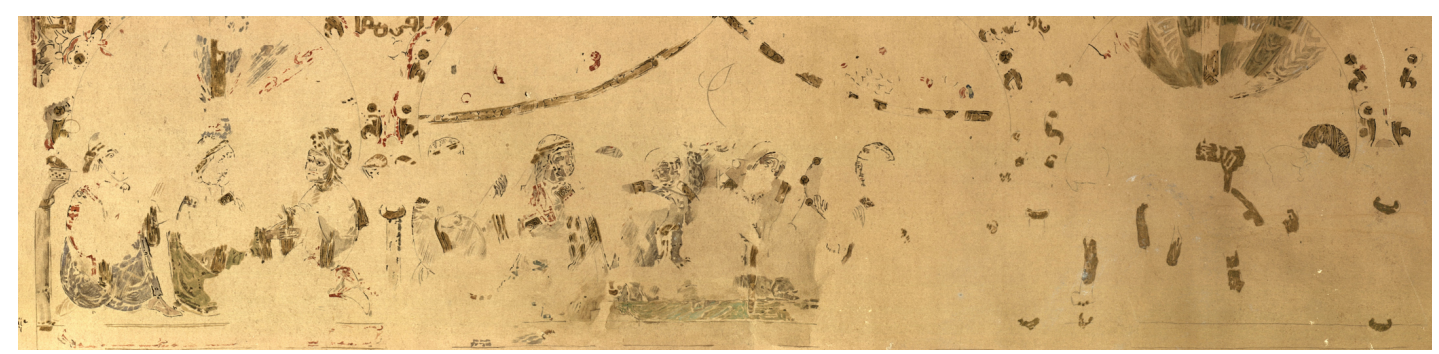

Figura 13. Detalle del mural del Partal de Isidoro Marín.

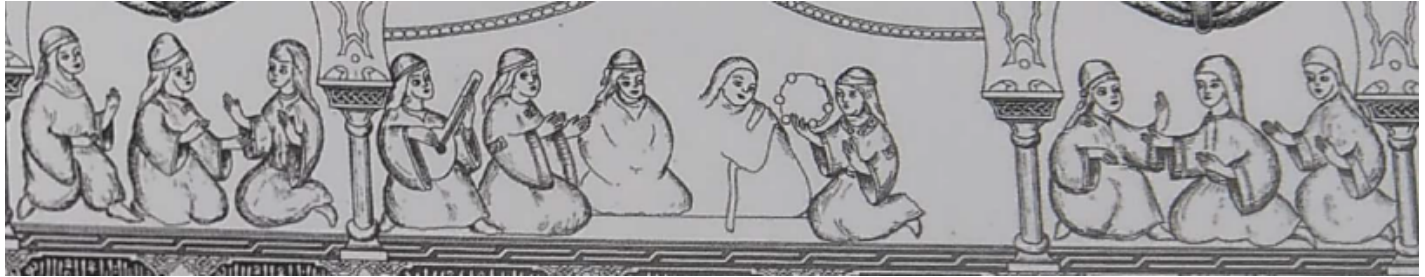

Figura 14. Detalle del mural del Parta de Manuel López Reche- Antonio Fernández Puertas.

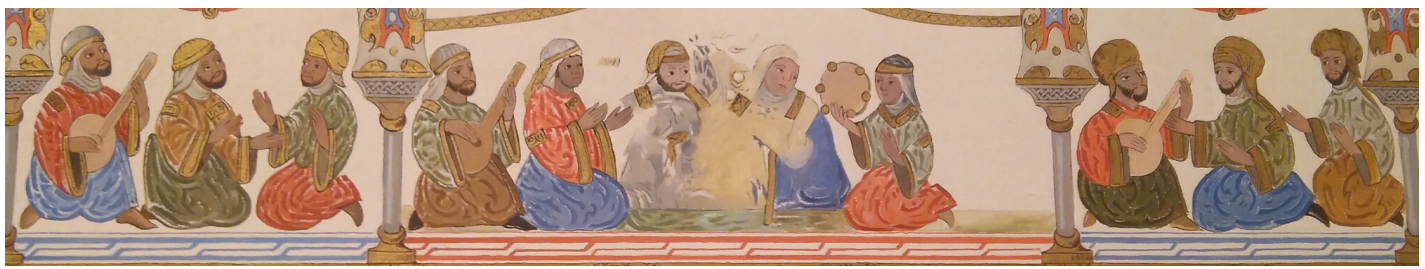

Figura 15. Detalle del mural del Partal de Manuel López Vázquez.

solo se observan ropajes y turbantes. De la escena izquierda del mural sí que se observa algo que podría interpretarse como un mástil de un cordófono el cual podría contar con cuatro cuerdas, lo que podría concordar con un laúd en un momento dado, aunque igualmente la reproducción realizada por Manuel López no coincidiría con los instrumentos de la época.

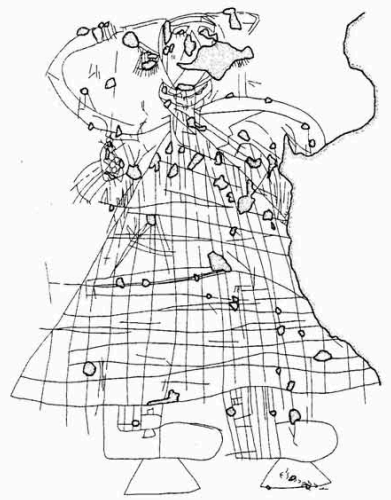

Figura 16. Gliptografía danzante en Granada XVI.
Dejando a un lado las imágenes del Partal y trasladando el centro de atención a otro punto de Granada, aunque muy probablemente se encuentre fuera de la fecha de esta investigación, no puede dejar de mencionarse la existencia en esta misma ciudad, de una de las primeras representaciones gliptográficas en una casa 
reconstruida en el siglo $\mathrm{XVI}^{420}$, posiblemente sobre restos de viviendas anteriores. Esta fue uno de los hogares que acogieron a las familias que se vieron envueltas en la implantación del programa de segregación social, donde se reubicaba a la población musulmana $^{421}$. En la misma se encontraron varias representaciones, entre ellas, una figura femenina danzando. Los grafitos fueron hechos sobre yeso, posiblemente tras el abandono o reocupación de la casa ${ }^{422}$. Se piensa que es una representación de una morisca, al llevar parte del rostro cubierto, aunque colgado del brazo podría tener un rosario o cordón trenzado ${ }^{423}$. Estos no serán los únicos grafitos que se encuentren en la Península Ibérica, existen otros danzantes, por ejemplo, en las figuras del Castell d'Oroners $^{424}$.

\section{Imagen caza sala Reyes de la Alhambra. S.XIV. Anexo 12-13}

En uno de los techos de la sala de los Reyes de la Alhambra, al lado del Patio de los Leones, se encuentra una habitación con distintas pinturas sobre piel en los techos. Una de ellas, con forma de elipse, recoge escenas variadas que van desde la rutina diaria a escenas de caza. En los ejes menores se representan las escenas más cotidianas observándose en uno de los vértices a seis figuras, tres masculinas y tres femeninas que asoman por ventanas y puertas de lo que parece un castillo. En el exterior de este hay una gran fuente protagonizada por un perro en su parte más alta el cual vierte agua por su boca. A la derecha e izquierda de esta imagen, en mayor tamaño representando la cercanía de estos nuevos personajes, se observan distintas figuras que conversan entre ellas pudiendo recrear un día cotidiano en el zoco. De forma paralela a esta escena, aparece otra fuente más grandiosa con un animal igualmente en su parte más alta, aunque en este caso no mana el agua de su boca, pero sí de una de las cabezas de leones que rodean la parte inferior de la misma. Esta segunda fuente está rodeada por dos mujeres, una de ellas con la cabeza cubierta, permaneciendo ambas a cada uno de los lados de esta. El resto de la imagen, coincidiendo prácticamente con sus vértices, recrea una gran escena de caza en la que puede observarse distintos animales como pájaros o conejos, codiciadas presas para

\footnotetext{
420 José Ignacio Barrera Maturana, "Grafitos Históricos en la Casa Morisca de Calle San Martín, 16 (Granada)", Arqueología y Territorio Medieval 15, 2008, 91-126.

421 Ibidem, 93.

422 Ibídem, 94.

423 Ibidem, 95.

${ }^{424}$ Ibidem, 96.
} 
distintos cazadores que a pie o a caballo intentan capturarlos por medio de lanzas y arcos. Los jinetes, rodeados de sus perros cómplices, apresan animales de mayor tamaño como es el caso de un león.

Tras uno de los jinetes que se encuentra en plena caza ayudado por dos perros aparece una figura a pie que se inclina sobre el suelo con un cuerno de gran tamaño. El sonido del instrumento parece dirigido al suelo donde se encuentra una gran cantidad de pequeños animales, no solo en este lado de la pintura sino por toda la recreación. Sobre esta figura y subido en un árbol aparece una figura infantil sentado entre las ramas, con una mano se aferra a una de éstas para no caer y con la otra sostiene lo que parece un silbato, un reclamo, de gran tamaño que enfoca al cielo haciendo pensar que va dirigido a los numerosos pájaros que por allí vuelan. Esta iconografía resulta única ya que no se había encontrado hasta el momento tal representación de este instrumento. La importancia de esta también corrobora su uso como reclamo y su lazo con los niños. De este tipo de aerófonos se hablará más ampliamente en el siguiente capítulo a través de las evidencias físicas que llegan a nuestros días a través de excavaciones arqueológicas.

\section{Aclaración iconográfica sobre la "Capa de Fermo" - "Casula di Thomas Becket"}

Conocida en España como "La Capa de Fermo" y en Italia como "La Casula di Thomas Becket", esta pieza custodiada actualmente por el Museo Diocesano de
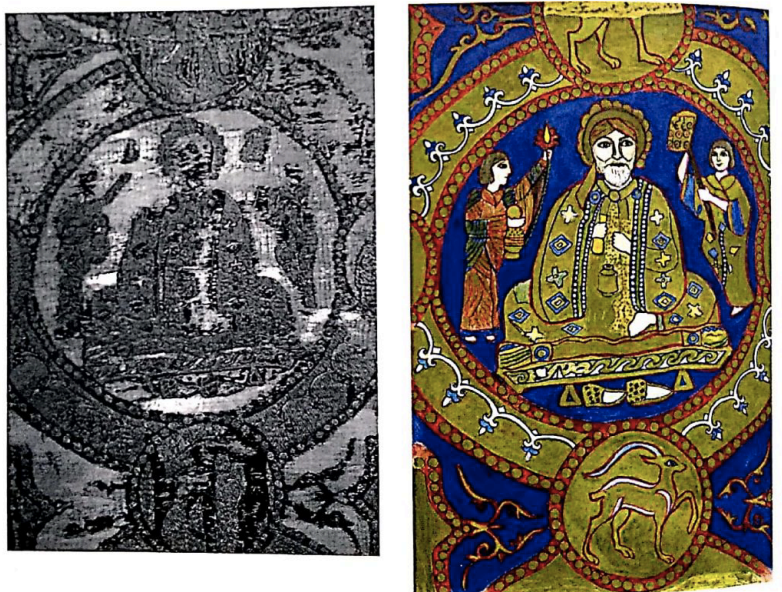

Figura 17. Detalle de la Capa de Fermo por Laura Ciampini.
Fermo procede de la manufactura hispanomusulmana almeriense. Según el propio museo parece que pudo ser donada por Thomas Becket (Londres, 1118- Canterbury, 1170) a un obispo de Fermo ${ }^{425}$. Según Cristina Partearroyo, el diseño de la capa podría haberse realizado para el monarca almorávide Alí ben Yusuf

\footnotetext{
425 Casula di Thomas Becket http://www.museodiocesanofermo.it/la-casula/ (Última consulta: 4-022020).
} 
(1107- 1143) o para algún regalo diplomático ya que el intercambio de tejidos o bordados era una costumbre frecuente en la época ${ }^{426}$. Se conoce la datación y lugar de fabricación de la misma gracias a que cuenta con una inscripción "En el nombre de Allah (...). Bendición la mayor: salud perfecta y felicidad a su dueño (...). En el año 510 en al Mariyya"427, lo que la sitúa en Almería (al Mariyya) entre 1116 y $1117^{428}$. Posiblemente en su origen sería rectangular ${ }^{429}$, pero por su posterior uso se terminó modificando hasta dejarla con forma semicircular. Cuenta con filas de círculos unidos de dos tamaños 10 y $20 \mathrm{~cm}$, donde se observan principalmente representaciones de distintas aves y elefantes acompañados en alguna ocasión con figuras humanas, menos en dos de estas imágenes donde aparece una escena con un soberano repetida e invertida ya que posiblemente se usase un cartón con el diseño al revés durante su fabricación ${ }^{430}$. Precisamente esta escena es la que le hace que esta pieza se incluya en esta investigación ya que en varias ocasiones se ha afirmado que este soberano podría estar acompañado por un sirviente y por un músico correspondiendo así la imagen a un Banquete Celeste ${ }^{431}$. Cristina Partearroyo en 2007 publica un artículo titulado “Tejidos andalusíes" donde afirma que hay "dos escenas de corte, mediante un personaje real entronizado con un músico y un sirviente, donde se alude al Banquete Celeste, está en parte deteriorado, aunque se aprecian todavía detalles como el rico

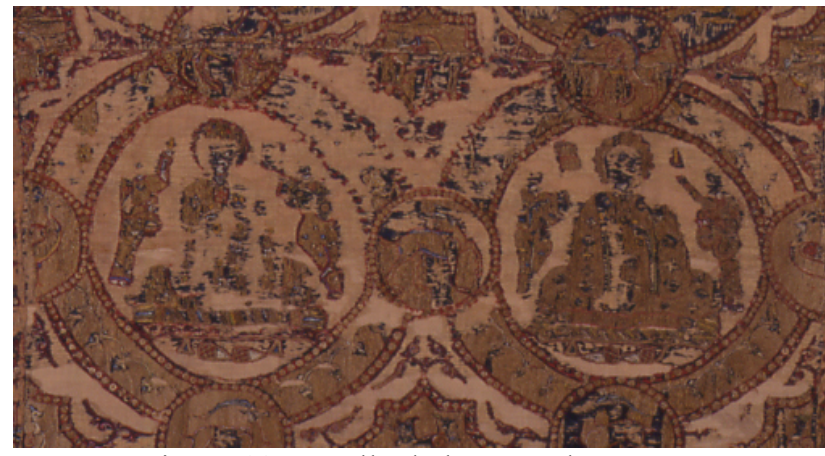

Figura 18. Detalle de la Capa de Fermo. calzado del soberano; ha sido dibujado por Ciampini en su estudio".

Posteriormente, en 2010 Francisco de Asís comenta que la imagen de esta capa se corresponde con la iconografía común donde los soberanos eran

\footnotetext{
${ }^{426}$ Cristina Partearroyo Lacaba, "Tejidos Andalusíes”, Artigrama, Revista del Departamento de Historia del Arte de la Universidad de Zaragoza, 22, 2007, 384.

427 Ibidem, 383- 384.

428 Casula di Thomas Becket http://www.museodiocesanofermo.it/la-casula/ (Última consulta: 4-022020).

429 Ibídem, 384.

${ }^{430}$ Laura Ciampini, "La Capa de Fermo: Un Bordado de Al-Andalus”, Arte y cultura: patrimonio hispanomusulmán en Al-Andalus, 2009, 158.

${ }^{431}$ Cristina Partearroyo Lacaba, "Tejidos Andalusíes", Artigrama, Revista del Departamento de Historia del Arte de la Universidad de Zaragoza, 22, 2007, 384.
} 
acompañados por músicos ${ }^{432}$ reforzando así la posibilidad de que esta escena contase con iconografía musical. Posteriormente a estos trabajos, Laura Ciampini realiza un nuevo estudio sobre la pieza que publica en el artículo "La capa de fermo: un bordado de al-Andalus" realizando la siguiente afirmación: "la escena representa un momento de la vida de corte, y alude al Banquete Celeste que muestra a los soberanos en el trono, rodeado por músicos y sirvientes, según la iconografía de la época califal”433 pero en este caso, como puede observarse, la afirmación no la concreta sobre esta imagen sino que la menciona como una generalidad o así debe entenderse ya que posteriormente en la descripción de la misma y la reconstrucción que proponen del dibujo no hace referencia a la presencia musical que podría tener la escena. Después de este debate y ante la duda de si esta capa podría contar o no con iconografía musical se le solicitó una fotografía al Museo Diocesano de Fermo lo permitió un estudio detallado de la pieza tras el cual se puede afirmar que esta capa no cuenta con iconografía musical ni en esta escena ni en otra donde aparecen igualmente figuras representadas de menor tamaño.

\subsubsection{Relación de instrumentos musicales en la iconografía hispanomusulmana}

\section{tratada}

\section{Nombre: Bote de al-Mughira}

Fecha: 968

Procedencia: Probablemente Madinat al-Zahra (Córdoba)

Lugar donde se conserva:

Museo del Louvre, París

Instrumentos musicales:

- Idiófonos: -

- Membranófonos: -

- Cordófonos: 'ud

- Aerófonos: -

432 Asís García García, "El Soberano En Al-Andalus”, Revista Digital de Iconografía Medieval, nº 4, 2010, 63

433 Laura Ciampini, "La Capa de Fermo: Un Bordado de Al-Andalus", Arte y cultura: patrimonio hispanomusulmán en Al-Andalus, 2009, 157. 


\begin{tabular}{|l|}
\hline Nombre: Bote de Davillier \\
\hline Fecha: $960-970$ (Omeya) \\
\hline Lugar de procedencia: Probablemente Madinat al-Zahra (Córdoba). \\
\hline Lugar donde se conserva: \\
Museo del Louvre, París \\
\hline Instrumentos musicales: \\
- Idiófonos: - \\
- Membranófonos: - \\
- Cordófonos: 'ud \\
- Aerófonos: - \\
\hline
\end{tabular}

\begin{tabular}{|l|}
\hline Nombre: Arqueta de Leyre \\
\hline Fecha: $1004-1005$ \\
\hline Lugar de procedencia: Madinat al-Zahra (Córdoba). \\
\hline Lugar donde se conserva: \\
Museo de Navarra \\
\hline Instrumentos musicales: \\
- Idiófonos: - \\
- Membranófonos: - \\
- Cordófonos: 'ud \\
- Aerófonos: flauta doble, albogue \\
\hline
\end{tabular}

\begin{tabular}{|l|}
\hline Nombre: Arqueta Museo Victoria \& Albert \\
\hline Fecha: $1000-1025$ \\
\hline Lugar de procedencia: ¿Córdoba? \\
\hline Lugar donde se conserva: \\
Museo Victoria \& Albert \\
\hline Instrumentos musicales: \\
- Idiófonos: - \\
- Membranófonos: - \\
- Cordófonos: 'ud \\
- Aerófonos: albogue
\end{tabular}




\begin{tabular}{|l|}
\hline Nombre: Botella de los músicos \\
\hline Fecha: 900-1000 (Califal) \\
\hline Lugar de procedencia: C/ Alfonso X el Sabio, Córdoba \\
\hline Lugar donde se conserva: \\
Museo Arqueológico y Etnológico de Córdoba \\
\hline Instrumentos musicales: \\
- Idiófonos: - \\
- Membranófonos: adufe \\
- Cordófonos: - \\
- Aerófonos: albogue
\end{tabular}

\begin{tabular}{|l|}
\hline Nombre: Capitel de los músicos \\
\hline Fecha: $976-1000$ (Califal) \\
\hline Lugar de procedencia: - \\
\hline Lugar donde se conserva: \\
Museo Arqueológico y Etnológico de Córdoba \\
\hline Instrumentos musicales: \\
- Idiófonos: - \\
- Membranófonos: - \\
- Cordófonos: rebab, 'ud \\
- Aerófonos: - \\
\hline
\end{tabular}

\begin{tabular}{|l|}
\hline Nombre: Tañedora de tamborcillo \\
\hline Fecha: 976-1000 (Califal) \\
\hline Lugar de procedencia: \\
\hline Lugar donde se conserva: \\
Museo Arqueológico y Etnológico de Córdoba \\
\hline Instrumentos musicales: \\
- Idiófonos: - \\
- Membranófonos: tamborcillo \\
- Cordófonos: - \\
- Aerófonos: - \\
\hline
\end{tabular}




\begin{tabular}{|l|}
\hline Nombre: Codex. Vat. Arabo 368 \\
\hline Fecha: XIII \\
\hline Lugar de procedencia: ¿al-Andalus? \\
\hline Lugar donde se conserva: \\
Biblioteca Apostólica de la Ciudad del Vaticano \\
\hline Instrumentos musicales: \\
- Idiófonos: - \\
- Membranófonos: - \\
- Cordófonos: 'ud \\
- Aerófonos: - \\
\hline
\end{tabular}

\begin{tabular}{|l|}
\hline Nombre: Pintura de moros en el Partal \\
\hline Fecha: XIV \\
\hline Procedencia: Alhambra, Granada \\
\hline Lugar donde se conserva: \\
Habitación contigua en la Torre de la Damas, El Partal, Alhambra, Granada. \\
\hline Instrumentos musicales: \\
- Idiófonos: - \\
- Membranófonos: tambor, tar \\
- Cordófonos: ¿? \\
- Aerófonos: - \\
\hline
\end{tabular}

\begin{tabular}{|l|}
\hline Nombre: Escena de caza \\
\hline Fecha: XIV \\
\hline Procedencia: Sala de los Reyes, Alhambra \\
\hline Lugar donde se conserva: \\
Alhambra \\
\hline Instrumentos musicales: \\
- Idiófonos: - \\
- Membranófonos: - \\
- Cordófonos: - \\
- Aerófonos: cuerno, silbato \\
\hline
\end{tabular}


Quedando clasificados por familias de instrumentos genéricas:

\begin{tabular}{|l|l|}
\hline $\begin{array}{l}\text { Aerófonos } \\
\text { Albogue } \\
\text { Flauta doble } \\
\text { Cuerno } \\
\text { Silbato (reclamo) }\end{array}$ & $\begin{array}{l}\text { Cordófonos } \\
\text { 'ud } \\
\text { Rebab }\end{array}$ \\
\hline Idiófonos & \\
& $\begin{array}{l}\text { Membranófonos } \\
\text { Tamborcillo } \\
\text { Tambor } \\
\text { Pandero/ tar } \\
\text { ¿Kuba? }\end{array}$ \\
\hline
\end{tabular}

Aerófonos

Albogue (Buq)

Término usado de forma genérica para referirse a aerófonos árabes, ya que, como afirma Christian Poché, nunca ha sido definido con precisión ${ }^{434}$. A pesar de ello, se considera que es un instrumento "tipo cuerno" como el proprio Poché afirmaba años antes en su libro La música arábigo-andaluza ${ }^{435}$, recalcando de éste que se encontraba reflejado en la Arqueta del Museum Victoria \& Albert acompañado por el ' $u d$. Este dúo es catalogado por el propio investigador como una agrupación "muy rara en el mundo árabe, [que] pudo estar destinada en cierta época al acompañamiento del sawt y de la muwassaha y figurar en un posible instrumental de la $n u b a$, pero después no se mantuvo"436. Según el alfaquí tunecino al-Tifasi (siglo XIII) era el instrumento de viento preferido por el público de al-Andalus, perfecto para acompañar la danza ${ }^{437}$. De este instrumento, al-Tifasi comenta que contaba con una embocadura formada por una serie de piezas de caña que encajaban y terminaban con una lengüeta ${ }^{438}$. Además de encontrar este instrumento en la iconografía citada,

\footnotetext{
434 Christian Poché, "Buq", en Grove Music Online, Oxford University Press, 2001, https://www.oxfordmusiconline.com/grovemusic/view/10.1093/gmo/9781561592630.001.0001/omo9781561592630-e-0000004336?rskey=Z5TjMB\&result=1 (Última consulta: 10-11-2019).

435 Christian Poché, La Música Arábigo-Andaluza. Ediciones Akal, 1997, 101.

436 Ídem.

437 Ibidem, 99.

${ }^{438}$ Ídem.
} 
Poché lo relaciona con el aerófono de la Cantiga $n^{\text {o }} 300$, s. XIII ${ }^{439}$. Asimismo, Farmer puntualiza que probablemente se hacía con cuerno animal, al igual que el shaipur ${ }^{440}$.

\section{Flauta doble}

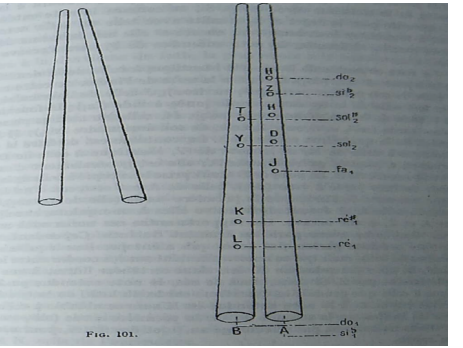

Figura 19. Flauta doble según al-Farabi.

Tal y como se percibe en la imagen de la Arqueta de Leyre, este instrumento está compuestos por dos tubos cilíndricos que aparentan tener distinto tamaño. Tal y como muestra el filósofo medieval turco al-Farabi (IX-X) las flautas dobles en el libro realizado en La musique arabe, éstas cuentan con dos tubos exactamente iguales en largo y diámetro, aunque éstos tienden a aumentar el mismo de forma progresiva hacia el final del instrumento y no cuentan con embocadura externa. Durante la época medieval se dieron dos tipos de aerófonos dobles, una de ellas contaba con doble lengüeta y la otra con lengüeta simple. En el caso de esta representación, coincidiendo con la opinión de Reynaldo Fernández ${ }^{441}$ parece ser un instrumento de lengüetas simples, ya que los labios del intérprete quedan definidamente presentes. Sin embargo, si se tratase de un instrumento con lengüeta doble, lo que se deduce por la posición de los labios del instrumentista.

En realción con las flautas dobles Ramón Andrés, este tipo de flautas se dan de forma paralela al nacimiento de las verticales y transversales, "unas veces con los tubos dispuestos en ángulo, otras veces paralelamente" ${ }^{442}$. Existen, asimismo, evidencias iconográficas donde se muestra este instrumento con largos distintos en cada tubo como en el caso del ángel músicos del retablo de alabastro de Antoni Dalmau y Juliá lo Florenti (1444-1446) en la Catedral de Valencia.

\footnotetext{
439 Ibidem, 101.

${ }^{440}$ Henry George Farmer, "Instruments of Music on Taq-i Bustan Bas-Reliefs", en Studies in Oriental Musical Instruments. Glasgow: The civic press, 1939, 82.

${ }^{441}$ Reynaldo Fernández Manzano, "Diversos aspectos sobre los cordófonos en Al-Andalus y la etapa Morisca”, Revista de Musicología 16, 3, 1993, 1374.

442 Ramón Andrés, Diccionario de instrumentos musicales. Desde la Antigüedad a J.S. Bach. Barcelona: Ediciones Península, 2009, 193.
} 


\section{Cuerno}

Del uso de este instrumento musical se tiene evidencias desde el Neolítico ${ }^{443}$. Este tipo de instrumentos se realizaba con bronce, metal, marfil o madera. Cuenta Ramón Andrés que hasta el siglo X su sonido fundamental solo se modificaba mediante notas armónicas a través de los labios del intérprete, pero que a partir de entonces se le creó una boquilla y orificios para su digitación ${ }^{444}$. Su uso, en un principio, se limitaba a las señales durante la guerra y para la caza ${ }^{445}$. Existe una representación de este en una de las miniaturas de las Cantigas de Santa María. En el caso de esta representación, no parece contar con agujeros digitales ya que el intérprete lo rodea con su mano izquierda posicionándola cerca de la embocadura.

\section{Silbato/ reclamo}

Este instrumento se presentará de forma extensa y contextualizada en el capítulo dedicado a los instrumentos encontrados en las excavaciones arqueológicas.

\section{Cordófonos}

\section{Laúd ('ud)}

De este esencial instrumento musical para la música árabe se conserva muy copiosa iconografía andalusí, fatimí y oriental, entre otras, al igual que relevante información en los manuscritos, pero al estar construido con material perecedero no llega ningún ejemplar a nuestros días.

El 'ud se considera un instrumento musical de gran riqueza simbólica, recibiendo incluso la denominación de instrumento confidente, amigo de los sentimientos ${ }^{446}$. Acorde a esta afirmación, el filósofo al-Farabi comentaba: "habla al corazón como si tuviera lengua; y expresa sus sentimientos mejor que la pluma en mano de un enamorado" 447.

\footnotetext{
${ }^{443}$ Ibidem, 163.

444 Ídem.

${ }^{445}$ Françoise-René Tranchefort, Los instrumentos musicales en el mundo. Alianza Editorial, 2008, 273.

${ }^{446}$ Ramón Andrés, Diccionario de música, mitología, magia y religión. Barcelona: Acantilado, 2012, 931.

${ }^{447}$ Rodolphe D’Erlanger, Al-Farabi La musique arabe, ed. Les Geuthner. París: Société nouvelle librairie orientaliste Paul Geuthner, S.A., 1935, 53.
} 
Cortés García subraya que es considerado "el sultán de los instrumentos" sirviendo de base para la configuración de la teoría musical árabe "de tal forma que los teóricos definieron, sobre él, su estructura, afinación, ligaduras y pulsación" ${ }^{448}$.

Este instrumento no se limita a la cultura árabe, su evolución y difusión le hace que vaya modificando su forma, adaptándola a cada una de las culturas a la que se acerca, relacionándose directamente con las creencias mitológicas de cada una de ellas. Su origen parece remontarse al II milenio anterior a la actual era, relacionado con civilizaciones sumerias: "allí debió nacer una especie de laúd de corto mango y recia caja, que de Babilonia - quizá del núcleo formado por Agadé, Nippur y Abaditineró hacia los territorios asirios del norte, por Assur, Umm Dabagiya, Monsul y Nínive, donde pudo perfeccionarse" ${ }^{" 49}$. Este territorio creó una vía de transmisión con lugares como China, donde aparecería la $p^{\prime} i p^{\prime} a$ o su antecesora la biwa, laúd japonés.

En el mundo árabe, los orígenes del laúd de mástil corto se sitúan en la época de los sasánidas (224-642), recibiendo el nombre persa de barbat o barbut, cuyo significado literal es "pecho de ánade". Esta denominación se relaciona con la forma de la caja de resonancia del instrumento. La tapa armónica del mismo era de piel, posteriormente pasaría a realizarse de madera, de ahí el nombre del instrumento, $u d$ ("varilla flexible", "ramita" y por deducción "pieza de madera" ${ }^{450}$ ), y a aumentarse su tamaño ${ }^{451}$.

Según la versión mitológica árabe del origen de este instrumento fue Lamek, hijo predilecto de Metuchalej, hijo de Mahawil, hijo de Abad, hijo de Januj, hijo de Caín, hijo de Adán, quien realizó el instrumento tras la muerte de su hijo, al que amaba tremendamente. Lamek suspendió de un árbol el cuerpo de su hijo, quedándose con el tiempo desgarrado del muslo a los dedos del pie. Cuentan que Lamek cogió un trozo de madera y trabajándola con esmero hizo un laúd imitando las formas del cuerpo que de su hijo habían quedado: caja de resonancia imitando al muslo, mástil imitando a la pierna y clavijero imitando el pie. Las clavijas eran los dedos y las cuerdas las arterias. Una vez fabricado el instrumento cuentan que con él

\footnotetext{
448 Manuela Cortés García, La música en la Zaragoza islámica. Zaragoza: Instituto de Estudios Islámicos y del Oriente Próximo, 2009, 33.

449 Ramón Andrés, Diccionario de instrumentos musicales. Desde la Antigüedad a J.S. Bach. Barcelona: Península, 2009, 261.

${ }^{450}$ Rosario Mazuela Coll, "Traducción del manuscrito 334/5307 de la Biblioteca Nacional de Madrid". Universidad de Granada, 1986, 39.

${ }^{451}$ Ramón Andrés, Diccionario de música, mitología, magia y religión. Barcelona: Acantilado, 2012, 930 .
} 
acompañó sus cantos fúnebres. Este instrumento musical no será el único al que se le otorga su nacimiento en referencia a la familia de Lamek, ya que a su hijo Tubal se le atribuye haber introducido el tabl (tambor) y el duff (pandereta), y su hija Dilal se le hace responsable de el ma'azif (arpas y liras) ${ }^{452}$.

La grandeza y relevancia de este instrumento es realizada igualmente desde el punto de vista musical por el turco al-Farabi:

"Las perfecciones del temperamento de los tales instrumentos (...) es la que sale del laúd; porque este instrumento circula por todas las potencias de manera que en él solo hallamos todas las Negramas accidentales pertenecientes a los instrumentos que conforme a su naturaleza los dan como naturales" ${ }^{453}$.

Añade, igualmente, que ni el Miurabi ni el rebab llega a esta.

En el siglo IX, el jurista de Bagdad Mawardi, ensalzó su uso en el tratamiento de enfermedades, idea que se siguió defendiendo en al-Andalus mediante sabios como Ibn $\mathrm{Hazm}^{454}$, entre otros.

Asimismo, tuvo tanta relevancia que hasta la valía del músico se medía según la interpretación de este instrumento, comprobando a través de él su virtuosismo y capacidad. El arabista Julián Ribera se hace eco de esto a través de la referencia de Tuéis, uno de los tres artistas considerados de la primera generación de cantores musulmanes del que cuenta que:

"Nació a tiempo de morir Mahoma. Se dice de él que introdujo el elemento rítmico en el arte musical árabe. No sabía tañer el laúd y acompañábase únicamente con el adufe, lo cual nos hace sospechar que sus cantos no fueron de arte muy complicados y exquisito" ${ }^{255}$.

Mediante esta afirmación, al mismo tiempo, se refleja su protagonismo como acompañamiento perfecto para la $\mathrm{voz}^{456}$, de ahí el amplio uso e iconografía resultante.

Este instrumento, considerado en numerosas ocasiones por su superficial parecido estructural a la guitarra española, no tendría que ver de forma directa con el

\footnotetext{
452 Rosario Mazuela Coll, “Traducción Del Manuscrito 334/5307 de La Biblioteca Nacional de Madrid”. Universidad de Granada, 1986, 28-29.

453 Rodolphe D'Erlanger, Al-Farabi La musique arabe, ed. Les Geuthner. París: Société nouvelle librairie orientaliste Paul Geuthner, S.A., 1935, 25-33.

454 Christian Poché, "'ud”, Grove Music Online, Oxford University Press, 2001. https://www.oxfordmusiconline.com/grovemusic/view/10.1093/gmo/9781561592630.001.0001/omo9781561592630-e-0000028694?rskey=1MW3Ve (Última consulta: 13-11-2019).

455 Julián Ribera y Tarragó, La música árabe y su influencia en la española. Valencia: Pre-Textos (Música "la Huella Sonora"), 2000, 61.

456 Ibídem, 107.
} 
desarrollo de este instrumento, ya que los orígenes del mismo se ven relacionados con la llamada "guitarra medival o morisca". Siendo éste otro de los grandes cordófonos presentes en esta época, aunque más cercano a los cristianos que a los musulmanes a su llegada a la Península Ibérica ${ }^{457}$, es reflejada por la iconografía hispana ya desde los siglos XII y XIII. Sobre este instrumento la investigadora Rosario Álvarez realiza el artículo titulado "Iconografía de la "guitarra" medieval, su origen centroasiático y sus derivados europeos", donde comenta las distintas hipótesis que intentan esclarecer el origen de la guitarra medieval. Este cordófono puede verse reflejado en las Cantigas de Santa María en cinco ocasiones al igual que en el Libro de ajedrez y dados, ambas fuentes cristianas que evidencian su cercanía a esta parte de la población posiblemente acontecida por la rápida adopción, por parte de éstos, del instrumento a su llegada a la Península Ibérica desde, probablemente, Sicilia o el Egipto fatimí sin llegar a pasar previamente por ser un emblema árabe ${ }^{458}$.

\section{Rabab}

Instrumento considerado por Tranchefort "sin duda el único realmente árabe" ${ }^{459}$ difiere de la opinión de Christian Poché, quien afirma que "su origen y etimología no han cesado de discutirse" 460 , asimismo Farmer diferencia entre el rabab y rubab, posiblemente de origen persa, más cercano al laúd ${ }^{461}$. En esta línea Poché afirma que la posibilidad de que el rabab derive del ' $u d$ no puede descartarse ${ }^{462}$ como así lo muestran los estudios organológicos ${ }^{463}$. En el siglo X es descrito por al-Farabi como un instrumento cuya ejecución depende de la longitud de las cuerdas al ser presionadas horizontalmente sin llegar a tocar el mango y frotadas con un arco, técnica de ejecución que lo enlaza con un posible origen persa. La gran expansión del islam hace que se creen distintos tipos de rabab, uno de cuerda punteada y otros de

\footnotetext{
${ }^{457}$ Rosario Álvarez Martínez, "Iconografía de la "guitarra" medieval, su origen centroasiático y sus derivados europeos", en El sonido de la Piedra, Actas del encuentro sobre instrumentos en el Camino De Santiago, 2005, 226-227.

458 Ibidem, 241.

${ }^{459}$ Françoise Tranchefort, Los instrumentos musicales en el mundo. Alianza Editorial, 2008, 144.

${ }^{460}$ Christian Poché, La música arábigo-andaluza. Ediciones Akal, 1997, 104.

461 Alastair Dick et al., "Rabab", Grove Music Online, Oxford University Press, 2001. https://www.oxfordmusiconline.com/grovemusic/view/10.1093/gmo/9781561592630.001.0001/omo9781561592630-e-0000022763? (Última consulta: 12-11-2019).

462 Ídem.

463 Christian Poché, La música arábigo-andaluza. Ediciones Akal, 1997, 105.
} 
$\operatorname{arco}^{464}$. Una de estas variantes, distinguida por Villoteau ${ }^{465}$, será el rabab al-sha'ir, violín del poeta, de una sola cuerda y con caja de resonancia trapezoidal o rectangular de madera la cual se cubre con piel de cabra o carnero ${ }^{466}$. Otro de los rebab será el $a l$ mughanni, del cantante, éste cuenta con dos cuerdas de crin y una caja de resonancia hecha con la cáscara de un coco abierta sobre la que se tensa una membrana de cuero $^{467}$. Asimismo, al-Tifasi señalaba que "existían dos tipos de rabab, el andalusí y el sharqi (oriental) ${ }^{468}$. El andalusí, de dos cuerdas, está compuesto por una caja ovalada y alargada de madera de nogal. La caja armónica se divide en dos partes, la parte superior está hecha con madera y la parte inferior con pergamino o piel de tripa. Este instrumento se apoya sobre la rodilla del intérprete durante su ejecución.

La leyenda del origen de este instrumento viene recogida a finales del siglo XIX en la región de Orán por Gaëtan Delphin y L. Guin, quienes cuenta que fue un prisionero de al-Andalus quien, con el fin de distraer sus largos y monótonos días, ahuecó un tronco y destripó animales para fabricar sus cuerdas, tras probar el punteo finalmente realizó un arco para su ejecución. Los carceleros, sorprendidos ante el sonido de aquel instrumento, informaron al rey quien decidió liberar de forma inmediata al prisionero y cubrirle de presentes ${ }^{469}$. Demostrando el peso de este instrumento en al-Andalus, el rebab, al igual que el 'ud, son citados con bastante frecuenta en las antologías poéticas ${ }^{470}$.

Con respecto a la parte iconográfica, Pavón Maldonado afirma que "desde el siglo XIII aparece habitualmente en esculturas, miniaturas y decoración de retablos ${ }^{471}$. Igualmente, este instrumento viene reflejado en varias miniaturas de las Cantigas.

\footnotetext{
464 Françoise Tranchefort, Los instrumentos musicales en el mundo. Alianza Editorial, 1985, 144.

465 Alastair Dick et al., "Rabab”, Grove Music Online, Oxford University Press, 2001. https://www.oxfordmusiconline.com/grovemusic/view/10.1093/gmo/9781561592630.001.0001/omo9781561592630-e-0000022763? (Última consulta: 12-11-2019).

${ }^{471}$ Basilio Pavón Maldonado, "Iconografia hispanomusulmana: naturalismo, fauna y árbol de la vida", (2013), http://www.basiliopavonmaldonado.es/Documentos/icohispa.pdf, 44 (Última consulta: 12-112019).
} 


\section{Membranófonos}

\section{Tar}

Instrumento de una sola membrana y pequeños crótalos o platillos sujetos en la estructura de este. El término deriva de soqotri que significa "objeto redondo" o "marco de tambor" $" 72$. Fue conocido en gran parte del territorio árabe desde la época abbasí $^{473}$. El Líbano y Siria no cuentan con este instrumento, pero sí con la presencia del riqq ${ }^{474}$, junto a Egipto, Iraq, Líbano, Palestina y Sudán ${ }^{475}$. A diferencia del $d u f f$ muestra una presencia preislámica ya que existe una gran difusión de este instrumento con variantes en forma ${ }^{476}$. Tanto el riqq como el tar adquirieron sus nombres en el siglo XIX para ser diferenciados del $d u f f^{477}$. Existen en distintos tamaños que van desde los 7-8 $\mathrm{cm}$ a los 11-25 $\mathrm{cm}$ de diámetro ${ }^{478}$ aunque estas medidas según la zona pueden variar y aumentar considerablemente ${ }^{479}$. El tar pequeño suele asociarse al intérprete formado mientras que el grande está ligado a la adoración ${ }^{480}$. Aunque ofrece muchas posibilidades es menos flexible que el riqq ${ }^{481}$.

\section{Adufe (Duff)}

Es difícil saber exactamente cuándo aparecieron este tipo de instrumentos, las primeras iconografías a cerca de ellos aparecen en Mesopotamia y Egipto,

\footnotetext{
472 Christian Poché, “Tar", Grove Music Online, Oxford University Press, 2001, https://www.oxfordmusiconline.com/grovemusic/view/10.1093/gmo/9781561592630.001.0001/omo9781561592630-e-0000027503 (Última consulta: 9-12-2019).

${ }^{473}$ Lois Ibsen Faruqi, An Annotated Glossary of Arabic Musical Term. United Estates of America: Greenwood Press, 1981, 347.

${ }^{474}$ Christian Poché, "Tar", Grove Music Online, Oxford University Press, 2001, https://www.oxfordmusiconline.com/grovemusic/view/10.1093/gmo/9781561592630.001.0001/omo9781561592630-e-0000027503 (Última consulta: 09-12-2019).

475 Christian Poché, “Riqq”, Grove Music Online, Oxford University Press, 2001, https://www.oxfordmusiconline.com/grovemusic/view/10.1093/gmo/9781561592630.001.0001/omo9781561592630-e-0000046903 (Última consulta: 09-12-2019).

${ }^{476}$ Christian Poché, “Tar", Grove Music Online, Oxford University Press, 2001, https://www.oxfordmusiconline.com/grovemusic/view/10.1093/gmo/9781561592630.001.0001/omo9781561592630-e-0000027503 (Última consulta: 09-12-2019).

477 Christian Poché, "Riqq", Grove Music Online, Oxford University Press, 2001, https://www.oxfordmusiconline.com/grovemusic/view/10.1093/gmo/9781561592630.001.0001/omo9781561592630-e-0000046903 (Última consulta: 09-12-2019).

${ }^{478}$ Lois Ibsen Faruqi, An Annotated Glossary of Arabic Musical Term. United Estates of America: Greenwood Press, 1981, 350.

479 Ídem.

480 Christian Poché, "Tar", Grove Music Online, Oxford University Press, 2001, https://www.oxfordmusiconline.com/grovemusic/view/10.1093/gmo/9781561592630.001.0001/omo9781561592630-e-0000027503 (Última consulta: 9-12-2019).

481 Ídem.
} 
pertenecientes al III milenio antes de nuestra era. La versión de la antigüedad grecorromana eran los tympana y se utilizaban para ritos sagrados y fiestas populares. Asimismo, la versión griega, tympanon, podía contar con cintas de adorno y solía ser utilizado por mujeres. Esta relación del instrumento con la figura femenina se ve reflejada, igualmente, en los textos bíblicos, Éxodo, el Libro de los Profetas ${ }^{482}$, así como en el periodo preislámico en Egipto, donde se utilizaba para acompañar la danza, aunque su uso no solo se limitaba a este contexto festivo ya que en el Próximo Oriente éste también se utilizó para acompañar cantos religiosos ${ }^{483}$. Esta presencia del instrumento en el contexto místico podía deberse al uso que le fue dado por el Profeta Muhammad (siglo VII), ya que lo utilizó en distintos contextos, como entretenimiento, celebraciones o batallas. Este hecho pudo ser el motivo de que el $d u f f$ llegase a evadir las condenas oficiales que recibieron los instrumentos musicales ${ }^{484}$. Asimismo, está relacionado con el tof hebreo, ambos cuentan con esta denominación onomatopéyica por el sonido que realizan al ser percutidos ${ }^{485}$. Este instrumento tiene de media unos treinta centímetros de diámetro. Generalmente se sujeta con la mano izquierda y se golpea con la derecha. Cuenta con platillos para adornar su sonido. $\mathrm{Su}$ versión con forma cuadrada es la que se introdujo en la Península Ibérica ${ }^{486}$.

La presencia de la mujer en la interpretación de este tipo de instrumentos conllevará un rechazo tajante hacia el hombre que lo interpreta, llegando a ser tachado de "afeminado". Un ejemplo de este tipo de instrumentos sería el $d u f f$, éste fue por excelencia uno de los instrumentos considerados de mujeres, ya que se utilizó con gran frecuencia para acompañar las danzas femeninas ${ }^{487}$ : "Atributo musical indispensable de las mujeres, tanto en la alegría como en el duelo, y también como instrumentos rítmicos con los cuales las profesionales acompañaban sus canciones y danzas" ${ }^{488}$.

A pesar de su gran uso y presencia, instrumentos como el adufe se consideraban vulgares como podemos comprobar a través del siguiente poema

\footnotetext{
482 Ibidem, 80.

483 Ibidem, 79.

484 Conway R. Morris et al., "Duff", Grove Music Online, Oxford University Press, 2001, https://www.oxfordmusiconline.com/grovemusic/view/10.1093/gmo/9781561592630.001.0001/omo9781561592630-e-0000007050? (Última consulta: 12-11-2019).

485 Ídem

486 Ibidem, 80.

487 Ídem.

${ }^{488}$ Françoise Tranchefort, Los instrumentos musicales en el mundo. Alianza Editorial, 1985, 235.
} 
recitado por un padre a su hijo, casado con una mujer "ligera": "No te basta con cometer el pecado de fornicación y beber vino fresco y embriagador para que además toques el tamboril en público asegurándote una mala reputación: ¡ven a mi!”489.

Otro ejemplo de estos instrumentos que le acarrearían a sus intérpretes masculinos la "deshonra" de ser "afeminados" sería una variante de los diversos adufes, el duff murabba, pandero rectangular, instrumento musical existente desde el periodo faraónico ${ }^{490}$. El uso de este instrumento fue por lo tanto prohibido, aunque esta prohibición fue rebatida por especialistas integrantes en los zahiri, los cuales comparaban el considerar ilícito un instrumento musical porque fuese interpretado por los "afeminados" con dejar de lavar la ropa porque ellos así lo hiciesen ${ }^{491}$.

Investigadores como Curt Sachs enlazan el que este instrumento pudiese ser cercano a las mujeres por la similitud que existe en su construcción con el utensilio para limpiar el grano, "en el caso particular de España encontramos que durante el siglo XIV un tipo de criba se conocía también con el nombre de pandero"492.

\section{Naqqara}

Naqqarat en plural. Su origen se remonta a las primeras dinastías del Imperio persa donde era utilizado por los ejércitos con la finalidad de intimidar al enemigo. Se trata de unos pequeños timbales hemisféricos de unos $25 \mathrm{~cm}$ de diámetro hechos de madera, arcilla o cobre los cuales son unidos entre sí por una correa de cuero. Los parches suelen hacerse de tripa de cabra y se tensan mediante cuerdas que se enlazan por el cuerpo del instrumento. Éstos solían ser percutidos con pequeñas baquetas recubiertas de tela ${ }^{493}$ y eran ampliamente utilizado en la música militar, religiosa y ceremonial $^{494}$. Es considerado un símbolo de realeza y suele interpretarse junto a trompetas $^{495}$ o añafiles como puede observarse en la iconografía. Solían transportarse

\footnotetext{
489 Henri Pérès, Esplendor de al-Andalus. Madrid: Libros Hiperión, 1983, 383.

${ }^{490} \mathrm{M}^{\mathrm{a}}$ Dolores Guardiola, "El Tratado de Música Árabe Kitab Al-Imta Bi-Ahkam Al-Sama”.

Universidad de Granada, 1992, 105.

491 Ibídem, 118.

492 Mauricio Molina, "Tympanistria nostra: la reconstrucción del contexto y la práctica musical de las pandereteras y aduferas medievales a través de sus representaciones en el Arte Románico español", Cuadernos de investigación del monasterio de Santa María la Real 26, 2010, 83.

${ }^{493}$ Françoise Tranchefort, Los instrumentos musicales en el mundo. Alianza Editorial, 1985, 79.

494 William J. Conner, Milfie Howell y Robert Atayan, "Naqqara", Grove Music Online, Oxford University Press, 2001 , https://www.oxfordmusiconline.com/grovemusic/view/10.1093/gmo/9781561592630.001.0001/omo9781561592630-e-0000019571? (Última consulta: 13-11-2019).

495 Ídem.
} 
sobre caballos o camellos ${ }^{496}$. Este instrumento suele ir en pareja con distinta afinación manteniendo el más agudo a la derecha ${ }^{497}$. A partid de la Edad Media empieza a estar presente en Turquía, Siria o Egipto ${ }^{498}$.

\section{Tambor/ Tamborcillo}

Nombre genérico que incluye gran variedad de membranófonos que serán tratado de forma más concreta en el siguiente capítulo donde se abordarán los distintos membranófonos tipo darbouka encontrados en excavaciones arqueológicas andalusíes.

Con respecto al tamborcillo, el instrumento que interpreta esta figura se asemeja al encontrado en Puebla del Río, Sevilla, pero el instrumento representado cuenta con una base que se ensancha en forma de copa. La parte de la membrana tiene forma tubular tendiendo de forma leve y progresiva a cónica.

\subsubsection{Iconografía musical en el territorio andalusí no andaluz}

Aún no formando parte de los límites geográficos marcados en esta investigación debe tenerse en cuenta otra importante iconografía andalusí existente fuera del actual territorio andaluz. A continuación, se hará un breve repaso por cada y uno de ellos.

\section{Tañedora de nai, s. XII, Palacio Pequeño de Ibn Mardanis (Murcia)}

Esta pieza es un fragmento de la cúpula de

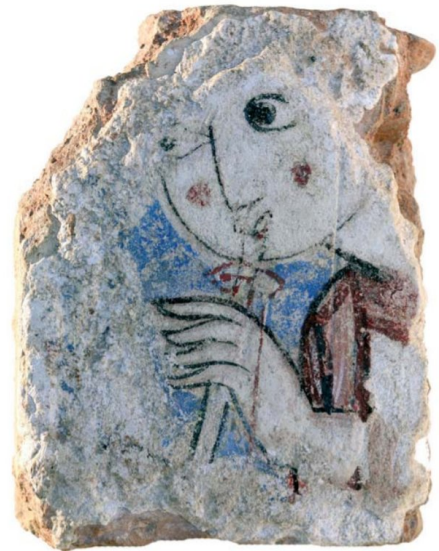

Figura 20. Tañedora de nai, Murcia. mocárabes. Cuenta con una decoración de tallos vegetales que enmarcan figuras de animales y seres humanos cuya iconografía Fernández Manzano, basado en la propuesta de Mazuela, la adscribe al "ciclo señorial" de la pintura monumental islámica ${ }^{499}$.

En la imagen se puede observar un rostro femenino de ojos grandes y expresivos con una

\footnotetext{
496 Ídem.

497 Ídem

498 Ídem.

${ }^{499}$ Reynaldo Fernández Manzano, Música de al-Andalus. Universidad de Granada, 2016, 169.
} 
larga nariz y pómulos resaltados con pequeños círculos de color rojizo. La boca se encuentra con unos labios bien definidos que se apoyan en el instrumento. La nano de la intérprete parece apoyada en el instrumento de forma que descartaría el que éste contase con agujeros digitales. La postura de la intérprete es verosímil pero la sujeción del instrumento parece muy superficial. La mirada de la intérprete se dirige a la izquierda del espectador donde parece mirar a un punto fijo. El fragmento de vestimenta que se observa es de color rojizo, muy semejante al color dado en la cara.

Esta pieza se conserva actualmente en el Museo Regional de Murcia emplazado en el Convento de Santa Clara.

\section{Tañedora de laúd, segundo cuarto s. XIII, Murcia}

Fragmento de vaso cerámico, mide 10,8 por $6,5 \mathrm{~cm}$ con un grosor de $3 \mathrm{~mm}$ en la parte superior y $5 \mathrm{~mm}$ en la parte inferior ${ }^{500}$. Pieza hallada de forma fortuita en el centro urbano durante trabajos de cimentación de unas viviendas en calle de Cadenas, "antiguo camino que comunicaba una de las puertas de la muralla ciudad (Bab as-Suq o del mercado), con otra del cerco del arrabal, llamada Puerta de Castilla. Esta calle

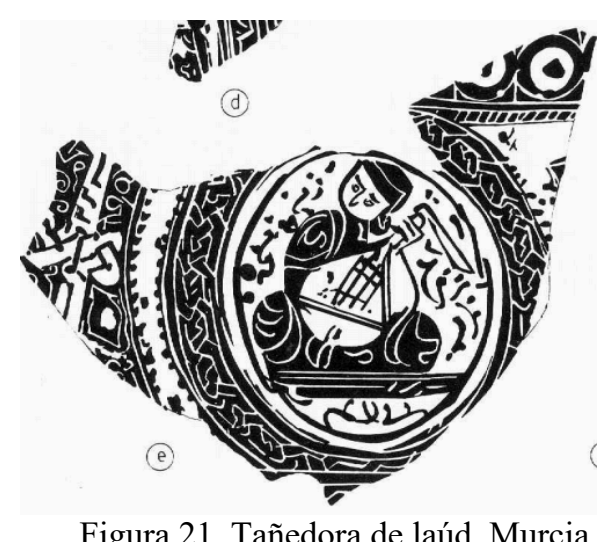

Figura 21. Tañedora de laúd, Murcia. estaba situada a extramuros, en el interior de la Arrixaca Vieja (antigua morería), cuya tradición alfarera ha perdurado hasta nuestros días" $" 501$.

La imagen principal del vaso es una tañedora de laúd sentada con las piernas recogidas. Sobre estas apoya su instrumento que cuenta con cuatro cuerdas que solo atraviesan la caja de resonancia, no llegando al mástil. Cuenta con un clavijero arqueado sin clavijas. La mano izquierda, no muy definida, sujeta el instrumento por el mástil, la postura hace pensar que la intérprete muestra el instrumento. La mano derecha parece estar tras el laúd. La intérprete, con la cabeza tapada, dirige la mirada hacia su lado derecho, lo que puede dar la sensación al

\footnotetext{
500 Julio Navarro Palazón, "Cerámica Musulmana de Murcia (España) con representaciones Humanas", en La Céramique Médiévale En Méditerranée Occidentale. X-XV Siècles, 1978, 318.

${ }^{501}$ Ídem.
} 
observador de estar posando. Cejas, ojos y nariz son definidas en la imagen, pero no así la boca.

\section{Fragmento de vaso con escena festiva, s. XIII, Murcia}

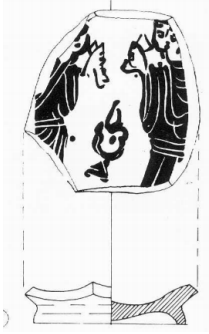

Figura 22. Vaso con escena festiva (aerófono) Murcia.

Esta pieza se encontró en el mismo lugar que la anterior.

El personaje de la izquierda parece toca un instrumento de viento el cual queda alejado de su boca. Solo se ve la mano derecha del intérprete que rodea el instrumento pudiendo dejar la posibilidad de que sus dedos estén tapando unos posibles agujeros digitales. Parece que la parte baja del tubo se ensancha, lo que puede evocar la forma de un mizmar sin boquilla. El personaje de la derecha parece beber mientras escucha al, o a la, intérprete. En medio de ambos se puede observar un objeto que puede tener la identificación de botella. Según Navarro Palazón este fragmento "reúne todos los elementos imprescindibles para representar una escena de bebedores: músico, bebedor y botella" ${ }^{\circ 02}$. Igualmente, este arqueólogo comenta que debido al reducido tamaño de la pieza el artista no pudo plasmar de forma más explícita el tema representado ${ }^{503}$.

\section{Pila de Játiva}

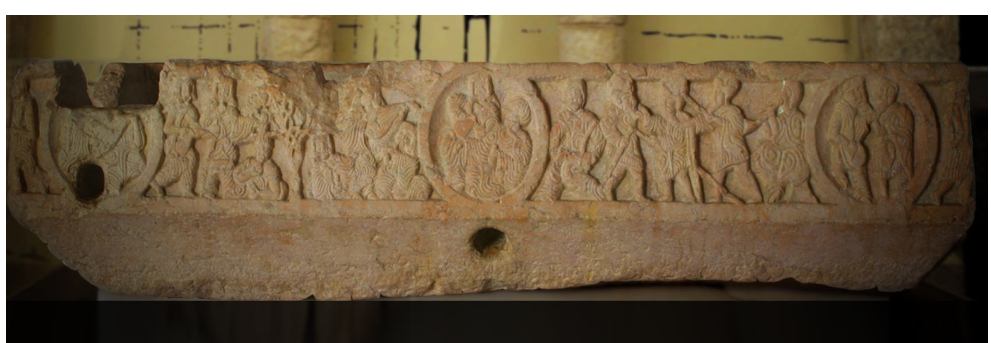

Figura 23. Pila de Játiva.

Pila labrada en el siglo XI en mármol rosa. Hasta el siglo XVIII se utilizó como abrevadero de animales. Analizando la técnica en las incisiones, hace pensar que fueron al menos dos escultores quienes la tallaron ya que se observa unos trazos más esquemáticos y otro más gruesos y robustos según nos informa la propia web del

\footnotetext{
502 Julio Navarro Palazón, La ceramica esgrafiada andalusí de Murcia. Madrid: Publications de la Casa de Velázquez, 1986, 69.

503 Ídem.
} 
museo donde se encuentra Museo del Almodín ${ }^{504}$. Esta pieza representa escenas de marfiles y tejidos.

Susana Gómez recalca la rareza de esta pieza, junto al capitel de los músicos, al recrear diversas escenas cortesanas ${ }^{505}$, ya que en esta puede observarse un conjunto de músicos, entre otras protagonizadas por personas y animales. Cuenta con relieves figurados con motivos animalísticos y antropomorfos, treinta y dos siluetas en total que según Basilio Pavón "muchas de las cuales nos aproximan a los marfiles califales y marfiles y maderas fatimíes del siglo XI de El Cairo"506. A lo largo de la pila existen varias escenas musicales que pueden ir observándose. En una de ellas se encuentra un laúd cuya talla se ha hecho de forma minuciosa coincidiendo el número de cuerdas trazadas en el cuerpo del instrumento con las clavijas representadas, cuatro cuerdas simples. El clavijero se encuentra arqueado y el intérprete coloca sus manos sobre el instrumento de forma realista. En el cuerpo del instrumento puede observarse el puente y dos codos en forma de una especie de " $\mathrm{f}$ ". El o la intérprete viste una túnica con amplias mangas que caen dejando solo a la vista las manos del ejecutante. Bajo este instrumento asoma otro músico con lo que parece ser un zulamiy o algaitha.

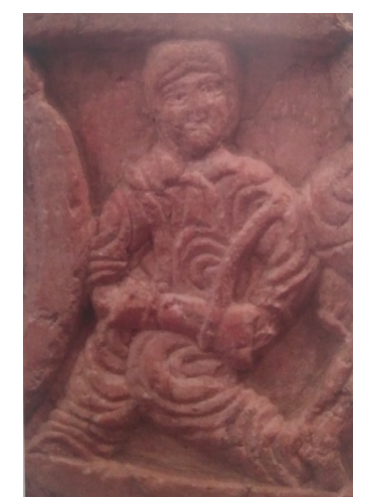

Figura 24. Detalle de bimembranófono Pila de Játiva

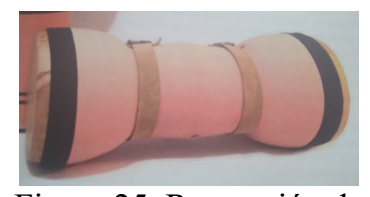

Figura 25. Recreación de bimembranófono de la Pila de Játiva de Jota Martínez.
El músico coloca ambas manos sobre el tubo del instrumento dando la sensación de que cuenta con agujeros digitales. No son muy perceptibles los detalles de este instrumento ya que la mayor parte del mismo está cubierto por las manos del intérprete, mientras que la base, que parece ensancharse, se presta a la suposición de la falta de un fragmento.

El músico medievalista Jota Martínez ha realizado una recreación de lo que podría ser este instrumento musical basándose en los instrumentos populares de los países árabes del Mediterráneo Oriental. Al final del tubo del aerófono han colocado una calabaza como resonador y le han unido un disco

\footnotetext{
504 “Museo del Almodí”, http://xativaturismo.com/museo-del-almodi/\#primera (Última consulta: 0811-2019).

505 Manuel Gómez Martínes, "Imágenes del cuerpo en el día a día de al-Andalus”, digitar, 2, 2015, 12.

506 Basilio Pavón Maldonado, "Iconografia Hispanomusulmana: Naturalismo, Fauna y Árbol de La Vida”, 2013, http://www.basiliopavonmaldonado.es/Documentos/icohispa.pdf, 17 (Última consulta: 09-11-2019).
} 
de madera junto a la boquilla ante la duda de que lo que parece ser un bigote o barba del músico pueda tratarse en realidad de este complemento ${ }^{507}$. Estos músicos están acompañados en la escena por lo que parece ser un lector.

Otra escena musical cuenta con un intérprete de buq, albogue, acompañado por un tocador de membranófono posiblemente doble. El intérprete lo tiene colgado del cuello, pero se encuentra sentado durante su posible ejecución con el instrumento apoyado en la rodilla izquierda, lo que refuerza la posibilidad de tratarse de un bimembranófono. Del mismo, Jota Martínez con la colaboración de Ximo Pascual realiza una posible recreación ${ }^{508}$. Este instrumento Faustino Porras lo denomina erróneamente como darbuka ${ }^{509}$, suponemos que llevado por la difusión y generalidad con la que se ha usado el término.

Revisando los posibles membranófonos orientales y andalusíes que puedan contar con doble membrana, se ha llegado al término kuba. Cortés y Berlanga utilizan este término para hacer referencia al tamborcillo de la figura de Córdoba y el de la cantiga CCC de Alfonso X el Sabio, donde aparece una mujer interpretando un tambor tubular sobre su hombro acompañada por un hombre con un cuerno ${ }^{510}$. Según el diccionario de términos realizado por Lois Ibsen al Faruqi, kuba se refiere a un tambor en forma de reloj de arena y de un solo parche: "Un tambor en forma de reloj de arena con un solo parche que data del siglo IX o antes. Hoy se conoce como tabl mukhannath o tabl al sudan. La interpretación de este tambor fue prohibida por el jurista Shafi al Nawawi en el siglo XIII por su uso por los homosexuales"511.

Coincidiendo con esta descripción, Farmer, en The sources in arabian music y A maghribi work on musical instruments comenta que la kuba fue descrita por los juristas para ser así reconocida por los creyentes dentro de los instrumentos prohibidos, la descripción de este era un instrumento "estrecho en el medio y ancho

\footnotetext{
507 Jota Martínez, Instrumentos musicales de la tradición medieval española (s. V al s. XV), $2^{\circ}$ edición. Círculo Rojo, 2019, 126-127.

508 Jota Martínez, Instrumentos musicales de la tradición medieval española (s. $V$ al s. XV), $2^{\circ}$ edición. Círculo Rojo, 2019, 24-25.

${ }^{509}$ Faustino Porras Robles, "Iconografía musical en la escultura hispanomusulmana", Nassarre: Revista aragonesa de musicología, 25, 2009, 48.

510 Manuela Cortés García y Marcos González Berlanga, "Ibn Al-Darray”, en Enciclopedia de la cultura andalusí: apéndice. Fundación Ibn Tufayl de estudios árabes, 2012, 171.

${ }^{511}$ Lois Ibsen Faruqi, An Annotated Glossary of Arabic Musical Term. United Estates of America: Greenwood Press, 1981, 149.
} 
en sus extremos" ${ }^{512}$. Esta no será la única referencia que haga este investigador sobre la $k u b a$, las siguientes dejan de reflejar un instrumento caracterizado por la forma de reloj de arena, o no de forma tan señalada, y pasan a referenciar un instrumento bimembranófono cercano físicamente al aquí representado. Al trabajar iconografía musical mesopotámica relaciona el término con un instrumento que no cuenta claramente con cintura estrecha, sino que hay una leve curvatura. El intérprete lo apoya sobre su pierna izquierda quedando el instrumento de forma cruzada al cuerpo del músico durante su ejecución ${ }^{513}$. En este caso, la forma del mismo se asemeja al que se observa en la pila, pero la forma sostenerlo por parte del músico conduce a pensar en un unimembranófono. Por otro lado, en el pie de nota de una imagen donde se observa un músico con un instrumento sobre sus piernas cruzadas, resulta relevante que coloca sus manos a cada uno de los lados del instrumento donde queda visible la representación de ambos parches, Farmer puntualiza que se trata de una $k u b a^{514}$. Asimismo, vuelve a hacer referencia a este tipo de instrumentos con dos parches bajo en nombre de kuba en Instruments of music dentro de The music of islam ${ }^{515}$, lo que puede llegar a relacionar este instrumento con el comentado con Farmer, a pesar de que el membranófono de la pila aparenta contar con una forma tubular entre ambos extremos que terminan en forma de copa, guardan gran semejanza con el instrumento representado en esta iconografía.

Por otro lado, el músico del aerófono se encuentra de perfil, por lo que puede observarse claramente el largo del instrumento que podría llevar a pensar en otro aerófono por su excesiva longitud. Ambas manos del intérprete rodean el instrumento pudiéndose observar el trazo de cada uno de los dedos. El tubo del aerófono termina con la característica forma del cuerno como resonador que se le incluye a este instrumento. Al igual que el mencionado anteriormente, Jota Martínez realiza una recreación de este con la ayuda de las técnicas artesanales que utilizan en Marruecos para fabricar estos instrumentos actualmente ${ }^{516}$.

\footnotetext{
512 Henry George Farmer, “A Maghribi Work on Musical Instruments”, en Studies in Oriental Musical Instruments. Glasgow: The civic press, 1939, 23.

${ }^{513}$ Henry George Farmer, “Arabian Musical Instruments”, en Studies in Oriental Musical Instruments. Glasgow: The civic press, 1939, 68.

${ }^{514}$ Henry George Farmer y E Neubauer, Studies in Oriental Music, Vol. 1. Frankfurt: Institute for the History of arabic-islamic Science at the Johann Wolfgang Goethe University, 1997, 117.

515 Ibídem, 172.

${ }^{516}$ Ibídem, 110-111.
} 
Otro laúd puede observarse en esta pieza. En este caso el intérprete se conserva de forma parcial quedando a la vista prácticamente solo el instrumento y parte del cuerpo. Las manos del músico se colocan sobre el instrumento de forma realista, mano derecha sobre las cuerdas e izquierda sobre el mástil. El clavijero se ve arqueado y parece contar, al igual que el anterior, con cuatro clavijas. Las cuerdas en este caso no son visibles y los posibles adornos y/o codos en el instrumento no resultan evidentes al conservarse deteriorada la caja de resonancia del laúd.

\section{Almohada de Berenguela de Castilla}

Por otro lado, reflejada en una tela se cuenta la iconografía de la Almohada de Berenguela de Castilla (hacia 1180-1246). Realizada en tafetán carmesí, cuenta con un medallón central rodeado con letra árabe en cursiva. La medida de la almohada es 86 x $50 \mathrm{~cm}$. En medio de este se encuentran dos danzarinas enfrentadas separadas por lo que parece ser un árbol de la vida. La almohada perteneció a Berenguela I de Castilla, Reina de Castilla (1217), hija primogénita de Alfonso VIII y Leonor de Plantagenet. La pieza se encuentra en el Museo de Telas Medievales, en Burgos, inaugurado en 1987 y reabierto en 2008 tras una ampliación.

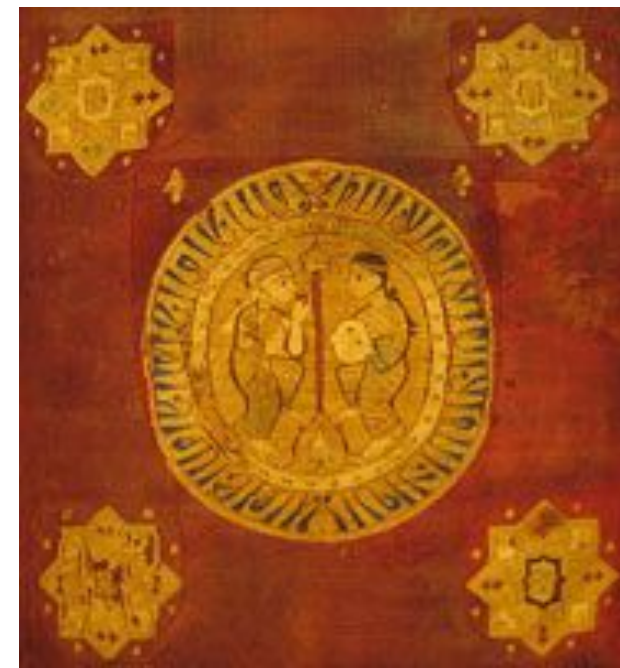

Figura 26. Almohada de Berenguela de Castilla.

Este museo se encuentra situado en el monasterio de Santa María la Real de Huelgas, abadía cisterciense fundada por Alfonso VIII y Leonor de Plantagenet en 1187 y convertida en panteón real ${ }^{517}$. La danzarina izquierda sostiene en su mano una especie de vaso, lleva la cabeza cubierta y va descalza. La danzarina de la derecha lleva la cabeza al descubierto con el pelo recogido con una tiara. En su mano sostiene un pandero con el que acompaña su danza. Ambas cuentan con rasgos y vestimentas cercanos a la cultura árabe. La imagen pertenece al Registro General de Patrimonio Nacional.

\footnotetext{
517 


\section{Tejido de las músicas}

Esta pieza del siglo XIII se encuentra fragmentada conservándose el grueso de la misma en el Instituto de Valencia Don Juan de Madrid. En este lugar se conservan

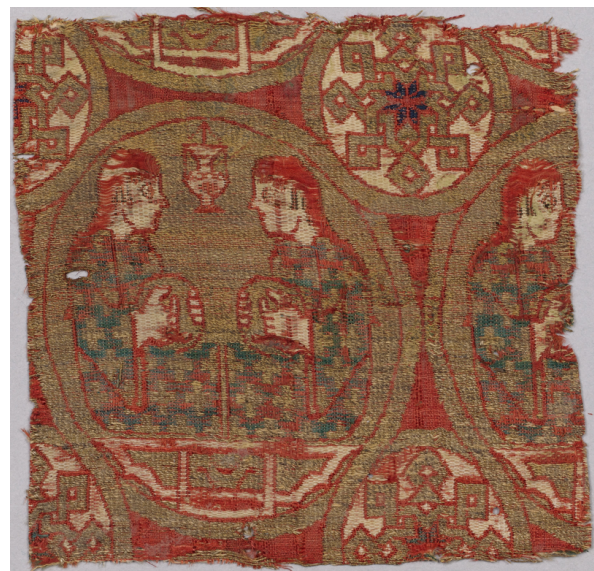

Figura 27. Detalle Tejido de las músicas. cinco fragmentos de la pieza, dos circulares $\mathrm{y}$ tres cuadrangulares $\mathrm{y}$ en el Metropolitan Museum de Nueva York un fragmento cuadrangular. Del total de la pieza se encontraron 14 fragmentos que se descubrieron entre las páginas de un manuscrito, también del siglo XIII, en la catedral de Vich, Valencia ${ }^{518}$. Los fragmentos circulares se adaptan a los bullones metálicos de libros cantorales que seguramente se forraron con este tejido ${ }^{519}$. Uno de los detalles que más puede llamar la atención de las personas que se acerquen a estos fragmentos es la combinación de la estética andalusí con los detalles simbólicos cristianos en las vestimentas de las figuras representadas donde se observan unas cruces. Cuando se observa la explicación que el Metropolitan Museum de Nueva York ofrece sobre el fragmento que custodia de este textil, comenta que esta fue al principio catalogada como pieza de la Península Ibérica, pero tras el estudio realizado por la investigadora María Judith Feliciano se decantaron por especificar su procedencia andalusí al realizarse en "talleres reales musulmanes" 520 . Al revisar la publicación "Muslim Shrouds for Christian Kings?: A Reassessment of Andalusi Textiles in Thirteenth-Century Castilian Life and Ritual" 521 de esta investigadora defiende que los textiles del siglo XIII realizados por los árabes y utilizados por los cristianos no debe entenderse como

\footnotetext{
518 Fragmento de la tela en el MET:

https://www.metmuseum.org/art/collection/search/448222?searchField=All\&amp;sortBy=Relevance\& amp; $\mathrm{ft}=$ vich\&amp;offset=0\&amp;rpp=20\&amp;pos=3 (Última consulta: 04-02-2020).

519 Laura Rodríguez Peinado, "Morfología de la encuadernación textil en la Edad Media", en Doce siglos de materialidad del libro: estudios sobre manuscritos e impresos entre los siglos VIII y XIX. Zaragoza: Prensas Universitarias de Zaragoza, 2017, 26.

${ }^{520}$ Fragmento de la tela en el MET:

https://www.metmuseum.org/art/collection/search/448222? searchField=All\&amp;sortBy=Relevance\& amp; ft=vich\&amp;offset=0\&amp;rpp=20\&amp;pos=3 (Última consulta: 04-02-2020).

${ }_{521}$ María Judith Feliciano Chaves, "Muslim Shrouds for Christian Kings? A Reassessment of Andalusi Textiles in Thirteenth-Century Castilian Life and Ritual", en Under the influence: Questioning the comparative in Medieval Castile, 2005.
} 
"servilismo y subyugación del islam ibérico"522, sino como una estética apreciada. En estos fragmentos puede observarse dos figuras femeninas sentadas, con las piernas recogidas o extendidas hacia el otro lado de la imagen, que se observan mientras parecen golpear unos panderos sin sonajas visibles, ambas visten túnicas de mangas anchas y parecen tener la cabeza al descubierto con el pelo recogido. La figura de la derecha sujeta el instrumento con la mano derecha y percute con la izquierda mientras que la figura de la izquierda lo hace al contario seguramente representadas así por su concordancia estética, sea como fuere la postura de ambas mujeres es verosímil. Observando los fragmentos que de este textil queda se presupone que toda la tela contaba con este dibujo de forma repetida.

\subsubsection{Algunos ejemplos de pervivencia árabe en la iconografía musical cristiana}

No tan solo en la iconografía andalusí vienen representados instrumentos musicales pertenecientes a esta cultura y época. A pesar de no ser la iconografía cristiana protagonista en esta investigación debe ser tenida igualmente en cuenta al igual que puesta en valor, es por ello por lo que se revisarán de forma breve algunas de las fuentes más relevantes que guardan relación con la iconografía hispanomusulmana.

\section{Cantigas de Alfonso X el sabio}

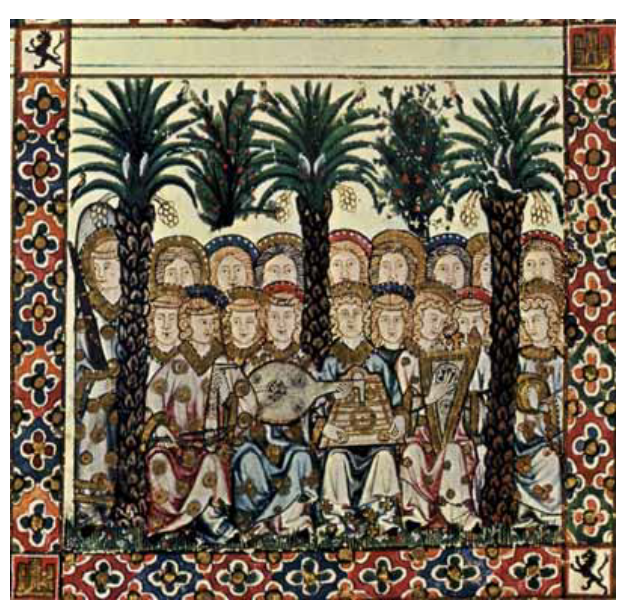

Figura 28. Miniatura de la Cantiga de Alfonso X.
Durante la contextualización de los instrumentos musicales en la iconografía andalusí se ha hecho ya referencia a estas obras tan relevantes para el estudio de la música medieval cristiana y musulmana, es por ello por lo que debe ponerse en valor para el estudio de los instrumentos musicales las miniaturas de la misma, donde se cuenta con importante iconografía musical. Estas miniaturas han sido

522 Ibidem, 104. 
ampliamente estudiadas por expertos como Rosario Álvarez ${ }^{523}$, quien informa sobre estos dos códices con las Cantigas de Santa María que se realizaron bajo la atenta supervisión de Alfonso X en los scriptoria reales, uno realizado para ser colocado en un atril y otro de uso manual ${ }^{524}$. En el primer volumen, el cual se encuentra actualmente en la Biblioteca del Escorial (T I 1) Rosario Álvarez recalca que contó con la participación del monarca de "forma muy activa y directa", mientras que el segundo se conserva en la Biblioteca Nazionale Centrale de Florencia, ms. Bancorari, $20^{525}$. Otro de los libros dedicados a las Cantigas y con gran iconografía es el códice $b$ I 2 de la biblioteca de El Escorial ${ }^{526}$. Además de estos trabajos, Rosario Álvarez añade el techo de la catedral de Teruel como fuente esencial para el estudio de los instrumentos musicales durante el siglo XIII ${ }^{527}$.

El arabista Julián Ribera y Tarrago, afirma que Alfonso X el sabio, durante su juventud recorrió los territorios recién conquistados quedándose especialmente encariñado al oír la música del actual territorio andaluz. Se interesó por la cultura andaluza e intentó perpetuarla incentivando su aprendizaje y expansión a través de recopilaciones y estudios de sabios y filósofos musulmanes. Le dio especial importancia al arte musical y lo impulsó para que llegara a convertirse en arte cristiano. Con la ayuda de músicos profesionales y expertos del pueblo vencido, recopiló melodías de su repertorio y a éstas les acopló letras gallegas que narraban los milagros de la Virgen María con la finalidad de que pudiesen ser aprendidas y conservadas $^{528}$, por lo que no serían solo las miniaturas las que reflejarían la cultura e hibridación musical de esta época.

Entre las miniaturas, Rosario Álvarez recalca la cantiga $\mathrm{C}$, donde aparecen cordófonos como el rebab, el 'ud,

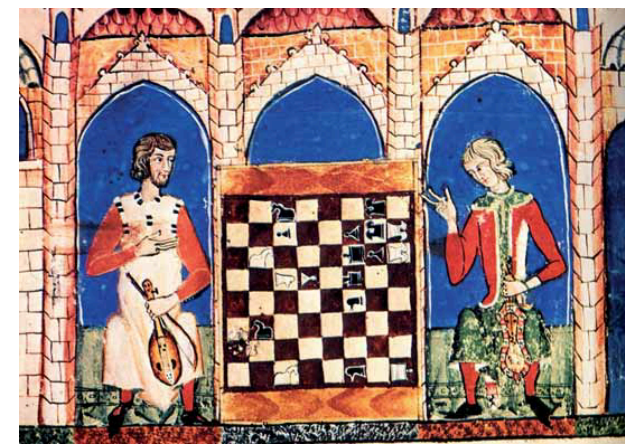

Figura 29. Miniatura del Libro de ajedrez y dados, Lámina 15, folio $31 \mathrm{v}^{\mathbf{o}}$.

\footnotetext{
523 Rosario Álvarez Martínez, "Música y Pintura promovidas por un sabio monarca: las imágenes Musicales de los Códices Alfonsinos entre el testimonio de la vida musical de su corte y el pensamiento Artístico de sus pintores" en M. PÁEZ, Ars Musica de Juan Gil de Zamora, 2010.

524 Ibídem, 55.

525 Ibidem, 56.

526 Ídem.

527 Ibídem, 57.

528 Julián Ribera y Tarragó, La música árabe y su influencia en la española. Valencia: Pre-Textos (Música "la Huella Sonora”), 2000, 39-41.
} 
la cítara persa santur $\mathrm{y}$, el arpacítara y címbalos bizantinos presentando una agrupación musical de la época. Lo curioso de esta imagen es la paradoja de estar recreando el paraíso cristiano contando con instrumentos islámico que áún no se encontraban extendido por el ámbito cristiano en España ${ }^{529}$ como son los tres primeros mencionados.

Asimismo, la cantiga de loor CXXX, cuenta entre el conjunto instrumental con un qanun rectangular ${ }^{530}$. Y en el caso de las cantigas CLXV y CLXXXV se vislumbra música militar de los ejércitos musulmanes donde se observan nafir y naqqarat a lomos de caballos dos siglos antes de que estos membranófonos se extendieran por el resto de Europa ${ }^{531}$.

Resultan, por lo tanto, una gran fuente de información documental sobre la música medieval cristina y musulmana, mostrando una vez mas la complicidad de ambas culturas.

\section{Libro de ajedrez y dados}

Este libro realizado en Sevilla y terminado en 1283 es una traducción del árabe

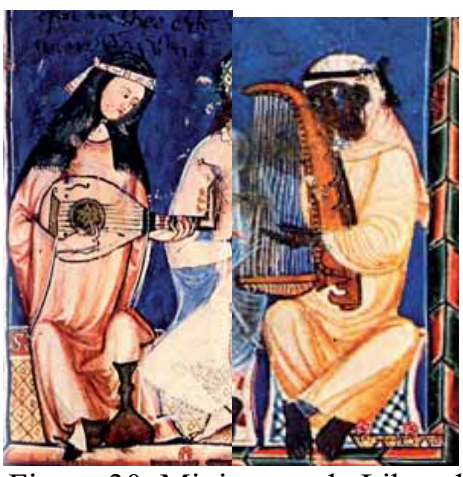

Figura 30. Miniaturas de Libro de ajedrez y dados, Lámina 14, Folio $22 \mathrm{R}^{\mathrm{o}}$

Figura 31. Miniaturas de Libro de ajedrez y dados. Lámina 13 , Folio $18 \mathrm{R}^{\mathrm{o}}$ sobre las dificultades del ajedrez, posteriormente se adaptó y añadieron juegos europeos. Este trabajo se realizó para uso y disfrute del rey y su círculo cortesano, "las tres primeras partes están dedicadas al ajedrez, dados $\mathrm{y}$ tablas $\mathrm{y}$ el resto a otros juegos" 532 . Cuenta con 196 páginas y 150 miniaturas ${ }^{533}$, son cinco de ellas las que cuentan con presencia de músicos ${ }^{534}$. María Teresa López recalca, de las figuras representadas en estas imágenes, que "el gesto, especialmente de manos y

\footnotetext{
${ }^{529}$ Rosario Álvarez Martínez, "Música y Pintura Promovidas Por Un Sabio Monarca: Las Imágenes Musicales de Los Códices Alfonsinos Entre El Testimonio de La Vida Musical de Su Corte y El Pensamiento Artístico de Sus Pintores" en M. PAEZ, Ars Musica de Juan Gil de Zamora, 2010, 65.

${ }^{530}$ Ibidem, 66.

531 Ibidem, 67.

532 María Teresa López de Guereño Sanz, "Arte y Gestualidad en el Libro del Acedrex, Dados e Tablas de Alfonso X El Sabio”, Laboratorio de Arte, no. 29, 2017, 25.

${ }^{533}$ Rosario Álvarez Martínez, "Música y Pintura Promovidas por un Sabio Monarca: Las Imágenes Musicales de los Códices Alfonsinos entre el testimonio de la vida musical de su corte y el pensamiento artístico de sus Pintores" en M. PÁEZ, Ars Musica de Juan Gil de Zamora, 2010, 70. ${ }^{534}$ Ibidem, 71.
} 
rostro, se convierte en un recurso visual que permite conocer las emociones, intenciones e, incluso, los sentimientos de sus protagonistas" ${ }^{535}$, los que hace que las miniaturas resulten clave para la comprensión del texto al que acompañan, ya que aportan información intrínseca.

La función que cumplen estos músicos reflejados en las miniaturas según sostiene María Teresa López es la de “amenizar" la partida ${ }^{536}$. Éstos parecen acompañar a un jugador determinado, lo que para Rosario Álvarez demuestra el elevado rango de los participantes, y solo aparecen en el libro del ajedrez, seguramente para "mitigar las largas esperas e inspirar al jugador" 537 . Pero en ciertos casos tal y como puntualiza Rosario Álvarez son los propios músicos los que participan en el juego basándose en la miniatura de la lámina 15, folio $31 \mathrm{v}^{\mathbf{0} 538}$. En esta imagen puede observarse dos figuras masculinas sentadas a ambos lados del tablero de ajedrez, el personaje de la izquierda sostiene la vihuela de arco mientras parece explicar algo a su contrincante quien sujeta una guitarra mientras dirige su mirada al tablero de juego. Tratándose de instrumentos musicales cristianos, es importante recalcar el protagonismo y presencia de estos músicos en estos eventos. Asimismo, en otras dos miniaturas aparecen esclavas cantoras, una interpretando un 'ud árabe y otra con un arpa oriental.

Aún siendo de las más citadas ambas fuentes, no serán las únicas que reflejen iconografía musical cristiana enlazada con la cultura musulmana, sin intentar hacer un estudio exhaustivo de las mismas sino una muestra de la variedad existente a tener en cuenta para el estudio de los instrumentos musicales andalusíes y su difusión y uso, se nombrarán por último tres fuentes de diversa índole que se acogen a este cometido, en primer lugar el Mural Champassak, s. XIV, conservado actualmente en el Museo de Mallorca, donde puede observarse una escena de caballeros acompañados por músicos. Entre estos se encuentra una esclava cantora interpretando un 'ud, con el clavijero arqueado y con punta zoomorfa, la intérprete lleva la cabeza cubierta. Por otro lado, en el Tríptico del Monasterio de Piedra, asimismo, aparecen ángeles tañendo distintos instrumentos, entre ellos se puede observar un rebab árabe y un ' $u d$,

\footnotetext{
535 María Teresa López de Guereño Sanz, “Arte y Gestualidad en el Libro del Acedrex, Dados e Tablas de Alfonso X El Sabio”, Laboratorio de Arte, no. 29, 2017, 28.

536 Ibidem, 29.

${ }^{537}$ Rosario Álvarez Martínez, "Música y pintura promovidas por un sabio monarca: las imágenes musicales de los Códices Alfonsinos entre el testimonio de la vida musical de su corte y el pensamiento artístico de sus pintores" en M. PÁEZ, Ars Musica de Juan Gil de Zamora, 2010, 71.

${ }^{538}$ Ibidem, 70.
} 
ambos con el característico clavijero arqueado. Por último, podría mencionarse el Cancionero de Ajuda, de procedencia galaicoportuguesa, s. XIII-XIV, donde aparecen intérpretes de qanun. Además de estas fuentes iconográficas citadas, es importante tener en cuenta la existente en catedrales, palacios y pequeños lugares y trabajos medievales que tanto aportan al estudio iconográfico musical medieval. Resulta tan copiosa la presencia de instrumentos musicales de origen árabe en representaciones cristianas que la revisión de las mismas sería digna de un trabajo concreto.

\subsubsection{Iconografía musical fatimí}

Al-Muizz li Din Allah al-Fatimi, considerado descendiente del Profeta a través

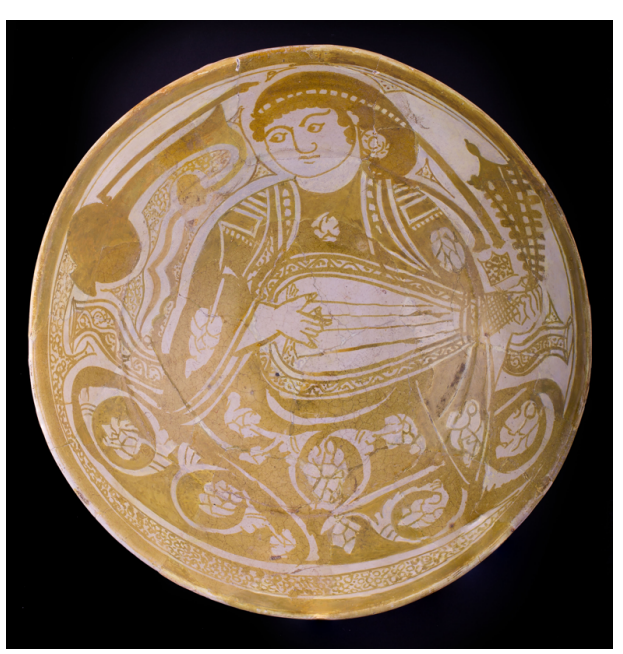

Figura 33. Ataifor fatimí Alhambra (laúd).

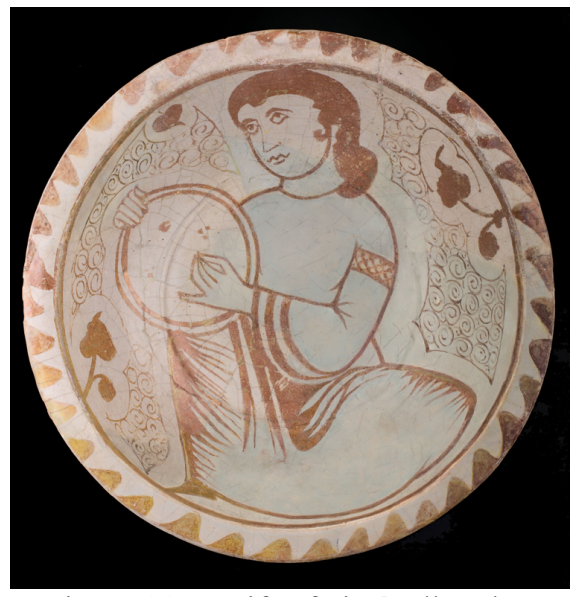

Figura 32. Ataifor fatimí Alhambra (pandero). de su hija Fátima y del primo del éste, Alí, fundó la dinastía fatimí, nacida por los mismos cismas que provocaron la división del Imperio musulmán entre suníes y chiíes, aconteciendo la ramificación chií de la que nacería el ismaelismo. Un misionero ismaelita se trasladó desde Bagdad a Egipto y logró conseguir gran número de adeptos quienes se movilizaron para que el pueblo decidiera sustituir a su ultimo gobernante y proclamar un nuevo reino que se extendió por el norte de África, desde Túnez a Marruecos, liderado en sus inicios por el propio alMuizz. Este Califato de dos siglos y medio de duración, 909-1171 de la era actual, con sede central en Egipto ${ }^{539}$ recogió las técnicas artísticas características del mediterráneo y oriente ${ }^{540}$ lo que le hace contar con considerables similitudes con el arte andalusí, de ahí que se le dedique una breve

\footnotetext{
539 Afaf Lutfi al-Sayyid, Historia de Egipto. De la Conquista Árabe al Presente (Ediciones Akal, 2008), 25.

${ }^{540}$ Marianne Barrucand, "El Arte Del Califato Fatimí: ¿ Arte Mediterráneo o Arte Oriental?” en $L a$ Aljafería y el Arte del Islam Occidental en el siglo XI, 2012.
} 
entrada para poner en valor este patrimonio.

El Museo de la Alhambra cuenta con tres ataifores fatimíes adornados con iconografía musical. Los tres ejemplares se han datado a finales del siglo $\mathrm{X}$ y principios del XI, 969-1050, y su procedencia se sitúa en Fustat, El Cairo, Egipto, todas ellas fueron compradas por el Estado. A continuación se presentarán cada una de las piezas.

El primer ataifor cuenta con la figura de una tañedora de laúd. Si se comparan los rasgos de esta figura femenina con otras similares de iconografía andalusí, prácticamente las diferencias se centran en detalles faciales como nariz y ojos. En este caso la figura se representa con el pelo al descubierto durante la interpretación del instrumento, su mano derecha reposa sobre las cuerdas mientras que la mano izquierda pulsa el mástil, haciendo verosímil la interpretación. Son cuatro las cuerdas que cruzan el instrumento que son pulsadas por unas largas uñas o plectos digitales. El instrumento se encuentra ricamente adornado pudiendo contarse, en su mástil arqueado, dieciocho clavijas. La intérprete sentada a la turca viste una túnica de amplias mangas y se adorna con unos grandes pendientes y su mirada se dirige hacia la derecha.

El segundo ejemplar de iconografía musical fatimí coincide en origen y datación con el anterior. En este caso la imagen representada se corresponde con una figura femenina que interpreta un pandero. Esta mujer apoya el instrumento sobre su rodilla derecha golpeando el parche con los dedos de la mano izquierda mientras que

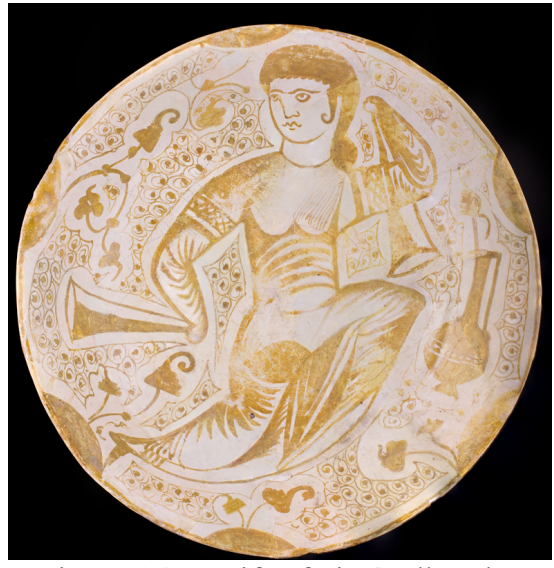

Figura 34. Ataifor fatimí Alhambra (danzante). con la derecha sujeta el instrumento por la parte superior. La mano que ejecuta el instrumento tiene cuatro de sus cinco dedos juntos, dando la sensación de que excluye para la interpretación o golpe representado, el dedo meñique. El parche del instrumento pudo contar con un adorno y las manchas que aparecen sobre este podrían simplemente ser causadas por el tratamiento recibido para su tensión. La mirada de la figura se dirige hacia arriba dando la sensación de estar mirando a personas que podrían estar de pie o estar concentrada con la vista perdida manteniendo una postura verosímil. La ropa que viste resulta más sencilla que la anterior, tratándose de una túnica de manga 
acampanada pero más estrecha, con un único adorno visible, una especie de brazalete grabado.

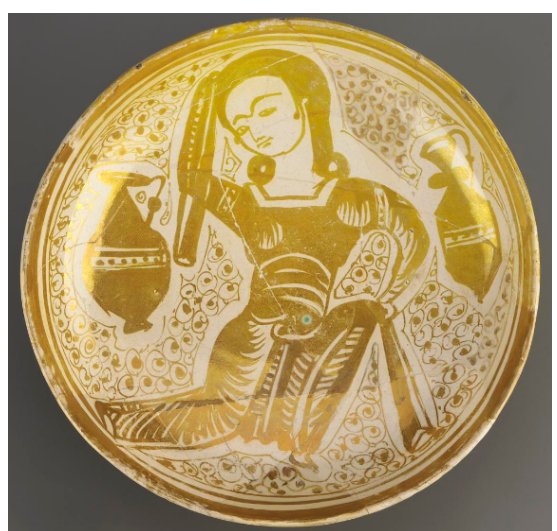

Figura 35. Ataifor fatimí Freer Gallery of Arts de Nueva York (danzante).
El tercer ataifor cuenta con otra figura femenina que parece danzar ya que tiene la pierna izquierda doblada, la derecha estirada hacia atrás, el brazo izquierdo hacia arriba y el derecho tras el cuerpo. En sus manos parece sostener, lo que interpretan en el Museo de la Alhambra como objetos a modo de velos, fundas o campanas. La forma acampanada de estos objetos, que al verlos así representados dan a pensar que podrían ser rígidos, deja

abierta la interpretación, aunque parece recordar una danza con velos. El vestido de la mujer es una túnica que podría envolver las manos de la danzante a la que tampoco se le observan los pies y parece llevar un complemento en la cabeza que le cubre parte del pelo. Esta figura se asemeja a la representada en el ataifor que guarda el Freer Gallery of Arts de Nueva York perteneciente al siglo XII donde aparece una figura femenina que sostiene unos objetos similares, aunque menos acampanados. La postura de la danza es parecida a la anterior, pero esta segunda figura se encuentra agachada, apoyada sobre la rodilla derecha donde apoya uno de los objetos con los que se acompaña. En este caso, esta segunda imagen parece mirar de frente, algo que no suele pasar en este tipo de representaciones.

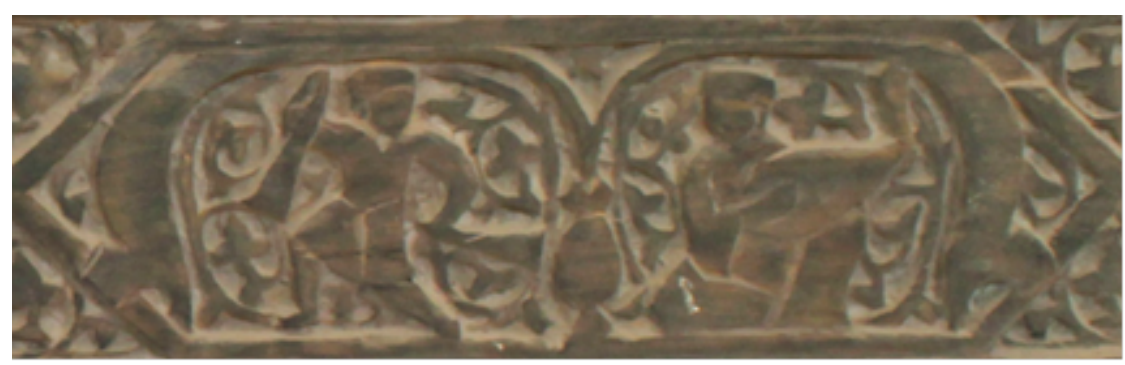

Figura 36. Friso fatimí Alhambra- El Cairo (danzante).

Otra figura danzante puede observarse en una de las piezas del Palacio del Oeste fatimí en El Cairo datadas en 1058, cuyos originales se encuentran en el Museo Islámico del Cairo, pero de las que existe una réplica en el Museo de la Alhambra. En este caso puede verse una figura que podría ser masculina danzando acompañado. por un laudista. El danzante sostiene los velos en una postura muy similar al segundo 
ataifor, manteniendo su brazo derecho hacia arriba y su brazo izquiedo abajo mientras flexiona levemente la rodilla derecha y mantiene la pierna izquierda estirada. Viste una túnica corta que deja las piernas al descubierto y cuenta con un cinturón anudado $\mathrm{y}$ un turbante.

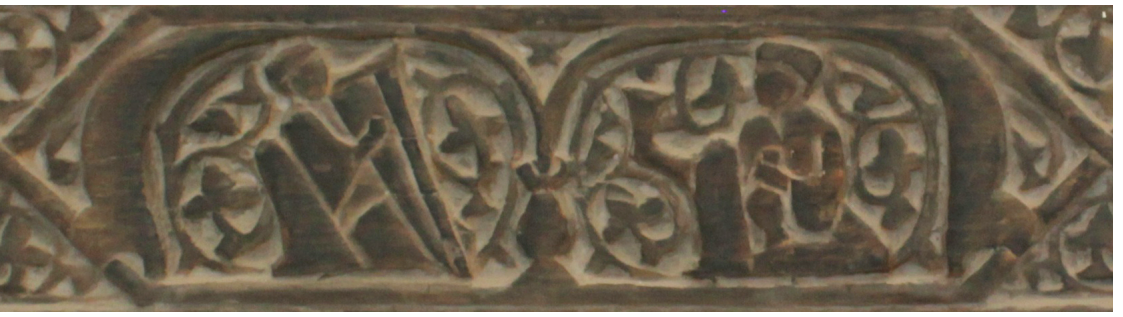

Figura 37. Friso fatimí Alhambra- El Cairo (arpista). Por otro lado, el laudista se encuentra sentado sobre el suelo y apoya su instrumento en la rodilla izquierda la mano derecha la mantiene sobre las cuerdas y la izquierda sobre el mástil que cuenta con el clavijero inclinado. Viste una túnica larga más amplia que la del danzante con mangas anchas e igualmente cuenta con un turbante. Los integrantes de esta escena parecen mirarse y la postura de ambos hace que parezca verosímil la interpretación. Al otro lado de esta misma pieza se cuenta

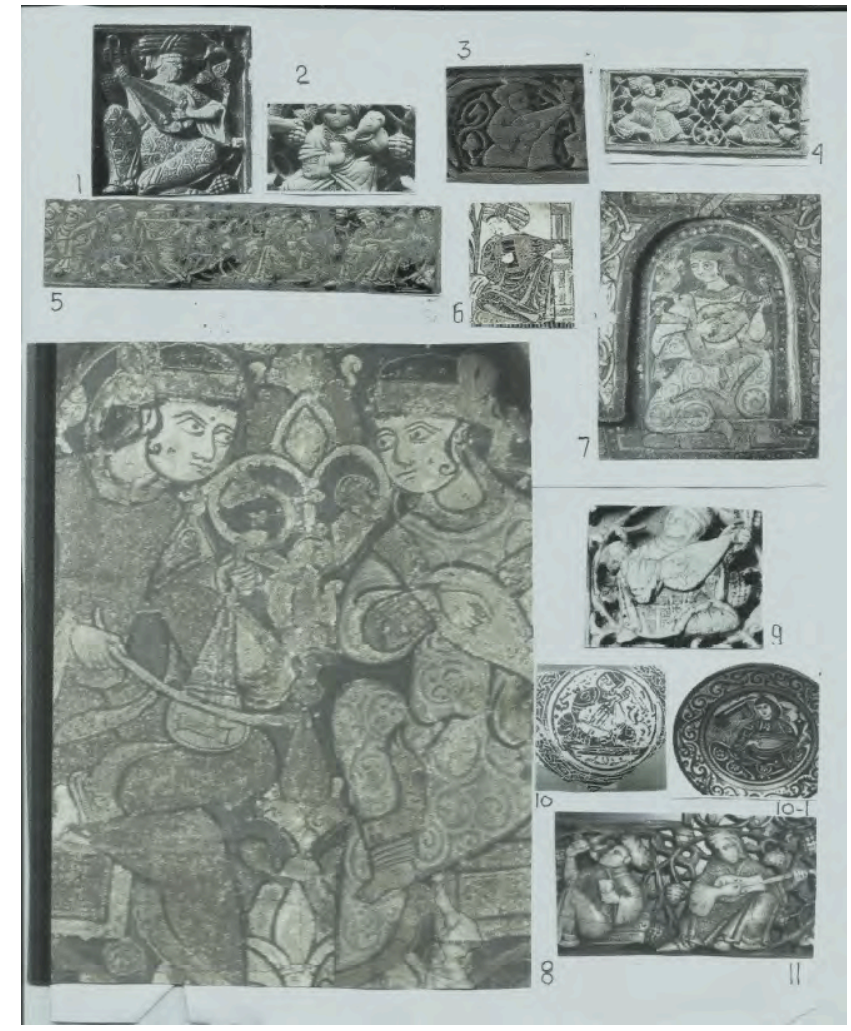

Figura 38. Imágenes fatimíes artículo Basilio Pavón. con otra escena musical que denota su procedencia fatimí ya que en este caso el instrumento representado es una especie de arpa de gran tamaño que el o la intérprete apoya sobre su cuerpo. Puede observase su mano derecha sobre lo que serían las cuerdas del instrumento mientras que la izquierda no queda visible, por lo que se presupone que se encuentra al otro lado de las cuerdas del instrumento. La o el tañedor viste una túnica ancha con amplias mangas $\mathrm{y}$ mantiene la cabeza cubierta con un turbante o velo. La segunda figura de esta imagen es el oyente que parece sostener una botella mientras observa al músico. 
Estas imágenes fatimíes no serán las únicas que se conserven con iconografía musical, ni éstos los únicos soportes, ya que existen otras piezas custodiadas por Museos como el Victorian and Albert y el British Museum de Londres, así como en Boston en el Museum of Fine Arts. En el artículo "Iconografía hispanomusulma (matizaciones y connotaciones): naturalismo, fauna y árbol de la vida" de Basilio Pavón aparece una selección de imágenes fatimíes recogidas de distintos lugares del mundo, acompañadas con las siguientes referencias:

“1, marfil del Museo de Bargello de Florencia, de época fatimí; 2, marfil del Museo de Pergamo, Berlín; 3, madera fatimí de palacio de el Cairo; 4, placa al parecer prefatimí del Museo de Bargello de Florencia; 5, otros pasajes de marfiles fatimíes de El Cairo; 6, del manuscrito de Bayad y Ride la Biblioteca Apostólica Vaticana92; 7, 8, pinturas de la Capilla Palatina de Palermo; 9, marfil

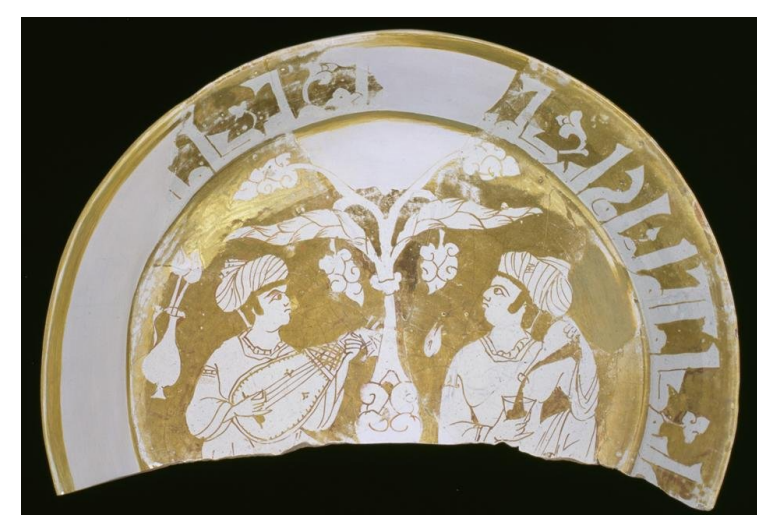

Figura 39. Ataifor del Benaki Museum de Grecia (laudista). hispanomusulmán del Louvre; 10, plato levantino, siglo XIV; 11, marfil del Museo Pergamo de Berlin".

Como puede comprobarse en este conjunto de imágenes recogidas por Basilio Pavón también existen representaciones con figuras masculinas. El Benaki Museum de Grecia, cuenta con un ataifor donde

pueden observarse dos figuras masculinas rodeando un árbol de la vida. El personaje de la izquierda interpreta el laúd, mientras que el de la derecha se sirve una bebida. La mano derecha del laudista parece sostener un plectro mientras que la izquierda se coloca sobre el mástil arqueado del instrumento, que consta de cuatro cuerdas lo que le hace tener una postura verosímil. Las vestimentas de ambos personajes son túnicas amplias y turbante.

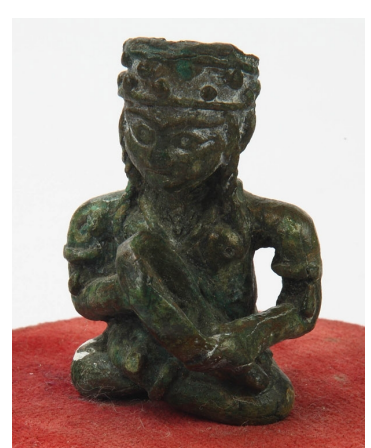

Figura 40. Estatuilla del Musée d'art islamique, Doha, Catar (pandero).

Por último, se pondrá en valor, asimismo, la presencia de iconografía en otro tipo de soportes, como ya mostraba Basilio Pavón, a través de estatuillas. En Fustat, El Cairo se encontró la llamada "Estatuilla de un músico" perteneciente al siglo XI y fabricada en bronce que hoy en día se conserva en el Musée d'art islamique en Doha, Catar. En esta estatuilla de 5 x $3 \mathrm{~cm}$ puede 
observarse una figura femenina adornada con pulseras y tocado sentada a la turca tocando un pandero ${ }^{541}$.

Con esta breve introducción a la iconografía musical fatimí puede comprobarse la variedad y riqueza de referencias existentes al respecto.

541 Estatuilla de un músico, https://www.qantara-med.org/public/show document.php?do id=1088\# (Última consulta 5-02-2020). 


\subsection{Instrumentos musicales en excavaciones arqueológicas andaluzas}

Al hacer una recopilación sobre la variedad de instrumentos musicales encontrados en excavaciones arqueológicas y éstos compararlos con los instrumentos que se mencionan en manuscritos o poesías, así como los reflejados en la iconografía, nos encontramos con el hándicap de que la mayoría de los instrumentos que se recogen en estas fuentes documentales no trascienden hasta nuestra época por estar construidos con materiales perecederos. Si nos ciñésemos al estudio organológico de la vida musical en al-Andalus solo a través de las piezas que llegan hasta nuestros días la visión de esta estaría más que sesgada, asimismo, si solo se estudiasen las fuentes documentales citadas igualmente habría una considerable carencia informativa, ya que unas y otras fuentes de estudios aportan distinta información y perspectiva al estudio de los instrumentos y la música en al- Andalus. Una de las piezas musicales más presente en las excavaciones arqueológicas son los silbatos. Si solo consultásemos las fuentes documentales para saber de ellos sería muy parcial igualmente la información que obtendríamos ya que solo son mencionados, apenas sin contexto, por juristas como al-Turtusi para oponerse al uso de estos por las sospechas de su posible procedencia cristiana como se ha tratado anteriormente. Es aquí donde los restos arqueológicos suponen una fuente documental esencial ya que sin ellos esta simple mención del instrumento no pondría en valor la importante y tan numerosa presencia de este. Asimismo, para la contextualización de este instrumento se vuelve de vital importancia mirar hacia otros lugares que cuenten con silbatos, ya que tan desamparada información se puede ver complementada gracias a la comparativa etnológica. Consciente de esta importante perspectiva, durante esta investigación se ha acudido a Marruecos, ya que junto a Argelia fueron los principales lugares a donde marcharon los andalusíes expulsados de España, con la esperanza de comprobar su vigencia o conocer más sobre ellos, aunque hayan caído en desuso. Igualmente se comprobó la similitud de los restos arqueológicos que llegan hasta nuestros días también en este territorio.

Al ser por lo tanto muy distinto el listado de instrumentos desde la óptica arqueológica ya que los instrumentos musicales que podemos encontrarnos en excavaciones arqueológicas, reconocidos como tal son: tamborcillos o atabales, piezas catalogadas como flautas o aerófonos, silbatos, campanas, crótalos o cascabeles, el orden de estudio de los mismo se realizará desde los más numerosos a los más escasos siguiendo la Clasificación de Hornbostel y Sachs, es decir, se comenzarán con los 
aerófonos, se continuará con los membranófonos y por último serán presentados los idiófonos. Asimismo, una vez presentados de forma genérica se clasificarán por las ciudades donde se han encontrado y se realizará un estudio de mayor detalle sin la fase documental así lo permite.

\subsubsection{Instrumentos aerófonos}

Dentro de este campo los instrumentos que nos encontramos serían silbatos y piezas catalogadas como flautas. Como la ordenación en el tratamiento de los instrumentos musicales se ha fijado por el número de ejemplares encontrados de los mismos, se empezarán por los silbatos.

\subsubsection{Silbatos}

“...ahora son simples elementos lúdicos, otrora tuvieron un valor salutifero importante, pues el ruido no siempre fue una molestia", Guillermo Rosselló Bordoy. El largo camino de la investigación 542

\section{Orígenes}

La constante curiosidad del hombre por conocer y controlar la naturaleza acompaña al ser humano desde los primeros tiempos. La carencia de conocimientos se suplía en un principio, con creencias mitología y leyendas que les aportaban un esclarecimiento a ese vacío de respuestas. Esto puede justificar la representación de figuras abstractas o concretas ${ }^{543}$.

Los silbatos son uno de los instrumentos musicales más antiguos cuyas evidencias arqueológicas llegan hasta nuestros días desde el Paleolítico Medio y las culturas antiguas como la mesopotámica, egipcia o china, a través de los yacimientos arqueológicos y comprobándose su contante presencia por toda Europa ${ }^{544}$. Existen ejemplares de formas similares en el área Mediterránea desde el periodo prehelénico, la antigua Grecia y Chipre. En zonas islámicas orientales trascienden ejemplos

\footnotetext{
${ }^{542}$ Guillermo Rosselló Bordoy, “El largo camino de una investigación”, en Del rito al juego: jueguetes y silbatos de cerámica desde el Islam hasta la actualidad. Junta de Andalucía: 2006, 15.

${ }^{543}$ Manuel Espinar Moreno, "Instrumentos musicales de barro: silbatos zoomorfos, antropomorfos y otros vestigios musicales", Música Oral Del Sur: Revista Internacional 2, 1996, 63.

${ }^{544}$ Carlos García Benito, "Arqueología musical prehistórica: aproximación a través de la arqueología experimental aplicada a la arqueo-organología, de la arqueoacústica y de la iconografía musical prehistórica". Tesis doctoral Universidad de Zaragoza, 2014, 122.
} 
pertenecientes a culturas mesopotámicas, donde los silbatos se encuentran trabajados en arcilla o terracota con acabados vidriados azules y formas zoomorfas. Evidencias sobre estos instrumentos se encuentran en Irán, Norte de África y comunidades musulmanas del este de Europa ${ }^{545}$. Como afirma el investigador Rafael Pérez Arroyo, todas las civilizaciones se han valido de culturas anteriores para realizar sus instrumentos musicales a semejanza ${ }^{546}$.

Los silbatos han creado gran controversia a la hora de su estudio, ya que en ciertos ejemplares, como los investigados por el Doctor en prehistoria Léon-Henri Martin (1864-1936) en 1910 sobre los hallados en La Quina (Charente), con la colección que fundó la Société préhistorique française en $1904^{547}$ o la ya mencionada "flauta" Divje Babe $e^{548}$, demuestra que los orificios en ambos objetos fueron realizados por un animal, por lo que sus investigadores rechazan la idea de considerarlo un instrumento musical ya que su creación fue casual sin contemplar que una ver realizados pudieron tener ese uso. En el caso de los silbatos la continua aparición de estas piezas en diversas excavaciones Prehistóricas, algunos de ellos con formas antrópicas, constata su uso como aerófonos ${ }^{549}$.

Investigadores como Cid Priego, con el objetivo de contextualizar los orígenes de los siurells, compara las similitudes que presentan con pequeñas piezas usadas como ofrendas y exvotos que el pueblo micénico consagraba a sus divinidades, hallando semejanzas en los detalles de la indumentaria femenina: faldas, delantales, tiaras, temas decorativos de carácter vegetal, etc. ${ }^{550}$ Rosselló Bordoy en su estudio sobre la versión mallorquina moderna de los siurells, apostilla la siguiente afirmación de Cid:

"En la arqueocivilización no es inverosímil ni absurdo suponer, provisionalmente, que los modelos originarios de los siurells fuesen cretenses o al menos procedentes del Mediterráneo

\footnotetext{
545 Purificación Marinetto Sánchez, "Juegos y distracciones de los niños en la ciudad de la Alhambra", en Del rito al juego: jueguetes y silbatos de cerámica desde el Islam hasta la actualidad. Junta de Andalucía: 2006, 75-76.

546 Rafael Pérez Arroyo, La música en la era de las pirámides. Centro de Estudios Egipcios, 2001, 27.

547 “Léon-Henri Martin”, https://musee-archeologienationale.fr/objet/leon-henri-martin (Última consulta: 15-10-2019).

548 Ivan Turk, Mousterion bone flute and other finds from Divje Babe I cave site in Slovenia. Institut za Arhaeologijo, 1997.

549 Carlos García Benito, “Arqueología musical prehistórica: aproximación a través de la arqueología experimental aplicada a la arqueo-organología, de la arqueoacústica y de la iconografía musical prehistórica", Universidad de Zaragoza, 2014, 122.

550 Guillermo Rosselló Bordoy, "El largo camino de una investigación”, en Del rito al juego: jueguetes y silbatos de cerámica desde el Islam hasta la actualidad. Junta de Andalucía: 2006, 21.
} 
Oriental, y que sean la continuidad de un arte popular degenerado que repite en todo mínimo las producciones de aquel viejísimo centro artístico. En muchos miles de otros aspectos se admite que del Mediterráneo Oriental proceden muchas formas culturales que llegaron a Occidente a través de las islas del Mediterráneo Central" 551.

Ramón Andrés defiende que los silbatos son patrimonio de las más diversas culturas $^{552}$. Según Tranchefort, este objeto extendido por todo el mundo se remonta a la Edad de Piedra y fue creado como reclamo, para atraer pájaros o alejar animales de presa, o incluso como objeto de imitación ${ }^{553}$.

Los silbatos pueden fabricarse con distintos materiales tales como hueso, cuerno, caña, corteza, madera, marfil, piedra, arcilla o metal ${ }^{554}$. La información que Jeremy Montagu ofrece sobre este instrumento es que normalmente se confunde con aerófonos tipo flauta llegando a no ser considerado un instrumento musical: "It is normally considered that flutes are used for music and whistles for signalling, leaving a grey area for those instruments which are used, either by the same or by different peoples, for both purposes (e.g. Swanee whistle)" ${ }^{\text {"555 }}$.

Según Montargu, los silbatos eran flautas agudas y cortas sin conducto que podían o no contar con algún orificio ${ }^{556}$. Ciertos investigadores como Karel Absolon sostienen que estos silbatos pudieron ser la parte no perecedera de instrumentos musicales aerófonos, llegando hasta nuestros días solo la parte de la boquilla de estas $^{557}$. Coincidiendo con esta hipótesis, F.W. Galpin en sus estudios sobre los instrumentos mesopotámicos sostiene que el silbato pudo ser concebido por culturas antiguas como el principio de la embocadura, ya que facilitaría la producción del sonido de la flauta vertical (nai) ${ }^{558}$. Remontándonos al origen de estos instrumentos musicales, lo cierto es que las distintas investigaciones llevadas a cabo demuestran la

\footnotetext{
551 Ibidem, 22.

552 Ramón Andrés, Diccionario de instrumentos musicales. Desde la Antigüedad a J.S. Bach. Barcelona: Ediciones Península, 2009, 399.

${ }^{553}$ Françoise-René Tranchefort, Los instrumentos musicales en el mundo (Alianza Editorial, 1985), 222.

${ }^{554}$ Ibídem, 220.

555 Jeremy Montagu, "Whistle", Grove Music Online, Oxford University Press, 2001, http://www.oxfordmusiconline.com/subscriber/article/grove/music/30201 (Última consulta el 18/07/2019).

556 Ídem.

${ }^{557}$ Kalen Absolon, "Les flûtes paléolithiques de l'Aurignacien et du Magdalénien de Moravie, analyse musical et ethnologique comparative avec démonstration", Congrès Préhistorique de France, CompteRendu de la XIIe Session. Toulouse, 1937, 770-84.

558 Francis William Galpin, The music of the sumerians and their immediate successors the Babylonians \& Assyrians. Vestport (Connecticut): Greenwood, 1970, 14.
} 
intencionalidad en su fabricación con una finalidad y función concreta dentro de cada una de las sociedades donde aparecen.

En el caso del periodo andalusí, resulta muy escasa la información general en documentos escritos que llegan hasta nuestros días de este tipo de instrumentos musicales en comparación con otros, como pueden ser los instrumentos de membrana. Quizás a los tratadistas, como afirma Torres Balbás, pudo ocurrirle lo que a los propios arqueólogos, que por su humildad y pobre aspecto estos aerófonos llegasen a pasar desapercibido ${ }^{559}$. A pesar de ello, existe una gran cantidad de silbatos que se han encontrado en numerosas excavaciones realizadas en distintos puntos de España como Palma de Mallorca, Teruel, Madrid, Alicante, Murcia, Granada, Jaén o Almería $^{560}$. Estas piezas suelen rondar los $10 \mathrm{~cm}$ y mayoritariamente cuentan con representaciones figurativas zoomorfas y antropomorfas. Como afirma Rosselló Bordoy, el zoomorfismo y antropormorfismo fueron elementos que estuvieron presentes en la decoración andalusi ${ }^{561}$, ya que, como afirma el académico y estudioso Emilio García Gómez, "no es cierto que el Corán tenga una absoluta prohibición contra la representación de seres vivos, como tradiciones espirituales orientales" ${ }^{262}$, mientras que Espinar Moreno señala que esta prohibición de representar figuras y representaciones antropomorfas se ceñía solo a las mezquitas ${ }^{563}$. En esta línea, esta supuesta reticencia ante la representación humana y, en concreto, en los instrumentos musicales fue debatida en al-Andalus. Ibn Qasim, aseveraba que estos "juguetes" tenían procedencia cristiana y por lo tanto los musulmanes debían dejar de utilizarlos $^{564}$. Esta idea era compartida por el alfaquí y cadí al-'Uqbani (1320 1401/8) quien se escudaba en lo que sostenían eminentes juristas andalusíes como Ibn Rusd, por lo tanto, los silbatos debían ser considerada como una manifestación cultural ajena al mundo musulmán y aceptada solo por las comunidades cristianas con

\footnotetext{
${ }^{559}$ Leopoldo Torres Balbás, “Animales de juguete”, Crónica arqueológica de la España musulmana XXXIX, 1956, 118.

${ }^{560}$ Isabel Flores Escobosa, Vivir en al-Andalus. Exposición de cerámica (s.IX-XV), ed. $\mathrm{M}^{\mathrm{a}}$ del Mar Muñoz Martin. Almería: Instituto de Estudios Almerienses, 1993, 216.

561 Guillermo Rosselló Bordoy, El ajuar de las casas andalusies. Málaga: Sarriá, 2002, 13.

562 Basilio Pavón Maldonado, "Iconografia hispanomusulmana: naturalismo, fauna y árbol de la vida", http://www.basiliopavonmaldonado.es/Documentos/icohispa.pdf, 7. (Última consulta: 15-10-2019).

${ }^{563}$ Espinar Moreno, "Instrumentos musicales de barro: silbatos zoomorfos, antropomorfos y otros vestigios musicales”, Música oral del Sur: revista internacional, 2, 2016, 67.

${ }^{564}$ Ibídem, 70.
} 
las que se convivía en hermandad ${ }^{565}$. Por el tratado de hisba, de Muhammad Ibn Ahmad ibn Qasim de Tremecén (XV) se sabe que se citaron prohibiciones anteriores como la realizada por el abuelo de Averroes, y el ya mencionado cadí de Córdoba Ibn Rusd que además condenaba la costumbre de la fabricación de juguetes con forma de animales, sobre todo jirafas ${ }^{566}$.

No obstante, los silbatos se siguieron utilizando ya que se cree que su uso podía tener un trasfondo mágico, atribuyéndoseles el poder de alejar los malos espíritus $^{567}$, más allá del simple hecho de su consideración como juguetes para armar ruido y $\sin$ otras connotaciones específicas ${ }^{568}$. Según el trabajo de investigación realizado por Carmen Peral Bejarano y Sonia López Chamizo con las terracotas rituales de las culturas más antiguas a las cuales se les atribuye un uso mágico, tendría sentido relacionarlas con el paso a los juguetes cerámicos en épocas medievales y modernas manteniendo y uniendo el uso mágico-religioso al uso infantil ${ }^{569}$.

"De éstas procedían aquellas actuales manifestaciones que si bien, cada lugar lo fabricaba dentro de unas formas y soluciones estéticas propias, todas ellas surgían de una fuente común, en la cual la magia y la esperanza en un vivir mejor, se reflejaba en todos ellos mediante los silbidos estridentes, aquella ansia humana en alejar los espíritus malignos se materializaba" 570 .

Algunos investigadores señalan que los silbatos podían invisibilidad a su propietario u ofrecerle toda clase de gracias ante los demás ${ }^{571}$. Al considerarse un objeto de protección se los regalaban a los hijos e hijas como juguetes: "una forma de acercar estos objetos a sus hijos era convertirlos en juguetes. En ocasiones se les

\footnotetext{
565 Guillermo Rosselló Bordoy, “El largo camino de una investigación”, en Del rito al juego: jueguetes y silbatos de cerámica desde el Islam hasta la actualidad. Junta de Andalucía: 2006, 26.

566 Espinar Moreno, "Instrumentos musicales de barro: silbatos zoomorfos, antropomorfos y otros vestigios musicales", Música oral del Sur: revista internacional, 2, 2016, 68.

567 Guillermo Rosselló Bordoy, "El largo camino de una investigación”, en Del rito al juego: jueguetes y silbatos de cerámica desde el Islam hasta la actualidad. Junta de Andalucía: 2006, 37.

${ }^{568}$ Guillermo Rosselló Bordoy, "De nuevo los animales de juguete y otros aspectos de coroplastia andalusí", en Actas Del IV Coloquio Hispano-Tunecino. Palma de Mallorca, 1979, 206.

${ }^{569}$ Carmen Peral Bejarano y Sonia López Chamizo, "Aproximación al juguete en su contexto arqueológico en Málaga", en Del rito al juego: jueguetes y silbatos de cerámica desde el Islam hasta la actualidad. Junta de Andalucía: 2006, 113.

570 Guillermo Rosselló Bordoy, “El largo camino de una investigación”, en Del rito al juego: jueguetes y silbatos de cerámica desde el Islam hasta la actualidad. Junta de Andalucía: 2006, 37.

${ }^{571}$ Salvador Palomar Abadia, "Instrumentos populares de barro en el sur de Catalunya", Música Oral del Sur: Revista Internacional 2, 1996, 19-27.
} 
adosa un silbato con el que pueden jugar, divertirse y producir silbidos o gorgojeos imitando a ciertas aves cantoras, ranas y otros animales" ${ }^{\prime \prime 72}$.

Estas piezas acercaban a los más pequeños a un amplio legado cultural pudiendo aficionarlos a la música a través de estos pequeños objetos de barro que terminarán precediendo a elementales armónicas y pitos. Centrados en la época medieval, se piensa que este juguete de dicha trataba de imitar a la naturaleza constituyendo, asimismo, una forma de ocio y un negocio para sus fabricantes ${ }^{573}$.

Las primeras fuentes documentales andalusí-persa pertenecientes a los siglos IX y XI son tratadas por el analista Henry George Farmer, quien se hace eco de las primeras noticias sobre los silbatos árabes y de culturas colindantes. Entre ellas, la ofrecida por el historiador persa Ibn Jurdadbih (ca. 820-912), quien recogió la voz de al-Mas'udi (m. ca. 956) en Muruj al-dahal (Las praderas de oro) ${ }^{574}$. El filólogo Barbier de Meynard realiza una traducción de este trabajo donde menciona varios instrumentos musicales árabes. Entre los instrumentos de viento cita que "los pastores y los kurdos inventaron diferentes tipos de instrumentos para silbar, silbatos (safara)", por lo tanto, están relacionados con la ganadería, de ahí que, en fuentes posteriores a este estudio, a este instrumento se le atribuye una función pastoril ${ }^{575}$. Farmer en $A$ history of Arabian music: to the XIIIth century, ofrece una lista de instrumentos musicales árabes citando la zurna o surnay, la flauta oblicua (nai), la shabbaba y el saffara (silbato) ${ }^{576}$. Igualmente, Faruqi en su diccionario de términos musicales recoge el saffarah afirmando que puede aparecer con distintas variantes, pero siempre referido a un silbato, aunque este mismo término también se utilice para denominar a las flautas de forma genérica en Egipto y en el Magreb ${ }^{577}$. Durante el siglo X el matemático persa al-Juwarismi (m. 997) en Mafatih al- 'ulum (Las llaves de las ciencias) dedica un espacio a la música donde detalla instrumentos musicales de la

\footnotetext{
572 Isabel Flores Escobosa et al., "Juguetes, silbatos e instrumentos musicales en tierras almerienses", en Del rito al juego: jueguetes y silbatos de cerámica desde el Islam hasta la actualidad. Junta de Andalucía, 2006, 64.

573 Ibídem, 65.

574 Henry George Farmer, "Ninth century musical instruments", en Studies in Oriental Musical Instruments: First and Second Series. Boston: Longwood Press, 1978, 53-54.

575 Ibídem, 55.

${ }^{576}$ Henry George Farmer, A history of arabian music to the XIIIth Century. Luzac, 1929, 210.

${ }^{577}$ Lois Ibsen Faruqi, An annotated glossary of arabic musical term. United Estates of America: Greenwood Press, 1981, 287.
} 
época mencionando el saffara entre ellos ${ }^{578}$. Más tarde, en el siglo XI, los Ijwan alSafa' (Hermanos de la Pureza) en su tratado musical Risala fi 'l-musiki (Epístola sobre la música) incluyen una mención al mismo ${ }^{579}$.

En Siyahat nama (Libro de viaje), realizado por el turco Ewliya Chelebi (16111669), se recogen tres términos referidos a los silbatos turcos conocidos como safir, safir-i bulbul y meninski. El primero, safir, estaba compuesto por dos piezas de hueso. El segundo, safir-i bulbul, Faruqi lo define como "silbido" que se utiliza en el sama $^{\prime 580}$. La invención de este silbato se le atribuye a Ibn Sina (Avicena, m.1037) y su finalidad era la imitación del ruiseñor ${ }^{581}$. Sobre el último tipo de silbato, meninski, según Farmer, equivaldría al término persa sutak, consistiendo en un recipiente de metal con un silbato incorporado ${ }^{582}$. Según el lexicógrafo y sabio Ibn Sida (10071065), el término árabe de este instrumento es saffara, y su fabricación se realizaba en cobre tal y como refiere el también lexicógrafo árabe Firuzabadi (1329-1414), siendo un silbato de agua, trataba de imitar el canto de los pájaros. Este instrumento en su evolución terminará siendo de barro ${ }^{583}$.

Resulta curioso que ninguna de las fuentes que llegan hasta nuestros días perteneciente a los primeros periodos de al-Andalus, periodos Emiral (756-929) y Califal (929-1031) mencione los silbatos al hablar de los instrumentos de viento. No será hasta el inicio de los Reinos de Taifas (1031-1090) cuando se empiezan a encontrar referencias a este instrumento en la obra de Ibn Sida (1007-1065), conocido como "El ciego de Murcia". Según el estudio realizado por Ewliya Chelebi, el lexicógrafo murciano las define como: "una cosa hueca en la cual los niños le silban a las palomas" ${ }^{584}$, definición que muestra la relación del silbato con la naturaleza y los niños.

\footnotetext{
578 Amnon Shiloah, The theory of music in arabic writings (c.900-1900). Descriptive catalogue of manuscripts in libraries of Europe and the U.S.A. Munich: G. Henle Verlag München, 1979, 251-252. ${ }^{579}$ Ibidem, 231.

${ }^{580}$ Lois Ibsen Faruqi, An annotated glossary of arabic musical term. United Estates of America: Greenwood Press, 1981, 287.

${ }^{581}$ Henry George Farmer, "Turkish instruments of music in the seventeenth century: as described in the Siyahat Nama of Ewliya Chelebi", en Studies in Oriental Music. Frankfurt: , Institut fur geschicte de Arabisch-Islamichen wissenschaften an der Johann Wofgang Goethe Universitat, 1986, 653.

582 Lois Ibsen Faruqi, An annotated glossary of arabic musical term. United Estates of America: Greenwood Press, 1981, 287.

${ }^{583}$ Henry George Farmer, "Turkish instruments of music in the seventeenth century: as described in the Siyahat Nama of Ewliya Chelebi", en Studies in Oriental Music. Frankfurt: Institut fur geschicte de Arabisch-Islamichen wissenschaften an der Johann Wofgang Goethe Universitat, 1986, 23.

${ }^{584}$ Ídem.
} 
El testimonio del teórico Ibn Arabi (1165-1240) en su Libro de los placeres y la música, recogido por García Barriuso en La Música Hispano-Musulmana en Marruecos, se hace eco de una anécdota donde Aben Omar escucha la axabeba y al sofar al-ray en una sesión de danza donde se quejaba del sonido tan penetrante del instrumento que por ello ya había sido prohibido ${ }^{585}$. Asimismo, especifica que el sofar al-ray era "un silbato pastoril de acentos chillones y subidos, capaces de herir los oídos más perros" ${ }^{\$ 86}$, quedando emparentado el término con el instrumento safir. Quizás por esta razón Omar Metioui en el artículo "Historia y evolución del instrumentarium Andalus-magrebí" contextualiza el saffarrat al-ra'i como el silbato del pastor ${ }^{587}$, además de aportar el dato de su uso para acompañar a la danza.

De igual forma, había un día específico en el mundo musulmán en el que el silbato era el protagonista del nayruz o nawruz, llamada por investigadores como Lévi Provençal fiesta astronómica, ya que correspondía con el equinoccio primavera y otoño. Esta fiesta no es de origen musulmán "era de origen persa; los dulces y regalos abundaban esa noche, considerada propicia para la celebración del matrimonio" 588 . fiesta en el calendario musulmán de origen persa que coincidía con el primer día del año solar, primer día del año y con la Epifanía ${ }^{589}$. Sobre esta festividad y la controversia por las posibles connotaciones cristianas al-'Uqbani menciona tradiciones procedentes de diferentes zonas geográficas del Islam Occidental, llamando la atención de investigadores como Torres Balbás con la siguiente afirmación:

"Ellas [las mujeres] vestían telas, frecuentemente realzadas con dibujos de seres animados, Ibn Rusd, sin embargo, toleraba tales telas, pues decía que estos dibujos al no ser en relieve, no podían proyectar sombra. Sí condenaba los juguetes en forma de animales, como las jirafas que había por costumbre fabricar en al-Andalus con motivo del Año Nuevo (la fiesta de Nayruz), Al-'Uqbânî, en este sentido, recordaba que igual costumbre existía en Tlemcen, a lo largo del

585 Patrocinio García Barriuso, La música hispano-musulmana en Marruecos: Padre Patrocinio García Barriuso; Presentación, vida y obra del autor, Manuela Cortés García. Instituto Cervantes: Fundación del Monte, 2001, 72.

586 Ídem.

587 Omar Metioui, "Historia y evolución del instrumentarium andalusí-magrebí", en Al-Andalus y el norte de África: Relaciones e influencias, ed. Pablo Beneito y Fátima Roldán. Sevilla: Fundación El Monte, 2004, 125.

${ }^{588}$ María Luisa Ávila Navarro, "La sociedad”, en Historia de España. Ramón Menéndez Pidal. Tomo VIII Los Reinos de Taifas al-Andalus en el siglo XI. Madrid: Espasa-Calpe, 1994, 371.

589 Purificación Marinetto Sánchez, "Juegos y distracciones de los niños en la ciudad de la Alhambra", en Del rito al juego: jueguetes y silbatos de cerámica desde el Islam hasta la actualidad. Junta de Andalucía: 2006, 75-76. 
mes de enero, añadiendo que, de manera general, se fabricaban juguetes semejantes en ocasión de todas las fiestas, costumbre a su entender que denotaba un origen cristiano"590

Otra de las fuentes del siglo XIII que menciona los silbatos es la escrita por Ibn al-Darray de Ceuta, quien en su libro Kitab al- 'imta' wa-l-intifa' (Libro del goce y el provecho), nombra al saffara entre los aerófonos y citando a al-Zabandi quien afirma que consiste en "una cosa hueca en la que se silba" de Faruqi quien lo denomina como "una especie de flautín"592. La discordancia existe entre Ibn al Darray al relacionarlo con un instrumento pastoril, mientras que Faruqi lo identifica con la flauta oblicua (nai) ${ }^{593}$.

Posteriormente a estas menciones sobre los silbatos en el siglo XIII, en la corte catalano-aragonesa de Juan I se encuentra un documento fechado el 16 de marzo de 1394 donde figura el término "ciuet", siruells en catalán, donde se hace un equivalente a silbato o silbido desde la perspectiva cristiana en el contexto del sonido de un cuerno: "lo Rey. Com haiam entes que vos havets un ciulet de banya de unicorn, manam vos que, vistes les presents, no portets lo dit ciulet o 1 nos trametats per persona certa" 594 .

El arqueólogo e investigador Rosselló Bordoy, experto en los silbatos musulmanes y en la comparación de estos con los actuales siruells mallorquines puntualiza que eran juguetes para armar ruido y el regalo que los niños obtenían en la feria del pueblo, aunque actualmente es más probable verlos en tiendas de recuerdos de Mallorca ${ }^{595}$. Rosselló Bordoy puntualiza que el primer investigador que se preguntó a cerca de estos instrumentos fue J.F. Ràfols en su trabajo "Historia del Arte" en 1936:

“Los pitos cerámicos de Mallorca son un testimonio vivo de cómo a lo largo de los siglos pueden perdurar las formas en el arte del pueblo (...) los personajes y animales que componen

\footnotetext{
590 Guillermo Rosselló Bordoy, "El largo camino de una investigación”, en Del rito al juego: jueguetes y silbatos de cerámica desde el islam hasta la actualidad. Junta de Andalucía: 2006, 24-25.

591 Rosario Mazuela Coll, "Edición, traducción y comentario del 'Libro de Los Instrumentos Musicales' Incluido En El 'Kitab Al-Inta Wa Al-Imtifa Fi Mas'alat Sama' Al-Sama' de Al-Salahi”. Instituto hispano árabe de cultura, 1988, 66.

592 Ibídem, 80.

593 Ibídem, 66.

594 Ramón Andrés, Diccionario de instrumentos musicales. Desde la Antigüedad a J.S. Bach. Barcelona: Península, 2009, 399.

595 Guillermo Rosselló Bordoy, "El largo camino de una investigación”, en Del rito al juego: jueguetes y silbatos de cerámica desde el islam hasta la actualidad. Junta de Andalucía, 2006, 15.
} 
la temática de los pitos de Mallorca, reflejan tal sentido del hieratismo y de la decoración arbitraria que no se concibe puedan seguir produciéndose en nuestros días" ${ }^{596}$.

Asimismo, el investigador Josep Crivillé incluye en su libro El Folklore musical ${ }^{597}$ un espacio dedicado a este instrumento musical, donde comenta que se encuentra esparcido por España bautizado con diversos nombres como: Canario, Filomena, Pito o Cantarillo, llegando a ser utilizado como sinónimo de pito, de flautilla aguda e incluso de pífano ${ }^{598}$. Crivillé indica que están fabricados con barro cocido y que algunos se llenan de agua para conseguir un gorgojeo similar al de un pajarillo. Posteriormente hablará de los siurells y de las referencias más antiguas del instrumento musical que se remontan al siglo XIII ${ }^{599}$.

Ulteriormente a las menciones del silbato del siglo XIV por fuentes cristianas, de la corte catalano-aragonesa será en el siglo XV cuando por su uso corriente se generalizará este instrumento musical. Covarrubias recoge el término en 1611: "El sonido que se haze con la boca y el que da algún pájaro [...] Silvato, con el que los niños silvan" ${ }^{600}$.

Sobre los silbatos posteriores a la época medieval, siglos XVI-XVII, existe un catálogo coordinado por Navarro Ortega donde se catalogan gran número de silbatos que guardan semejanzas con los andalusíes ${ }^{601}$. El estudio de estos muestra que durante el siglo XVII hubo una nueva tendencia a representar figuritas humanas.

Según la investigadora Scheherazade Qassim, estos instrumentos actualmente en Irak son interpretados por niños pudiendo incluso ser construidos por ellos. A los silbatos hoy en día se les denomina en árabe masüla, en siríaco zumbarta y en kurdo soranita, fita y fikna. Los nombres de estos también pueden variar según el material con el que están fabricados. Cuenta, asimismo, que pueden tener o no boquilla al igual

\footnotetext{
596 Ibídem, 16.

597 Josep Crivillé i Bargalló, Historia de la música española. 7. El folklore musical. Madrid: Alianza musical, 2004.

598 Ibídem, 398.

599 Ibidem, 364.

600 Ramón Andrés, Diccionario de instrumentos musicales. Desde la Antigüedad a J.S. Bach. Barcelona: Península, 2009, 398.

601 Guillermo Rosselló Bordoy, Navarro Ortega y Flores Escobosa, Del rito al juego: juguetes y silbatos de cerámica desde el Islam hasta la actualidad. Junta de Andalucía: 2006, 203-204, 211-225 y 229 .
} 
que con agujeros, normalmente dos o tres, y que éstos pueden tener formas zoomorfas $^{602}$.

Centrándonos en el interés de esta investigación, a continuación, se realizará una numeración y contextualización de los silbatos encontrados en una de las zonas geográficas españolas que cuentan con gran evidencia de estos instrumentos en la época islámica, Andalucía.

\section{Los silbatos en la arqueología andalusí}

Existe una gran variedad de silbatos que llegan hasta nuestros días a través de las excavaciones arqueológicas de distintos puntos de Andalucía. Las principales ciudades que cuentan con más ejemplares son Almería, Granada y Jaén, y en menor medida Cádiz, Córdoba, Málaga y Sevilla. En las ciudades andaluzas se está llevando a cabo una importante actividad arqueológica. El consecuente tratamiento de restos arqueológicos, los estrictos plazos de estudio del material junto al escaso personal con el que se cuenta para gestionarlo han llevado a que nos encontremos referencias sobre piezas, en los distintos estudios presentados por los yacimientos, que lamentablemente luego no llegan a localizarse. A pesar de este contratiempo, existen casos en los que al menos se cuenta con el dibujo de la pieza en paradero desconocido.

Entre las piezas encontradas, existen ejemplares con forma de caballos, caballos con jinetes, aves, toros o figuras humanas masculinas o femeninas. Estas tipologías nos llevan a establecer una clasificación polarizada en dos grupos: antropomorfos y zoomorfos ${ }^{603}$.

Entre los zoomorfos, uno de los más comunes en al-Andalus y que trascienden hasta nuestra época, son los caballos ${ }^{604}$. Sobre ellos Torres Balbás afirmaba lo siguiente:

"En excavaciones hechas en algunos lugares, Córdoba, Almería y la Alhambra de Granada entre ellos, han aparecido toscos cuadrúpedos de barro cocido, de unos 7 a 10 centímetros de altura, caballos al parecer la mayoría, algunos con jinete. Varios están perforados y sirvieron de pitos.

\footnotetext{
${ }^{602}$ Schéhérazade Qassim Hassan, Les instruments de musique en Irak. París: Cahiers de l'homme, $1980,55$.

${ }^{603}$ Guillermo Rosselló Bordoy, "De nuevo los animales de juguete y otros aspectos de coroplastia andalusi', en Actas del IV Coloquio hispano-tunecino, 1979, 206.

${ }^{604}$ Purificación Marinetto Sánchez, "Juegos y distracciones de los niños en la ciudad de la Alhambra", en Del rito al juego: jueguetes y silbatos de cerámica desde el Islam hasta la actualidad. Junta de Andalucía: 2006, 76.
} 
Los hay de barro vidriado; otros, en la Alhambra, de arcilla muy blanca tienen sencilla decoración de rayas negras pintadas. Uno, procedente de Córdoba, en la colección Gómez Moreno, está vidriado sobre color verde. También los hay en el alcázar granadino con vidrio melado. Por su pobre aspecto y la humildad de su material y de su arte, apenas si han sido objeto de atención. De clasificación difícil, no podía asegurarse que pertenecieran a época hispanomusulmana, al no registrarse su hallazgo entre restos, cerámicos principalmente, pertenecientes a ella. Productos de arte popular es fácil señalar semejanzas entre sus formas esquemáticas y otras de cuadrúpedos de bronce de civilizaciones orientales y mediterráneas de la edad Antigua, semejanzas frecuentes entre las obras de arte popular y las de pueblos primitivos" 605 .

\section{Clasificación por tipología y características}

Debido a la rica variedad de silbatos encontrados, el clasificarlos solo por su condición de zoomorfos o antropomorfos resultaría limitado, Rosselló Bordoy proponen realizar una ordenación según la estructura física del instrumento, especificando qué tipo de animal representa o si existe una combinación entre antropomorfos y zoomorfos ${ }^{606}$. Basado en el trabajo del arqueólogo mallorquín se comenzará a establecer, por lo tanto, una primera tipología en función de la estructura de la pieza:

\section{A. Clasificación por su estructura física:}

\begin{tabular}{|c|c|}
\hline Zoomorfos & \\
\hline & Caballitos sin arreos \\
\hline & Caballitos con silla y atalaje \\
\hline & Felinos \\
\hline & Aves \\
\hline & Ofidios \\
\hline Mixtos & \\
\hline & Caballitos con jinete \\
\hline Antropomorfos $^{607}$ & \\
\hline & Orantes \\
\hline & "Cadufes" \\
\hline Animales fantásticos & \\
\hline & Cabezas aberrantes de la Alhambra \\
\hline
\end{tabular}

Esta clasificación resulta bastante completa para el estudio de la estructura de la pieza, por lo que se combinará con la última versión en español de la clasificación de

\footnotetext{
${ }^{605}$ Guillermo Rosselló Bordoy, “El largo camino de una investigación”, en Del rito al juego: jueguetes y silbatos de cerámica desde el Islam hasta la actualidad. Junta de Andalucía: 2006, 25.

${ }^{606}$ Guillermo Rosselló Bordoy, "De nuevo los animales de juguete y otros aspectos de coroplastia andalusí", en Actas del IV Coloquio hispano-tunecino, 1979, 208.

${ }^{607}$ En este apartado Rosselló Bordoy incluye también las campanillas de arcilla o barro que en esta investigación se incluirán en los idiófonos.
} 
instrumentos musicales realizada por Curt Sachs y Erich von Hornbostel, y traducida por Javier Serrano Godoy ${ }^{608}$.

La clasificación organológica por lo tanto sería la siguiente:

\section{B. Clasificación organológica:}

B) Silbatos globulares (tipos 421.221.4: 421.221.41/421.221.42)

B.1. Silbatos globulares antropomorfos

B.2. Silbatos globulares zoomorfos

B.3. Silbatos globulares mixtos

B.4. Silbatos globulares de agua

B.5. Silbatos globulares con otras formas

C) Silbatos tipo ocarina (tipo 421.221.421/421.221.422)

\section{A) Silbatos globulares (tipos 421.221.4: 421.221.41/421.221.42)}

Los epígrafes de la clasificación que se ajusta a la catalogación de los silbatos andalusíes encontrados serían los siguiente:

421.221.4 Flautas globulares con canal de insuflación interno

421.221.41 Flautas globulares con canal de insuflación interno sin agujeros digitales

421.221.42 Flautas globulares con canal de insuflación interno con agujeros digitales

421.221.421 Flautas globulares con canal de insuflación interno con un solo agujero

421.221.422 Flautas globulares con canal de insuflación interno con dos o más agujeros

Siendo éstos los puntos clasificatorios que se ajustan a la colección de piezas con la que se trabaja, se les reservará un espacio en la ficha de catalogación para poder puntualizar todas las características de los mismos.

Este tipo de instrumentos musicales se caracterizan por contar con una caja de resonancia de forma redondeada, ovalada o globular. El funcionamiento de estos

\footnotetext{
${ }^{608}$ Javier Serrano Godoy, Versión en español de la clasificación de instrumentos musicales de Curt Sachs y Erich von Hornbostel, Según la edición CIMCIM - MIMO 2011 / 2017. Madrid: Universidad Complutense de Madrid, 2018.
} 
instrumentos consistiría en concentrar la insuflación del aire en el canal o embocadura contando con un bisel que le otorga las posibilidades sonoras. En el caso de que el instrumento cuente con agujeros digitales, el sonido podrá modificarse al taparlos llegando a conseguir tanto sonidos como los orificios y armónicos permitan.

Al existir gran variedad de ejemplares de este tipo de silbatos adosados a figuras zoomorfas o antropomorfas, se detallarán a continuación, asimismo, las características propias de cada uno.

La mayoría de los silbatos cuenta con forma zoomorfa o antropomorfa, por lo que en la ficha de catalogación de los mismo cuando se hable de su función se indicará que será lúdica ya que, según lo mencionado en el apartado iconográfico, las representaciones figurativas no solían formar parte de contextos religiosos.

\section{A.1. Silbatos globulares antropomorfos}

Este tipo de silbatos suele ser escaso, no obstante, existen piezas que representan las figuras femeninas, como ocurre con las piezas número 39 y 44. También, figuras aparentemente masculinas, como la pieza número 2 y bustos o máscaras masculinas como las piezas número 10, 16 y 40 respectivamente. En referencia a la pieza 41 no llega hasta nuestros días la cabeza, pero por el cuerpo de la figura parece representar un hombre con los brazos apoyados sobre el cuerpo. En el caso de las máscaras éstas pudieron formar parte de un silbato de agua ya que existen referencias a otros silbatos con adornos de estas caras barbadas. En el caso de la pieza 16 las facciones recuerdan más a representaciones africanas.

\section{A.2. Silbatos globulares zoomorfos}

Los silbatos con forma de animales son los más numerosos. Entre los encontrados existen distintos tipos de aves como podemos observar en a las piezas número $11,17,24,38,43,50$ y 51 . Las piezas zoomorfas más numerosas tras las aves son los caballos sin jinete, correspondientes a las piezas: 5, 9, 12, 15, 27, 29 y 35 y la pieza 46 siendo el silbato la cabeza del caballo. También se pueden encontrar toros, como $\operatorname{los} n^{\circ} 4$ y 42 ; peces, $n^{\circ} 1$ y 23 ; osos, $n^{\circ} 25,30$ y 31 ; un reptil, $n^{\circ} 47$, un lagarto $\mathrm{n}^{\mathrm{o}} 14$, la cabeza de un lagarto o camaleón, $\mathrm{n}^{\mathrm{o}} 13$; un caracol, $\mathrm{n}^{\mathrm{o}} 33$, lo que parecer ser un camello, $\mathrm{n}^{\mathrm{o}} 21$; una gallina, $\mathrm{n}^{\circ} 48$ y una serpiente, $\mathrm{n}^{\mathrm{o}}$ 45. Asimismo, existen otros silbatos, $\mathrm{n}^{\mathrm{o}} 8$ y 36 con forma zoomorfa no identificada pudiendo representar un 
animal imaginario o siendo irreconocible este por la posible pérdida de algunas de sus partes, en el caso del 8 se intuye que pudo contar con orejas e incluso pico.

\section{A.3. Silbatos globulares mixtos}

Estos resultan los más escasos encontrados, aunque con más proyección futura como se verá después del siglo XV y hasta nuestros días: los jinetes con caballos. De estos solo se han encontrado hasta ahora $\operatorname{los} \mathrm{n}^{\mathrm{o}} 28$ y 37.

\section{A.4. Silbatos globulares de agua}

Los silbatos de agua se han encontrado tienen forma de jarrita como son los $n^{\circ}$ $3,6,7,18,19,26,32$ y 34 y algunos de ellos cuentan con una máscara masculina a modo de adorno. De estos se han encontrado otro tipo de figuras que podrían servir para construirlas como el molde de máscara que se conserva en el Museo de Jaén y máscaras sueltas con el mismo dibujo que las que vienen adosadas con los silbatos pero encontradas de forma independiente a estos instrumentos musicales.

\section{A.5. Silbatos globulares con otras formas}

Igualmente, se han encontrado otro tipo de silbatos con un diseño más sencillo, como las piezas 20, 22, 49 y 52 .

El siguiente cuadro recoge las piezas clasificadas según el lugar de procedencia donde se han encontrado quedando la ficha completa de los instrumentos en el Anexo II.

Cuadro de silbatos por ciudades de Andalucía

\begin{tabular}{|c|c|c|c|c|}
\hline Silbato & Cronología & $\begin{array}{c}\text { Lugar } \\
\text { encontrado }\end{array}$ & $\begin{array}{c}\text { Numeraci } \\
\text { ón Anexo }\end{array}$ & Inventario \\
\hline $\begin{array}{c}\text { Silbato (Alcazaba, } \\
\text { Almería) }\end{array}$ & XII & $\begin{array}{c}\text { Alcazaba de } \\
\text { Almería }\end{array}$ & Ficha 1 & CE28174 \\
\hline $\begin{array}{c}\text { Silbato } \\
\text { antropomorfo } \\
\text { (Almería) }\end{array}$ & XII & $\begin{array}{c}\text { Plaza Virgen del } \\
\text { Mar. }\end{array}$ & Ficha 2 & 83912 \\
\hline $\begin{array}{c}\text { Silbato de agua } \\
\text { (Alcazaba, Almería) }\end{array}$ & XIII-XIV & $\begin{array}{c}\text { Alcazaba de } \\
\text { Almería }\end{array}$ & Ficha 3 & CE28446 \\
\hline $\begin{array}{c}\text { Silbato zoomorfo } \\
\text { (Almería) }\end{array}$ & XII & $\begin{array}{c}\text { Calle Pablo } \\
\text { Iglesias }\end{array}$ & Ficha 4 & 83913 \\
\hline $\begin{array}{c}\text { Silbato zoomorfo } \\
\text { (Almería) }\end{array}$ & XI-XII & $\begin{array}{c}\text { Calle Pablo } \\
\text { Iglesias }\end{array}$ & Ficha 5 & DJ83982 \\
\hline Silbato de agua & XIV & Alcazaba de & Ficha 6 & CE28445 \\
\hline
\end{tabular}




\begin{tabular}{|c|c|c|c|c|}
\hline (Alcazaba, Almería) & & Almería & & \\
\hline $\begin{array}{l}\text { Silbato de agua } \\
\text { (Almería) }\end{array}$ & $\mathrm{X}-\mathrm{XV}$ & Calle Real, 5 & Ficha 7 & DJ84671 \\
\hline $\begin{array}{c}\text { Silbato zoomorfo } \\
\text { (Alcazaba, Almería) }\end{array}$ & VIII-XV & $\begin{array}{c}\text { Alcazaba de } \\
\text { Almería }\end{array}$ & Ficha 8 & 28448 \\
\hline $\begin{array}{l}\text { Silbato zoomorfo } \\
\text { (Almería) }\end{array}$ & XIV-XV & [Particular] & Ficha 9 & - \\
\hline Silbato (Almería) & XIV-XV & [Particular] & Ficha 10 & - \\
\hline $\begin{array}{l}\text { Silbato zoomorfo } \\
\text { (Cádiz) }\end{array}$ & & $\begin{array}{l}\text { Yacimiento casa } \\
\text { del obispo }\end{array}$ & Ficha 11 & \\
\hline $\begin{array}{l}\text { Silbato zoomorfo } \\
\text { (Jerez, Cádiz) }\end{array}$ & XII-XIII & Alcázar de Jerez & Ficha 12 & $00965-002$ \\
\hline $\begin{array}{l}\text { Silbato zoomorfo } \\
\text { (Jerez, Cádiz) }\end{array}$ & XII-XIII & C/ Castellanos, 3 & Ficha 13 & $01470-040$ \\
\hline $\begin{array}{l}\text { Silbato zoomorfo } \\
\text { (Jerez, Cádiz) }\end{array}$ & XII-XIII & Plaza Belén & Ficha 14 & $1499-00255$ \\
\hline $\begin{array}{l}\text { Silbato zoomorfo } \\
\text { (Jerez, Cádiz) }\end{array}$ & & Alcázar Jerez & Ficha 15 & $\begin{array}{c}\text { N-III/GH- } \\
10191\end{array}$ \\
\hline $\begin{array}{c}\text { Silbato } \\
\text { antropomorfo (Jerez, } \\
\text { Cádiz) }\end{array}$ & & Calle Lacería & Ficha 16 & $\begin{array}{c}\text { LAN/87/A- } \\
7 /-194 / 21\end{array}$ \\
\hline $\begin{array}{c}\text { Silbato zoomorfo } \\
\text { (Córdoba) }\end{array}$ & X-XII & $\begin{array}{c}\text { Plaza de Jerónimo } \\
\text { Páez }\end{array}$ & Ficha 17 & CE031614 \\
\hline Silbato (Córdoba) & VIII-XV & $\begin{array}{l}\text { Calle Conde de } \\
\text { Arenales, } 22\end{array}$ & Ficha 18 & DJ032691 \\
\hline $\begin{array}{l}\text { Silbato de agua } \\
\text { (Córdoba) }\end{array}$ & X-XIV & $\begin{array}{l}\text { Calle María } \\
\text { Auxiliadora }\end{array}$ & Ficha 19 & 192 \\
\hline Silbato (Córdoba) & X-XIV & - & Ficha 20 & DJ1374C \\
\hline $\begin{array}{l}\text { Silbato zoomorfo } \\
\text { (Córdoba) }\end{array}$ & XII-XIII & Avenida Ollerías & Ficha 21 & - \\
\hline Silbato (Alhambra) & XIV-XV & Alhambra & Ficha 22 & 4795 \\
\hline $\begin{array}{l}\text { Silbato zoomorfo } \\
\text { (Alhambra) }\end{array}$ & XIV-XV & Alhambra & Ficha 23 & 005050 \\
\hline $\begin{array}{l}\text { Silbato zoomorfo } \\
\text { (Alhambra) }\end{array}$ & XIV-XV & Alhambra & Ficha 24 & 4776 \\
\hline $\begin{array}{l}\text { Silbato zoomorfo } \\
\text { (Alhambra) }\end{array}$ & XIV-XV & Alhambra & Ficha 25 & 7069 \\
\hline $\begin{array}{l}\text { Silbato de agua } \\
\text { (Alhambra) }\end{array}$ & XIV-XV & Alhambra & Ficha 26 & 4753 \\
\hline $\begin{array}{l}\text { Silbato zoomorfo } \\
\text { (Alhambra) }\end{array}$ & XIV-XV & Alhambra & Ficha 27 & 1185 \\
\hline $\begin{array}{l}\text { Silbato zoomorfo } \\
\text { (Alhambra) }\end{array}$ & XIV-XV & Alhambra & Ficha 28 & 1412 \\
\hline $\begin{array}{c}\text { Silbato zoomorfo } \\
\text { (Alhambra) }\end{array}$ & XIV-XV & Alhambra & Ficha 29 & 4845 \\
\hline $\begin{array}{l}\text { Silbato zoomorfo } \\
\text { (Alhambra) }\end{array}$ & XIV-XV & Alhambra & Ficha 30 & 4763 \\
\hline $\begin{array}{l}\text { Silbato zoomorfo } \\
\text { (Alhambra) }\end{array}$ & XIV-XV & Alhambra & Ficha 31 & 7072 \\
\hline
\end{tabular}




\begin{tabular}{|c|c|c|c|c|}
\hline $\begin{array}{l}\text { Silbato de agua } \\
\text { (Alhambra) }\end{array}$ & VIII-XV & Alhambra & Ficha 32 & 4070 \\
\hline $\begin{array}{l}\text { Silbato zoomorfo } \\
\text { (Granada) }\end{array}$ & XII-XV & $\begin{array}{c}\text { Necrópolis de las } \\
\text { Cuevas de la } \\
\text { Arena, Baza }\end{array}$ & Ficha 33 & DJ00740 \\
\hline $\begin{array}{l}\text { Silbato de agua } \\
\text { (Granada) }\end{array}$ & $\mathrm{XV}$ & - & Ficha 34 & 2209 \\
\hline $\begin{array}{l}\text { Silbato zoomorfo } \\
\text { (Granada) }\end{array}$ & - & - & Ficha 35 & - \\
\hline $\begin{array}{l}\text { Silbato (Baza, } \\
\text { Granada) }\end{array}$ & XII-XV & $\begin{array}{c}\text { Necrópolis de las } \\
\text { Cuevas de la } \\
\text { Arena, Baza }\end{array}$ & Ficha 36 & DJ00740 \\
\hline $\begin{array}{c}\text { Silbato } \\
\text { antropomorfo (Baza, } \\
\text { Granada) }\end{array}$ & XII-XV & $\begin{array}{c}\text { Necrópolis de las } \\
\text { Cuevas de la } \\
\text { Arena, Baza }\end{array}$ & Ficha 37 & DJ00742 \\
\hline $\begin{array}{l}\text { Silbato zoomorfo } \\
\text { (Baza, Granada) }\end{array}$ & XII-XV & $\begin{array}{c}\text { Necrópolis de las } \\
\text { Cuevas de la } \\
\text { Arena, Baza } \\
\end{array}$ & Ficha 38 & DJ00739 \\
\hline $\begin{array}{c}\text { Silbato } \\
\text { antropomorfo } \\
\text { (Algarinejo, } \\
\text { Granada) }\end{array}$ & $\begin{array}{l}\text { Hispanomus } \\
\text { ulmán }\end{array}$ & $\begin{array}{l}\text { Avenida de la } \\
\text { Constitución }\end{array}$ & Ficha 39 & - \\
\hline $\begin{array}{c}\text { Silbato } \\
\text { antropomorfo } \\
\text { (Huelva) }\end{array}$ & Edad Media & Calle Puerto $\mathrm{n}^{\circ} 9$ & Ficha 40 & A/CE07054 \\
\hline $\begin{array}{c}\text { Silbato } \\
\text { antropomorfo (Jaén) }\end{array}$ & XII-XIII & $\begin{array}{l}\text { C/ Baños de la } \\
\text { Audiencia }\end{array}$ & Ficha 41 & DJ/DA02883 \\
\hline $\begin{array}{l}\text { Silbato zoomorfo } \\
\text { (Jaén) }\end{array}$ & XII $i ?$ & $\begin{array}{c}\text { Zona } \\
\text { Arqueológica de } \\
\text { Marroquíes Bajos }\end{array}$ & Ficha 42 & 4466 \\
\hline $\begin{array}{l}\text { Silbato zoomorfo } \\
\text { (Jaén) }\end{array}$ & XV-XVI & Baños árabes & Ficha 43 & - \\
\hline $\begin{array}{c}\text { Silbato } \\
\text { antropomorfo (Jaén) }\end{array}$ & XV-XVI & Baños árabes & Ficha 44 & - \\
\hline $\begin{array}{l}\text { Silbato zoomorfo } \\
\text { (Jaén) }\end{array}$ & XV-XVI & Baños árabes & Ficha 45 & - \\
\hline $\begin{array}{l}\text { Silbato zoomorfo } \\
\text { (Martos, Jaén) }\end{array}$ & IX-X & $\begin{array}{l}\text { Esquina Avda. } \\
\text { San Amador C/ } \\
\text { Alfonso XII, } \\
\text { Polideportivo de } \\
\text { Martos }\end{array}$ & Ficha 46 & - \\
\hline $\begin{array}{l}\text { Silbato zoomorfo } \\
\text { (Andújar, Jaén) }\end{array}$ & XII & $\begin{array}{l}\text { Calles Alcázar, } \\
\text { Deán Pérez de } \\
\text { Vargas y Parras } \\
\text { de la localidad de } \\
\text { Andújar }\end{array}$ & Ficha 47 & DJ/DA02884 \\
\hline $\begin{array}{l}\text { Silbato zoomorfo } \\
\text { (Baeza, Jaén) }\end{array}$ & XV-XVI & $\begin{array}{l}\text { C/ S. Vicente } \\
\text { (Baeza) }\end{array}$ & Ficha 48 & 4606 \\
\hline Silbato & Edad Media & Muralla de Baeza & Ficha 49 & DJ/DA05590 \\
\hline
\end{tabular}




\begin{tabular}{|c|c|c|c|c|}
\hline $\begin{array}{c}\text { Silbato zoomorfo } \\
\text { (Andújar, Jaén) }\end{array}$ & XII & $\begin{array}{c}\text { Calles Alcázar, } \\
\text { Deán Pérez de } \\
\text { Vargas y Parras } \\
\text { de la localidad de } \\
\text { Andújar }\end{array}$ & Ficha 50 & DJ/DA02886 \\
\hline $\begin{array}{c}\text { Silbato zoomorfo } \\
\text { (Andújar, Jaén) }\end{array}$ & XII & $\begin{array}{c}\text { Calles Alcázar, } \\
\text { Deán Pérez de } \\
\text { Vargas y Parras } \\
\text { de la localidad de } \\
\text { Andújar }\end{array}$ & Ficha 51 & DJ/DA02885 \\
\hline $\begin{array}{c}\text { Silbato (Estepona, } \\
\text { Málaga) }\end{array}$ & XII-XIII & Castillo & Ficha 52 & EST09-789 \\
\hline
\end{tabular}

\section{Varias puntualizaciones:}

\section{Jaén}

Los silbatos expuestos en los Baños Árabes de Jaén pertenecen a la Diputación Provincial de la citada ciudad y tras indagar acerca de estas piezas, su responsable Rosa María Morales Ocaña afirmaba que no tenían datación por las circunstancias en las que fueron encontradas:

"Le informo que ambos silbatos no están datados y que fueron encontrados junto con el resto de materiales expuestos en las vitrinas de dichas salas, durante las labores de destierro de los

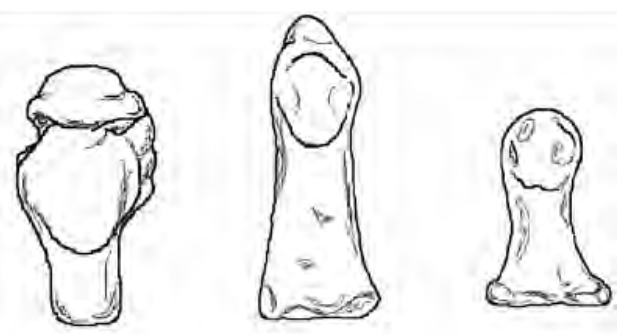

Baños Árabes. El material que se utilizó para rellenar los Baños Árabes y poder utilizarlos como cimientos del Palacio que mandó edificar en el s. XVI el Conde de Villardompardo fueron escombros traídos de otras edificaciones".

Ante la posibilidad de que puedan acogerse a estas fechas se han

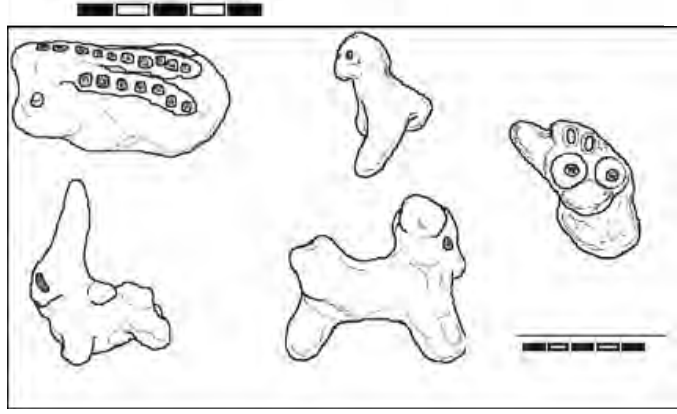

Figura 41. Silbatos del Anuario Arqueológico de Andalucía 2004 incluido en la catalogación, a pesar de que los rasgos de uno de los silbatos, el que representa una figura femenina (ficha 38) pueda parecer cristiana. Este silbato es semejante al encontrado en Málaga, en la calle Gaona reflejado en el libro Del Rito al Juego, cuya cronología, igualmente, es 
indeterminada ${ }^{609}$. Rosselló Bordoy en su artículo "De nuevo animales de juguete..." puntualiza tener "una certeza casi absoluta de su vinculación al mundo islámico" 610 cuando habla sobre los silbatos encontrados en los Baños árabes de Jaén.

Por otro lado, Rosselló Bordoy afirma que existe un silbato con forma de perro en los Baños Árabes de Jaén ${ }^{611}$ y suponemos que se refiere a la pieza número 41 ya que en el libro Del Rito al Juego se indica que puede representar un perro o gato ${ }^{612}$ en vez de un reptil, hipótesis planteada por el museo y que se ha visto más acorde después de estudiar la pieza.

Asimismo, en el Anuario arqueológico de Andalucía de 2004 se incluían dos imágenes con algunas figuras encontradas en la excavación puntualizando que varias de ellas eran silbatos, aunque sin entrar en mayor especificación:

\footnotetext{
"Igualmente se encontraron diversas figuritas animales que podrían datarse al menos desde época Almohade. Algunas de ellas presentaban un agujero en la parte trasera (posiblemente pitos), dos de ellas estaban vidriadas, algunas eran de apariencia más o menos antropomorfa (podría tratarse tal vez de peones de ajedrez) y otras indeterminadas que podrían ser fallos de horno".
}

De estos dibujos solo se ha localizado un silbato el cual se ha incluido en la investigación (ficha 37).

\section{Málaga}

Por desgracia son varios los silbatos de los que se tiene conocimiento que se han encontrado en distintas excavaciones arqueológicas malagueñas que se quedan fuera de esta investigación por motivos que escapan a nuestras posibilidades. Por un lado, después de la entrevista con la arqueóloga Carmen Íñiguez, ésta nos informó acerca de unos silbatos islámicos que se encontraron en una excavación de urgencia en Calle Muro de Santa Ana. Íñiguez recuerda la presencia de al menos tres caballitos con silbatos adosados, por desgracia después de acudir a Urbanismo y al Museo de

\footnotetext{
${ }^{609}$ Guillermo Rosselló Bordoy, Navarro Ortega y Flores Escobosa, Del Rito al Juego: Juguetes y Silbatos de Cerámica desde el islam Hasta la Actualidad. Junta de Andalucía: 2006, 238.

${ }^{610}$ Guillermo Rosselló Bordoy, "De nuevo los animales de juguete y otros aspectos de coroplastia andalusí”, en Actas del IV Coloquio hispano-tunecino, 1979, 206.

611 Guillermo Rosselló Bordoy, "El largo camino de una investigación", en Del Rito al Juego: Juguetes y Silbatos de Cerámica desde el islam hasta la Actualidad. Junta de Andalucía, 2006, 28. ${ }^{612}$ Guillermo Rosselló Bordoy, Navarro Ortega y Flores Escobosa, Del Rito al Juego: Juguetes y Silbatos de Cerámica desde el islam hasta la Actualidad. Junta de Andalucía: 2006, 174.
} 
Málaga nada se ha podido saber a cerca de esta colección que se vio envuelta en graves conflictos legales.

Por otro lado, existe otro silbato islámico procedente de una excavación arqueológica en la Cueva de la Pileta actualmente conservada en el Museo de Málaga. Esta pieza fue encontrada por el arqueólogo Miguel Cortés y estudiada por José Manuel Jiménez Arena. Nada más se ha podido saber de ella ya que forma parte de una futura publicación sobre el yacimiento y hasta ese momento sus responsables no ofrecen más información al respecto. 


\subsubsection{Flautas}

Estos instrumentos musicales de tan remotos orígenes, considerados incluso como uno de los primeros inventados por el hombre ${ }^{613}$, tienen gran presencia en la inmensa mayoría de las culturas musicales desde épocas prehistóricas, descartando Australia y Groenlandia ${ }^{614}$, llegando, según la línea más directa de investigación, a Egipto, Grecia, Roma o el Imperio Islámico. En el caso de la cultura egipcia, según Pérez Arroyo, investigador especializado en esta temática, este instrumento supone uno de los poco predinásticos capaces de producir una melodía y articular frases cercanas al lenguaje, por lo que es tal la relevancia que adquiere dentro de esta cultura, que forja su propia teoría musical ${ }^{615}$. Tranchefort confirma, igualmente, la antigüedad de las flautas o aerófonos comentando que los primeros ejemplares encontrados tienen de 25.000 a 12.000 años, y que incluso existe iconografía sumeria y egipcia que datan del III milenio antes de nuestra era ${ }^{616}$, normalmente enlazadas a escenarios mágicos y guerreros ${ }^{617}$. El investigador Ramón Andrés, coincidiendo con estas opiniones, llega a afirmar que la flauta es uno de los instrumentos musicales más antiguos del patrimonio musical de la Humanidad ${ }^{618}$ como demuestran las ocho piezas encontradas en el yacimiento de Suabia en Alemania, de 30.000 años de antigüedad construidas con huesos de aves como cisnes o buitres leonados. En el año 2009 se encontró las más antigua hasta ahora en el yacimiento de Hohle Fels, hecha con un hueso de buitre leonado de 40.000 años de antigüedad. Asimismo, en España, en 1960, se encontró un ejemplar con 8.000 años cerca de Gernika y que se encuentra actualmente en el Museo Arqueológico de Bilbao ${ }^{619}$.

Por otro lado, el estudio documental de este instrumento ha sido muy conflictivo a lo largo de los años ya que este término se ha utilizado indistintamente para denominar gran variedad de aerófonos de los que no se han detallado tipos de embocadura o número de perforaciones digitales. Este hándicap en el estudio de estos instrumentos, lo plantea, igualmente, el musicólogo y arabista Henry George Farmer

\footnotetext{
${ }^{613}$ Angelo Zaniol, "La flauta recta en los siglos XIII-XV”, en Flûte à Bec, 1982, 285.

614 Jeremy Montagu, Howard Mayer Brown y Frank Ardal Powell, "Flute", Grove Music Online, Oxford University Press, 2011.

${ }^{615}$ Rafael Pérez Arroyo, La música en la era de las pirámides. Centro de Estudios Egipcios, 2001, 38.

616 Ibídem, 205.

${ }^{617}$ François-René Tranchefort, Los instrumentos musicales en el mundo. Ediciones Akal, 1985, 202.

618 Ramón Andrés, Diccionario de instrumentos musicales. Desde la Antigüedad a J.S. Bach. Barcelona: Ediciones Península, 2009, 192.

${ }^{619}$ Ibidem, 192-193.
} 
en "A note of Mizmar and Nay" 620 donde comenta que, en el caso árabe, este mismo hecho ocurre con el término nai o nay (traducido como flauta de caña) o mizmar (término traducido hoy en día como aerófono de doble lengüeta), ambos utilizados para referirse a distintos tipos de aerófonos árabes, creando una gran confusión ya desde épocas preislámicas. Esto, como ya se ha comentado, no es algo exclusivo de la cultura árabe, en el caso de los persas el término genérico utilizado para denominar los aerófonos tipo flautas ha sido nai siyah. Asimismo, Farmer puntualiza que para los persas hay una clasificación entre los distintos tipos de nai según el material con el que estén fabricados, entre los que se encuentran nay siyah (flauta de caña negra) y nay safid (flauta blanca) ${ }^{621}$.

Un ejemplo del uso indiscriminado de términos genéricos para referirse a flautas o aerófonos concretos lo recalca Farmer ya sobre los propios tratadistas de la época, como es el caso de la afirmación que realiza al-Darray, quien comenta: "[el mizmar] es un instrumento conocido como el nay" ${ }^{622}$, asimismo, al-Husain ibn Zaila (d. 1048) sostiene que: "el nay es el mizmar"623. Posteriormente Farmer apoyado en la opinión de al-Farabi (d.950) y Ikhwan al-Safa (s. X) confirma la diferencia entre ambos instrumentos ya que en ambas fuentes lo puntualizan explícitamente ${ }^{624}$.

Después de varios estudios organológicos que han procurado esclarecer a qué instrumento se quería hacer referencia concretamente bajo el término nai, éste se llegó a definir como flauta de caña sin embocadura ${ }^{625}$ pero sí con un estrechamiento en esa zona $^{626}$. Este instrumento, exclusivamente reservado para los hombres ${ }^{627}$, se caracteriza por tratarse de un tubo abierto en ambos extremos con la parte superior tallada en forma de cono truncado contando, generalmente, con siete agujeros, uno de ellos en la parte posterior. La distancia entre los nudos del bambú debe ser las mismas

\footnotetext{
${ }^{620}$ Henry George Farmer, “A note on the mizmar and nay”, Journal of the Royal Asiatic Society, 61, 1 $1929,119-21$.

${ }^{621}$ Ibidem, 76-77.

${ }^{622}$ Schéhérazade Qassim Hassan, Les instruments de musique en Irak. París: Cahiers de 1'homme, 1980,82 .

${ }^{623}$ Henry George Farmer, “A note on the mizmar and nay”, Journal of the Royal Asiatic Society 61, 1, 1929,75 .

624 Ibidem, 76.

${ }^{625}$ Ibídem, 236.

${ }^{626}$ Schéhérazade Qassim Hassan, Les instruments de musique en Irak. París: Cahiers de l'homme, 1980,52

${ }^{627}$ Ibídem, 209-210.
} 
situándose el agujero posterior en el centro del tubo, sirviendo este de referencia para determinar la altura del resto de agujeros en la cara anterior ${ }^{628}$.

Reynaldo Fernández, asimismo, añade que la flauta recibe distintas denominaciones dependiendo del tamaño y nota base de cada ejemplar: "Podemos distinguir cuatro para la tabqa kabira (gran registro): nayat dukah (re, $60 \mathrm{~cm}$ ) y nawa (sol, 44,5 cm); busalik (mi, $54 \mathrm{~cm}$ ) y husayni (la, 40,5 cm). Tres para la tabqa sagira (pequeño registro): rast (do, $68 \mathrm{~cm})$, jaharka (fa, $51 \mathrm{~cm})$ y ayam (si bemol, 37,5 $\mathrm{cm}) "{ }^{\prime 629}$. Asimismo, añade que puede contar con seis orificios anteriores y uno en la cara posterior ${ }^{630}$. Otra de las variedades de nai que puede encontrarse es la mencionada por al-Farabi con "siete orificios anteriores, uno posterior y otro final de salida de aire" ${ }^{\prime 631}$.

Una vez definido de forma concreta este instrumento, puede estudiarse dentro de la cultura islámica, donde se encuentra especialmente presente dentro de la música sufí y profana ${ }^{632}$ e incluso la andalusí-magrebí clásica ${ }^{633}$, siendo uno de los instrumentos más presentes en la vida social andalusí ${ }^{634}$. Según el musicólogo François-René Tranchefort, el nai: "es el único instrumento de viento que la música culta árabe ha conservado y que ha conquistado derecho de ciudadanía en el ritual musulmán”635.

Por otro lado, dentro de la variedad de aerófonos, según la configuración y situación de la embocadura, se determinan dos tipos: verticales y transversales. Dentro del primer grupo, las verticales, se derivan tres variantes, "con escotaduras", que se caracterizan por tener una embocadura simple formada por el corte superior del tubo abierta en dos extremos en forma de V, ya que son biseladas o cortadas; en segundo lugar las "oblicuas", donde el instrumento es inclinado lateralmente y soplado por un lado de la boca; y por último, las flautas a bisel, con una embocadura

\footnotetext{
628 Ídem.

629 Ídem.

630 Ídem.

631 Ídem.

632 Scheherezade Qassim Hassan y Jean During, "Nay", en The New Grove Dictionary of Musical Instruments. London: MacMillan Publishing Co., 1991, 751.

633 Schéhérazade Qassim Hasan, Les instruments de musique en Irak et leur rôle dans la société traditionnelle. Editions de 1'Ecole des Hautes Etudes en Sciences Sociales, 1980, 751.

634 Reynaldo Fernández Manzano, “Árabe, Música”, en Diccionario de la Música Española e Hispanoamericana. Madrid: Sociedad General de Autores y Editores, 1999, 505-20.

${ }^{635}$ Françoise-René Tranchefort, Los instrumentos musicales en el mundo. Alianza Editorial, 1985, 209.
} 
de cera o madera que desvían el aire y lo proyectan contra el borde de un orificio ${ }^{636}$. La característica común para toda esta variedad de aerófonos es el material con el que fueron construidas, siendo los más comunes caña o hueso, pudiendo llegar a marcar también el propio nombre del instrumento como es el caso del nai. El segundo material mencionado, el hueso, siendo no perecedero, es el que más transciende desde épocas prehistóricas.

A través de la iconografía musical se pueden tener nuevos datos sobre este tipo de instrumentos. Investigadores como Rosario Álvarez a través de su trabajo Música y pintura promovidas por un sabio monarca: las imágenes musicales de los códices alfonsinos entre el testimonio de la vida musical de su corte y el pensamiento artístico de sus pintores ${ }^{637}$ donde, analizando las miniaturas de las cantigas de Alfonso $X$ sobre este instrumento, hace referencia a la $n^{0} 340$ y a la $n^{0} 370$ comentando que la primera parece enlazada a un ambiente pastoril mientras interpretan una flauta de pico y que la segunda se trata de una pequeña flauta recta acompañada por un tamboril ${ }^{638}$.

\section{Variedad de aerófonos según los sabios andalusíes}

Dentro de la cultura islámica, cuando se revisa las referencias a este tipo de instrumentos de mano de los tratadistas se llega al siguiente listado: abu qarun, buq, iran (tipo mizmar), karriy (flauta caña), mizmar (aerófono tipo dulzaina), nai (flauta de caña), nura (aerófono triple), sabbába (axabeba), suqra (flauta barítona), ya-ra' (flauta pastoril), zammara (aerófono pastoril). A continuación se presentarán cada uno de ellos:

- abu qarun: denominado por Faruqi como el "padre de los cuernos". De este instrumento detalla su gran tamaño y la forma cónica. Farmer lo menciona como un $\operatorname{largo}$ cuerno ${ }^{639}$.

636 Françoise-René Tranchefort, Los instrumentos musicales en el mundo. Alianza Editorial, 1985, 204-205.

637 Ídem.

638 Rosario Álvarez Martínez, "Música y pintura promovidas por un sabio monarca: las imágenes musicales de los códices alfonsinos entre el testimonio de la vida musical de su corte y el pensamiento artístico de sus pintores", en M. PÁEZ, Ars Musica de Juan Gil de Zamora. Murcia: Real Academia de Bellas Artes de Santa María de la Arrixaca, LIII-CLXX, 2, 2010, 148.

${ }^{639}$ Henry George Farmer, "Early references to music in western Sudan", en Oriental Studies: Mainly Musical. Londres: Stephen Austin and Sons, 1953, 4. 
- buq: es considerado un término genérico para referirse a los instrumentos de la familia del cuerno o la trompeta, aunque Farmer afirma que engloba a todo instrumento musical que cuente con orificio cónico ${ }^{640}$. Faruqi, por otro lado, puntualiza que cuando el buq se empezó a fabricar en metal se usó para fines militares y que la medida de este fue documentada en el siglo $\mathrm{X}$ en 1,8 metros. Una de las variantes de este instrumento que cuenta con doble lengüeta es el buq zamri cuyo uso se documenta en al-Andalus durante el siglo $\mathrm{X}^{641}$, y sí que contaría con agujeros digitales $^{642}$. Según Schéhérazade Qassim, en Irak esta denominación se utiliza para los instrumentos con curva tipo trompa y trompeta ${ }^{643}$.

- iran: normalmente este término ha sido relacionado con aerófonos tipo mizmar, pero al utilizarse de forma genérica se duda de si podría ser un aerófono de una o dos lengüetas e incluso un silbato, ya que se ha definido de maneras diferentes ${ }^{644}$.

- karriy, karranay o karrana: definida por Faruqi como "horn nay", cuya traducción podría ser cuerno tipo flauta, es un instrumento preislámico ${ }^{645}$.

- mizmar: término genérico para referirse a los instrumentos de viento madera, según García Gómez, desde épocas preislámicas hasta la actualidad ${ }^{646}$. Ciertamente se usa de forma genérica pero normalmente para los instrumentos de lengüeta. Farmer puntualiza que su uso también se encuentra ligado a los instrumentos hechos con caña que no puedan ser clasificadas como gaitas al está enlazado con los instrumentos de doble lengüeta tipo oboe. Asimismo, añade que en un principio este instrumento pudo ser un tubo de caña simple con una lengüeta simple ${ }^{647}$. Una versión de menor tamaño podía tocarse en parejas bajo el nombre de sibs, el aerófono que realizaría las

\footnotetext{
${ }^{640}$ Lois Ibsen al Faruqi, An annotated glossary of arabic musical term. Greenwood Press, 1981, 43.

641 Ídem.

642 Ídem.

${ }^{643}$ Schéhérazade Qassim Hasan, Les instruments de musique en Irak et leur rôle dans la société traditionnelle. Editions de 1'Ecole des Hautes Etudes en Sciences Sociales, 1980, 218.

644 Lois Ibsen al Faruqi, An annotated glossary of arabic musical term. Greenwood Press, 1981, 110.

645 Ibidem, 140.

${ }^{646}$ Emilio García Gomez, Elogio al Islam. Valladolid: Publicaciones de las Escuelas de Estudios Árabes de Madrid y Granada: Serie B. Núm. 2, 2005, 189.

${ }^{647}$ Henry George Farmer, "Meccan musical instruments", en Studies in Oriental Music Vol. 2. Londres: Longwood Press, 1931, 77-87.
} 
melodías y jawra el que haría el acompañamiento ${ }^{648}$. A este instrumento se le hace referencia en el capítulo de iconografía musical.

Igualmente, como se ha mencionado anteriormente, el término mizmar se utilizó para referirse a cordófonos árabes con anterioridad al siglo XIII. Por último, Farmer puntualiza que también sirvió para denominar cada uno de los tubos del órgano ${ }^{649}$. En el siglo VI ya era mencionado por el poeta al-Muzarrid como instrumento presente en las fiestas ${ }^{650}$, aunque durante el siglo siguiente aparece junto al duff como instrumento marcial de las "tribus" judías de al-Hijaz ${ }^{651}$. Con el tiempo se convertirá en el instrumento de acompañamiento de las festividades por excelencia $^{652}$.

- nura: Según Faruqi se trata de un término utilizado en el siglo XIII que podría estar relacionado con instrumentos de viento madera o alguno cuerda no determinado e, igualmente, podría estar emparentado con el mizmar ${ }^{653}$. Corroborando su presencia en al-Andalus, Farmer se hace eco de las palabras de al-Shaqandi (1231), quien menciona la gran importancia de Sevilla como distribuidora de instrumentos musicales y menciona la presencia de éste ${ }^{654}$. Igualmente, en otro de sus trabajos, Farmer nombra este instrumento según la referencia del mismo sabio: "al-shaquira y al-nura son mazamir" ${ }^{655}$ (plural de mizmar), afirmando que el primero tiene un sonido seductor y el segundo muy delicado. Aquí Farmer justifica la confusión al tomar el mizmar por instrumento de cuerda referido a shaquira, siendo el primero, mizmar, junto a la nura de viento ${ }^{656}$.

- sabbába (axabeba): relacionada por Faruqi con la posición de los dedos sobre los trastes en el laúd u otra variante de este instrumento ${ }^{657}$. Comenta Ramón

\footnotetext{
${ }^{648}$ Schéhérazade Qassim Hasan, Les instruments de musique en Irak et leur rôle dans la société traditionnelle. Editions de 1'Ecole des Hautes Etudes en Sciences Sociales, 1980, 189.

649 Ídem.

${ }^{650}$ Henry George Farmer, "Meccan musical instruments", en Studies in Oriental Music Vol. 2, 1931, 77.

${ }^{651}$ Ibidem, 78.

${ }^{652}$ Fernández Manzano, “Árabe, Música”, en Diccionario de la música española e hispanoamericana. Fundación Autor. Sociedad General de Autores y Editores, 1999, 513.

${ }^{653}$ Lois Ibsen al Faruqi, An annotated glossary of arabic musical term. Greenwood Press, 1981, 244.

${ }^{654}$ Henry Georges Farmer, "The mediaeval psaltery in the Orient”, en Studies in Oriental Musical Instruments. Londres: Longwood Press, 1931, 19.

${ }^{655}$ Henrgy George Farmer, "The origin of the eschaquiel”, en Studies in Oriental Musical Instruments. Londres: Longwood Press, 1931, 21.

656 Ídem.

${ }^{657}$ Lois Ibsen al Faruqi, An annotated glossary of arabic musical term. Greenwood Press, 1981, 286.
} 
Andrés que originariamente este termino se aplicó a la flauta recta pero debido a las invasiones en la Península Ibérica pasó a designar a un aerófono oblicuo ${ }^{658}$. Según Fernández Manzano, se trata de una flauta vertical hecha con caña de unos $80 \mathrm{~cm}$ de longitud abierta por ambos extremos contando con un bisel muy pronunciado en la parte superior ${ }^{659}$. Farmer puntualiza que en Egipto es conocida como flauta de caña ${ }^{660}$.

- suqra: Aerófono barítono relacionada con un tipo de gaita del Magreb ${ }^{661}$. Este aerófono de tubo cónico cuenta con lengüeta doble y podía tener un fuelle ${ }^{662}$.

- ya-ra': aerófono de lengüeta asociada a los pastores ${ }^{663}$. Farmer lo traduce como flageolet ${ }^{664}$ y haciendo referencia a las palabras de Ibn Sina (1037) equipara el yara con el surnay: "soplas desde un agujero como el yara que se conoce como el surnay" ${ }^{665}$. En esta misma línea se menciona al-Husain ibn Zaila (d. 1048) quien afirma que "el surnay es el saffara y del mismo modo el yara" ${ }^{666}$. Esta última afirmación resulta confusa ya que el término saffara se ha relacionado habitualmente con los silbatos, como se muestra en el capítulo anterior, según las indicaciones dadas sobre este instrumento por Ibn Sida, quien lo describía como "una cosa hueca en la que un niño silba a las palomas" ${ }^{667}$. El surnay se duda si puede ser tipo oboe o flauta de caña, según Farmer es difícil determinarlo668.

-zammara: antiguamente este término también se empleó para un instrumento de un solo tubo enlazado con el uso pastoril ${ }^{669}$. Actualmente se trata de un aerófono de dos tubos utilizado con la música popular ${ }^{670}$. En el siglo XI, afirma Farmer, que el

658 Ramón Andrés, Diccionario de instrumentos musicales. Desde la Antigüedad a J.S. Bach. Barcelona: Península, 2009, 27.

${ }^{659}$ Reynaldo Fernández Manzano, Música de al-Andalus. Universidad de Granada, 2016, 188.

${ }^{660}$ Henry George Farmer, "Meccan musical instruments", en Studies in Oriental Music Vol. 2, 1931, 83.

${ }^{661}$ Lois Ibsen al Faruqi, An annotated glossary of arabic musical term. Greenwood Press, 1981, 321.

662 Ibidem, 405.

663 Ibidem, 392.

${ }^{664}$ Henry George Farmer, "Ninth Century Musical Instruments", en Studies in Oriental Musical Instruments: first and second series, 1978, 72.

${ }^{665}$ Henry George Farmer, "A Note on the Mizmar and Nay”, Journal of the Royal Asiatic Society, 61, $1,1929,75$.

666 Ídem.

${ }^{667}$ Henry George Farmer, "Turkish instruments of music in the seventeenth century: as described in the Siyahat Nama of Ewliya Chelebi”, en Studies in oriental music, 1986, 653.

${ }^{668}$ Henry George Farmer, "Early references to music in western Sudan", Oriental studies: mainly musical, 1953, 6 .

${ }^{669}$ Lois Ibsen al Faruqi, An annotated glossary of arabic musical term. Greenwood Press, 1981, 399.

${ }^{670}$ Ídem. 
nombre de este instrumento se modificó por el de zummara, el cual contaba con una lengüeta doble ${ }^{671}$. Asimismo, en el norte de África lo asemejan al flageolet ${ }^{672}$.

Según Pérez Arroyo, el predecesor directo de este aerófono sería la flauta egipcia faraónica. Estas flautas oblicuas se remontan a la época Predinástica (ca. 3150 a.C.) resultando tan clave para comprender la teoría musical egipcia ${ }^{673}$, como el laúd para la árabe. El saïbit, perteneciente a esta cultura, es una flauta egipcia compuesta por un tubo abierto por ambos extremos que se interpretaba en posición oblicua midiendo entre veinticinco centímetros y un metro aproximadamente, y que se utilizaba para acompañar cantos y danzas. Asimismo, existía el maït, considerado el antepasado del zamr y cercano al oboe ${ }^{674}$, por lo que éstos quedarían emparentados con el mizmar. Además, existen unos clarinetes árabes llamados aeghoul, "arghül" extendidos por la mayor parte de los países del Próximo oriente y África cuya referencia más antigua se remonta al Imperio Antiguo egipcio conocida bajo el nombre de zummara. Este instrumento puede verse en un bajorrelieve que data de 2.700 a.C. que conserva el Museo de El Cairo, así como su imagen aparece reflejada igualmente en numerosas tumbas egipcias del silgo I antes de nuestra era. Se trata de un instrumento con dos tubos cilíndricos paralelos, normalmente construidos en caña o madera, pegados o atados juntos. La embocadura de la zammara forma una lengüeta rectangular contando con orificios equidistantes cuyo número oscila de cuatro a seis. A veces pueden contar con un cuerno en la parte inferior del tubo que funciona como amplificador sonoro ${ }^{675}$.

\section{Las "flautas" en la arqueología andalusí}

Estos instrumentos musicales son de los más conflictivos en su estudio debido a que suele catalogarse, muchas veces con premura, como flauta cualquier pieza que se asemeje o se trate de un tubo con orificios. Un caso concreto sería la "flauta" de Divje Babe, que fue presentada en su momento, 1997, por medios divulgativos como

\footnotetext{
${ }^{671}$ Henry George Farmer, "Meccan musical instruments", en Studies in Oriental Music Vol. 2, 1931, 78.

672 Ibidem, 78-79.

${ }^{673}$ Rafael Pérez Arroyo, La música en la era de las pirámides. Centro de Estudios Egipcios, 2001, 38

${ }^{674}$ François-René Tranchefort, Los instrumentos musicales en el mundo. Alianza Editorial, 1985, 207.

${ }^{675}$ Ibidem, 230.
} 
"el instrumento musical encontrado más antiguo de la historia" ${ }^{676}$. Aún sigue vigente el debate científico sobre esta pieza a pesar de haber sido protagonista de numerosas investigaciones para esclarecer su viabilidad como instrumento musical. Desde su descubrimiento se dudó sobre si su fabricación pudo ser realizada por la mano del hombre para lo que se hicieron distintas réplicas con las que se demostró su valía sonora y musical, con reproducciones del objeto según se halló, así como con hipotéticas reconstrucciones con sus posibles formas originarias. La copiosa cantidad de estudios realizados sobre esta pieza parecen concluir con el artículo publicado sobre la misma, en 2015, donde se demuestra que los orificios de esta pieza fueron consecuencia de un depredador, en este caso concreto una hiena ${ }^{677}$. Esta información ha hecho que los investigadores se dividan en dos, entre los que concluyen que no se trata de un instrumento musical ya que no fue fabricado conscientemente por el hombre: "The 'cave bear cub femora with holes' are, in all cases, neither instruments nor human made at all"678, y los que sostienen que el que no fuese realizado por el hombre no excluye la posibilidad de poder ser utilizado como instrumento musical una vez hecho el hallazgo en la época ${ }^{679}$.

Por otro lado, y corroborando la complejidad en la catalogación de estas piezas, el investigador Carlos García Benito comenta en su tesis doctoral la dificultad añadida a la hora del estudio de la pieza al ser catalogada como flauta pudiendo corresponder con cualquier otro tipo de aerófono:

\begin{abstract}
"Se advierte que la mayoría de objetos que han sido estudiados y publicados de este particular tipo aerófono, si no todos, se les ha definido tradicionalmente como flautas, si bien en muchos casos esto es seguramente erróneo pudiendo ser realmente cualquier otro tipo de aerófono con perforaciones para su digitación en el propio cuerpo del instrumento como un clarinete, trompa, oboe, etc., además de flautas, según la embocadura que se aplique. (...) Por este motivo creemos que es más conveniente hablar en este caso de la forma más aséptica posible y referirnos a estas "flautas" como aerófonos con perforaciones para su digitación" $" 680$.
\end{abstract}

\footnotetext{
${ }^{676}$ Ivan Turk, Mousterion bone flute and other finds from Divje Babe I cave site in Slovenia. Institut za Arhaeologijo, 1997.

${ }^{677}$ Cajus G. Diedrich, "Neanderthal bone flutes: simply products of Ice Age spotted hyena scavenging activities on cave bear cubs in european cave bear dens", Royal Society Open Science 2, 2015.

${ }^{678}$ Ibidem, 14.

${ }^{679}$ Philip G. Chase y April Nowell, "Taphonomy of a suggested middle palaeolithic bone flute from Slovenia", en Current Anthropology 39, 1998, 549-53.

680 Carlos García Benito, "Arqueología musical prehistórica: aproximación a través de la arqueología experimental aplicada a la arqueo-organología, de la arqueoacústica y de la iconografía musical Prehistórica". Tesis doctoral Universidad de Zaragoza, 2014, 103.
} 
En esta línea, el diccionario de instrumentos musicales realizado por Ramón Andrés comienza definiendo la flauta como aerófono de nombre genérico con tubo abierto $^{681}$.

En lo que se refiere a las llamadas "flautas" andalusíes, existen varios artículos publicados al respecto para valorar si podrían o no ser instrumentos musicales. En el artículo "Examen arqueométrico de un objeto de hueso decorado de época Almohade (siglo XIII d.C.) procedente de la excavación arqueológica de la Calle San Fernández, Sevilla" de Mark A. Hunt Ortiz, M. ${ }^{a}$ Ángeles Ontalba Salamanca, Inés Ortega Feliú, Blanca Gómez Tubío, Eloisa Bernáldez Sánchez y Pina López Torres, los investigadores realizan varias pruebas mediante técnicas IBA (Ion Beam Analysis) a una de las piezas que fueron consideradas, y que hoy en día sigue catalogada por el museo que la acoge, como posible flauta. En estas pruebas intentaban comprobar si los agujeros pudieron ser taponados con membranas como en el caso del aerófono chino $d i z i^{682}$. Las pruebas finalmente no aportan datos claros a cerca del uso que pudo tener esta pieza ${ }^{683}$, pero no descartan su "valía" musical por la comparativa con otras piezas de similares características que igualmente han sido catalogadas como tal.

En el trabajo "Musical vultures in the Iberian Peninsula: sounds through the wings" de Marta Moreno-García, Carlos Pimienta y Mario Gros, analizan piezas catalogadas como flautas en Mértola, Portugal, de similares características a las encontradas en Andalucía. En este trabajo sostienen tres hipótesis sobre los objetos estudiados, bien que puedan ser un instrumento musical tipo flauta, que puedan ser el mástil de un instrumento o bien que pudiera ser otro tipo de instrumento musical. Siempre, por lo tanto, otorgándole la valía sonora.

De Marta Moreno y Carlos Pimienta es también el artículo "Instrumentos musicales medievales en hueso de Albarracín (Teruel): contextualización y lectura arqueozoológica". En este estudio sobre esta pieza dudan sobre su uso como parte de un cordófono ya que el desgaste de los orificios no se correspondería con un objeto que pudo moverse en ambos sentidos. A pesar de ello, estos investigadores no terminan de descartar la idea ya que justifican que existe gran número de córdófonos,

\footnotetext{
681 Ramón Andrés, Diccionario de instrumentos musicales. Desde la Antigüedad a J.S. Bach. Barcelona: Ediciones Península, 2009, 191.

682 Ibídem, 169.

683 Ibídem, 173.
} 
que ellos mismos mencionan, y sostienen que podría pertenecer en un momento dado a alguno de ellos, no concluyendo tajantemente su uso concreto.

El hecho de que existan estos trabajos realizados por reconocidos investigadores donde se afirma de forma hipotética que podrían tratarse de instrumentos musicales,

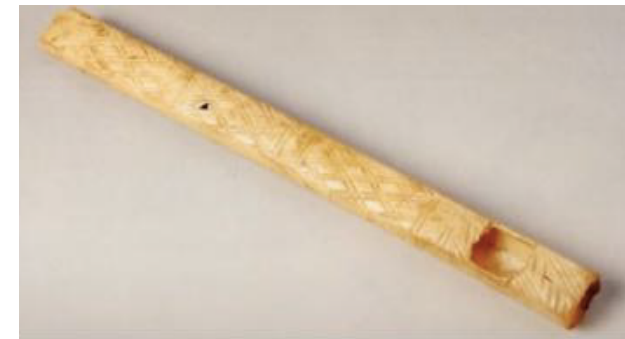

Figura 42. Pieza catalogada como silbato en el Museo Arqueológico de Ciudad Real. se considera que puede llegar a condicionar a posteriores estudiosos. Ya enlazadas estas piezas al contexto musical se les dio una segunda interpretación, donde se les otorgaba el formar parte de un cordófono, excusando así la peculiar distribución de los orificios de la pieza. Una vez recopilada la información de los instrumentos a través de las descripciones que los tratadistas de la época, se comprueba que estas piezas no se ajustan a ninguna descripción ni de aerófonos ni de cordófonos. Es por ello que como último paso se han hecho réplicas de varias piezas, para valorar al menos si podrían tener facultades sonoras, cosa que en todas las piezas se ha ido descartando menos en una, la encontrada en Estepona. Esto no quiere decir que se considere que sea un instrumento musical, ya que tampoco se ajusta a ninguna de las descripciones de los instrumentos. Un ejemplar con un solo orificio es el encontrado en Alarcos, Ciudad Real, el cual se encuentra en el Museo Arqueológico de esta ciudad. En este caso, el orificio sí que podría ser interpretado como un bisel, aunque no cuenta con ninguno más que permita variar el sonido, por lo que lo han catalogado como un silbato. En este caso se podría decir que sí que se trata de un objeto sonoro, pero resulta igualmente poco fundamentado el considerarlo un instrumento musical.

\subsection{Réplicas de las piezas catalogadas como flautas}

Con la intención de fundamentar el rechazo a que estas piezas cuenten con posibilidades sonoras se ha realizado una investigación particular, como pueden verse en las imágenes, en las que se realizaron reproducciones en caña con el propósito de ir obstruyendo varios de estos orificios e ir probando sus posibilidades acústicas. Para ello se cortaron cañas y, antes de que estas se secasen, se quemó el interior de estas con un tubo de metal para dejarlas huecas. Una vez el tubo listo, siguiendo las medidas de cada una de las piezas se procedió a realizarle los orificios con varas de metal de distinto diámetro. Las varas se fueron calentando con un soplete y 
lentamente se fuero introduciendo por el tubo para ir quemando la caña. Una vez hecha la reproducción se intentó hacer pruebas sonoras con resultado acústico fallido. Posteriormente se taponaron distintos agujeros con cera de abeja y se obtubo la misma negativa sonora. Aún planteando un aerófono de mayor tamaño se comprobó que éste no obtenía resultados acústicos con la disposición de los agujeros planteados en estas piezas, por lo que se descarta el que estos objetos puedan ser considerados como aerófonos.
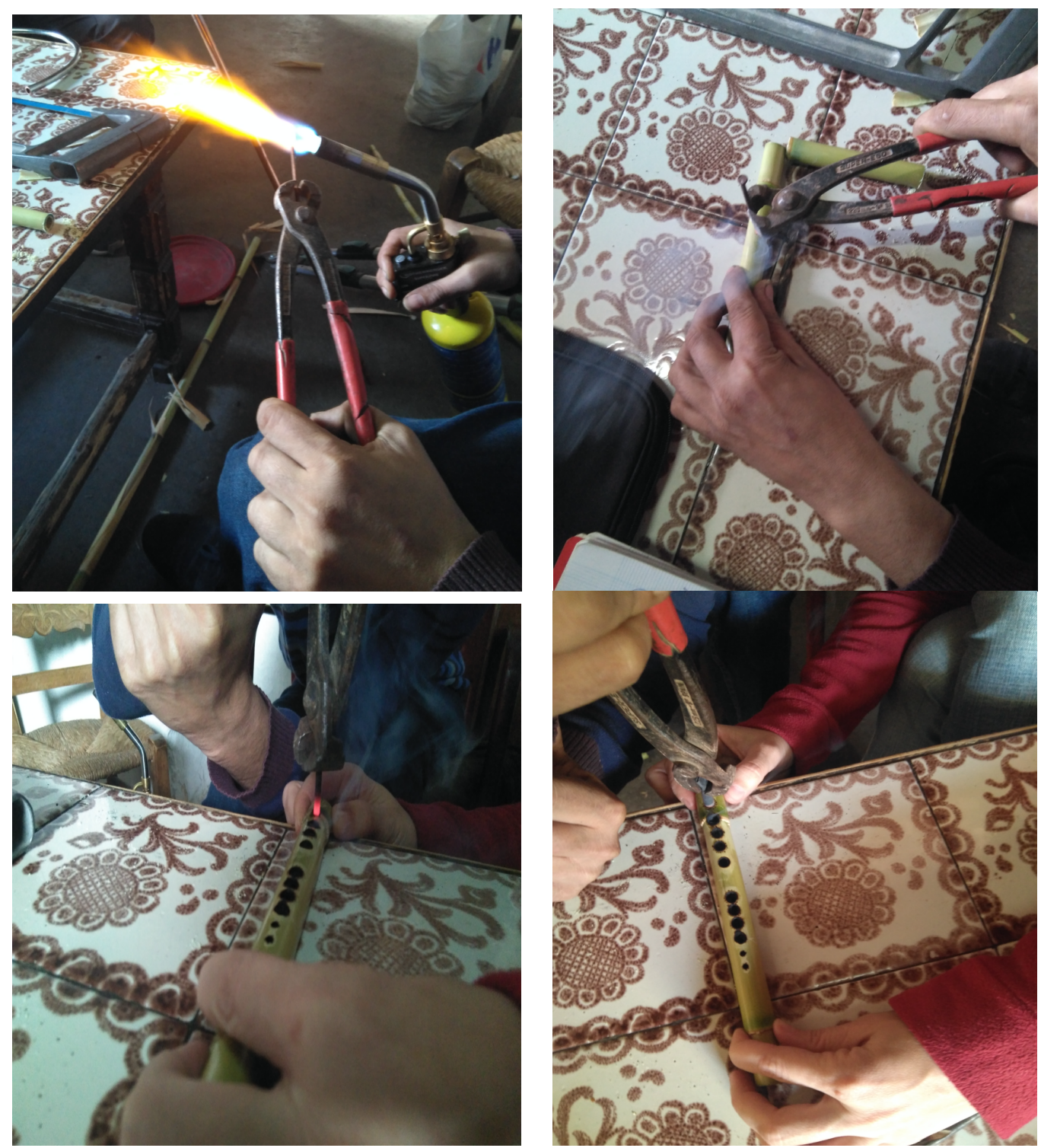

Figura 43. Proceso de construcción de recreación de piezas arqueológicas catalogadas como flautas.

Carlos García Benito en su tesis doctoral cuando presenta la pieza DJ/DA03057 del Museo de Jaén afirma que algunos investigadores, basándose en la 
disposición de los orificios, consideran que algunos de ellos podrían ser agujeros de resonancia. Carlos García, a pesar de estas opiniones, sostiene que no puede ser considerado un aerófono, pero no descarta que pueda ser parte de un cordófono ${ }^{684}$.

Además de las evidencias planteadas al realizar las réplicas de estas piezas, son tres las razones que igualmente fundamentan que estos objetos no pueden ser considerados aerófonos, la primera de ellas es la contrariedad de realizar orificios en ambas caras del tubo con la finalidad de ser finalmente taponadas de forma permanente durante la interpretación, la segunda sería la dificultad de realizar orificios contiguos que aún tapados no se corresponden con ninguna escala árabe y la tercera sería la contradicción de realizar un número de agujeros digitales superior al número de dedos de un músico, ya que el uso de llaves que pudieran tapar de forma indirecta los orificios son muy posteriores. Es por todas estas razones por las que se descarta que las siguientes piezas sean instrumentos musicales o partes de estos, considerando que el uso de los mismo pudo estar más cercano al ámbito doméstico, pudiendo ser enmangues de cuchillos, o formar parte de los telares, cantonera de un libro, mango de un abanico o incluso piezas de ajedrez.

\section{Pieza no 1 Puerto de Santa María (Cádiz)}

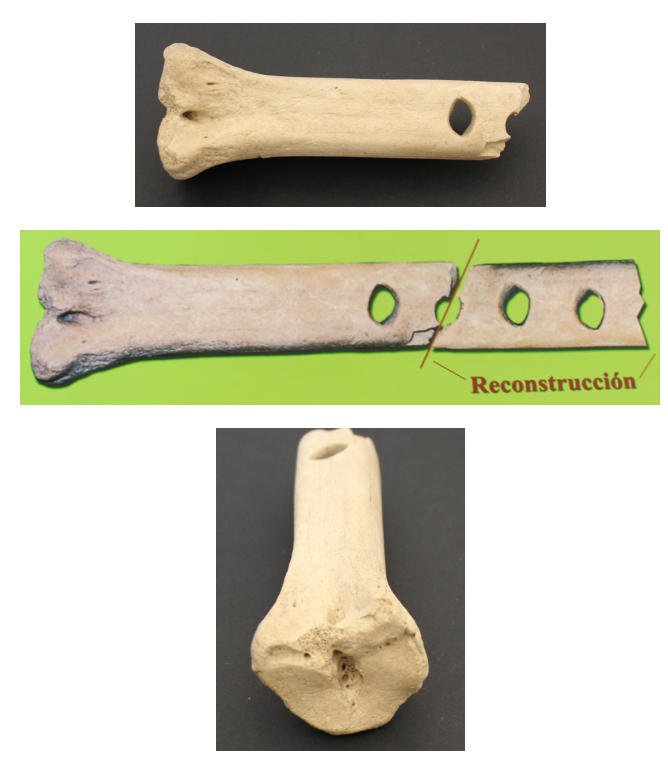

Figura 44. Pieza catalogada como flauta en el Museo del Puerto de Santa María, Cádiz.
Esta pieza fue encontrada en la Plaza del Castillo de San Marcos en la excavación de Juan de la Cosa.

La imagen de esta pieza apareció en la publicación La huella de al- Ándalus en El Puerto de Santa María, Cádiz realizado por Juan José López Amador, José Antonio Ruiz Gil y Francisco Giles Pacheco. En este trabajo aparecía la hipótesis planteada por el museo sobre su reconstrucción y

684 Carlos García Benito, “Arqueología Musical Prehistórica: Aproximación a Través de La Arqueología Experimental Aplicada a La Arqueo-Organología, de La Arqueoacústica y de La Iconografía Musical Prehistórica”. Tesis doctoral Universidad de Zaragoza, 2014, Anexos I, 2496. 
era catalogada como "Fragmento de flauta fabricada en hueso" 685.

Juan José Delgado Aguilera, restaurador y diseñador del Museo Municipal del Puerto de Santa María, comenta que se encontró en la excavación Alquería Alcanatif y actualmente la pieza se encuentra en la vitrina 15 en sede Hospitalito.

Como puede observarse en la tercera imagen incluida, este supuesto aerófono no contaría con agujero de salida de aire. La hipotética reconstrucción de la pieza le otorga mayor número de agujeros de los que pueden percibirse por lo que a simple vista puede parecer una flauta. En esta pieza, a pesar de no asemejarse al resto de las mencionadas y contando con los orificios solo por uno de los lados de la misma queda descartada igualmente como instrumento musical ya que no es posible conseguir sonido a través de ella ni se ajusta a ninguna descripción de aerófonos de la época.

\section{Pieza no 2 Jerez, Cádiz}

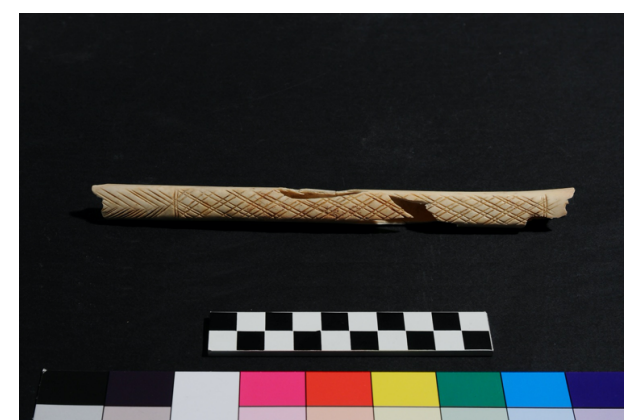

Figura 46. Mango de abanico del Museo Arqueológico de Jerez de la Frontera. Imagen extraída del TFM de Carmen Salvador.
En el Museo Arqueológico Municipal de Jerez de la Frontera hay una pieza de hueso perteneciente a los siglos XIXII catalogada como "Mango de abanico". Carmen Salvador, en su mencionada investigación de fin de Máster incluyó esta pieza como posible aerófono. Tal y como el museo ha determinado, no se considera que esta pieza pueda ser considerada por sí misma, o como complemento, como instrumento musical.

\section{Pieza n 3 Jerez, Cádiz. Fragmento}

Un caso similar al anterior sería el de este fragmento de hueso del siglo XIII catalogado por el museo como posible "cantonera de libro". Cuenta con una inscripción que el

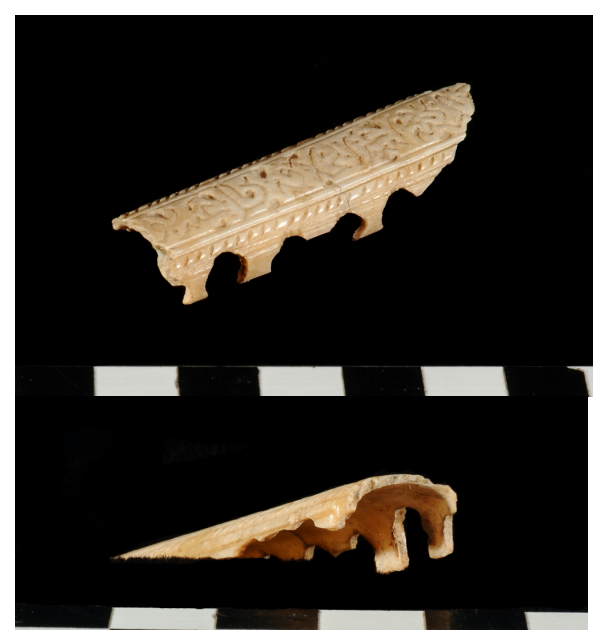

Figura 45. Piezas del Museo Arqueológico de Jerez.

685 Juan José López Amador, José Antonio Ruiz Gil y Francisco Giles Pacheco, La huella de alÁndalus en el Puerto de Santa María, Cádiz. Puerto de Santa María, Cádiz: Ingrasa S.L. Artes Gráficas, 2011, 95. 
propio museo ha traducido como: "La gloria sea para el califato de Ibn`Abd ( ¿alMu'min?)". Carmen Salvador, por su semejanza con las piezas que se analizarán a continuación, también plantea la posibilidad de que este fragmento pudiese ser un instrumento musical. Puede observarse que los agujeros, al igual que los casos que veremos a continuación, están en ambas caras de lo que sería el tubo del instrumento. Después de las pruebas que se han hecho sobre cañas con similares características tapando incluso algunos de estos orificios con cera, no se ha comprobado viabilidad sonora, por lo que se descarta su uso como aerófono.

\section{Pieza no 4 Jaén.}

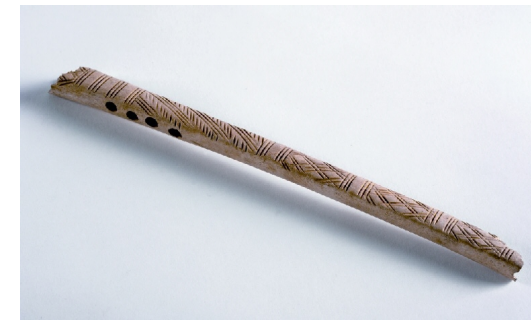

Figura 47. Pieza catalogada como flauta en el Museo Arqueológico de Sevilla.

\section{0}

Figura 48. Recreación de la pieza del museo de Sevilla.
Tubo de hueso, posiblemente ulna (cúbito) de buitre según su ficha de catalogación, de 20,20 $\mathrm{cm}$ de largo. Esta pieza fue catalogada inicialmente como flauta, pero tras un estudio de Marcos Hunt y Marta Moreno, el museo decidió modificar la información de esta siguiendo la hipótesis planteada por estos investigadores, quedando su descripción en “¿Instrumento musical?”. Debido a que solo cuenta con cuatro clavijas se descarta el que pudiera pertenecer a un cordófono ya que no coincide con ninguna descripción que se asemeje a estas características. Por el mismo motivo se descarta que sea un aerófono ya que no cuenta con posibilidades sonoras.

\section{Pieza no 5 Málaga (Estepona)}

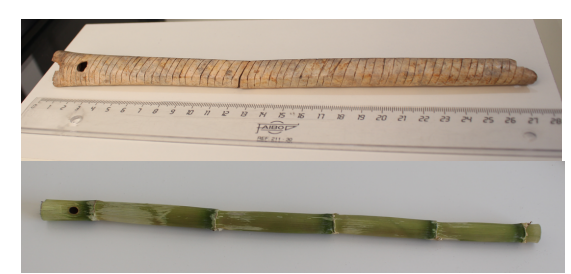

Figura 49. Pieza catalogada como posible flauta en el Museo de Estepona y recreación de la pieza en caña.
Esta pieza encontrada en la excavación del siglo XII-XIII en el casco histórico de Estepona por el arqueólogo Ignacio Navarro, está expuesta actualmente en el Museo de Estepona con una cartela que indica su posible función de “¿flauta?”. Tras la reproducción de esta se ha podido comprobar que en este caso la pieza sí 
tiene viabilidad sonora. Cuenta con un agujero simple en uno de sus extremos y otro de menor diámetro en el otro extremo del tubo, en otra de sus caras no pareciendo tener relación los agujeros ya que incluso son de diámetros muy dispares entre ellos.

\section{Pieza no 6 Málaga (Estepona)}

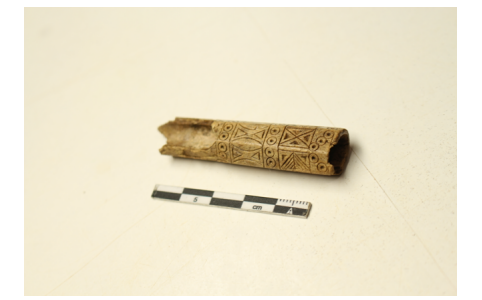

Figura 50. Fragmento del Museo de Estepona.

Otra de las piezas con las que cuenta el Museo de Estepona es este fragmento de hueso. Debido a la similitud de esta pieza con la anterior y por su semejanza en el dibujo con el resto de las piezas catalogadas como instrumentos musicales de Andalucía, que aquí se incluyen, el museo se preguntaba si podría tener también esta interpretación. Ciertamente los dibujos resultan semejantes, pero no al contar con más datos para realizar una posible reconstrucción resulta muy arriesgado plantear esta hipótesis ya que no cuenta con agujeros visibles.

\section{Pieza $n^{0} 7$ Sevilla}

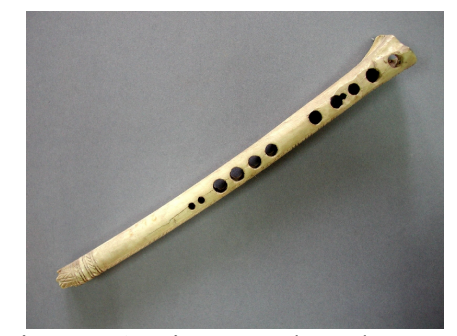

Figura 51. Pieza catalogada como flauta en el Museo Arqueológico de Sevilla.

\section{0 ..}

Figura 52. Recreación de la pieza catalogada como flauta en el Museo Arqueológico de Sevilla.
Tubo de hueso de 19,7 cm de longitud, perteneciente a época almohade (s. XIII). Es llamativa la decoración del tubo, contando incluso con una inscripción: Al-yumn wa-al iqbal cuyo significado es: "La felicidad y la prosperidad" según su ficha de catalogación en la plataforma CERES. Tiene once agujeros por cada cara, sumando un total del veintidós. Esta pieza se encuentra expuesta en el Museo Arqueológico de Sevilla y ha sido una de las que más se ha hablado en el campo de la arqueomusicología. Después de realizar una réplica de esta en caña se ha comprobado, como ya se ha explicado, que no tiene posibilidades sonoras aún tapando parte de los agujeros con cera de abejas. 


\section{Pieza no 8 Sevilla}

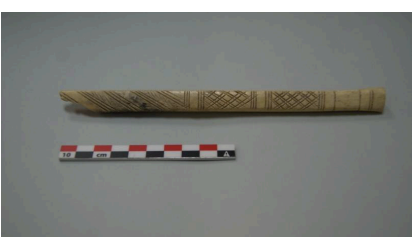

Figura 53. Pieza catalogada como flauta en el Museo Arqueológico de Sevilla. Imagen extraída del TFM de Carmen Salvador.
Pieza actualmente en estudio en el Museo Arqueológico de Sevilla. Carmen Salvador incluye este instrumento en su trabajo final de máster como posible aerófono tras ser catalogado por el propio museo como "flauta" ${ }^{686}$. Se trata de un hueso de 20 $\mathrm{cm}$ de época almohade (s. XIII), no tiene orificios y cuenta en una de sus caras con un adorno realizado con líneas rectas y oblicuas. Siendo un tubo sin agujeros deja abierta cualquier interpretación pero lejana sus posibilidades sonoras. Igualmente, la semejanza de los dibujos de estas piezas tampoco resulta esclarecedor ya que las piezas con las que es comparada, como se ha mencionado anteriormente y en cada uno de los casos, no son consideradas aerófonos ni parte de cordófonos.

\section{Pieza no 9 Sevilla Calle San Fernando}

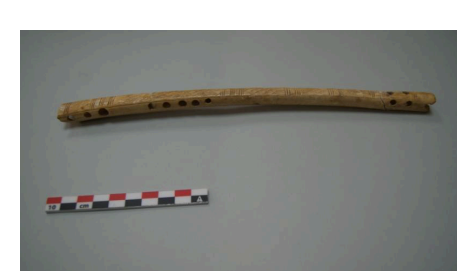

Figura 54. Pieza catalogada como flauta en el Museo Arqueológico de Sevilla. Imagen extraída del TFM de Carmen Salvador.
Esta pieza de hueso de $27 \mathrm{~cm}$ de longitud es de época almohade, s. XIII. Se trata de una ulna de buitre con veintidós orificios. En uno de sus extremos cuenta con dos orificios en todas las caras del tubo, sumando un total de ocho. De la mitad hacia el otro extremo de la pieza cuenta con cinco orificios dobles, es decir, que están por ambos lados del hueso. Este segundo extremo cuenta con otros dos orificios dobles lo que descartaría igualmente la segunda hipótesis planteada sobre ser considerada como un mástil de un cordófono. $\mathrm{Su}$ perspectiva como posible aerófono queda igualmente desechada por los motivos expuestos anteriormente, ni cumple ninguna descripción de este tipo de instrumentos ni cuenta con posibilidades acústicas.

\footnotetext{
${ }^{686}$ Carmen Salvador González, "Música y Organología en la Sevilla Islámica: Análisis de las fuentes documentales árabes y de los hallazgos arqueológicos". Trabajo Final de Máster Universidad de Granada, 2017, 61.
} 


\section{Pieza n⿳0 10 Montemayor (Córdoba)}

Esta pieza ha sido catalogada por el museo como flauta. Se trata de un tubo de hueso con cuatro agujeros de pequeño tamaño dispuestos de forma transversal al sentido del

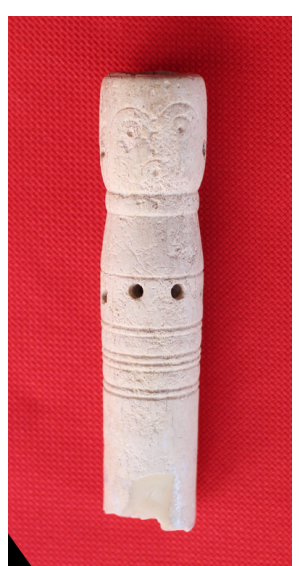

Figura 55. Pieza catalogada como flauta en el Museo de Montemayor. tubo. Cuenta con adornos antropomorfos representando una figura con rostro y unos adornos circulares en la parte posterior de la pieza, por encima y mayoritariamente por debajo de estos orificios. La directora del museo, tras consultar varios trabajos apoyándose en la publicación de Ruíz Nieto "Representaciones antropomorfas hispanomusulmanas sobre hueso" 687 se decantó por la hipótesis musical de esta pieza. Al no contar con un bisel las posibilidades sonoras de esta pieza quedan descartadas.

Esta catalogación no resulta un hecho aislado ya que existen otras piezas similares a esta que han sido catalogadas como tal. Normalmente se trata de partes de ruecas y de piezas de ajedrez como se comprobará en las siguientes piezas marroquíes.

\section{Piezas nº 11- 24 Tetuán, Marruecos}

En la ciudad de Tetuán, Marruecos, se encuentra el Museo Arqueológico donde hay expuestas distintas piezas encontradas en excavaciones arqueológicas pertenecientes al yacimiento arqueológico Linux, situado a $3,5 \mathrm{~km}$ al Noroeste de Larache sobre la orilla derecha del río Lukkos y al borde de la carretera principal que une Tánger con Rabat. Según documenta el propio museo, es la colonia fenicia más antigua de Occidente fundada en el siglo XII (a. J.C.). A través del panel informativo a la entrada al museo se pueden contextualizar históricamente las piezas que se verán a continuación:

\footnotetext{
"Según los vestigios arqueológicos (...) era una de las ciudades más grandes de Occidente, próspera, opulenta, protegida por sólidas murallas, que acuñaba su propia moneda y desarrollaba una importante actividad comercial. En el transcurso de la etapa púnica (talasocracia de Cartago), Lixus prosigue su apertura comercial. A partir del siglo III a J.C. conoce un gran desarrollo urbano, particularmente bajo el reinado de Juba II y de su hijo Ptolomeo, Lixus se convirió de este modo en un ejemplo excepcional de ocupación del suelo en la costa atlántica marroquí en la época prerromana.
}

${ }^{687}$ Eduardo Ruíz Nieto, "Representaciones Antropomorfas Hispanomusulmanas sobre hueso", Anales de Arqueología Cordobesa, 12, 2001. 
A partir del año 42-43 de la era cristiana, bajo el reinado del emperador Claudio, Lixus se convirtió en una colonia romana. (...). La ciudad se dota de monumentos públicos importantes como el teatro-anfiteatro y las termas decoradas con frescos y mosaicos. (...). Destruida en el siglo III, después de la retirada de la administración romana, se convierte al cristianismo. (...). En la época islámica, se habla en los textos árabes de una ciudad con el nombre de "Tuchummus" construida sobre las ruinas de la ciudad antigua. Los vestigios arqueológicos son escasos. En el Museo se muestras testimonios que se remontan al siglo XIII”.

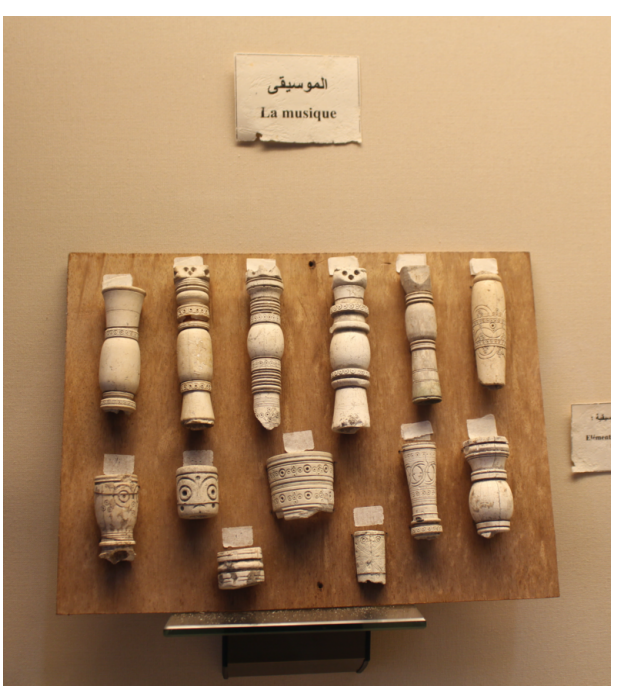

Figura 56. Piezas expuestas como flautas en el Museo Arqueológico de Tetuán.
Perteneciente por lo tanto a este lugar y época, estas son las piezas catalogadas como instrumentos musicales. Similares al caso anterior, en algunas de ellas pueden observarse el adorno de las torres, relacionándolas directamente con piezas de ajedrez, otras, al igual que la pieza anteriormente presentada de Montemayor, se piensa que pueden estar relacionadas con ruecas. 


\subsubsection{Instrumentos membranófonos}

Una de las piezas musicales que de forma más numerosa puede encontrarse en excavaciones arqueológicas son los pequeños tambores que, desde sus hallazgos llamaron la atención de arqueólogos y musicólogos. De estos, al igual que los silbatos, se pensó que podrían tratarse de juguetes ${ }^{688}$, idea que pronto se desecharía como se verá a continuación. Las evidencias documentales de los membranófonos de forma genérica se remontan a civilizaciones musicales antiguas tales como Mesopotamia y Egipto, llegando algunas representaciones datadas en el siglo III a.C. así como frescos en tumbas egipcias del Imperio Medio (II milenio) enlazadas a funciones religiosas o militares ${ }^{689}$, y es desde este punto donde se puede empezar la reconstrucción histórica de estos tambores, aunque el primer ejemplar andalusí se encontrase en 1973, datado en el siglo X, entre los restos de una nave islámica de posible procedencia almeriense que se había hundido al sur de Francia ${ }^{690}$.

\section{Recorrido a través de la historia de los membranófonos andalusíes y sus conflictos terminológicos}

Dentro de los instrumentos de membrana sin duda el más conocido y extendido sería todo aquel que cupiese dentro de la catalogación de tambor, nombre genérico de procedencia persa, tabir $^{691}$. El investigador Ramón Andrés afirma que esta palabra quedó descontextualizada ya que "debió confundirse con el nombre de un cordófono del tipo laúd llamado tanbur, cuya tabla armónica estaba construida por una membrana" ${ }^{692}$. Sin embargo, Faruqi emparenta el término tabir con un derivado de $t a b l$ afirmando que se trata de un tambor en forma de reloj de arena usado desde tiempos preislámicos el cual fue denominado $k u b a^{693}$. El término $t a b l$ fue, igualmente, uno de los de uso más genérico para denominar a varios tipos de tambores, hecho que

\footnotetext{
${ }^{688}$ Raquel Jiménez Pasalodos y Alexandra Bill, "Music and identities al-Andalus clay drums and the study of popular musical behaviors through the archaeological record", Studien Zur Musikarchäologie X, DAI Orient Archäologie, 2016, 85.

${ }^{689}$ François-René Tranchefort, Los instrumentos musicales en el mundo. Alianza Musical, 1985, 80.

${ }^{690}$ Rosario Álvarez y Rosselló Bordoy, "Hallazgo de Tambores de la España Islámica (Siglos IXXIV)", Revista de Musicología, 12, 2, 1985, 411.

${ }^{691}$ Ramón Andrés, Diccionario de música, mitología, magia y religión. Barcelona: Acantilado, 2012, 1535 .

692 Ramón Andrés, Diccionario de instrumentos musicales. Desde la Antigüedad a J.S. Bach. Barcelona: Península, 2009, 406.

${ }^{693}$ Lois Ibsen al Faruqi, An annotated glossary of arabic musical term. Greenwood Press, 1981, 327.
} 
ha reflejado, entre otros, el etnomusicólogo Jean During ${ }^{694}$ y Farmer, quien añade que se usa indistintamente para una amplia gama de tambores y timbales ${ }^{695}$. Este mismo investigador en el artículo "Ninth Century Musical Instruments" se hace eco de la mención del oficial de correos de origen persa Ibn Jurdadbih, quien nombra varios instrumentos de membrana como el tubul, tabl y el kabar, relacionando el tabl con el acompañamiento de las flautas de caña o chirimía (surnay) y el kabar con el arpa $(\text { sanj })^{696}$.

Por otro lado, volviendo a las cuestiones terminológicas, otro de los términos utilizados de forma genérica para referirse a distintos tipos de membranófonos es tabal o atabal. Ramón Andrés explica las peculiaridades de esta palabra mediante la afirmación de Antonio de Nebrija quien recalca la diferencia entre tambor y atabal: "Ambas voces fueron tomadas a menudo como sinónimos, aunque ello resulte incorrecto, puesto que el atabal o timbal tiene una sola membrana y su cuerpo es semiesférico, mientras que el tambor, como se ha dicho, presenta una o dos membranas y su estructura es la de un cilindro cerrado a ambos lados por los citados parches" $" 697$.

Según Francis W. Galpin en su obra The music of the Sumerians and their immediate successors the Babylonians \& Assyrians los membranófonos eran agrupados y denominados en estos territorios por el tamaño que poseían, siendo los de menor tamaño denominados balag, o balag-tur ${ }^{698}$, en forma de reloj de arena, y otros algo mayores $u b$, o $u b$-tur ${ }^{699}$, aunque el más pequeño de ellos sería el balag-di, balag, conocido como el "tambor del cantor"700.

Por otro lado, según Galpin, el instrumento más semejante a la darbuka sería el lilis, el cual cuenta con dos variedades según sus dimensiones, siendo el de mayor tamaño tipo timbal y el de menor tamaño usado para procesiones ${ }^{701}$. Asimismo, este investigador conjetura que en la antigua Persia el lilis pudo denominarse como

\footnotetext{
694 Jean During, "Drums, large group of percussion instruments", en Encyclopaedia Iranica, http://www.iranicaonline.org/articles/drums (Última consulta 03-03-2019).

${ }^{695}$ Henry George Farmer, "Tabl”, en Encyclopaedia of Islam, Vol. X. Ed. Brill Leiden, 2003, 32.

${ }^{696}$ Henry George Farmer, "Ninth century musical instruments", en Studies in Oriental Musical Instruments: first and second series, 1978, 53-54.

697 Ramón Andrés, Diccionario de instrumentos musicales. Desde la Antigüedad a J.S. Bach. Barcelona: Península, 2009, 407.

698 Ídem.

${ }^{699}$ Ibidem, 2-3.

700 Ibidem, 5 .

${ }^{701}$ Ibidem, 7.
} 
donbek $^{702}$ aunque actualmente sea conocido como duhul y en turco dawul según afirma Farmer ${ }^{703}$. De este último tipo de membranófono se puede encontrar ejemplos, asimismo, en la música egipcia, donde estos instrumentos son representados de forma iconográfica en tumbas, como la de la esposa de Kai-Khent de la V Dinastía, donde aparece una figura femenina interpretando este instrumento estando de cuclillas, así como en diversas estatuillas de músicos encontradas en el Serdab de Nanupkaw (ca. 2504-2216 a.C.). Estas piezas se encuentran expuestas en El Hammamiya y Oriental Institute de Chicago respectivamente ${ }^{704}$.

De los membranófonos se afirma que tienen un fuerte carácter telúrico y mágico, Ramón Andrés llega a realizar la siguiente afirmación, “[del tambor] se ha dicho repetidamente que expresa el ritmo del mundo y el pulso de la naturaleza: los hace explícitos. Es el corazón humano que bate, el corazón del animal, el pálpito que acompasa lo viviente" 705 .

En cuanto al material con el que se realizaban los membranófonos tipo tamborcillo, Rosselló Bordoy y Álvarez García puntualizan que la cerámica ha sido el principal material para la construcción de este tipo de instrumentos desde el Neolítico ya que en muchas ocasiones se les daba un segundo uso a los utensilios de cocina, a los que se le colocaba una membrana pudiendo tener una bifuncionalidad o quedar finalmente encasillado para esta función. De este material se pasará a la madera, según estos investigadores, por sus cualidades acústicas ${ }^{706}$.

Asimismo, el material usado para las membranas de estos instrumentos podía hacerse con cordero, becerro, cabra, camello, toro, antílope, tiburón o raya, éste último usado para el tar islámico ${ }^{707}$. Estas solían unirse al cuerpo del instrumento con hebras vegetales o cintas de cáñamo o cuero ${ }^{708}$. De la importancia de la afinación de

\footnotetext{
702 Francis William Galpin, The music of the sumerians and their immediate successors the babylonians \& assyrians. Greenwood, 1970, 1.

${ }^{703}$ Henry George Farmer, "The Music of Islam", en The New Ixfird History of Music: Ancient and Oriental Music. New York: Oxford University Press, 1986, 442.

${ }^{704}$ Rafael Pérez Arroyo, La música en la era de las pirámides. Centro de Estudios Egipcios, 2001, 230.

${ }^{705}$ Ramón Andrés, Diccionario de música, mitología, magia y religión. Barcelona: Acantilado, 2012, 1535 .

706 Rosario Álvarez y Guillermo Rosselló Bordoy, "Hallazgo de tambores de la España islámica (siglos IX-XIV)", Revista de Musicología XII, n², 1989, 416-417.

707 Ramón Andrés, Diccionario de instrumentos musicales. Desde la Antigüedad a J.S. Bach. Barcelona: Península, 2009, 408.

${ }^{708}$ Ramón Andrés, Diccionario de música, mitología, magia y religión. Barcelona: Acantilado, 2012, 1537.
} 
estas membranas, Julián Ribera hace referencia mediante la siguiente anécdota: "Cuentan de Cháfar, el tamborilero, que, para templar su tamboril, exigía al cantor a quién había de acompañar que insinuara la salida de su canción. Al oírla, se daba cuenta de cómo había de templar su instrumento, y, una vez éste templado, dicen que acompañaba divinamente" 709 .

\subsubsection{Membranófonos y género}

Por otro lado, los membranófonos tienen una marcada segregación por género llegando a conllevar discriminaciones sociales por la interpretación de un determinado tipo de instrumento relacionado con el otro sexo en público. Un ejemplo de estos sería el duff, considerado instrumento femenino y relacionado con el acompañamiento de las danzas ${ }^{710}$. Esta relación entre el adufe y la mujer se ve reflejada, igualmente, en los textos bíblicos, Exxodo o el Libro de los Profetas ${ }^{711}$ así como en el periodo preislámico en Egipto, donde se utilizaba para acompañar la danza. Su uso no solo se limitaba a este contexto festivo ya que en el Próximo Oriente éste también se utilizó para acompañar cantos religiosos ${ }^{712}$. Esta presencia del instrumento en el contexto místico podía deberse al uso que le fue dado por el Profeta Muhammad (siglo VII) quien lo utilizó en distintos entornos, como entretenimiento, celebraciones o batallas. Este hecho pudo ser el motivo de que el duff llegase a evadir las condenas oficiales que recibieron los instrumentos musicales ${ }^{713}$.

Existe, asimismo, una gran variedad de adufes, uno de ellos es el duff murabba, pandero rectangular, instrumento musical existente desde el periodo faraónico, su uso fue prohibido porque era un instrumento que solían interpretar los llamados "afeminados"714. Esta prohibición fue rebatida por especialistas integrantes en los zahiri, los cuales comparaban el considerar ilícito un instrumento musical

\footnotetext{
709 Julián Ribera y Tarragó, La música árabe y su influencia en la española. Valencia: Pre-Textos (Música "la Huella Sonora"), 2000, 101.

${ }^{710}$ Françoise-René Tranchefort, Los instrumentos musicales en el mundo. Alianza Editorial, 1985, 79.

711 Ibidem, 80.

712 Ibídem, 79.

713 Conway R. Morris et al., "Duff", Grove Music Online, Oxford University Press, 2001, https:/www.oxfordmusiconline.com/grovemusic/view/10.1093/gmo/9781561592630.001.0001/omo9781561592630-e-0000007050? (Última consulta: 12-11-2019).

$714 \mathrm{M}^{\mathrm{a}}$ Dolores Guardiola, "El Tratado de Música Árabe Kitab Al-Imta Bi-Ahkam Al-Sama". Universidad de Granada, 1992, http://digibug.ugr.es/handle/10481/14149 (Última consulta: 5-032019), 105
} 
porque fuese interpretado por los "afeminados", con dejar de lavar la ropa porque "ellos" así lo hiciesen" ${ }^{715}$.

Instrumentos como el tambor de copa, según el musicólogo francés Tranchefort, podían estar reservados para ser interpretados exclusivamente por hombres. En el caso de este instrumento, actual darbuka, Tranchefort concreta que podía ser ejecutado por mujeres, pero que en el ámbito de la "música culta" estaba reservado solo para hombres ${ }^{716}$.

Otro de los instrumentos denominados femeninos serían los tambores de marco, considerados "atributo musical indispensable de las mujeres, tanto en la alegría como en el duelo, y también como instrumentos rítmicos con los cuales las profesionales acompañaban sus canciones y danzas"717. Investigadores como Curt Sachs enlazan el que este instrumento pudiese ser cercano a las mujeres por la similitud que existe en su construcción con el utensilio para limpiar el grano, «en el caso particular de España encontramos que durante el siglo XIV un tipo de criba se conocía también con el nombre de pandero"718.

Por lo tanto, la documentación que llega hasta nuestros días sitúa estos instrumentos en manos de mujeres durante las festividades de las bodas, como complemento de acompañamiento a cantos y danzas. Corroborando esta información, Raquel Jiménez y Alexandra Bill parafraseando a Manuela Marín afirman ${ }^{719}$ :

\footnotetext{
"Llama nuestra atención el hecho de que en Mug rib, Ibn Sa id (fallecido en 1286) describió como 'ahir, una mujer libertina, bailaba en bodas acompañada por su marido (un famoso poeta erudito) mientras se acompañaba del tambor. Esta fuerte relación entre tambores e intérpretes femeninas (profesionales o semiprofesionales) presentes en bodas u otras festividades aún se puede ver en el Magreb"720.
}

\footnotetext{
715 Ibídem, 118.

716 Ibídem, 78.

717 Ibídem, 235.
}

718 Mauricio Molina “Tympanistria nostra: la reconstrucción del contexto y la práctica musical de las pandereteras y aduferas medievales a través de sus representaciones en el arte románico español”. Codex Avquilarensis: Cuadernos del Monasterio de Santa María la Real, 26, 2011, 83.

719 Raquel Jiménez Pasalodos y Alexandra Bill, "Music and identities al-Andalus clay drums and the study of popular musical behaviors through the archaeological record", Studien zur Musikarchäologie X, DAI Orient Archäologie, 2016, 90- 91.

720 “draws our attention to the fact that in his Mug rib, Ibn Sa id (d. 1286) described as 'ahir, or a libertine woman, someone who danced at weddings accompanied by her husband (a famous erudite poet) playing the frame drum. This strong relationship between drums and female players (professional or semi-professional) performing at weddings or other festivities can still be seen in today's Maghreb". Traducción propia. 
De la presencia de estos tambores en el norte de África se hacían eco Rosario Álvarez y Rosselló Bordoy quienes indicaban “en Marruecos es posible hallar darbukas de tamaño diminuto" 721 en comparación con la pieza encontrada en Benetússer. Actualmente el uso de estos instrumentos musicales está siendo estudiado en Marruecos, uno de los principales lugares al que acudieron los árabes una vez expulsados de España, lo que está ayudando en la interpretación y planteamiento de hipótesis sobre el uso y función que pudieron tener en al-Andalus. Como afirma Mauricio Molina, "sabemos por las fuentes iconográficas y literarias de la Antigüedad que los panderos eran utilizados principalmente por mujeres en el antiguo Mediterráneo y el Oriente Próximo para acompañar la música de rituales

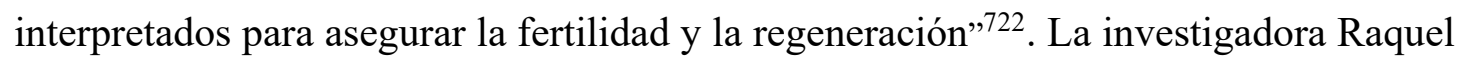
Jiménez y el investigador Matías Nicolás Isolabella, ambos de la Universidad de Valladolid, forjan el equipo del proyecto ta 'rijas financiado por la Marie Curie Action "International Research Staff Exchange Scheme" dan a conocer el uso de este tipo de tamborcillos en rituales femeninos marroquíes en los que las intérpretes caen en trance y son poseídas por espíritus, lo que les permite abrir un lazo de conexión con el cielo. Asimismo, cuentan que antes eran las mujeres las que fabricaban este tipo de instrumentos pero que actualmente no continúan con su fabricación ya que existe un importante mercado de tamborcillos en el sur de Marruecos, realizados por hombres, cuyos costes son mucho menores. Ambas líneas de investigación ya han sido presentadas en distintos eventos académicos y serán próximamente publicadas.

\section{Los membranófonos en la arqueología andalusí}

Durante la fase de recopilación de membranófonos andaluces, han sido veintiuna las piezas encontradas, siendo seis de ellas inéditas, consiguiéndose, asimismo, la fotografía, también inédita, de uno de los tambores del que hasta ahora solo se tenía un dibujo. Estas piezas han sido catalogadas y pueden encontrarse en los anexos de esta investigación ordenadas según las ciudades donde se encontraron y clasificadas según los parámetros que se expondrán a continuación.

\footnotetext{
${ }^{721}$ Rosario Álvarez y Guillermo Rosselló Bordoy, "Hallazgo de tambores de la España islámica (siglos IX-XIV)", Revista de Musicología XII, n², 1989, 416.

722 Mauricio Molina "Tympanistria nostra: la reconstrucción del contexto y la práctica musical de las pandereteras y aduferas medievales a través de sus representaciones en el arte románico español", Codex Avquilarensis: Cuadernos del Monasterio de Santa María la Real, 26, 2011, 83.
} 
Dentro de este tipo de instrumentos existe gran variedad en forma y estructura siendo cilíndricos, cónicos, cuadrados, en forma de vasija, copa y de doble cuerpo cónico, donde las bases pueden llegar a unir varios ejemplares en la parte estrecha. Asimismo, existe la variedad de instrumentos con forma de reloj de arena y el llamado de barril, con dos parches cuyo origen se remonta hacia el 2000 a.C. en Asia Menor pasando por Grecia y Roma bajo la denominación de symphonia ${ }^{723}$. Éste se extendería por el Mediterráneo partiendo de Grecia donde era denominado tympanon y que contaba a menudo con cascabeles o sonajas en su marco, donde también guardaba un emblema de los cultos dionisíacos y funerarios ${ }^{724}$.

Quedarían por lo tanto agrupadas, según Tranchefort, en tres formas básicas, la tubular, la hemisférica y la circular ${ }^{725}$. Por lo tanto, los tambores se clasificarían en palabras de Tranchefort, "según la forma de su resonador, según el número, la calidad y el modo en que se fijan las membranas, y finalmente, según las técnicas para ponerlas en vibración" 726 .

El tambor con forma de cubilete es el más común en el mundo árabe. Se puede encontrar con la denominación de zarb o dombak en Irán y darbuka en el Próximo Oriente y el Magreb. Las encontradas en excavaciones arqueológicas andalusíes fabricadas en barro eran interpretadas, según su tamaño, percutiéndolas con las $\operatorname{manos}^{727}$, como puede comprobarse en la iconografía del Beato de Valladolid, donde puede distinguirse un intérprete que sostiene un tambor cuya membrana dirige al suelo y golpea con una de sus manos ${ }^{728}$. Sobre la darbuka, William Conner, Milfie Howell y Tony Langlois comentan que el parche se solía hacer con piel de cabra, carnero o perro y que éste apoyado sobre la rodilla o cadera era percutido por las manos, manteniendo la izquierda sobre el borde del mismo y la derecha golpeando con los dedos planos sobre el centro de la membrana ${ }^{729}$. Curiosamente Farmer y

\footnotetext{
723 Ibídem, 407- 408.

724 Ibidem, 408.

725 François-René Tranchefort, Los instrumentos musicales en el mundo (Alianza Editorial, 1985), 73.

726 Ídem.

727 Ibídem, 78.

728 Rosario Álvarez García, "La iconografía musical de los Beatos de los siglos X y XI y su procedencia", Anuario del Departamento de Historia y Teoría del Arte, Vol. 5, 1993, 217.

729 William J. Conner, Milfie Howell y Tony Langlois, "Darabukka", en Grove Music Online, Oxford University Press, 2011 , https:/www.oxfordmusiconline.com/grovemusic/view/10.1093/gmo/9781561592630.001.0001/omo9781561592630-e-0000007209?rskey=j1t5Eo\&result=1 (Última consulta: 10-10-2019).
} 
Guettat fundamentan que estos instrumentos pudieron ser conocido bajo el nombre de durraj, ya que la denominación darbuka no aparece en ningún manuscrito ${ }^{730}$.

En este punto, deben recordarse los términos que reflejan los sabios andalusíes cuando se refieren a este tipo de instrumentos, así como las referencias compiladas tras el estudio iconográfico de estos membranófonos. Este sería, por lo tanto, el listado de instrumentos clasificados según su forma:

- Tambor: aqwal (especie de tambor), tabl (atabal).

- Tambor de un parche (unimembranófono): kabar (tipo darbuka de barro o cerámica), kassaba (tipo darbuka),

- Tambor de doble parche (bimembranófono): $k u b a$

- Tambor de marco: daff (adufe).

Esta clasificación se correspondería igualmente a la reflejada en el diccionario realizado por Louis Ibsen al Faruqi, donde los instrumentos membranófonos son divididos entre tambores de marco, tambores y timbales. Asimismo, diferencia dentro de los tambores los términos según su forma de barril, maceta o en forma de reloj de arena (waisted) y el número de parches con el que cuentan, uno o dos, y los no identificados $^{731}$.

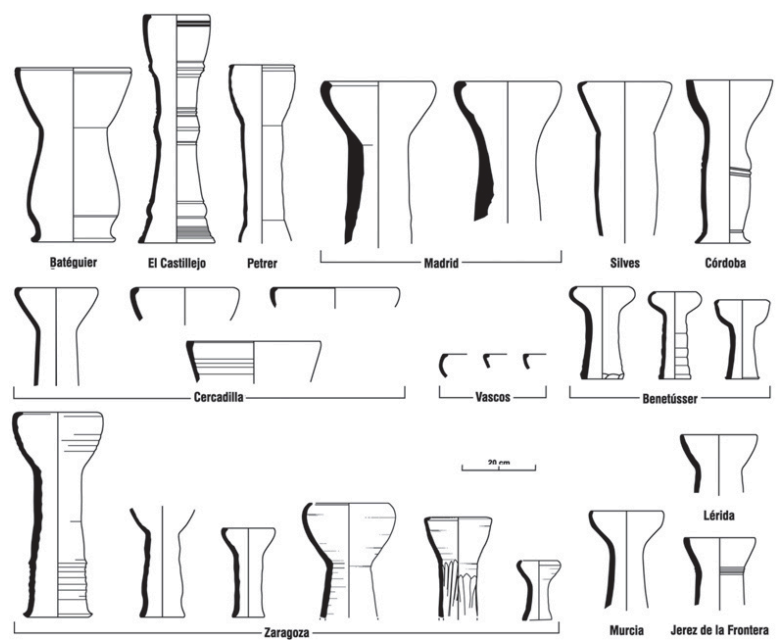

Figura 57. Dibujos de membranófonos del artículo de Francisco de Asís.

Francisco de Asís Escudero en su artículo "Los tambores musulmanes del alfar de la calle San Pablo, 95-103 de Zaragoza" 732 incluye un dibujo completo y representativo con la variedad de los tambores andalusíes que se habían encontrado hasta el momento pertenecientes a al-Andalus. Todos los que se incluyen de

\footnotetext{
${ }^{730}$ Henry Georges Farmer, “Tabl”, en Encyclopaedia of Islam, Vol. X. Ed. Brill Leiden, 2003, 33; Mahmoud Guettat, La musique classique du Maghreb. París: Sindbad, 1980, 143.

${ }^{731}$ Lois Ibsen al Faruqi, An annotated glossary of arabic musical term. Greenwood Press, 1981, 421.

732 Francisco de Asís Escudero, "Los Tambores Musulmanes del Alfar de la Calle San Pablo" Saldvie: Estudios de prehistoria y arqueología, 11, 2012.
} 
forma inédita en esta investigación se ajustarían en su forma a esta representación que realiza este autor.

Las investigadoras Raquel Jiménez y Alexandra Bill en el artículo "Los tambores de cerámica de al-Andalus (ss. VIII-XIV): Una aproximación desde la Arqueología Musical"733 realizan un amplio recorrido por los tambores andalusíes encontrados en excavaciones arqueológicas españolas señalando de estos la siguiente clasificación: "Se pueden clasificar en dos tipos principales considerando la forma de la copa hemisférica o troncocónica-, con tres tipos diferentes de bases -cónica, cilíndrica o fusiforme" ${ }^{734}$. Esta clasificación se correspondería igualmente con la variedad de tambores encontrados, ya que algunos de los andaluces incluidos en esta investigación eran ya conocidos por estas investigadoras, pero al priorizar la perspectiva organológica se ha decidido utilizar la clasificación planteada por Hornbostel y Sachs, por lo que los puntos clasificatorios que se aplicarían a los tambores encontrados en excavaciones arqueológicas andaluzas serían los siguientes:

- Unimembranófonos tubulares

- Uniembranófonos de copa (darbuka)

\section{Clasificación organológica}

A continuación se presentarán las piezas encontradas según su clasificación organológica.

\section{Unimembranófonos tubulares (con forma de copa)}

Estos membranófonos son los que fácilmente pudieron ser confundidos con tuberías, canalización o desagüe ya que no cumplen las características formas de tamborcillo tipo darbuka, siendo el que cuenta con mayor popularidad. Normalmente este tipo de tambores se encuentran incompletos conservándose solo la parte media del instrumento que suele estar caracterizada por una franja intermedia (moldura central) que divide al instrumento en dos partes.

De todos estos unimembranófonos tubulares el que se encuentra en mejor estado de conservación es el del Castillejo de los Guájares, este instrumento fue uno de los primeros que se encontraron en Andalucía en el año 1985 por lo que por su

\footnotetext{
733 Raquel Jiménez Pasalodos y Alexandra Bill, "Los Tambores de Cerámica de Al-Andalus (ss. VIIIXIV): Una Aproximación desde la Arqueología Musical”, Nassarre, 2012.

${ }^{734}$ Ibidem, 20.
} 
exclusividad llamó la atención de investigadores que se acercaron a la pieza y se preocuparon de presentarla y ponerla en valor. Rosselló Bordoy y Rosario Álvarez comparan esta pieza con la ilustración de "Los Beatos de Valladolid (fol. 199v.), Seo de Urgel (fol. 213v.), ambos del siglo X, y el de Fernando I (fol. 272v.) del siglo XI"735. Estos investigadores sostienen que este instrumento se ejecuta de la forma mostrada en estas imágenes, manteniendo el instrumento de forma vertical con el parche hacia abajo mientras se golpea con una de las manos. Asimismo, lo asemejan a la imagen de la mencionada cantiga CCC donde la intérprete sostiene el instrumento sobre su hombro mientras la membrana aparece pegada al rostro. Ambas posibilidades de ejecución las fundamentan en el nudo central del instrumento, que facilitaría tanto la sujeción con la mano como el apoyo sobre el hombro ${ }^{736}$.

Otra de las curiosidades de este instrumento es en el contexto en el que se encontró, en una pequeña habitación ${ }^{737}$ junto a una jarrita y a una redoma ${ }^{738}$. Por el grabado que tiene la pieza, Allah, la investigadora Manuela Cortés afirma que induce a pensar que se pudo tratar de un instrumento utilizado por un miembro de alguna cofradía granadina ${ }^{739}$.

Ejemplares de similares características encontrados en otros puntos del territorio andalusí sería por por ejemplo el encontrado en Petre, Alicante B-80/238 (X-XI), algunos de la calle San Pablo de Zaragoza, como el 16262 o 16854 (XI).

La relación de membranófonos encontrados en Andalucía con esta clasificación sería:

\begin{tabular}{|c|c|c|c|}
\hline Lugar & Cronología & Inventario & Anexo \\
\hline Alcazaba de Almería & XII-XIII & CE28175 & 1 \\
\hline Alcazaba de Almería & XI-XV & CE28029 & 2 \\
\hline Alcazaba de Almería & XI-XV & CE28028 & 3 \\
\hline Castillejo de los Guájares & XIV & C-85 20417-E & 16 \\
\hline
\end{tabular}

735 Ibidem, 419.

736 Ídem.

737 Antonio Malpica Cuello et al., "Excavación en El Castillejo (Los Guájares, Granada), 1985", Anuario Arqueológico de Andalucía, 1985, 446.

738 Guillermo Rosselló Bordoy, El ajuar de las casas andalusíes. Málaga: Sarriá, 2002, 89.

${ }^{739}$ Manuela Córtés García, "La música andalusí en el Reino de Granada”, en La música andalusí en el Reino de Granada. Fundación Pública Andaluza Centro de Estudios andaluces. Consejería de la Presidencia e Igualdad. Junta de Andalucía, 2012, 23. 


\begin{tabular}{|c|c|c|c|}
\hline (Granada) & & & \\
\hline Calle Dos aceras (Málaga) & XIV-XV & - & 17 \\
\hline Calle Dos aceras (Málaga) & XIV-XV & - & 21 \\
\hline $\begin{array}{c}\text { Estacada de Faro (Puebla } \\
\text { del Río, Sevilla) }\end{array}$ & XII-XIII & REP22960 & \\
\hline
\end{tabular}

\section{Unimembranófonos de copa}

Dentro de la clasificación de Hornbostel y Sachs solo se plantea la posibilidad de especificar la parte superior de estos instrumentos. Con la intención de conseguir exhaustividad en la descripción de los membranófonos se ha hecho un puntual apunte a uno de los ejemplares encontrados en Jerez de la Frontera, donde se aclara que la base de este instrumento tiene una forma abombada. Este tipo de instrumento son los más característicos ya que guardan semejanza con los tambores tipo darbuka. Existe gran número de unimembranófonos que se ajustan a estas características entre los encontrados en excavaciones andalusíes, ejemplos de los mismos serían el encontrado en Medellín, Badajoz; Silves: Cast. Q3/C8-47; Madrid: AM-84/30/254 y AM84/30/256; Benetússer, Valencia: DO6/01325 (X-XI); Palma de Mallorca: - (XI); Faro, Portugal: 999.2.6 (XI) o Murcia: M76-1-1-561 (XI-XIII).

La realción de membranófonos andalusíes en Andalucía con estas características son los siguientes:

\begin{tabular}{|c|c|c|c|}
\hline Lugar & Cronología & Inventario & Anexo \\
\hline $\begin{array}{c}\text { Plaza de Belén (Jerez de la } \\
\text { Frontera) }\end{array}$ & X & BEL-04/UE 274 & 4 \\
\hline Villamartín, Cádiz & VIII-X & - & 7 \\
\hline $\begin{array}{c}\text { Avenida de las Ollerías } \\
\text { (Córdoba) }\end{array}$ & VIII-XII & B912 & 8 \\
\hline Yacimiento de Cercadilla & VIII-XII & - & 10 \\
\hline Yacimiento de Cercadilla & X-XI & $18 / 2508$ & 14 \\
\hline $\begin{array}{c}\text { Palenque Silo, Priego de } \\
\text { Córdoba (Córdoba) }\end{array}$ & XII-XIII & - & 19 \\
\hline Calle Almacenes (Málaga) & X-XI & $8516 / 194$ & \\
\hline
\end{tabular}




\section{Unimembranófono de copa (con cuerpo abombado)}

Son escasos los ejemplares de estas características encontrados en el territorio andalusí, es por ello por lo que se puntualiza su forma. Se cuenta con otro ejemplo llegado a través de una naviera al sur de Francia en Cannes (5514-9), la pieza encontrada en Andalucía es:

\begin{tabular}{|c|c|c|c|}
\hline Lugar & Cronología & Inventario & Anexo \\
\hline $\begin{array}{c}\text { Calle Salas (Jerez de la } \\
\text { Frontera) }\end{array}$ & XII-XIII & J/03/E21/20 & 6 \\
\hline
\end{tabular}

\section{Fragmentos:}

Aunque resulta complejo en muchos casos determinar la forma que estos fragmentos de membranófonos podían tener, existen ejemplares donde esta se puede intuir, es por ello que se incluye una clasificación no integrada con el resto de las piezas ya que esta es hipotética pudiendo variar la perspectiva si de estos tambores se encontrasen otras partes:

\begin{tabular}{|c|c|c|c|c|}
\hline Lugar & Cronología & Inventario & $\begin{array}{c}\text { Posible } \\
\text { catalogación }\end{array}$ & Anexo \\
\hline $\begin{array}{c}\text { Calle Justicia } \\
\text { (Jerez de la } \\
\text { Frontera) }\end{array}$ & XII & JUS-39/94/3/1 & $\begin{array}{c}\text { Unimembranófono } \\
\text { tubular (con forma } \\
\text { de copa) }\end{array}$ & 5 \\
\hline $\begin{array}{c}\text { Yacimiento de } \\
\text { Cercadilla, } \\
\text { Córdoba }\end{array}$ & IX & - & - & 11 \\
\hline $\begin{array}{c}\text { Yacimiento de } \\
\text { Cercadilla, } \\
\text { Córdoba }\end{array}$ & IX & - & - & 12 \\
\hline $\begin{array}{c}\text { Yacimiento de } \\
\text { Cercadilla, } \\
\text { Córdoba }\end{array}$ & X-XI & - & Unimembranófono & 15 \\
\hline $\begin{array}{c}\text { Calle Real, 15 } \\
\text { (Priego de }\end{array}$ & XII-XIII & - & de copa & \\
\hline
\end{tabular}




\begin{tabular}{|c|c|c|c|c|}
\hline Córdoba) & & & & \\
\hline $\begin{array}{c}\text { Teatro Romano } \\
\text { (Málaga) }\end{array}$ & XIII-XV & $110 \mathrm{~b}$ & - & 20 \\
\hline
\end{tabular}

\subsubsection{Instrumentos idiófonos}

Esta familia de instrumento sería la gran olvidada por los sabios andalusíes, ya que tan solo llega hasta nuestros días una referencia de idiófono a través de ellos, los hayra'a (crótalos). Por supuesto, no será el único instrumento musical dentro de esta clasificación del que se sepa su presencia en al-Andalus. A través de las excavaciones arqueológicas llegan campanas (de arcilla o bronce), cascabeles y cencerros. De éstos, los más numerosos son las campanas de pequeño tamaño, aunque los instrumentos que más han llamado la atención de los investigadores han sido las campanas de arcilla pese a dudar de su enlace con la cultura andalusí.

\subsubsection{Crótalos}

Instrumento procedente de antiguas civilizaciones como la mesopotámica o egipcia $^{740}$. Los primeros ejemplares de este instrumento se realizaban con madera, boj o ébano y eran unidas mediante cintas de cuero y se ejecutaban entrechocándolas como las castañuelas ${ }^{741}$. Asimismo, Ramón Andrés puntualiza que "con cierta frecuencia, en ánforas, bajorrelieves y mosaicos observamos cómo los bailarines, además de tañerlos con las manos, llevaban los crótalos colgados de las orejas, el cuello o la cintura" ${ }^{742}$. Estos instrumentos, asimismo, estaban realcionados con los gnawas una cofradía de esclavos que sirvieron en al-Andalus de origen subsahariano, con tradición musical propia poco relacionada con la árabe o bereber ${ }^{743}$. Para esta cultura estos instrumentos eran denominados qraqeb y son definidos como dos pesados discos en forma de cuchara o platillos unidos por una tira de cuero de unos 30 $\mathrm{cm}^{744}$ utilizados en contextos religiosos y de culto como instrumento que establece una conexión con otra dimensión o lugar sirviendo como herramienta para llegar al

\footnotetext{
${ }^{740}$ Ramón Andrés, Diccionario de Instrumentos Musicales. Desde la Antigüedad a J.S. Bach. Barcelona: Península, 2009, 161.

741 Ídem.

742 Ídem.

743 Jordi Aguadé, "Sobre los Gnawa y su origen", Estudios de dialectología norteafricana y andalusí, 4, 1999, 157.

744 Christian Poché, “Qraqeb”, en The New Grove Dictionary of Musical Instruments, editado por Stanley Sadie. Macmillan Press, 2001, 375.
} 
éxtasis $^{745}$. Para esta función, estos instrumentos que podían ser de madera o metal, eran acompañados por tambores ${ }^{746}$.

Según nos informan investigadores como Farmer, existían distintos tipos de crótalos, éstos variaban según su función. Entre ellos se encontraban los kasat (kas o kasa en singular) o ku'us (en singular $k a^{\prime} s$ ), éstos tenían forma de cuenco mientras que los sunuj (en singular sanj) tenían forma de placa ${ }^{747}$. Sobre ellas Farmer afirma en otro trabajo que "el platillo era la kasa, nombre que también se le dio a la castañuela, cuya forma plana se llamaba sinj" ${ }^{\prime 748}$.

De toda esta terminología kas o $k a$ 's según Faruqi, basado en la opinión de Farmer $^{749}$, serían los crótalos de dedos de mayor tamaño con forma de cuenco y plato plano $^{750}$. Según Christian Poché y Amnon Shiloah eran éstos los que se utilizaban para las procesiones religiosas ${ }^{751}$.

Sanj, es el nombre más genérico dentro de los crótalos. Cuenta Faruqi que este término tiene origen persa, aunque Farmer afirma que podría tener origen asirio ${ }^{752}$. Existen evidencias del uso de este instrumento desde épocas preislámicas referido a castañuelas y crótalos de varios tipos, no obstante, a partir del siglo XIII el término empezó a referir a los crótalos de mayor tamaño ${ }^{753}$. Por otro lado, Sachs y Ribera relacionan este término con los cascabeles adosados a un pandero ${ }^{754}$. En su variante en singular, sinj Faruqi lo relaciona con los crótalos grandes de dedos ${ }^{755}$. Según

\footnotetext{
${ }^{745}$ Laura Eugenia Tudoras, "El viaje de los sentidos en los jardines Mogador”, Revista de Filología Románica, anejo IV, 2006, 396.

746 Reynaldo Fernández Manzano, "Gnawa”, Granada hoy, (29 de diciembre 2019), https://www.granadahoy.com/opinion/articulos/Gnawa 0 1423357734.html (Última consulta 9-022020).

${ }^{747}$ Henry George Farmer, "The Minstrelsy of the arabian nights", en Studies in Oriental Music Vol. 1, ed. Eckhard Neubauer. Frankfurt: Institute for the History of Arabic-Islamic Science at the Johann Wolfgang Goethe University Frankfurt am Main, 1986, 96.

748 Henry George Farmer y E Neubauer, Studies in Oriental Music, Vol. 1. Frankfurt: Institute for the History of arabic-islamic Science at the Johann Wolfgang Goethe University, 1997, 135.

${ }^{749}$ Lois Ibsen Faruqi, An Annotated Glossary of Arabic Musical Term. Greenwood Press, 1981, 140.

750 Ídem.

${ }^{751}$ Christian Poché y Amnon Shiloah, “Arab Music”, Grove Music Online, Oxford University Press, 2011, https://www.oxfordmusiconline.com/grovemusic/view/10.1093/gmo/9781561592630.001.0001/omo9781561592630-e-0000001139, (Última consulta: 10-10-2019).

${ }_{752}$ Lois Ibsen Faruqi, An Annotated Glossary of Arabic Musical Term. Greenwood Press, 1981, 295.

753 Ídem.

754 Ídem.

${ }^{755}$ Ibidem, 316.
} 
Christian Poché y Amnon Shiloah, los sunuj eran los que se ataban en los dedos pulgar e índice las bailarinas y se acompañaban con ellos ${ }^{756}$.

También se utilizó el término Sany o Sunny, crótalos, considerado además del instrumento musical del mismo nombre, sany, la denominación de la mujer instrumentista que se especializaba en é ${ }^{757}$. Este instrumento estuvo muy presente como acompañamiento en las danzas, como es el caso de las gawazis, "tribu" de mujeres y hombre gitanos que se dedicaban a echar la buena ventura. La profesión de estos estaba centrada en las danzas acompañadas por crótalos y tamborcillos ${ }^{758}$.

De estos instrumentos musicales ningún ejemplar andalusí llega hasta nuestros días, al menos hasta el momento, en Andalucía, pero en lugares como Zaragoza sí que

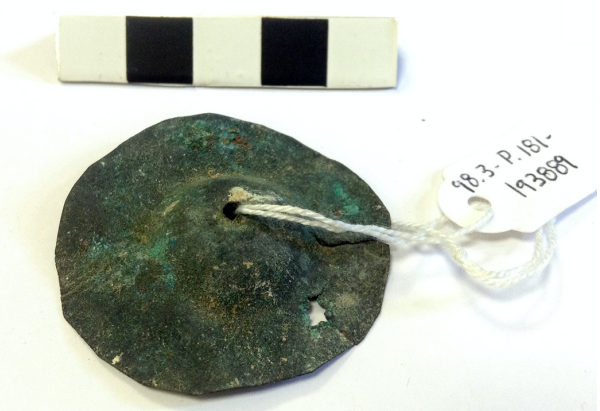

Figura 58. Pieza catalogada como crótalo del Museo de Zaragoza. Imagen cedida por Aránzazu Mendívil. se ha encontrado una pieza con esta perspectiva en una de las excavaciones arqueológicas realizadas en el teatro romano. La investigadora Aránzazu Mendívil incluye en su trabajo "La cerámica andalusí y otros materiales singulares del teatro romano de Zaragoza: herramientas de aproximación cultural" comenta que pueden ser crótalos, parte de un tocado femenino o decoración de una moldura para caballos. Lo que sí se han encontrado en Andalucía, en la Alhambra, son dos platillos que bien pudieron ser parte de un pandero, riqq, de época musulmana, aunque la datación de los mismos no está determinada.

\footnotetext{
756 Christian Poché y Amnon Shiloah, "Arab Music”, Grove Music Online, Oxford University Press, 2011, https://www.oxfordmusiconline.com/grovemusic/view/10.1093/gmo/9781561592630.001.0001/omo9781561592630-e-0000001139, (Última consulta: 10-10-2019).

${ }_{757}$ Henri Pérès, Esplendor de Al-Andalus. Libros Hiperión, 1983, 388.

${ }^{758}$ Manuela Cortés García, "Estatus de la mujer en la cultura islámica. Las esclavas-cantoras (ss.IXXIX)”, Mujer versus Música. Colección Feminismo Musical. Editorial Rivera Mota, 2011, 139-98.
} 


\subsubsection{Campanas}

Instrumento asociado desde su origen al ultramundo ${ }^{759}$, Ramón Andrés afirma que "se tenía la convicción de que las campanas eran capaces de alejar el mal, y que su tañido alejaba las tormentas y provocaban la huida de entidades malignas" 760 . Tranchefort comenta que resulta difícil precisar los orígenes de estos instrumentos cuyos ejemplares se remontan al primer milenio (a.C.) en China y a los ejemplares asirios de 800 a.C. Asimismo, afirma que se han descubierto algunos ejemplares egipcios y griegos que se remontan varios siglos antes de nuestra era ${ }^{761}$.

Según la investigadora Nieves Jiménez Díaz, quien realizó en 1998 su tesis doctoral sobre la campana, comenta que durante los siglos XI, XII y XIII se fabricaban con forma de "colmenas, dedales o barriles, estrecha y de anchura desproporcionada, perforadas en lo alto con tres o cuatro pequeñas aberturas triangulares o agujeros redondos, que servían para hacer más terrible el sonido y ahuyentar a los espíritus malignos"762. Revisando los ejemplares aquí recopilados, la mayor parte de los mismos entrarían dentro de esta clasificación, siendo, mayormente, campanas de pequeño tamaño que bien pudieron estar relacionadas con este fin ${ }^{763}$. Asimismo, durante los primeros siglos del cristianismo estas se utilizaron fuera del culto público más cercanas al uso de juguete infantil o joya, pero Nieves Jimenez puntualiza que la carencia de documentación en la época no descarta que pudieran ser utilizadas para anunciar asambleas ${ }^{764}$.

Conocidas, igualmente, como jalajil (en singular juljul) y ajras (en singular jaras), estas campanas que podían tener distintos tamaños y formas, cónicas o cuadradas $^{765}$. Estas campanas podían utilizarse como adorno en los vestidos de caballos o camellos, aunque en lugares como el antiguo Egipto llegaron a usarse para colocárselos a los criminales ${ }^{766}$. En este respecto, existe un proverbio árabe que

\footnotetext{
${ }^{759}$ Ramón Andrés, Diccionario de Música, Mitología, Magia y Religión. Barcelona: Acantilado, 2012, 395.

760 Ídem.

${ }^{761}$ Françoise Tranchefort, Los Instrumentos Musicales en el Mundo. Alianza Editorial, 1985, 44.

762 Nieves Jiménez Díaz, "Historia de laas campanas de Granada". Tesis doctoral de la Universidad de Granada, dirigida por Domingo Sánchez Mesa Martín, 1998, 19.

763 Ídem.

764 Ibidem, 43.

${ }^{765}$ Henry George Farmer, "The minstrelsy of the arabian nights", en Studies in Oriental Music Vol. 1, ed. Eckhard Neubauer. Frankfurt: Institute for the History of Arabic-Islamic Science at the Johann Wolfgang Goethe University Frankfurt am Main, 1986, 96.

${ }^{766}$ Ídem.
} 
afirma que el hombre que usa un juljul se pone innecesariamente en peligro ${ }^{767}$. De este instrumento Rosselló Bordoy comenta:

"Dentro del campo de la percusión la campana o yulyul en árabe tenía una presencia, menguada si se quiere, pero real. La tipología jugaba siempre con la figura femenina vestida con falda cónica, de base inferior de gran diámetro y elementos internos para sostener el badajo. En este caso no cabe aducir que la campana fuera un elemento extraño dentro de las costumbres de época musulmana. Tal vez la campana como símbolo cristiano para la convocatoria de los fieles sí fuera un elemento fuera de lugar dentro de los avisos rituales islámicos para convocar la oración cotidiana, sin embargo en cuanto al uso doméstico tenemos documentadas las campanitas metálicas como la diminuta, en bronce, del Museo de Mallorca" 768 .

El término jaras Faruqi lo define como campana cónica o cuadrada con badajo $^{769}$ asimismo cuando se refiere al término jalajil puntualiza que se tratan de unas campanas usadas como instrumento musical ${ }^{770}$, dejando abierta la opción de que tuviesen otro uso. Esta idea enlazada a la presencia de las diminutas campanitas que comentaba en la anterior afirmación Rosselló Bordoy se complementa con la información que aportan los descubrimientos arqueológicos. En Zaragoza en la necrópolis de El Quez (Alberite de San Juan), entre el ajuar de la tumba de un niño de época hispanomusulmana (ss. XI-XIII) se encontró una campanita de pequeño tamaño (3,1 cm. longitud máx. X 1,7 cm. anchura máx.). Rafael Carmona, director del Museo Histórico Municipal de Priego, afirma que esta campanita se encontraba junto a los restos de un gato, lo que enlazaría el instrumento con el conocido uso relacionado con este animal. En el caso de la campanita de Priego de Córdoba afirma que podría haber

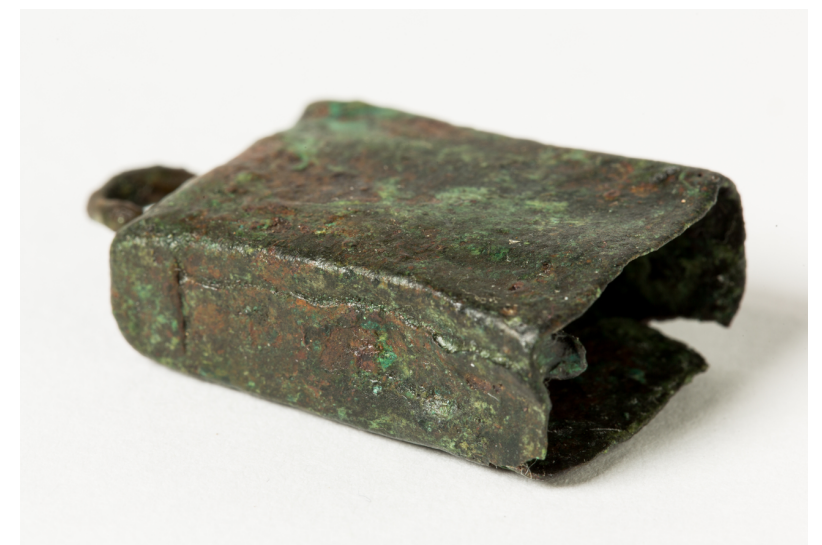

Figura 59. Campana. Museo de Zaragoza. Imagen realizada por J. Garrido. NIG: 50983. tenido el mismo uso $\mathrm{y}$, por semejanza, tres de las campanas de la Alhambra podrían añadirse a esta hipótesis. La campana de Zaragoza tiene forma cuadrada mientras que la cordobesa y las granadinas son cónicas. La forma de la primera, la zaragozana, igualmente, recuerda a la conservada en el Museo de

\footnotetext{
767 Ídem.

768 Guillermo Rosselló Bordoy, "El largo camino de una investigación”, en Del rito al juego: juguetes y silbatos de cerámica desde el islam hasta la actualidad. Junta de Andalucía: 2006, 38-39.

769 Lois Ibsen Faruqi, An Annotated Glossary of Arabic Musical Term. Greenwood Press, 1981, 123.

770 Ibídem, 118.
} 
Huelva, de la que se han realizado varios estudios por su característica forma cuadrada, en este caso con los bordes más redondeados. El museo recalca en la ficha de catalogación que: "esta campana procede de una ermita o iglesia rural (Kanisa), y es muestra de la tolerancia religiosa de los musulmanes a la liturgia cristiana de la población mozárabe, que era mayoritaria”, lo que la dejaría en otro contexto totalmente distinto al citado limitándose la similitud de ambas campanas a su fisonomía. También mozárabes son las campanas que se pueden encontrar en el Museo Arqueológico y Etnológico de Córdoba y en el Museo Arqueológico de Sevilla. En este caso las piezas, cordobesa y sevillana, cuentan con la característica forma semiovoidea del instrumento.

Por último, estarían los naqus (en plural nawaqis), se trata de unas placas de madera o metal usadas como un gong por los cristianos en tierras de habla árabe. Este instrumento servía para congregar a los devotos en la iglesia cristiana ${ }^{771}$.

\section{Cascabeles y sonajas}

Por otro lado, existen los qalaqil (en singular qalqal) que son los cascabeles. Éstos junto a las campanas también podía formar parte de la vestimenta de mulos y camellos con la intención de intimidar al enemigo ${ }^{772}$.

Igualmente, estarían las khalakhil (en singular khalkhal) y ahjal (en singular hijl) que son anillos o tobilleras de metal para acompañar el baile de las mujeres ${ }^{773}$.

Los términos qalaqil o kalakil son descritos por Faruqi como cascabeles o campanas que eran adheridas a los animales durante las batallas para crearles confusión ${ }^{774}$.

De estas piezas se conserva una considerable muestra en el Museo de la Alhambra donde se pueden ver distintos tamaños y formas de este tipo de instrumentos. De la datación de las mismas el museo informa que es complejo esclarecerla ya que los cambios en este tipo de piezas son mínimos a lo largo de los siglos y su hallazgo muy antiguo, por lo que no se puede asegurar una fecha concreta. Debido al peso de este lugar dentro de la historia de al-Andalus y la gran variedad de

\footnotetext{
771 Ídem.

772 Ídem.

773 Ibidem, 97.

774 Lois Ibsen Faruqi, An Annotated Glossary of Arabic Musical Term. Greenwood Press, 1981, 253.
} 
piezas encontradas se ha decidido añadir estos instrumentos, aunque se encuentren sin una datación concreta.

Relación de piezas encontradas en excavaciones arqueológicas andaluzas:

\begin{tabular}{|c|c|c|c|}
\hline Pieza & Lugar & Cronología & Inventario \\
\hline Campana & $\begin{array}{l}\text { Alhambra, } \\
\text { Granada }\end{array}$ & XV-XVI & R1410 \\
\hline Campana & $\begin{array}{c}\text { Alhambra, } \\
\text { Granada }\end{array}$ & Desconocida & R104937 \\
\hline Campana & $\begin{array}{c}\text { Alhambra, } \\
\text { Granada }\end{array}$ & Desconocida & R10977 \\
\hline Campana & $\begin{array}{c}\text { Alhambra, } \\
\text { Granada }\end{array}$ & Desconocida & R10978 \\
\hline Campana & $\begin{array}{c}\text { Alhambra, } \\
\text { Granada }\end{array}$ & Desconocida & R10980 \\
\hline Campana & $\begin{array}{c}\text { Alhambra, } \\
\text { Granada }\end{array}$ & Desconocida & R10981 \\
\hline Campana & $\begin{array}{c}\text { Alhambra, } \\
\text { Granada }\end{array}$ & Desconocida & R10984 \\
\hline Campana & $\begin{array}{c}\text { Alhambra, } \\
\text { Granada }\end{array}$ & Desconocida & R10982 \\
\hline Campana & $\begin{array}{c}\text { Alhambra, } \\
\text { Granada }\end{array}$ & Desconocida & R10983 \\
\hline Campana & $\begin{array}{l}\text { Alhambra, } \\
\text { Granada }\end{array}$ & Desconocida & R10988 \\
\hline Campana & $\begin{array}{l}\text { Alhambra, } \\
\text { Granada }\end{array}$ & Desconocida & R10996 \\
\hline Campana & $\begin{array}{l}\text { Alhambra, } \\
\text { Granada }\end{array}$ & Desconocida & R10998 \\
\hline Campana & $\begin{array}{c}\text { Calle Tinajeros, } \\
\text { Jaén }\end{array}$ & - & A-4619 \\
\hline Campana & $\begin{array}{c}\text { Los Ronzones, } \\
\text { Huelva }\end{array}$ & $\mathrm{XI}$ & 2901 \\
\hline
\end{tabular}




\begin{tabular}{|c|c|c|c|}
\hline Campana & Espiel, Córdoba & $\mathrm{X}$ & CE000430 \\
\hline Campana & $\begin{array}{c}\text { Vega del } \\
\text { Guadalquivir, } \\
\text { Sevilla }\end{array}$ & $\mathrm{X}$ & REP06396 \\
\hline Campana & $\begin{array}{l}\text { Calle Zurbarán, } \\
\text { Priego, Córdoba }\end{array}$ & - & - \\
\hline Campana & Teba, Málaga & X-XIII & 779 \\
\hline Campana & Teba, Málaga & VIII-XIII & 1901 \\
\hline Campana & Teba, Málaga & VIII-XIII & 1902 \\
\hline Cascabel & $\begin{array}{l}\text { Jerez de la } \\
\text { Frontera, Cádiz }\end{array}$ & XII-XIII & $816 / 00732-014$ \\
\hline Cascabel & $\begin{array}{c}\text { Alhambra, } \\
\text { Granada }\end{array}$ & Desconocida & R10987 \\
\hline Cascabel & $\begin{array}{l}\text { Alhambra, } \\
\text { Granada }\end{array}$ & Desconocida & R10990 \\
\hline Cascabel & $\begin{array}{l}\text { Alhambra, } \\
\text { Granada }\end{array}$ & Desconocida & R10991 \\
\hline Cascabel & $\begin{array}{l}\text { Alhambra, } \\
\text { Granada }\end{array}$ & Desconocida & R10993 \\
\hline Cascabel & $\begin{array}{l}\text { Alhambra, } \\
\text { Granada }\end{array}$ & Desconocida & R10997 \\
\hline Cascabel & $\begin{array}{c}\text { Alhambra, } \\
\text { Granada }\end{array}$ & Desconocida & R11002 \\
\hline Cascabel & $\begin{array}{c}\text { Alhambra, } \\
\text { Granada }\end{array}$ & Desconocida & R11003 \\
\hline Cascabel & $\begin{array}{l}\text { Alhambra, } \\
\text { Granada }\end{array}$ & Desconocida & R11005 \\
\hline Cascabel & $\begin{array}{c}\text { Alhambra, } \\
\text { Granada }\end{array}$ & Desconocida & R11006 \\
\hline Cascabel & $\begin{array}{l}\text { Alhambra, } \\
\text { Granada }\end{array}$ & Desconocida & R11008 \\
\hline Cascabel & $\begin{array}{l}\text { Alhambra, } \\
\text { Granada }\end{array}$ & Desconocida & R11009 \\
\hline
\end{tabular}




\begin{tabular}{|c|c|c|c|}
\hline Cascabel & $\begin{array}{c}\text { Alhambra, } \\
\text { Granada }\end{array}$ & Desconocida & R11010 \\
\hline Cascabel & $\begin{array}{c}\text { Alhambra, } \\
\text { Granada }\end{array}$ & Desconocida & R11011 \\
\hline Cascabel & $\begin{array}{c}\text { Alhambra, } \\
\text { Granada }\end{array}$ & Desconocida & R11012 \\
\hline Cascabel & $\begin{array}{c}\text { Alhambra, } \\
\text { Granada }\end{array}$ & Desconocida & R11013 \\
\hline Cascabel & $\begin{array}{c}\text { Alhambra, } \\
\text { Granada }\end{array}$ & Desconocida & R11014 \\
\hline Cascabel & $\begin{array}{c}\text { Alhambra, } \\
\text { Granada }\end{array}$ & Desconocida & R11015 \\
\hline Cascabel & $\begin{array}{c}\text { Alhambra, } \\
\text { Granada }\end{array}$ & Desconocida & R11016 \\
\hline Cascabel & $\begin{array}{c}\text { Alhambra, } \\
\text { Granada }\end{array}$ & Desconocida & R11019 \\
\hline Cascabel & $\begin{array}{c}\text { Alhambra, } \\
\text { Granada }\end{array}$ & Desconocida & R11020 \\
\hline Cascabel & $\begin{array}{c}\text { Alhambra, } \\
\text { Granada }\end{array}$ & Desconocida & R11018 \\
\hline Cascabel & $\begin{array}{c}\text { Alhambra, } \\
\text { Granada }\end{array}$ & Desconocida & R11017 \\
\hline $\begin{array}{c}\text { Platillo } \\
\text { (címbalo) }\end{array}$ & $\begin{array}{c}\text { Alhambra, } \\
\text { Granada }\end{array}$ & Desconocida & R10985 \\
\hline $\begin{array}{c}\text { Platillo } \\
\text { (címbalo) }\end{array}$ & $\begin{array}{c}\text { Alhambra, } \\
\text { Granada }\end{array}$ & Desconocida & R10986 \\
\hline
\end{tabular}




\section{Conclusiones}

La organología, siendo una fuente tangible dentro de un arte etéreo, es una importante herramienta a tener en cuenta cuando se realiza una investigación sobre la música en general y específicamente sobre las culturas antiguas. A través de los códices de los sabios andalusíes de la época, en numerosas ocasiones, se ha intentado reconstruir la historia sumándole la tradición oral que trasciende a través del tiempo. La posibilidad de acceder a estas importantes piezas testigos de las costumbres de la época resulta esencial para poder tener una visión global de lo que fue la música en al-Andalus. Es, por este motivo, por lo que esta investigación comenzó sus andaduras, con la finalidad de recopilar todos los instrumentos musicales que hasta el momento han aparecido en las distintas excavaciones arqueológicas y darlos a conocer.

Se han visitado los distintos museos de temática arqueológica, se ajusten o no a la época, para poder dar con especialistas, arqueólogos y arqueólogas, lo que ha permitido recopilar un total de ciento cuarenta y dos instrumentos musicales. De éstos, cincuenta y dos son silbatos, veintiuno son membranófonos, veinticuatro catalogados o mencionados en alguna investigación como aerófonos y cuarenta y cinco son idiófonos. Esta cantidad de piezas puede incrementarse con el paso del tiempo, gracias a la activa labor arqueológica que existe actualmente en Andalucía, de la que se documentaron setenta y dos yacimientos arqueológicos andalusíes en 2009 por Jesús Pérez Ordóñez ${ }^{775}$, cantidad que ha ido en aumento a lo largo de estos años.

Una vez recopilados los instrumentos musicales se han catalogado mediante fichas adaptadas a este tipo de colección, donde se han podido detallar los datos concretos de cada una de estas piezas. Igualmente, en el grueso del texto aparecen las características comunes y posibles clasificaciones para su estudio.

Además de los instrumentos musicales se han recopilado, estudiado y catalogado dieciséis imágenes de las que se tienen la certeza o se piensan que pudieron proceder del territorio andaluz en la época. Asimismo, se ha incluido iconografía musical de las mismas fechas que se dieron en otros lugares con la finalidad de comparar y contextualizar los distintos instrumentos musicales que en excavaciones arqueológicas podrían llegar a encontrarse.

\footnotetext{
775 “Al-Andalus. Yacimientos arqueológicos" http://digital.csic.es/bitstream/10261/9627/1/YACIMIENTOS\%20DE\%20ALANDALUS.pdf (Última consulta 15-01-2019).
} 
Desgraciadamente, una gran parte de los instrumentos musicales se realizaban con materiales perecederos, por lo que no suelen llegar hasta nuestros días. Esta línea de estudio arqueomusicológico que aquí se plantea y que abarca desde los sabios andalusíes, a la iconografía musical y los restos arqueológicos, se ve sesgada para este tipo de instrumentos. En cambio, esta retroalimentación de estos tres campos se ve beneficiada en el caso de los instrumentos realizados con metal o arcilla, ya que arrojan nuevos datos a los que los documentos escritos y la tradición oral prestaban inicialmente, como es el caso de los silbatos y tamborcillos.

De los sibatos que llegan hasta nuestros días, existieron debates entre juristas de la época que se planteaban la idoneidad del uso de estos instrumentos. A pesar de ello, puede comprobarse que su uso no llegó a perderse ya que se conservan piezas pertenecientes a todos estos siglos, desde el IX al XV, e incluso se cuenta con una importante representación iconográfica en la Sala de los Reyes de la Alhambra, donde puede además contextualizarse uno de los escenarios en los que estos tenían cabida, como era la caza. Esta imagen, además, confirma que los silbatos solían estar en manos de infantes y justificaría sus representaciones zoomorfas al ser utilizados como reclamo. No serán éstas las únicas formas que se encontrarán en estos instrumentos, ya que también se han hallado antropomorfos y otros con un modelado más sencillo. Esta importante variedad y numerosa presencia otorga mayor protagonismo a estos instrumentos que tan desapercibidos habían pasado a lo largo de la historia. Asimismo, gracias a la documentación arqueológica durante las excavaciones, se ha podido conocer que la mayor parte de ellos se han encontrado enlazados a ámbitos domésticos. Al ser instrumentos muy humildes y seguramente muy comunes en la sociedad, han llegado a encontrarse, igualmente, en vertederos y entre los materiales de construcción de edificaciones de la época.

Otro de los instrumentos que se ven beneficiados por la línea documental: tratadistas, iconografía y arqueología, son los tamborcillos. De estos se conserva numerosa terminología en los tratados, pero por desgracia las descripciones no se realizaron de forma tan exhaustiva como para diferenciar actualmente qué término corresponde con cada modelo. La iconografía aporta información sobre su forma de ejecución como reflejan fuentes cristianas y musulmanas. El tamaño de los tamborcillos ha suscitado gran debate entre los estudiosos, ya que en un principio incluso fueron enlazados, al igual que los silbatos, a los infantes, pero gracias a la comparativa etnológica y el trabajo de campo en zonas afines a esta antigua cultura, 
como Marruecos, se confirma su enlace con la figura de la mujer. A este respecto, son varias las referencias de los sabios andalusíes que los relaciona con la mujer, ya que los interpretaría durante festividades como podrían ser las bodas. Incluso cabe la posibilidad de que pudieran ser fabricados también por las mujeres tal y como es tradición en algunos lugares de Marruecos, pero a día de hoy no existe ningún documento que así lo corrobore, por lo que deberá mantenerse latente este campo ante posibles novedades documentales que puedan surgir.

Igualmente, al revisar los trabajos de investigadores esenciales en este campo de la arqueomusicología andalusí como es Farmer, éste trabaja con distintos términos referidos a los tambores donde existen varios casos que recuerdan a la iconografía musical reflejada en la Pila de Játiva, en la que se observa un bimembranófono. Esta tipología es relacionada por este arabista y musicólogo con el término kuba refiriéndose a tambores con forma de reloj de arena que son percutidos por ambos lados.

Por otro lado, llegan a través de las excavaciones arqueológicas tubos con distintos largos y agujeros a lo largo de su cuerpo que han sido clasificados por los arqueólogos y arqueólogas como posibles flautas. Este arduo debate lleva años vigente llegando incluso a contemplar entre las hipótesis de uso planteadas de estas piezas la posibilidad de ser un mástil de un cordófono. Ante esta situación, en esta investigación se ha optado por evaluar las posibilidades sonoras de estos instrumentos mediante representaciones en caña. Por supuesto, no resultan unas copias totalmente fidedignas de las piezas, ya que las cañas cuentan con un grosor y diámetros distintos a las piezas representadas, pero esto no debería impedir la comprobación de sus posibilidades sonoras. Después de realizar, por lo tanto, estas reproducciones, se ha intentado evaluar su viabilidad no consiguiendo obtener sonido alguno a pesar de taponar con cera de abejas alguno de los agujeros, como así indicaban los tratadistas. Igualmente, se ha trazado una comparativa etnológica con flautas que son utilizadas actualmente en Argelia, pero ni el número de agujeros ni la disposición de estos coincide con ninguna de estas piezas. La información más concreta que nos llega de las flautas se da de la mano de sabios como al-Farabi, quien aporta datos sobre estos aerófonos que no coinciden con la distribución de orificios en ninguna de ellas. Queda, por lo tanto, la duda sobre si estas piezas, realizadas en hueso, pudieron tener otro uso incluso no musical. De igual manera, se descarta que ciertas piezas que pudieron ser utilizadas en la época como fichas de ajedrez o partes de una rueca 
tengan posibilidades sonoras y por lo tanto puedan ser consideradas instrumentos musicales. Esta catalogación errónea sucedida igualmente en Marruecos se ve tajantemente descartada al no contar ninguna de las piezas con un bisel, siendo los orificios de las piezas, posiblemente, simples adornos.

En el caso de los idiófonos son pocos ejemplares los que llegan a través de los yacimientos, siendo campanas y cascabeles los encontrados. Las campanas, relacionadas con la religión cristiana, parece que pudieron crear controversias en su uso por parte de los seguidores de la religión musulmana, lo que sí se confirma una vez más, es que ambas creencias convivían de forma pacífica como muestra el grabado de la campana mozárabe encontrada en Huelva. Las campanas de arcilla, igualmente, pudieron estar más relacionadas con la religión cristiana y que su presencia se impulsase a partir del siglo XV. En el caso de las campanas de metal, siendo además de pequeño tamaño, posiblemente estuvieron relacionadas con animales domésticos. Esta hipótesis se ve también confirmada a través del hallazgo de la campana zaragozana de similares características a la encontrada en Priego de Córdoba, la cual se descubrió junto a los restos de un gato, coincidiendo su localización con el cuello del animal, lo que recuerda al clásico objeto sonoro adosado a estos sigilosos felinos. Asimismo, los tratadistas árabes hacen referencia a este tipo de instrumentos adheridos a la vestimenta de animales durante la batalla con la finalidad de intimidar al enemigo.

Por último, el vaciado de datos con referencia a los instrumentos musicales en los tratados andalusíes que se incluyen en esta investigación confirma la variedad e importancia de estos instrumentos en la sociedad andalusí. El peso de los mismos se comprueba a través de las restricciones por parte de los juristas al estar, por ejemplo, enlazados a festividades que podían incitar al consumo de bebidas alcohólicas. Asimismo, la segregación de los instrumentos por género queda igualmente reflejada por estos sabios que especifican quiénes no podían interpretar determinados instrumentos, como cierta variedad de pandero, pudiendo ser tachados los hombres de "afeminados" por hacerlo en público. Tanto los panderos como los tambores no militares quedarían enlazados, de forma general, con la figura femenina.

Todo este recorrido a través de la organología andalusí pone al mismo tiempo en valor el patrimonio cultural de esta Comunidad Autónoma, caracterizada por su rica arquitectura andalusí que más allá de satisfacer al observador, arroja importantes datos históricos. Estas piezas exponen los sucesos en estos lugares llenándolos de 
vida, y revelan costumbres y tradiciones más cercanas a culturas actuales, como la andaluza, de lo que a simple vista pudiese parecer. 


\section{Bibliografía}

Aa.vv. Músicas En la Antigüedad. Madrid: Obra Social "la Caixa”, 2018.

“Abes. Agence Bibliographique de L'enseignement Supérieur," http://es.abes.fr/Sudoc/Sudoc-catalogo (Última consulta: 18-10-2019)

Absolon, Kalen. "Les Flûtes Paléolithiques de l'Aurignacien et du Magdalénien de Moravie, Analyse Musical et Ethnologique Comparative Avec Démonstration". In Congrès Préhistorique de France, Compte-Rendu de La XIIe Session, 770-84. Toulouse: 1937.

“Academia.edu”. academia.edu (Última consulta: 10-02-2020).

Agricola, Martin. Musica Instrumentalis Deudsch. Wittenberg: Georg Rhaw, 1529.

Aguadé, Jordi. "Sobre los Gnawa y su origen". Estudios de dialectología norteafricana y andalusí, 4, 1999.

Akasoy, Anna. "Ibn Sab'in”. En Enciclopedia de La Cultura Andalusí, Vol. 5, 29-38. Fundación Ibn Tufayl de estudios árabes, 2004.

“Al-Andalus. Yacimientos arqueológicos" http://digital.csic.es/bitstream/10261/9627/1/YACIMIENTOS\%20DE\%20ALA NDALUS.pdf(Última consulta 10-02-2020).

Álvarez Martínez, Rosario. "Iconografía Musical y Organología: Un estado de la Cuestión”. En Revista de Musicología, Ejemplar Dedicado Al IV Congreso de La Sociedad Española de Musicología. La Investigación Musical En España, 76782. Madrid, 1997.

- "Incidencia de una forma de trabajo en la representación de los instrumentos musicales: la copia de códices en la Edad Media”. Nassarre: Revista Aragonesa de Musicología 23, 1 (2007): 53-86.

—. "La Iconografía Musical de Los Beatos de Los Siglos X y XI y Su Procedencia". Anuario del Departamento de Historia y Teoría del Arte $\mathrm{n}^{0} 5$ (1993): 201-18.

—_ "Los Instrumentos musicales en los Códices Alfonsinos: su tipología, su uso y su origen. Algunos problemas iconográficos”. Revista de Musicología X, n 1 (1987): 67-104.

- "Música y pintura promovidas por un sabio monarca: las imágenes musicales de los códices alfonsinos entre el testimonio de la vida musical de su corte y el pensamiento artístico de sus pintores". En M. PÁEZ, Ars Musica de Juan Gil de Zamora. Murcia: Real Academia de Bellas Artes de Santa María de la Arrixaca, 
LIII-CLXX, 2, 2010.

. "Los Instrumentos Musicales de al-Andalus en la Iconografía Medieval Cristiana". En Música y Poesía del Sur de al-Andalus, 93-124. Granada-Sevilla, 1995.

—. "Iconografía de la "guitarra" medieval, su origen centroasiático y sus derivados europeos". En El sonido de la Piedra. Actas del encuentro sobre instrumentos en el Camino De Santiago, (2005): 223-280.

Álvarez, Rosario y Guillermo Rosselló Bordoy. "Hallazgo de Tambores de la España Islámica (Siglos IX-XIV)”. Revista de Musicología XII, n² (1989): 411-21.

Andrés, Ramón. Diccionario de Instrumentos Musicales. Desde La Antigüedad a J.S. Bach. Barcelona: Ediciones Península, 2009.

—. Diccionario de Música, Mitología, Magia y Religión. Barcelona: Acantilado, 2012.

"Anuario Arqueológico de Andalucía", https://www.juntadeandalucia.es/organismos/culturaypatrimoniohistorico/areas/b ienes-culturales/actividades-arqueologicas/anuario-arqueologico.html (Última consulta 10-02-2020).

Aparicio Sánchez, Laura y Encarnación Cano Montoro. "Fragmento cerámico con decoración antropomorfa en verde y manganeso hallado en el Arrabal de 'El Fontanar' ( Córdoba )". Antiquitas 22 (2010): 183-96.

Arianna, D'Ottone. "Il Manoscritto Vaticano Arabo 368, Hadit Bayad Wa Riyad. Il Codice, Il Testo, Le Immagini”. Rivista Di Storia Della Miniatura 14 (2010): $55-70$.

—. La Storia Di Bayad e Riyad (Vat. Ar. 368): Una Nuova Edizione e Traduzione, 2013.

Ariza Rodríguez, Francisco Javier. “A.A.P. En La Avd. de Las Ollerías, No16, de Córdoba". Anuario Arqueológico de Andalucía 1 (2004): 521-31.

"Arqueta Museo Victoria \& Albert", http://collections.vam.ac.uk/item/O70461/casket-unknown/. (Última consulta: 10-02-2020).

Asensio, $\mathrm{M}^{\mathrm{a}}$ Soledad e Inmaculada Morales. "Instrumentos Musicales de Barro Cocido En Andalucía (I). Aerófonos”. Música Oral Del Sur 2 (1996): 85-186.

Asín Palacios, Miguel. "Tratado de Avempace sobre la unión del Intelecto con el hombre". Al-Andalus: Revista de Las Escuelas de Estudios Árabes de Madrid y 
Granada VII (1942): 1-47.

Ávila Navarro, María Luisa. "La Sociedad”. En Historia de España. Ramón Menéndez Pidal. Tomo VIII Los Reinos de Taifas Al-Andalus en el Siglo XI, 301-95. Madrid: Espasa-Calpe, 1994.

Baena, Javier, Consolación Casarrubios e Isabel Rubio de Miguel. "Etnoarqueología y Música: Flautas y Silbatos Primitivos". Separata de La Revista de Musicología XX, 2 (1997): 867-74.

Barrera Maturana, José Ignacio. “Grafitos Históricos en la Casa Morisca de Calle San Martín, 16 (Granada)”. Arqueología y Territorio Medieval 15 (2008): 91-126.

Barrucand, Marianne. "El Arte Del Califato Fatimí: ¿Arte Mediterráneo o Arte Oriental?". En La Aljafería y el Arte del Islam Occidental en el siglo XI, 2012.

Bermudo, Fray Juan. Declaración de Instrumentos Musicales. Osuna: Juan de León, 1555 .

Bernis Madrazo, Carmen. "Las Pinturas de la Sala de los Reyes de La Alhambra: Los Asuntos, Los Trajes, La Fecha”. Cuadernos de La Alhambra 18 (1982): 21-50.

Beyhom, Amine, and Hamdi Makhlouf. "Frettage Du 'ud (Luth Arabe) Dans La Théorie Musicale Árabe et Influence Sur La Pratique”. En Congres Interdisciplinaire de Musique (CIM), 53. París, 2009.

"Biblioteca Digital Musical”, http://biblioteca-musical.weebly.com/. (Última consulta 10-02-2020).

Bill, Alexandra, Raquel Jiménez Pasalodos y Carlos García Benito. “A Classification of Clay Drums from Al-Andalus (9th-14th Centuries AD)". En Proceedings of the 16th Symposium on Mediterranean Archaeology, II: 893-94, 2012.

Biot, Édouard. No Le Tcheou-Li Ou Rites Des Tcheou. Editado por L'Impremerie Nationale. Paris.

Bordas Ibáñez, Cristina. Instrumentos Musicales en Colecciones Españolas: Museos de Titularidad Estatal, Ministerio de Educación y Cultura (Vol. 1). Madrid: Centro de Documentación de Música y Danza. INAEM, 1999.

- Instrumentos Musicales en Colecciones Españolas: Museos de Titularidad Estatal (Vol. II). Ministerio. Madrid: Centro de Documentación de Música y Danza - INAEM, 2001.

—. "Los Instrumentos Musicales y Sus Colecciones: Nuevas Perspectivas Desde La Organología y La Museología”. En La Gestion Del Patrimonio Musical. Situación Actual y Perspectivas de Futuro, 83-90. Madrid: Centro de 
Documentación de Música y Danza. INAEM, 2014.

Bordas Ibáñez, Cristina y Elena Vázquez. Las Colecciones de Instrumentos Musicales y su Valor Patrimonial. España En El Contexto Internacional en Colecciones de Instrumentos Musicales. Recomendaciones Para Su Gestión. Madrid: Centro de Documentación de las Artes Escénicas y la Música. INAEM, 2019.

"Bote de Zamora", http://www.man.es/man/coleccion/catalogo-cronologico/edadmedia/bote-zamora.html. (Última consulta: 10-02-2020).

"Bote Ziyad”, http://collections.vam.ac.uk/item/O76682/pyxis-unk (Última consulta 10-02-2020).

"Botella de los Músicos", http://ceres.mcu.es/pages/ResultSearch?txtSimpleSearch=C/\%20Alfonso\%20X $\% 20 \mathrm{el} \% 20$ Sabio\&simpleSearch=0\&hipertextSearch=1\&search=simpleSelection \&MuseumsSearch=MAECO\%7C\&MuseumsRolSearch=2\&listaMuseos=[Muse o\%20Arqueol\%F3gico\%20y\%20Etnol\%F3gico\%20de\%20C\%F3rdoba] (Última consulta: 10-02-2020).

Bourges, Maurice. "L'archeologie Musicale”. Revue et Gazatte Musicale. 1848.

Cámara de Landa, Enrique. Etnomusicología. Madrid: Instituto Complutense de Ciencias Musicales. ICCMU, 2004.

Campos Paulo, Luís. “O Simbolismo Da Purificaçao. O 'Vaso de Tavira': Iconografia e Interpretaçao". Revista Portuguesa de Arqueología 10 (2007): 289-316.

Capdepón Verdú, Paulino. "Felipe Pedrell Sabaté", http://dbe.rah.es/biografias/8205/felipe-pedrell-sabate. (Última consulta 10-022020).

“Capitel de los Evangelistas", http://ceres.mcu.es/pages/ResultSearch?txtSimpleSearch=Capitel de los Evangelistas\&simpleSearch $=0 \&$ hipertextSearch $=1 \&$ search $=$ simpleSelection\&M useumsSearch=MAECO \%7C\&MuseumsRolSearch=2\&listaMuseos $=[$ Museo Arqueol\%F3gico y Etnol\%F3gico de C\%F3rdoba]. (Última consulta: 10-022020).

“Capitel de los Músicos", http://ceres.mcu.es/pages/ResultSearch?txtSimpleSearch=Capitel\%20de\%20los $\% 20 \mathrm{M} \%$ FAsicos\&simpleSearch $=0 \&$ hipertextSearch $=1 \&$ search $=$ simpleSelection $\&$ MuseumsSearch=MAECO\%7C\&MuseumsRolSearch=2\&listaMuseos=[Muse o\%20Arqueol\%F3gico\%20y\%20Etnol\%F3gico\%20de\%20C\%F3rdoba] (Última 
consulta: 10-02-2020).

Casares Rodicio, Emilio, Ismael Fernández de la Cuesta y José López-Calo. Diccionario de la Música Española e Hispanoamericana. Fundación Autor. Sociedad Genral de Autores y Editores, 1999.

Casula di Thomas Becket. http://www.museodiocesanofermo.it/la-casula/ (Última consulta: 10-02-2020).

Cerone, Pietro. El Melopeo y Maestro: Tractado de Musica Theorica y Pratica. Nápoles: Juan Bautista Gargano y Lucrecio Nucci, 1613.

Chase, Philip G. y April Nowell. "Taphonomy of a Suggested Middle Palaeolithic Bone Flute from Slovenia”. Current Anthropology 39 (1998): 549-53.

Chottin, Alexis. Tableau de La Musique Marocaine. París: P. Geuthner, 1939.

Ciampini, Laura. "La Capa de Fermo: Un Bordado de Al-Andalus". Arte y cultura: patrimonio hispanomusulmán en Al-Andalus, 2009.

Conner, William J., Milfie Howell y Robert Atayan. "Naqqara". Grove Music Online, Oxford University Press, 2001. https://www.oxfordmusiconline.com/grovemusic/view/10.1093/gmo/978156159 2630.001.0001/omo-9781561592630-e-0000019571? (Última consulta: 10-022020).

Conner, William J., Milfie Howell y Tony Langlois. "Darabukka". Grove Music Online, Oxford University 2001. https://www.oxfordmusiconline.com/grovemusic/view/10.1093/gmo/978156159 2630.001.0001/omo-9781561592630-e-0000007209?rskey=hn914g (Última consulta: 10-02-2020).

Cortés García, Manuela. "Escuelas Musicales Andalusíes y Magrebíes: Perfiles y Sistemas Pedagógicos". Revista del Centro de Estudios Históricos de Granada y su Reino, no. 23 (2012): 31-65.

_. "Estatus de la Mujer en la Cultura Islámica. Las Esclavas-Cantoras (ss.IXXIX)". Mujer versus Música. Colección Feminismo Musical, Editorial Rivera Mota (2011): 139-98.

_. "Fuentes Escritas para el Estudio de la Música en al-Andalus (Siglos XIIIXVI)”. En Fuentes Musicales en la Península Ibérica, editada por Maricarmen Gómez y Màrius Bernadó, 289-304. Lleida, 2002.

—. "La Música, los Instrumentos y las Danzas Andalusíes y Moriscas en las Fuentes Árabes y Cristianas (ss. IX-XVII)”. Cuadernos del CEMYR 25 (2017): 
147-90.

- La Música Árabe y Andalusí de las dos Orillas en los Estudios

Musicológicos (Ss. XVIII-XXI). Málaga: Ediciones del Genal, 2018.

- "La Música en la Andalucía Islámica”. Andalucía en la Historia, 2019, 8-12.

—. La Música en la Zaragoza Islámica. Zaragoza: Instituto de Estudios Islámicos y del Oriente Próximo, 2009.

—. Música y Poesía en el Esplendor Omeya. Córdoba: Ayuntamiento y Fundación Foros de Córdoba, 2001.

—. "Nuevos datos para el Estudio de la Música en al-Andalus de dos autores

Granadinos: As-Sustárí e Ibn Al-Jatíb”. Música Oral del Sur: Revista Internacional, 1995, 177-94.

—. "Organología Oriental en al-Andalus". Separata de: Boletín de La Asociación Española de Orientalistas, 1990, 303-32.

_. Pasado y Presente de la Música Andalusí. Sevilla: El Monte, 1996.

- "Sobre la música y sus efectos terapéuticos en la Epístola sobre las Melodías de Ibn Bayya”. Separata de la Revista de Musicología XIX, no. 12 (1996): 1123.

—. "Tratados Musicales Andalusíes de la Escuela Levantina y Aportaciones al Marco Interdisciplinar (ss. XI-XIII)". ITAMAR. Revista de Investigación Musical: Territorios Para El Arte 1, Facultad de Filosofía y Ciencias de la Educación. Universitat de València (España) (2008): 178-202.

—. "La Música Andalusí en el Reino de Granada”. En La Música Andalusí en el Reino de Granada, 5-37. Fundación Pública Andaluza Centro de Estudios andaluces. Consejería de la Presidencia e Igualdad. Junta de Andalucía, 2012.

Cortés García, Manuela y Marcos González Berlanga. "Ibn Al-Darray”. En Enciclopedia de La Cultura Andalusí: Apéndice, 169. Fundación Ibn Tufayl de estudios árabes, 2012.

Crivillé i Bargalló, Josep. Historia de La Música Española. 7. El Folklore Musical. Madrid: Alianza musical, 2004.

D’Erlanger, Rodolphe. Al-Farabi. La Musiqe Arabe. Edited by Les Geuthner. París: Société nouvelle librairie orientaliste Paul Geuthner, S.A., 1935.

Danielson, Virginia, Dwight Reynolds y Scott Marcus. "The Middle East". En The Garland Encyclopedia of Word Music, 2002.

“Dart-Europe,” http://www.dart-europe.eu/basic-search.php. (Última consulta: 10-02- 
2020).

"Dialnet", https://dialnet.unirioja.es/. (Última consulta: 10-02-2020)

Dick, Alastair, Christian Poché, Jack Percival, Baker Dobbs, Margaret J. Kartomi, Jean During y John Baily. "Rabab", 2001. https://www.oxfordmusiconline.com/grovemusic/view/10.1093/gmo/978156159 2630.001.0001/omo-9781561592630-e-0000022763?print=pdf.

(Última consulta: 10-02-2020).

Diedrich, Cajus G. "Neanderthal Bone Flutes': Simply Products of Ice Age Spotted Hyena Scavenging Activities on Cave Bear Cubs in European Cave Bear Dens". Royal Society Open Science 2 (2015).

Dumbrill, Richard y Irving Finkel, eds. Proceedings of the Internacional Conference of Near Easten Archaeomusicology. London: ICONEA publications, 2010.

During, Jean. "Drums, Large Group of Percussion Instruments". Encyclopaedia Iranica, http://www.iranicaonline.org/articles/drums. (Última consulta: 10-022020).

Escudero, Francisco. "Los Tambores Musulmanes del Alfar de La Calle San Pablo". Saldvie: Estudios de Prehistoria y Arqueología, no. 11 (2012): 147-74.

Espinar Moreno, Manuel. "Instrumentos Musicales de Barro: Silbatos Zoomorfos, Antropomorfos y Otros Vestigios Musicales”. Música Oral Del Sur: Revista Internacional 2 (1996): 63-84.

"Estatuilla de un músico". https://www.qantaramed.org/public/show_document.php?do_id=1088\# (Última consulta: 10-022020).

"European Music Archaeology Project (EMAP)", http://www.emaproject.eu/emap/description.html. (Última consulta: 10-022020).

Farmer, Henri George. "Was the Arabian and Persian Lute Fretted?" Journal of the Royal Asiatic Society 69 (1937): 453-60.

Farmer, Henry George. A History of Arabian Music to the XIIIth Century. Luzac, 1929.

-. "A Maghribi Work on Musical Instruments". En Studies in Oriental Musical Instruments, 19-35. Glasgow: The civic press, 1939.

—. "A Note on the Mizmar and Nay". Journal of the Royal Asiatic Society 61, 1 (1929): 119-21. 
. "An Old Moorish Lute Tutor". Journal of the Royal Asiatic Society of Great Britain \& Ireland, 64, 1932, 379-89.

. “Arabian Musical Instruments". En Studies in Oriental Musical Instruments, 65-68. Glasgow: The civic press, 1939.

—. "Arabian Musical Instruments on a Thirteenth Century Bronze Bowl". Journal of the Royal Asiatic Society 82 (1950): 110-11.

- "Early References to Music in Western Sudan". En Oriental Studies: Mainly Musical, 1-13. Londres: Stephen Austin and Sons, 1953.

- Historical Facts for the Arabian Musical Influence. Londres: Villiam Reeves, 1930.

_. "Instruments of Music on Taq-i Bustan Bas-Reliefs". En Studies in Oriental Musical Instruments, 70-85. Glasgow: The civic press, 1939.

_. "Meccan Musical Instruments". En Studies in Oriental Music Vol. 2, 77-87. Londres: Longwood Press, 1931.

—. "Music: The Priceless Jewel. From the Kitab Al-'iqd Al-Farid of Ibn 'Abd Rabbihi (d. 940). Edited and Translated”. En Studies in Oriental Music, 1-27. Frankfurt: Institut für Geschichte der Arabisch-Islamischen Wissenschaften, 1986.

- "Ninth Century Musical Instruments". En Studies in Oriental Musical Instruments: First and Second Series. Boston: Longwood Press, 1978.

- Studies in Oriental Music Vol. 2. Frankfurt am Main, Institut fur geschicte der Arabisch- Islamichen wissenschaften an der Johann Wofgang Goethe Universitat, 1986.

- The Arabic Musical Manuscripts in the Bodleian Library: A Descriptive Catalogue with Illustrations of Musical Instruments. W. Reeves, 1925.

—. "The Lute Scale of Avicenna". The Journal of the Royal Asiatic Society of Great Britain and Ireland, $N^{\circ} 2,1937,245-57$.

_. "The Minstrelsy of the Arabian Nights". En Studies in Oriental Music Vol. 1, editado por Eckhard Neubauer, 59-98. Frankfurt: Institute for the History of Arabic-Islamic Science at the Johann Wolfgang Goethe University Frankfurt am Main, 1986.

—. "The Music of Islam". En The New Ixfird History of Music: Ancient and Oriental Music. New York: Oxford University Press, 1986.

- "The Origin of the Arabian Lute and Rebec". The Journal of the Royal 
Asiatic Society of Great Britain and Ireland, $N^{\circ} 4,1930,767-83$.

. "The Origin of the Eschaquiel". En Studies in Oriental Musical Instruments,

19-23. Londres: Longwood Press, 1931.

- "The Structure of the Arabian and Persian Lute in the Middel Ages". The Journal of the Royal Asiatic Society of Great Britain and Ireland, $N^{\circ} 1,1939,41-$ 51.

- "Turkish Instruments of Music in the Seventeenth Century: As Described in the Siyahat Nama of Ewliya Chelebi”. En Studies in Oriental Music. Frankfurt: Institut fur geschicte de Arabisch-Islamichen wissenschaften an der Johann Wofgang Goethe Universitat, 1986.

Farmer, Henry George y E Neubauer. Studies in Oriental Music, Vol. 1. Frankfurt: Institute for the History of arabic-islamic Science at the Johann Wolfgang Goethe University, 1997.

Farmer, Henry Georges. “Tabl”. En Encyclopaedia of Islam, Vol. X, edited by Brill Leiden, 2003.

—. The Arabian Influence on Musical Theory. Londes, 1925.

—. "The Mediaeval Psaltery in the Orient". En Studies in Oriental Musical Instruments. Londres: Longwood Press, 1931.

Faruqi, Lois Ibsen. An Annotated Glossary of Arabic Musical Term. United Estates of America: Greenwood Press, 1981.

Feliciano Chaves, María Judith. "Muslim Shrouds for Christian Kings? A Reassessment of Andalusi Textiles in Thirteenth-Century Castilian Life and Ritual". En Under the influence: Questioning the comparative in Medieval Castile (2005).

Fernádez Manzano, Reynaldo. "Introduccion al Estudio de los Instrumentos Musicales de Al-Andalus". Cuadernos de Estudios Medievales y Ciencias y Técnicas Historiográficas 12.13 (1983): 47-77.

—. “Árabe, Música”. En Diccionario de la Música Española e Hispanoamericana, ed. Emilio Casares Rodicio, Madrid: Sociedad General de Autores y Editores, (1999): 505-20

-."Avempace (Abu Bakr Muhammad Ibn Yayà Ibn al-Sa'ig Ibn Baya). En Diccionario de la Música Española e Hispanoamericana, V.1. Madrid: 1999, 880-881.

. "Ibn Baya: músico, teórico y filósofo de Zaragoza, en la segunda mitad del s. 
XI y primer tercio del siglo XII". Nassarre: Revista aragonesa de musicología $3.2,1987,19-25$.

. "Diversos aspectos sobre los Cordófonos en Al-Andalus y la Etapa Morisca". Revista de Musicología 16, 3 (1993): 1373-93.

—. "Instrumentos Musicales en Al-Andalus". El Saber en Al-Andalus Vol. 1 (1997): 101-36.

- "Gnawa". Granada hoy, 29 de diciembre 2019, https://www.granadahoy.com/opinion/articulos/Gnawa_0_1423357734.html

(Última consulta: 10-02-2020).

—. "La Música de al-Andalus en su Marco Interdisciplinar. Aspectos Metodológicos”. Gazeta de Antropología 1 (1982). https://www.ugr.es/ pwlac/G01_06Reynaldo_Fernandez_Manzano.html.

(Última consulta: 10-02-2020).

—. Música de Al-Andalus. Granada: Universidad de Granada, 2016.

Fernández Manzano, Reynaldo, M ${ }^{\text {a }}$ Soledad Asensio Cañadas e Inmaculada Morales Jiménez. Instrumentos Musicales de Barro en Andalucía. Piel y Barro (III). Andalucía, https://www.youtube.com/watch?v=jmVLybsC5zQ. (Última consulta 10-02-2020).

Fernández Manzano, Reynaldo, $M^{\mathrm{a}}$ Soledad Asensión Cañadas e Inmaculada Morales Jiménez. Instrumentos Musicales de Barro en Andalucía. Aire y Barro (II). Andalucía, https://www.youtube.com/watch?v=foBFc3XY-ak\&t=22s. (Última consulta 10-02-2020).

- Instrumentos Musicales de Barro en Andalucía. El Ritmo Del Barro (I). Andalucía, https://www.youtube.com/watch?v=9sUwaWidDZY. (Última consulta $10-02-2020)$.

Fernández Manzano, Reynaldo y Emilio de Santiago. Música y Poesía del Sur de AlAndalus. Granada: Fundación El Legado Andalusí, 1995.

Fernández Puertas, Antonio. Alhambra. Muhammad V. El Mawlid de 764/ 1362. Granada: Almed, 2018.

Ferrandis, José. Marfiles Árabes de Occidente. Tomo I. Madrid: Facultativo de Archiveros, Bibliotecarios y Arqueólogos, 1935.

- Marfiles Árabes de Occidente. Tomo II. Madrid: Facultativo de Archiveros, Bibliotecarios y Arqueólogos, 1940.

—. Marfiles y Azabaches Españoles. Barcelona-Buenos Aires: Editorial Labor, 
S.A., 1928.

Fetís, François-Joseph. Histoire Generale de La Musique Dépuis Les Temps Les plus Anciens Jusqu'a Nos Jours. París: Firmin Didot, 1876.

Fétis, François-Joseph. Histoire Générale de La Musique Depuis Les Temps Les plus Anciens Jusqu'a Nos Jours. Librairie. París: L'institut, 1869.

Fierro, Maribel. “Al-Turtusi, Abu Bakr”. En Enciclopedia de La Cultura Andalusí, Vol. 7, 500. Fundación Ibn Tufayl de estudios árabes, 2012.

Flores Escobosa, Isabel. Vivir En Al-Andalus. Exposición de Cerámica (s.IX-XV). Editado por $\mathrm{M}^{\mathrm{a}}$ del Mar Muñoz Martin. Almería: Instituto de Estudios Almerienses, 1993.

Flores Escobosa, Isabel, María Garrido Garrido, Ma del Mar Muñoz Martín y Manuel Salas Barón. "Juguetes, Silbatos e Instrumentos Musicales en Tierras Almerienses". En del Rito al Juego: Jueguetes y Silbatos de Cerámica desde el islam hasta la Actualidad, 53-71. Junta de Andalucía, 2006.

Fontbona, Francesc. "Cid Priego, Carlos”. Diccionari d'historiadors de l'art català, valencià $i$ balear, https://dhac.iec.cat/dhac_mp.asp?id_personal=202. (Última consulta: 10-02-2020).

Fragmento de la tela en el MET: https://www.metmuseum.org/art/collection/search/448222?searchField=All\&am p;sortBy=Relevance\&amp;ft=vich\&amp;offset=0\&amp;rpp=20\&amp;pos=3 (Última consulta: 10-02-2020).

"François Joseph Fétis", https://www.biografiasyvidas.com/biografia/f/fetis.htm. (Última consulta: 10-02-2020).

"Friso de los Danzantes", https://www.metmuseum.org/art/collection/search/446285?searchField=All\&am $\mathrm{p}$;sortBy=Relevance\&amp; $\mathrm{ft}=\mathrm{al}-$

andalus\&amp;offset=0\&amp;rpp=20\&amp;pos=3 (Última consulta: 10-022020).

Galán y Galindo, Ángel. "Las Arquetas de Trovadores, Canciones, Música y Amor. Desde Bagdad, a los Trovadores Medievales, Pasando por Córdoba". Arte, Arqueología e Historia 18 (2011): 77-106.

Gallardo Carrillo, Juan, María Dolores Párraga Jiménez, Ana Rufina Llorach Asunción y Pedro Pérez Mulero. "Un Conjunto de Silbatos y Figurillas de Época Moderna del Alfar de Avenida Santa Clara (Lorca, Murcia)”. Alberca 9 (2011): 
$135-61$.

Galpin, Francis William. The Music of the Sumerians and Their Immediate Successors the Babylonians \& Assyrians. Vestport (Connecticut): Greenwood, 1970

- The Music of the Sumerians and their Immediate Successors the Babylonians and Assyrians, described and illustrated from Original Sources, 1936.

García Barriuso, Patrocinio. La Música Hispano-Musulmana en Marruecos: Padre Patrocinio García Barriuso; Presentación, Vida y Obra Del Autor, Manuela Cortés García. Instituto Cervantes: Fundación del Monte, 2001.

García Benito, Carlos, Directores: Carlos Mazo Pérez y Luis Prensa Villegas. “Arqueología Musical Prehistórica: Aproximación a través de la Arqueología Experimental Aplicada a la Arqueo-Organología, de la Arqueoacústica y de la Iconografía Musical Prehistórica". Tesis doctoral de la Universidad de Zaragoza, 2014.

García Benito, Carlos y Raquel Jiménez Pasalodos. “Archaeoacoustics, Experimental Archaeology and Music: Theoretical and Methodological Challenges In Music Archaeological Research". En IV Jornadas de Jovens Em Investigação Arqueológica, 409-10, 2011.

—. "La Música Enterrada: Historiografía y Metodología de la Arqueología Musical". Cuadernos de Etnomusicología, 2011, 80-108.

García Benito, Carlos, Raquel Jiménez Pasalodos y Juan Jesús Padilla Fernández. "The Clay Rattles of the Numantine Museum of Soria (Spain). An Approach from Experimental Archaeology". En 8th Symposium of the International Study Group on Music Archaeology in Suzhou and Beijing, 47-63. China, 2012.

García García, Asís. "El Soberano en Al-Andalus”. Revista Digital de Iconografía Medieval, $\mathrm{n}^{\circ}$ 4, (2010): 61-71.

García Gomez, Emilio. Elogio Al Islam Español. Maxtor. Valladolid: Publicaciones de las Escuelas de Estudios Árabes de Madrid y Granada: Serie B. Núm. 2, 2005. García Moreno, Marta, Carlos M. Pimienta y Mario Gros. "Musical Vultures in the Iberian Peninsula: Sounds through Their Wings". En Fathers, Grit and Symbolism. Birds and Humans in the Ancient Old and New Worlds. Proceedings of the 5th Meeting of the ICAZ Bird Working Group in Munich, Verlag Marie Leidorf, Rahden/Westf, editado por Grupe, G, Peters, 327-45. Munich: Documenta Archaeobiologiae, 2005. 
García Porras, Alberto. La Cerámica del Poblado Fortificado Medieval de "El Castillejo” (Los Guájares, Granada). Athos-Pérgamos, 2001.

Gaya, Juan Antonio. Escultura Ibérica. Madrid: Aguilar, 1964.

Gétreau, Florence. "Quelques Cabinets d'instruments de Musique Au Temps Des Rois Bourbons”. Musique. Images. Instruments, Klincksieck 8 (2006): 25-44.

Godoy, Javier Serrano. Versión En Español de La Clasificación de Instrumentos Musicales de Curt Sachs y Erich von Hornbostel, Según La Edición CIMCIMMIMO 2011 / 2017. Madrid: Universidad Complutense de Madrid, 2018.

Gómez Martínes, Susana. "Imágenes del Cuerpo en el día a día de al-Andalus". DigitAR 2 (2015): 10-22.

Gómez Moreno, Manuel. "Pinturas de Moros en El Partal (Alhambra)". Textos de Gómez-Moreno Sobre La Alhambra Musulmana (1912): 155-64.

“Google Scholar,” https://scholar.google.es/schhp?hl=es (Última consulta: 10-022020).

"Grupo Complutense de Iconografía Musical”, http://www.imagenesmusica.es/. (Última consulta: 10-02-2020).

Guardiola, Ma Dolores. "El Tratado de Música Árabe Kitab Al-Imta Bi-Ahkam AlSama”. Universidad de Granada, 1992. http://digibug.ugr.es/handle/10481/14149. (Última consulta: 10-02-2020).

Guettat, Mahmoud. La Música Andalusí en el Magreb. Simbiosis Musical entre las dos Orillas del Mediterráneo. Sevilla: Fundación El Monte, 1999.

—. La Musique Classique Du Maghreb. París: Sindbad, 1980.

Haremska, Julia. "Ibn 'Abd Rabbihi, Abu 'Umar". En Enciclopedia de la Cultura Andalusí, Vol. 1. Fundación Ibn Tufayl de estudios árabes, 2012.

Hasan, Schéhérazade Qassim. Les Instruments de Musique En Irak et Leur Rôle Dans La Société Traditionnelle. Editado por 1'Ecole des Hautes Etudes en Sciences Sociales, 1980.

Hassan, Scheherezade Qassim y Jean During. "Nay”. En The New Grove Dictionary of Musical Instruments, 751-52. London: MacMillan Publishing Co., 1991.

"Henri Pérès", https://data.bnf.fr/fr/11919115/henri_peres/. (Última consulta: 10-022020).

Hickmann, Ellen. "Archaeomusicology". En Grove Music Online, http://www.oxfordmusiconline.com/subscriber/articl. Oxford University Press, 2001. (Última consulta: 10-02-2020). 
Hickmann, Hans. Catalogue Général Des Antiquités Égyptiennes Du Musée Du Caire. Nos. 69201-69852. Instruments de Musique. El Cairo: 1'Institut Français d'Archéologie orientale, 1949.

—. Terminologie Arabe Des Instruments de Musique. Editado por Verlang nicht Ermittelbar. El Cairo, 1947.

Hoenerbach, Wilhelm. Dichterische Vergleiche Der Andalus-Araber I Und II. Boon: Selbstverlag des Orientalischen Seminars del Universität Bonn, 1973.

Holter, Kurt. Die Islamischen Miniaturhandschriften Vor 1350. Otto Harrassowitz, 1937.

Homo-Lechner, Catherine y Christian Rault. Instruments de Musique Du Maroc et d'al-Andalus. París: Fondation Royaumont-CERIMM, 1999.

Hornbostel, Enrich y Curt Sachs. "Systematik Der Musikinstrumente”. Zeitschrift Für Ethonologie 46 (1914): 553-90.

. "Classification of Musical Instruments: Translated from the Original German by Anthony Baines and Klaus P. Wachsmann”. The Galpin Society Journal 14 (1961): 3-29.

Hortelano Piqueras, Laura. "Un Pito Procedente de Ibiza en el Museo de Prehistoria de Valencia”. SAGVNTVM. Papeles Del Laboratorio de Arqueología de Valencia 32 (2000): 191-94.

Hortelano Piqueras, Laura. "Arqueomusicología: Bases para el estudio de los Artefactos Sonoros Prehistóricos". Trabajo de tercer ciclo de la Universitat de Valencia, 2003.

Houtsma, M. Th, T.W. Arnold, R. Basset y R. Hartmann, eds. Encyclopaedia of Islam. Rowman \& Littlefield, 1980.

Hunt Ortíz, Mark A, M. Ángeles Ontalba Salamanca, Inés Ortega Feliú, Blanca Gómez Tubío, Eloisa Bernáldez Sánchez y Pina López Torres. "Examen Arqueométrico de un Objeto de Hueso Decorado de Época Almohade (Siglo XIII d. C.) Procedente de la Excavación Arqueológica de La Calle San Fernándo, Sevilla”. En VIII Congreso Ibérico de Arqueometría, 165-74, 2009.

"International Council of Middel Eastern Archaeomusicology (ICONEA)", http://www.iconea.org/. (Última consulta: 10-02-2020).

"International Music Score Library Project (IMSLP)", https://imslp.org/wiki/Main_Page. (Última consulta: 10-02-2020).

“ISeek”, http://education.iseek.com/iseek/home.page (Última consulta: 10-02-2020). 
Jenkins, Jean y Poul Rovsing Olsen. Music and Musical Instruments in the World of Islam. London: Wordl od Islam Festival Publishing Company, 1976.

Jiménez Díaz, Nieves. "Historia de laas campanas de Granada". Tesis doctoral de la Universidad de Granada, dirigida por Domingo Sánchez Mesa Martín, 1998.

Jimenez Pasalodos, Raquel. "Introduction to the Volume. Ritual Music and Archaeology: Problems and Perspectives." In Music and Ritual. Bridging Material and Living Cultures, editado por Ekho Verlag, 17-23. Berlín: Publications of the ICTM Study Group on Music Archaeology Vol. 1, 2013.

Jiménez Pasalodos, Raquel. “A 'Phenomenology of Soundscape': Archaeoacoustics, Landscapes and Environment in Music Archaeology". En IV Jornadas de Jovens En Investigaçao Arqueológica, editado por J. Cascalheira and C. Gonçalves, 443-46. Promotoria Monografica, 2011.

—. "Arqueología Musical y Etnomusicología: Por una Interpretación Etnomusicológica de los Materiales Arqueológicos". Etno-Folk: Revista Galega de Etnomusicoloxía 14 (2009): 637-54.

Jiménez Pasalodos, Raquel y Alexandra Bill. "Los Tambores de Cerámica de AlAndalus (ss. VIII-XIV): Una Aproximación desde la Arqueología Musical”. Nassarre, (2012): 13-42.

—. "Music and Identities Al-Andalus Clay Drums and the Study of Popular Musical Behaviors Through the Archaeological Record". Studien Zur Musikarchäologie X, DAI Orient Archäologie, (2016): 83-102.

Jimenez Pasalodos, Raquel, Carlos García Benito y Juan Jesús Padilla Fernández. "Modelando Sonidos: Instrumentos Musicales de Barro en los Museos Españoles. Una Aproximación desde la Etnoarqueología, Etnomusicología y la Arqueología Experimental". MENGA. Revista de Prehistoria de Andalucía, 2018, 615-34.

Jiménez Pasalodos, Raquel y Juan Jesús Padilla. "Las Trompas Numantinas: Aproximación a su Estudio Acústico en una Cocción Experimental con una Reproducción de un Horno de la Edad del Hierro". En 3er Congreso Internacional de Arqueología Experimental, 387-95. Girona, 2013.

Jiménez Pasalodos, Raquel, Rupert Till y Mark Howell, eds. Music and Ritual. Bridging Material And Living Cultures. Publications of the ICTM Study Group on Music Archaeology Vol. 1, 2013.

Martínez, Jota. Instrumentos musicales de la tradición medieval española (s. $V$ al s. 
$X V)$. Círculo Rojo, 2019.

“Jstor”. https://www.jstor.org/. (Última consulta: 10-02-2020).

Juan i Nebrot, M. Antonia. "Versión Castellana de La Clasificación de Instrumentos Musicales Según Erich von Hornbostel y Curt Sachs (Galpin Society Journal XIV, 1961)”. Nassarre: Revista Aragonesa de Musicología XIV, 1 (1998): 36587.

“Julián Ribera y Tarragó”, http://dbe.rah.es/biografias/4193/julian-ribera-y-tarrago. (Última consulta: 10-02-2020).

“Jurn”, http://www.jurn.org/\#gsc.tab=0 (Última consulta: 10-02-2020).

Knighton, Tess. "John Brande Trend (1887-1958) and His Musical 'Iter Hispanicum"”. Music and Letters 95, no. 4 (2014): 550-83.

Kykl, Alois Richard. Historia de Los Amores de Bayad y Rijad, 1941.

"Latindex". http://www.latindex.org/latindex/inicio. (Última consulta: 10-02-2020).

Lavignac, Albert y La Laurencie, eds. L'Encyclopédie de La Musique et Dictionnaire du Conservatoire. Ch. Delagrave, 1913.

“Léon-Henri Martin”, https://musee-archeologienationale.fr/objet/leon-henri-martin. (Última consulta: 10-02-2020).

Levi della Vida, Giorgio. Elenco Dei Manoscritti Arabi Islamici Della Biblioteca Vaticana. Città del Vaticano, 1935.

Lillo, Mercedes. "La Figura del Intérprete Musical en los Marfiles Califales Andalusíes". Cuadernos de Arte e Iconografía Tomo 6, nº (1993): 143-50.

Lirola Delgado, Joaquín. "Ibn Al-Jatib Al-Salmani, Lisan Al-Din”. En Enciclopedia de La Cultura Andalusí, Vol. 3, 643-98. Fundación Ibn Tufayl de estudios árabes, 2012.

Lirola Delgado, Jorge. "Ibn Rusd”. En Enciclopedia de La Cultura Andalusí, Vol. 4. Fundación Ibn Tufayl de estudios árabes, 2012.

Lirola Delgado, Jorge y José Miguel Puerta Vílchez. Biblioteca de Al-Andalus. El Legado Andalusí. Almería: Fundación Ibn Tufayl de estudios árabes, 2012.

—. Enciclopedia de Al-Andalus. Diccionario de Autores y Obras Andalusíes. Granada: El Legado Andalusí, 2002.

Lomba Fuentes, Joaquín y José Miguel Puertas Vílchez. "Ibn Bayya, Abu Bark”. En Enciclopedia de La Cultura Andalusí, Vol. 2, 624. Fundación Ibn Tufayl de estudios árabes, 2012.

Lomba, Joaquín. "Avempace. Tratado de la Unión del Intelecto con el Hombre”. 
Anaquel de Estudios Árabes VII (2000): 369-91.

López Amador, Juan José, José Antonio Ruiz Gil y Francisco Giles Pacheco. La Huella de Al-Ándalus en el Puerto de Santa María, Cádiz. Puerto de Santa María, Cádiz: Ingrasa S.L. Artes Gráficas, 2011.

López de Guereño Sanz, María Teresa. “Arte y Gestualidad en el Libro del Acedrex,

Dados e Tablas de Alfonso X El Sabio”. Laboratorio de Arte, no. 29 (2017): 2352.

López y López, Ángel Custodio. “Al-Saqundi, Abu-I-Walid”. En Enciclopedia de la Cultura Andalusí, Vol. 7, 295. Fundación Ibn Tufayl de estudios árabes, 2012.

Lund, Cajsa. "The Archaeomusicology of Scandinavia". Word Archaeology 12, 3 (1981): 146-265.

Lutfi al-Sayyid, Afaf. Historia de Egipto. De la Conquista Árabe al Presente. Ediciones Akal, 2008.

Mahillon, Victor-Charles. Catalogue Descriptif \& Analytique Du Musée Instrumental Du Conservatoire Royal de Bruxelles. Bruselas, 1880.

Malinowski, Tadeusz. “Archaeology and Musical Instruments in Poland”. World Archaeology 12, 3 (1981): 266-72.

Malpica Cuello, Antonio, Miguel Barcelo i Perello, Patrice Cressier, Guillermo Rosselló Bordoy y Nicolás Marín Díaz. "Excavación En El Castillejo (Los Guájares, Granada), 1985”. Anuario Arqueológico de Andalucía, 1985, 436-66.

Marinetto Sánchez, Purificación. “Juegos y Distracciones de los Niños en la Ciudad de la Alhambra". En Del Rito al Juego: Jueguetes y Silbatos de Cerámica desde el Islam hasta la Actualidad, 75-92. Junta de Andalucía, 2006.

—. "Juguetes y Silbatos Infantiles de Época Nazarí". MEAH, Sección árabeislam 46 (1997): 183-205.

Martín Moreno, Antonio. Historia de La Música Andaluza. Granada: Biblioteca de la cultura andaluza. Vol. 13, 1985.

Martínez, Jota. Instrumentos Musicales de la Tradición Medieval Española (s. $V$ al s. $X V) .2^{\circ}$. Círculo Rojo, 2019.

“Maurice Bourges", https://data.bnf.fr/fr/14847453/maurice_bourges/. (Última consulta 10-02-2020).

Mazuela Coll, Rosario. "Edición, Traducción y Comentario Del 'Libro de Los Instrumentos Musicales' Incluido en el 'Kitab Al-Inta Wa Al-Imtifa Fi Mas'alat Sama' Al-Sama' de Al-Salahi”. Instituto hispano árabe de cultura, 1988. 
—. "Traducción del Manuscrito 334/5307 de La Biblioteca Nacional de Madrid". Universidad de Granada, 1986.

“Mendeley”. https://www.mendeley.com/newsfeed. (Última consulta: 10-02-2020).

Menéndez Pidal, Ramón, ed. Historia de España. Madrid: Espasa-Calpe, 1935.

Merriam, Alan P. The Anthropology of Music. The Antropology of Music. Illinois: Northwestern University Press, 1964.

Mersenne, Marin. Traite de l'harmonie Universelle. Indiana: Indiana University, 1962.

Metioui, Omar. "Historia y evolución del Instrumentarium Andalusí-Magrebí”. En $\mathrm{Al}$ Andalus y El Norte de África: Relaciones e Influencias, editado por Pablo Beneito y Fátima Roldán, 111-51. Sevilla: Fundación El Monte, 2004.

Molina Fajardo, Eduardo. "Caza en el Recinto de la Alhambra". Cuadernos de la Alhambra 3 (1967): 31-53.

Molina, Mauricio. Frame Drums in the Medieval Iberian Peninsula. Nueva York: University of New York, 2006.

_. "Tympanistria Nostra: La Reconstrucción del Contexto y la Práctica Musical de las Pandereteras y Aduferas Medievales a través de sus Representaciones en el Arte Románico Español”. Cuadernos de Investigación del Monasterio de Santa María La Real 26 (2010): 77-103.

Monneret de Villard, Ugo. "Un Codice Arabo-Spagnolo Con Miniature". La Bibliofilía 43 n. 10/1 (1941): 209-23.

Montagu, Jeremy. "Whistle". Grove Music Online, Oxford University Press, 2001. http://www.oxfordmusiconline.com/subscriber/article/grove/music/30201.

(Última consulta: 10-02-2020).

Montagu, Jeremy, Howard Mayer Brown y Frank Ardal Powell. "Flute". En Grove Music Online, Oxford University Press, 2001. https://www.oxfordmusiconline.com/grovemusic/view/10.1093/gmo/978156159 2630.001.0001/omo-9781561592630-e-0000040569?rskey=lunqBw\&result $=4$ (Última consulta: 10-02-2020).

Moral, Celia del. "Contribución a la Historia de la Mujer a partir de las Fuentes Literarias Andalusíes". En La Sociedad Medieval a Través de La Literatura Hispanojudía. VI Curso de Cultura Hispano-Judía y Sefardí de La Universidad de Castilla-La Mancha, 101-20, 1998.

Moreno, Marta y Carlos M. Pimienta. "Comentarios Arqueo-Zoológicos sobre el 
Aerófono de la Necrópolis de Afligidos, Villa Romana del Val (Alcalá de Henares, Madrid)". En La Investigación Arqueológica de la Época Visigoda en la Comunidad de Madrid. III. La Cultura Material, 796-803, 2006.

—. "Evidencias Arqueológicas y Etnográficas de Instrumentos Musicales Elaborados en un Hueso del Ala de Buitre”. Revista de Estudios Mirobrigenses II (2007): 237-54.

Morris, Conway R., Cvjetko Rihtman, Christian Poché y Veronica Doubleday. "Duff”. Grove Music Online, Oxford University Press, 2001. https://www.oxfordmusiconline.com/grovemusic/view/10.1093/gmo/978156159 2630.001.0001/omo-9781561592630-e-0000007050? (Última consulta: 10-022020).

Moya Morales, Javier. Obra Dispersa e Inédita. Manuel Gómez-Moreno González, 2004.

Mulet, Antoni. "Los Recientes Hallazgos de Cerámica en Palma". Boletín de La Sociedad Arqueológica Luliana 27 (1938): 169-80.

—. Pitos y Cántaros de Mallorca. Palma de Mallorca: Imprenta Sucesores de Amengual y Muntaner, 1949.

Muntané, Ma del Carmen. La Música Medieval en España. Edition Reichenberger, 2001

"Museo de Telas Medievales", museodeburgos.com/index.php?option $=$ com_content\&task $=$ section\&id=16\&Ite mid=149 (Última consulta: 10-02-2020).

"Museo Del Almodí", http://xativaturismo.com/museo-del-almodi/ (Última consulta: 10-02-2020).

"Musical Instrument Museums Online (MIMO)", http://www.mimointernational.com/MIMO/. (Última consulta: 10-02-2020).

Nassarre, Pablo. Escuela de Música. Zaragoza, 1723.

Navarro i Ortiz, E. “Al-Ramadi, Yusuf”. En Enciclopedia de La Cultura Andalusí, Vol. 7. Fundación Ibn Tufayl de estudios árabes, 2012.

Navarro Palazón, Julio. "Cerámica Musulmana de Murcia (España) con Representaciones Humanas”. En La Céramique Médiévale en Méditerranée Occidentale. X-XV Siècles, 317-20, 1978.

—. La Ceramica Esgrafiada Andalusi de Murcia. Madrid: Publications de la Casa de Velázquez, 1986. 
Navarro Palazón, Julio y Pedro Jimenez del Castillo. "La Cerámica Andalusí de Murcia a La Llegada de Alfonso X”. En Alfonso X y su Época. Catalogo de la Exposición Celebrada en Murcia, 695-704, 2009.

Padilla, Juan Jesús, Raquel Jiménez Pasalodos, Carlos García Benito y Linda Chapon. “La Cadena Técnico-Operativa del Alarde las Cogotas (Cardeñosa, Ávila): La Construcción Experimental de un Horno Cerámico de la II Edad del Hierro". Sèrie Monogràfica Del MAC-Girona 25, 2 (2013): 467-75.

Palomar Abadia, Salvador. "Instrumentos Populares de Barro en el Sur de Catalunya". Música Oral Del Sur: Revista Internacional 2 (1996): 19-27.

Partearroyo Lacaba, Cristina. "Tejidos Andalusíes". Artigrama, Revista del Departamento de Historia del Arte de la Universidad de Zaragoza, 22, (2007):271-419.

Pavón Maldonado, Basilio. "Iconografia Hispanomusulmana: Naturalismo, Fauna y $\begin{array}{llll}\text { Árbol de } & \text { La } & 2013 .\end{array}$ http://www.basiliopavonmaldonado.es/Documentos/icohispa.pdf. (Última consulta: 10-02-2020).

Pedrell, Felipe. Emporio Científico e Histórico de Organografía Musical Antigua Española. J. Gili, 1901.

Peral Bejarano, Carmen y Sonia López Chamizo. “Aproximación al Juguete en su Contexto Arqueológico en Málaga". En Del Rito al Juego: Jueguetes y Silbatos de Cerámica desde el Islam hasta la Actualidad, 113-31. Junta de Andalucía, 2006.

Pérès, Henri. Esplendor de Al-Andalus. Madrid: Libros Hiperión, 1983.

Pérez Arroyo, Rafael. La Música en la era de las Pirámides. Centro de Estudios Egipcios, 2001.

Pérez de Arce, José y Francisca Gili. "Clasificación Sachs-Hornbostel de Instrumentos Musicales: una Revisión y Aplicación desde la Perspectiva Americana". Revista Musical Chilena 219 (2013): 42-80.

"Píxile Madinat Al-Zahra. Hispanic Society of America", http://hispanicsociety.emuseum.com/objects/3620/pyxis-or--box?ctx=c9985cb5159e-4b81-8aa8-bb48f66c5027\&idx=41. (Última consulta 10-02-2020).

Poché, Christian. "'ud". En Grove Music Online, Oxford University Press, 2001. https://www.oxfordmusiconline.com/grovemusic/view/10.1093/gmo/978156159 2630.001.0001/omo-9781561592630-e-0000028694?rskey=ClfFrv

(Última 
consulta: 10-02-2020).

—. "Buq". En Grove Music Online, Oxford University Press, 2001. https://www.oxfordmusiconline.com/grovemusic/view/10.1093/gmo/978156159 2630.001.0001/omo-9781561592630-e-0000004336?rskey=Z5TjMB\&result=1. (Última consulta: 10-02-2020).

—. Dictionnaire des Musiques et Danses Traditionnelles de la Méditerranée. Francia: Éditions Fayard, 2005.

—. La Música Arábigo-Andaluza. Ediciones Akal, 1997.

—. "Qraqeb". En The New Grove Dictionary of Musical Instruments, editado por Stanley Sadie. Macmillan Press, 2001.

—. "Riqq". En Grove Music Online, Oxford University Press, 2001. https://www.oxfordmusiconline.com/grovemusic/view/10.1093/gmo/978156159 2630.001.0001/omo-9781561592630-e-0000046903. (Última consulta: 10-022020).

https://www.oxfordmusiconline.com/grovemusic/view/10.1093/gmo/978156159 2630.001.0001/omo-9781561592630-e-0000027502?rskey=kNNDGp\&result $=1$ (Última consulta: 10-02-2020).

Porras, Faustino. "Los Instrumentos Musicales en la Poesía Castellana Medieval: Enumeración y Descripción Organológica". Lemir: Revista de Literatura Española Medieval y Del Renacimiento 12 (2008): 113-36.

Porras Robles, Faustino. "Iconografía Musical en la Escultura Hispanomusulmana”. Nassarre: Revista Aragonesa de Musicología 25, no. 1 (2009): 39-56.

"ProQuest Dissertations \& Theses Global". https://www.proquest.com/productsservices/pqdtglobal.html (Última consulta: 10-02-2020).

Puertas Vílchez, José Miguel. "Ibn Hazm, Abu Muhammad”. En Enciclopedia de La Cultura Andalusí. Fundación Ibn Tufayl de estudios árabes, 2012.

Qassim Hassan, Schéhérazade. Les Instruments de Musique en Irak. París: Cahiers de l'homme, 1980.

"Questia", https://www.questia.com/ (Última consulta. 10-02-2020).

"Recolecta", https://www.recolecta.fecyt.es/. (Última consulta 10-02-2020).

"Red Digital de Colecciones de Museos de Epaña (CERES)", $\mathrm{http}: / /$ ceres.mcu.es/pages/SimpleSearch?index=true. (Última consulta: 10-022020). 
“Redalyc”, http://www.redalyc.org/home.oa. (Última consulta: 10-02-2020).

Redín Armañanzas, Ana Elena. "Arqueta de Leyre", http://ceres.mcu.es/pages/ResultSearch?txtSimpleSearch=Arqueta de Leire\&simpleSearch=0\&hipertextSearch=1\&search=simpleGroup\&MuseumsSe arch=MNANA\%7C\&MuseumsRolSearch=1\&. (Última consulta: 10-02-2020).

"Redoma de las Liebres", http://ceres.mcu.es/pages/Main?idt=127790\&inventary=CE00677\&table=FMUS \&museum=MAEGR (Última consulta: 10-02-2020).

Répertoire International d'Iconographie Musicale (RIdIM). https://ridim.org/ridimdatabase/ (Última consulta: 17-02-2020).

Ribera y Tarragó, Julián. La Música Árabe y su Influencia en la española. Valencia: Pre-Textos (Música "la Huella Sonora”), 2000.

—. La Música de las Cantigas, Estudio sobre su Origen y Naturaleza. Madrid: Real Academia Española de la Historia, 1922.

Robinson, Cynthia. "The Lover, His Lady, Her Lady, and a Thirteenth-Century Celestina: A Recipe for Love Sickness from Al-Andalus”. En Islamic Art and Literature, 79-115, 2001.

Robson, James y Henry George Farmer. Ancient Arabian Musical Instruments: As Described by Al-Mufaddal Ibn Salama (Ninth Century) in the Unique Istanbul Manuscript If the Kitab Al-Malahf in the Handwriting of Yaqut Al-Musta'sima (d. 1298). Glasgow: Civic, 1938.

Rodríguez Peinado, Laura. "Morfología de la encuadernación textil en la Edad Media”. En Doce siglos de materialidad del libro: estudios sobre manuscritos e impresos entre los siglos VIII y XIX. Zaragoza: Prensas Universitarias de Zaragoza, 2017.

Rosselló Bordoy, Guillermo. "De nuevo los Animales de Juguete y otros Aspectos de Coroplastia Andalusí". En Actas Del IV Coloquio Hispano-Tunecino, 205-12. Palma de Mallorca, 1979.

— El Ajuar de las Casas Andalusies. Málaga: Sarriá, 2002.

- "El Largo Camino de una Investigación”. En Del Rito al Juego: Jueguetes y Silbatos de Cerámica desde el islam hasta la Actualidad, 15-50. Junta de Andalucía, 2006.

—. "Instrumentos en Barro Cocido: Una Pervivencia Medieval". Música Oral del Sur 2 (1996): 28-51. 
_. "Silbatos Mallorquines". Al-Andalus 1 (1957): 196-98.

—. "Siurells". Boletín de la COCIN 636 (1964): 185-93.

Rosselló Bordoy, Guillermo, Ana Dolores Navarro Ortega e Isabel Flores Escobosa. Del Rito al Juego: Juguetes y Silbatos de Cerámica desde el islam hasta la Actualidad. Junta de Andalucía, 2006.

Rosselló, Guillermo. "Música y Arqueología: Organología Musical y Hallazgos Arqueológicos”. En Música y Poesía del Sur de Al-Andalus. Sevilla-Granada: Fundación El Legado Andalusí, 1995.

Rubiera Mata, María Jesús. "Cuando Los Andaluces Cantaban En Árabe: La Poesía Andalusí En Época Omeya (Siglos VIII-IX)”. En Música y Poesía del Sur de AlAndalus, Lunwerg Ed., 125-33. Granada-Sevilla, 1995.

Rubio de Miguel, Isabel. "Instrumentos Musicale de La Prehistoria: El Paleolítico (II)". Boletín de La Asociación Española de Amigos de La Arqueología 32 (1992): 2-11.

Ruíz Nieto, Eduardo. Representaciones Antropomorfas Hispanomusulmanas sobre hueso". Anales de Arqueología Cordobesa, Tesis doctoral de la Universidad de Córdoba, 2001.

Sachs, Curt. Historia Universal de los Instrumentos Musicales. Buenos Aires, 1947.

—. La Música en el Mundo Antiguo. Oriente y Occidente, 1981.

Sadie, Stanley y John Tyrrell, eds. The New Grove Dictionary of Music an Musicians. $2^{\circ}$. Nueva York: Macmillan Publishers, 2001.

Salius, Jesús. Etnoarqueomusicología. La Producción de Sonidos y la Reproducción Social en las Sociedades Cazadoras-Recolectoras. Madrid: Consejo Superior de Investigaciones Científicas (CSIC), 2015.

Salvador Daniel, Francisco. Musiques et Instruments de Musique du Maghreb. La Boîte à Documents. París, 1986.

Salvador González, Carmen. "Música y Organología en la Sevilla Islámica: Análisis de las Fuentes Documentales Árabes y de los Hallazgos Arqueológicos”. Trabajo Final de Máster de la Universidad de Granada, 2017.

Sawa, George Dimitri. "Musical Humour in the Kitab Al-Aghani". En Losod Islamikos: Studia Islamica in Honorem Georgii Michaelis Wickens, editado por Roger M. Savory y Dionisius Agius. Toronto: Pontificial Institute of Medieval Studies, 1984.

Sazatornil Ruiz, Luis. "El Barón Davillier: Hispanista, Anticuario y Viajero por 
España”. En El Arte y El Viaje, editado por A. López-Yarto Elizald, W. Rincón García y M. Cabañas Bravo, 353-68. Madrid: Colección Biblioteca de Historia del Arte, CSIC, 2011.

Schofield, John. "The Archaeology of Sound and Music". World Archaeology 46, 3 (2014): 289-91.

"Scopus", https://www.scopus.com/search/form.uri?display=basic. (Última consulta: 10-02-2020).

Serrano-Niza, Dolores. Glosario Árabe Español de Indumentaria según el "Kitab AlMujassas” de Ibn Sidah. Madrid: Editorial CSIC-CSIC Press, 2005.

—. "Ibn Sida, Abu 1-Hasan". En Enciclopedia de la Cultura Andalusí, Vol. 5, 352. Fundación Ibn Tufayl de estudios árabes, 2012.

Shiloah, Amnon. "The 'ud and the Origin of Music". Studia Orientalia, Memorae DH Baneth, 1979, 395-407.

-. The Theory of Music in Arabic Writing (c. 900-1900). Munich: International Musicological Society and the International Association of Music Libraries, 1979.

- The Theory of Music in Arabic Writings (c.900-1900). Descriptive Catalogue of Manuscripts in Libraries of Egypt, Israel, Morocco, Russia, Tunisia, Uzbekistan, and Supplement to B X. Munich: G. Henle Verlag München, 2003.

- The Theory of Music in Arabic Writings (c.900-1900). Descriptive Catalogue of Manuscripts in Libraries of Europe and the U.S.A. Munich: G. Henle Verlag München, 1979.

—_. "Un Ancien Traité Sur Le 'ud D'Abu Yuful Al-Kindi”. Israle Oriental Music IV (1974): 179-205.

"Sistema Integrado de Documentación y Gestión Museográfica (DOMUS)", http://www.juntadeandalucia.es/cultura/WEBDomus/buscador.do?lng=es.

(Última consulta: 10-02-2020).

Soriano Fuertes, Mariano. Música Árabe-Española y Conexión de la Música con la Astronomía, Medicina y Arquitectura. D. Juan Oliveres, Impresor de S.M., 1853. "Teseo", https://www.educacion.gob.es/teseo/irGestionarConsulta.do;jsessionid=826320B F472FE502438852FA282EFC0F. (Última consulta: 10-02-2020).

Torres Balbás, Leopoldo. “Animales de Juguete”. Crónica Arqueológica de la España Musulmana XXXIX (1956): 373-75. 
Torres, Claudio. "O Vaso de Tavira: Uma Proposta de Interpretaçao". Campor Arqueológico de Mértola, 2004.

Torres Mulas, Jacinto. "Los Instrumentos de Música en las Miniaturas de las Cantigas de Santa María”. Bellas Artes 48 (1975): 25-29.

Touma, Habib Hassan. La Música de los Árabes. Editorial Alpuerto. Junta de Andalucía, 1998.

Tranchefort, Françoise-René. Los Instrumentos Musicales en el Mundo. Alianza Editorial, 1985.

Trend, John Brande. The Music of Spanish History to 1600. Nueva York: University Press: Humpherey Milford, 1965.

Trichet, Pierre. Traité des Instruments de Musique (Vers 1640). Publié Avec Une Introduction et des Notes Par François Lesure. Editado por Société de musique D’autrefois. Genève: Minkoff Reprint, 1957.

Tudoras, Laura Eugenia. "El viaje de los sentidos en los jardines Mogador". Revista de Filología Románica, anejo IV, 2006.

Turk, Ivan. Mousterion Bone Flute and Other Finds from Divje Babe I Cave Site in Slovenia. Institut za Arhaeologijo, 1997.

Veglison, Josefina. El Collar Único de Ibn Abd Rabbihi. Madrid: Editorial Síntesis, 2007.

Villoteau, Guillaume-André. Description Historique, Technique et Littéraire, des Instrumens de Musique des Orientaux. París: Impre. impériale, 1812.

Vindry, Georges. "Présentation de L'épave Árabe Du Batéguier (Baie de Cannes, Provence Orientale)". Archéologie Médiévale. La Céramique Médiévale en Méditerranée Occidentale 584 (1976): 221-26.

Williamson, Rosemary. "Galpin, Francis William”. En Grove Music Online. Oxford Music Online, https://www.oxfordmusiconline.com/grovemusic/view/10.1093/gmo/978156159 2630.001.0001/omo-9781561592630-e-0000010591. (Última consulta: 10-022020).

"WorldCat", https://www.worldcat.org/ (Última consulta: 10-02-2020).

Zaniol, Angelo. "La Flauta Recta En Los Siglos XIII-XV”. En Flûte à Bec, 285-90, 1982. 


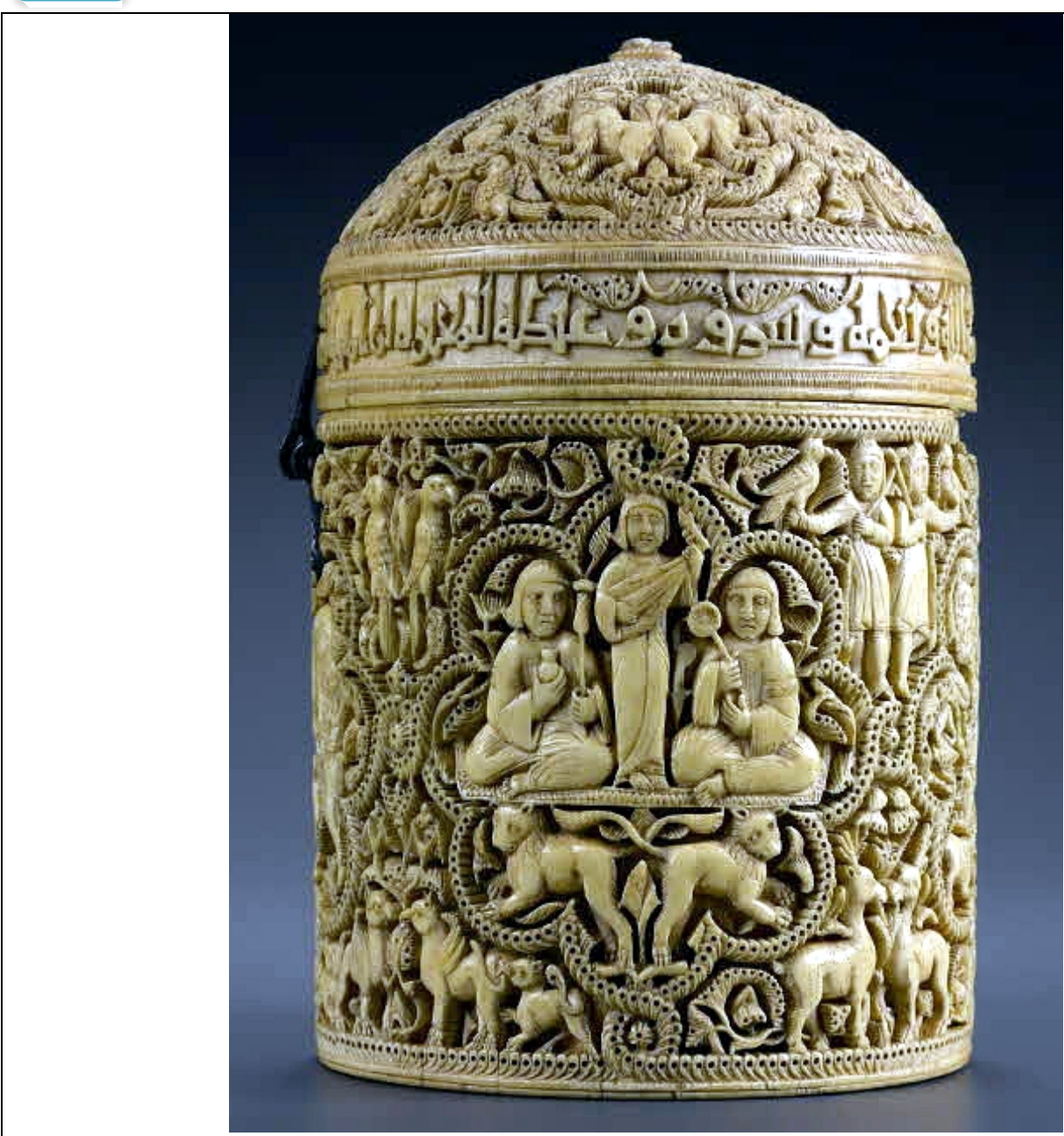

\section{Datos generales}

\begin{tabular}{|l|l|}
\hline Nombre & Bote de al-Mughira \\
\hline $\mathbf{N}^{\mathbf{0}}$ de inventario & 4068 \\
\hline Cronología & 968 (Omeya) \\
\hline
\end{tabular}

\section{Localización}

\begin{tabular}{|l|l|}
\hline Procedencia & Probablemente Madinat al-Zahra (Córdoba) \\
\hline Ubicación actual & Museo del Louvre \\
\hline Ciudad & París \\
\hline
\end{tabular}




\section{Descripción física}

\begin{tabular}{|l|l|}
\hline Dimensiones & $\begin{array}{l}\text { Altura: } 16 \mathrm{~cm} ; \text { Diámetro: } 11.8 \mathrm{~cm} \text {; Grosor: } 1,8 \mathrm{~cm} ; \\
\text { Inscripciones: } 1,5 \mathrm{~cm} \text { de profundidad. }\end{array}$ \\
\hline Materiales & Marfil tallado \\
\hline $\begin{array}{l}\text { Características } \\
\text { morfológicas }\end{array}$ & $\begin{array}{l}\text { Obra cortada en un solo bloque de marfil. La caja } \\
\text { cuenta con distintas imágenes, siendo sesenta y nueve } \\
\text { el total entre personas y animales representado. }\end{array}$ \\
\hline Inscripción & $\begin{array}{l}\text { "Bendición de Dios, bendición, alegría, dicha para al- } \\
\text { Mughira, hijo del Comandante de los Creyentes, que } \\
\text { Dios tenga misericordia de él por lo que hizo en el año } \\
\text { trescientos cincuenta y siete" [968 d.C.]. }\end{array}$ \\
\hline
\end{tabular}

\section{Descripción escena musical}

\begin{tabular}{|c|c|}
\hline Género & Profano \\
\hline Tema & Intérprete acompaña momento solemne. \\
\hline Tipo escena & Práctica. \\
\hline Escena general & $\begin{array}{l}\text { Escenificación de la lucha de los omeyas contra los } \\
\text { abasíes. }\end{array}$ \\
\hline Escena musical & $\begin{array}{l}\text { Contextualizada en la "escena del trono". Son tres los } \\
\text { personajes que aparecen. Uno cuenta con el cetro tejido } \\
\text { de los omeyas simbolizando el poder, mientras el otro } \\
\text { sostiene un flabellum, representando su condición } \\
\text { subordinada. En medio de ambas figuras aparece una } \\
\text { laudista con un gesto facial más relajado que el resto de } \\
\text { las figuras. La intérprete permanece en pie mientras } \\
\text { que las otras dos figuras a las que acompaña están } \\
\text { sentadas. Asimismo, se percibe un tamaño menor de la } \\
\text { tañedora con respecto a los personajes que aparecen en } \\
\text { esta escena pudiendo reflejar dentro de tan solemne } \\
\text { representación un discreto segundo plano en la escena. }\end{array}$ \\
\hline
\end{tabular}




\section{Participantes}

\begin{tabular}{|c|c|}
\hline \multicolumn{2}{|l|}{ Laudista } \\
\hline Instrumento & $\begin{array}{l}\text { 321.321 Laúd. Laúdes con mástil fijado al resonador, } \\
\text { con clavijero y caja abombada }\end{array}$ \\
\hline Descripción & $\begin{array}{l}\text { El laúd cuenta con dos clavijas visibles y dos cuerdas } \\
\text { tensadas a lo largo del diapasón. El clavijero está } \\
\text { inclinado hacia atrás. Tiene dos codos en forma de "f". } \\
\text { Las cuerdas, comenzando desde el mástil, atraviesan } \\
\text { todo el instrumento visible tapando el intérprete con su } \\
\text { mano derecha el final y la sujeción de las mismas. La } \\
\text { postura de la tañedora es verosímil. }\end{array}$ \\
\hline
\end{tabular}

\section{Bibliografía}

Makariou, Sophie. "Pyxide d'al-Mughira". En Les Arts de l'Islam au musée du Louvre, Makariou S. (dir.), 118-123. Paris: 2012; Makariou, Sophie. Un chef-d'œuvre de la sculpture d'ivoire: la pyxide d'al-Mughira. Paris: 2012; Martinez-Gros, Gabriel y Sophie Makariou. "Art et politique en al-Andalus, Xe-XIe s". En Les Andalousies de Damas à Cordoue, Cat. exp. 72-79. Paris: Institut du monde arabe, 2000-2001; Prado-Vilar, Francisco. "Circular Visions of Fertility and Punishment: Caliphal Ivory Caskets from al-Andalus" Muqarnas, Vol. XIV, (1997): 22, fig. 5, 23, fig. 7, 26, fig. 10, 27, fig. 12; Red Digital de Colecciones de Museos en España: http://ceres.mcu.es/pages/Main?idt=102481\&inventary=1982\%2F38\%2FC\%2F395\&t able=FDOC\&museum=MAN\#.X1VcQ68N6X0 (Última consulta: 25-02-2020).

\section{Imagen}

\section{Propiedad}

(C) Museo del Louvre 


\section{$\mathrm{N}^{\mathrm{a}} 2$}

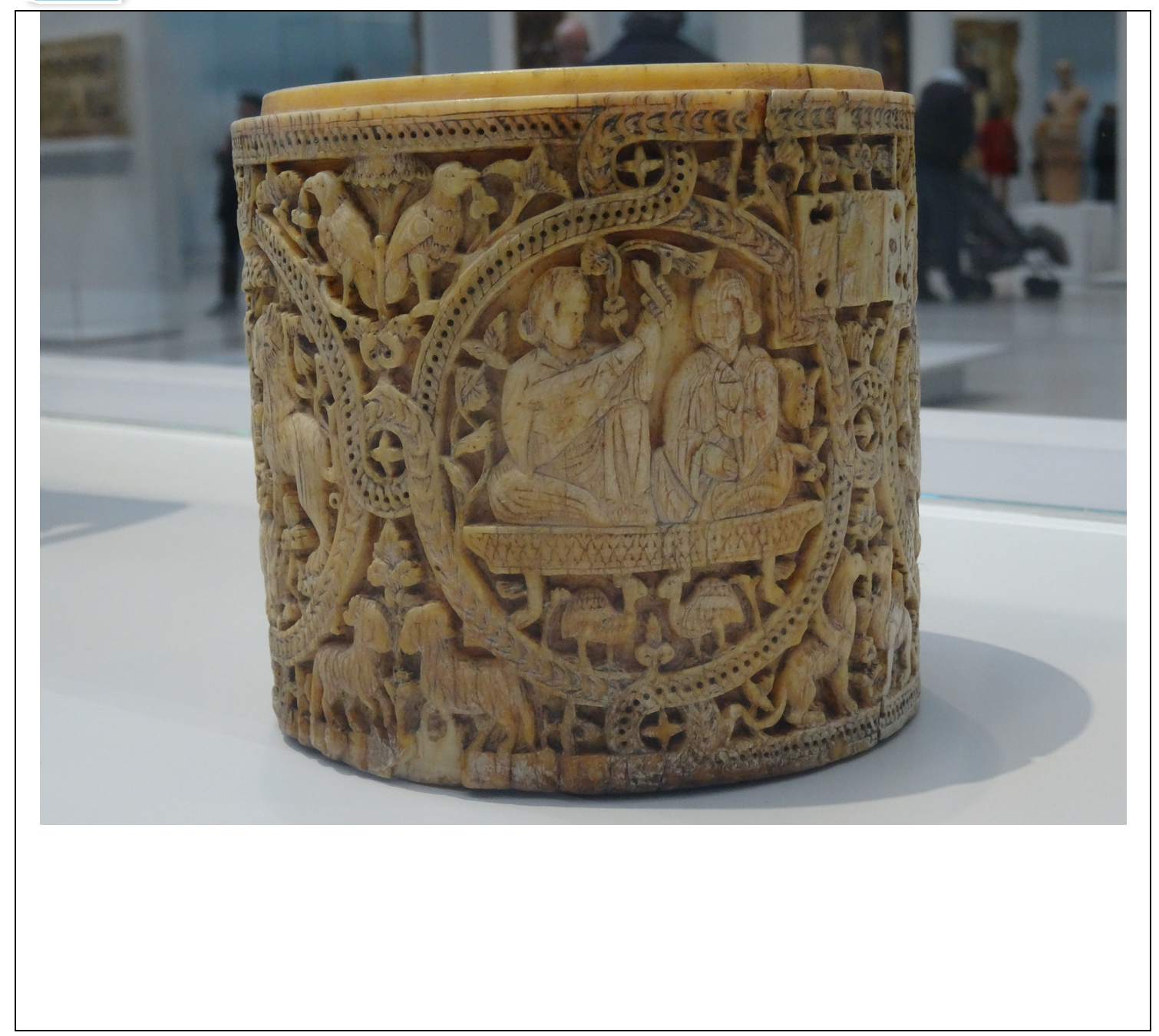

Datos generales

\begin{tabular}{|l|l|}
\hline Nombre & Bote de Davillier \\
\hline $\mathbf{N}^{\mathbf{0}}$ de inventario & OA 2774 \\
\hline Cronología & $960-970$ (Omeya) \\
\hline
\end{tabular}

\section{Localización}

\begin{tabular}{|l|l|}
\hline Procedencia & $\begin{array}{l}\text { Probablemente Madinat al-Zahra (Córdoba). } \\
\text { Colección privada del hispanista Charles Davillier. }\end{array}$ \\
\hline Ubicación actual & Museo del Louvre \\
\hline Ciudad & París \\
\hline
\end{tabular}




\section{Descripción física}

\begin{tabular}{|l|l|}
\hline Dimensiones & \\
\hline Materiales & Marfil tallado \\
\hline $\begin{array}{l}\text { Características } \\
\text { morfológicas }\end{array}$ & $\begin{array}{l}\text { Obra cortada en un solo bloque de marfil. La caja ha } \\
\text { perdido la tapa. }\end{array}$ \\
\hline Inscripción & - \\
\hline
\end{tabular}

\section{Descripción escena musical}

\begin{tabular}{|l|l|}
\hline Género & Profano \\
\hline Tema & Intérprete acompaña momento solemne. \\
\hline Tipo escena & Práctica. \\
\hline Escena general & $\begin{array}{l}\text { Dos cenefas enlazadas mediante cuatro medallones une } \\
\text { las escenas que transcurren con animales y personas como } \\
\text { protagonistas. }\end{array}$ \\
\hline Escena musical & $\begin{array}{l}\text { Dos personajes sentados sobre un estrado, uno de ellos } \\
\text { toca el laúd y el otro sostiene un vaso. Se piensa que la } \\
\text { tañedora de laúd puede ser una mujer. La intérprete de } \\
\text { laúd se representa de perfil y apoya el instrumento sobre } \\
\text { la pierna doblada. La otra figura que le acompaña está } \\
\text { sentada con ambas piernas dobladas. Sostiene una copa } \\
\text { con la mano izquierda sobre el pecho mientras que la otra } \\
\text { mano reposa sobre su pierna. }\end{array}$ \\
\hline
\end{tabular}

\section{Participantes}

\begin{tabular}{|l|l|}
\hline \multicolumn{2}{|l|}{ Laudista } \\
\hline Instrumento & $\begin{array}{l}321.321 \text { Laúd. Laúdes con mástil fijado al resonador, con } \\
\text { clavijero y caja abombada }\end{array}$ \\
\hline \multirow{2}{*}{ Descripción } & $\begin{array}{l}\text { El laúd cuenta con seis clavijas visibles, tres a cada lado. } \\
\text { Las cuerdas no se encuentran definidas. Se intuye la mano } \\
\text { derecha del intérprete sobre el instrumento. El clavijero } \\
\text { está inclinado hacia atrás. No se definen rosetas ni codos. }\end{array}$ \\
\hline
\end{tabular}


La postura de la tañedora es verosímil.

\section{Bibliografía}

Marinetto Sánchez, Purificación. "Plaquitas y bote de marfil del taller de Cuenca". Miscelánea de estuios árabes y hebraicos. Sección Árabe-Islam. Vol. 34 (1985) (1987): 45-100; Asís García, Francisco de. "El Soberano en alAndalus". Revista Digital de Iconografía Medieval 2.4 (2010): 61-71; Díez Giménez, José Luis. "El halcón en Al-Andalus". Revista Digital de Iconografía Medieval 7.13 (2015): 33-53; Gómez Muñoz, Guadalupe. "El rey-profeta Salomón y la imagen del soberano islámico a partir de una pieza inédita cordobesa". SPAL, 16, (2007): 225232; Bouterse, Curtis. "Reconstructing the Medieval Arabic Lute: A Reconsideration of Farmer's' Structure of the Arabic and Persian Lute"'. The Galpin Society Journal (1979): 2-9; Fuertes Santos, María del Camino. "Peines de marfil tallados con decoración zoomorfa. Dos ejemplares califales procedentes de Córdoba-Cercadilla-y Sevilla y un ejemplar del siglo XI de Jerez de la Frontera". Romula 14 (2015): 267292.

\section{Imagen}

\section{Propiedad}

(C) Museo del Louvre 


\section{$\mathbf{N}^{\mathrm{a}} 3$}

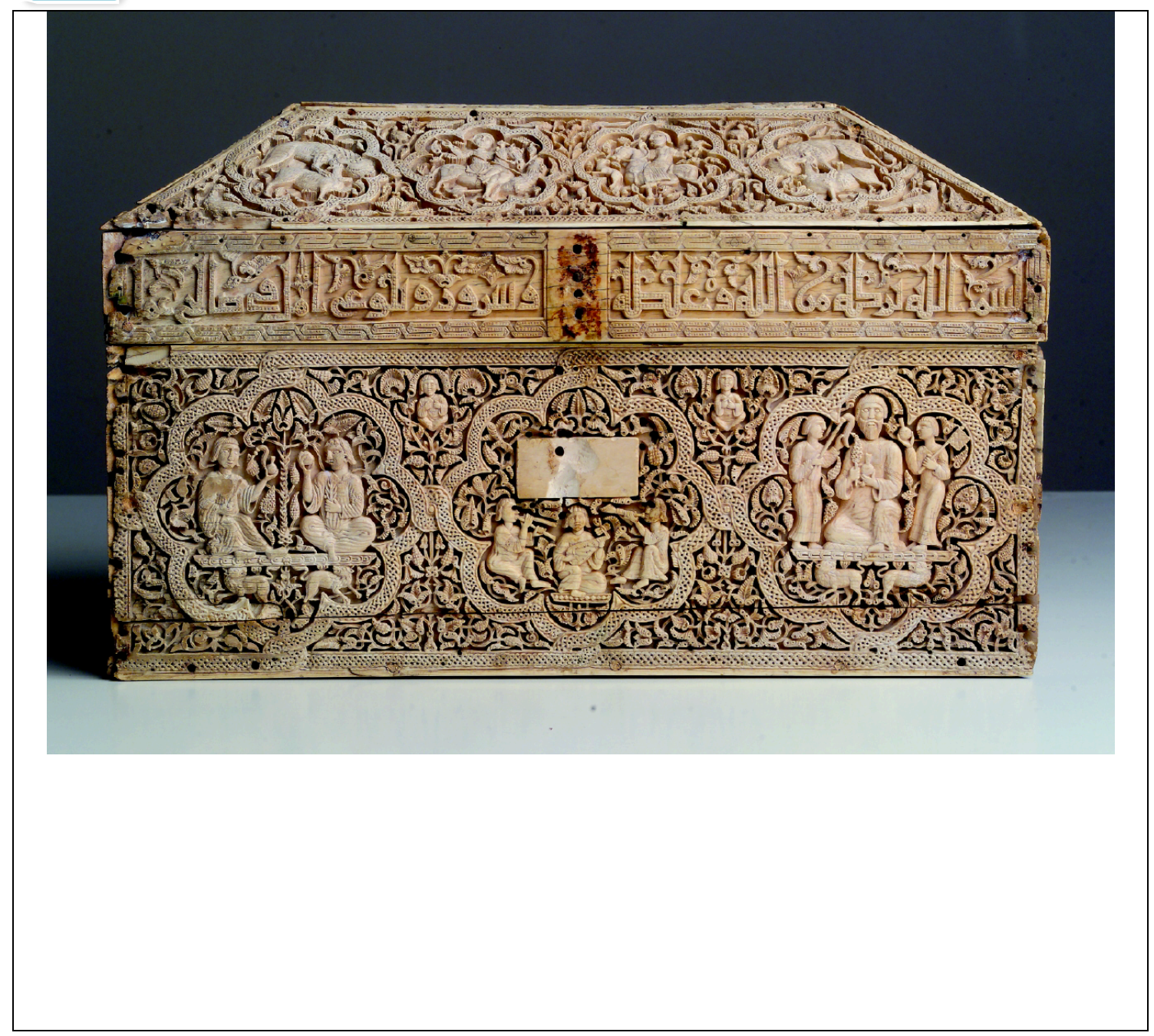

\section{Datos generales}

\begin{tabular}{|l|l|}
\hline Nombre & Arqueta de Leyre \\
\hline $\mathbf{N}^{\mathbf{0}}$ de inventario & CE000038 \\
\hline Cronología & $1004-1005$ (Califal) \\
\hline
\end{tabular}

\section{Localización}

\begin{tabular}{|l|l|}
\hline Procedencia & Madinat al-Zahra, Córdoba. Catedral de Iruña (Pamplona) \\
\hline Ubicación actual & Museo del Navarra \\
\hline Ciudad & Navarra \\
\hline
\end{tabular}




\section{Descripción física}

\begin{tabular}{|c|c|}
\hline Dimensiones & $\begin{array}{l}\text { Altura: } 23 \mathrm{~cm} \text {; Anchura: } 38,50 \mathrm{~cm} \text {; Profundidad: } 23,50 \\
\mathrm{~cm}\end{array}$ \\
\hline Materiales & Marfil tallado \\
\hline $\begin{array}{l}\text { Características } \\
\text { morfológicas }\end{array}$ & $\begin{array}{l}\text { Cofre de diecinueve placas de marfil talladas en sus caras } \\
\text { externas cuenta con veintitrés medallones. } \\
\text { La tapa con forma de tronco de pirámide trucada está } \\
\text { formada por cinco placas con trece medallones y una } \\
\text { inscripción cúfica. } \\
\text { El cuerpo, con forma de prisma rectangular, cuenta con } \\
\text { tres florones de ocho lóbulos en su cara frontal, la } \\
\text { posterior cuenta con tres medallones y los laterales con } \\
\text { dos. }\end{array}$ \\
\hline Inscripción & $\begin{array}{l}\text { Exterior: "En el nombre de Alláh, Prosperidad, Alegría, } \\
\text { Esperanza de obras buenas, Retraso del momento } \\
\text { supremo para el Hayib Saif al-Dawin ABD Al-Malik IBN } \\
\text { al Mansur (hijo de Almanzor), Dios le asista, de lo que le } \\
\text { mandó hacer por orden suya bajo la dirección del Fata Al- } \\
\text { Kabir Zuhayr ibn Muhammad. Al-amiri su esclavo. Año } \\
\text { cinco, noventa y trescientos)" } \\
\text { Interior: "Fue hecho por Faray con sus discípulos". }\end{array}$ \\
\hline
\end{tabular}

\section{Descripción escena musical}

\begin{tabular}{|l|l|}
\hline Género & Profano \\
\hline Tema & Tres mujeres interpretando flauta doble, laúd y albogue. \\
\hline Tipo escena & Específica. \\
\hline Escena general & $\begin{array}{l}\text { La arqueta enmarca escenas palaciegas y de cacería. } \\
\text { Asimismo muestra imágenes de justas y animales reales e } \\
\text { imaginarios. El resto del espacio está cubierto con } \\
\text { palmeras, tallos, frutos y piñas junto a animales y } \\
\text { pequeñas figuras masculinas y femeninas. }\end{array}$ \\
\hline Escena musical & Esta escena reflejada en el medallón central, bajo el \\
\hline
\end{tabular}




\begin{tabular}{|l|l|}
\hline espacio reservado a la cerradura, muestra a las tres \\
músicos. En el centro se encuentra la tañedora de laúd de \\
frente, la cual apoya el instrumento sobre su rodilla \\
derecha mientras parece sentada sobre su pierna \\
izquierda. A la derecha de ésta, se encuentra la intérprete \\
de flauta doble quien sentada mantiene las piernas \\
curvadas. En similar postura que esta última y con las \\
piernas recogidas, se encuentra la tañedora de albogue. \\
Ambas aparecen de perfil con una incisión en la frente.
\end{tabular}

\section{Participantes}

\begin{tabular}{|l|l|}
\hline \multicolumn{2}{|l|}{ Laudista } \\
\hline Instrumento & $\begin{array}{l}321.321 \text { Laúd. Laúdes con mástil fijado al resonador, con } \\
\text { clavijero y caja abombada }\end{array}$ \\
\hline Descripción & $\begin{array}{l}\text { El laúd cuenta con seis clavijas visibles, tres a cada lado. } \\
\text { Las cuerdas no se encuentran definidas. Se intuye la } \\
\text { mano derecha del intérprete sobre el instrumento. El } \\
\text { clavijero está inclinado hacia atrás. No se definen rosetas } \\
\text { ni codos. La postura de la tañedora es verosímil. }\end{array}$ \\
\hline
\end{tabular}

\begin{tabular}{|c|c|}
\hline \multicolumn{2}{|c|}{ Tañedora flauta doble } \\
\hline Instrumento & $\begin{array}{l}421.222 \text { Conjunto de flautas con canal de insuflación } \\
\text { interno }\end{array}$ \\
\hline Descripción & $\begin{array}{l}\text { Ambos tubos están posicionados sobre la boca de la } \\
\text { intérprete cuyos labios se encuentran bien definidos. No } \\
\text { se le observa ninguna incisión a modo de agujero digital } \\
\text { en el instrumento. Con la mano izquierda sostiene una de } \\
\text { las flautas mientras que con la mano derecha parece } \\
\text { rodear ambos tubos que cuentan prácticamente el mismo } \\
\text { largo y diámetro. La postura de la tañedora no es } \\
\text { verosímil por la forma en la que sujeta el instrumento. }\end{array}$ \\
\hline
\end{tabular}

Tañedora albogue 


\begin{tabular}{|l|l|}
\hline Instrumento & $\begin{array}{l}423.121 .22 \text { Aerófono por vibración labial de tubo curvo } \\
\text { con boquilla añadida. }\end{array}$ \\
\hline El cuerno se encuentra apoyado sobre los labios de la \\
intérprete mientras es sostenido por ambas manos. No \\
parece que el instrumento cuente con agujeros digitales. \\
Las manos quedan prácticamente de forma paralela con el \\
instrumento en medio de ambas. El albogue queda \\
paralelo a la cabeza de la intérprete. La postura de la \\
tañedora es verosímil.
\end{tabular}

\section{Bibliografía}

Navascués, Jorge de. "Una escuela de eboraria, en Córdoba, de fines del siglo IV de la Héjira (XI de JC), o Las inscripciones de la arqueta hispano-musulmana llamada de Leyre". Al-Andalus 29.1 (1964): 199; Walker, Daniel. "Arqueta de Leyre". AlAndalus. Las artes islámicas en España, catálogo de la exposición (Nueva YorkGranada, 1992). El Viso, Madrid. (1992): 198-203; Navascués, Jorge de. "Aclaraciones sobre mis estudios y conclusiones de la llamada "Arqueta de Leyre"”. Príncipe de Viana 37.144 (1976): 375-380; Pérez Higuera, Teresa. "El Jardín del Paraíso: paralelismos iconológicos en el arte hispano musulmán y cristiano medieval”. Archivo español de arte 61.241 (1988): 37; Asís García, Francisco de. "El Soberano en al-Andalus", Revista Digital de Iconografía Medieval 2.4 (2010): 61-71; López, Carlos María. "Apuntes para una historia de Leyre". Príncipe de Viana 25.94 (1964): 139-168; Aranda Vázquez, Elena. "Arqueta de Leyre". Románico: Revista de arte de amigos del románico (AdR) 24 (2017): 58-61; Porras Robles, Faustino. "Iconografía musical en la escultura hispanomusulmana". Nassarre 25 (2009): 39-56; Red Digital de Colecciones de Museos en España: http://ceres.mcu.es/pages/Main?idt=121710\&inventary $=$ CE000038\&table=FMUS\&m useum=MNANA\#.XlVcnEevbQQ (Última consulta: 25-02-2020).

\section{Imagen}

\begin{tabular}{|l|l|}
\hline Propiedad & (C) Museo de Navarra \\
\hline
\end{tabular}




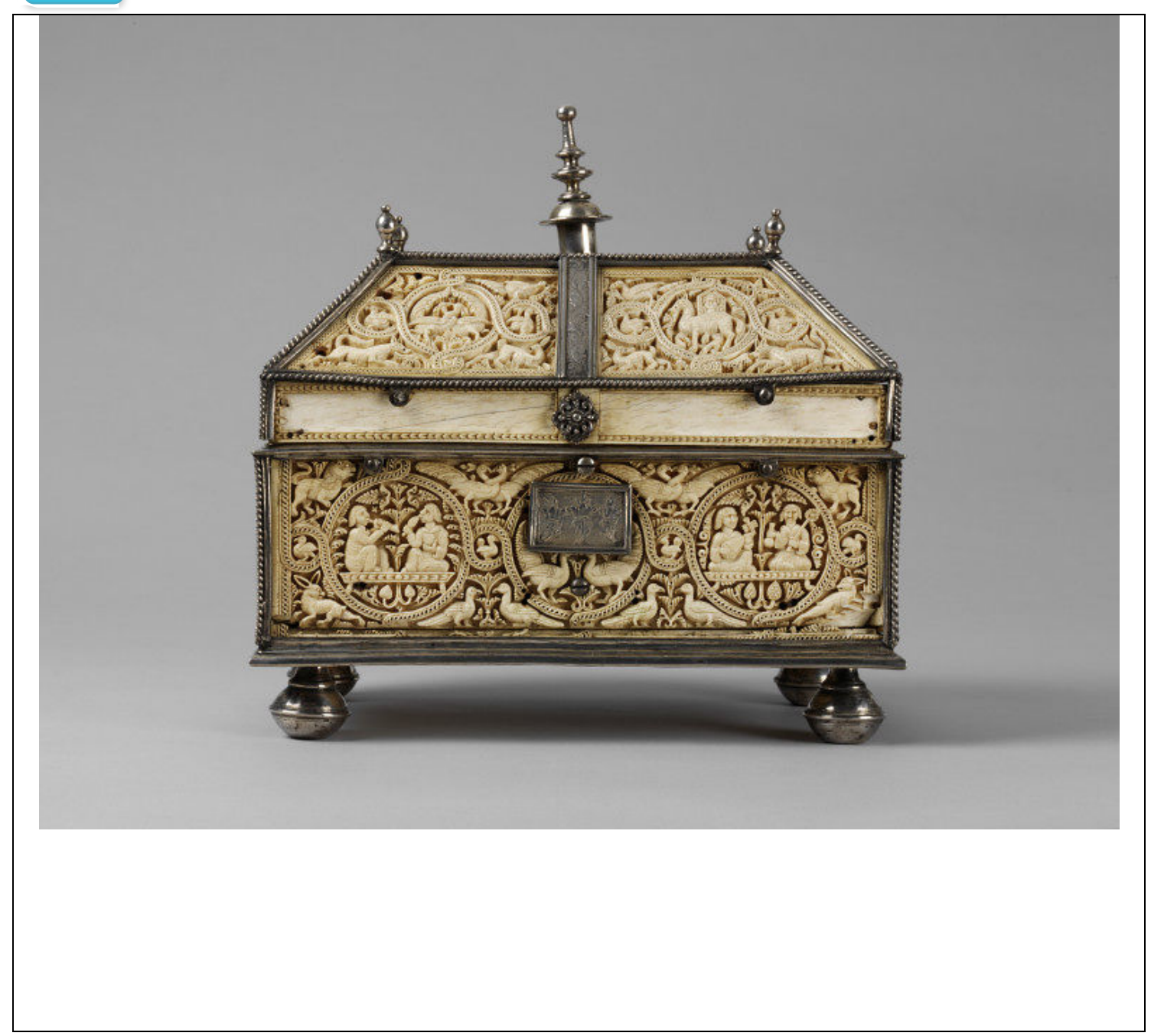

\section{Datos generales}

\begin{tabular}{|l|l|}
\hline Nombre & Arqueta Museo Victoria \& Albert \\
\hline $\mathbf{N}^{\mathbf{o}}$ de inventario & $10-1866$ \\
\hline Cronología & $1000-1025$ (Califal) \\
\hline
\end{tabular}

\section{Localización}

\begin{tabular}{|l|l|}
\hline Procedencia & ¿Córdoba? Vendida en Cuenca. \\
\hline Ubicación actual & Museo Victoria \& Albert \\
\hline Ciudad & Londres \\
\hline
\end{tabular}




\section{Descripción física}

\begin{tabular}{|c|c|}
\hline Dimensiones & Altura: $26.8 \mathrm{~cm}$, Longitud: $26.2 \mathrm{~cm}$, Profundidad: $16.2 \mathrm{~cm}$ \\
\hline Materiales & Marfil tallado con monturas plateadas \\
\hline $\begin{array}{l}\text { Características } \\
\text { morfológicas }\end{array}$ & $\begin{array}{l}\text { La arqueta reposa sobre cuatro soportes de plata. Este } \\
\text { mismo material perfila el contorno de la pieza adornando } \\
\text { los broches de la misma. La parte superior de la arqueta } \\
\text { cuenta con cuatro adornos que ensalzan las esquinas } \\
\text { superiores y una borla central. }\end{array}$ \\
\hline Inscripción & Eliminada entre los siglos XVII-XVIII. \\
\hline
\end{tabular}

\section{Descripción escena musical}

\begin{tabular}{|l|l|}
\hline Género & Profano \\
\hline Tema & $\begin{array}{l}\text { La vida en la corte, animales y reuniones sociales con } \\
\text { músicos. }\end{array}$ \\
\hline Tipo escena & Específica. \\
\hline Escena general & $\begin{array}{l}\text { La arqueta muestra en los medallones parejas de animales } \\
\text { así como escenas que podían desarrollarse en la corte. } \\
\text { Diversas parejas de aves y animales sueltos adornan los } \\
\text { contornos. En su parte frontal los hombres comen y beben } \\
\text { mientras escuchan música. }\end{array}$ \\
\hline Escena musical & $\begin{array}{l}\text { Existen dos parejas como protagonistas en los dos } \\
\text { medallones que hacen alusión a la música. En el medallón } \\
\text { izquierdo se observan a un músicos interpretando un } \\
\text { albogue acompanado por un hombre que parece comer un } \\
\text { racimo de uvas. En el medallón derecho se observa como } \\
\text { una laudista ameniza a un hombre sentado que bebe. }\end{array}$ \\
\hline
\end{tabular}

\section{Participantes}

Laudista

Instrumento

321.321 Laúd. Laúdes con mástil fijado al resonador, con clavijero y caja abombada 


\begin{tabular}{|l|l|}
\hline \multirow{2}{*}{ Descripción } & $\begin{array}{l}\text { El laúd cuenta con seis clavijas visibles, tres a cada lado. } \\
\text { Las cuerdas están perfectamente definidas aunque pueden } \\
\text { contarse cuatro en vez de seis. El clavijero está inclinado } \\
\text { hacia atrás y cuenta con una voluta perfectamente } \\
\text { definida. No se definen rosetas ni codos. La postura de la } \\
\text { tañedora es verosímil. }\end{array}$ \\
\hline
\end{tabular}

\begin{tabular}{|l|l|}
\hline \multicolumn{2}{|l|}{ Tañedora albogue } \\
\hline Instrumento & $\begin{array}{l}423.121 .22 \text { Aerófono por vibración labial de tubo curvo } \\
\text { con boquilla añadida. }\end{array}$ \\
\hline Descripción & $\begin{array}{l}\text { El cuerno se encuentra apoyado sobre unos labios } \\
\text { perfectamente definidos de la intérprete mientras es } \\
\text { sostenido por ambas manos. Las manos abrazan el } \\
\text { instrumento, lo que hace pensar que éste no cuenta con } \\
\text { agujeros digitales. El albogue queda paralelo a la cabeza } \\
\text { de la intérprete. La postura de la tañedora es verosímil. }\end{array}$ \\
\hline
\end{tabular}

\section{Bibliografía}

Williamson, Paul ed. European Sculpture at the Victoria and Albert Museum. London: Victoria and Albert Museum, 1996; Pérez Higuera, Teresa. "El Jardín del Paraíso: paralelismos iconológicos en el arte hispano musulmán y cristiano medieval". Archivo español de arte 61.241 (1988): 37; Silva Santa-Cruz, Noelia. "Un ejemplo excepcional de marfil pintado nazarí: la arqueta del rey de Aragón Don Martín el Humano1/ An outstanding example of Nasrid painted ivory: the casket of Martin the Humane, King of Aragon". Anales de historia del arte. Vol. 20. Universidad Complutense de Madrid, 2010; Asís García, Francisco. "El Soberano en al-Andalus". Revista Digital de Iconografía Medieval 2.4 (2010): 61-71; Silva SantaCruz, Noelia. "Dádivas preciosas en marfil: la política del regalo en la corte omeya andalusí/ Precious Ivory Presents: Politics of Gift in the Andalusi Umayyad Court". Anales de Historia del Arte. Vol. 24. Universidad Complutense de Madrid, 2014. 
Imagen

Propiedad

(C) Museo Victoria \& Albert 


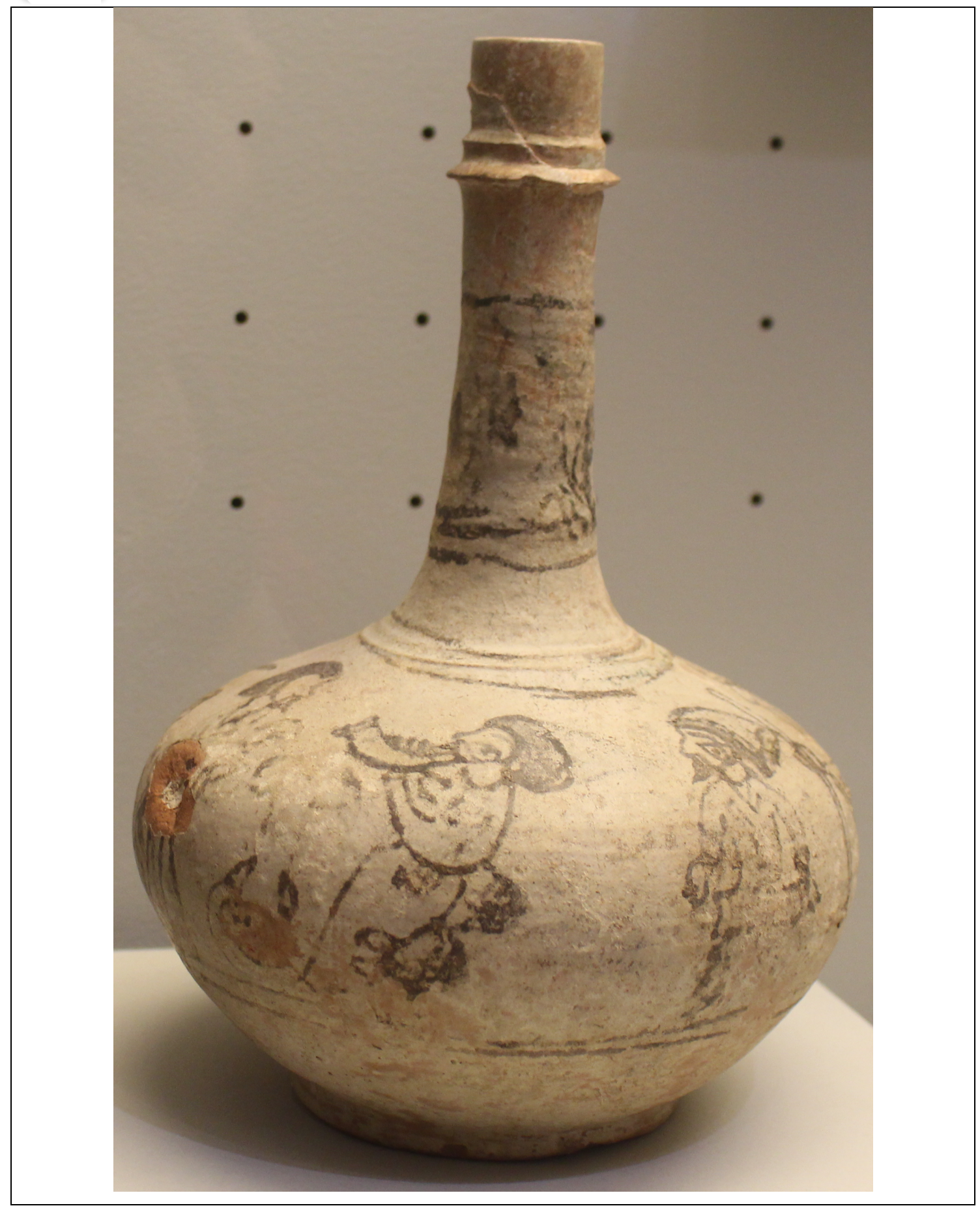

\section{Datos generales}

\begin{tabular}{|l|l|}
\hline Nombre & Botella de los músicos \\
\hline $\mathbf{N}^{\mathbf{0}}$ de inventario & CE011282 \\
\hline Cronología & $900-1000$ (Califal) \\
\hline
\end{tabular}




\section{Localización}

\begin{tabular}{|l|l|}
\hline Procedencia & C/ Alfonso X el Sabio (Córdoba) \\
\hline Ubicación actual & Museo Arqueológico y Etnológico de Córdoba \\
\hline Ciudad & Córdoba \\
\hline
\end{tabular}

\section{Descripción física}

\begin{tabular}{|c|c|}
\hline Dimensiones & Altura: $24,50 \mathrm{~cm}$; Diámetro: $17 \mathrm{~cm}$ \\
\hline Materiales & Arcilla rojiza \\
\hline $\begin{array}{l}\text { Características } \\
\text { morfológicas }\end{array}$ & $\begin{array}{l}\text { Botella de cuerpo panzudo con pie angular y cuello } \\
\text { alargado, alto y estrecho con estrangulaciones en la } \\
\text { boca. El color de la misma viene por el vidrio de plomo } \\
\text { sobre un engobe blanco y cuenta con una decoración } \\
\text { verde por cobre y negruzco manganeso. En la franja } \\
\text { central cuenta con representaciones de figuras } \\
\text { masculinas. }\end{array}$ \\
\hline Inscripción & - \\
\hline
\end{tabular}

\section{Descripción escena musical}

\begin{tabular}{|l|l|}
\hline Género & Profano. \\
\hline Tema & Zambra. \\
\hline Tipo escena & Específica. \\
\hline Zscena general & $\begin{array}{l}\text { Zambra protagonizada por ocho figuras masculinas que } \\
\text { interpretan instrumentos o bailan mientras miran un } \\
\text { elemento central que podría ser una cabra. }\end{array}$ \\
\hline Escena musical & $\begin{array}{l}\text { Sobre la franja central puede observarse ocho personajes } \\
\text { que parecen desfilar unos detrás de otros. La figura que } \\
\text { tiene un color más claro interpreta un cuerno o un } \\
\text { albogue, a esta figura le sigue un intérprete con lo que } \\
\text { parece ser un pandero (adufe) en mano. A su lado hay } \\
\text { otro intérprete de un instrumento de viento } \\
\text { indeterminado. Al otro lado de la figura más clara }\end{array}$ \\
\hline
\end{tabular}




\begin{tabular}{|l|l|}
\hline aparece un hombre sentado que observa a los músicos \\
acompañado por un hombre que parece sostener una \\
larga vara. Por último hay un juglar o saltimbanqui \\
dando una pirueta.
\end{tabular}

\section{Participantes}

\begin{tabular}{|c|c|}
\hline \multicolumn{2}{|c|}{ Intérprete adufe } \\
\hline Instrumento & 211.211.1 Unimembranófonos cilíndricos individuales. \\
\hline Descripción & $\begin{array}{l}\text { Una figura masculina barbada parece sostener en sus } \\
\text { manos un elemento en forma de círculo, lo que se ha } \\
\text { interpretado como un } d u f f \text {, pero ciertamente la imagen se } \\
\text { encuentra muy difusa, la pieza circular no llega a } \\
\text { completar la circunferencia. La mano derecha del } \\
\text { músico se encuentra sobre el instrumento, por lo que } \\
\text { podría estar golpeando el pandero o incluso sujetando } \\
\text { unos crótalos de gran tamaño. }\end{array}$ \\
\hline
\end{tabular}

\begin{tabular}{|c|c|}
\hline \multicolumn{2}{|c|}{ Intérprete albogue } \\
\hline Instrumento & $\begin{array}{l}423.121 .22 \text { Aerófono por vibración labial de tubo curvo } \\
\text { con boquilla añadida. }\end{array}$ \\
\hline Descripción & $\begin{array}{l}\text { El personaje parece desfilar durante la interpretación de } \\
\text { este instrumento. Del albogue se observa la estructura y } \\
\text { una boquilla. A pesar de estar sujetando el instrumento } \\
\text { con ambas manos ninguna de ella cruza por encima de la } \\
\text { imagen lo que permite observad de forma prácticamente } \\
\text { completa el instrumento. El intérprete tiene barba pero } \\
\text { se ve cómo se apoya el instrumento sobre una línea que } \\
\text { parece representar la boca ya que los labios no están } \\
\text { definidos. La postura del intérprete es verosímil pero la } \\
\text { posición de las manos es confusa. }\end{array}$ \\
\hline
\end{tabular}

\section{Bibliografía}

Dabrio González, Ma Teresa (et álii). Guía Artística de Córdoba y su provincia. 
Sevilla-Córdoba: Fundación José Manuel Lara y Ayuntamiento de Córdoba, 2006; Fernández Manzano, Reynaldo. Música y poesía del sur de Al-Andalus. (Catálogo de la exposición), 1995; Martínez Caviró, Balbina. Cerámica hispanomusulmana. Andalusí y Mudéjar. Edición El Viso, 1991; Pareja López, Enrique. "El arte en el sur de Al-Andalus". Historia del Arte en Andalucía, vol. II. Sevilla: 1988; Rosselló Bordoy, Guillermo. El ajuar de las casas andalusies, Málaga: Colección Al-Andalus Ed. Sarriá, 2002; Santos Jener, Samuel. "Botella de cerámica hispanomusulmana con representaciones humanas". Boletín de la Real Academia de Córdoba, de Ciencias, Bellas Artes y Nobles Artes, enero - junio 1954 Núm. 70. Córdoba: Ed. Tipográfica Artísitica, (1954): 401; Torres Balbás, Leopoldo. “España Musulmana. Arte Califal”. Revista Al-Andalus $n^{\circ}$ XVII. Madrid-Granada: Ed. Maestre, (1952): figs. 657,659; Álvarez de Morales, Camilo. Las Andalucías, de Damasco a Córdoba (Catálogo de la Exposición organizada por el Instituto del Mundo Árabe del 28 de noviembre del 2000 al 15 de abril del 2001), Paris, 2000. 2001; Red Digital de Colecciones de Museos en

España: http://ceres.mcu.es/pages/Main?idt=137143\&inventary=CE011282\&table=FMUS\&m useum=MAECO\#.XIVc44WiPaE (Última consulta: 25-02-2020).

\section{Imagen}

\begin{tabular}{|l|l|}
\hline Propiedad & (C) Archivo personal \\
\hline
\end{tabular}




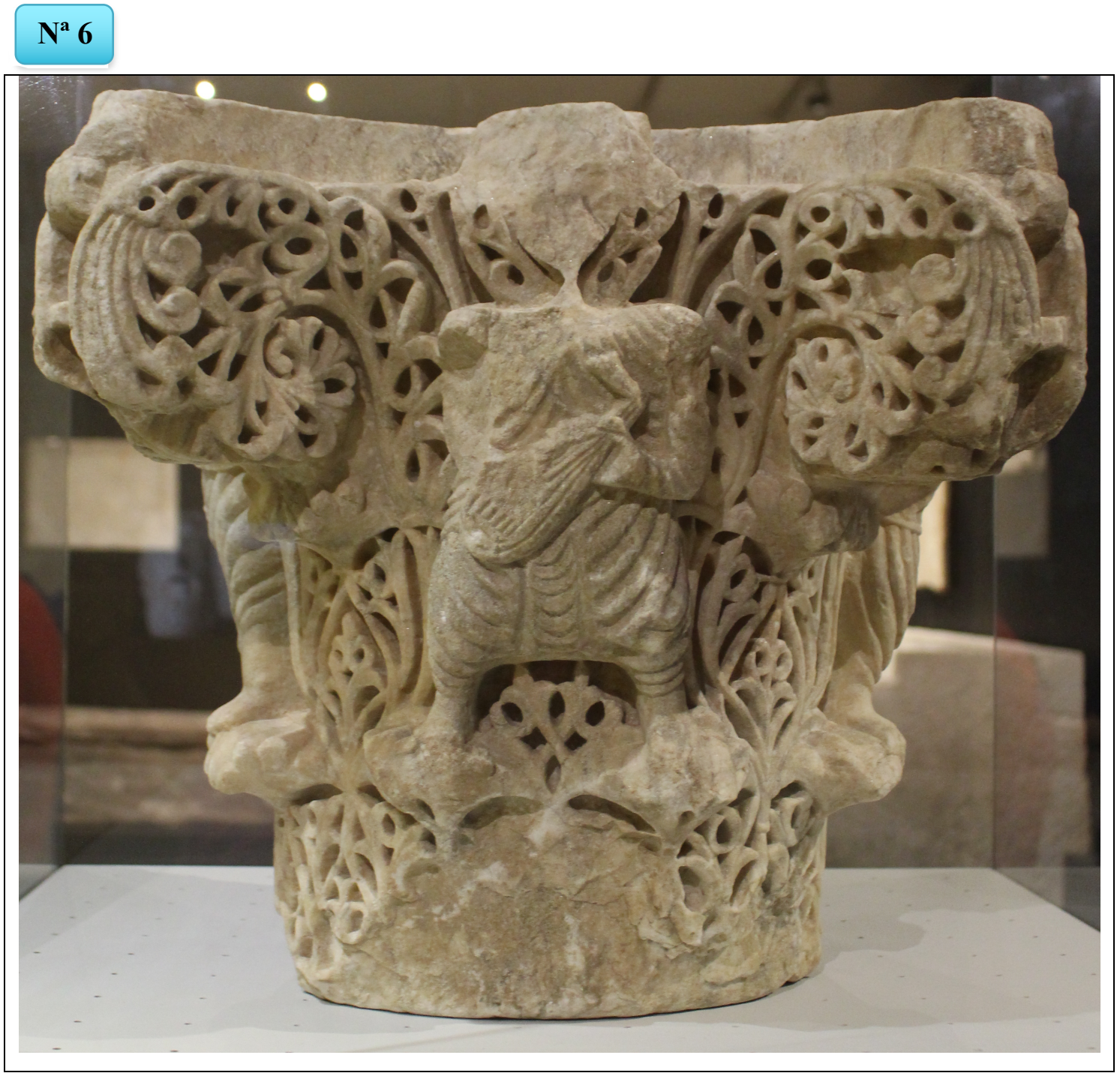

\section{Datos generales}

\begin{tabular}{|l|l|}
\hline Nombre & El capitel de los músicos \\
\hline $\mathbf{N}^{\mathbf{0}}$ de inventario & DOCC133 \\
\hline Cronología & $976-1000$ (Califal) \\
\hline
\end{tabular}

\section{Localización}

\begin{tabular}{|l|l|}
\hline Procedencia & Desconocida \\
\hline Ubicación actual & Museo Arqueológico y Etnológico de Córdoba \\
\hline Ciudad & Córdoba \\
\hline
\end{tabular}




\section{Descripción física}

\begin{tabular}{|l|l|}
\hline Dimensiones & $\begin{array}{l}\text { Altura: } 43 \mathrm{~cm} \text {; Diámetro base: } 26 \mathrm{~cm} \text {; Voluta: Anchura: } 5 \\
\mathrm{~cm}\end{array}$ \\
\hline Materiales & Mármol blanco \\
\hline $\begin{array}{l}\text { Características } \\
\text { morfológicas }\end{array}$ & $\begin{array}{l}\text { Capitel compuesto por tres volutas talladas y cuatro } \\
\text { músicos decapitados intencionadamente. El tamaño de los } \\
\text { músicos en pie define prácticamente el alto de la pieza. }\end{array}$ \\
\hline Inscripción & - \\
\hline
\end{tabular}

\section{Descripción escena musical}

\begin{tabular}{|l|l|}
\hline Género & Profano. \\
\hline Tema & Zambra. \\
\hline Tipo escena & Específica. \\
\hline Escena general & Posible zambra con cuatro músicos. \\
\hline Escena musical & $\begin{array}{l}\text { Cada una de las caras del capitel presenta un músico } \\
\text { separados mediante volutas. Los músicos permanecen en } \\
\text { pie con un gran tamaño que eclipsa la pieza. Tres de ellos } \\
\text { interpretan un cordófono, un rabel y dos laúdes, y el otro } \\
\text { parece interpretar lo que podría ser un instrumento de } \\
\text { viento, aunque investigadores como Rosselló Bordoy } \\
\text { sostienen que podría sujetar una especie de abanico } \\
\text { siendo el señor que presidía la zambra. }\end{array}$ \\
\hline
\end{tabular}

\section{Participantes}

\begin{tabular}{|l|l|}
\hline \multicolumn{2}{|l|}{ Intérprete rabel } \\
\hline Instrumento & $\begin{array}{l}321.321 .71 \text { Laúdes con mástil fijado al resonador, con } \\
\text { clavijero y caja abombada con sonido por fricción } \\
\text { tangencial sobre las cuerdas con arco. }\end{array}$ \\
\hline Descripción & $\begin{array}{l}\text { El rabel parece contar con tres cuerdas que son frotadas } \\
\text { por un arco de pequeño tamaño. El intérprete lo sujeta de } \\
\text { forma transversal a su cuerpo por lo que el arco se mueve }\end{array}$ \\
\hline
\end{tabular}




\begin{tabular}{|l|l|}
\hline de forma vertical sobre el pecho del músico. La mano \\
derecha que sujeta el arco no está del todo definida \\
aunque parece sujetar discretamente un extremo de este \\
pequeño arco, la mano izquierda sujeta el mástil del \\
instrumento rodeándolo por completo lo que dificultaría la \\
interpretación del mismo. El mástil parece contar con un \\
clavijero inclinado pero no llegan a definirse las clavijas. \\
La postura del intérprete no es verosímil.
\end{tabular}

\begin{tabular}{|l|l|}
\hline Laudista 1 & $\begin{array}{l}321.321 \text { Laúd. Laúdes con mástil fijado al resonador, con } \\
\text { clavijero y caja abombada. }\end{array}$ \\
\hline $\begin{array}{l}\text { El laúd se encuentra bastante difuminado por lo que es } \\
\text { difícil percibir detalles, parece que podría contar con unas } \\
\text { cuatro cuerdas observando la parte inferior del } \\
\text { instrumento. La mano izquierda se encuentra apoyada en } \\
\text { un mástil que parece contar con un clavijero inclinado } \\
\text { aunque no llegan a observarse de forma nítida las clavijas. } \\
\text { El brazo derecho no se conserva aunque por la muesca del } \\
\text { laúd podría haber estado apoyado sobre las cuerdas del } \\
\text { mismo. La postura del laudista podría ser verosímil pero } \\
\text { la mano que se conserva sujeta el mástil rodea todas las } \\
\text { cuerdas, lo que haría inviable la interpretación. Este laúd } \\
\text { siendo de menor tamaño que el segundo hace pensar a } \\
\text { estudiosos como Reynaldo Fernández que podría tratarse } \\
\text { de un antecesor del laúd mientras que otros como Noack } \\
\text { Hale mantienen que podría tratarse de un kamman. }\end{array}$ \\
\hline
\end{tabular}

\begin{tabular}{|l|l|}
\hline \multicolumn{2}{|l|}{ Laudista 2 } \\
\hline Instrumento & $\begin{array}{l}321.321 \text { Laúd. Laúdes con mástil fijado al resonador, con } \\
\text { clavijero y caja abombada. }\end{array}$ \\
\hline Descripción & $\begin{array}{l}\text { El segundo laudista supone prácticamente una copia del } \\
\text { primero en su postura corporal y en la forma de sujetar el }\end{array}$ \\
\hline
\end{tabular}




\begin{tabular}{|l|l|}
\hline instrumento. La diferencia entre ambos instrumentos sería \\
el tamaño, este segundo laúd es más grande que el \\
primero. Del intérprete en este caso sí se conservan ambas \\
manos, por lo que estudiando la posición de ambas podría \\
corroborarse la conjetura de que el primero podría tener \\
apoyada su mano derecha sobre las cuerdas ya que así lo \\
hace este segundo músico. La forma de sujeción del \\
instrumento sigue dificultando la interpretación del \\
mismo por lo que ésta se considera inviable.
\end{tabular}

\section{Bibliografía}

Dabrio González, Ma Teresa (et álii). Guía Artística de Córdoba y su provincia. Sevilla-Córdoba: Fundación José Manuel Lara y Ayuntamiento de Córdoba Febrero, 2006; Fernández Manzano, Reynaldo. Música y poesía del sur de Al-Andalus. (Catálogo de la exposición). 1995, 79, 89, fig. 4; Martínez Caviró, Balbina. Cerámica hispanomusulmana andalusí y mudéjar. Madrid, Ediciones El Viso, 1991: 43; Pareja López, Enrique. "El arte en el sur de Al-Andalus". Historia del Arte en Andalucía, vol.II, Sevilla: 1988, 415- 416, fig. 422; Rosselló Bordoy, Guillermo. El ajuar de las casas andalusíes. Colección Al-Andalus Ed. Sarriá Málaga, 2002, 92; Santos Jener, Samuel. "Museo Arqueológico de Córdoba". Boletín de la Real Academia de Córdoba, de Ciencias, Bellas Artes y Nobles Artes, enero - junio 1954 Núm. 70. Córdoba: Ed. Tipográfica Artística, 1954, 305-307; Santos Jener, Samuel. "Botella de cerámica hispanomusulmana con representaciones humanas". Revista Al-Andalus $n^{o}$ XVII. Madrid-Granada: Ed. Maestre, 1952, 401; Torres Balbás, Leopoldo. "España Musulmana. Arte Califal”. Revista Al-Andalus $n^{\circ}$ XVII. Madrid-Granada: Ed. Maestre, 1952, figs. 657, 659; Álvarez de Morales, Camilo. Las Andalucías, de Damasco a Córdoba (Catálogo de la Exposición organizada por el Instituto del Mundo Árabe del 28 de noviembre del 2000 al 15 de abril del 2001), Paris, 2000. 2001; Red Digital de Colecciones de Museos en España: http://ceres.mcu.es/pages/Main?idt=129132\&inventary=DOCC133\&table=FMUS\&m useum=MAECO\#.XlVdEIPx-1Y (Última consulta: 25-02-2020). 
Imagen

Propiedad

(C) Archivo personal 


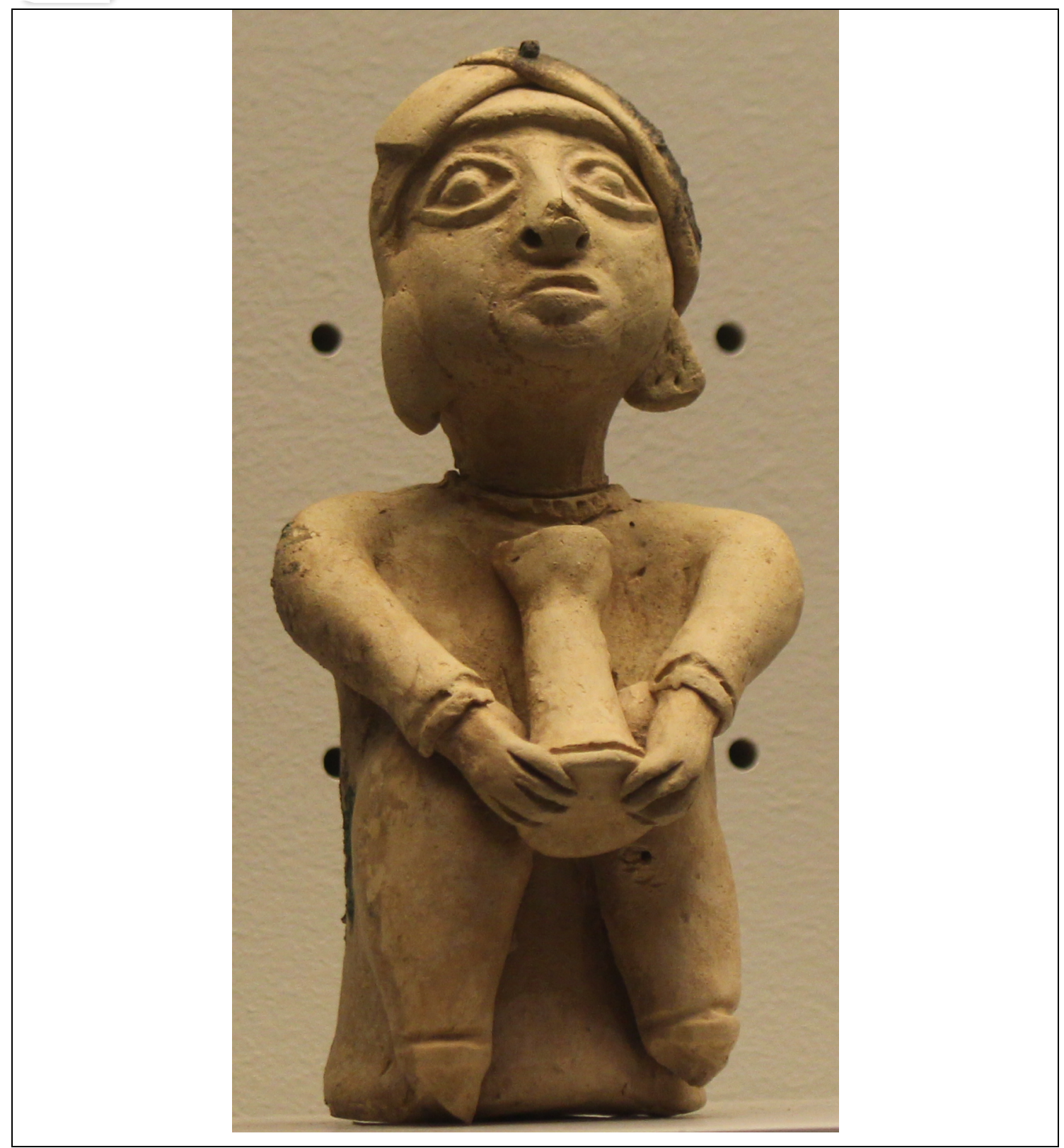

\section{Datos generales}

\begin{tabular}{|l|l|}
\hline Nombre & Tañedora tambor \\
\hline $\mathbf{N}^{\mathbf{0}}$ de inventario & 33340 \\
\hline Cronología & XI-XII (Califal-Almohade) \\
\hline
\end{tabular}

\section{Localización}

Procedencia

Calle Ollerías 


\begin{tabular}{|l|l|}
\hline Ubicación actual & Museo Arqueológico y Etnológico de Córdoba \\
\hline Ciudad & Córdoba \\
\hline
\end{tabular}

\section{Descripción física}

\begin{tabular}{|l|l|}
\hline Dimensiones & - \\
\hline Materiales & Arcilla \\
\hline Características & $\begin{array}{l}\text { Figura femenina con lo que parece un pañuelo cubriendo } \\
\text { su cabello sentada con las piernas estiradas sobre una } \\
\text { morfológicas }\end{array}$ \\
$\begin{array}{l}\text { especie de roca entre las cuales interpreta con sus manos } \\
\text { un pequeño tambor. El soporte sobre el que parece reposar } \\
\text { la pieza forma parte del cuerpo de la intérprete. }\end{array}$ \\
\hline Inscripción & - \\
\hline
\end{tabular}

\section{Descripción escena musical}

\begin{tabular}{|l|l|}
\hline Género & Profano \\
\hline Tema & Tañedora de tamborcillo \\
\hline Tipo escena & Específica \\
\hline Escena general & $\begin{array}{l}\text { Tañedora sujeta entre sus piernas un tambor que parece } \\
\text { percutir con las manos. }\end{array}$ \\
\hline Escena musical & $\begin{array}{l}\text { Tañedora percute con sus manos un tambor de pequeño } \\
\text { tamaño el cual parece contar con un solo parche. }\end{array}$ \\
\hline
\end{tabular}

\section{Participantes}

\begin{tabular}{|c|c|}
\hline \multicolumn{2}{|c|}{ Tañedora tamborcillo } \\
\hline Instrumento & 211.26 Membranófono en forma de copa. \\
\hline Descripción & $\begin{array}{l}\text { El tamborcillo cuenta con una sola membrana. Su forma } \\
\text { es de copa siendo la parte del parche más larga que la de } \\
\text { la base. El parche queda sujeto en uno de los extremos del } \\
\text { instrumento que progresivamente va estrechando su } \\
\text { diámetro hasta llegar cerca del otro extremo del } \\
\text { tamborcillo donde vuelve a ensancharse de forma } \\
\text { progresiva. La tañedora lo sujeta entre sus piernas y lo }\end{array}$ \\
\hline
\end{tabular}


golpea con sus manos. La postura de la tañedora es verosímil.

\section{Bibliografía}

Salinas Pleguezuelo, Elena. La cerámica islámica de Madinat Qurtuba de 1031 a 1236: cronotipología y centros de producción. Córdoba: Universidad de Córdoba, 2012, 401.

\section{Imagen}

Propiedad (C) Archivo personal 


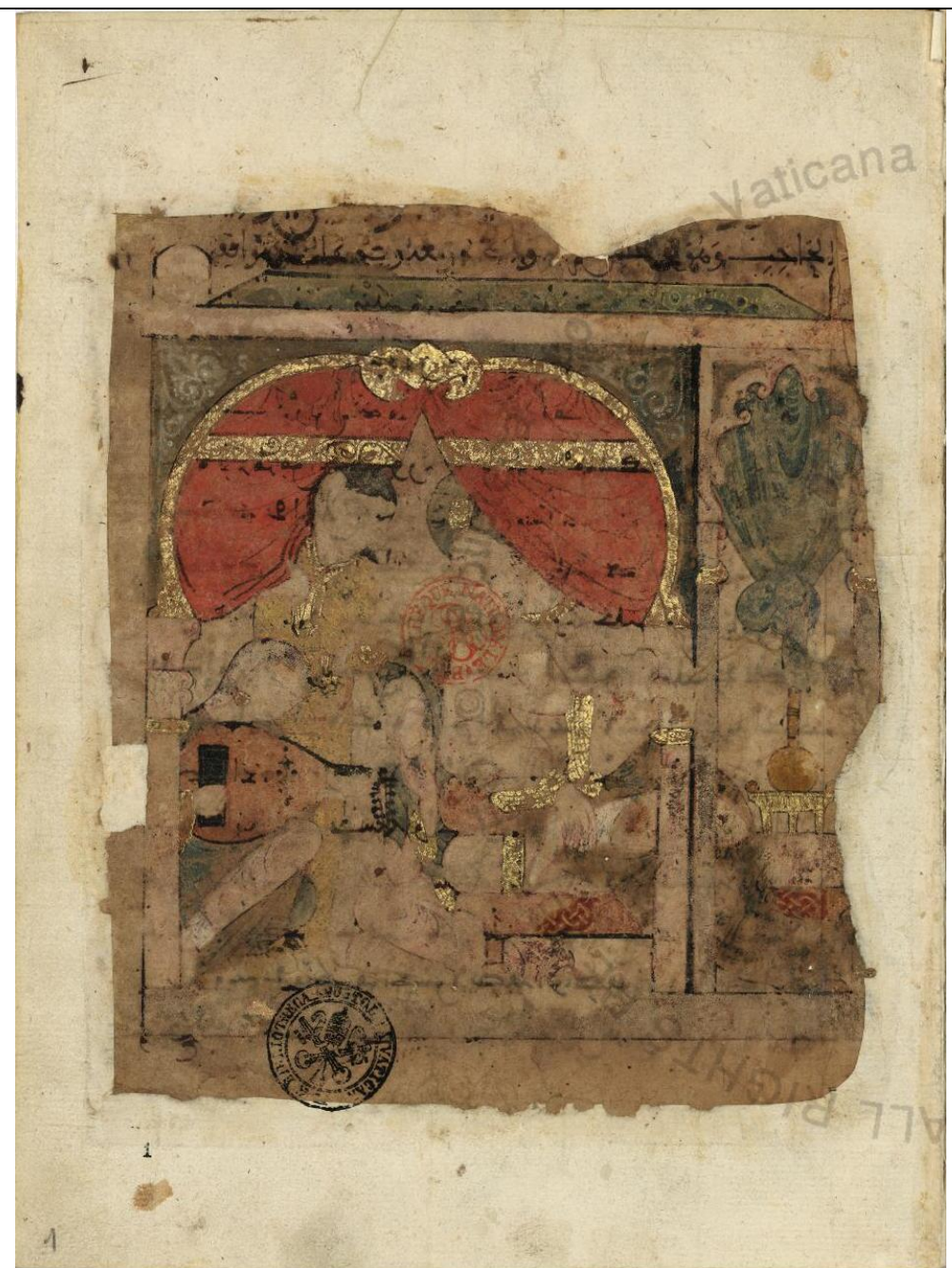

\section{Datos generales}

\begin{tabular}{|l|l|}
\hline Nombre & Imagen 1r manuscrito "Hadith o Qissat Bayad wa Riyad" \\
\hline $\mathbf{N}^{\mathbf{0}}$ de inventario & Codex. Vat. Arabo 368 \\
\hline Cronología & XIII (Almohade) \\
\hline
\end{tabular}

\section{Localización}

\begin{tabular}{|l|l|}
\hline Procedencia & Al-Andalus o el Magreb \\
\hline Ubicación actual & Biblioteca Apostólica de la Ciudad del Vaticano \\
\hline Ciudad & Vaticano \\
\hline
\end{tabular}




\section{Descripción escena musical}

\begin{tabular}{|l|l|}
\hline Género & Profano \\
\hline Tema & $\begin{array}{l}\text { Cuento que refleja una historia de amor entre dos jóvenes. } \\
\text { Las imágenes van recreando las escenas relatadas. }\end{array}$ \\
\hline Tipo escena & $\begin{array}{l}\text { Específica } \\
\text { cantora toca un laúd acompañada por dos personas, una } \\
\text { permanece de pie y otra se sienta a su lado. No se } \\
\text { distingue si las figuras que acompañan a la intérprete son } \\
\text { masculinas o femeninas. La escena transcurre en una sala } \\
\text { de palacio con grandes cortinas donde se vislumbra al } \\
\text { hayib sentado sobre una tarima. }\end{array}$ \\
\hline Escena musical & $\begin{array}{l}\text { Toda la atención de la escena se enfoca sobre la esclava } \\
\text { cantora que se encuentra en la esquina inferior izquierda } \\
\text { ya que, por el estado de conservación de la imagen, resulta } \\
\text { la parte más nítida de esta. Se puede observar a la esclava } \\
\text { cantora con la cabeza cubierta que se inclina sobre el laúd } \\
\text { durante la interpretación dando la sensación de apoyar su } \\
\text { cara sobre el instrumento. El resto de figuras parecen } \\
\text { escucharle. }\end{array}$ \\
\hline
\end{tabular}

\section{Participantes}

\begin{tabular}{|l|l|}
\hline \multicolumn{2}{|l|}{ Laudista } \\
\hline Instrumento & $\begin{array}{l}321.321 \text { Laúd. Laúdes con mástil fijado al resonador, con } \\
\text { clavijero y caja abombada. }\end{array}$ \\
\hline \multirow{3}{*}{ Descripción } & $\begin{array}{l}\text { A pesar de lo deteriorada que se encuentra la imagen } \\
\text { pueden verse detalles del instrumento que interpreta la } \\
\text { esclava cantora. Ella se encuentra sentada y apoya el } \\
\text { instrumento sobre su rodilla derecha permaneciendo la } \\
\text { izquierda más baja que la anterior. Su mano derecha } \\
\text { reposa sobre las cuerdas mientras que se intuye que la } \\
\text { izquierda lo hace en el mástil. El cuerpo del laúd se }\end{array}$ \\
\hline
\end{tabular}


encuentra totalmente definido pudiéndose ver adornos en el mismo pero no se observan las cuerdas a lo largo del instrumento. El clavijero arqueado parece contar con once clavijas. La postura de la intérprete de laúd es verosímil.

\section{Bibliografía}

della Vida, Giorgio Levi. Elenco dei manoscritti arabi islamici della Biblioteca Vaticana. Città del Vaticano: 1935; Holter, Kurt. Die islamischen miniaturhandschriften Vor 1350. Otto Harrassowitz, 1937; Monneret de Villard, Ugo. "Un codice arabo-spagnolo con miniature". La Bibliofilía, 43 n. 10/12, 1941, 209-23; Kykl, Alois Richard. Historia de los amores de Bayad y Rijad. 1941; Robinson, Cynthia. "The lover, his lady, her lady, and a Thirteenth-Century Celestina: a recipe for love sickness from al-Andalus". En Islamic Art and Literature, 79-115, 2001; D'Ottone, Arianna. "Il manoscritto Vaticano Arabo 368, Hadit Bayad wa Riyad. Il codice, il testo, le immagini”. Rivista di storia della miniatura. 2010; D'Ottone Arianna. La storia di Bayad e Riyad (Vat. Ar. 368): Una nuova edizione e traduzione. 2013.

\section{Imagen}

\section{Propiedad}

(C) Biblioteca Apostólica de la Ciudad del Vaticano 


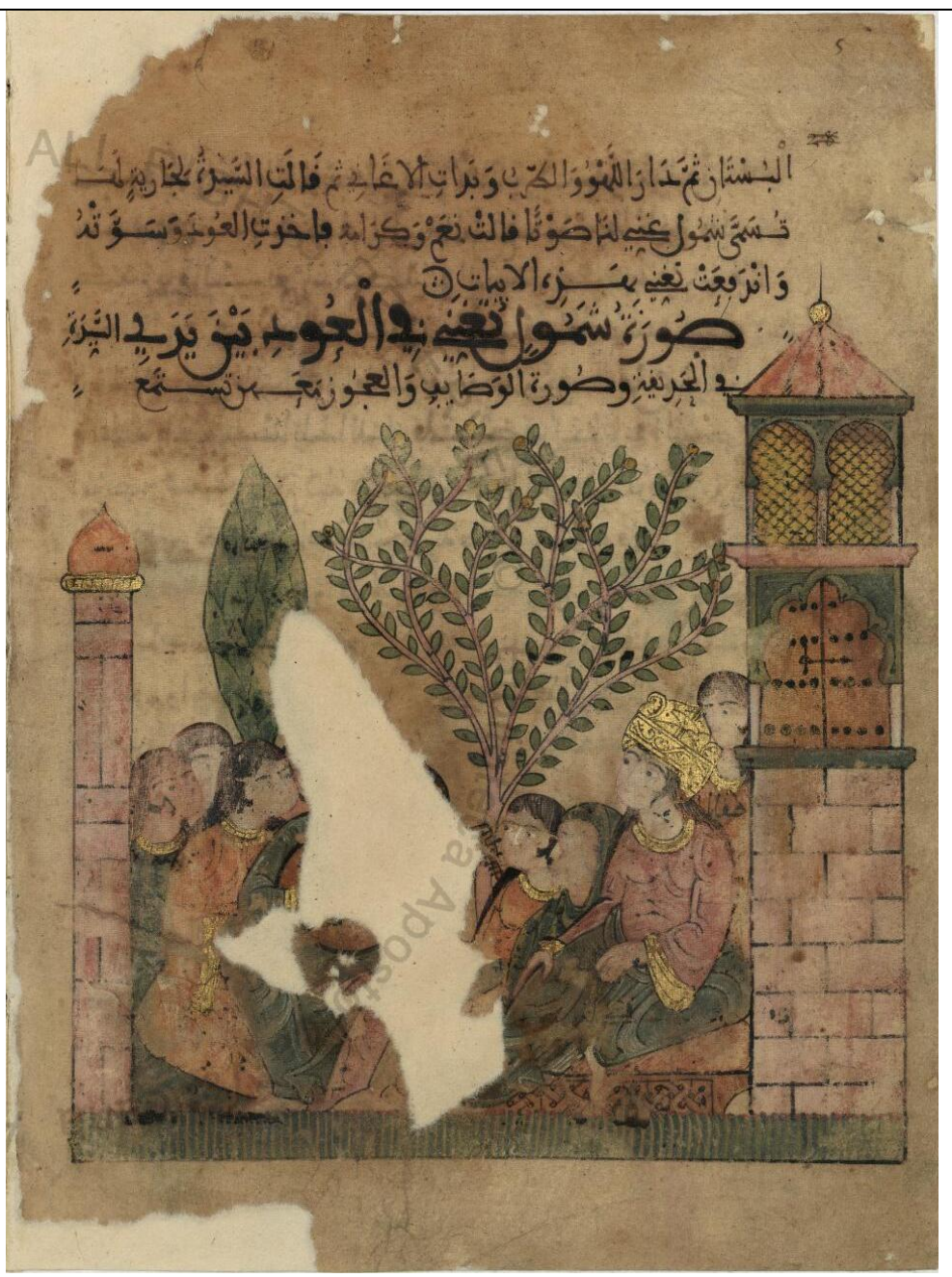

\section{Datos generales}

\begin{tabular}{|l|l|}
\hline Nombre & Imagen 4v manuscrito "Hadith o Qissat Bayad wa Riyad" \\
\hline $\mathbf{N}^{\mathbf{0}}$ de inventario & Codex. Vat. Arabo 368 \\
\hline Cronología & XIII (Almohade) \\
\hline
\end{tabular}

\section{Localización}

\begin{tabular}{|l|l|}
\hline Procedencia & Al-Andalus o el Magreb \\
\hline Ubicación actual & Biblioteca Apostólica de la Ciudad del Vaticano \\
\hline Ciudad & Vaticano \\
\hline
\end{tabular}




\section{Descripción escena musical}

\begin{tabular}{|l|l|}
\hline Género & Profano \\
\hline Tema & Específica \\
\hline Tipo escena & $\begin{array}{l}\text { Esta transcurre en el jardín del palacio donde la Sayyida } \\
\text { preside la velada, Shumul toca el laúd. Hay un intérprete } \\
\text { de laúd que se ve rodeado por las esclavas y una anciana. } \\
\text { La arquitectura y decoración evoca a la estética andalusí. }\end{array}$ \\
\hline Escena musical & $\begin{array}{l}\text { El músico, Shumul, preside la imagen rodeado de } \\
\text { esclavas. }\end{array}$ \\
\hline
\end{tabular}

\section{Participantes}

\begin{tabular}{|l|l|}
\hline Laudista & $\begin{array}{l}321.321 \text { Laúd. Laúdes con mástil fijado al resonador, con } \\
\text { clavijero y caja abombada }\end{array}$ \\
\hline \multirow{2}{*}{ Descripción } & $\begin{array}{l}\text { Por lo deteriorada que se encuentra la imagen no se puede } \\
\text { observar apenas más que el contorno de la caja de } \\
\text { resonancia del instrumento. El intérprete se encuentra } \\
\text { sentado y su mano derecha parece reposar sobre las } \\
\text { cuerdas del instrumento. Parece contar con un clavijero } \\
\text { arqueado. }\end{array}$ \\
\hline
\end{tabular}

\section{Bibliografía}

della Vida, Giorgio Levi. Elenco dei manoscritti arabi islamici della Biblioteca Vaticana. Città del Vaticano: 1935; Holter, Kurt. Die islamischen miniaturhandschriften Vor 1350. Otto Harrassowitz, 1937; Monneret de Villard, Ugo. “Un codice arabo-spagnolo con miniature”. La Bibliofilía, 43 n. 10/12, (1941): 20923; Kykl, Alois Richard. Historia de los amores de Bayad y Rijad. 1941; Robinson, Cynthia. "The lover, his lady, her lady, and a Thirteenth-Century Celestina: a recipe for love sickness from al-Andalus". En Islamic Art and Literature, 79-115. 2001; D'Ottone, Arianna. "Il manoscritto Vaticano Arabo 368, Hadit Bayad wa Riyad. Il codice, il testo, le immagini”. Rivista di storia della miniatura. 2010; D'Ottone 
Arianna. La storia di Bayad e Riyad (Vat. Ar. 368): Una nuova edizione e traduzione. 2013.

\section{Imagen}

Propiedad

(C) Biblioteca Apostólica de la Ciudad del Vaticano 


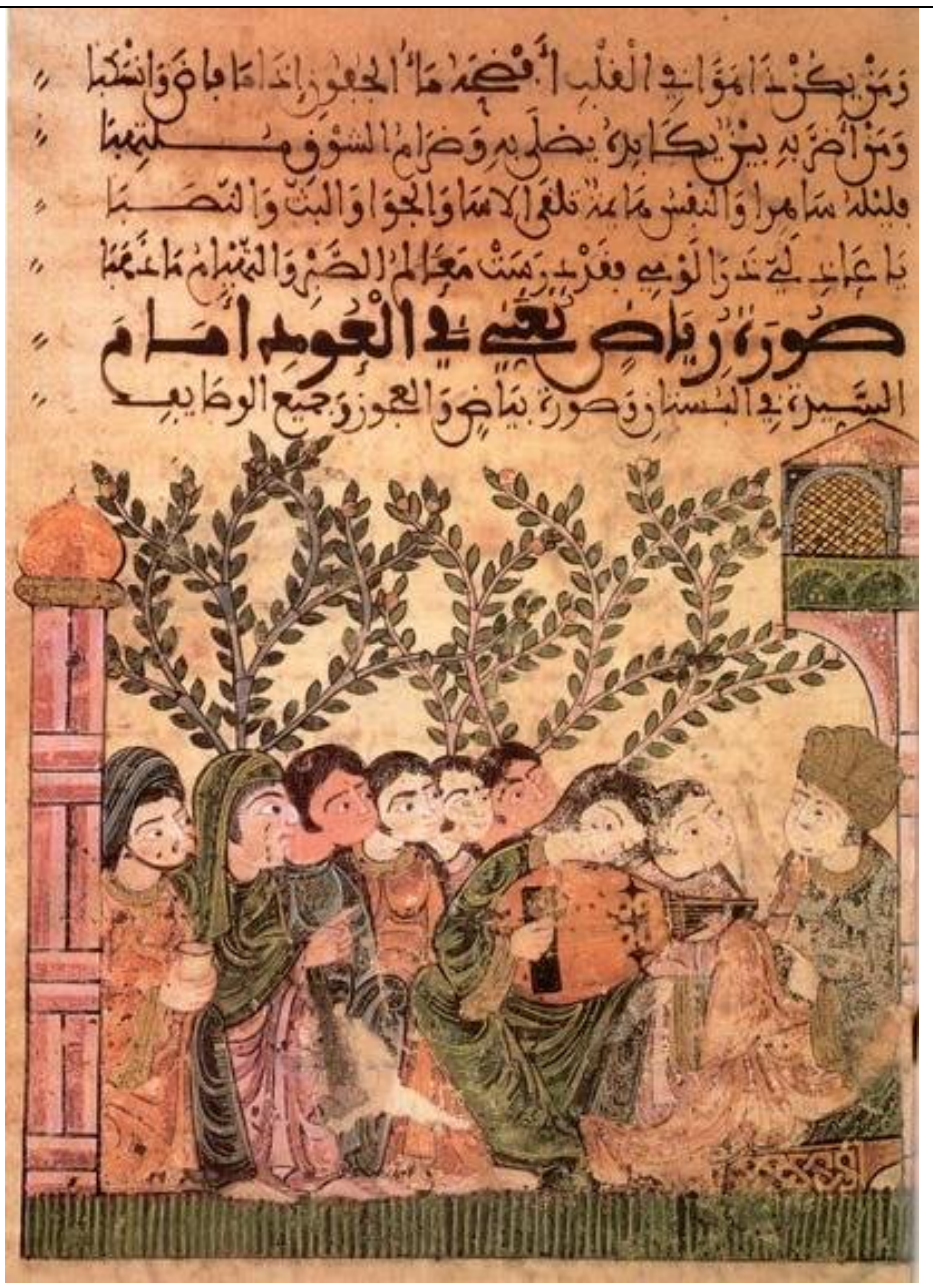

\section{Datos generales}

\begin{tabular}{|l|l|}
\hline Nombre & Imagen 9r manuscrito “Hadith o Qissat Bayad wa Riyad” \\
\hline $\mathbf{N}^{\mathbf{0}}$ de inventario & Codex. Vat. Arabo 368 \\
\hline Cronología & XIII (Almohade) \\
\hline
\end{tabular}

\section{Localización}

\begin{tabular}{|l|l|}
\hline Procedencia & Al-Andalus o el Magreb \\
\hline Ubicación actual & Biblioteca Apostólica de la Ciudad del Vaticano \\
\hline Ciudad & Vaticano \\
\hline
\end{tabular}




\section{Descripción escena musical}

\begin{tabular}{|l|l|}
\hline Género & Profano \\
\hline Tema & Específica \\
\hline Tipo escena & $\begin{array}{l}\text { Escena musical que transcurre posiblemente en el exterior } \\
\text { del palacio, Riyad interpreta el laúd mientras la Sayyida, } \\
\text { situada sobre una tarima con un turbante, y el resto de } \\
\text { invitados le escucha. Uno de los oyentes sostiene un vaso } \\
\text { mientras que la anciana con la cabeza cubierta señala con } \\
\text { el dedo de su mano derecha a la laudista. }\end{array}$ \\
\hline Escena musical & $\begin{array}{l}\text { La laudista, a la derecha de la imagen, cuenta con la } \\
\text { atención de todas las figuras representadas. Por la } \\
\text { disposición de las figuras en la imagen puede deducirse } \\
\text { que el autor o autora de la misma pretendía dar el } \\
\text { protagonismo a la intérprete. }\end{array}$ \\
\hline
\end{tabular}

\section{Participantes}

\begin{tabular}{|l|l|}
\hline \multicolumn{1}{|l|}{ Laudista } & $\begin{array}{l}321.321 \text { Laúd. Laúdes con mástil fijado al resonador, con } \\
\text { clavijero y caja abombada }\end{array}$ \\
\hline \multirow{2}{*}{ Descripción } & $\begin{array}{l}\text { La laudista sujeta un laúd con adornos negros en forma de } \\
\text { estrella sobre su rodilla izquierda. Se encuentra sentada } \\
\text { con las piernas recogidas. Parecen contarse cinco cuerdas } \\
\text { sobre el mástil del instrumento. Su mano derecha rasga las } \\
\text { cuerdas mientras su mano izquierda las presiona sobre el } \\
\text { mástil. El puente es muy visible ya que está en negro y } \\
\text { atraviesa casi toda la caja de resonancia de forma } \\
\text { transversal. La postura de interpretación de la laudista es } \\
\text { verosímil. }\end{array}$ \\
\hline
\end{tabular}

\section{Bibliografía}

della Vida, Giorgio Levi. Elenco dei manoscritti arabi islamici della Biblioteca 
Vaticana. Città del Vaticano: 1935; Holter, Kurt. Die islamischen miniaturhandschriften Vor 1350. Otto Harrassowitz, 1937; Monneret de Villard, Ugo. “Un codice arabo-spagnolo con miniature”. La Bibliofilía, 43 n. 10/12, (1941): 20923; Kykl, Alois Richard. Historia de los amores de Bayad y Rijad. 1941; Robinson, Cynthia. "The lover, his lady, her lady, and a Thirteenth-Century Celestina: a recipe for love sickness from al-Andalus". En Islamic Art and Literature, 79-115. 2001; D'Ottone, Arianna. "Il manoscritto Vaticano Arabo 368, Hadit Bayad wa Riyad. Il codice, il testo, le immagini”. Rivista di storia della miniatura. 2010; D'Ottone Arianna. La storia di Bayad e Riyad (Vat. Ar. 368): Una nuova edizione e traduzione. 2013.

Imagen

\begin{tabular}{|l|l|}
\hline Propiedad & C Biblioteca Apostólica de la Ciudad del Vaticano
\end{tabular} 


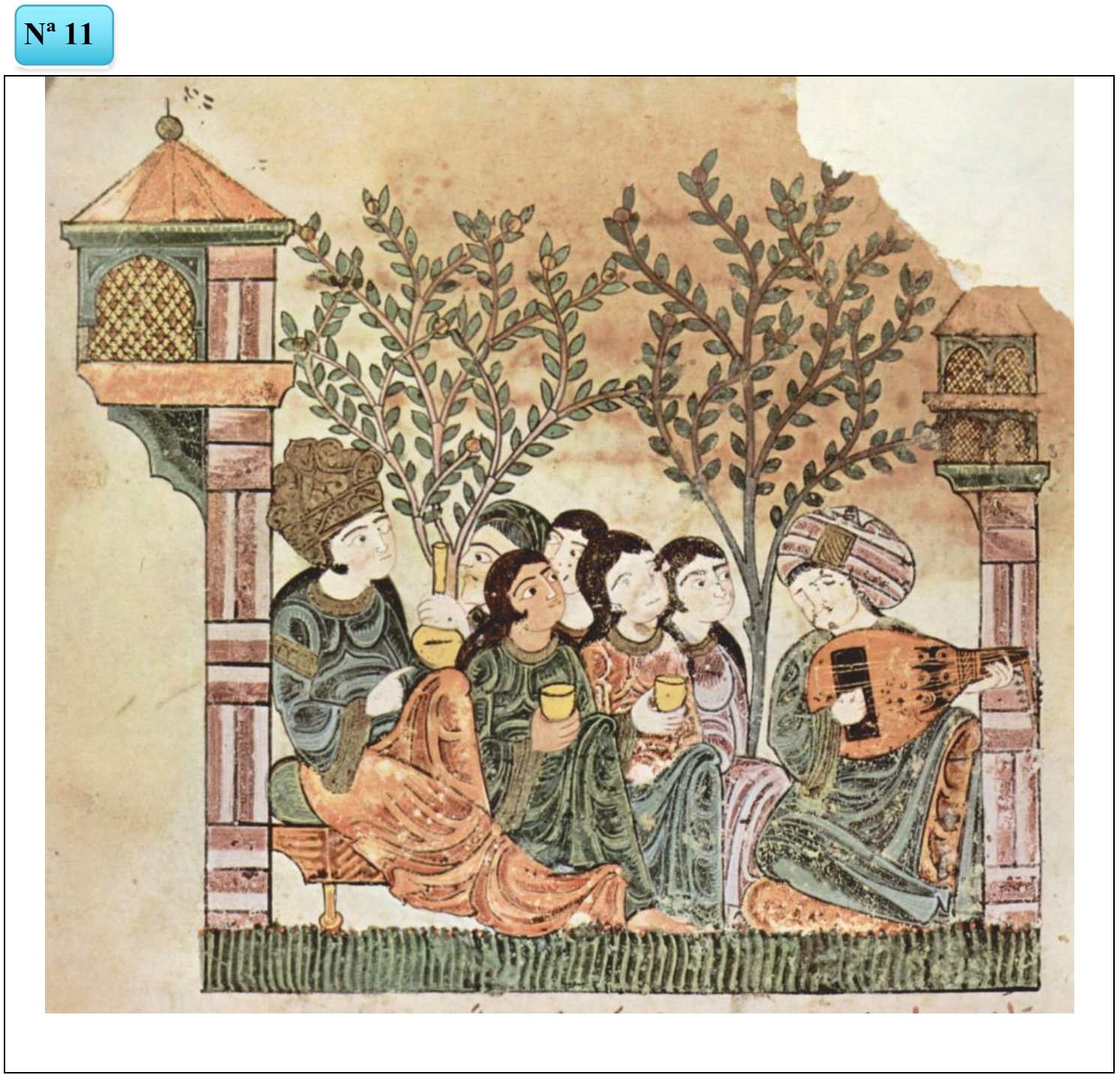

\section{Datos generales}

\begin{tabular}{|l|l|}
\hline Nombre & Imagen 10r manuscrito "Hadith o Qissat Bayad wa Riyad" \\
\hline $\mathbf{N}^{\mathbf{0}}$ de inventario & Codex. Vat. Arabo 368 \\
\hline Cronología & XIII (Almohade) \\
\hline
\end{tabular}

\section{Localización}

\begin{tabular}{|l|l|}
\hline Procedencia & Al-Andalus o el Magreb \\
\hline Ubicación actual & Biblioteca Apostólica de la Ciudad del Vaticano \\
\hline Ciudad & Vaticano \\
\hline
\end{tabular}




\section{Descripción escena musical}

\begin{tabular}{|l|l|}
\hline Género & Profano \\
\hline Tema & Específica \\
\hline Tipo escena & $\begin{array}{l}\text { La escena transcurre en un jardín exterior del palacio ya } \\
\text { que se observan árboles delgados de fondo. Bayad } \\
\text { interpreta el laúd en público. La Sayyida cuenta con una } \\
\text { elegante tiara y preside la velada desde una tarima. Siendo } \\
\text { el laudista el centro de atención a pesar de estar a una lado } \\
\text { de la imagen. En la escena se observan a seis personas } \\
\text { más a parte del músico. Todas las oyentes son mujeres, } \\
\text { dos de ellas llevan la cabeza cubierta, otras dos sujetan } \\
\text { copas y una en segundo plano lleva una redoma en su } \\
\text { mano. }\end{array}$ \\
\hline Escena musical & $\begin{array}{l}\text { El músico colocado a la derecha de la imagen capta la } \\
\text { mirada de cuatro de las seis oyentes de la escena. Éste } \\
\text { cuenta con un turbante que cubre su cabeza. }\end{array}$ \\
\hline
\end{tabular}

\section{Participantes}

\begin{tabular}{|l|l|}
\hline Laudista & $\begin{array}{l}321.321 \text { Laúd. Laúdes con mástil fijado al resonador, con } \\
\text { clavijero y caja abombada }\end{array}$ \\
\hline Descripción & $\begin{array}{l}\text { El laudista apoya el instrumento sobre la rodilla izquierda } \\
\text { mientras parece sentarse sobre la pierna derecha. La mano } \\
\text { derecha del mismo reposa sobre las cuerdas. Justo debajo } \\
\text { de esta mano el laúd tiene un adorno negro, una franja que } \\
\text { atraviesa casi toda la caja de resonancia. En la parte más } \\
\text { pegada al mástil el laúd se ve finamente adornado. La } \\
\text { mano derecha del intérprete se encuentra sobre el mástil } \\
\text { con los dedos bien definidos, se puede observar dónde } \\
\text { coloca exactamente la mano. El clavijero arqueado cuenta } \\
\text { con unas once clavijas. La postura del intérprete es }\end{array}$ \\
\hline
\end{tabular}


verosímil.

\section{Bibliografía}

della Vida, Giorgio Levi. Elenco dei manoscritti arabi islamici della Biblioteca Vaticana. Città del Vaticano: 1935; Holter, Kurt. Die islamischen miniaturhandschriften Vor 1350. Otto Harrassowitz, 1937; Monneret de Villard, Ugo. “Un codice arabo-spagnolo con miniature”. La Bibliofilía, 43 n. 10/12, (1941): 20923; Kykl, Alois Richard. Historia de los amores de Bayad y Rijad. 1941; Robinson, Cynthia. "The lover, his lady, her lady, and a Thirteenth-Century Celestina: a recipe for love sickness from al-Andalus". En Islamic Art and Literature, 79-115. 2001; D'Ottone, Arianna. "Il manoscritto Vaticano Arabo 368, Hadit Bayad wa Riyad. Il codice, il testo, le immagini”. Rivista di storia della miniatura. 2010; D'Ottone Arianna. La storia di Bayad e Riyad (Vat. Ar. 368): Una nuova edizione e traduzione. 2013.

\section{Imagen}

\begin{tabular}{|l|l|}
\hline Propiedad & C Biblioteca Apostólica de la Ciudad del Vaticano
\end{tabular}




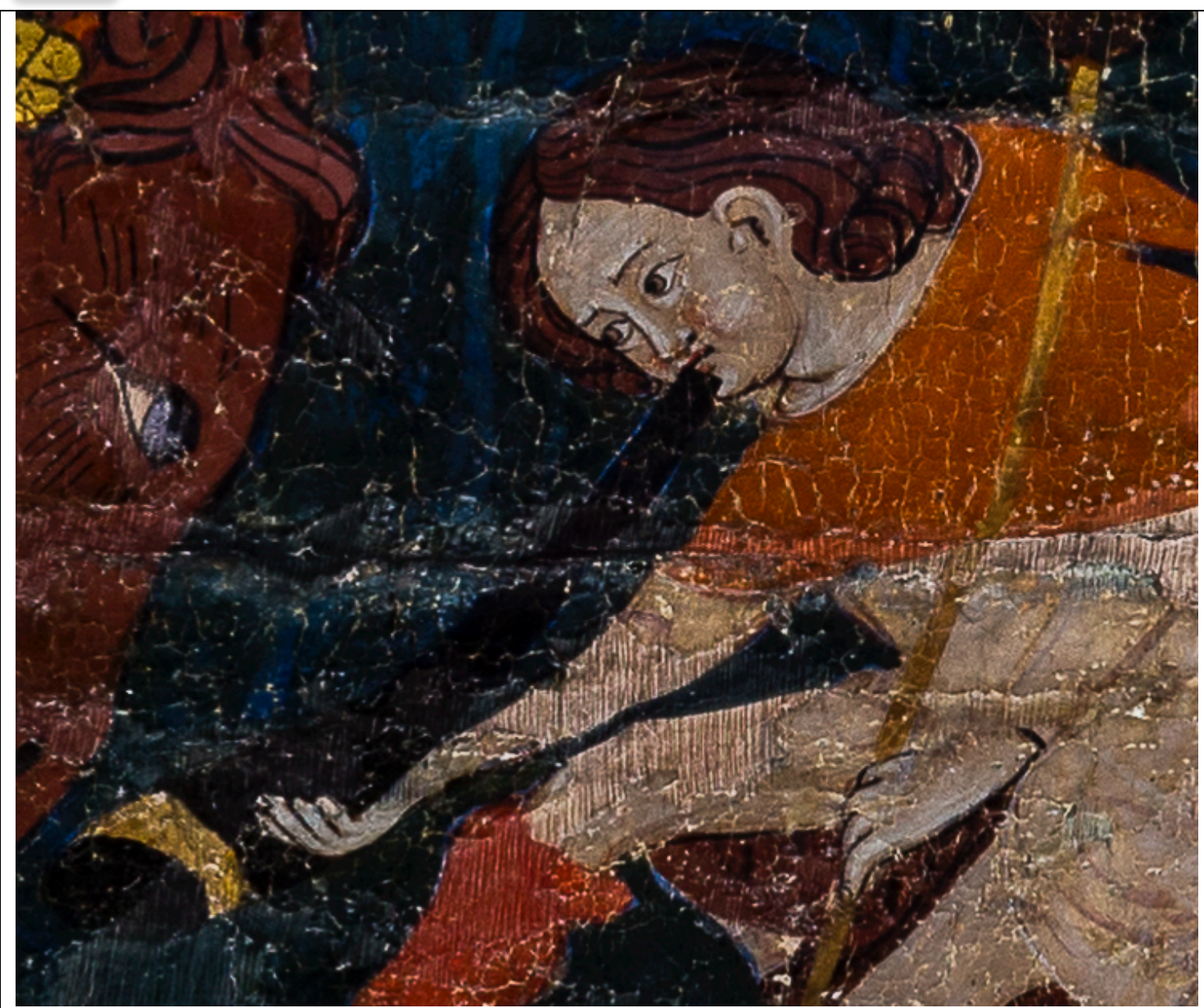

Datos generales

\begin{tabular}{|l|l|}
\hline Nombre & Escena de caza \\
\hline $\mathbf{N}^{\mathbf{0}}$ de inventario & - \\
\hline Cronología & XIV (Nazarí) \\
\hline
\end{tabular}

\section{Localización}

\begin{tabular}{|l|l|}
\hline Procedencia & Sala de los Reyes, Alhambra \\
\hline Ubicación actual & Sala de los Reyes, Alhambra \\
\hline Ciudad & Granada \\
\hline
\end{tabular}




\section{Descripción escena musical}

\begin{tabular}{|l|l|}
\hline Género & Profano \\
\hline Tema & Escena de caza \\
\hline Tipo escena & Específica \\
\hline Escena general & Escena de caza \\
\hline Escena musical & $\begin{array}{l}\text { En un fragmento de la imagen aparecen dos músicos } \\
\text { colaborando con la caza al intentar llamar a los } \\
\text { pájaros para se pongan en vuelo. }\end{array}$ \\
\hline
\end{tabular}

\section{Participantes}

\begin{tabular}{|l|l|}
\hline Cuerno & \multicolumn{2}{|l|}{$\begin{array}{l}\text { Instrumento } \\
\text { son flautas }\end{array}$} \\
\hline \multirow{3}{*}{ Descripción } & $\begin{array}{l}\text { Aerófono de gran tamaño realizado con un cuerno } \\
\text { animal es sujeto por el intérprete con la mano } \\
\text { derecha. La forma de hacerlo sonar da a entender } \\
\text { que no cuenta con agujeros digitales. El instrumento } \\
\text { se va ensanchando de forma progresiva desde la } \\
\text { ranura de soplo hasta el final del mismo. La postura } \\
\text { del intérprete es verosímil. }\end{array}$ \\
\hline
\end{tabular}

\section{Bibliografía}

Molina Fajardo, Emilio. "Caza en el recinto de la Alhambra", Cuadernos de la Alhambra, n.3, 1967, 45-46; Bermúdez Pareja: Pinturas sobre piel en la Alhambra de Granada, 1987, 31, láms. 6, 12; Fernández Manzano, Reynaldo. Música de AlAndalus. Granada: Universidad de Granada, 2016, 170.

\section{Imagen}

\section{Propiedad}

(C) Libro Pinturas sobre piel en la Alhambra de Granada 


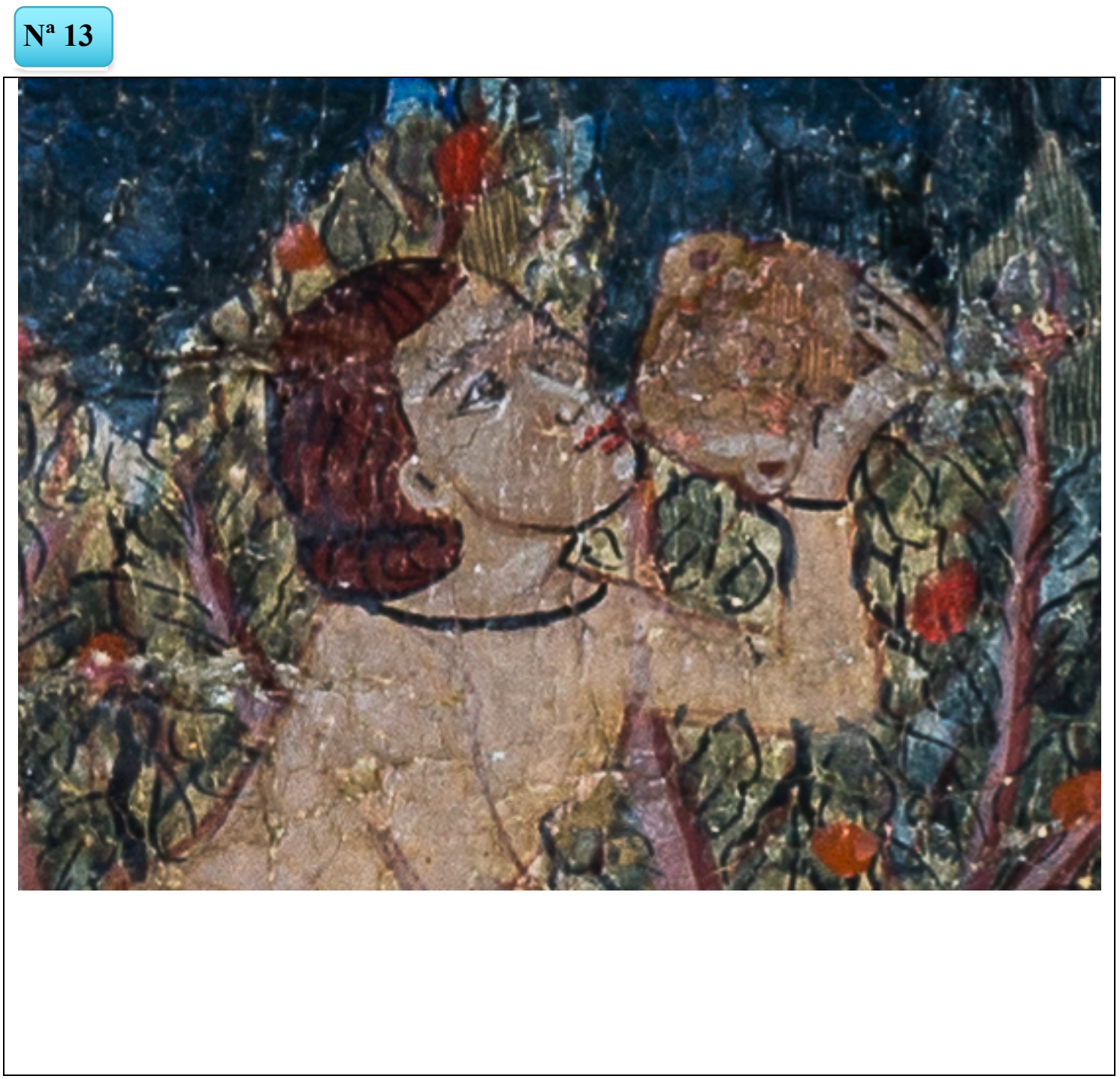

\section{Datos generales}

\begin{tabular}{|l|l|}
\hline Nombre & Escena de caza \\
\hline $\mathbf{N}^{\mathbf{0}}$ de inventario & - \\
\hline Cronología & XIV (Nazarí) \\
\hline
\end{tabular}

\section{Localización}

\begin{tabular}{|l|l|}
\hline Procedencia & Sala de los Reyes, Alhambra \\
\hline Ubicación actual & Sala de los Reyes, Alhambra \\
\hline Ciudad & Granada \\
\hline
\end{tabular}




\section{Descripción escena musical}

\begin{tabular}{|l|l|}
\hline Género & Profano \\
\hline Tema & Escena de caza \\
\hline Tipo escena & Específica \\
\hline Escena general & Escena de caza \\
\hline Escena musical & $\begin{array}{l}\text { En un fragmento de la imagen aparecen dos músicos } \\
\text { colaborando con la caza al intentar espantar a los pájaros } \\
\text { para se pongan en vuelo. }\end{array}$ \\
\hline
\end{tabular}

\section{Participantes}

Silbato/ reclamo

\begin{tabular}{|l|l|}
\hline Instrumento & 421.13 Flautas globulares (sin boquilla diferenciada) \\
\hline Descripción & $\begin{array}{l}\text { Instrumento de considerable tamaño que reposa sobre la } \\
\text { mano del intérprete para ser soplado. Parece contar con } \\
\text { una especie de embocadura ligada al instrumento que } \\
\text { podría tener forma zoomorfa, la forma de ejecutarlo } \\
\text { refleja que no cuenta con agujeros digitales. La postura } \\
\text { del intérprete es verosímil. }\end{array}$ \\
\hline
\end{tabular}

\section{Bibliografía}

Molina Fajardo, Emilio. "Caza en el recinto de la Alhambra", Cuadernos de la Alhambra, n.3, 1967, 45-46; Bermúdez Pareja: Pinturas sobre piel en la Alhambra de Granada, 1987, 31, láms. 6, 12; Fernández Manzano, Reynaldo. Música de AlAndalus. Granada: Universidad de Granada, 2016, 170.

\section{Imagen}

\section{Propiedad}

(C) Libro Pinturas sobre piel en la Alhambra de Granada 


\section{Anexos II: Silbatos}

\section{$\mathbf{N}^{\mathrm{a}} 1$}

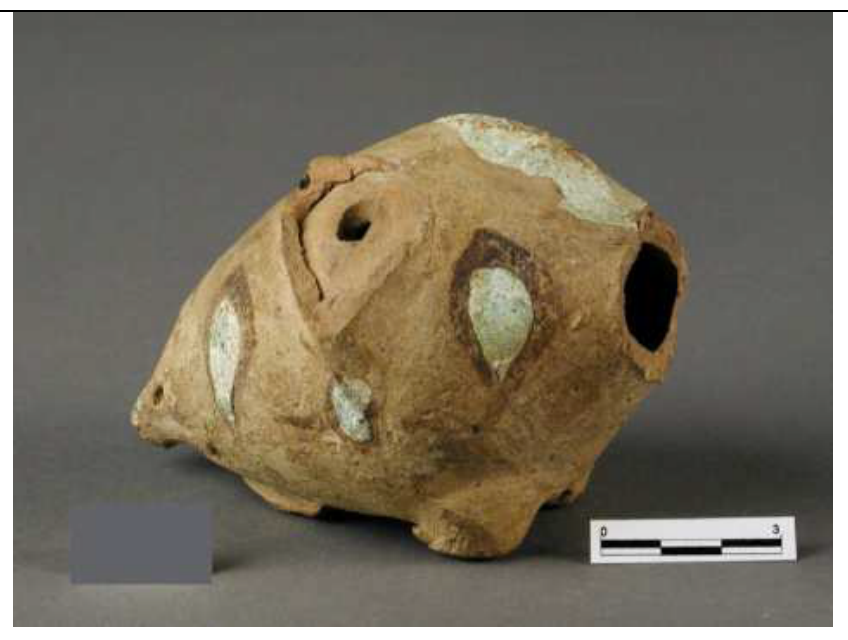

Datos generales

\begin{tabular}{|l|l|}
\hline Nombre & Silbato \\
\hline $\mathbf{N}^{\mathbf{0}}$ de inventario & CE28174 \\
\hline Ubicación actual & Alcazaba de Almería \\
\hline Procedencia & Alcazaba de Almería \\
\hline Dimensiones & $\begin{array}{l}\text { Diámetro mayor: } 7,3 \mathrm{~cm} \text {; Altura: 7,2 cm; } \\
\text { Longitud: 1,10 cm }\end{array}$ \\
\hline Cronología & \begin{tabular}{l} 
Almería \\
\hline S. XII (Almohade)
\end{tabular} \\
\hline Características morfológicas & $\begin{array}{l}\text { Este silbato tipo ocarina con forma de } \\
\text { globular. En uno de sus extremos } \\
\text { representando la boca del pez tiene un } \\
\text { orificio como si se mantuviese abierta, } \\
\text { donde puede verse el interior del } \\
\text { instrumento. En el extremo contrario a } \\
\text { esta boca, el cuerpo se va estrechando de } \\
\text { forma progresiva hasta llegar a una } \\
\text { especie de cola. Mediante apliques } \\
\text { plásticos se le realizan unas aletas }\end{array}$ \\
\hline
\end{tabular}




\begin{tabular}{|l|l|}
\hline & $\begin{array}{l}\text { dorsales y cuenta con un soporte } \\
\text { mediante apoyos inferiores. Se } \\
\text { distinguen varios colores por los distintos } \\
\text { materiales que lo componen. Cuenta con } \\
\text { dos agujeros digitales. }\end{array}$ \\
\hline Materiales & Arcilla \\
\hline
\end{tabular}

Datos organológicos

\begin{tabular}{|l|l|}
\hline Tipo de instrumento & Aerófono \\
\hline Clasificación por estructura física & B.2. Silbatos globulares zoomorfos \\
\hline Clasificación organológica & $\begin{array}{l}421.221 .42 \text { Flautas globulares con canal } \\
\text { de insuflación interno con agujeros } \\
\text { digitales }\end{array}$ \\
\hline Función & Lúdica \\
\hline Fabricación & Alfares \\
\hline Características musicales & $\begin{array}{l}\text { Aerófono con canal de insuflación. } \\
\text { Cuenta con dos agujeros digitales que } \\
\text { permite modificar su sonido. }\end{array}$ \\
\hline
\end{tabular}

\section{Datos arqueológicos}

\begin{tabular}{|l|l|}
\hline Yacimiento & - \\
\hline Responsable de la excavación & - \\
\hline
\end{tabular}

\section{Bibliografía}

\begin{tabular}{|l|l|}
\hline Documentación del Museo & Pieza con ficha de catalogación. \\
\hline
\end{tabular}

Duda, Dorothea. Spanisch-islamische Keramik aus Almería vom 12. bis 15. Jahrhundert. Kerle, 1970; Muñoz Martín, María del Mar y Flores Escobosa, Isabel Flores. "Cerámica esmaltada dorada, azul y dorada y decorada en azul de cobalto nazaríes; la loza dorada procedente de los alfares cristianos: Manises-paterna. La cerámica importada y de cuerda seca (depositadas en el Museo de Almería)". En Anuario arqueológico de Andalucía (1986): 544-553; Marinetto Sánchez, Purificación. “Juguetes y Silbatos Infantiles de Época Nazarí”. MEAH, Sección árabe-islam 46 (1997): 176; Rosselló Bordoy, Guillermo, Ana Navarro Ortega e 
Isabel Flores Escobosa. Del rito al juego: juguetes y silbatos de cerámica desde el islam hasta la actualidad. Junta de Andalucía, 2006, 70 y 173; Flores Escobosa, Isabel. Vivir en al-Andalus. Almería: Instituto de Estudios Almerienses, 1993, 176; García Benito, Carlos. “Arqueología Musical Prehistórica: aproximación a través de la Arqueología Experimental aplicada a la Arqueo-Organología, de la Arqueoacústica y de la Iconografía Musical Prehistórica”. Tesis doctoral, Universidad de Zaragoza, 2014, 1718; Red Digital de Colecciones de Museos en España: http://ceres.mcu.es/pages/Main?idt=124814\&inventary=CE28174\&table=FMUS\&mu seum=MAL\#.XkuYHFbWQPo (Última consulta: 18-02-2020). 


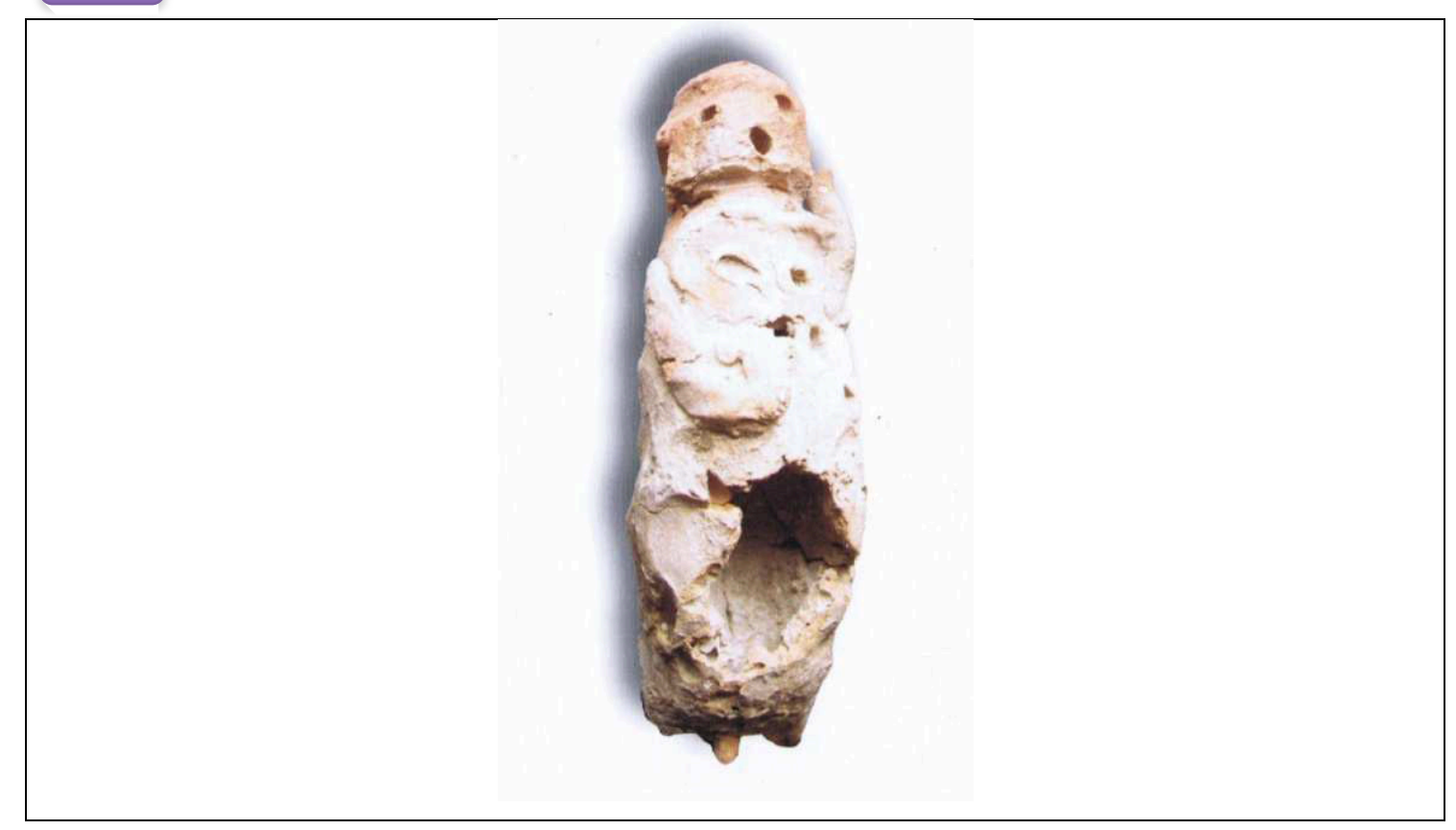

Datos generales

\begin{tabular}{|c|c|}
\hline Nombre & Silbato \\
\hline$N^{0}$ de inventario & 83912 \\
\hline Ubicación actual & Museo de Almería \\
\hline Procedencia & Plaza Virgen del Mar. \\
\hline Dimensiones & Anchura:12 cm; Altura: $3,5 \mathrm{~cm}$ \\
\hline Ciudad & Almería \\
\hline Cronología & s. XII (Almohade) \\
\hline $\begin{array}{l}\text { Características } \\
\text { morfológicas }\end{array}$ & $\begin{array}{l}\text { Este instrumento recrea una figura humana de género no } \\
\text { identificado. Parece vestir una túnica que llega hasta el } \\
\text { final del instrumento, aunque ha perdido un fragmento, lo } \\
\text { que forma el cuerpo del mismo. Una de las manos se } \\
\text { dirige a la cabeza mientras que la otra parece sostener algo } \\
\text { que parece tener forma de cesta. Cuenta con incisiones en } \\
\text { el rostro a modo de rasgos faciales. Los orificios que } \\
\text { producen el cambio de sonidos del instrumento se } \\
\text { encuentran en el cuerpo de la figura. }\end{array}$ \\
\hline
\end{tabular}




\begin{tabular}{|l|l|}
\hline Materiales & Arcilla \\
\hline \multicolumn{2}{|c|}{ Datos organológicos } \\
\begin{tabular}{|l|l|}
\hline Tipo de instrumento & Aerófono \\
\hline $\begin{array}{l}\text { Clasificación por } \\
\text { estructura física }\end{array}$ & B.1. Silbatos globulares antropomorfos \\
\hline $\begin{array}{l}\text { Clasificación } \\
\text { organológica }\end{array}$ & $\begin{array}{l}\text { 421.221.42 Flautas globulares con canal de insuflación } \\
\text { interno con agujeros digitales }\end{array}$ \\
\hline Función & Lúdica \\
\hline Fabricación & Alfares \\
\hline Características \\
musicales
\end{tabular} & $\begin{array}{l}\text { El silbato cuenta con posiblemente tres agujeros que } \\
\text { permiten modificar el sonido del instrumento, el resto de } \\
\text { ellos no llegan a comunicarse con el canal interno por lo } \\
\text { que están hechos para definir los rasgos de la figura } \\
\text { representada. }\end{array}$ \\
\hline
\end{tabular}

\section{Datos arqueológicos}

\begin{tabular}{|l|l|}
\hline Yacimiento & - \\
\hline $\begin{array}{l}\text { Responsable } \\
\text { excavación }\end{array}$ & - \\
\hline
\end{tabular}

\section{Bibliografía}

\begin{tabular}{|l|l|}
\hline Documentación del Museo & Pieza con ficha de catalogación. \\
\hline Rosselló Bordoy, Guillermo, Ana Navarro Ortega e Isabel Flores Escobosa. Del rito \\
al juego: juguetes y silbatos de cerámica desde el Islam hasta la actualidad. Junta de \\
Andalucía, 2006, 173; García Benito, Carlos. "Arqueología Musical Prehistórica: \\
aproximación a través de la Arqueología Experimental aplicada a la Arqueo- \\
Organología, de la Arqueoacústica y de la Iconografía Musical Prehistórica". Tesis \\
doctoral, Universidad de Zaragoza, 2014, 1712.
\end{tabular}




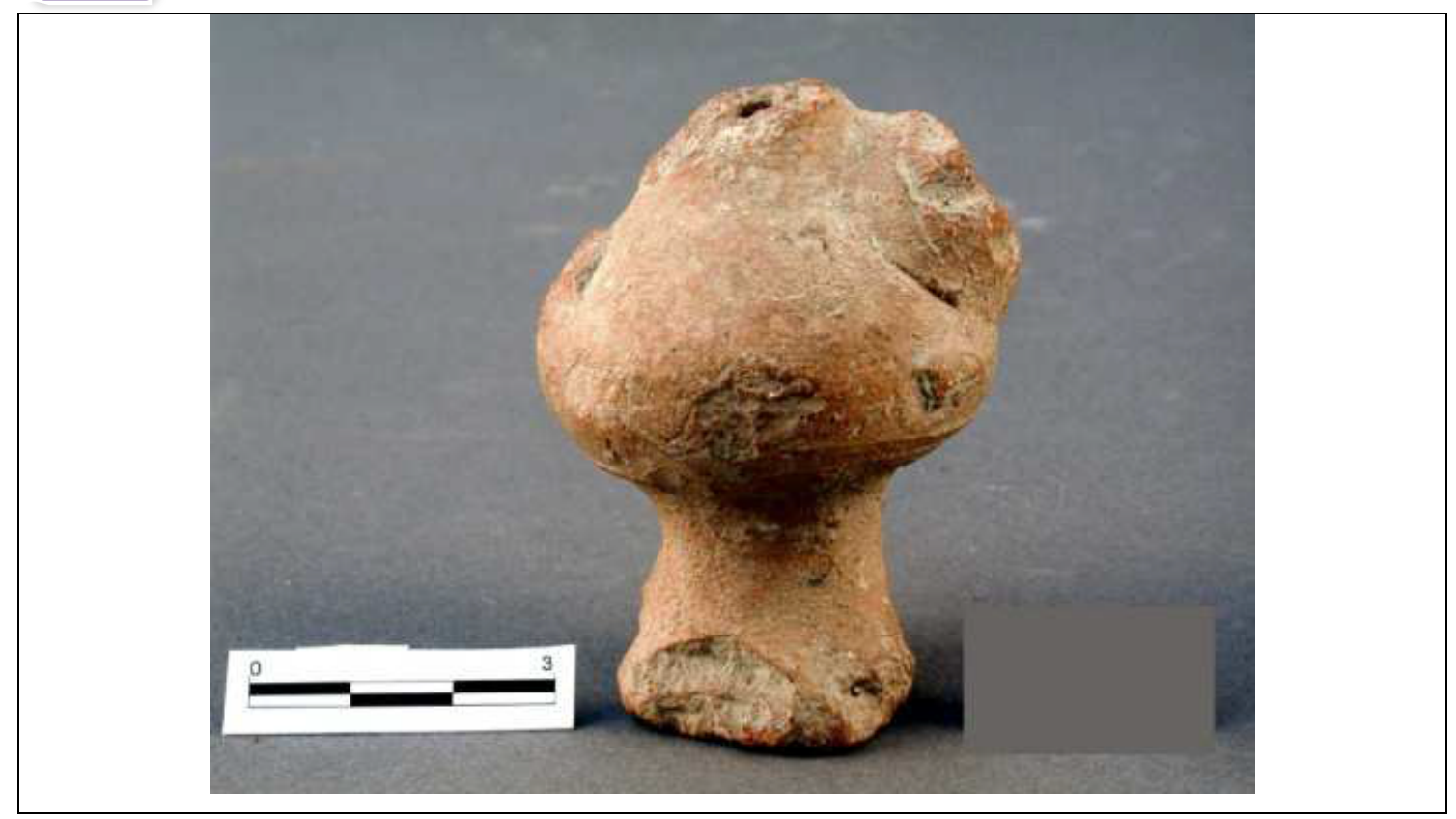

Datos generales

\begin{tabular}{|l|l|}
\hline Nombre & Silbato de agua \\
\hline $\mathbf{N}^{\mathbf{0}}$ de inventario & CE28446 \\
\hline Ubicación actual & Museo de Almería \\
\hline Procedencia & Alcazaba de Almería \\
\hline Dimensiones & $\begin{array}{l}\text { Altura: } 6,1 \mathrm{~cm} \text {; Grosor: 0,60 cm; Anchura máxima: } \\
4,5 \mathrm{~cm} .\end{array}$ \\
\hline Ciudad & Almería \\
\hline Cronología & ss. XIII-XIV (Almohade-Nazarí) \\
\hline $\begin{array}{l}\text { Características } \\
\text { morfológicas }\end{array}$ & $\begin{array}{l}\text { Este ejemplar es uno de los modelos más repetidos } \\
\text { encontrados en excavaciones arqueológicas dentro de } \\
\text { los silbatos de agua. Se encuentra incompleto, solo } \\
\text { conserva el cuerpo piriforme apoyado sobre una } \\
\text { peana y el arranque de un pitorro y un asa. Esta pieza } \\
\text { no parece haber sido tintada. }\end{array}$ \\
\hline Materiales & \begin{tabular}{l} 
Arcilla \\
\hline
\end{tabular} \\
\hline
\end{tabular}




\section{Datos organológicos}

\begin{tabular}{|l|l|}
\hline Tipo de instrumento & Aerófono \\
\hline $\begin{array}{l}\text { Clasificación por } \\
\text { estructura física }\end{array}$ & B.4. Silbatos globulares de agua \\
\hline Clasificación organológica & $\begin{array}{l}421.221 .41 \quad \text { Flautas globulares con canal de } \\
\text { insuflación interno sin agujeros digitales }\end{array}$ \\
\hline Función & Lúdica \\
\hline Fabricación & Alfares \\
\hline Características musicales & $\begin{array}{l}\text { Este aerófono sin agujeros digitales conserva solo la } \\
\text { caja del instrumento habiendo perdido la embocadura } \\
\text { de insuflación de aire. }\end{array}$ \\
\hline
\end{tabular}

\section{Datos arqueológicos}

\begin{tabular}{|l|l|}
\hline Yacimiento & - \\
\hline $\begin{array}{l}\text { Responsable de la } \\
\text { excavación }\end{array}$ & - \\
\hline
\end{tabular}

\section{Bibliografía}

\begin{tabular}{|l|l|}
\hline Documentación del Museo & Pieza con ficha de catalogación. \\
\hline Asensio Cañadas, María Soledad y Morales Jiménez, Inmaculada. "Instrumentos \\
musicales de barro en Andalucía (I): Aerófonos”. Música oral del Sur, 2, (1996): 85 y \\
186; García Benito, Carlos. “Arqueología Musical Prehistórica: aproximación a través \\
de la Arqueología Experimental aplicada a la Arqueo-Organología, de la \\
Arqueoacústica y de la Iconografía Musical Prehistórica”, Tesis doctoral, Universidad \\
de Zaragoza, 2014, 1769; Red Digital de Colecciones de Museos en España: \\
http://ceres.mcu.es/pages/Main?idt=125022\&inventary=CE28446\&table=FMUS\&mu \\
$\underline{\text { seum=MAL\#.XkuXn2XaGnE (Última consulta: 18-02-2020). }}$
\end{tabular}




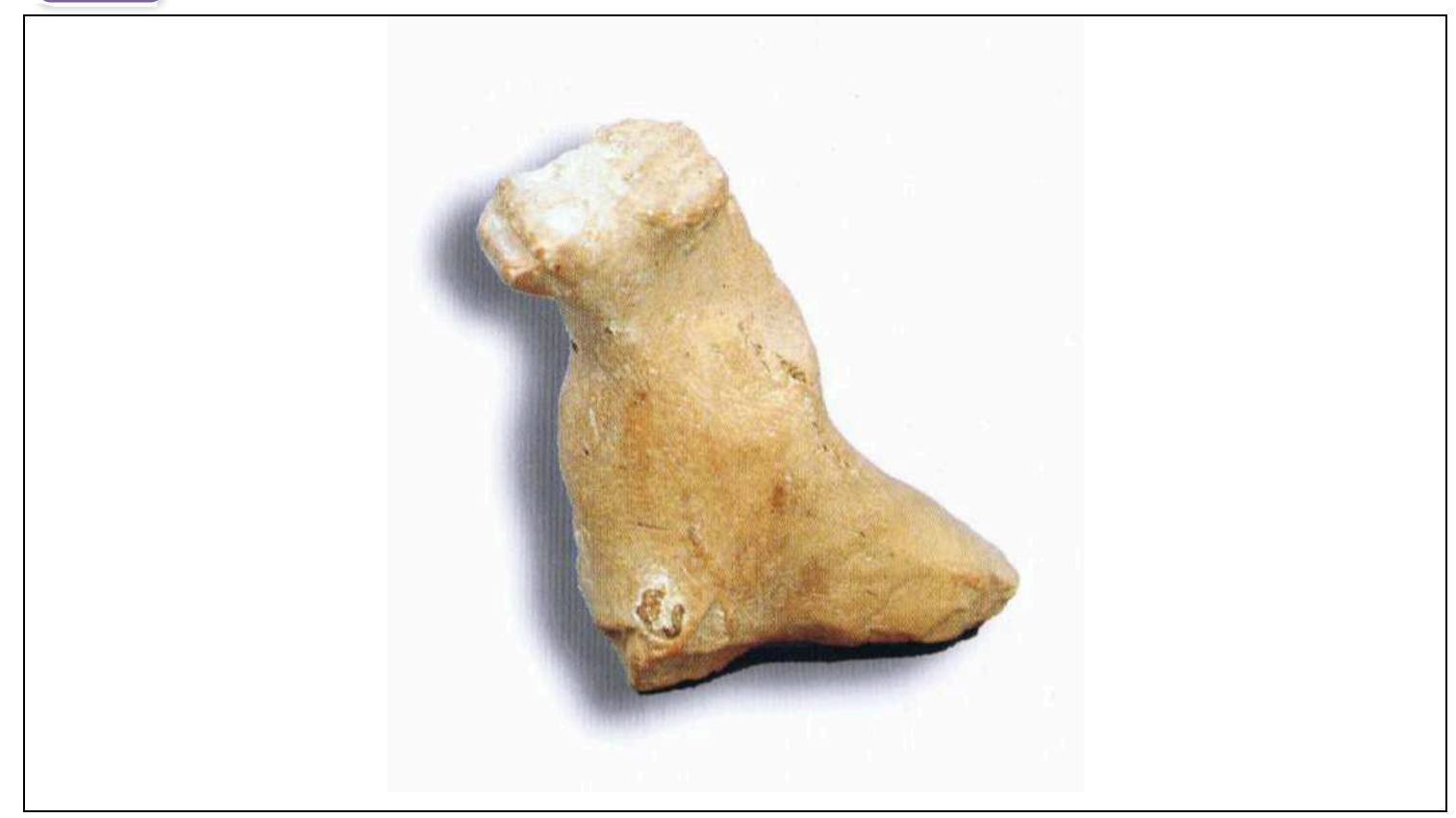

Datos generales

\begin{tabular}{|c|c|}
\hline Nombre & Silbato \\
\hline$N^{0}$ de inventario & 83913 \\
\hline Ubicación actual & Museo de Almería \\
\hline Procedencia & C/ Pablo Iglesias (Almería) \\
\hline Dimensiones & Altura: $3,4 \mathrm{~cm}$; Anchura: $2 \mathrm{~cm}$; Longitud: $3,5 \mathrm{~cm}$ \\
\hline Ciudad & Almería \\
\hline Cronología & s. XII (Almohade) \\
\hline $\begin{array}{l}\text { Características } \\
\text { morfológicas }\end{array}$ & $\begin{array}{l}\text { Silbato zoomorfo en forma de toro el cual no conserva los } \\
\text { característicos cuernos. Sus rasgos faciales se han } \\
\text { realizado mediante incisiones representando orificios } \\
\text { nasales y los ojos. La embocadura se encuentra } \\
\text { representando las patas traseras del animal sirviendo las } \\
\text { delanteras de apoyo. Al no conservar los cuernos, por la } \\
\text { forma del cuerpo éste recuerda a otras figuras como } \\
\text { pájaros. }\end{array}$ \\
\hline Materiales & Arcilla \\
\hline
\end{tabular}




\section{Datos organológicos}

\begin{tabular}{|l|l|}
\hline Tipo de instrumento & Aerófono \\
\hline $\begin{array}{l}\text { Clasificación por } \\
\text { estructura física }\end{array}$ & B.2. Silbatos globulares zoomorfos \\
\hline $\begin{array}{l}\text { Clasificación } \\
\text { organológica }\end{array}$ & $\begin{array}{l}421.221 .41 \text { Flautas globulares con canal de insuflación } \\
\text { interno sin agujeros digitales }\end{array}$ \\
\hline Función & Lúdica \\
\hline Fabricación & Alfares \\
\hline musicales & $\begin{array}{l}\text { Este silbato con forma de toro cuenta con una embocadura } \\
\text { pronunciada que representa las patas de atrás del animal. } \\
\text { No tiene orificios digitales solo cuenta con el agujero de } \\
\text { salida del aire cerca de la embocadura en la parte inferior } \\
\text { de la misma que le otorga posibilidades sonoras al } \\
\text { instrumento. }\end{array}$ \\
\hline
\end{tabular}

\section{Datos arqueológicos}

\begin{tabular}{|l|l|}
\hline Yacimiento & - \\
\hline $\begin{array}{l}\text { Responsable de la } \\
\text { excavación }\end{array}$ & - \\
\hline
\end{tabular}

\section{Bibliografía}

\begin{tabular}{|l|l|}
\hline Documentación del Museo & Pieza con ficha de catalogación. \\
\hline Rosselló Bordoy, Guillermo, Ana Navarro Ortega e Isabel Flores Escobosa. Del rito \\
al juego: juguetes y silbatos de cerámica desde el islam hasta la actualidad. Junta de \\
Andalucía, 2006, 173; García Benito, Carlos. “Arqueología Musical Prehistórica: \\
aproximación a través de la Arqueología Experimental aplicada a la Arqueo- \\
Organología, de la Arqueoacústica y de la Iconografía Musical Prehistórica”. Tesis \\
doctoral, Universidad de Zaragoza, 2014, 1709.
\end{tabular}




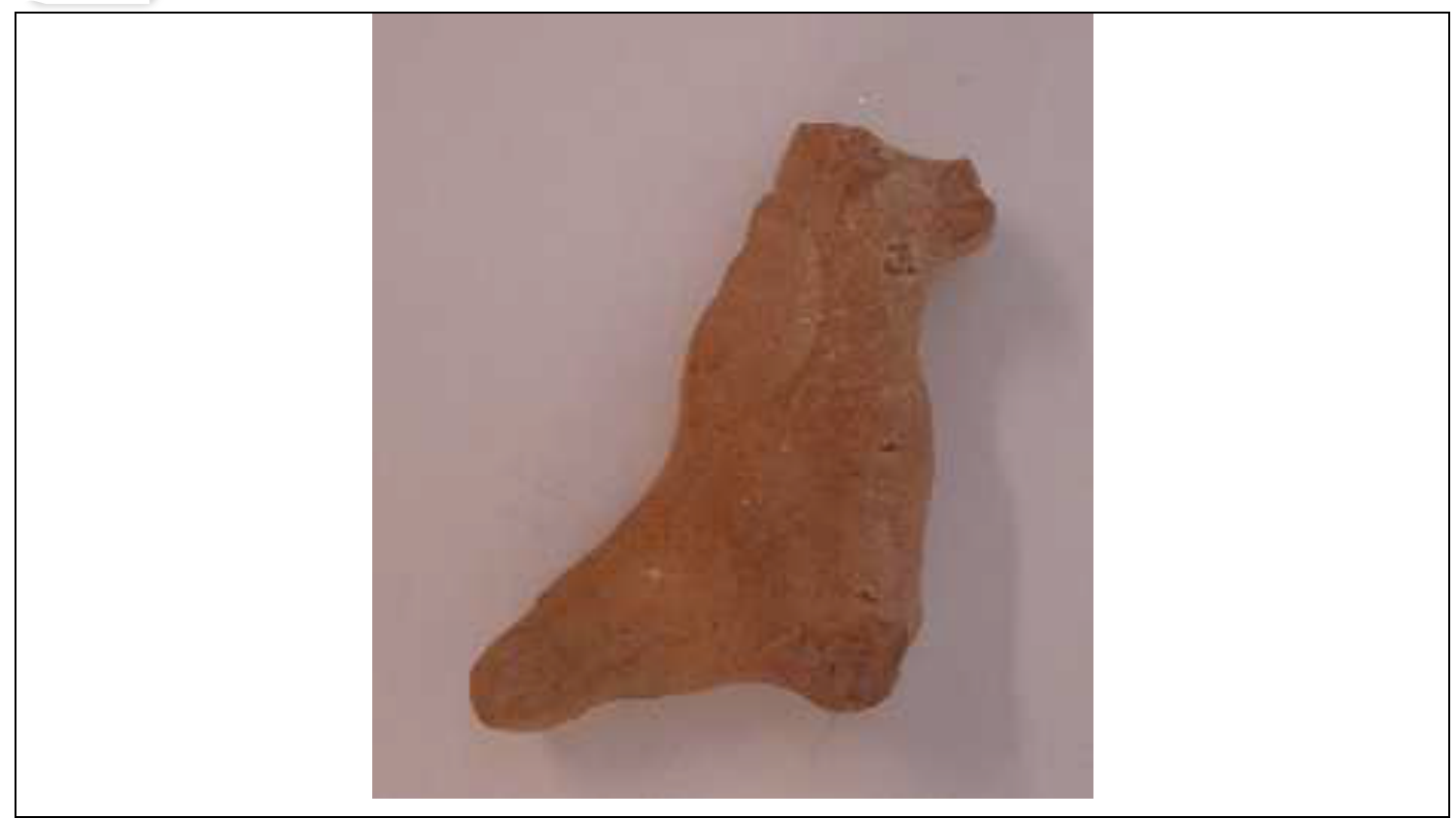

\section{Datos generales}

\begin{tabular}{|l|l|}
\hline Nombre & Silbato \\
\hline $\mathbf{N}^{\circ}$ de inventario & DJ83982 \\
\hline Ubicación actual & Museo de Almería \\
\hline Procedencia & C/ Pablo Iglesias (Almería) \\
\hline Dimensiones & Alto: $4,8 \mathrm{~cm}$; Ancho: 2,1 cm \\
\hline Ciudad & Almería \\
\hline Cronología & ss. XI-XII (Califal-Almohade) \\
\hline Características morfológicas & $\begin{array}{l}\text { Este aerófono guarda gran semejanza con el de la } \\
\text { ficha } 4, \text { pero a diferencia de este cuenta con un } \\
\text { hocico más pronunciado, es por ello que los } \\
\text { arqueólogos se han decantado por considerarlo un } \\
\text { caballo. Al igual que el aerófono con forma de } \\
\text { toro, sus patas traseras son las que forman la } \\
\text { embocadura. Sobre su cabeza se empieza a formar } \\
\text { la crin del caballo que parece llegar hasta el cuello } \\
\text { quedando cortada por una rotura en la pieza. Los } \\
\text { rasgos faciales están hechos mediantes incisiones, }\end{array}$ \\
\hline
\end{tabular}




\begin{tabular}{|l|l|}
\hline & $\begin{array}{l}\text { dos representando los ojos y otros dos los orificios } \\
\text { nasales. }\end{array}$ \\
\hline Materiales & Arcilla \\
\hline
\end{tabular}

\section{Datos organológicos}

\begin{tabular}{|l|l|}
\hline Tipo de instrumento & Aerófono \\
\hline $\begin{array}{l}\text { Clasificación por estructura } \\
\text { físa }\end{array}$ & B.2. Silbatos globulares zoomorfos \\
\hline Clasificación organológica & $\begin{array}{l}421.221 .41 \text { Flautas globulares con canal de } \\
\text { insuflación interno sin agujeros digitales }\end{array}$ \\
\hline Función & Lúdica \\
\hline Fabricación & Alfares \\
\hline Características musicales & $\begin{array}{l}\text { Silbato sin agujeros digitales con embocadura } \\
\text { incluida en el cuerpo del instrumento. La } \\
\text { embocadura cuenta con un bisel en la parte } \\
\text { inferior de la misma. }\end{array}$ \\
\hline
\end{tabular}

Datos arqueológicos

\begin{tabular}{|l|l|}
\hline Yacimiento & - \\
\hline Responsable de la excavación & - \\
\hline
\end{tabular}

\section{Bibliografía}

\begin{tabular}{|l|ll|}
\hline Documentación del Museo & Pieza con ficha de catalogación. \\
\hline Rosselló Bordoy, Guillermo, Ana Navarro Ortega e Isabel Flores Escobosa. Del rito \\
al juego: juguetes y silbatos de cerámica desde el islam hasta la actualidad. Junta de \\
Andalucía, 2006. (Publicada con el número de inventario & $83.913)$; Red Digital de \\
Colecciones & de & en
\end{tabular}




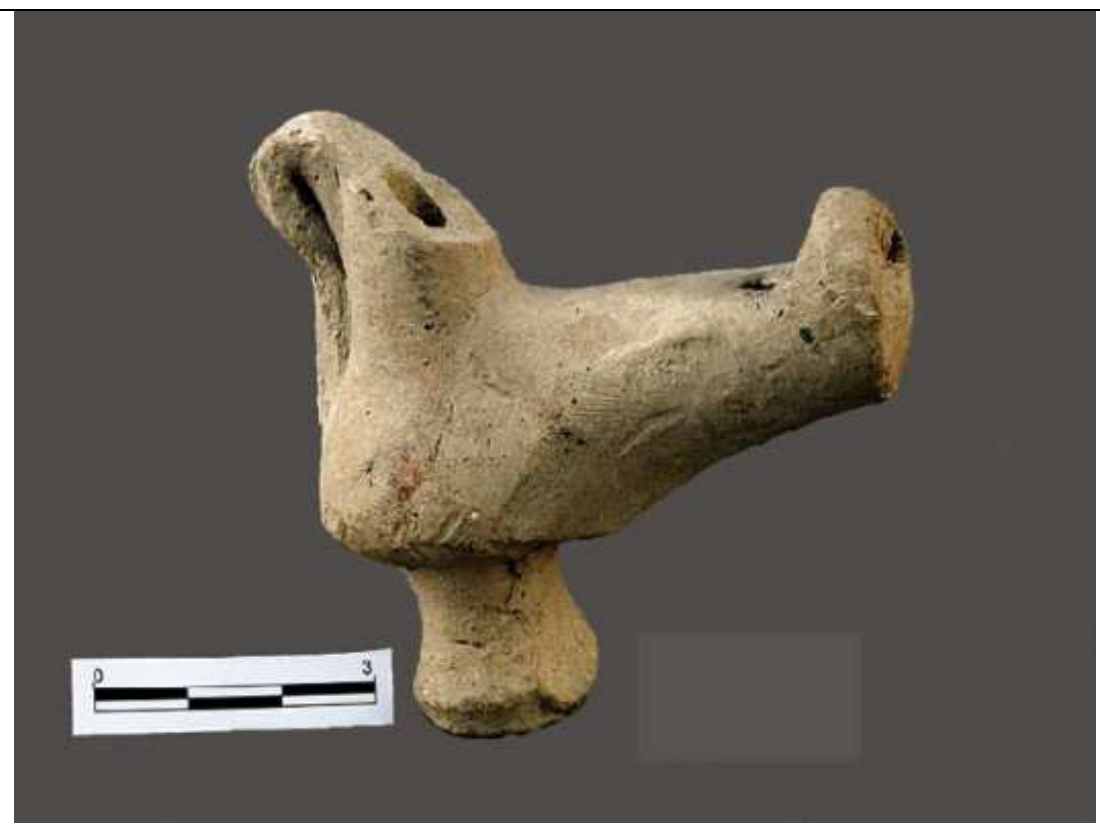

Datos generales

\begin{tabular}{|c|c|}
\hline Nombre & Silbato de agua \\
\hline $\mathrm{N}^{0}$ de inventario & CE28445 \\
\hline Ubicación actual & Alcazaba de Almería \\
\hline Procedencia & Alcazaba de Almería \\
\hline Dimensiones & Altura: $6,8 \mathrm{~cm}$; Longitud: $6,9 \mathrm{~cm}$. \\
\hline Ciudad & Almería \\
\hline Cronología & s. XIV (Nazarí) \\
\hline $\begin{array}{l}\text { Características } \\
\text { morfológicas }\end{array}$ & $\begin{array}{l}\text { Silbato de agua en forma de jarro bitroncocónico. } \\
\text { Cuenta con un pie plano y macizo y un asa pegada al } \\
\text { cuello. Se encuentra en buen estado de conservación. } \\
\text { La embocadura forma parte del cuerpo del } \\
\text { instrumento haciéndole medir prácticamente lo } \\
\text { mismo de alto que de largo. }\end{array}$ \\
\hline Materiales & Arcilla \\
\hline
\end{tabular}

Datos organológicos

\begin{tabular}{|l|l|}
\hline Tipo de instrumento & Aerófono \\
\hline
\end{tabular}




\begin{tabular}{|l|l|}
\hline $\begin{array}{l}\text { Clasificación por } \\
\text { estructura física }\end{array}$ & B.4. Silbatos globulares de agua \\
\hline Clasificación organológica & $\begin{array}{l}421.221 .41 \text { Flautas globulares con canal de } \\
\text { insuflación interno sin agujeros digitales }\end{array}$ \\
\hline Función & Lúdica \\
\hline Fabricación & Alfares \\
\hline Características musicales & $\begin{array}{l}\text { Silbato en forma de jarrito con embocadura adherida } \\
\text { al cuerpo y sin agujeros digitales. Sobre la } \\
\text { embocadura se encuentra el bisel. }\end{array}$ \\
\hline
\end{tabular}

\section{Datos arqueológicos}

\begin{tabular}{|l|l|}
\hline Yacimiento & - \\
\hline $\begin{array}{l}\text { Responsable de la } \\
\text { excavación }\end{array}$ & - \\
\hline
\end{tabular}

\section{Bibliografía}

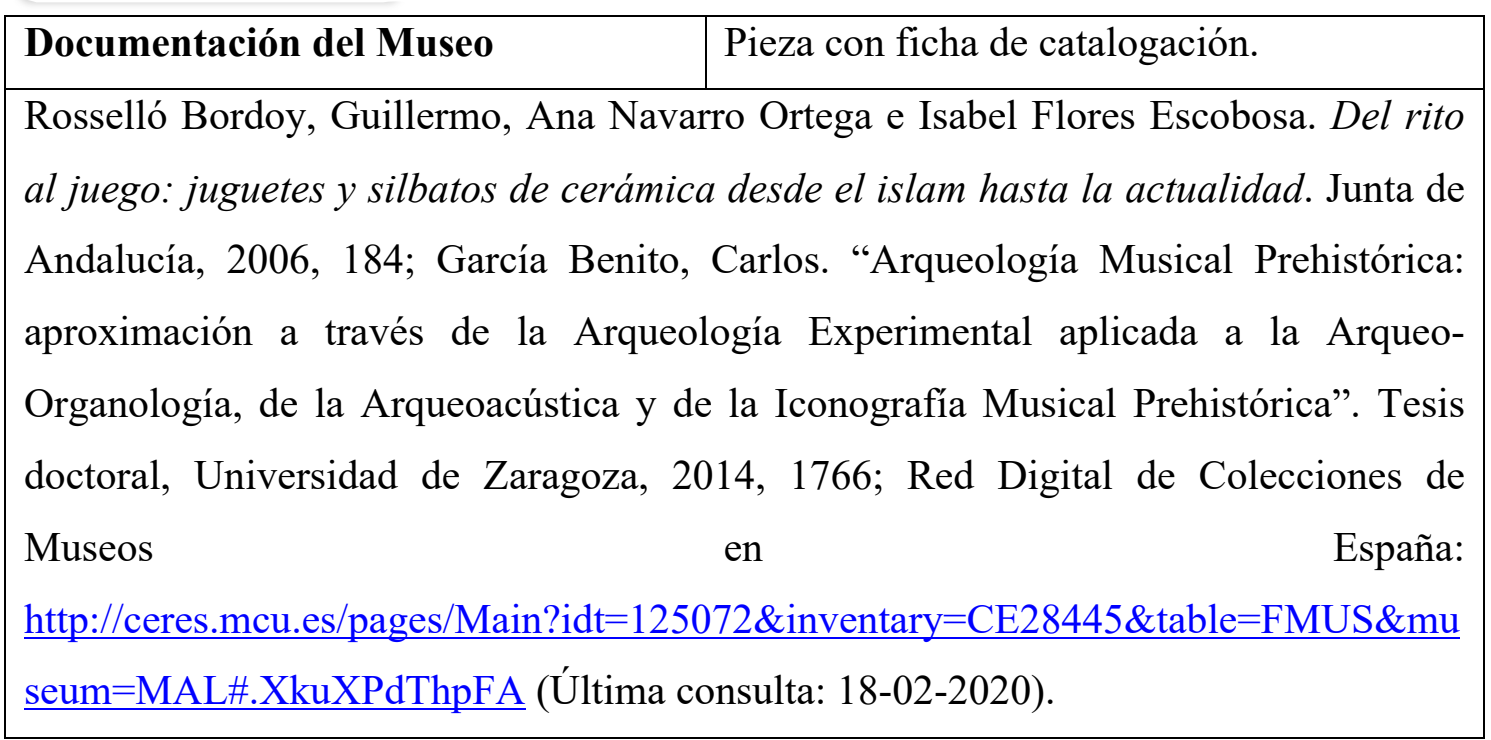




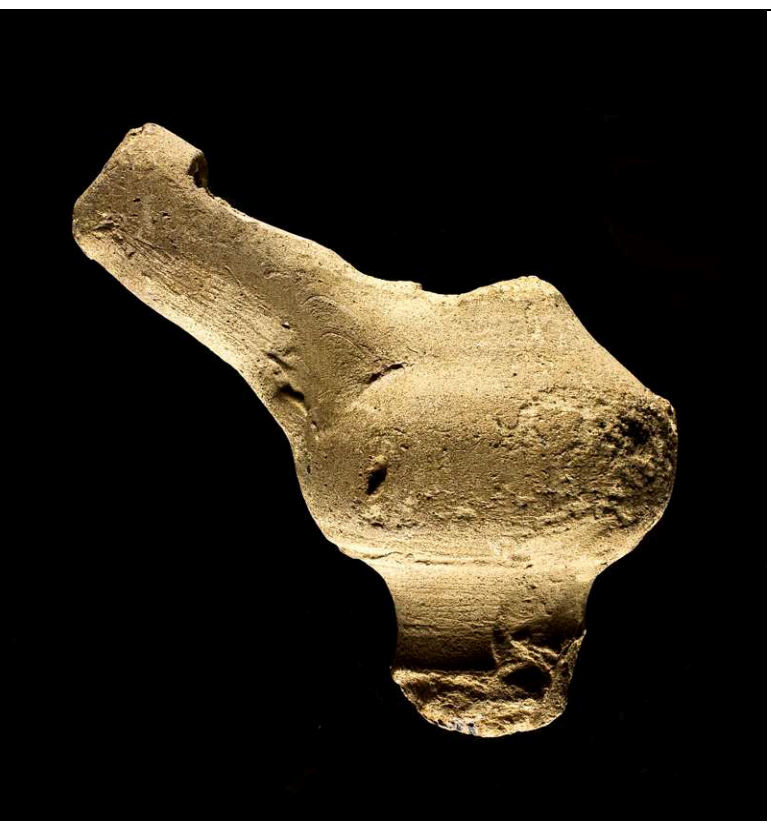

\section{Datos generales}

\begin{tabular}{|l|l|}
\hline Nombre & Silbato de agua \\
\hline $\mathbf{N}^{\mathbf{0}}$ de inventario & DJ84671 \\
\hline Ubicación actual & Museo de Almería \\
\hline Procedencia & C/ Real, 5 (Almería) \\
\hline Dimensiones & Ancho: $9,6 \mathrm{~cm}$; Alto: $5,3 \mathrm{~cm}$ \\
\hline Ciudad & Almería \\
\hline Cronología & ss. X-XV (Califal-Nazarí) \\
\hline $\begin{array}{l}\text { Características } \\
\text { morfológicas }\end{array}$ & $\begin{array}{l}\text { Silbato de agua en forma de jarro. No se conserva entero, } \\
\text { se le intuye un pie plano de base y un asa pegada al cuello. }\end{array}$ \\
\hline Materiales & Arcilla \\
\hline
\end{tabular}

\section{Datos organológicos}

\begin{tabular}{|l|l|}
\hline Tipo de instrumento & Aerófono \\
\hline $\begin{array}{l}\text { Clasificación por } \\
\text { estructura física }\end{array}$ & B.4. Silbatos globulares de agua \\
\hline $\begin{array}{l}\text { Clasificación } \\
\text { organológica }\end{array}$ & $\begin{array}{l}421.221 .41 \text { Flautas globulares con canal de insuflación } \\
\text { interno sin agujeros digitales }\end{array}$ \\
\hline
\end{tabular}




\begin{tabular}{|l|l|}
\hline Función & Lúdica \\
\hline Fabricación & Alfares \\
\hline $\begin{array}{l}\text { Características } \\
\text { musicales }\end{array}$ & $\begin{array}{l}\text { La embocadura del silbato se encuentra fragmentada, así } \\
\text { como su caja de resonancia. }\end{array}$ \\
\hline
\end{tabular}

\section{Datos arqueológicos}

\begin{tabular}{|l|l|}
\hline Yacimiento & - \\
\hline $\begin{array}{l}\text { Responsable de la } \\
\text { excavación }\end{array}$ & - \\
\hline
\end{tabular}

\section{Bibliografía}

\begin{tabular}{|l|l}
\hline Documentación del Museo & Pieza con ficha de catalogación.
\end{tabular}

Inédito 


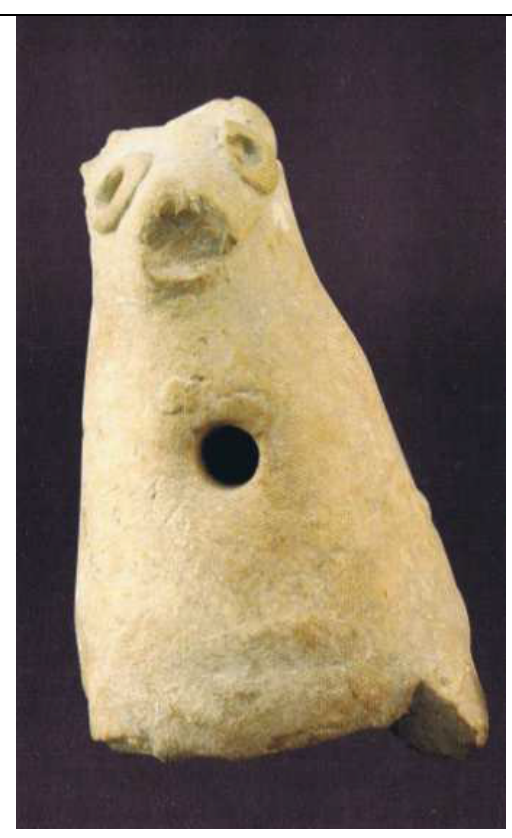

\section{Datos generales}

\begin{tabular}{|l|l|}
\hline Nombre & Silbato \\
\hline $\mathbf{N}^{\mathbf{0}}$ de inventario & 28448 \\
\hline Ubicación actual & Alcazaba de Almería \\
\hline Procedencia & Alcazaba de Almería \\
\hline Dimensiones & Altura: $5,9 \mathrm{~cm}$; Anchura: $3,7 \mathrm{~cm}$. \\
\hline Ciudad & Almería \\
\hline Cronología & ss. VIII-XV (Emiral-Nazarí) \\
\hline $\begin{array}{l}\text { Características } \\
\text { morfológicas }\end{array}$ & $\begin{array}{l}\text { Silbato tipo ocarina de forma cónica. Presenta huellas de } \\
\text { haber podido tener orejas y pico. Su forma zoomorfa } \\
\text { resulta confusa por lo que puede ser un animal inventado. } \\
\text { Cuenta con dos apliques plásticos que forman sus ojos. }\end{array}$ \\
\hline Materiales & Arcilla \\
\hline
\end{tabular}

\section{Datos organológicos}

\begin{tabular}{|l|l|}
\hline Tipo de instrumento & Aerófono \\
\hline $\begin{array}{l}\text { Clasificación por } \\
\text { estructura física }\end{array}$ & B.2. Silbatos globulares zoomorfos \\
\hline
\end{tabular}




\begin{tabular}{|l|l|}
\hline $\begin{array}{l}\text { Clasificación } \\
\text { organológica }\end{array}$ & $\begin{array}{l}421.221 .421 \text { Flautas globulares con canal de insuflación } \\
\text { interno con un solo agujero. }\end{array}$ \\
\hline Función & Lúdica \\
\hline Fabricación & Alfares \\
\hline $\begin{array}{l}\text { Características } \\
\text { musicales }\end{array}$ & $\begin{array}{l}\text { Aerófono con canal de insuflación en lo que representaría } \\
\text { la parte posterior del animal que cuenta con un agujero } \\
\text { digital en el cuerpo del instrumento que permite } \\
\text { modificar su sonido. }\end{array}$ \\
\hline
\end{tabular}

\section{Datos arqueológicos}

\begin{tabular}{|l|l|}
\hline Yacimiento & - \\
\hline $\begin{array}{l}\text { Responsable de la } \\
\text { excavación }\end{array}$ & - \\
\hline
\end{tabular}

\section{Bibliografía}

\begin{tabular}{|l|l|}
\hline Documentación del Museo & Pieza con ficha de catalogación. \\
\hline Rosselló Bordoy, Guillermo, Ana Navarro Ortega e Isabel Flores Escobosa. Del rito \\
al juego: juguetes y silbatos de cerámica desde el islam hasta la actualidad. Junta de \\
Andalucía, 2006, 199; García Benito, Carlos. “Arqueología Musical Prehistórica: \\
aproximación a través de la Arqueología Experimental aplicada a la Arqueo- \\
Organología, de la Arqueoacústica y de la Iconografía Musical Prehistórica”. Tesis \\
doctoral, Universidad de Zaragoza, 2014, 1625.
\end{tabular}




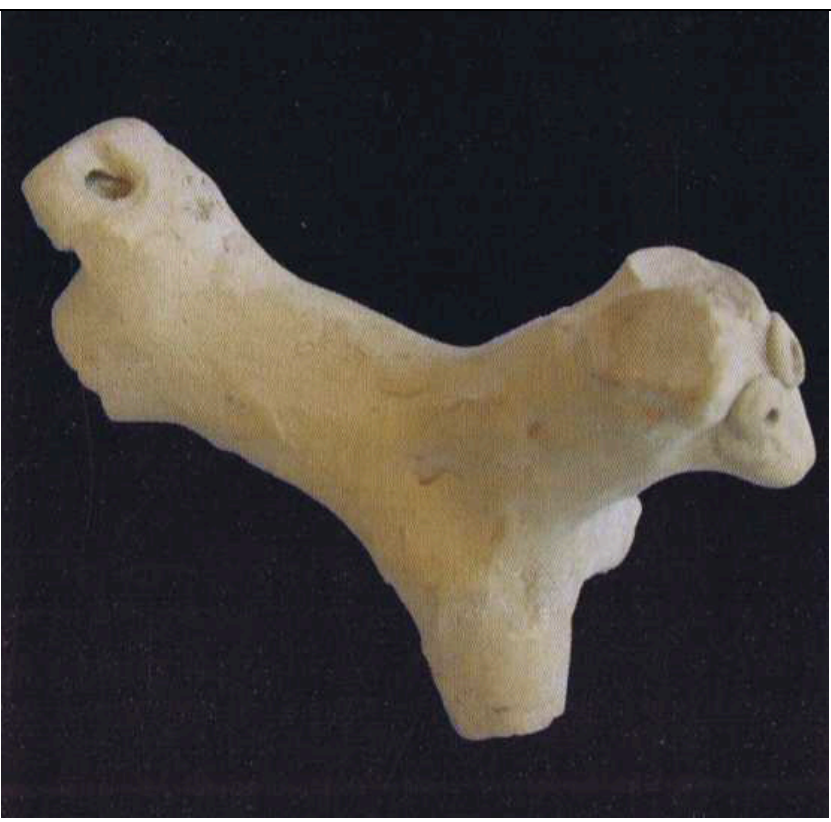

\section{Datos generales}

\begin{tabular}{|c|c|}
\hline Nombre & Silbato zoomorfo \\
\hline $\mathrm{N}^{0}$ de inventario & - \\
\hline Ubicación actual & Particular \\
\hline Procedencia & - \\
\hline Dimensiones & Altura: $6,5 \mathrm{~cm}$; Anchura: $9 \mathrm{~cm}$. \\
\hline Ciudad & Almería \\
\hline Cronología & ss. XIV-XV (Nazarí) \\
\hline $\begin{array}{l}\text { Características } \\
\text { morfológicas }\end{array}$ & $\begin{array}{l}\text { Aerófono con forma de caballo conserva prácticamente } \\
\text { todas las partes del mismo: patas, cabeza, hocico y orejas, } \\
\text { a excepción de una oreja y patas traseras. Los ojos están } \\
\text { formados por dos apliques plásticos. }\end{array}$ \\
\hline Materiales & Arcilla \\
\hline
\end{tabular}

\section{Datos organológicos}

\begin{tabular}{|l|l|}
\hline Tipo de instrumento & Aerófono \\
\hline $\begin{array}{l}\text { Clasificación por } \\
\text { estructura física }\end{array}$ & B.2. Silbatos globulares zoomorfos \\
\hline
\end{tabular}




\begin{tabular}{|l|l|}
\hline $\begin{array}{l}\text { Clasificación } \\
\text { organológica }\end{array}$ & $\begin{array}{l}421.221 .41 \text { Flautas globulares con canal de insuflación } \\
\text { interno sin agujeros digitales }\end{array}$ \\
\hline Función & Lúdica \\
\hline Fabricación & Alfares \\
\hline $\begin{array}{l}\text { Características } \\
\text { musicales }\end{array}$ & $\begin{array}{l}\text { Silbato con embocadura unida al canal en la parte } \\
\text { posterior del instrumento. En la parte superior de la } \\
\text { misma puede verse el bisel. }\end{array}$ \\
\hline
\end{tabular}

\section{Datos arqueológicos}

\begin{tabular}{|l|l|}
\hline Yacimiento & - \\
\hline $\begin{array}{l}\text { Responsable de la } \\
\text { excavación }\end{array}$ & - \\
\hline
\end{tabular}

\section{Bibliografía}

\section{\begin{tabular}{|l|l}
\hline Documentación del Museo & Pieza con ficha de catalogación.
\end{tabular}}

Rosselló Bordoy, Guillermo, Ana Navarro Ortega e Isabel Flores Escobosa. Del rito

al juego: juguetes y silbatos de cerámica desde el islam hasta la actualidad. Junta de Andalucía, 2006, 187. 


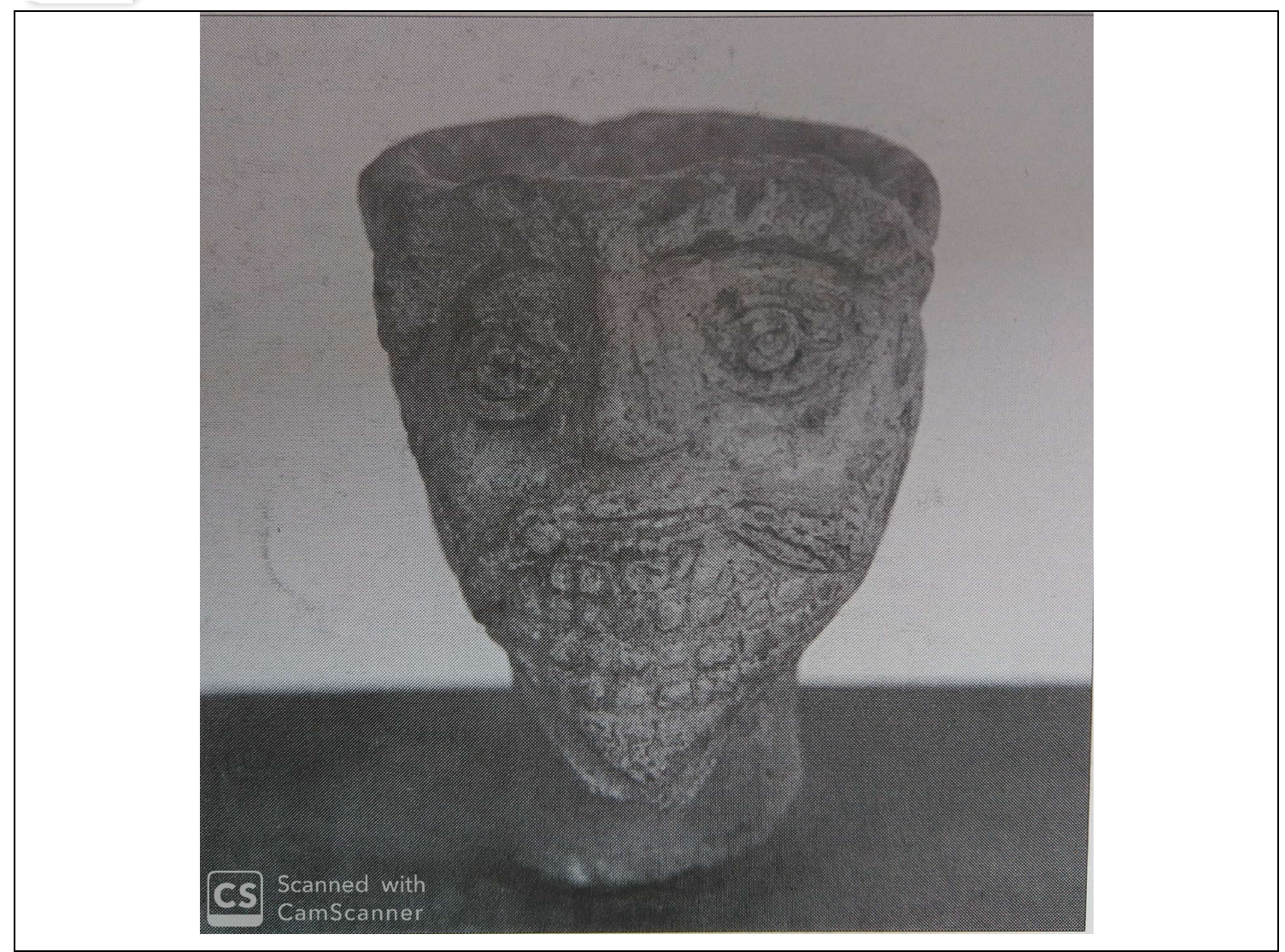

\section{Datos generales}

\begin{tabular}{|l|l|}
\hline Nombre & Silbato antropomorfo \\
\hline $\mathbf{N}^{\mathbf{0}}$ de inventario & - \\
\hline Ubicación actual & Particular \\
\hline Procedencia & Calle Duende, Almería \\
\hline Dimensiones & Altura: $4 \mathrm{~cm}$; Anchura: $3 \mathrm{~cm}$; Grosor: $0,5 \mathrm{~cm}$ \\
\hline Ciudad & Almería \\
\hline Cronología & Ss. XIV-XV (Nazarí) \\
\hline Características & $\begin{array}{l}\text { Posible parte de un silbato donde aparece una máscara de } \\
\text { un hombre con barba. En la parte posterior se intuye que } \\
\text { pudo tener un asa y bajo la cabeza, por paralelismos con } \\
\text { otras piezas, se piensa que pudo ser un silbato. }\end{array}$ \\
\hline Materiales & \begin{tabular}{l} 
Arcilla \\
\hline
\end{tabular}
\end{tabular}




\section{Datos organológicos}

\begin{tabular}{|l|l|}
\hline Tipo de instrumento & Aerófono \\
\hline $\begin{array}{l}\text { Clasificación por } \\
\text { estructura física }\end{array}$ & B.1. Silbatos globulares antropomorfos \\
\hline $\begin{array}{l}\text { Clasificación } \\
\text { organológica }\end{array}$ & $\begin{array}{l}421.221 .41 \text { Flautas globulares con canal de insuflación } \\
\text { interno sin agujeros digitales }\end{array}$ \\
\hline Función & Lúdica \\
\hline Fabricación & Alfares \\
\hline musicales & $\begin{array}{l}\text { Por el estado de conservación de la pieza no se pueden } \\
\text { observar los rasgos musicales del instrumento por lo que } \\
\text { se supone un silbato de agua por paralelismo con otras } \\
\text { piezas. }\end{array}$ \\
\hline
\end{tabular}

\section{Datos arqueológicos}

\begin{tabular}{|l|l|}
\hline Yacimiento & - \\
\hline $\begin{array}{l}\text { Responsable de la } \\
\text { excavación }\end{array}$ & - \\
\hline
\end{tabular}

\section{Bibliografía}

\begin{tabular}{|l|l|}
\hline Documentación del Museo & Pieza con ficha de catalogación. \\
\hline Flores Escobosa, Isabel. Vivir en al-Andalus. Almería: Instituto de Estudios \\
Almerienses, 1993, 224.
\end{tabular}




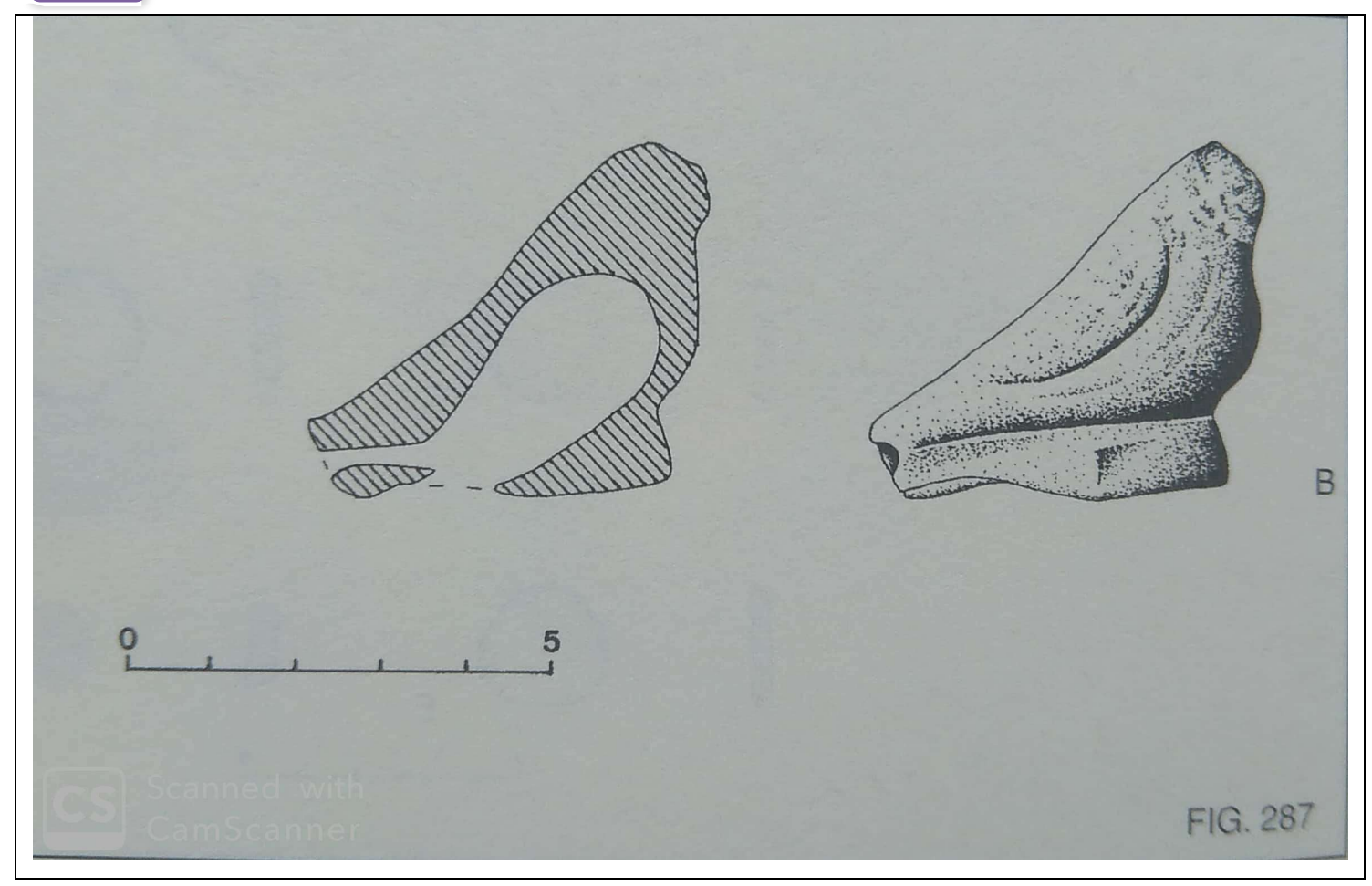

\section{Datos generales}

\begin{tabular}{|l|l|}
\hline Nombre & Silbato zoomorfo \\
\hline $\mathbf{N}^{\mathbf{0}}$ de inventario & - \\
\hline Ubicación actual & - \\
\hline Procedencia & Yacimiento Casa del Obispo \\
\hline Dimensiones & - \\
\hline Ciudad & Cádiz \\
\hline Cronología & Almohade \\
\hline Características morfológicas & $\begin{array}{l}\text { Silbato con forma de ave de la cual no se conserva } \\
\text { la cabeza. El dibujo parece mostrar que las alas y } \\
\text { formas se han realizado mediante pequeñas } \\
\text { incisiones. Cuenta con una base como soporte sobre } \\
\text { la que parece reposar. }\end{array}$ \\
\hline Materiales & Arcilla \\
\hline
\end{tabular}

\section{Datos organológicos}




\begin{tabular}{|l|l|}
\hline $\begin{array}{l}\text { Clasificación por estructura } \\
\text { física }\end{array}$ & B.2. Silbatos globulares zoomorfos \\
\hline Clasificación organológica & $\begin{array}{l}421.221 .41 \text { Flautas globulares con canal de } \\
\text { insuflación interno sin agujeros digitales }\end{array}$ \\
\hline Función & Lúdica \\
\hline Fabricación & Alfares \\
\hline Características musicales & $\begin{array}{l}\text { Aerófono con embocadura de bisel. La cola forma } \\
\text { la embocadura del instrumento siendo el filo la zona } \\
\text { de soplo y estando el agujero de salida bajo este. }\end{array}$ \\
\hline
\end{tabular}

\section{Datos arqueológicos}

\begin{tabular}{|l|l|}
\hline Yacimiento & - \\
\hline Responsable de la excavación & - \\
\hline
\end{tabular}

Bibliografía

\begin{tabular}{|l|l|}
\hline Documentación del Museo & Pieza no inventariada. \\
\hline $\begin{array}{l}\text { Cavilla Sánchez-Molero, Francisco. La cerámica Almohade de la isla de Cádiz } \\
\text { (Yazirat Qadis). Cádiz: Universidad de Cádiz, 2005, 275-576. }\end{array}$ \\
\hline
\end{tabular}




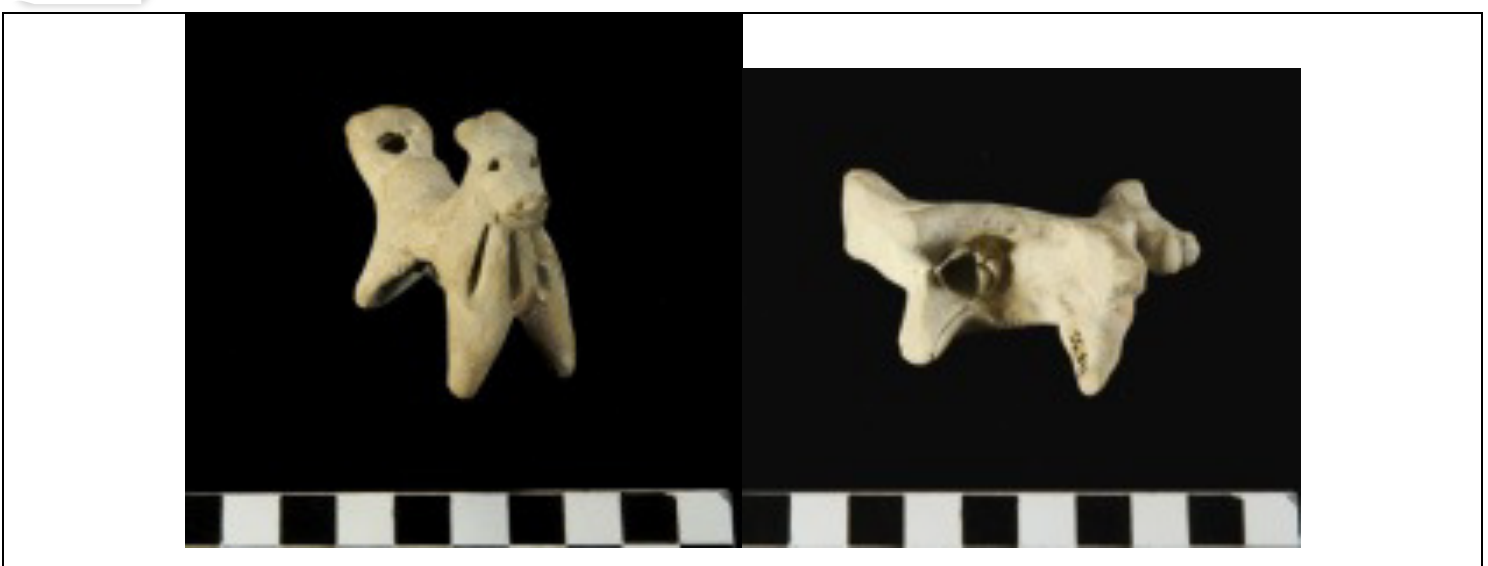

\section{Datos generales}

\begin{tabular}{|l|l|}
\hline Nombre & Silbato zoomorfo \\
\hline $\mathbf{N}^{\mathbf{0}}$ de inventario & $\mathrm{N}^{\mathrm{a}}$ IG 842 Na REG. 00965-002 \\
\hline Ubicación actual & Museo Arqueológico de Jerez \\
\hline Procedencia & Alcázar de Jerez \\
\hline Dimensiones & Longitud: 6,8 cm; Altura: 5,2 cm \\
\hline Ciudad & Cádiz \\
\hline Cronología & Ss. XII-XIII (Almohade) \\
\hline Características & $\begin{array}{l}\text { Silbato con forma de caballo en buen estado de } \\
\text { conservación. Los rasgos faciales se han realizado } \\
\text { modiante incisiones. Cuenta con un adorno en la parte del } \\
\text { pecho, se tratan de tres líneas verticales hechas mediante } \\
\text { incisiones. }\end{array}$ \\
\hline Materiales & \begin{tabular}{l} 
Arcilla \\
\hline
\end{tabular} \\
\hline
\end{tabular}

\section{Datos organológicos}

\begin{tabular}{|l|l|}
\hline Tipo de instrumento & Aerófono \\
\hline $\begin{array}{l}\text { Clasificación por } \\
\text { estructura física }\end{array}$ & B.2. Silbatos globulares zoomorfos \\
\hline $\begin{array}{l}\text { Clasificación } \\
\text { organológica }\end{array}$ & $\begin{array}{l}421.221 .41 \text { Flautas globulares con canal de insuflación } \\
\text { interno sin agujeros digitales }\end{array}$ \\
\hline Función & Lúdica \\
\hline
\end{tabular}




\begin{tabular}{|l|l|}
\hline Fabricación & Alfares \\
\hline Características & $\begin{array}{l}\text { Silbato zoomorfo con embocadura situada en la cola del } \\
\text { caballo. El instrumento está hecho en una sola pieza. El } \\
\text { musicales }\end{array}$ \\
& $\begin{array}{l}\text { orificio de salida del aire se encuentra bajo las patas } \\
\text { traseras. }\end{array}$ \\
\hline
\end{tabular}

\section{Datos arqueológicos}

\begin{tabular}{|l|l|}
\hline Yacimiento & Alcázar 83. 2 Campaña \\
\hline $\begin{array}{l}\text { Responsable de la } \\
\text { excavación }\end{array}$ & María Luisa Méndez Reyes \\
\hline
\end{tabular}

\section{Bibliografía}

\begin{tabular}{|l|l|}
\hline Documentación del Museo & Pieza con ficha de catalogación. \\
\hline Inédito & \\
\hline
\end{tabular}




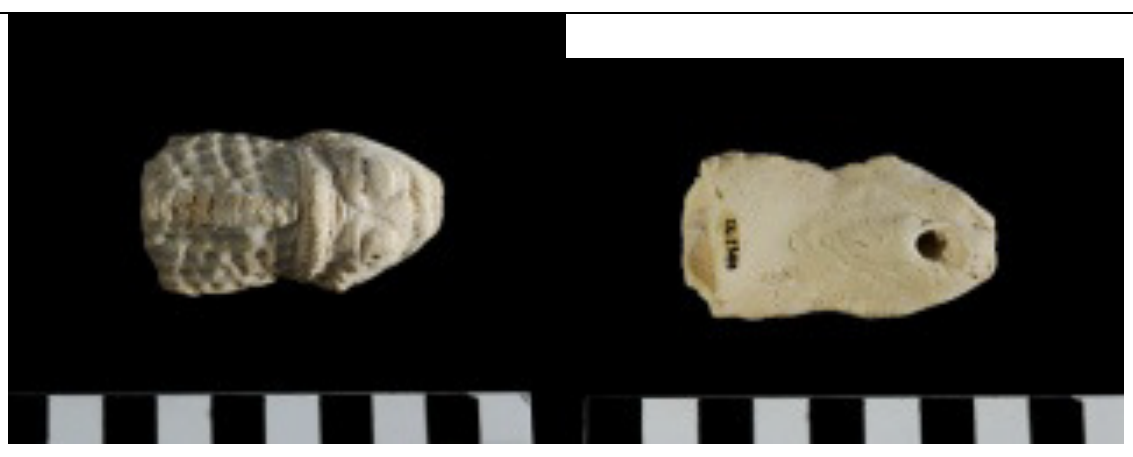

Datos generales

\begin{tabular}{|l|l|}
\hline Nombre & Silbato zoomorfo \\
\hline $\mathbf{N}^{\mathbf{0}}$ de inventario & $\mathrm{N}^{\mathrm{a}}$ IG 1500 Na RE. 01470-040 \\
\hline Ubicación actual & Museo Arqueológico de Jerez \\
\hline Procedencia & Calle Castellanos 3 (Casco Urbano) \\
\hline Dimensiones & Longitud: $5,8 \mathrm{~cm}$; Ancho: 3,2 cm; Grosor: 1,9 cm \\
\hline Ciudad & Cádiz \\
\hline Cronología & ss. XII-XIII (Almohade) \\
\hline Características \\
morfológicas & $\begin{array}{l}\text { Aerófono con forma de lagarto o camaleón. Cuenta con } \\
\text { incisiones a modo de adorno en la espalda del reptil } \\
\text { asemejando en el medio de la misma una especie de } \\
\text { cresta. Los rasgos faciales son modelados en el propio } \\
\text { cuerpo del instrumento resaltando el tamaño de los ojos. } \\
\text { Parece ser un fragmento de lo que pudo ser una pieza de } \\
\text { mayor tamaño. }\end{array}$ \\
\hline Materiales & Arcilla \\
\hline
\end{tabular}

Datos organológicos

\begin{tabular}{|l|l|}
\hline Tipo de instrumento & Aerófono \\
\hline $\begin{array}{l}\text { Clasificación por } \\
\text { estructura física }\end{array}$ & B.2. Silbatos globulares zoomorfos \\
\hline Clasificación & 421.221 .41 Flautas globulares con canal de insuflación \\
\hline
\end{tabular}




\begin{tabular}{|l|l|}
\hline organológica & interno sin agujeros digitales \\
\hline Función & Lúdica \\
\hline Fabricación & Alfares \\
\hline $\begin{array}{l}\text { Características } \\
\text { musicales }\end{array}$ & $\begin{array}{l}\text { Fragmento de silbato sin agujeros digitales. La } \\
\text { embocadura se encuentra en la boca del animal estando el } \\
\text { orificio de salida del aire bajo la cabeza del mismo. }\end{array}$ \\
\hline
\end{tabular}

Datos arqueológicos

\begin{tabular}{|l|l|}
\hline Yacimiento & CAST-3/04/ ZC-4/UE 6 \\
\hline $\begin{array}{l}\text { Responsable de la } \\
\text { excavación }\end{array}$ & $\mathrm{D}^{\text {a Carmen Reimondez Becerra }}$ \\
\hline
\end{tabular}

\section{Bibliografía}

Documentación del Museo

Pieza con ficha de catalogación.

Inédito 


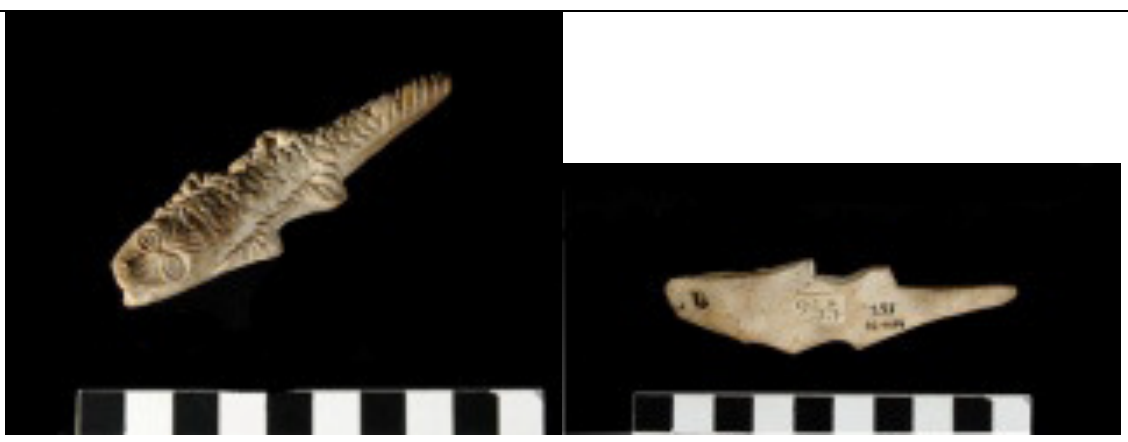

Datos generales

\begin{tabular}{|l|l|}
\hline Nombre & Silbato zoomorfo \\
\hline $\mathbf{N}^{\mathbf{0}}$ de inventario & $\mathrm{N}^{\mathrm{a}}$ IG $1499 \mathrm{~N}^{\mathrm{a}} \mathrm{RE} .00255$ \\
\hline Ubicación actual & Museo Arqueológico de Jerez \\
\hline Procedencia & Desconocida. Donación \\
\hline Dimensiones & $\begin{array}{l}\text { Longitud: } 9,2 \mathrm{~cm} \text {; Ancho máximo : 2,5 cm; Grosor } \\
\text { máximo: } 1,6 \mathrm{~cm} .\end{array}$ \\
\hline Ciudad & Cádiz \\
\hline Cronología & ss. XII-XIII (Almohade) \\
\hline morfológicas & $\begin{array}{l}\text { Silbato en forma de lagarto, o pez según su ficha de } \\
\text { catalogación. La pieza se conserva completa por lo que } \\
\text { pueden observarse claramente los detalles del instrumento } \\
\text { hecho en una pieza. Los adornos del cuerpo, a modo de } \\
\text { escamas, y rasgos faciales están representados en relieve. }\end{array}$ \\
\hline Materiales & \begin{tabular}{l} 
Arcilla \\
\hline
\end{tabular}
\end{tabular}

Datos organológicos

\begin{tabular}{|l|l|}
\hline Tipo de instrumento & Aerófono \\
\hline $\begin{array}{l}\text { Clasificación por } \\
\text { estructura física }\end{array}$ & B.2. Silbatos globulares zoomorfos \\
\hline $\begin{array}{l}\text { Clasificación } \\
\text { organológica }\end{array}$ & $\begin{array}{l}421.221 .41 \text { Flautas globulares con canal de insuflación } \\
\text { interno sin agujeros digitales }\end{array}$ \\
\hline
\end{tabular}




\begin{tabular}{|l|l|}
\hline Función & Lúdica \\
\hline Fabricación & Alfares \\
\hline Características & $\begin{array}{l}\text { Aerófono con canal de insuflación en la boca del animal, } \\
\text { el agujero de salida de aire del instrumento se encuentra } \\
\text { musicales }\end{array}$ \\
\hline
\end{tabular}

Datos arqueológicos

\begin{tabular}{|l|l|}
\hline Yacimiento & - \\
\hline $\begin{array}{l}\text { Responsable de la } \\
\text { excavación }\end{array}$ & - \\
\hline
\end{tabular}

\section{Bibliografía}

Documentación del Museo

Pieza con ficha de catalogación.

Inédito 


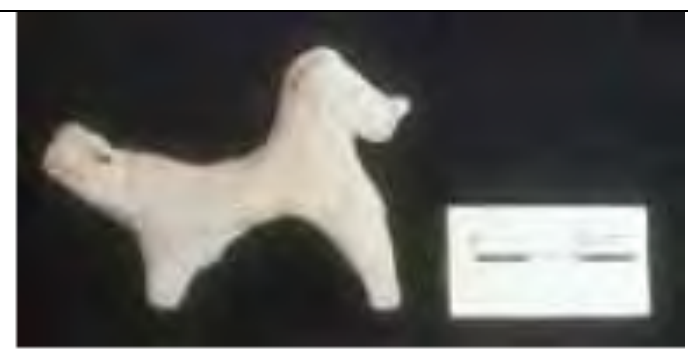

\section{Datos generales}

\begin{tabular}{|l|l|}
\hline Nombre & Silbato zoomorfo \\
\hline $\mathbf{N}^{\mathbf{0}}$ de inventario & N-III/ GH-10191 \\
\hline Ubicación actual & Museo Arqueológico Municipal de Jerez de la Frontera \\
\hline Procedencia & Alcázar de Jerez \\
\hline Dimensiones & Altura: $5,2 \mathrm{~cm}$; Longitud: $6,8 \mathrm{~cm}$ \\
\hline Ciudad & Cádiz \\
\hline Cronología & ss. XII-XIII (Almohade) \\
\hline $\begin{array}{l}\text { Características } \\
\text { morfológicas }\end{array}$ & $\begin{array}{l}\text { Caballito con hocico y crin prominente. Se encuentra } \\
\text { completa la pieza. }\end{array}$ \\
\hline Materiales & Arcilla \\
\hline
\end{tabular}

\section{Datos organológicos}

\begin{tabular}{|l|l|}
\hline Tipo de instrumento & Aerófono \\
\hline $\begin{array}{l}\text { Clasificación por } \\
\text { estructura física }\end{array}$ & B.2. Silbatos globulares zoomorfos \\
\hline $\begin{array}{l}\text { Clasificación } \\
\text { organológica }\end{array}$ & $\begin{array}{l}421.221 .41 \text { Flautas globulares con canal de insuflación } \\
\text { interno sin agujeros digitales }\end{array}$ \\
\hline Función & Lúdica \\
\hline Fabricación & Alfares \\
\hline $\begin{array}{l}\text { Características } \\
\text { musicales }\end{array}$ & $\begin{array}{l}\text { Caballito con silbato adosado en la parte trasera del } \\
\text { animal. }\end{array}$ \\
\hline
\end{tabular}




\section{Datos arqueológicos}

\begin{tabular}{|l|l|}
\hline Yacimiento & Alcázar de Jerez \\
\hline $\begin{array}{l}\text { Responsable de la } \\
\text { excavación }\end{array}$ & María Luisa Méndez Reyes \\
\hline
\end{tabular}

\section{Bibliografía}

\begin{tabular}{|l|l|}
\hline Documentación del Museo & Pieza con ficha de catalogación. \\
\hline García Benito, Carlos. "Arqueología Musical Prehistórica: aproximación a través de \\
la Arqueología Experimental aplicada a la Arqueo-Organología, de la Arqueoacústica \\
y de la Iconografía Musical Prehistórica”. Tesis doctoral, Universidad de Zaragoza, \\
2014, 1712.
\end{tabular}




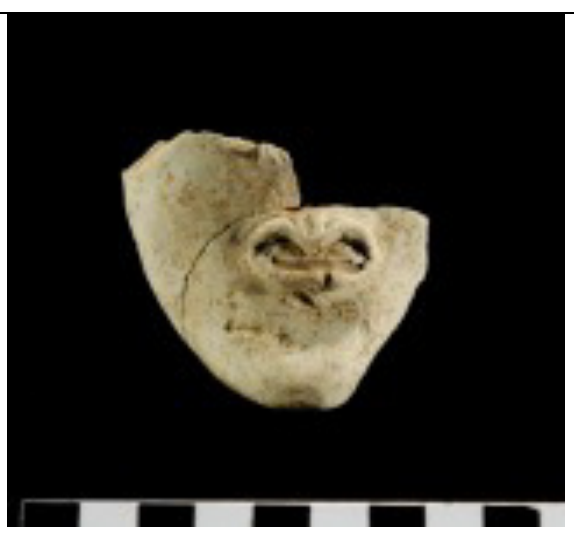

\section{Datos generales}

\begin{tabular}{|l|l|}
\hline Nombre & Silbato \\
\hline $\mathbf{N}^{\mathbf{0}}$ de inventario & LAN/87/A-7/-194/21 \\
\hline Ubicación actual & Museo Arqueológico Municipal de Jerez de la Frontera \\
\hline Procedencia & C/ Lancería $5-7$ \\
\hline Dimensiones & Altura: $5,5 \mathrm{~cm}$; Anchura: $5,7 \mathrm{~cm}$; Grosor $1,3 \mathrm{~cm}$ \\
\hline Ciudad & Cádiz \\
\hline Cronología & ss. XII-XIII (Almohade) \\
\hline $\begin{array}{l}\text { Características } \\
\text { morfológicas }\end{array}$ & Máscara que adorna silbatos de agua \\
\hline Materiales & Arcilla \\
\hline
\end{tabular}

\section{Datos organológicos}

\begin{tabular}{|l|l|}
\hline Tipo de instrumento & Aerófono \\
\hline $\begin{array}{l}\text { Clasificación por } \\
\text { estructura física }\end{array}$ & B.2. Silbatos globulares zoomorfos \\
\hline $\begin{array}{l}\text { Clasificación } \\
\text { organológica }\end{array}$ & $\begin{array}{l}421.221 .41 \text { Flautas globulares con canal de insuflación } \\
\text { interno sin agujeros digitales }\end{array}$ \\
\hline Función & Lúdica \\
\hline Fabricación & Alfares \\
\hline $\begin{array}{l}\text { Características } \\
\text { musicales }\end{array}$ & $\begin{array}{l}\text { Aerófono con canal de insuflación en la boca del animal, } \\
\text { el agujero de salida de aire del instrumento se encuentra }\end{array}$ \\
\hline
\end{tabular}


bajo la cabeza del mismo.

Datos arqueológicos

\begin{tabular}{|l|l|}
\hline Yacimiento & C/ Lancería 5-7 \\
\hline $\begin{array}{l}\text { Responsable de la } \\
\text { excavación }\end{array}$ & Rosalía González Rodríguez \\
\hline
\end{tabular}

\section{Bibliografía}

Documentación del Museo

Pieza con ficha de catalogación.

Inédito 


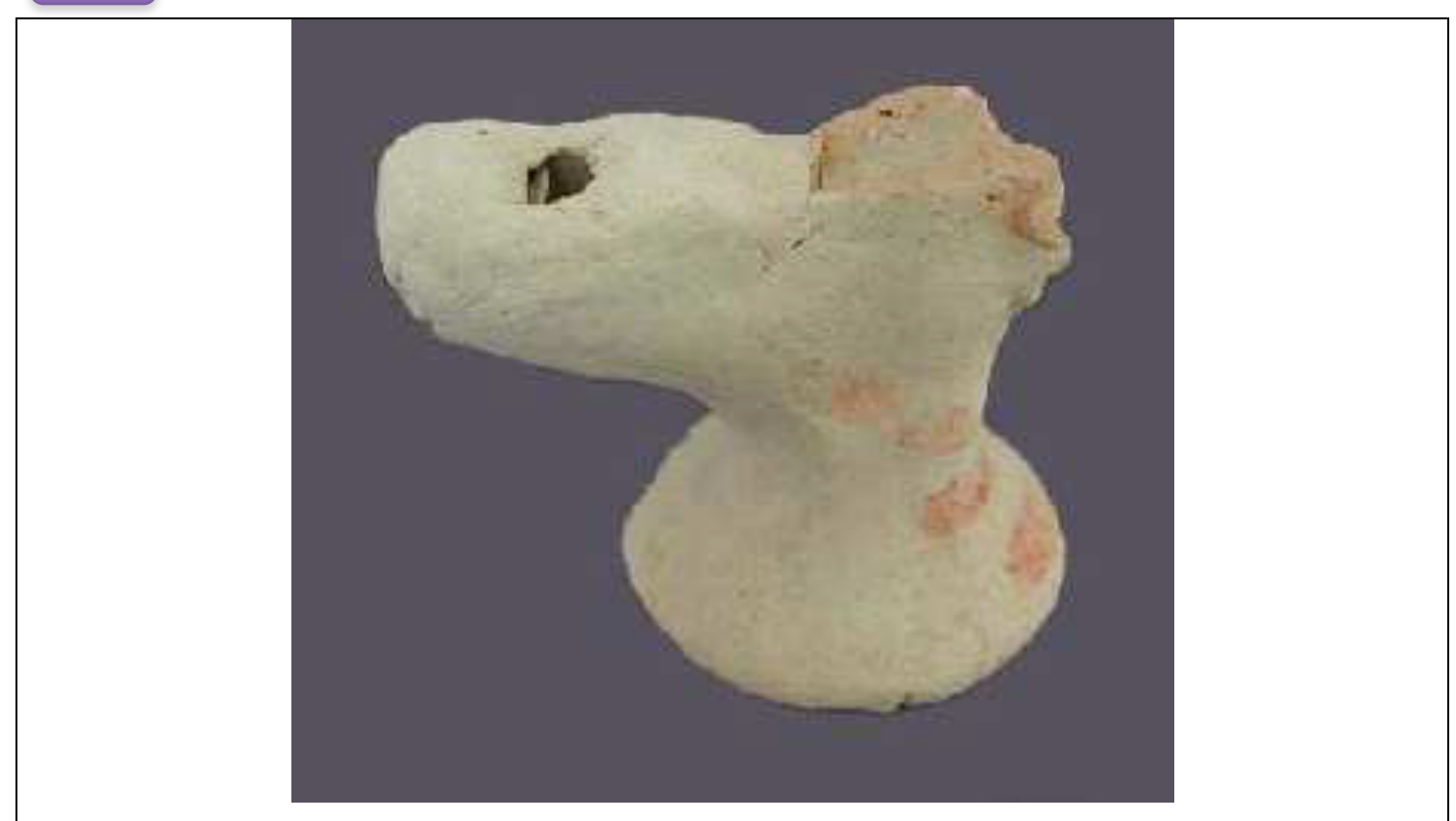

\section{Datos generales}

\begin{tabular}{|l|l|}
\hline Nombre & Silbato zoomorfo \\
\hline $\mathbf{N}^{\mathbf{0}}$ de inventario & CE031614 \\
\hline Ubicación actual & Museo Arqueológico y Etnológico de Córdoba \\
\hline Procedencia & Calle Conde de Arenales, 22 (Córdoba) \\
\hline Dimensiones & Alto: $4,3 \mathrm{~cm}$; Ancho: $5 \mathrm{~cm}$ \\
\hline Ciudad & Córdoba \\
\hline Cronología & Ss. XII-XIII (Almohade) \\
\hline Características morfológicas & $\begin{array}{l}\text { Fragmento de un silbato con forma de ave. Se } \\
\text { conserva la cola con lo que era la embocadura del } \\
\text { instrumento. Cuenta con un pie plano como soporte. }\end{array}$ \\
\hline Materiales & Arcilla \\
\hline
\end{tabular}

Datos organológicos

\begin{tabular}{|l|l|}
\hline Tipo de instrumento & Aerófono \\
\hline $\begin{array}{l}\text { Clasificación por estructura } \\
\text { física }\end{array}$ & B.2. Silbatos globulares zoomorfos \\
\hline
\end{tabular}




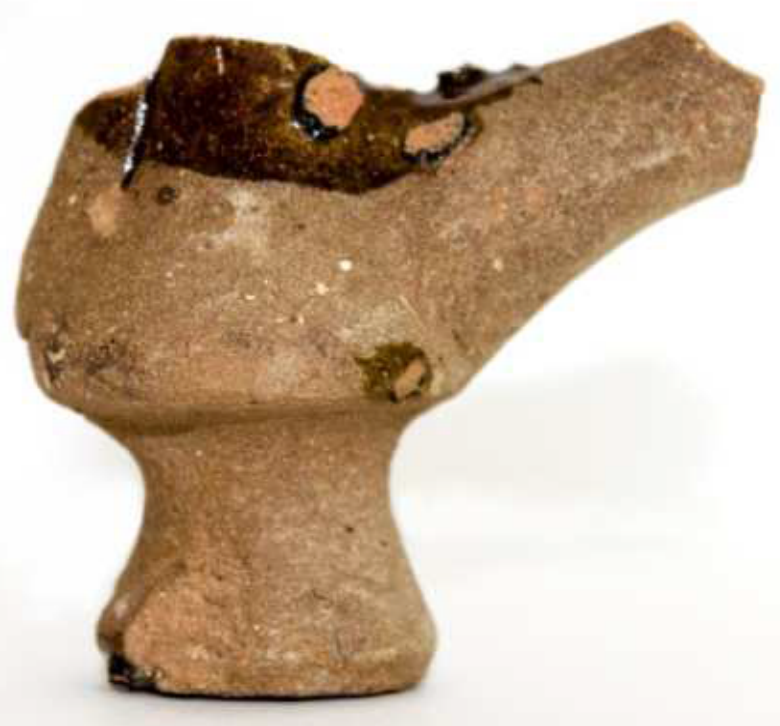

Datos generales

\begin{tabular}{|l|l|}
\hline Nombre & Silbato de agua \\
\hline $\mathbf{N}^{\mathbf{0}}$ de inventario & DJ032691 \\
\hline Ubicación actual & Museo Arqueológico y Etnológico de Córdoba \\
\hline Procedencia & C/ Conde de Arenales, 22 (Córdoba) \\
\hline Dimensiones & Alto: $5,5 \mathrm{~cm}$; Ancho 2,2 cm \\
\hline Ciudad & Córdoba \\
\hline Cronología & ss. X-XIV (Emiral-Nazarí) \\
\hline Características morfológicas & $\begin{array}{l}\text { Fragmento de silbato de agua con forma de jarrita. } \\
\text { Se conserva la base del instrumento y el conducto } \\
\text { de soplo del mismo. Cuenta con un pie plano como } \\
\text { soporte. }\end{array}$ \\
\hline Materiales & Arcilla \\
\hline
\end{tabular}

\section{Datos organológicos}

\begin{tabular}{|l|l|}
\hline Tipo de instrumento & Aerófono \\
\hline $\begin{array}{l}\text { Clasificación por estructura } \\
\text { física }\end{array}$ & B.4. Silbatos globulares de agua \\
\hline
\end{tabular}




\begin{tabular}{|l|l|}
\hline Clasificación organológica & $\begin{array}{l}421.221 .41 \text { Flautas globulares con canal de } \\
\text { insuflación interno sin agujeros digitales }\end{array}$ \\
\hline Función & Lúdica \\
\hline Fabricación & Alfares \\
\hline Características musicales & $\begin{array}{l}\text { Silbato de agua del que se conserva parte del cuerpo } \\
\text { y conducto de insuflación del aire. El bisel } \\
\text { seguramente se encontraría cercano al inicio de la } \\
\text { embocadura ahora incompleta. }\end{array}$ \\
\hline
\end{tabular}

\section{Datos arqueológicos}

\begin{tabular}{|l|l|}
\hline Yacimiento & - \\
\hline Responsable de la excavación & - \\
\hline
\end{tabular}

\section{Bibliografía}

\begin{tabular}{|l|l}
\hline Documentación del Museo & Pieza con ficha de catalogación.
\end{tabular}

Red Digital de Colecciones de Museos en España:

http://ceres.mcu.es/pages/Main?idt=137426\&inventary $=$ CE032691\&table=FMUS\&m useum=MAECO\#.XkuU3fw3YJc (Última consulta: 18-02-2020). 


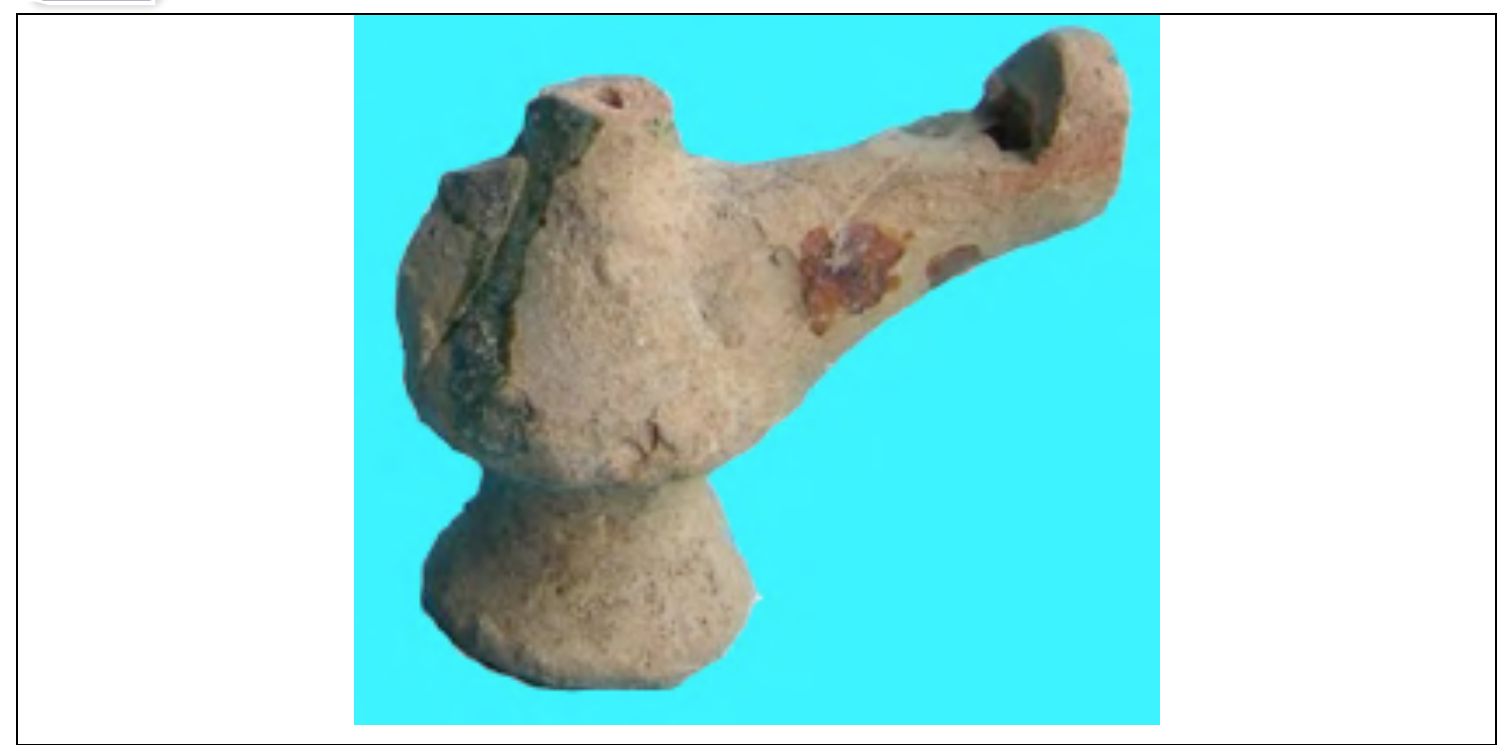

\section{Datos generales}

\begin{tabular}{|l|l|}
\hline Nombre & Silbato de agua \\
\hline $\mathbf{N}^{\mathbf{0}}$ de inventario & 192 \\
\hline Ubicación actual & Museo Arqueológico y Etnológico de Córdoba \\
\hline Procedencia & C/ María Auxiliadora (Córdoba) \\
\hline Dimensiones & Alto: $5,5 \mathrm{~cm}$; Ancho $2,2 \mathrm{~cm}$ \\
\hline Ciudad & Córdoba \\
\hline Cronología & s. XII (Almohade) \\
\hline Características & $\begin{array}{l}\text { Fragmento de silbato de agua con forma de jarrita. Se } \\
\text { conserva la base del instrumento y el conducto de soplo } \\
\text { del mismo. Cuenta con un pie plano como soporte. }\end{array}$ \\
\hline Materiales & Arcilla \\
\hline
\end{tabular}

Datos organológicos

\begin{tabular}{|l|l|}
\hline Tipo de instrumento & Aerófono \\
\hline $\begin{array}{l}\text { Clasificación por } \\
\text { estructura física }\end{array}$ & B.4. Silbatos globulares de agua \\
\hline $\begin{array}{l}\text { Clasificación } \\
\text { organológica }\end{array}$ & $\begin{array}{l}421.221 .41 \text { Flautas globulares con canal de insuflación } \\
\text { interno sin agujeros digitales }\end{array}$ \\
\hline Función & Lúdica \\
\hline
\end{tabular}




\begin{tabular}{|l|l|}
\hline Fabricación & Alfares \\
\hline $\begin{array}{l}\text { Características } \\
\text { musicales }\end{array}$ & $\begin{array}{l}\text { Silbato de agua del que se conserva parte del cuerpo y } \\
\text { conducto de insuflación del aire. Cercano a la embocadura } \\
\text { en la parte superior está el bisel. }\end{array}$ \\
\hline
\end{tabular}

\section{Datos arqueológicos}

\begin{tabular}{|l|l|}
\hline Yacimiento & C/ María Auxiliadora \\
\hline $\begin{array}{l}\text { Responsable de la } \\
\text { excavación }\end{array}$ & Álvaro Cánovas Ubera \\
\hline
\end{tabular}

\section{Bibliografía}

\begin{tabular}{|l|l}
\hline Documentación del Museo & Pieza con ficha de catalogación.
\end{tabular}

García Benito, Carlos. “Arqueología Musical Prehistórica: aproximación a través de la Arqueología Experimental aplicada a la Arqueo-Organología, de la Arqueoacústica y de la Iconografía Musical Prehistórica”. Tesis doctoral, Universidad de Zaragoza, 2014, 1811. 


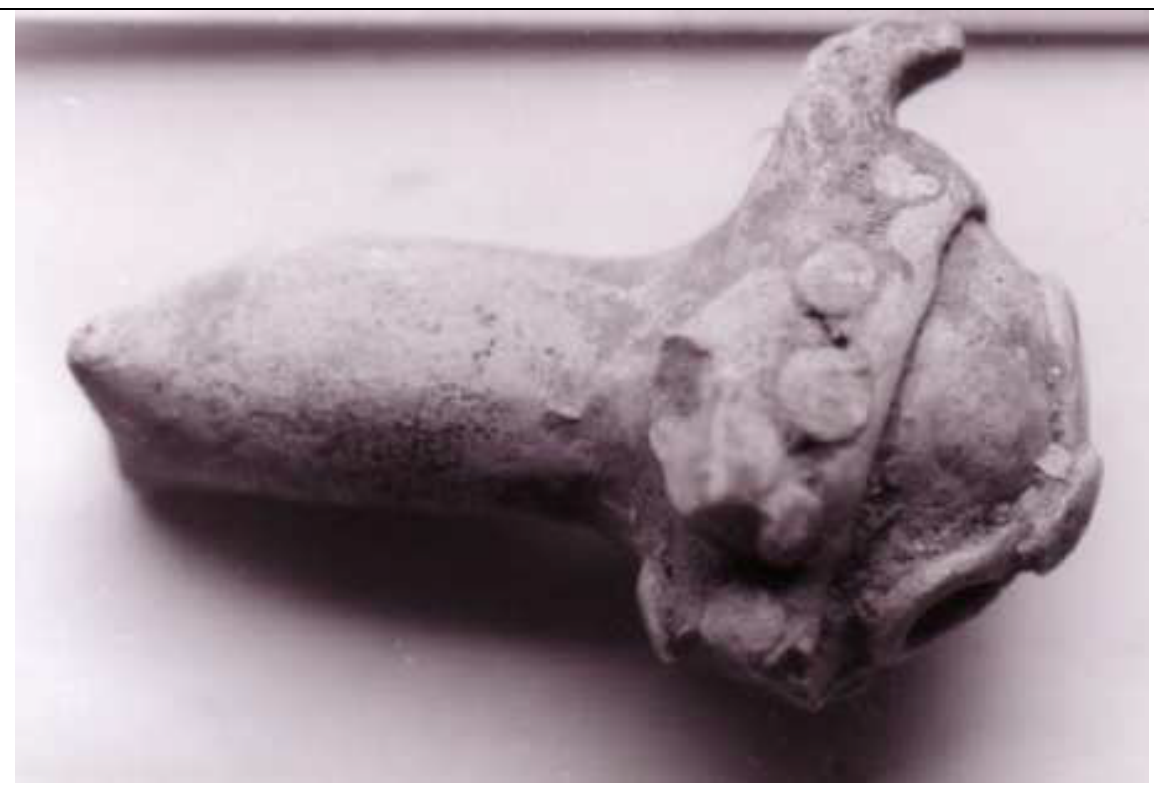

Datos generales

\begin{tabular}{|l|l|}
\hline Nombre & Silbato \\
\hline $\mathbf{N}^{\mathbf{0}}$ de inventario & DJ1374C \\
\hline Ubicación actual & Museo de Bellas Artes de Córdoba ¿? \\
\hline Procedencia & - \\
\hline Dimensiones & Anchura: $5 \mathrm{~cm}$; Altura: $7,5 \mathrm{~cm}$ \\
\hline Ciudad & Córdoba \\
\hline Cronología & ss. X-XIV (Emiral-Nazarí) \\
\hline morfológicas & $\begin{array}{l}\text { Pieza catalogada como silbato aunque actualmente } \\
\text { parece perdida. Tiene forma de nuez, al no contar más } \\
\text { que con una fotografía no pueden observarse sus } \\
\text { detalle. }\end{array}$ \\
\hline Materiales & Arcilla \\
\hline
\end{tabular}

Datos organológicos

\begin{tabular}{|l|l|}
\hline Tipo de instrumento & Aerófono \\
\hline $\begin{array}{l}\text { Clasificación por } \\
\text { estructura física }\end{array}$ & B.5. Silbatos globulares con otras formas \\
\hline Clasificación organológica & $421.221 .41 \quad$ Flautas globulares con canal de \\
\hline
\end{tabular}




\begin{tabular}{|l|l|}
\hline & insuflación interno sin agujeros digitales. \\
\hline Función & Lúdica \\
\hline Fabricación & Alfares \\
\hline Características musicales & $\begin{array}{l}\text { Por la fotografía que se cuenta no se observa } \\
\text { embocadura o bisel. }\end{array}$ \\
\hline
\end{tabular}

Datos arqueológicos

\begin{tabular}{|l|l|}
\hline Yacimiento & - \\
\hline $\begin{array}{l}\text { Responsable de la } \\
\text { excavación }\end{array}$ & - \\
\hline
\end{tabular}

\section{Bibliografía}

\begin{tabular}{|l|l}
\hline Documentación del Museo & Pieza con ficha de catalogación. Perdida.
\end{tabular}

Red Digital de Colecciones de Museos en España:

http://ceres.mcu.es/pages/Main?idt=123137\&inventary=DJ1374C\&table=FMUS\&mu seum=MBACO\#.XkuY6K7fDcc (Última consulta: 18-02-2020). 


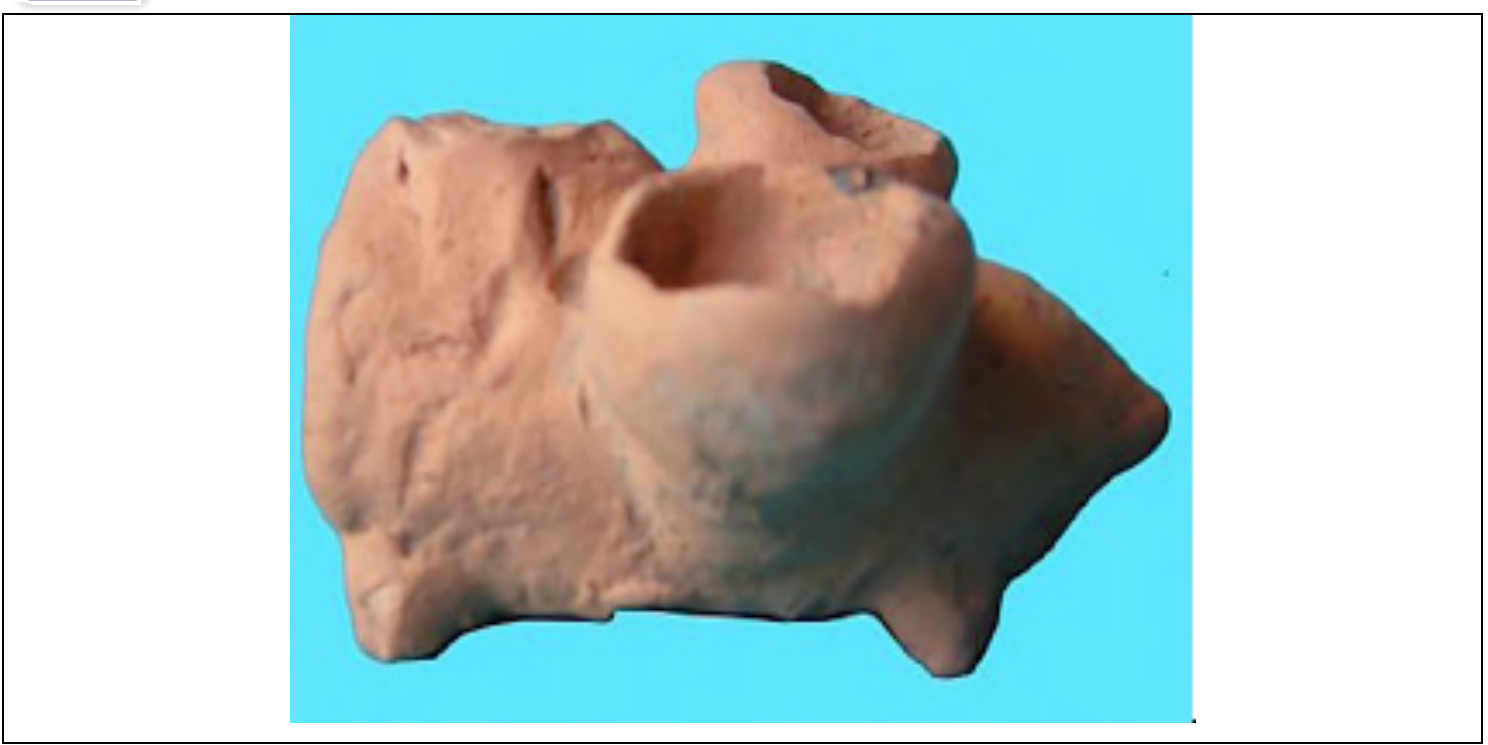

Datos generales

\begin{tabular}{|c|c|}
\hline Nombre & Silbato zoomorfo \\
\hline $\mathrm{N}^{0}$ de inventario & - \\
\hline Ubicación actual & - \\
\hline Procedencia & Avenida Ollerías \\
\hline Dimensiones & - \\
\hline Ciudad & Córdoba \\
\hline Cronología & ss. XI-XII (Califal- Almohade) \\
\hline $\begin{array}{l}\text { Características } \\
\text { morfológicas }\end{array}$ & $\begin{array}{l}\text { Figura zoomorfa con cuatro patas. Cuenta con un cuerpo } \\
\text { en forma cilíndrica horizontal con uno de sus lados planos } \\
\text { y otro estrecho de manera progresiva. A sus lados tiene } \\
\text { unos brazos. Pudo ser un silbato de agua. Conserva } \\
\text { manchas de pintura roja y negra. }\end{array}$ \\
\hline Materiales & Arcilla \\
\hline
\end{tabular}

Datos organológicos

\begin{tabular}{|l|l|}
\hline Tipo de instrumento & Aerófono \\
\hline $\begin{array}{l}\text { Clasificación por } \\
\text { estructura física }\end{array}$ & B.2. Silbatos globulares zoomorfos \\
\hline Clasificación & 421.221 .41 Flautas globulares con canal de insuflación \\
\hline
\end{tabular}




\begin{tabular}{|l|l|}
\hline organológica & interno sin agujeros digitales. \\
\hline Función & Lúdica \\
\hline Fabricación & Alfares \\
\hline $\begin{array}{l}\text { Características } \\
\text { musicales }\end{array}$ & $\begin{array}{l}\text { Embocadura del instrumento se encuentra en la parte } \\
\text { trasera del mismo. }\end{array}$ \\
\hline
\end{tabular}

\section{Datos arqueológicos}

\begin{tabular}{|l|l|}
\hline Yacimiento & Avenida Ollerías \\
\hline $\begin{array}{l}\text { Responsable de la } \\
\text { excavación }\end{array}$ & Antonio Molina Expósito y Agustín López Jiménez \\
\hline
\end{tabular}

\section{Bibliografía}

\begin{tabular}{|l|l|}
\hline Documentación del Museo & Pieza con ficha de catalogación. \\
\hline García Benito, Carlos. “Arqueología Musical Prehistórica: aproximación a través de \\
la Arqueología Experimental aplicada a la Arqueo-Organología, de la Arqueoacústica \\
y de la Iconografía Musical Prehistórica”. Tesis doctoral, Universidad de Zaragoza, \\
2014, 1682.
\end{tabular}




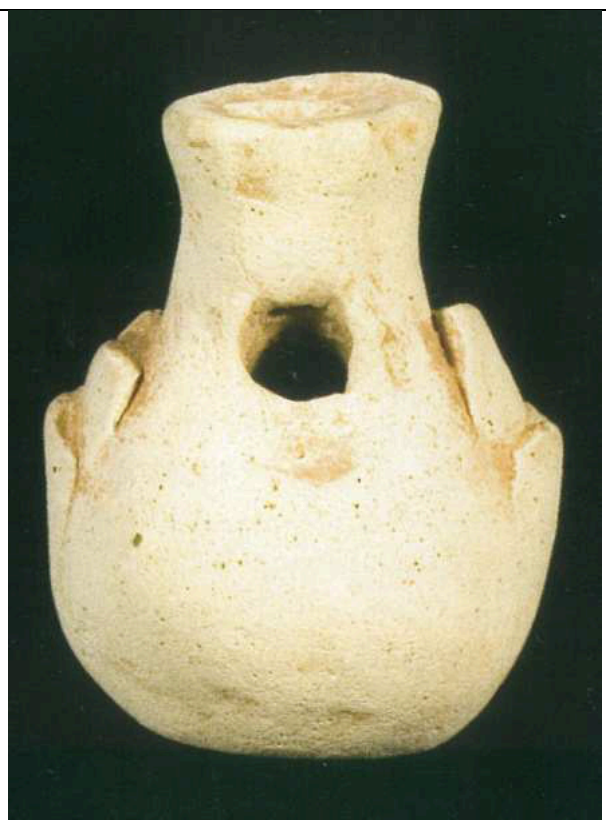

Datos generales

\begin{tabular}{|l|l|}
\hline Nombre & Silbato \\
\hline $\mathbf{N}^{\mathbf{0}}$ de inventario & 4795 \\
\hline Ubicación actual & Museo de la Alhambra (Granada) \\
\hline Procedencia & Alhambra \\
\hline Dimensiones & Altura: $3 \mathrm{~cm}$; Anchura: $2,8 \mathrm{~cm}$. \\
\hline Ciudad & Granada \\
\hline Cronología & ss. XIV-XV (Nazarí) \\
\hline Características \\
morfológicas & $\begin{array}{l}\text { Realizada con pasta clara, es una pieza de pequeño } \\
\text { tamaño con forma piriforme. Tiene una embocadura y } \\
\text { orificio de salida de aire. Cuenta con dos pequeñas } \\
\text { escamas a los lados como única decoración. }\end{array}$ \\
\hline Materiales & Arcilla \\
\hline
\end{tabular}

\section{Datos organológicos}

\begin{tabular}{|l|l|}
\hline Tipo de instrumento & Aerófono \\
\hline $\begin{array}{l}\text { Clasificación por } \\
\text { estructura física }\end{array}$ & B.5. Silbatos globulares con otras formas \\
\hline
\end{tabular}




\begin{tabular}{|l|l|}
\hline $\begin{array}{l}\text { Clasificación } \\
\text { organológica }\end{array}$ & $\begin{array}{l}421.221 .41 \text { Flautas globulares con canal de insuflación } \\
\text { interno sin agujeros digitales. }\end{array}$ \\
\hline Función & Lúdica \\
\hline Fabricación & Alfares \\
\hline $\begin{array}{l}\text { Características } \\
\text { musicales }\end{array}$ & $\begin{array}{l}\text { Silbato en su forma más simple con embocadura, cuerpo y } \\
\text { orificio de salida de aire en una de sus caras. }\end{array}$ \\
\hline
\end{tabular}

\section{Datos arqueológicos}

\begin{tabular}{|l|l|}
\hline Yacimiento & - \\
\hline $\begin{array}{l}\text { Responsable de la } \\
\text { excavación }\end{array}$ & - \\
\hline
\end{tabular}

\section{Bibliografía}

\begin{tabular}{|l|l}
\hline Documentación del Museo & Pieza con ficha de catalogación. \\
\hline
\end{tabular}

Marinetto, Purificación. "Juguetes y silbatos infantiles de época nazarí. Miscelánea de estudios árabes y hebraicos. Sección Árabe-Islam, Vol. 46. (1997): 183-205; Rosselló Bordoy, Guillermo, Ana Navarro Ortega e Isabel Flores Escobosa. Del rito al juego: juguetes y silbatos de cerámica desde el islam hasta la actualidad. Junta de Andalucía, 2006, 236. 


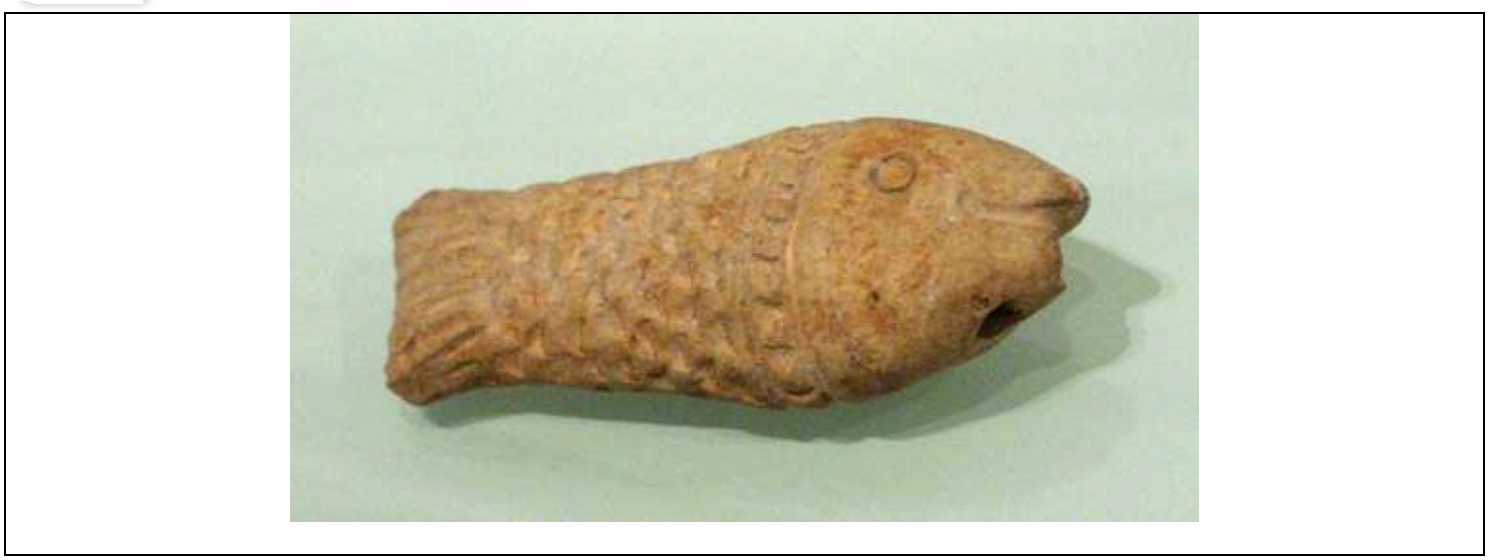

\section{Datos generales}

\begin{tabular}{|l|l|}
\hline Nombre & Silbato \\
\hline $\mathbf{N}^{\mathbf{0}}$ de inventario & 005050 \\
\hline Ubicación actual & Museo de la Alhambra (Granada) \\
\hline Procedencia & Alhambra \\
\hline Dimensiones & Alto: $3 \mathrm{~cm}$; ancho: 7,3 cm \\
\hline Ciudad & Granada \\
\hline Cronología & ss. XIV-XV (Nazarí) \\
\hline Características morfológicas & $\begin{array}{l}\text { Figura que representa un pez. Cuenta con } \\
\text { distintas incisiones a lo largo del cuerpo } \\
\text { representando las escamas y cola. Los rasgos } \\
\text { faciales se limitan a dos círculos pequeños } \\
\text { representando los ojos y una boca que parece } \\
\text { sonreír. }\end{array}$ \\
\hline Materiales & \begin{tabular}{l} 
Arcilla \\
\hline
\end{tabular} \\
\hline
\end{tabular}

Datos organológicos

\begin{tabular}{|l|l|}
\hline Tipo de instrumento & Aerófono \\
\hline $\begin{array}{l}\text { Clasificación por estructura } \\
\text { física }\end{array}$ & B.2. Silbatos globulares zoomorfos \\
\hline Clasificación organológica & $\begin{array}{l}421.221 .41 \text { Flautas globulares con canal de } \\
\text { insuflación interno sin agujeros digitales }\end{array}$ \\
\hline
\end{tabular}




\begin{tabular}{|l|l|}
\hline Función & Lúdica \\
\hline Fabricación & Alfares \\
\hline \multirow{3}{*}{ Características musicales } & $\begin{array}{l}\text { Silbato con embocadura en la cola del animal y } \\
\text { agujero de salida del aire bajo la boca del } \\
\text { mismo. }\end{array}$ \\
\hline
\end{tabular}

Datos arqueológicos

\begin{tabular}{|l|l|}
\hline Yacimiento & - \\
\hline Responsable de la excavación & - \\
\hline
\end{tabular}

\section{Bibliografía}

\begin{tabular}{|l|l}
\hline Documentación del Museo & Pieza con ficha de catalogación.
\end{tabular}

Marinetto, Purificación. "Juguetes y silbatos infantiles de época nazarí". Miscelánea de estudios árabes y hebraicos. Sección Árabe-Islam, Vol. 46. (1997): 183-205; Marinetto Sánchez, Purificación. “Juego y esparcimiento". En Vivir en Al-Andalus. Exposición de cerámica (S. IX-XV). Almedirerránea, Instituto de Estudios Almerienses, 1993, 219; Red Digital de Colecciones de Museos en España: http://ceres.mcu.es/pages/Main?idt $=122085 \&$ inventary $=005050 \&$ table $=$ FMUS\&muse

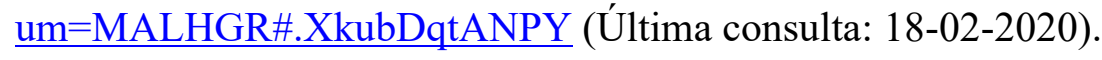




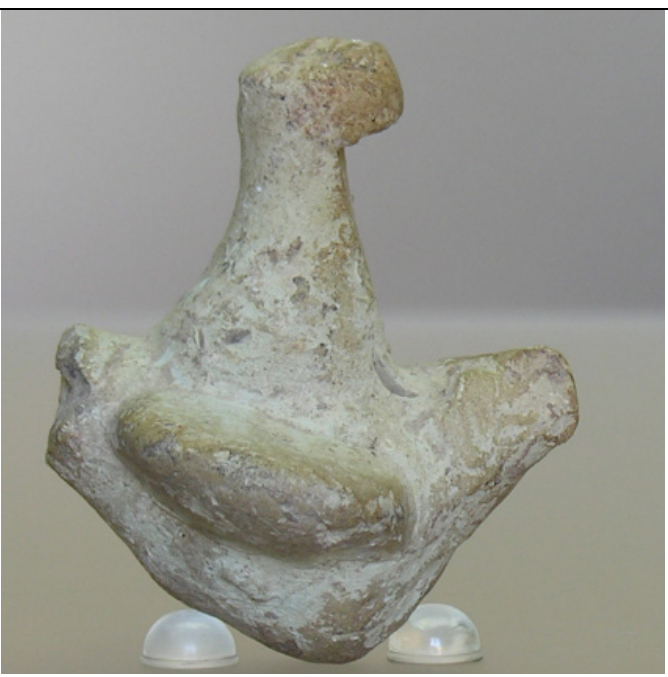

\section{Datos generales}

\begin{tabular}{|l|l|}
\hline Nombre & Silbato \\
\hline $\mathbf{N}^{\mathbf{0}}$ de inventario & 4776 \\
\hline Ubicación actual & Museo de la Alhambra (Granada) \\
\hline Procedencia & Alhambra \\
\hline Dimensiones & Alto: $6,11 \mathrm{~cm} ;$ Ancho: $5,55 \mathrm{~cm}$; Largo: $6,33 \mathrm{~cm}$ \\
\hline Ciudad & Granada \\
\hline Cronología & ss. XIV-XV (Nazarí) \\
\hline Características morfológicas & Silbato en forma de ave con las alas alzadas. \\
\hline Materiales & Arcilla \\
\hline
\end{tabular}

\section{Datos organológicos}

\begin{tabular}{|l|l|}
\hline Tipo de instrumento & Aerófono \\
\hline $\begin{array}{l}\text { Clasificación por estructura } \\
\text { física }\end{array}$ & B.2. Silbatos globulares zoomorfos \\
\hline Clasificación organológica & $\begin{array}{l}421.221 .41 \text { Flautas globulares con canal de } \\
\text { insuflación interno sin agujeros digitales }\end{array}$ \\
\hline Función & Lúdica \\
\hline Fabricación & Alfares \\
\hline Características musicales & Silbato con embocadura y bisel en la cola del animal. \\
\hline
\end{tabular}




\section{Datos arqueológicos}

\begin{tabular}{|l|l|}
\hline Yacimiento & - \\
\hline $\begin{array}{l}\text { Responsable de la } \\
\text { excavación }\end{array}$ & - \\
\hline
\end{tabular}

\section{Bibliografía}

\begin{tabular}{|c|c|}
\hline Documentación del Museo & Pieza con ficha de catalogación. \\
\hline $\begin{array}{l}\text { Marinetto, Purificación. "Jugu } \\
\text { de estudios árabes y hebrai } \\
\text { Marinetto Sánchez, Purificaci } \\
\text { Exposición de cerámica } \\
\text { Almerienses, 1993, } 219 .\end{array}$ & $\begin{array}{l}\text { batos infantiles de época nazarí". Miscelánea } \\
\text { ión Árabe-Islam, Vol. 46. (1997): 183-205; } \\
\text { o y esparcimiento". En Vivir en Al-Andalus. } \\
\text { ). Almedirerránea, Instituto de Estudios }\end{array}$ \\
\hline
\end{tabular}




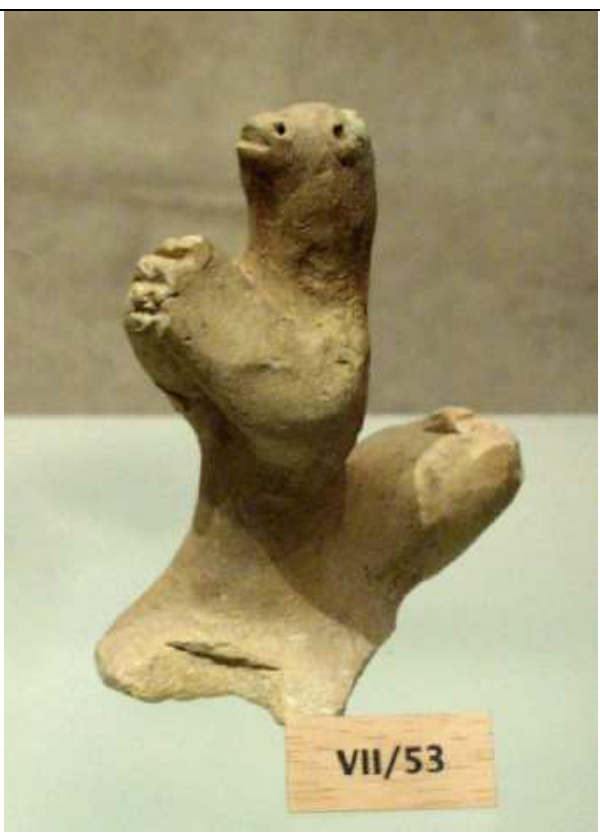

Datos generales

\begin{tabular}{|l|l|}
\hline Nombre & Silbato zoomorfo \\
\hline $\mathbf{N}^{\mathbf{0}}$ de inventario & 7069 \\
\hline Ubicación actual & Museo de la Alhambra (Granada) \\
\hline Procedencia & Alhambra \\
\hline Dimensiones & Alto: $8,5 \mathrm{~cm}$; Ancho: $7,5 \mathrm{~cm}$. \\
\hline Ciudad & Granada \\
\hline Cronología & ss. XIV-XV (Nazarí) \\
\hline Características morfológicas & $\begin{array}{l}\text { Silbato con forma de oso en pie con las patas } \\
\text { delanteras juntas en postura de súplica. Cuenta } \\
\text { con una base plana no detallándose las patas } \\
\text { traseras del animal. Los rasgos faciales se han } \\
\text { realizado mediante incisiones: dos para los ojos, } \\
\text { dos para los orificios nasales y una incisión } \\
\text { mayor para representar la boca. }\end{array}$ \\
\hline Materiales & Arcilla \\
\hline
\end{tabular}


Datos organológicos

\begin{tabular}{|l|l|}
\hline Tipo de instrumento & Aerófono \\
\hline $\begin{array}{l}\text { Clasificación por estructura } \\
\text { física }\end{array}$ & B.2. Silbatos globulares zoomorfos \\
\hline Clasificación organológica & $\begin{array}{l}421.221 .41 \text { Flautas globulares con canal de } \\
\text { insuflación interno sin agujeros digitales }\end{array}$ \\
\hline Función & Lúdica \\
\hline Fabricación & Alfares figura \\
\hline Características musicales & $\begin{array}{l}\text { Silbato con embocadura que forma parte del } \\
\text { cuerpo del instrumento tras la fige encuentra en el mismo } \\
\text { representada. El bisel se } \\
\text { conducto de la embocadura en la parte superior. }\end{array}$ \\
\hline
\end{tabular}

\section{Datos arqueológicos}

\begin{tabular}{|l|l|}
\hline Yacimiento & - \\
\hline Responsable de la excavación & - \\
\hline
\end{tabular}

\section{Bibliografía}

\section{Documentación del Museo Pieza con ficha de catalogación.}

Marinetto, Purificación. "Juguetes y silbatos infantiles de época nazarí". Miscelánea de estudios árabes y hebraicos. Sección Árabe-Islam, Vol. 46. (1997): 183-205; Red Digital de Colecciones de Museos en España: http://ceres.mcu.es/pages/Main?idt=122087\&inventary $=007069 \&$ table $=F M U S \&$ muse

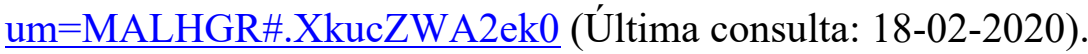




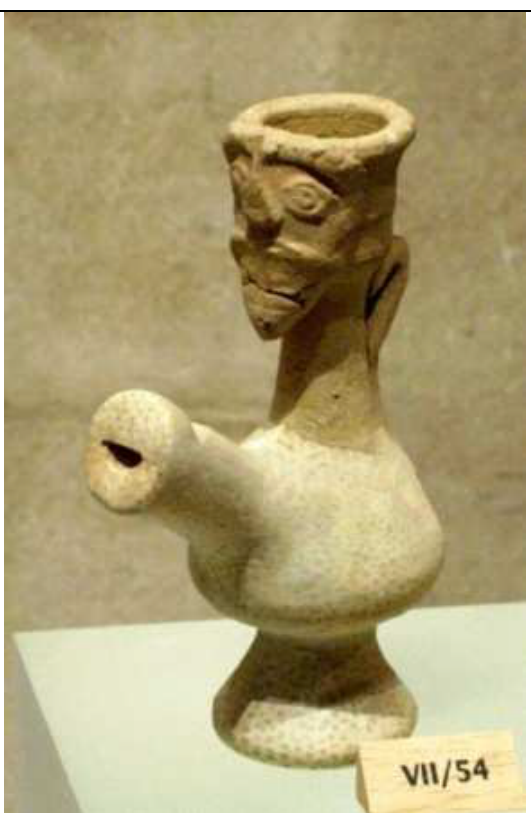

\section{Datos generales}

\begin{tabular}{|l|l|}
\hline Nombre & Silbato \\
\hline $\mathbf{N}^{\mathbf{0}}$ de inventario & 4753 \\
\hline Ubicación actual & Museo de la Alhambra (Granada) \\
\hline Procedencia & Alhambra \\
\hline Dimensiones & Alto: $10,8 \mathrm{~cm}$; Ancho: $4,1 \mathrm{~cm}$ \\
\hline Ciudad & Granada \\
\hline Cronología & ss. XIV-XV (Nazarí) \\
\hline Características morfológicas & $\begin{array}{l}\text { Silbato de agua con forma de jarrita y máscara } \\
\text { barbada. Se le ha hecho una reconstrucción de la } \\
\text { embocadura y pie plano de la pieza. Cuenta con } \\
\text { un asa. Los rasgos faciales de la máscara se han } \\
\text { realizado mediante incisiones. La nariz parece } \\
\text { hecha con apliques plásticos. }\end{array}$ \\
\hline Materiales & Arcilla \\
\hline
\end{tabular}

\section{Datos organológicos}

\section{Tipo de instrumento} Aerófono 


\begin{tabular}{|l|l|}
\hline $\begin{array}{l}\text { Clasificación por estructura } \\
\text { física }\end{array}$ & B.4. Silbatos globulares de agua \\
\hline Clasificación organológica & $\begin{array}{l}421.221 .41 \text { Flautas globulares con canal de } \\
\text { insuflación interno sin agujeros digitales }\end{array}$ \\
\hline Función & Lúdica \\
\hline Fabricación & Alfares \\
\hline Características musicales & $\begin{array}{l}\text { Aerófono reconstruido del que le ha recreado la } \\
\text { embocadura y el bisel sobre la misma. }\end{array}$ \\
\hline
\end{tabular}

\section{Datos arqueológicos}

\begin{tabular}{|l|l|}
\hline Yacimiento & - \\
\hline Unidad Estratigráfica & - \\
\hline
\end{tabular}

\section{Bibliografía}

\begin{tabular}{|l|l|}
\hline Documentación del Museo & Pieza con ficha de catalogación. \\
\hline Marinetto, Purificación. "Juguetes y silbatos infantiles de época nazarí. Miscelánea \\
de estudios árabes y hebraicos. Sección Arabe-Islam. Vol. 46. (1997): 183-205; \\
Marinetto Sánchez, Purificación. “Juego y esparcimiento”. En Vivir en Al-Andalus. \\
Exposición de cerámica (S. IX-XV). Almedirerránea, Instituto de Estudios \\
Almerienses, 1993, 223; Red Digital de Colecciones de Museos en España: \\
$\underline{\text { http://ceres.mcu.es/pages/Main?idt=122088\&inventary=004753\&table=FMUS\&muse }}$ \\
$\underline{\text { um=MALHGR\#.Xkuckdh_hwA (Última consulta: 18-02-2020). }}$
\end{tabular}




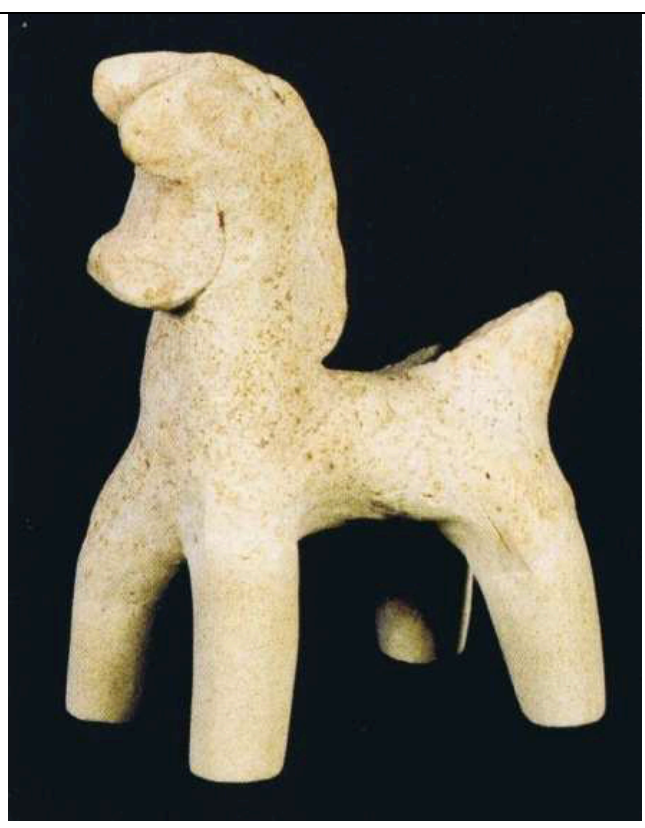

\section{Datos generales}

\begin{tabular}{|c|c|}
\hline Nombre & Silbato \\
\hline$N^{0}$ de inventario & 1185 \\
\hline Ubicación actual & Museo de la Alhambra (Granada) \\
\hline Procedencia & Alhambra \\
\hline Dimensiones & - \\
\hline Ciudad & Granada \\
\hline Cronología & ss. XIV-XV (Nazarí) \\
\hline $\begin{array}{l}\text { Características } \\
\text { morfológicas }\end{array}$ & $\begin{array}{l}\text { Figura de un caballo con crines. El hocico del animal } \\
\text { parece ser un aplique plástico unido al resto de la } \\
\text { estructura. Las orejas del animal se encuentran bien } \\
\text { pronuncias y la forma en la que se representan las crines } \\
\text { parecen voluminosas. }\end{array}$ \\
\hline Materiales & Arcilla \\
\hline
\end{tabular}

\section{Datos organológicos}

\begin{tabular}{|l|l|}
\hline Tipo de instrumento & Aerófono \\
\hline Clasificación por & B.2. Silbatos globulares zoomorfos \\
\hline
\end{tabular}




\begin{tabular}{|l|l|}
\hline estructura física & $\begin{array}{l}421.221 .41 \text { Flautas globulares con canal de insuflación } \\
\text { interno sin agujeros digitales }\end{array}$ \\
\hline $\begin{array}{l}\text { Organificación } \\
\text { Función }\end{array}$ & Lúdica \\
\hline Fabricación & Alfares \\
\hline musicales & $\begin{array}{l}\text { La embocadura de este silbato, al igual que en los demás } \\
\text { de este tipo, se encuentra en la parte posterior de la figura } \\
\text { pero no sobresale de forma excesiva quedando más } \\
\text { discreta que en otros caballitos. El bisel se intuye cercano } \\
\text { al inicio de la embocadura. }\end{array}$ \\
\hline
\end{tabular}

\section{Datos arqueológicos}

\begin{tabular}{|l|l|}
\hline Yacimiento & - \\
\hline $\begin{array}{l}\text { Responsable de la } \\
\text { excavación }\end{array}$ & - \\
\hline
\end{tabular}

\section{Bibliografía}

\begin{tabular}{|l|l|}
\hline Documentación del Museo & Pieza con ficha de catalogación. \\
\hline Rosselló Bordoy, Guillermo. "De nuevo los animales de juguete V otros aspectos de \\
coroplastia andalusí”. En Actas del IV Coloquio Hispano-Tunecino, Palma de \\
Mallorca, (1979): 205-212; Marinetto Sánchez, Purificación. "Juego y \\
esparcimiento". En Vivir en Al-Andalus. Exposición de cerámica (S. IX-XV). \\
Almedirerránea, Instituto de Estudios Almerienses, (1993): 213-276; Rosselló \\
Bordoy, Guillermo, Ana Navarro Ortega e Isabel Flores Escobosa. Del rito al juego: \\
juguetes y silbatos de cerámica desde el Islam hasta la actualidad. Junta de \\
Andalucía, 2006, 196.
\end{tabular}




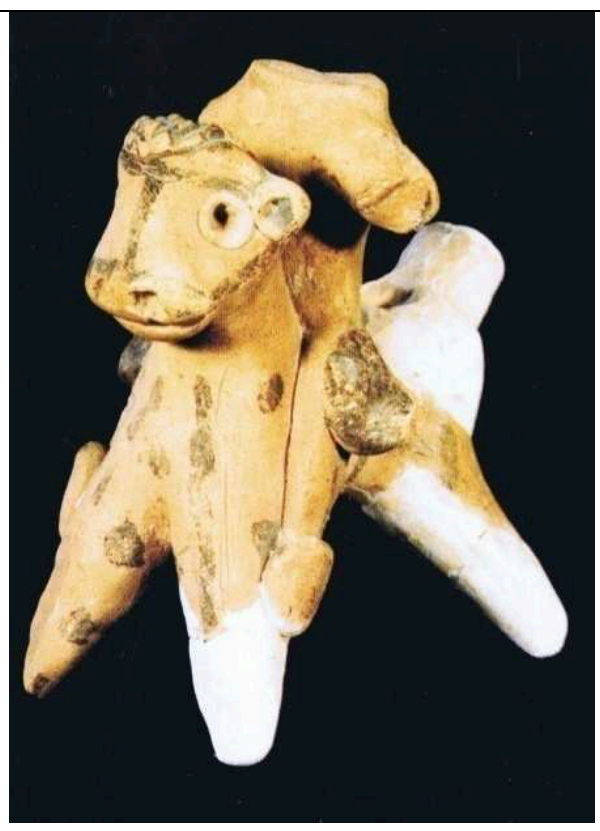

Datos generales

\begin{tabular}{|l|l|}
\hline Nombre & Silbato \\
\hline $\mathbf{N}^{\mathbf{0}}$ de inventario & 1412 \\
\hline Ubicación actual & Museo de la Alhambra (Granada) \\
\hline Procedencia & Alhambra \\
\hline Dimensiones & Altura: $7 \mathrm{~cm}$; Longitud: $7,7 \mathrm{~cm}$. \\
\hline Ciudad & Granada \\
\hline Cronología & ss. XIV-XV (Nazarí) \\
\hline $\begin{array}{l}\text { Características } \\
\text { morfológicas }\end{array}$ & $\begin{array}{l}\text { Silbato reconstruido de un caballo con jinete. Del caballo } \\
\text { se ha reconstruido la parte posterior donde se encuentra el } \\
\text { silbato. Del jinete solo se conserva el cuerpo, brazos y } \\
\text { piernas, no llega hasta nuestros días la cabeza. }\end{array}$ \\
\hline Materiales & Arcilla \\
\hline
\end{tabular}

\section{Datos organológicos}

\begin{tabular}{|l|l|}
\hline Tipo de instrumento & Aerófono \\
\hline $\begin{array}{l}\text { Clasificación por } \\
\text { estructura física }\end{array}$ & B.3. Silbatos globulares mixtos \\
\hline
\end{tabular}




\begin{tabular}{|l|l|}
\hline $\begin{array}{l}\text { Clasificación } \\
\text { organológica }\end{array}$ & $\begin{array}{l}421.221 .41 \text { Flautas globulares con canal de insuflación } \\
\text { interno sin agujeros digitales. }\end{array}$ \\
\hline Función & Lúdica \\
\hline Fabricación & Alfares \\
\hline $\begin{array}{l}\text { Características } \\
\text { musicales }\end{array}$ & $\begin{array}{l}\text { La embocadura, situada en la cola del animal, cuenta con } \\
\text { el bisel sobre la parte superior de ésta. }\end{array}$ \\
\hline
\end{tabular}

Datos arqueológicos

\begin{tabular}{|l|l|}
\hline Yacimiento & - \\
\hline $\begin{array}{l}\text { Responsable de la } \\
\text { excavación }\end{array}$ & - \\
\hline
\end{tabular}

\section{Bibliografía}

\begin{tabular}{|l|l|}
\hline Documentación del Museo & Pieza con ficha de catalogación. \\
\hline
\end{tabular}

Rosselló Bordoy, Guillermo. "De nuevo los animales de juguete V otros aspectos de coroplastia andalusí". En Actas del IV Coloquio Hispano-Tunecino, Palma de Mallorca, (1979): 205-212; Marinetto Sánchez, Purificación. “Juego y esparcimiento". En Vivir en Al-Andalus. Exposición de cerámica (S. IX-XV). Almedirerránea, Instituto de Estudios Almerienses, (1993): 213-276; Rosselló Bordoy, Guillermo, Ana Navarro Ortega e Isabel Flores Escobosa. Del rito al juego: juguetes y silbatos de cerámica desde el Islam hasta la actualidad. Junta de Andalucía, 2006, 196. 


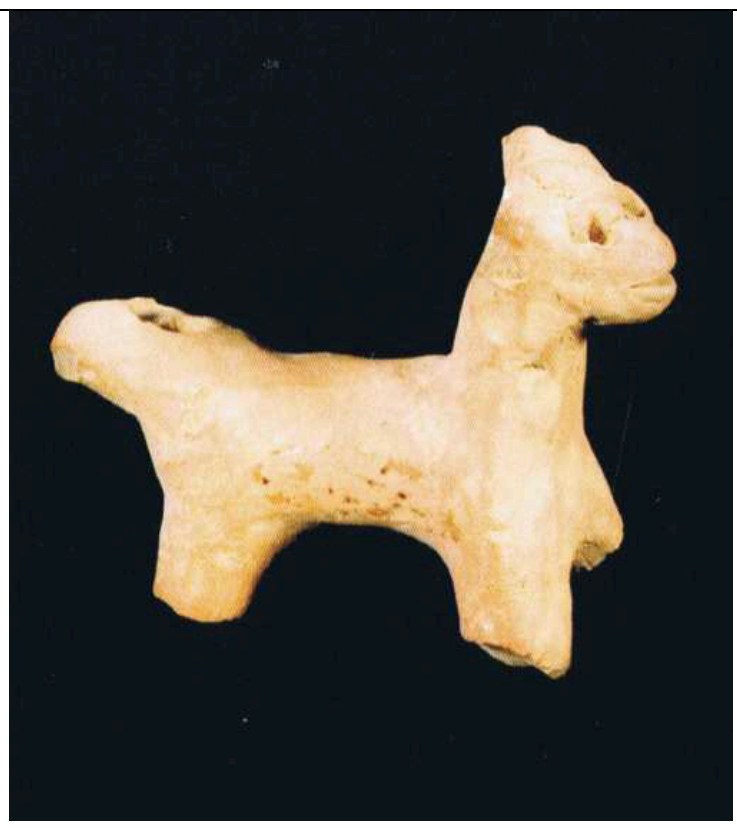

\section{Datos generales}

\begin{tabular}{|l|l|}
\hline Nombre & Silbato \\
\hline $\mathbf{N}^{\mathbf{0}}$ de inventario & 4845 \\
\hline Ubicación actual & Museo de la Alhambra (Granada) \\
\hline Procedencia & Alhambra \\
\hline Dimensiones & Altura: $6 \mathrm{~cm}$; Longitud: $7,8 \mathrm{~cm}$. \\
\hline Ciudad & Granada \\
\hline Cronología & ss. XIV-XV (Nazarí) \\
\hline $\begin{array}{l}\text { Características } \\
\text { morfológicas }\end{array}$ & $\begin{array}{l}\text { Caballo de una sola pieza con los ojos hechos mediante } \\
\text { incisión. Ha perdido parte de las patas y las orejas, que } \\
\text { solo se dejan intuir. }\end{array}$ \\
\hline Materiales & Arcilla \\
\hline
\end{tabular}

\section{Datos organológicos}

\begin{tabular}{|l|l|}
\hline Tipo de instrumento & Aerófono \\
\hline $\begin{array}{l}\text { Clasificación por } \\
\text { estructura física }\end{array}$ & B.2. Silbatos globulares zoomorfos \\
\hline Clasificación & 421.221 .41 Flautas globulares con canal de insuflación \\
\hline
\end{tabular}




\begin{tabular}{|l|l|}
\hline organológica & interno sin agujeros digitales \\
\hline Función & Lúdica \\
\hline Fabricación & Alfares \\
\hline $\begin{array}{l}\text { Características } \\
\text { musicales }\end{array}$ & $\begin{array}{l}\text { Aerófono con embocadura en la parte posterior del } \\
\text { animal. Ésta cuenta con un agujero de salida de aire sobre } \\
\text { lo que sería la cola del animal. }\end{array}$ \\
\hline
\end{tabular}

\section{Datos arqueológicos}

\begin{tabular}{|l|l|}
\hline Yacimiento & - \\
\hline $\begin{array}{l}\text { Responsable de la } \\
\text { excavación }\end{array}$ & - \\
\hline
\end{tabular}

\section{Bibliografía}

\begin{tabular}{|l|l|}
\hline Documentación del Museo & Pieza con ficha de catalogación.
\end{tabular}

Rosselló Bordoy, Guillermo. "De nuevo los animales de juguete V otros aspectos de coroplastia andalusí". En Actas del IV Coloquio Hispano-Tunecino, Palma de Mallorca, (1979): 205-212; Marinetto Sánchez, Purificación. "Juego y esparcimiento". En Vivir en Al-Andalus. Exposición de cerámica (S. IX-XV). Almedirerránea, Instituto de Estudios Almerienses, (1993): 213-276; Rosselló Bordoy, Guillermo, Ana Navarro Ortega e Isabel Flores Escobosa. Del rito al juego: juguetes y silbatos de cerámica desde el Islam hasta la actualidad. Junta de Andalucía, 2006, 196. 


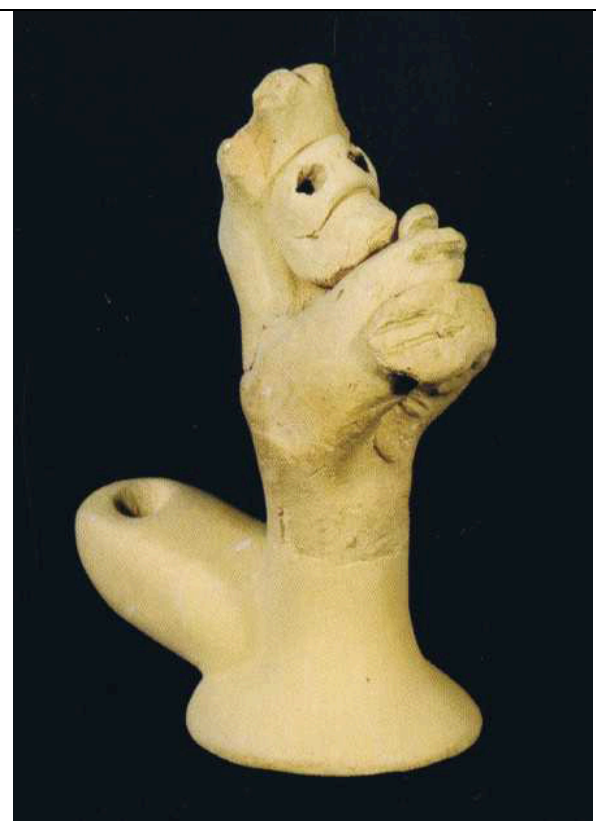

Datos generales

\begin{tabular}{|l|l|}
\hline Nombre & Silbato \\
\hline $\mathbf{N}^{\mathbf{0}}$ de inventario & 4763 \\
\hline Ubicación actual & Museo de la Alhambra (Granada) \\
\hline Procedencia & Alhambra \\
\hline Dimensiones & Altura: $9,8 \mathrm{~cm}$; Anchura: $3 \mathrm{~cm}$. \\
\hline Ciudad & Granada \\
\hline Cronología & ss. XIV-XV (Nazarí) \\
\hline $\begin{array}{l}\text { Características } \\
\text { morfológicas }\end{array}$ & $\begin{array}{l}\text { Silbato en forma de oso con los brazos cruzados por } \\
\text { delante. Cuenta con una base y aplicaciones plásticas en } \\
\text { los ojos, incisos, y pelaje en forma de diadema. }\end{array}$ \\
\hline Materiales & Arcilla \\
\hline
\end{tabular}

Datos organológicos

\begin{tabular}{|l|l|}
\hline Tipo de instrumento & Aerófono \\
\hline $\begin{array}{l}\text { Clasificación por } \\
\text { estructura física }\end{array}$ & B.2. Silbatos globulares zoomorfos \\
\hline Clasificación & 421.221 .41 Flautas globulares con canal de insuflación \\
\hline
\end{tabular}




\begin{tabular}{|l|l|}
\hline organológica & interno sin agujeros digitales \\
\hline Función & Lúdica \\
\hline Fabricación & Alfares \\
\hline $\begin{array}{l}\text { Características } \\
\text { musicales }\end{array}$ & $\begin{array}{l}\text { El silbato ha sido reconstruido y se encuentra tras el } \\
\text { animal. El bisel del instrumento se encuentra cercano a la } \\
\text { embocadura sobre ésta. }\end{array}$ \\
\hline
\end{tabular}

Datos arqueológicos

\begin{tabular}{|l|l|}
\hline Yacimiento & - \\
\hline $\begin{array}{l}\text { Responsable de la } \\
\text { excavación }\end{array}$ & - \\
\hline
\end{tabular}

\section{Bibliografía}

\begin{tabular}{|l|l|}
\hline Documentación del Museo & Pieza con ficha de catalogación. \\
\hline
\end{tabular}

Rosselló Bordoy, Guillermo. "De nuevo los animales de juguete V otros aspectos de coroplastia andalusí". En Actas del IV Coloquio Hispano-Tunecino, Palma de Mallorca, (1979: 205-212; Marinetto Sánchez, Purificación. “Juego y esparcimiento". En Vivir en Al-Andalus. Exposición de cerámica $(S . I X-X V)$. Almedirerránea, Instituto de Estudios Almerienses, (1993): 213-276; Rosselló Bordoy, Guillermo, Ana Navarro Ortega e Isabel Flores Escobosa. Del rito al juego: juguetes y silbatos de cerámica desde el islam hasta la actualidad. Junta de Andalucía, 2006, 197. 


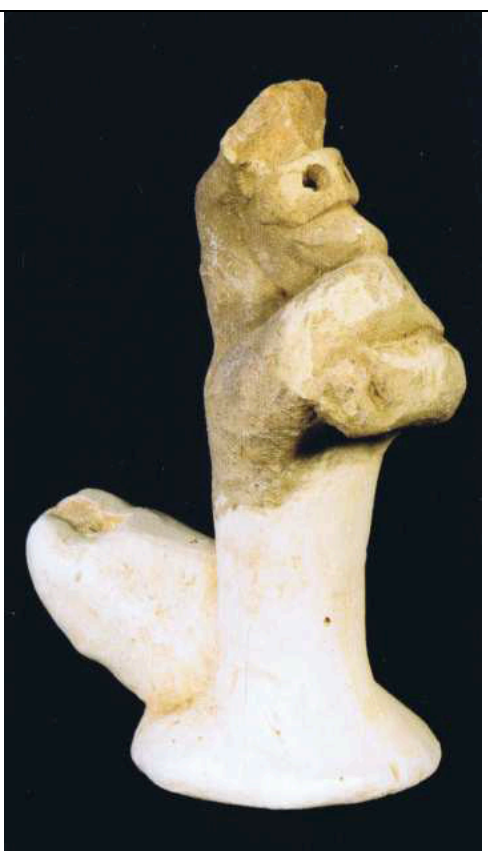

\section{Datos generales}

\begin{tabular}{|l|l|}
\hline Nombre & Silbato \\
\hline $\mathbf{N}^{\mathbf{0}}$ de inventario & 7072 \\
\hline Ubicación actual & Museo de la Alhambra (Granada) \\
\hline Procedencia & Alhambra \\
\hline Dimensiones & Altura: $9,8 \mathrm{~cm}$; Anchura: $3 \mathrm{~cm}$. \\
\hline Ciudad & Granada \\
\hline Cronología & ss. XIV-XV (Nazarí) \\
\hline Características & $\begin{array}{l}\text { Silbato en forma de oso con los brazos cruzados por } \\
\text { molante, parece abrazar algo. Cuenta con una base y } \\
\text { aplicaciones plásticas en los ojos, incisos, y pelaje en } \\
\text { forma de diadema. }\end{array}$ \\
\hline Materiales & Arcilla \\
\hline
\end{tabular}

\section{Datos organológicos}

\begin{tabular}{|l|l|}
\hline Tipo de instrumento & Aerófono \\
\hline $\begin{array}{l}\text { Clasificación por } \\
\text { estructura física }\end{array}$ & B.2. Silbatos globulares zoomorfos \\
\hline
\end{tabular}




\begin{tabular}{|l|l|}
\hline $\begin{array}{l}\text { Clasificación } \\
\text { organológica }\end{array}$ & $\begin{array}{l}421.221 .41 \text { Flautas globulares con canal de insuflación } \\
\text { interno sin agujeros digitales }\end{array}$ \\
\hline Función & Lúdica \\
\hline Fabricación & Alfares \\
\hline $\begin{array}{l}\text { Características } \\
\text { musicales }\end{array}$ & $\begin{array}{l}\text { El silbato ha sido reconstruido y se encuentra tras el } \\
\text { animal. El bisel del instrumento se encuentra cercano a la } \\
\text { embocadura sobre ésta. }\end{array}$ \\
\hline
\end{tabular}

\section{Datos arqueológicos}

\begin{tabular}{|l|l|}
\hline Yacimiento & - \\
\hline $\begin{array}{l}\text { Responsable de la } \\
\text { excavación }\end{array}$ & - \\
\hline
\end{tabular}

\section{Bibliografía}

\begin{tabular}{|l|l|}
\hline Documentación del Museo & Pieza con ficha de catalogación. \\
\hline Rosselló Bordoy, Guillermo. "De nuevo los animales de juguete V otros aspectos de \\
coroplastia andalusí". En Actas del IV Coloquio Hispano-Tunecino, Palma de \\
Mallorca, (1979): 205-212; Marinetto Sánchez, Purificación. "Juego y \\
esparcimiento". En Vivir en Al-Andalus. Exposición de cerámica (S. IX-XV). \\
Almedirerránea, Instituto de Estudios Almerienses. (1993): 213-276; Rosselló \\
Bordoy, Guillermo, Ana Navarro Ortega e Isabel Flores Escobosa. Del rito al juego: \\
juguetes y silbatos de cerámica desde el islam hasta la actualidad. Junta de \\
Andalucía, 2006, 197.
\end{tabular}




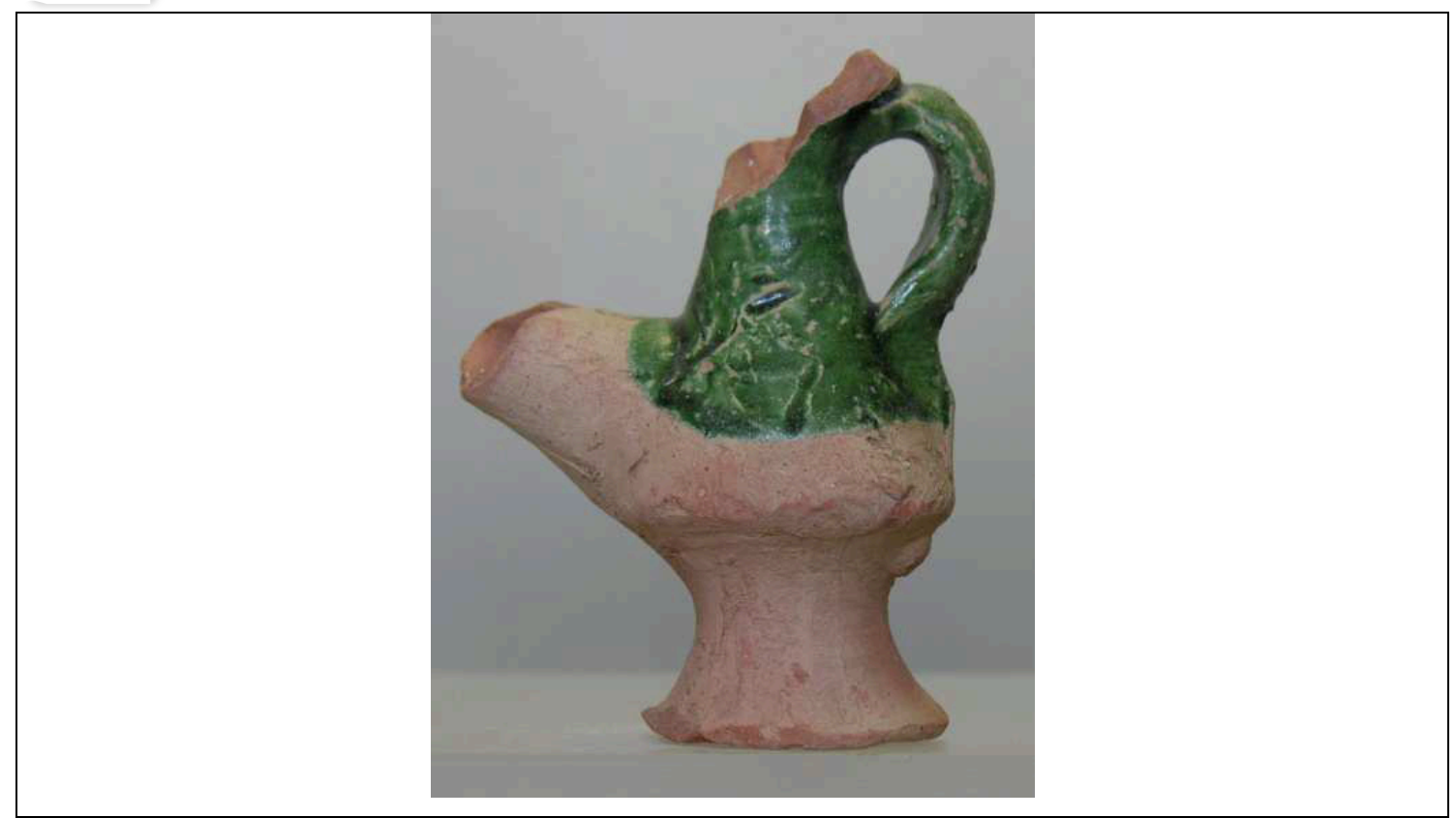

Datos generales

\begin{tabular}{|l|l|}
\hline Nombre & Silbato \\
\hline $\mathbf{N}^{\mathbf{0}}$ de inventario & 4770 \\
\hline Ubicación actual & Museo de la Alhambra (Granada) \\
\hline Procedencia & Alhambra \\
\hline Dimensiones & Alto: $7,9 \mathrm{~cm}$; Ancho: $6,2 \mathrm{~cm}$. \\
\hline Ciudad & Granada \\
\hline Cronología & ss. VIII-XV (Emiral-Nazaí) \\
\hline $\begin{array}{l}\text { Características } \\
\text { morfológicas }\end{array}$ & $\begin{array}{l}\text { Aerófono con forma de jarrita con pie cónico y cuerpo } \\
\text { piriforme. Solo una parte del figura se mantiene vidriada } \\
\text { en verde. Cuenta con un asa. No conserva la zona donde } \\
\text { pudo tener la característica máscara de adorno. }\end{array}$ \\
\hline Materiales & Arcilla \\
\hline
\end{tabular}

\section{Datos organológicos}

\begin{tabular}{|l|l|}
\hline Tipo de instrumento & Aerófono \\
\hline $\begin{array}{l}\text { Clasificación por } \\
\text { estructura física }\end{array}$ & B.4. Silbatos globulares de agua \\
\hline
\end{tabular}




\begin{tabular}{|l|l|}
\hline $\begin{array}{l}\text { Clasificación } \\
\text { organológica }\end{array}$ & $\begin{array}{l}421.221 .41 \text { Flautas globulares con canal de insuflación } \\
\text { interno sin agujeros digitales }\end{array}$ \\
\hline Función & Lúdica \\
\hline Fabricación & Alfares \\
\hline $\begin{array}{l}\text { Características } \\
\text { musicales }\end{array}$ & $\begin{array}{l}\text { Silbato de agua con conducto de aire fragmentado.No se } \\
\text { conserva el inicio de la embocadura ni bisel. }\end{array}$ \\
\hline
\end{tabular}

\section{Datos arqueológicos}

\begin{tabular}{|l|l|}
\hline Yacimiento & - \\
\hline $\begin{array}{l}\text { Responsable de la } \\
\text { excavación }\end{array}$ & - \\
\hline
\end{tabular}

\section{Bibliografía}

\begin{tabular}{|l|l|}
\hline Documentación del Museo & Pieza con ficha de catalogación.
\end{tabular}

Marinetto Sánchez, Purificación. "Juego y esparcimiento". En Vivir en Al-Andalus.

Exposición de 348 eramic $(S . \quad I X-X V)$. Almedirerránea, Instituto de Estudios Almerienses, (1993): 227. 
Datos generales

\begin{tabular}{|l|l|}
\hline Nombre & Silbato \\
\hline $\mathbf{N}^{\mathbf{0}}$ de inventario & DJ00740 \\
\hline Ubicación actual & Museo Arqueológico de Granada \\
\hline Procedencia & Necrópolis de las Cuevas de la Arena, Baza (Granada) \\
\hline Dimensiones & Altura: $2,4 \mathrm{~cm}$; Anchura: $1,3 \mathrm{~cm}$; Altura: $3,3 \mathrm{~cm}$ \\
\hline Ciudad & Granada \\
\hline Cronología & ss. XII-XV (Almohade-Nazarí) \\
\hline Características & Silbato de pequeño tamaño con concha y cuernos. Está \\
morfológicas & hecha con pasta rosa-anaranjada. \\
\hline Materiales & Arcilla \\
\hline
\end{tabular}

\section{Datos organológicos}

\begin{tabular}{|l|l|}
\hline Tipo de instrumento & Aerófono \\
\hline $\begin{array}{l}\text { Clasificación por } \\
\text { estructura física }\end{array}$ & B.2. Silbatos globulares zoomorfos \\
\hline $\begin{array}{l}\text { Clasificación } \\
\text { organológica }\end{array}$ & $\begin{array}{l}421.221 .41 \text { Flautas globulares con canal de insuflación } \\
\text { interno sin agujeros digitales }\end{array}$ \\
\hline
\end{tabular}




\begin{tabular}{|l|l|}
\hline Función & Lúdica \\
\hline Fabricación & Alfares \\
\hline $\begin{array}{l}\text { Características } \\
\text { musicales }\end{array}$ & $\begin{array}{l}\text { Pequeño silbato cuya embocadura es la cabeza del animal. } \\
\text { El bisel se encuentra sobre la cabeza del mismo. }\end{array}$ \\
\hline
\end{tabular}

\section{Datos arqueológicos}

\begin{tabular}{|l|l|}
\hline Yacimiento & Baños árabes. Judería de Baza \\
\hline $\begin{array}{l}\text { Responsable de la } \\
\text { excavación }\end{array}$ & Maryelle Bertrand y José Ramón Sánchez Viciana \\
\hline
\end{tabular}

\section{Bibliografía}

\begin{tabular}{|l|l|}
\hline Documentación del Museo & Pieza con ficha de catalogación. \\
\hline Rosselló Bordoy, Guillermo, Ana Navarro Ortega e Isabel Flores Escobosa. Del rito \\
al juego: juguetes y silbatos de cerámica desde el Islam hasta la actualidad. Junta de \\
Andalucía, 2006, 179; Bertrand, Maryelle y Sánchez Viciana, José Ramón. \\
“Intervenciones arqueológicas en apoyo a la restauración de los baños árabes de la \\
judería de Baza, Campaña 2003”. Anuario arqueológico de Andalucía, (2003): 178.
\end{tabular}




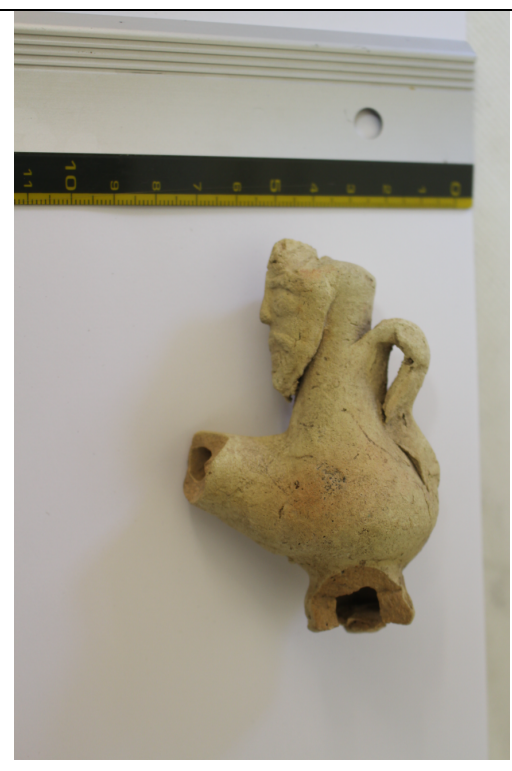

\section{Datos generales}

\begin{tabular}{|l|l|}
\hline Nombre & Silbato \\
\hline $\mathbf{N}^{\mathbf{0}}$ de inventario & 2209 \\
\hline Ubicación actual & Museo Arqueológico de Granada \\
\hline Procedencia & $\begin{array}{l}\text { Se duda de su procedencia. Comentan que pudo ser } \\
\text { comprado. }\end{array}$ \\
\hline Dimensiones & Alto: 0,9 cm \\
\hline Ciudad & Granada \\
\hline Cronología & s. XV (Nazarí) \\
\hline Características \\
morfológicas & $\begin{array}{l}\text { Silbato de agua con forma de jarrita con un asa. En la } \\
\text { parte alta de la pieza cuenta con una cara masculina con } \\
\text { barba. No se conserva parte de su base y de la boquilla. }\end{array}$ \\
\hline Materiales & Arcilla \\
\hline
\end{tabular}

\section{Datos organológicos}

\begin{tabular}{|l|l|}
\hline Tipo de instrumento & Aerófono \\
\hline $\begin{array}{l}\text { Clasificación por } \\
\text { estructura física }\end{array}$ & B.4. Silbatos globulares de agua \\
\hline Clasificación & 421.221 .41 Flautas globulares con canal de insuflación \\
\hline
\end{tabular}




\begin{tabular}{|l|l|}
\hline organológica & interno sin agujeros digitales \\
\hline Función & Lúdica \\
\hline Fabricación & Alfares \\
\hline $\begin{array}{l}\text { Características } \\
\text { musicales }\end{array}$ & $\begin{array}{l}\text { Silbato de agua con parte de la embocadura fracturada lo } \\
\text { que impide observar el bisel. }\end{array}$ \\
\hline
\end{tabular}

\section{Datos arqueológicos}

\begin{tabular}{|l|l|}
\hline Yacimiento & - \\
\hline $\begin{array}{l}\text { Responsable de la } \\
\text { excavación }\end{array}$ & - \\
\hline
\end{tabular}

\section{Bibliografía}

\begin{tabular}{|l|l|}
\hline Documentación del Museo & Pieza inventariada. \\
\hline Inédito & \\
\hline
\end{tabular}




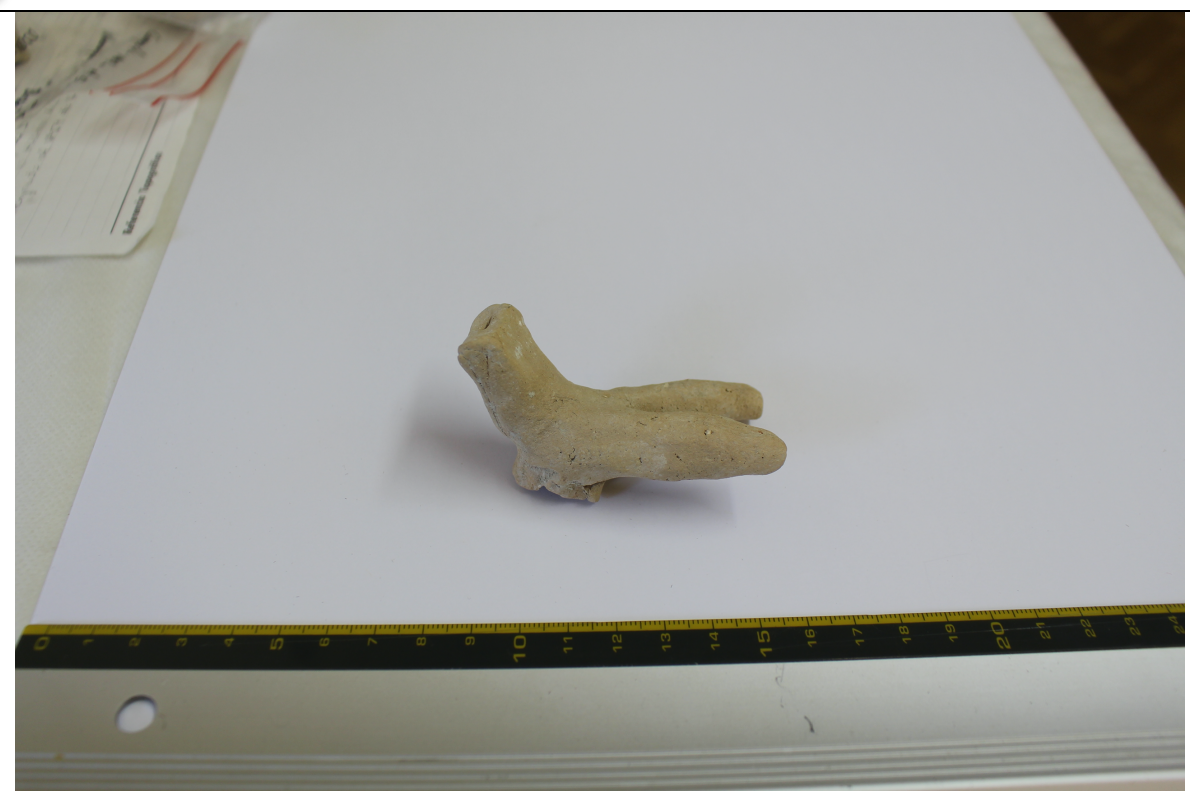

Datos generales

\begin{tabular}{|l|l|}
\hline Nombre & Silbato \\
\hline $\mathbf{N}^{\mathbf{0}}$ de inventario & - \\
\hline Ubicación actual & Museo Arqueológico de Granada \\
\hline Procedencia & Desconocida \\
\hline Dimensiones & Alto: $8 \mathrm{~cm}$; Ancho: $4 \mathrm{~cm}$ \\
\hline Ciudad & Granada \\
\hline Cronología & - \\
\hline Características & $\begin{array}{l}\text { Fragmento de caballo, solo quedan las dos patas traseras y } \\
\text { la embocadura del silbato. }\end{array}$ \\
\hline Materiales & Arcilla \\
\hline
\end{tabular}

Datos organológicos

\begin{tabular}{|l|l|}
\hline Tipo de instrumento & Aerófono \\
\hline $\begin{array}{l}\text { Clasificación por } \\
\text { estructura física }\end{array}$ & B.2. Silbatos globulares zoomorfos \\
\hline $\begin{array}{l}\text { Clasificación } \\
\text { organológica }\end{array}$ & $\begin{array}{l}421.221 .41 \text { Flautas globulares con canal de insuflación } \\
\text { interno sin agujeros digitales }\end{array}$ \\
\hline Función & Lúdica \\
\hline
\end{tabular}




\begin{tabular}{|l|l|}
\hline Fabricación & Alfares \\
\hline $\begin{array}{l}\text { Características } \\
\text { musicales }\end{array}$ & Silbato con bisel en la parte superior. \\
\hline
\end{tabular}

\section{Datos arqueológicos}

\begin{tabular}{|l|l|}
\hline Yacimiento & - \\
\hline $\begin{array}{l}\text { Responsable de la } \\
\text { excavación }\end{array}$ & - \\
\hline
\end{tabular}

\section{Bibliografía}

\begin{tabular}{|l|l|}
\hline Documentación del Museo & Pieza no inventariada. \\
\hline Inédito & \\
\hline
\end{tabular}




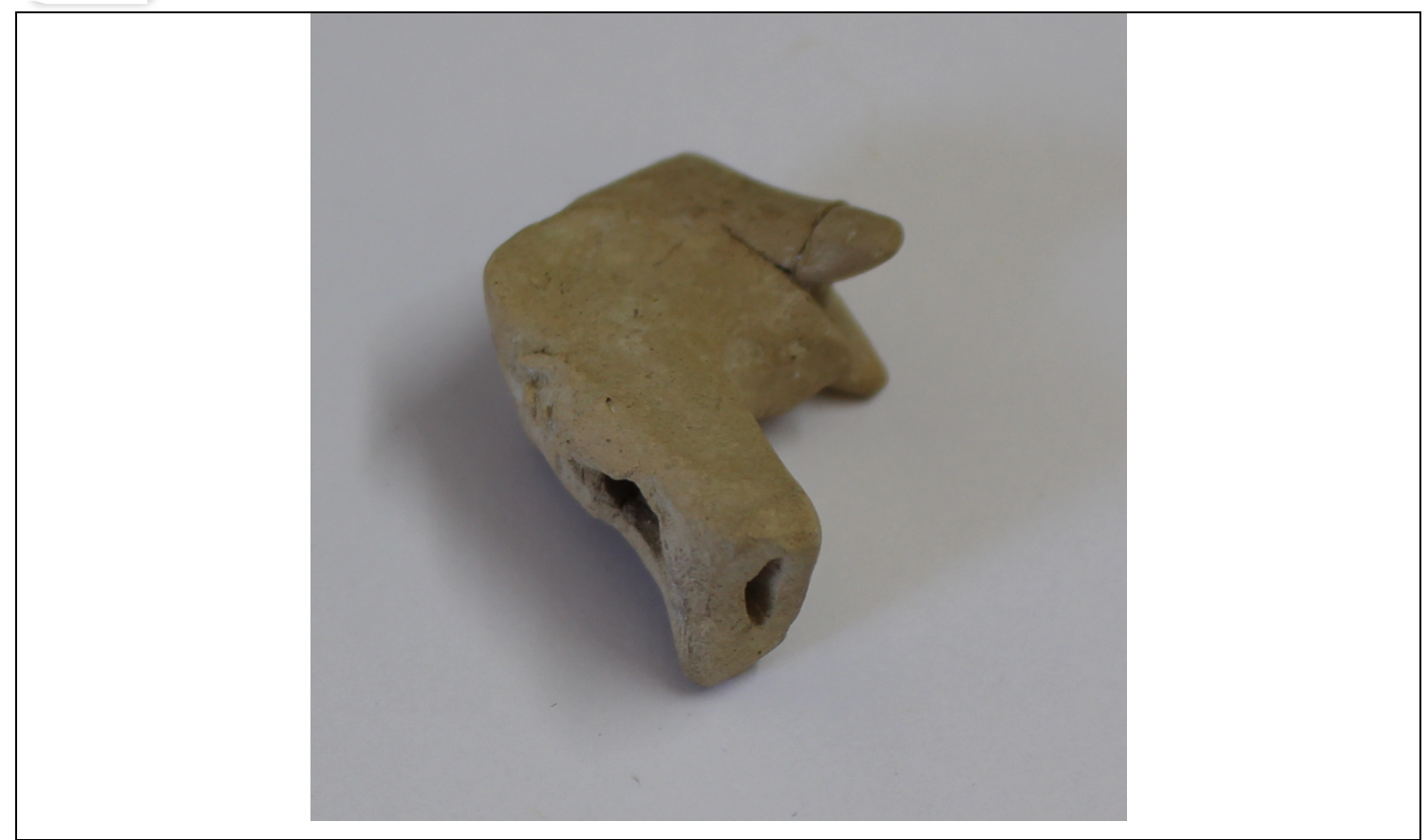

\section{Datos generales}

\begin{tabular}{|l|l|}
\hline Nombre & Silbato \\
\hline $\mathbf{N}^{\mathbf{0}}$ de inventario & DJ740 \\
\hline Ubicación actual & Museo Arqueológico de Granada \\
\hline Procedencia & Necrópolis de las Cuevas de la Arena, Baza \\
\hline Dimensiones & Ancho: $3,3 \mathrm{~cm} ;$ Alto: $2,4 \mathrm{~cm}$ \\
\hline Ciudad & Granada \\
\hline Cronología & Ss. XII-XV (Almohade-Nazarí) \\
\hline Características & Silbato sencillo de pequeño tamaño que parece representar \\
morfológicas & un animal sentado. \\
\hline Materiales & Arcilla \\
\hline
\end{tabular}

\section{Datos organológicos}

\begin{tabular}{|l|l|}
\hline Tipo de instrumento & Aerófono \\
\hline $\begin{array}{l}\text { Clasificación por } \\
\text { estructura física }\end{array}$ & B.2. Silbatos globulares zoomorfos \\
\hline $\begin{array}{l}\text { Clasificación } \\
\text { organológica }\end{array}$ & $\begin{array}{l}421.221 .41 \text { Flautas globulares con canal de insuflación } \\
\text { interno sin agujeros digitales }\end{array}$ \\
\hline
\end{tabular}




\begin{tabular}{|l|l|}
\hline Función & Lúdica \\
\hline Fabricación & Alfares \\
\hline $\begin{array}{l}\text { Características } \\
\text { musicales }\end{array}$ & $\begin{array}{l}\text { Silbato sencillo con forma acampanada. En bisel se } \\
\text { encuentra en la parte superior de la zona de soplo. }\end{array}$ \\
\hline
\end{tabular}

\section{Datos arqueológicos}

\begin{tabular}{|l|l|}
\hline Yacimiento & Baños árabes. Judería de Baza \\
\hline $\begin{array}{l}\text { Responsable de la } \\
\text { excavación }\end{array}$ & Maryelle Bertrand y José Ramón Sánchez Viciana \\
\hline
\end{tabular}

\section{Bibliografía}

\begin{tabular}{|l|l}
\hline Documentación del Museo & Pieza inventariada.
\end{tabular}

Inédito 


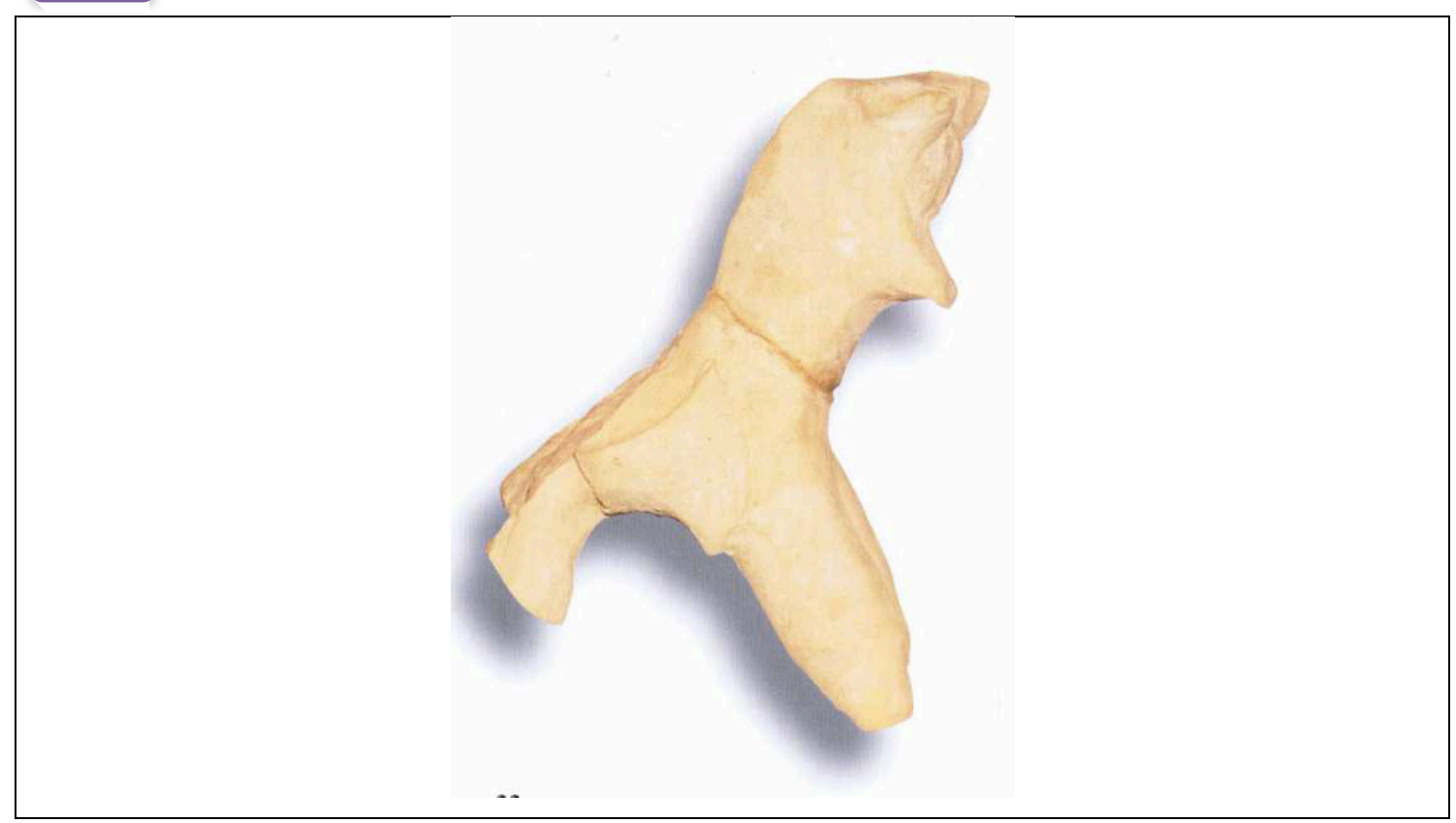

\section{Datos generales}

\begin{tabular}{|l|l|}
\hline Nombre & Silbato \\
\hline $\mathbf{N}^{\mathbf{0}}$ de inventario & DJ00742 \\
\hline Ubicación actual & Museo Arqueológico de Granada \\
\hline Procedencia & Necrópolis de las Cuevas de la Arena, Baza (Granada) \\
\hline Dimensiones & Altura: $1,8 \mathrm{~cm}$; Diámetro máximo: 2,8 cm \\
\hline Ciudad & Granada \\
\hline Cronología & ss. XII-XV (Almohad-Nazarí) \\
\hline $\begin{array}{l}\text { Características } \\
\text { morfológicas }\end{array}$ & $\begin{array}{l}\text { Parte de un caballito con jinete del cual conserva solo los } \\
\text { pies. }\end{array}$ \\
\hline Materiales & Arcilla \\
\hline
\end{tabular}

\section{Datos organológicos}

\begin{tabular}{|l|l|}
\hline Tipo de instrumento & Aerófono \\
\hline $\begin{array}{l}\text { Clasificación por } \\
\text { estructura física }\end{array}$ & B.3. Silbatos globulares mixtos \\
\hline $\begin{array}{l}\text { Clasificación } \\
\text { organológica }\end{array}$ & $\begin{array}{l}421.221 .41 \text { Flautas globulares con canal de insuflación } \\
\text { interno sin agujeros digitales }\end{array}$ \\
\hline
\end{tabular}




\begin{tabular}{|l|l|}
\hline Función & Lúdica \\
\hline Fabricación & Alfares \\
\hline $\begin{array}{l}\text { Características } \\
\text { musicales }\end{array}$ & $\begin{array}{l}\text { La embocadura del silbato no se conserva, se piensa que } \\
\text { llevaba endosado un silbato por el hueco en su interior. }\end{array}$ \\
\hline
\end{tabular}

\section{Datos arqueológicos}

\begin{tabular}{|l|l|}
\hline Yacimiento & Baños árabes. Judería de Baza \\
\hline $\begin{array}{l}\text { Responsable de la } \\
\text { excavación }\end{array}$ & Maryelle Bertrand y José Ramón Sánchez Viciana \\
\hline
\end{tabular}

\section{Bibliografía}

\begin{tabular}{|l|l|}
\hline Documentación del Museo & Pieza con ficha de catalogación. \\
\hline Salvatierra Cuenca, Vicente. "Necrópolis medievales I: Baza". Museo Arqueológico \\
de Granada, 1984; Rosselló Bordoy, Guillermo. "Instrumentos musicales en barro \\
cocido: una pervivencia medieval". Música oral del Sur: revista internacional 2, \\
(1996): 28-51; Bertrand, Maryelle y Sánchez Viciana, José Ramón. "Intervenciones \\
arqueológicas en apoyo a la restauración de los baños árabes de la judería de Baza, \\
Campaña 2003". Anuario arqueológico de Andalucía, (2003): 178; Rosselló Bordoy, \\
Guillermo, Ana Navarro Ortega e Isabel Flores Escobosa. Del rito al juego: juguetes \\
y silbatos de cerámica desde el Islam hasta la actualidad. Junta de Andalucía, 2006, \\
180.
\end{tabular}


Datos generales

\begin{tabular}{|l|l|}
\hline Nombre & Silbato \\
\hline $\mathbf{N}^{\mathbf{0}}$ de inventario & DJ00739 \\
\hline Ubicación actual & Museo Arqueológico de Granada \\
\hline Procedencia & Necrópolis de las Cuevas de la Arena, Baza (Granada) \\
\hline Dimensiones & Altura: $5,3 \mathrm{~cm}$; Anchura: $3,4 \mathrm{~cm}$ \\
\hline Ciudad & Granada \\
\hline Cronología & ss. XII-XV (Almohade-Nazaí) \\
\hline $\begin{array}{l}\text { Características } \\
\text { morfológicas }\end{array}$ & $\begin{array}{l}\text { Este silbato globular con forma de paloma que se apoya } \\
\text { sobre sus patas es parte de un ajuar funerario por el lugar } \\
\text { en el que se encontró. El silbato comienza en la parte } \\
\text { trasera formando la cola. }\end{array}$ \\
\hline Materiales & Arcilla \\
\hline
\end{tabular}

\section{Datos organológicos}

\begin{tabular}{|l|l|}
\hline Tipo de instrumento & Aerófono \\
\hline $\begin{array}{l}\text { Clasificación por } \\
\text { estructura física }\end{array}$ & B.2. Silbatos globulares zoomorfos \\
\hline
\end{tabular}




\begin{tabular}{|l|l|}
\hline $\begin{array}{l}\text { Clasificación } \\
\text { organológica }\end{array}$ & $\begin{array}{l}421.221 .41 \text { Flautas globulares con canal de insuflación } \\
\text { interno sin agujeros digitales }\end{array}$ \\
\hline Función & Lúdica \\
\hline Fabricación & Alfares \\
\hline $\begin{array}{l}\text { Características } \\
\text { musicales }\end{array}$ & $\begin{array}{l}\text { Silbato en embocadura en la cola del animal estando el } \\
\text { bisel en la parte de debajo de la cola. }\end{array}$ \\
\hline
\end{tabular}

Datos arqueológicos

\begin{tabular}{|l|l|}
\hline Yacimiento & Baños árabes. Judería de Baza \\
\hline $\begin{array}{l}\text { Responsable de la } \\
\text { excavación }\end{array}$ & Maryelle Bertrand y José Ramón Sánchez Viciana \\
\hline
\end{tabular}

\section{Bibliografía}

\begin{tabular}{|l|l|}
\hline Documentación del Museo & Pieza con ficha de catalogación. \\
\hline
\end{tabular}

Salvatierra Cuenca, Vicente. "Necrópolis medievales I: Baza". Museo Arqueológico de Granada, 1984; Rosselló Bordoy, Guillermo. "Instrumentos musicales en barro cocido: una pervivencia medieval". Música oral del Sur: revista internacional 2, (1996): 28-51; Bertrand, Maryelle y Sánchez Viciana, José Ramón. “Intervenciones arqueológicas en apoyo a la restauración de los baños árabes de la judería de Baza, Campaña 2003". Anuario arqueológico de Andalucía (2003): 178; Rosselló Bordoy, Guillermo, Ana Navarro Ortega e Isabel Flores Escobosa. Del rito al juego: juguetes y silbatos de cerámica desde el Islam hasta la actualidad. Junta de Andalucía, 2006, 179. 

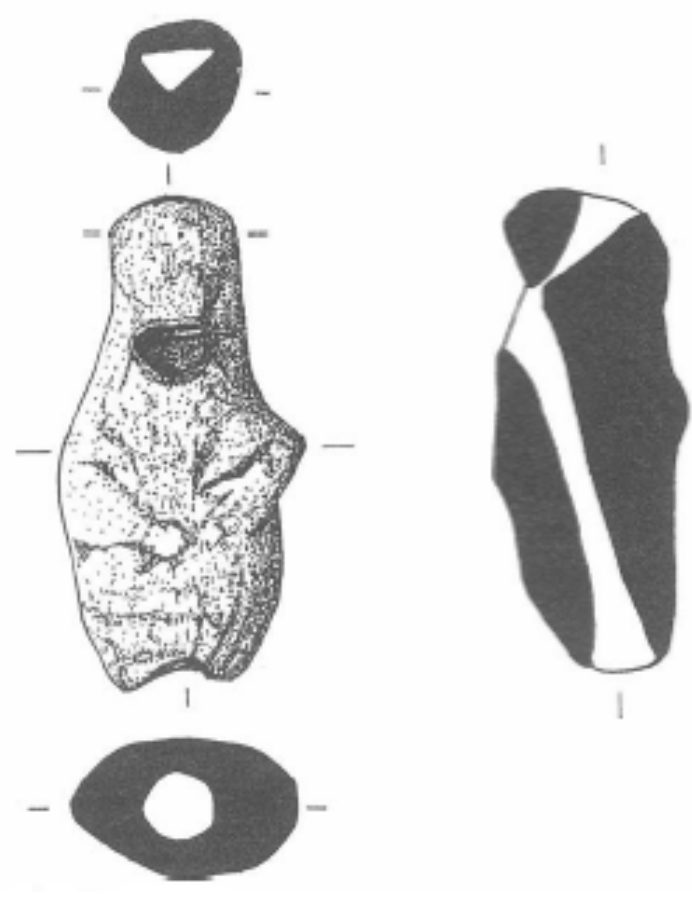

\section{Datos generales}

\begin{tabular}{|l|l|}
\hline Nombre & Silbato \\
\hline $\mathbf{N}^{\mathbf{0}}$ de inventario & - \\
\hline Ubicación actual & - \\
\hline Procedencia & Avenida de la Constitución, Algarinejo \\
\hline Dimensiones & - \\
\hline Ciudad & Granada \\
\hline Cronología & Hispano-musulmán \\
\hline $\begin{array}{l}\text { Características } \\
\text { morfológicas }\end{array}$ & $\begin{array}{l}\text { Por el dibujo parece que la zona de soplo podría ser la } \\
\text { parte superior o inferior de la figura. }\end{array}$ \\
\hline Materiales & Arcilla \\
\hline
\end{tabular}

\section{Datos organológicos}

\begin{tabular}{|l|l|}
\hline Tipo de instrumento & Aerófono \\
\hline $\begin{array}{l}\text { Clasificación por } \\
\text { estructura física }\end{array}$ & B.1. Silbatos globulares antropomorfos \\
\hline Clasificación & 421.221 .41 Flautas globulares con canal de insuflación \\
\hline
\end{tabular}




\begin{tabular}{|l|l|}
\hline organológica & interno sin agujeros digitales \\
\hline Función & Lúdica \\
\hline Fabricación & Alfares \\
\hline $\begin{array}{l}\text { Características } \\
\text { musicales }\end{array}$ & $\begin{array}{l}\text { Al no observarse el bisel de referencia del silbato no es } \\
\text { posible distinguir la zona de soplo del instrumento. }\end{array}$ \\
\hline
\end{tabular}

\section{Datos arqueológicos}

\begin{tabular}{|l|l|}
\hline Yacimiento & Solar Huerto de Megías \\
\hline $\begin{array}{l}\text { Responsable de la } \\
\text { excavación }\end{array}$ & $\begin{array}{l}\text { Juan Alonso Sánchez Martínez y Miguel Castellano } \\
\text { Gamez. }\end{array}$ \\
\hline
\end{tabular}

\section{Bibliografía}

\begin{tabular}{|l|l|}
\hline Documentación del Museo & Pieza perdida. \\
\hline Sánchez Martínez, Juan Alonso y Castellano Gámez, Miguel. "Excavación \\
arqueológica de urgencia en el solar del "Huerto de Megías", Avenida de la \\
Constitución s/n (Algarinejos, Granada)". Anuario arqueológico de Andalucía. \\
(1990): 163.
\end{tabular}




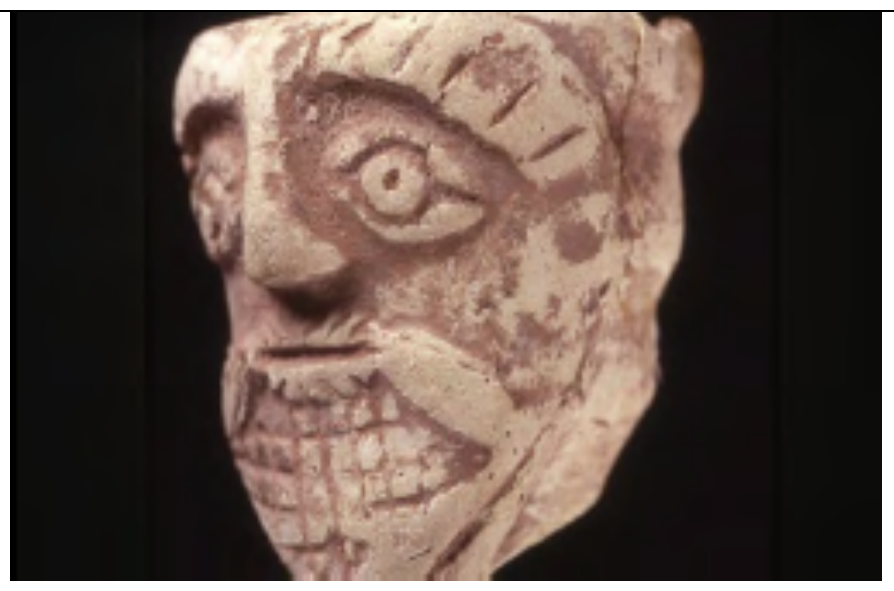

Datos generales

\begin{tabular}{|l|l|}
\hline Nombre & Silbato \\
\hline $\mathbf{N}^{0}$ de inventario & A/CE07054 \\
\hline Ubicación actual & Museo Provincial del Huelva \\
\hline Procedencia & C/ Puerto $\mathrm{n}^{\circ} 9$ \\
\hline Dimensiones & Altura: $3,3 \mathrm{~cm}$; Ancho: $3,8 \mathrm{~cm}$; Grosor: $0,5 \mathrm{~cm}$ \\
\hline Ciudad & Huelva \\
\hline Cronología & Edad Media \\
\hline Características morfológicas & Máscara barbada posible adorno de un sibato de \\
\hline Materiales & agua. \\
\hline
\end{tabular}

\section{Datos organológicos}

\begin{tabular}{|l|l|}
\hline Tipo de instrumento & Aerófono \\
\hline $\begin{array}{l}\text { Clasificación por estructura } \\
\text { fíca }\end{array}$ & B.4. Silbatos globulares de agua \\
\hline Clasificación organológica & $\begin{array}{l}421.221 .41 \text { Flautas globulares con canal de } \\
\text { insuflación interno sin agujeros digitales }\end{array}$ \\
\hline Función & Lúdica \\
\hline Fabricación & Alfares \\
\hline Características musicales & No conserva rasgos musicales identificables. \\
\hline
\end{tabular}




\section{Datos arqueológicos}

\begin{tabular}{|l|l|}
\hline Yacimiento & - \\
\hline Responsable de la excavación & - \\
\hline
\end{tabular}

\section{Bibliografía}

\begin{tabular}{|l|l|}
\hline Documentación del Museo & \multicolumn{3}{l|}{ Pieza con ficha de catalogación. } \\
\hline Red Digital de Colecciones de Museos en $\quad$ España: \\
http://ceres.mcu.es/pages/Main?idt=122054\&inventary=A\%2FCE07054\&table=FMU \\
S\&museum=MH\#.XkugHOPO100 (Última consulta: 18-02-2020); García Benito, \\
Carlos. "Arqueología Musical Prehistórica: aproximación a través de la Arqueología \\
Experimental aplicada a la Arqueo-Organología, de la Arqueoacústica y de la \\
Iconografía Musical Prehistórica". Tesis doctoral, Universidad de Zaragoza, 2014, \\
1709.
\end{tabular}




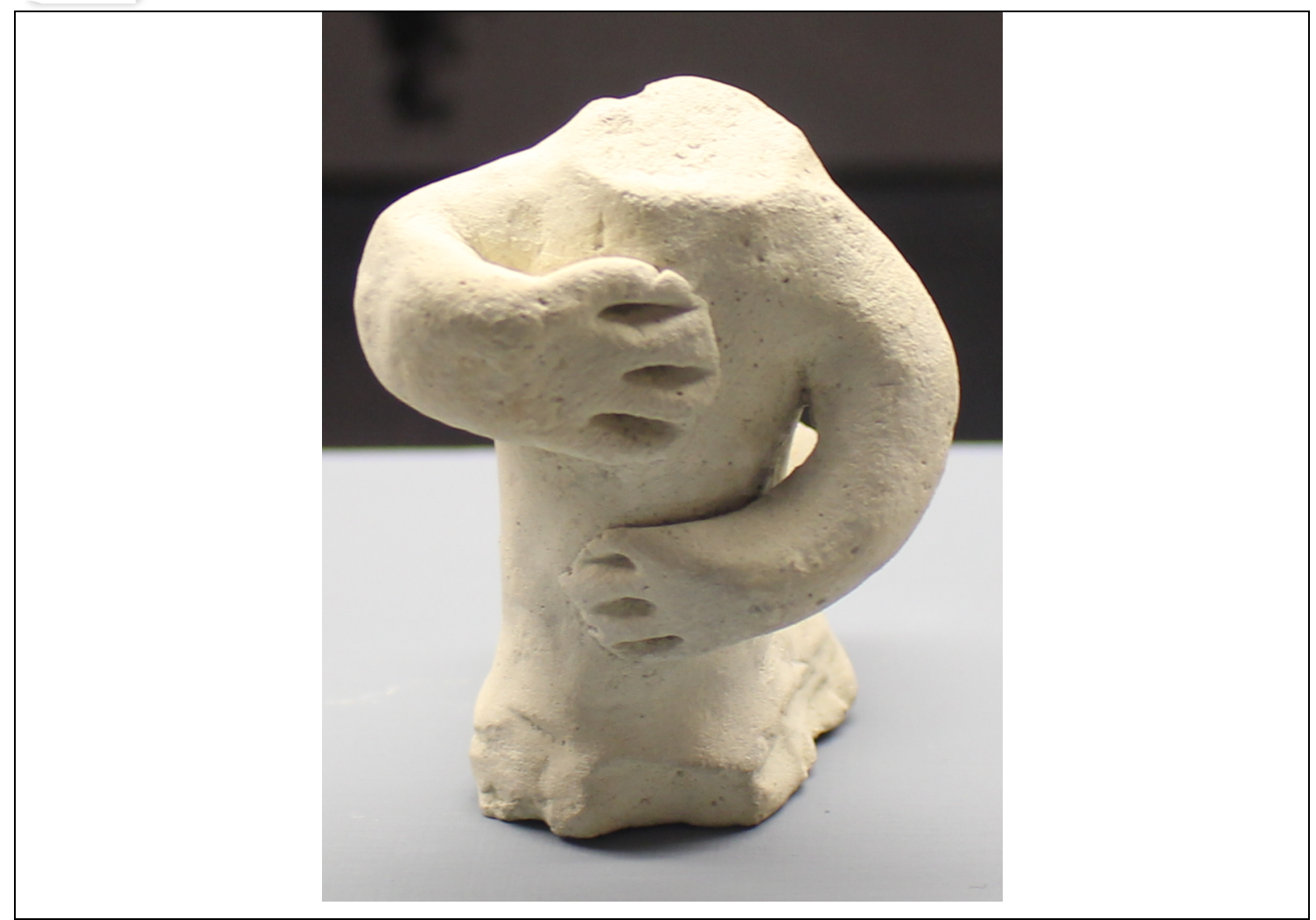

Datos generales

\begin{tabular}{|l|l|}
\hline Nombre & Silbato \\
\hline $\mathbf{N}^{\mathbf{0}}$ de inventario & DJ/DA02883 \\
\hline Ubicación actual & Museo Provincial de Jaén \\
\hline Procedencia & C/ Baños de la Audiencia (Jaén) \\
\hline Dimensiones & Alto: $5 \mathrm{~cm}$; Ancho: $3,5 \mathrm{~cm}$ \\
\hline Ciudad & Jaén \\
\hline Cronología & ss. XII-XIII (Almohade) \\
\hline Características morfológicas & $\begin{array}{l}\text { Fragmento que representa en busto de un hombre } \\
\text { con los brazo apoyados sobre su cuerpo. En la } \\
\text { parte inferior puede observarse el inicio de la caja } \\
\text { de resonancia por lo que se piensa que puede ser } \\
\text { parte de un jinete, aunque no se conservan más } \\
\text { evidencias. }\end{array}$ \\
\hline Materiales & Arcilla \\
\hline
\end{tabular}




\section{Datos organológicos}

\begin{tabular}{|l|l|}
\hline Tipo de instrumento & Aerófono \\
\hline $\begin{array}{l}\text { Clasificación por estructura } \\
\text { física }\end{array}$ & B.1. Silbatos globulares antropomorfos \\
\hline Clasificación organológica & $\begin{array}{l}421.221 .41 \text { Flautas globulares con canal de } \\
\text { insuflación interno sin agujeros digitales }\end{array}$ \\
\hline Función & Lúdica \\
\hline Fabricación & Alfares \\
\hline Características musicales & $\begin{array}{l}\text { No se conserva el silbato, solo la cavidad en el } \\
\text { interior de la figura. }\end{array}$ \\
\hline
\end{tabular}

\section{Datos arqueológicos}

\begin{tabular}{|l|l|}
\hline Yacimiento & Calle Baños de la Audiencia \\
\hline Responsable de la excavación & $\begin{array}{l}\text { Yolanda Jiménez Morillas, } \mathrm{M}^{\mathrm{a}} \text { del Pilar Chica Ruiz } \\
\text { y Juan Carlos Castillo Armenteros }\end{array}$ \\
\hline
\end{tabular}

\section{Bibliografía}

\begin{tabular}{|c|c|}
\hline Documentación del Museo & Pieza con ficha de catalogación. \\
\hline \multicolumn{2}{|c|}{ Jiménez Morillas, Yolanda, et al. "Intervención arqueológica de urgencia en la calle } \\
\hline \multicolumn{2}{|c|}{ Baños de la Audiencia (Jaén)”. Anuario arqueológico de Andalucía. (1991): 234-242; } \\
\hline \multicolumn{2}{|c|}{ Villar Raso, Manuel (com.). El Zoco: vida económica y artes tradicionales en Al- } \\
\hline \multicolumn{2}{|c|}{ Andalus y Marruecos. Fundación El legado andalusí, 1995, 138; Rosselló Bordoy, } \\
\hline \multicolumn{2}{|c|}{ Guillermo. "Instrumentos musicales en barro cocido: una pervivencia medieval". } \\
\hline \multicolumn{2}{|c|}{ Música oral del Sur: revista internacional 2 (1996): 28-51; Rosselló Bordoy, } \\
\hline \multirow{2}{*}{\multicolumn{2}{|c|}{$\begin{array}{l}\text { Guillermo, Ana Navarro Ortega e Isabel Flores Escobosa. Del rito al juego: juguetes } \\
\text { y silbatos de cerámica desde el islam hasta la actualidad. Junta de Andalucía, 2006, }\end{array}$}} \\
\hline & \\
\hline 179; $\quad$ Red Digital & iones de Museos en España: \\
\hline http://ceres.mcu.es/pages/M & Xinventary $=\mathrm{DJ} \% 2 \mathrm{FDA} 02883 \&$ \\
\hline & \\
\hline
\end{tabular}




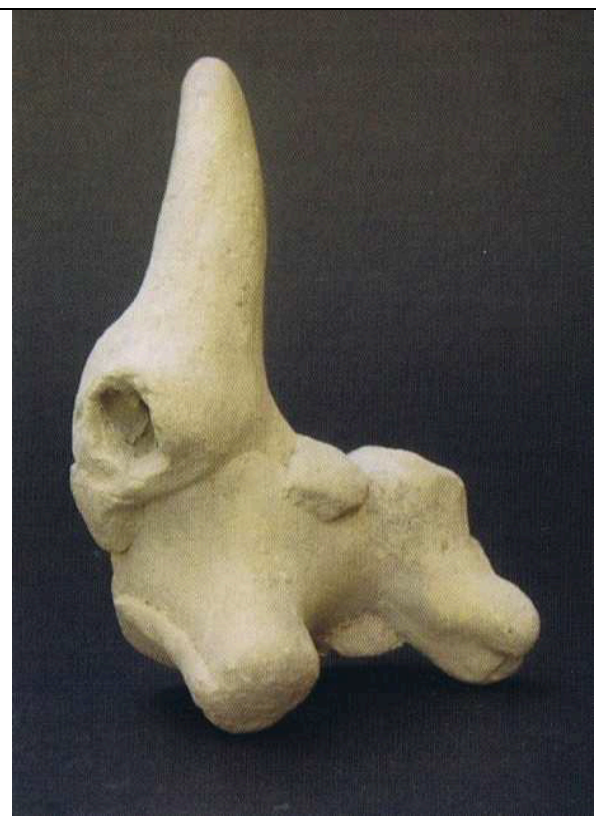

\section{Datos generales}

\begin{tabular}{|c|c|}
\hline Nombre & Silbato \\
\hline $\mathrm{N}^{\mathrm{o}}$ de inventario & 4466 \\
\hline Ubicación actual & Museo Provincial de Jaén \\
\hline Procedencia & $\begin{array}{l}\text { Zona Arqueológica de Marroquíes Bajos SUNP-1. } \\
\text { Excavación arqueológica de urgencia en la Parcela DEP } \\
\text { 1-1. }\end{array}$ \\
\hline Dimensiones & Longitud: $8,18 \mathrm{~cm}$; Altura: 6,20 cm; Grosor 3,50 cm. \\
\hline Ciudad & Jaén \\
\hline Cronología & s. XII (Almohade) \\
\hline $\begin{array}{l}\text { Características } \\
\text { morfológicas }\end{array}$ & $\begin{array}{l}\text { Silbato zoomorfo con forma aparente de un toro con la } \\
\text { pérdida de uno de sus cuernos donde se ve un orificio } \\
\text { ciego. Su interior está hueco. }\end{array}$ \\
\hline Materiales & Arcilla \\
\hline
\end{tabular}

\section{Datos organológicos}

\begin{tabular}{|l|l|}
\hline Tipo de instrumento & Aerófono \\
\hline Clasificación por & B.2. Silbatos globulares zoomorfos \\
\hline
\end{tabular}




\begin{tabular}{|c|c|}
\hline estructura física & \\
\hline $\begin{array}{l}\text { Clasificación } \\
\text { organológica }\end{array}$ & $\begin{array}{l}\text { 421.221.41 Flautas globulares con canal de insuflación } \\
\text { interno sin agujeros digitales }\end{array}$ \\
\hline Función & Lúdica \\
\hline Fabricación & Alfares \\
\hline $\begin{array}{l}\text { Características } \\
\text { musicales }\end{array}$ & $\begin{array}{l}\text { Parte de la embocadura del silbato se ha perdido, éste se } \\
\text { encuentra en la parte posterior de la figura. No se } \\
\text { conserva el bisel. }\end{array}$ \\
\hline
\end{tabular}

\section{Datos arqueológicos}

\begin{tabular}{|l|l|}
\hline Yacimiento & Parcela DEP. 1-1 de la Z. A. M. B. (Jaén) \\
\hline $\begin{array}{l}\text { Responsables de la } \\
\text { excavación }\end{array}$ & Alicia Nieto Ruiz y Emilio Plazas Beltrán \\
\hline
\end{tabular}

\section{Bibliografía}

\begin{tabular}{|l|l|}
\hline Documentación del Museo & Pieza con ficha de catalogación. \\
\hline Nieto Ruiz, Alicia y Plazas Beltrán, Emilio. “Intervención Arqueológica de urgencia \\
en la Parcela DEP. 1-1 de la Z. A. M. B. (Jaén)”. Anuario Arqueológico de Andalucía \\
(2004): 2057- 2061; Rosselló Bordoy, Guillermo, Ana Navarro Ortega e Isabel Flores \\
Escobosa. Del rito al juego: juguetes y silbatos de cerámica desde el islam hasta la \\
actualidad. Junta de Andalucía, 2006, 176.
\end{tabular}




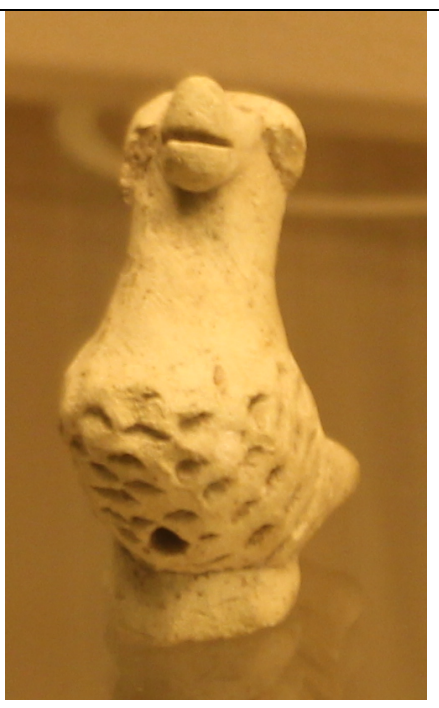

\section{Datos generales}

\begin{tabular}{|l|l|}
\hline Nombre & Silbato \\
\hline $\mathbf{N}^{\mathbf{0}}$ de inventario & - \\
\hline Ubicación actual & Baños árabes Jaén \\
\hline Procedencia & Baños árabes Jaén \\
\hline Dimensiones & - \\
\hline Ciudad & Jaén \\
\hline Cronología & ss. XV-XVI (Nazarí) \\
\hline Características & $\begin{array}{l}\text { Ave con pico y ojos realizados con apliques plásticos. El } \\
\text { plumaje está representado mediante incisiones. Cuenta } \\
\text { con una base que le permite permanecer en pie. }\end{array}$ \\
\hline Materiales & Arcilla \\
\hline
\end{tabular}

\section{Datos organológicos}

\begin{tabular}{|l|l|}
\hline Tipo de instrumento & Aerófono \\
\hline $\begin{array}{l}\text { Clasificación por } \\
\text { estructura física }\end{array}$ & B.2. Silbatos globulares zoomorfos \\
\hline $\begin{array}{l}\text { Clasificación } \\
\text { organológica }\end{array}$ & $\begin{array}{l}421.221 .41 \text { Flautas globulares con canal de insuflación } \\
\text { interno sin agujeros digitales }\end{array}$ \\
\hline Función & Lúdica \\
\hline
\end{tabular}




\begin{tabular}{|l|l|}
\hline Fabricación & Alfares \\
\hline $\begin{array}{l}\text { Características } \\
\text { musicales }\end{array}$ & $\begin{array}{l}\text { Silbato con agujero frente a la embocadura de soplo, en la } \\
\text { cola del ave. El bisel se encuentra en el pecho del animal. }\end{array}$ \\
\hline
\end{tabular}

\section{Datos arqueológicos}

\begin{tabular}{|l|l|}
\hline Yacimiento & Baños árabes Jaén \\
\hline $\begin{array}{l}\text { Responsable de la } \\
\text { Excavación }\end{array}$ & - \\
\hline
\end{tabular}

\section{Bibliografía}

\begin{tabular}{|l|l|}
\hline Documentación del Museo & Pieza no inventariada. \\
\hline Inédito & \\
\hline
\end{tabular}




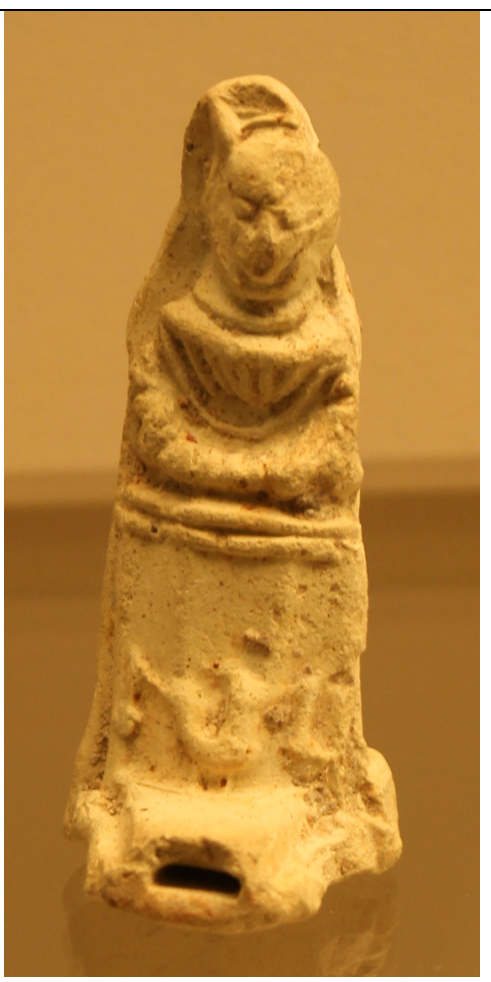

\section{Datos generales}

\begin{tabular}{|l|l|}
\hline Nombre & Silbato \\
\hline $\mathbf{N}^{\mathbf{0}}$ de inventario & - \\
\hline Ubicación actual & Baños árabes Jaén \\
\hline Procedencia & Baños árabes Jaén \\
\hline Dimensiones & - \\
\hline Ciudad & Jaén \\
\hline Cronología & ss. XV-XVI (Nazarí) \\
\hline Características & $\begin{array}{l}\text { Mujer con la cabeza cubierta y brazos cruzados por } \\
\text { molante del cuerpo. Parece estar representada hasta la } \\
\text { cintura creándose un enlace con el silbato mediante una } \\
\text { forma de falda. Los rasgos faciales y detalles de su } \\
\text { vestimenta están realizadas mediante incisiones. Parece } \\
\text { una figura cristiana. }\end{array}$ \\
\hline Materiales & Arcilla \\
\hline
\end{tabular}


Datos organológicos

\begin{tabular}{|l|l|}
\hline Tipo de instrumento & Aerófono \\
\hline $\begin{array}{l}\text { Clasificación por } \\
\text { estructura física }\end{array}$ & B.1. Silbatos globulares antropomorfos \\
\hline $\begin{array}{l}\text { Clasificación } \\
\text { organológica }\end{array}$ & $\begin{array}{l}421.221 .41 \text { Flautas globulares con canal de insuflación } \\
\text { interno sin agujeros digitales }\end{array}$ \\
\hline Función & Lúdica \\
\hline Fabricación & Alfares \\
\hline $\begin{array}{l}\text { Características } \\
\text { musicales }\end{array}$ & $\begin{array}{l}\text { Silbato con embocadura visible cuenta con un agujero en } \\
\text { la base de la figura. }\end{array}$ \\
\hline
\end{tabular}

Datos arqueológicos

\begin{tabular}{|l|l|}
\hline Yacimiento & Baños árabes de Jaén \\
\hline $\begin{array}{l}\text { Responsable de la } \\
\text { excavación }\end{array}$ & - \\
\hline
\end{tabular}

Bibliografía

\begin{tabular}{|l|l|}
\hline Documentación del Museo & Pieza no inventariada. \\
\hline Inédito & \\
\hline
\end{tabular}




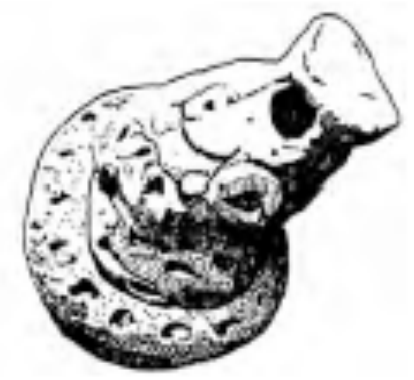

\section{Datos generales}

\begin{tabular}{|c|c|}
\hline Nombre & Silbato \\
\hline $\mathrm{N}^{\mathbf{0}}$ de inventario & - \\
\hline Ubicación actual & - \\
\hline Procedencia & Baños árabes Jaén \\
\hline Dimensiones & - \\
\hline Ciudad & Jaén \\
\hline Cronología & ss. XII-XIII (Almohade) \\
\hline $\begin{array}{l}\text { Características } \\
\text { morfológicas }\end{array}$ & $\begin{array}{l}\text { Silbato con forma de serpiente (áspid) enroscada. En la } \\
\text { parte media coge relieve la figura y forma el silbato. } \\
\text { Cuenta con varias incisiones represenando el } \\
\text { característico dibujo de este tipo de reptil. }\end{array}$ \\
\hline Materiales & Arcilla \\
\hline
\end{tabular}

\section{Datos organológicos}

\begin{tabular}{|l|l|}
\hline Tipo de instrumento & Aerófono \\
\hline $\begin{array}{l}\text { Clasificación por } \\
\text { estructura física }\end{array}$ & B.2. Silbatos globulares zoomorfos \\
\hline $\begin{array}{l}\text { Clasificación } \\
\text { organológica }\end{array}$ & $\begin{array}{l}421.221 .41 \text { Flautas globulares con canal de insuflación } \\
\text { interno sin agujeros digitales }\end{array}$ \\
\hline
\end{tabular}




\begin{tabular}{|l|l|}
\hline Función & Lúdica \\
\hline Fabricación & Alfares \\
\hline $\begin{array}{l}\text { Características } \\
\text { musicales }\end{array}$ & $\begin{array}{l}\text { Silbato en la boca del animal con bisel en la parte } \\
\text { superior. }\end{array}$ \\
\hline
\end{tabular}

\section{Datos arqueológicos}

\begin{tabular}{|l|l|}
\hline Yacimiento & Baños árabes de Jaén \\
\hline $\begin{array}{l}\text { Responsable de la } \\
\text { excavación }\end{array}$ & - \\
\hline
\end{tabular}

\section{Bibliografía}

\begin{tabular}{|l|l}
\hline Documentación del Museo & Pieza no inventariada.
\end{tabular}

Espinar Moreno, Manuel. "Instrumentos musicales de barro: silbatos zoomorfos, antropomorfos y otros vestigios musicales". Música oral del Sur: revista internacional. (1996): 63-84; García Benito, Carlos. “Arqueología Musical Prehistórica: aproximación a través de la Arqueología Experimental aplicada a la Arqueo-Organología, de la Arqueoacústica y de la Iconografía Musical Prehistórica”. Tesis doctoral, Universidad de Zaragoza, 2014, 1709. 


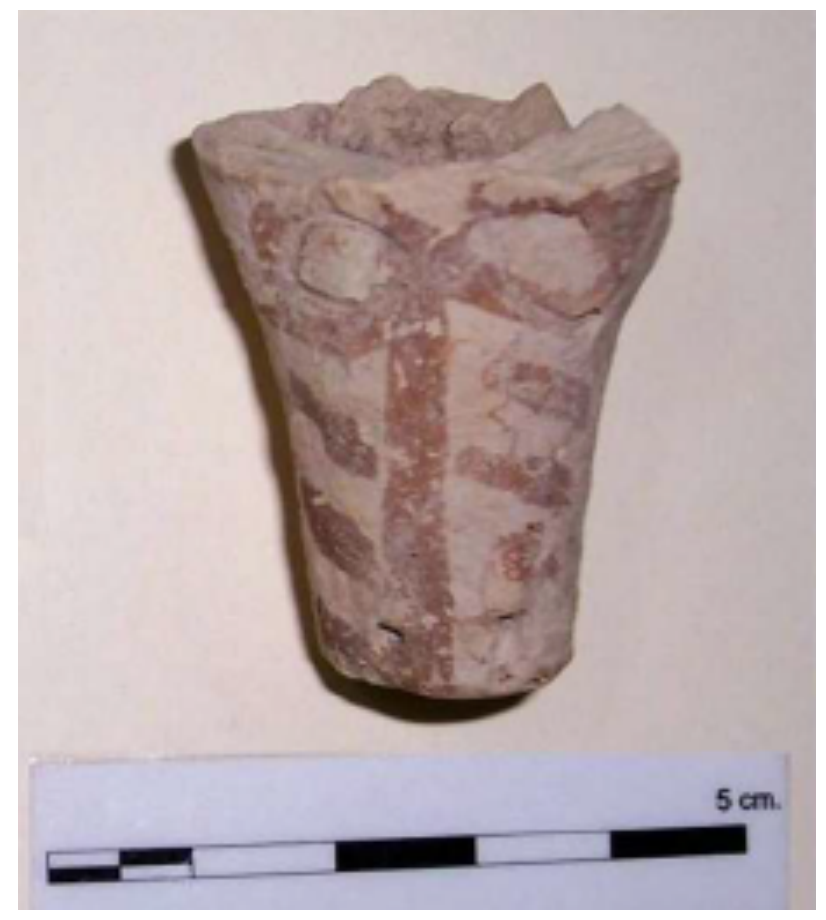

Datos generales

\begin{tabular}{|l|l|}
\hline Nombre & Silbato \\
\hline $\mathbf{N}^{\mathbf{0}}$ de inventario & - \\
\hline Ubicación actual & - \\
\hline Procedencia & Esquina Avda. San Amador C/ Alfonso XII, Martos \\
\hline Dimensiones & - \\
\hline Ciudad & Jaén \\
\hline Cronología & ss. IX-X (Emiral) \\
\hline Características & $\begin{array}{l}\text { Cabeza de un caballo con ojos formados por pellas de } \\
\text { arcilla en relieve. Cuenta con dos orificios simulando el } \\
\text { hocico del animal. La cabeza está pintada con trazos } \\
\text { rojizos alrededor de los ojos y a lo largo del hocico. }\end{array}$ \\
\hline Materiales & Arcilla \\
\hline
\end{tabular}

\section{Datos organológicos}

Tipo de instrumento

Aerófono 


\begin{tabular}{|l|l|}
\hline $\begin{array}{l}\text { Clasificación por } \\
\text { estructura física }\end{array}$ & B.2. Silbatos globulares zoomorfos \\
\hline $\begin{array}{l}\text { Clasificación } \\
\text { organológica }\end{array}$ & $\begin{array}{l}421.221 .41 \text { Flautas globulares con canal de insuflación } \\
\text { interno sin agujeros digitales }\end{array}$ \\
\hline Función & Lúdica \\
\hline Fabricación & Alfares \\
\hline $\begin{array}{l}\text { Características } \\
\text { musicales }\end{array}$ & $\begin{array}{l}\text { La hipótesis de que pueda tratarse de un silbato parece } \\
\text { fundamentarse en la cavidad interior del fragmento } \\
\text { encontrado. }\end{array}$ \\
\hline
\end{tabular}

\section{Datos arqueológicos}

\begin{tabular}{|l|l|}
\hline Yacimiento & Zona arqueológica del polideportivo de Martos \\
\hline $\begin{array}{l}\text { Responsable de la } \\
\text { excavación }\end{array}$ & Alicia Nieto Ruiz y Emilio Plazas Beltrán \\
\hline
\end{tabular}

\section{Bibliografía}

\begin{tabular}{|l|l}
\hline Documentación del Museo & Pieza no inventariada.
\end{tabular}

Nieto Ruiz, Alicia y Plazas Beltrán, Emilio. "Intervención arqueológica en la Avda. San Amador- Esquina calle Alfonso XII, zona arqueológica del polideportivo de Martos (Jaén)”. Anuario arqueológico de Andalucía, (2006): 2810. 


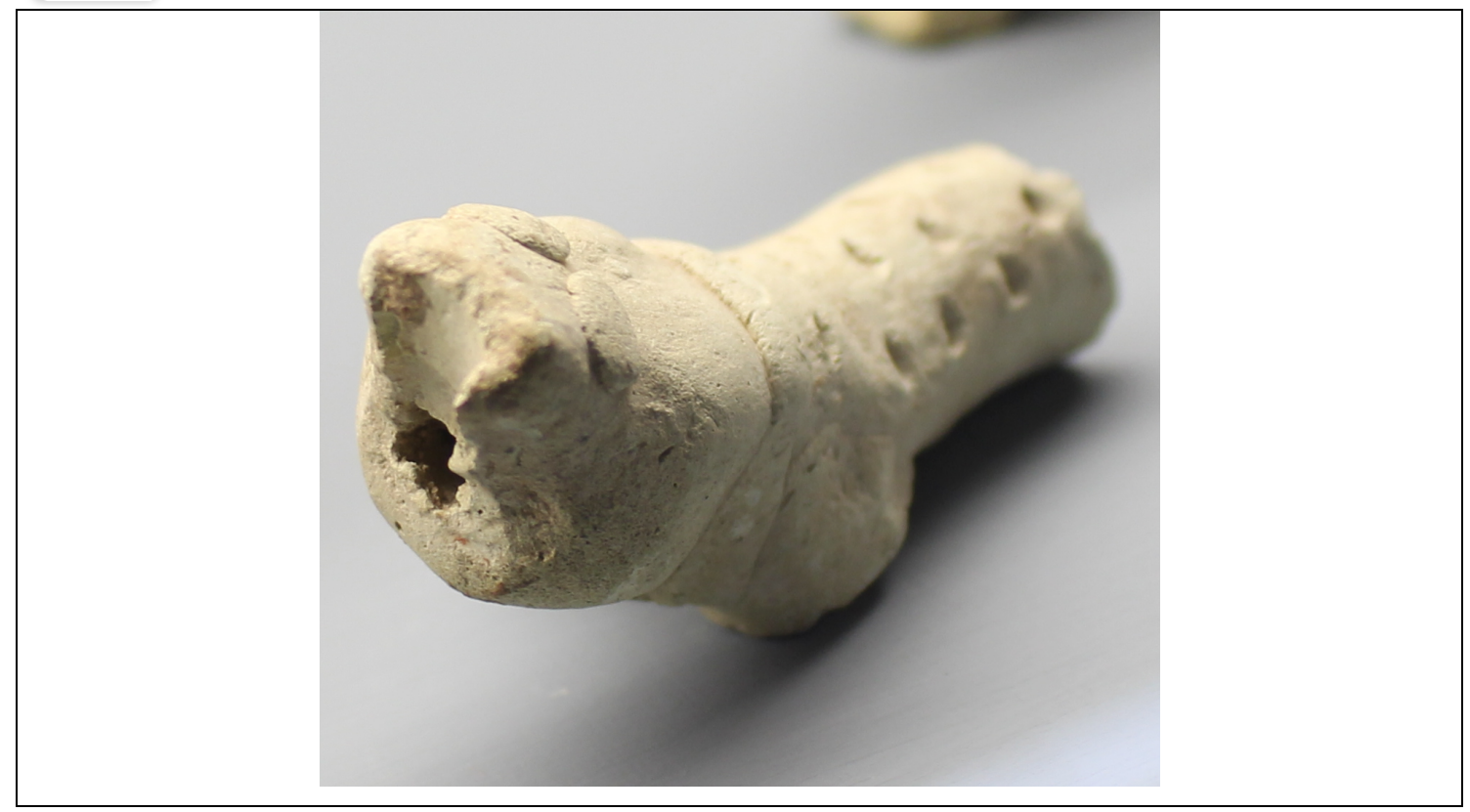

\section{Datos generales}

\begin{tabular}{|l|l|}
\hline Nombre & Silbato \\
\hline $\mathbf{N}^{\mathbf{0}}$ de inventario & DJ/DA02884 \\
\hline Ubicación actual & Museo Provincial de Jaén \\
\hline Procedencia & $\begin{array}{l}\text { Excavación arqueológica de urgencia en un solar } \\
\text { entre las calles Alcázar, Deán Pérez de Vargas y } \\
\text { Parras de la localidad de Andújar (Jaén). }\end{array}$ \\
\hline Dimensiones & Altura: 3,8 cm; Anchura: 1,9 cm; Longitud: $6,3 \mathrm{~cm}$. \\
\hline Ciudad & Jaén \\
\hline Cronología & s. XII (Almohade) \\
\hline Características morfológicas & $\begin{array}{l}\text { Silbato de forma zoomorfa que recuerda a un reptil. } \\
\text { Elaborado a partir de un cilindro al que se le fueron } \\
\text { superponiendo porciones irregulares. El orificio } \\
\text { para insuflar el silbato se encontraría en la parte } \\
\text { posterior del animal. }\end{array}$ \\
\hline Materiales & Arcilla \\
\hline
\end{tabular}




\section{Datos organológicos}

\begin{tabular}{|l|l|}
\hline Tipo de instrumento & Aerófono \\
\hline $\begin{array}{l}\text { Clasificación por estructura } \\
\text { Clasificación organológica }\end{array}$ & $\begin{array}{l}\text { B.2. Silbatos globulares zoomorfos } \\
\text { insuflación interno sin agujeros digitales }\end{array}$ \\
\hline Función & Lúdica \\
\hline Fabricación & Alfares \\
\hline Características musicales & $\begin{array}{l}\text { Silbato en la parte posterior del instrumento, se } \\
\text { conserva solo parte de este. El orificio de la boca no } \\
\text { forma parte del silbato. }\end{array}$ \\
\hline
\end{tabular}

\section{Datos arqueológicos}

\begin{tabular}{|l|l|}
\hline Yacimiento & $\begin{array}{l}\text { Solar Calle Alcázar-Altozano Deán Pérez de } \\
\text { Vargas y Parras }\end{array}$ \\
\hline Responsable de la excavación & José Carlos Castillo Armenteros \\
\hline
\end{tabular}

\section{Bibliografía}

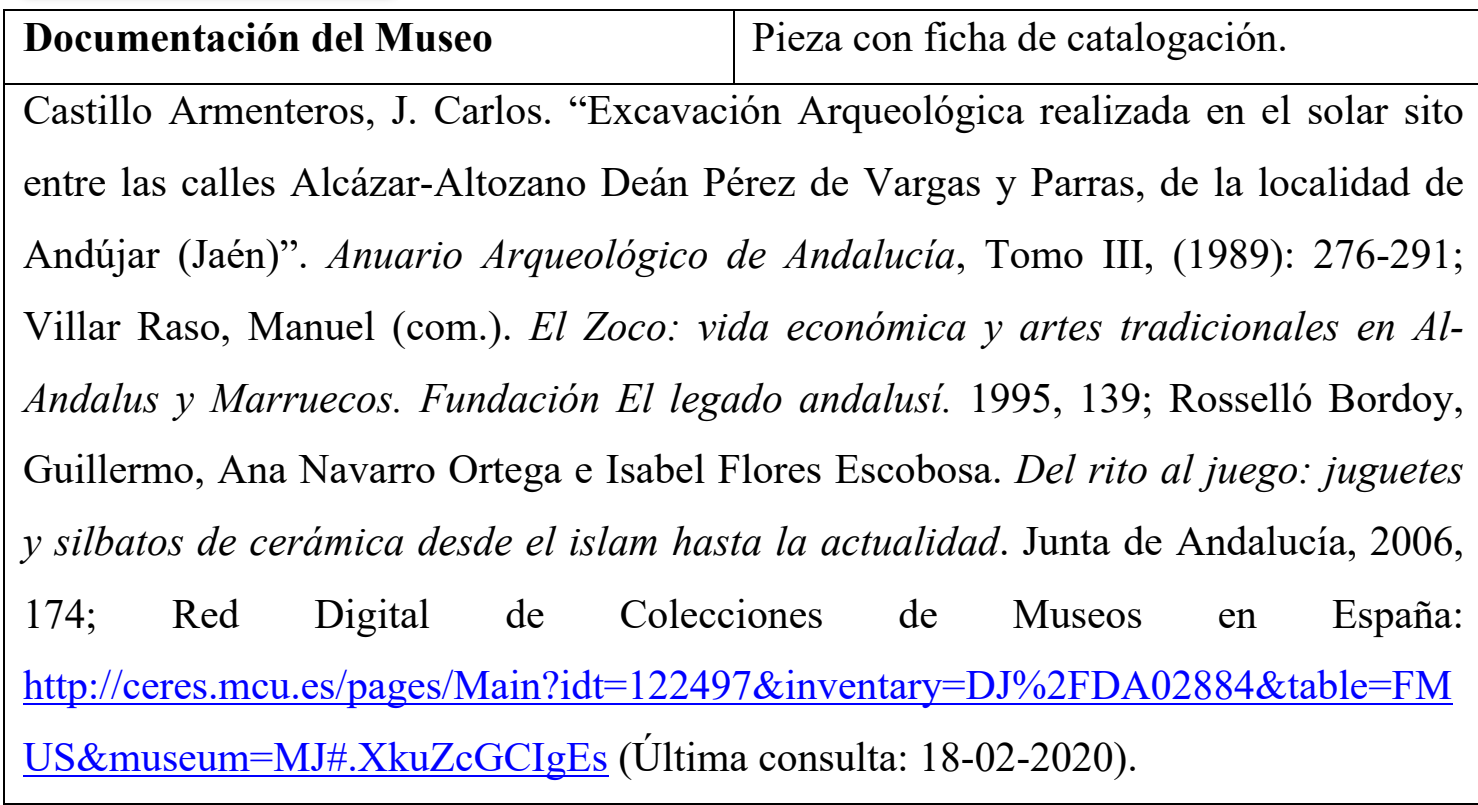




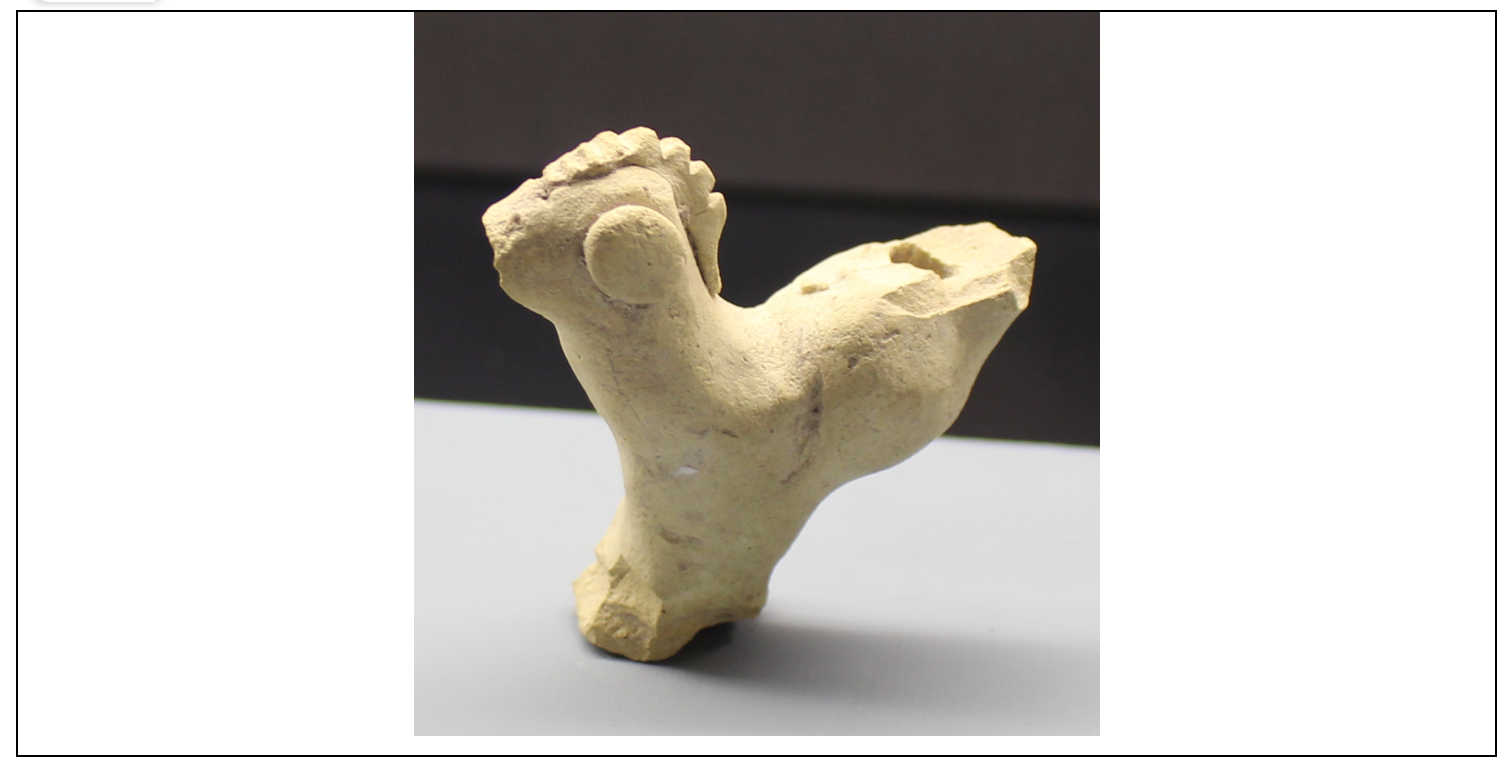

\section{Datos generales}

\begin{tabular}{|l|l|}
\hline Nombre & Silbato \\
\hline $\mathbf{N}^{\mathbf{0}}$ de inventario & 4606 \\
\hline Ubicación actual & Museo Provincial de Jaén \\
\hline Procedencia & C/ S. Vicente (Baeza) \\
\hline Dimensiones & $\begin{array}{l}\text { Altura: } 5 \mathrm{~cm} \text {; Grosor máximo: } 2 \mathrm{~cm} \text {; Anchura } \\
\text { máxima: } 5,2 \mathrm{~cm}\end{array}$ \\
\hline Ciudad & Jaén \\
\hline Cronología & ss. XV-XVI (Nazarí) \\
\hline Características morfológicas & $\begin{array}{l}\text { Gallina con ojos y cresta realizado con apliques } \\
\text { plásticos. La cresta consigue su característica } \\
\text { forma mediante incisiones. No cuenta con más } \\
\text { rasgos detallados. Tiene una pequeña base } \\
\text { cilíndrica como soporte. }\end{array}$ \\
\hline Materiales & \begin{tabular}{l} 
Arcilla \\
\hline
\end{tabular} \\
\hline
\end{tabular}

\section{Datos organológicos}

\begin{tabular}{|l|l|}
\hline Tipo de instrumento & Aerófono \\
\hline Clasificación por estructura & B.2. Silbatos globulares zoomorfos \\
\hline
\end{tabular}




\begin{tabular}{|l|l|}
\hline física & \\
\hline Clasificación organológica & $\begin{array}{l}421.221 .41 \text { Flautas globulares con canal de } \\
\text { insuflación interno sin agujeros digitales }\end{array}$ \\
\hline Función & Lúdica \\
\hline Fabricación & Alfares \\
\hline Características musicales & $\begin{array}{l}\text { Silbato en la parte posterior del animal con bisel } \\
\text { en la parte superior del mismo. }\end{array}$ \\
\hline
\end{tabular}

\section{Datos arqueológicos}

\begin{tabular}{|l|l|}
\hline Yacimiento & - \\
\hline Responsable de la excavación & - \\
\hline
\end{tabular}

\section{Bibliografía}

\begin{tabular}{|l|l}
\hline Documentación del Museo & Pieza con ficha de catalogación.
\end{tabular}

Red Digital de Colecciones de Museos en España:

http://ceres.mcu.es/pages/Main?idt=128272\&inventary=DJ\%2FDA04606\&table=FM

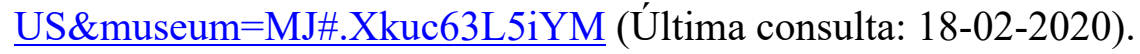




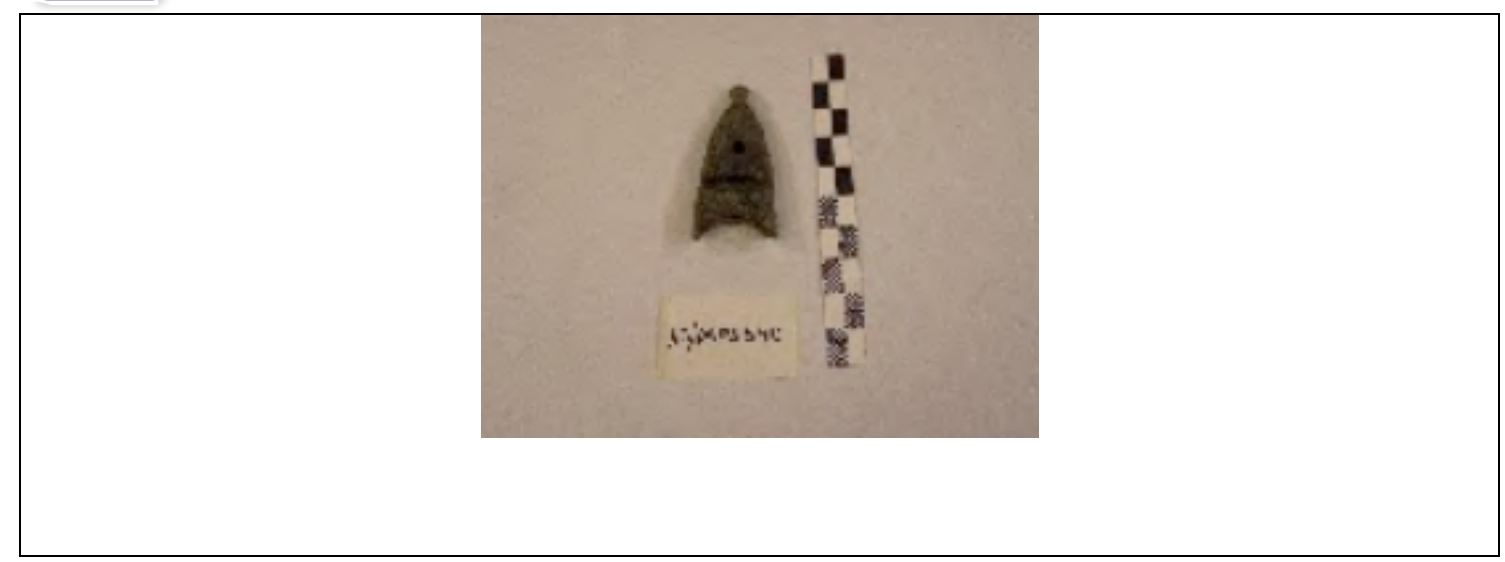

\section{Datos generales}

\begin{tabular}{|l|l|}
\hline Nombre & Silbato \\
\hline $\mathbf{N}^{\mathbf{0}}$ de inventario & DJ/DA05590 \\
\hline Ubicación actual & Museo Provincial de Jaén \\
\hline Procedencia & Muralla de Baeza \\
\hline Dimensiones & $\begin{array}{l}\text { Grosor máximo: } 0,5 \mathrm{~cm} \text {; Anchura máxima: } 2,5 \\
\mathrm{~cm} \text {; Longitud: } 5,2 \mathrm{~cm} .\end{array}$ \\
\hline Ciudad & Jaén \\
\hline Cronología & Época musulmana \\
\hline Características morfológicas & $\begin{array}{l}\text { Silbato con forma cónica. Tiene protuberancia en } \\
\text { la parte superior del mismo y un orificio que } \\
\text { recorre el cuerpo. La parte inferior cuenta con } \\
\text { una zona curva como embocadura. }\end{array}$ \\
\hline Materiales & Metal \\
\hline
\end{tabular}

Datos organológicos

\begin{tabular}{|l|l|}
\hline Tipo de instrumento & Aerófono \\
\hline $\begin{array}{l}\text { Clasificación por estructura } \\
\text { física }\end{array}$ & B.5. Silbatos globulares con otras formas \\
\hline Clasificación organológica & $\begin{array}{l}421.221 .42 \text { Flautas globulares con canal de } \\
\text { insuflación interno con agujeros digitales }\end{array}$ \\
\hline Función & Lúdica o religiosa \\
\hline
\end{tabular}




\begin{tabular}{|l|l|}
\hline Fabricación & Herrería \\
\hline Características musicales & Silbato con forma anatómica para la boca que \\
cuenta con una salida de aire en el extremo del \\
instrumento el cual sirve de adorno. El aire curza \\
todo el instrumento.
\end{tabular}

\section{Datos arqueológicos}

\begin{tabular}{|l|l|}
\hline Yacimiento & Muralla de Baeza \\
\hline Responsable de la excavación & Cristobal Pérez Bareas \\
\hline
\end{tabular}

\section{Bibliografía}

\begin{tabular}{|l|l|l|}
\hline \multicolumn{2}{|l|}{ Documentación del Museo } & \multicolumn{3}{l|}{ Pieza con ficha de catalogación. } \\
\hline Red Digital de Colecciones de $\quad$ Museos en $\quad \begin{array}{c}\text { España: } \\
\text { http://ceres.mcu.es/pages/Main?idt=130314\&inventary=DJ\%2FDA05590\&table=FM }\end{array}$ \\
US\&museum=MJ\#.XkuZ13MqXK0 (Última consulta: 18-02-2020); García Benito, \\
Carlos. "Arqueología Musical Prehistórica: aproximación a través de la Arqueología \\
Experimental aplicada a la Arqueo-Organología, de la Arqueoacústica y de la \\
Iconografía Musical Prehistórica". Tesis doctoral, Universidad de Zaragoza, 2014. \\
\hline
\end{tabular}




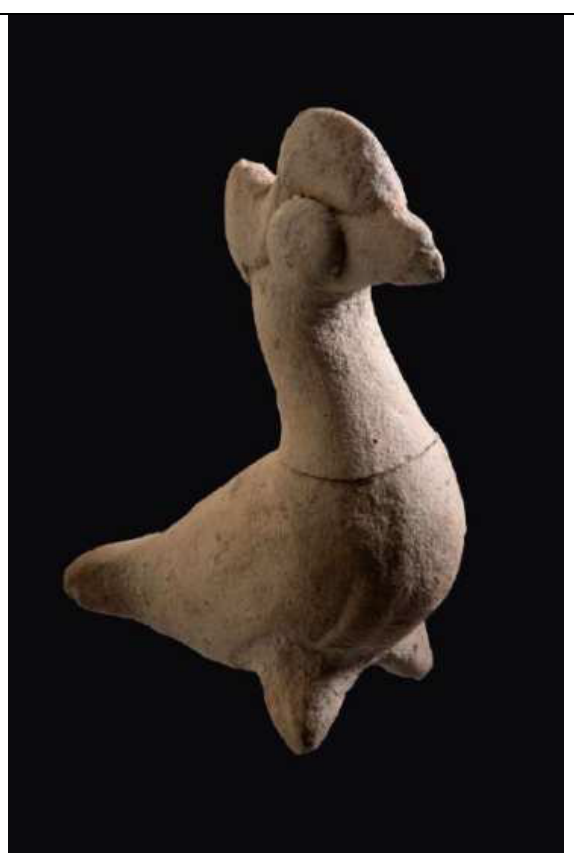

\section{Datos generales}

\begin{tabular}{|l|l|}
\hline Nombre & Silbato \\
\hline $\mathbf{N}^{\mathbf{0}}$ de inventario & DJ/DA02886 \\
\hline Ubicación actual & Museo Provincial de Jaén \\
\hline Procedencia & $\begin{array}{l}\text { Excavación arqueológica de urgencia en un solar } \\
\text { entre las calles Alcázar, Deán Pérez de Vargas y } \\
\text { Parras de la localidad de Andújar (Jaén). }\end{array}$ \\
\hline Dimensiones & Altura: 4 cm; Anchura: 13 cm; Longitud: 4 cm. \\
\hline Ciudad & Jaén \\
\hline Cronología & s. XII (Almohade) \\
\hline Características morfológicas & $\begin{array}{l}\text { Figura zoomórfica que representa un gallo hecho } \\
\text { de una pieza y con añadidos ojos y cresta. El } \\
\text { orificio de soplo está por la cola. }\end{array}$ \\
\hline Materiales & Arcilla \\
\hline
\end{tabular}

Datos organológicos

\begin{tabular}{|l|l|}
\hline Tipo de instrumento & Aerófono \\
\hline Clasificación por estructura & B.2. Silbatos globulares zoomorfos \\
\hline
\end{tabular}




\begin{tabular}{|l|l|}
\hline física & \\
\hline Clasificación organológica & $\begin{array}{l}421.221 .41 \text { Flautas globulares con canal de } \\
\text { insuflación interno sin agujeros digitales }\end{array}$ \\
\hline Función & Lúdica \\
\hline Fabricación & Alfares \\
\hline Características musicales & $\begin{array}{l}\text { Silbato en la parte posterior del animal. No } \\
\text { resulta claramente perceptible el silbato pasando } \\
\text { desapercibido en la forma de la figura. }\end{array}$ \\
\hline
\end{tabular}

\section{Datos arqueológicos}

\begin{tabular}{|l|l|}
\hline Yacimiento & $\begin{array}{l}\text { Solar Calle Alcázar-Altozano Deán Pérez de } \\
\text { Vargas y Parras }\end{array}$ \\
\hline Responsable de la excavación & José Carlos Castillo Armenteros \\
\hline
\end{tabular}

\section{Bibliografía}

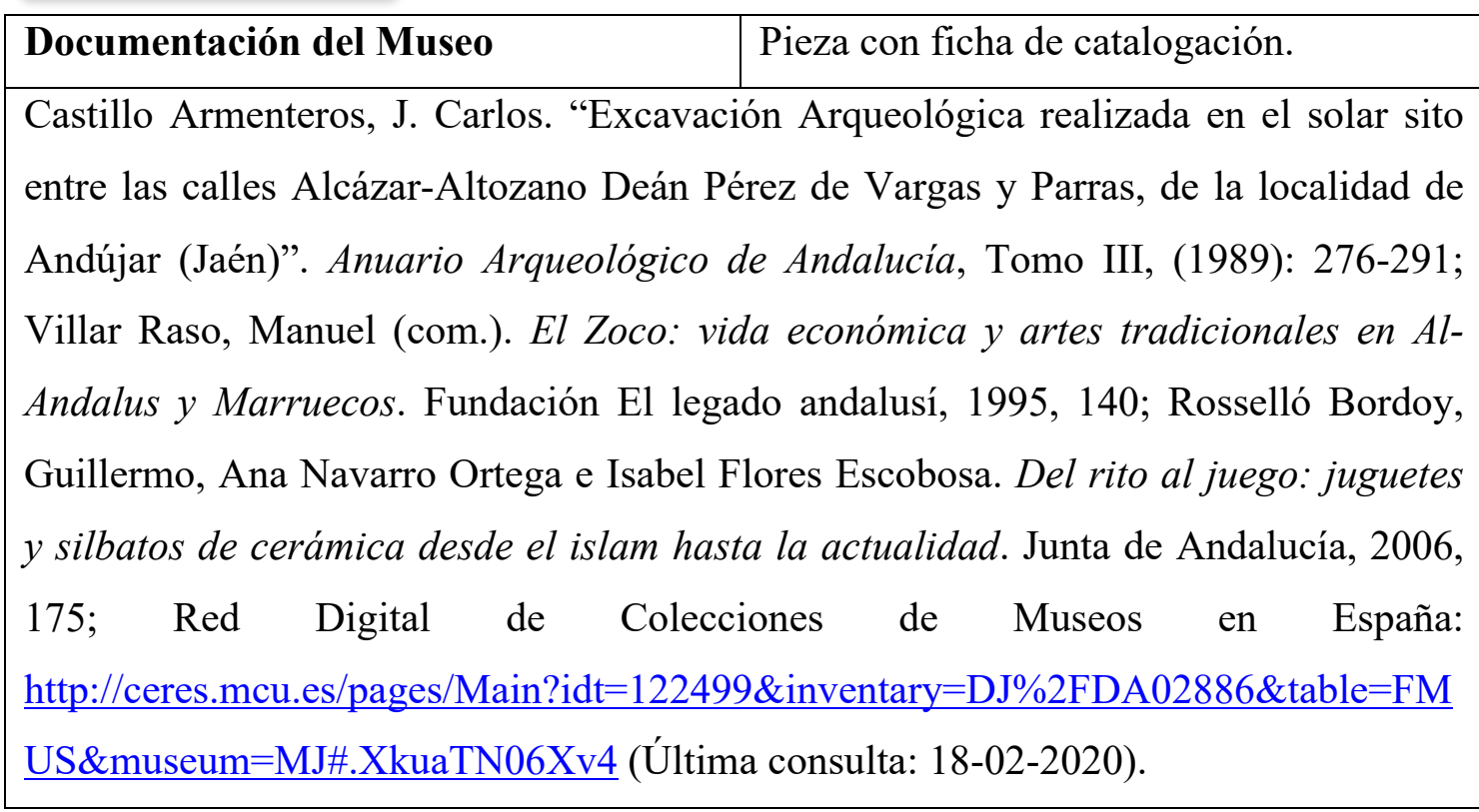




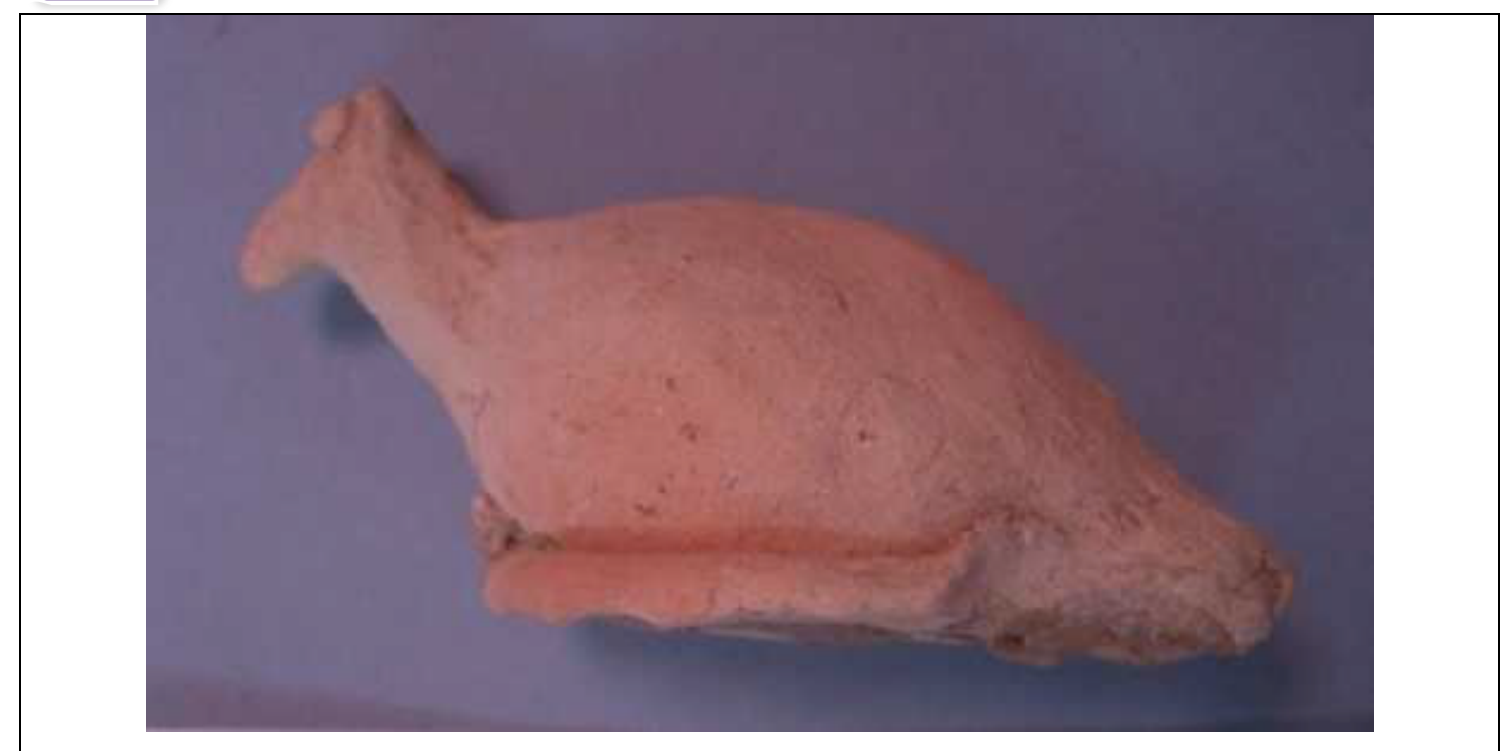

\section{Datos generales}

\begin{tabular}{|l|l|}
\hline Nombre & Silbato \\
\hline $\mathbf{N}^{\mathbf{0}}$ de inventario & DJ/DA02885 \\
\hline Ubicación actual & Museo Provincial de Jaén \\
\hline Procedencia & $\begin{array}{l}\text { Excavación arqueológica de urgencia en un solar entre } \\
\text { las calles Alcázar, Deán Pérez de Vargas y Parras de la } \\
\text { localidad de Andújar (Jaén). }\end{array}$ \\
\hline Dimensiones & Altura: 4 cm; Anchura: 3,2 cm; Longitud: 7,8 cm. \\
\hline Ciudad & Jaén \\
\hline Cronología & S. XII (Almohade) \\
\hline $\begin{array}{l}\text { Características } \\
\text { morfológicas }\end{array}$ & $\begin{array}{l}\text { Figura zoomorfa que parece imitar a una paloma } \\
\text { incubando. El orificio de soplo se realizaría por la cola. } \\
\text { La figura está realizada en una pieza con los ojos } \\
\text { añadidos mediante apliques plásticos. Cuenta con una } \\
\text { base de sujeción. }\end{array}$ \\
\hline Materiales & Arcilla \\
\hline
\end{tabular}

Datos organológicos

\begin{tabular}{|l|l|}
\hline Tipo de instrumento & Aerófono \\
\hline
\end{tabular}




\begin{tabular}{|l|l|}
\hline $\begin{array}{l}\text { Clasificación por } \\
\text { estructura física }\end{array}$ & B.2. Silbatos globulares zoomorfos \\
\hline Clasificación organológica & $\begin{array}{l}421.221 .41 \text { Flautas globulares con canal de insuflación } \\
\text { interno sin agujeros digitales }\end{array}$ \\
\hline Función & Lúdica \\
\hline Fabricación & Alfares \\
\hline Características musicales & $\begin{array}{l}\text { La embocadura del silbato se sitúa en la cola de la } \\
\text { paloma formando parte de la estructura del animal. El } \\
\text { bisel el pequeño y redondeado, se encuentra justo antes } \\
\text { de la base del instrumento en la parte de la cola. }\end{array}$ \\
\hline
\end{tabular}

\section{Datos arqueológicos}

\begin{tabular}{|l|l|}
\hline Yacimiento & $\begin{array}{l}\text { Solar Calle Alcázar-Altozano Deán Pérez de Vargas y } \\
\text { Parras }\end{array}$ \\
\hline $\begin{array}{l}\text { Responsable de la } \\
\text { excavación }\end{array}$ & José Carlos Armenteros \\
\hline
\end{tabular}

\section{Bibliografía}

\begin{tabular}{|l|l|}
\hline Documentación del Museo & Pieza con ficha de catalogación. \\
\hline Castillo Armentes
\end{tabular}

Castillo Armenteros, J. Carlos. "Excavación Arqueológica realizada en el solar sito entre las calles Alcázar-Altozano Deán Pérez de Vargas y Parras, de la localidad de Andújar (Jaén)". Anuario Arqueológico de Andalucía, Tomo III, (1989): 276-291; Villar Raso, Manuel (com.). El Zoco: vida económica y artes tradicionales en AlAndalus y Marruecos. Fundación El legado andalusí, (1995): 139; Rosselló Bordoy, Guillermo, Ana Navarro Ortega e Isabel Flores Escobosa. Del rito al juego: juguetes y silbatos de cerámica desde el islam hasta la actualidad. Junta de Andalucía, 2006,

174; Red Digital de Colecciones de Museos en España: http://ceres.mcu.es/pages/Main?idt=122498\&inventary $=$ DJ\%2FDA02885\&table=FM US\&museum=MJ\#.XkuaGg997Gk (Última consulta: 18-02-2020). 


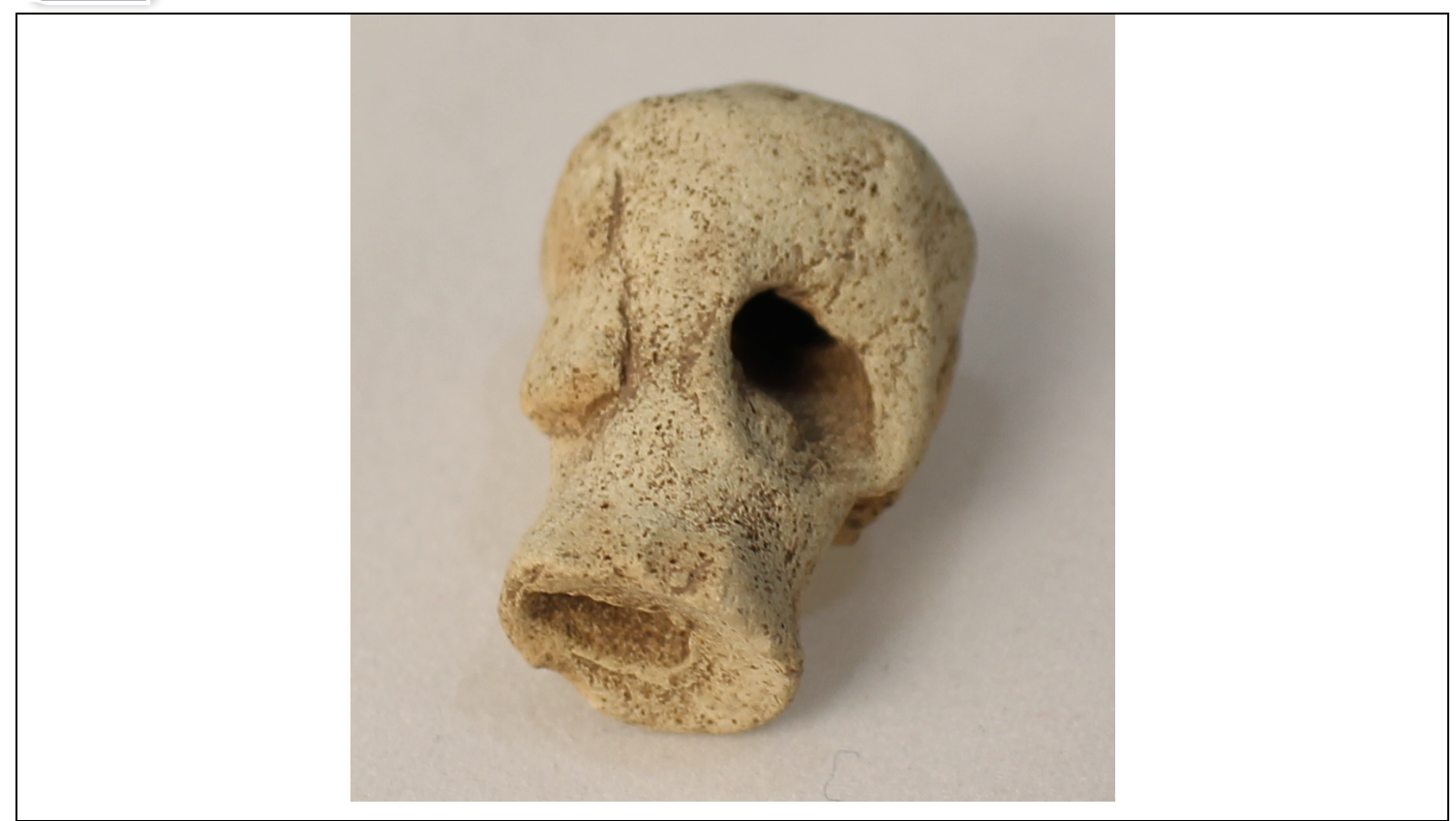

Datos generales

\begin{tabular}{|l|l|}
\hline Nombre & Silbato \\
\hline $\mathbf{N}^{\mathbf{0}}$ de inventario & EST09-789 \\
\hline Ubicación actual & Museo Arqueológico de Estepona \\
\hline Procedencia & Castillo \\
\hline Dimensiones & - \\
\hline Ciudad & Málaga \\
\hline Cronología & ss. XII-XIII (Almohade) \\
\hline $\begin{array}{l}\text { Características } \\
\text { morfológicas }\end{array}$ & $\begin{array}{l}\text { Silbato de pequeño tamaño con unas escamas en los lados } \\
\text { como único adorno. }\end{array}$ \\
\hline Materiales & Arcilla \\
\hline
\end{tabular}

Datos organológicos

\begin{tabular}{|l|l|}
\hline Tipo de instrumento & Aerófono \\
\hline $\begin{array}{l}\text { Clasificación por } \\
\text { estructura física }\end{array}$ & B.5. Silbatos globulares con otras formas \\
\hline $\begin{array}{l}\text { Clasificación } \\
\text { organológica }\end{array}$ & $\begin{array}{l}421.221 .41 \text { Flautas globulares con canal de insuflación } \\
\text { interno sin agujeros digitales }\end{array}$ \\
\hline
\end{tabular}




\begin{tabular}{|l|l|}
\hline Función & Lúdica \\
\hline Fabricación & Alfares \\
\hline Características & $\begin{array}{l}\text { Silbato con embocadura acampanada y cavidad } \\
\text { musicales }\end{array}$ \\
& \begin{tabular}{l} 
plano y un bisel circular. \\
\hline
\end{tabular} \\
\hline
\end{tabular}

Datos arqueológicos

\begin{tabular}{|l|l|}
\hline Yacimiento & Castillo de Estepona \\
\hline $\begin{array}{l}\text { Responsable de la } \\
\text { excavación }\end{array}$ & Ildefonso Navarro \\
\hline
\end{tabular}

\section{Bibliografía}

Documentación del Museo

Pieza inventariada.

Inédito 


\section{Anexos III: Membranófonos}

\section{$N^{\mathrm{a}} 1$}

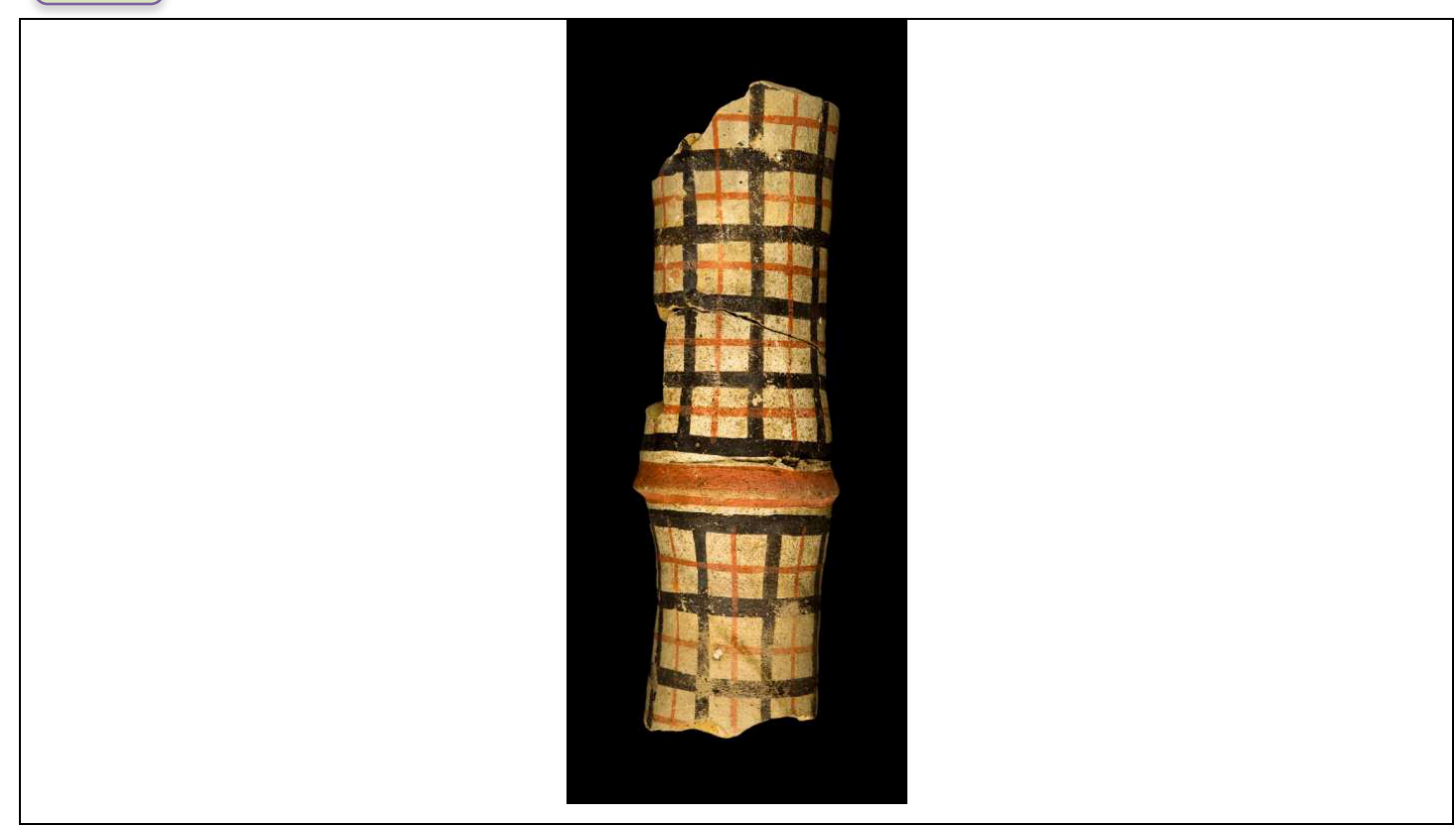

Datos generales

\begin{tabular}{|l|l|}
\hline Nombre & Tambor \\
\hline $\mathbf{N}^{\mathbf{0}}$ de inventario & CE28175 \\
\hline Ubicación actual & Museo Arqueológico de Almería \\
\hline Procedencia & Alcazaba de Almería \\
\hline Dimensiones & Alto: $21 \mathrm{~cm}$; Ancho: $7 \mathrm{~cm}$ \\
\hline Ciudad & Almería \\
\hline Cronología & ss. XII-XIII (Almohade) \\
\hline Características morfológicas & $\begin{array}{l}\text { Tambor de forma cilíndrica dividido en dos } \\
\text { partes por una moldura central. Su } \\
\text { superficie cuenta con decoración geométrica } \\
\text { con rectángulos irregulares rojos y negros. }\end{array}$ \\
\hline Materiales & Arcilla \\
\hline
\end{tabular}

\section{Datos organológicos}

\begin{tabular}{|l|l|}
\hline Tipo de instrumento & Membranófono \\
\hline Clasificación organológica & $211.211 .1 \quad$ Unimembranófonos cilíndricos \\
\hline
\end{tabular}




\begin{tabular}{|l|l|}
\hline Función & individuales \\
\hline Fabricación & Lúdica o religiosa \\
\hline \multirow{2}{*}{ Características musicales } & Alfares \\
\hline & $\begin{array}{l}\text { Posiblemente un unimembranófono tubular } \\
\text { de forma cilíndrica. Una de sus partes } \\
\text { parece contar con mayor diámetro lo que } \\
\text { recuerda al instrumento encontrado en Los } \\
\text { Guájares. }\end{array}$ \\
\hline
\end{tabular}

\section{Datos arqueológicos}

\begin{tabular}{|l|l|}
\hline Yacimiento & Alcazaba de Almería \\
\hline Responsable de la excavación & - \\
\hline
\end{tabular}

\section{Bibliografía}

\begin{tabular}{|l|l|}
\hline Documentación del Museo & Pieza con ficha de catalogación. \\
\hline Jiménez Pasalodos, Raquel y Alexandra Bill. "Los tambores de cerámica de al- \\
Andalus (ss. VIII-XIV): una aproximación desde la Arqueología Musical". \\
Nassarre, (2012): 15; Bill Alexandra, Raquel Jiménez Pasalodos y Carlos García \\
Benito. "A classification of clay drums from al-Andalus (9th-14th Centuries AD)". \\
En Proceedings of the 16th Symposium on Mediterranean Archaeology, (2012): \\
893-894.
\end{tabular}




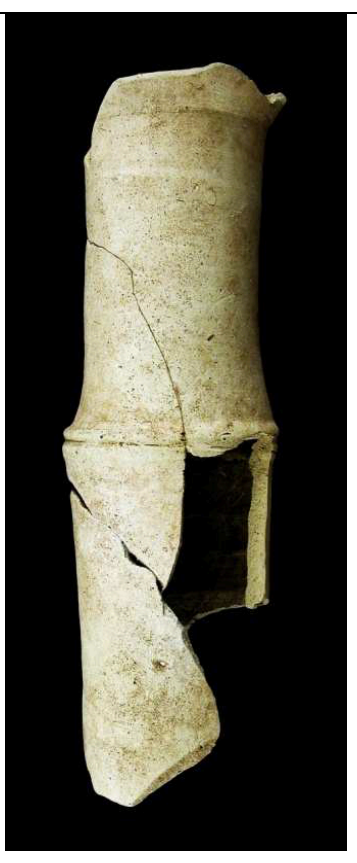

Datos generales

\begin{tabular}{|l|l|}
\hline Nombre & Tambor (fragmento) \\
\hline $\mathbf{N}^{\mathbf{0}}$ de inventario & CE28029 \\
\hline Ubicación actual & Museo Arqueológico de Almería \\
\hline Procedencia & Alcazaba de Almería \\
\hline Dimensiones & Alto: $22,2 \mathrm{~cm}$; Ancho: $6,5 \mathrm{~cm}$ \\
\hline Ciudad & Almería \\
\hline Cronología & ss. XI-XV (Califal-Nazarí) \\
\hline morfológicas & $\begin{array}{l}\text { Fragmento de tambor del que se conserva la parte media } \\
\text { del mismo. Se aprecia un adorno en la parte media más } \\
\text { grueso que el resto del tubo desde el que parten cada una } \\
\text { de las partes del instrumento. }\end{array}$ \\
\hline Materiales & Arcilla \\
\hline
\end{tabular}

\section{Datos organológicos}

\begin{tabular}{|l|l|}
\hline Tipo de instrumento & Membranófono \\
\hline $\begin{array}{l}\text { Clasificación } \\
\text { organológica }\end{array}$ & 211.211 .1 Unimembranófonos cilíndricos individuales \\
\hline
\end{tabular}




\begin{tabular}{|l|l|}
\hline Función & Lúdica o religiosa \\
\hline Fabricación & Alfares \\
\hline $\begin{array}{l}\text { Características } \\
\text { musicales }\end{array}$ & Membranófono de cuerpo tubular. \\
\hline
\end{tabular}

Datos arqueológicos

\begin{tabular}{|l|l|}
\hline Yacimiento & - \\
\hline $\begin{array}{l}\text { Responsable de la } \\
\text { excavación }\end{array}$ & - \\
\hline
\end{tabular}

Bibliografía

\begin{tabular}{|l|l}
\hline Documentación del Museo & Pieza con ficha de catalogación.
\end{tabular}

Inédito 


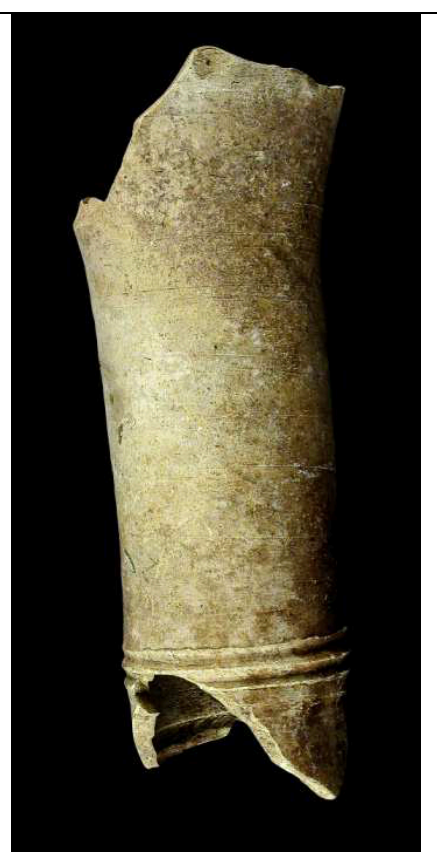

\section{Datos generales}

\begin{tabular}{|l|l|}
\hline Nombre & Tambor (fragmento) \\
\hline $\mathbf{N}^{\mathbf{0}}$ de inventario & CE28028 \\
\hline Ubicación actual & Museo Arqueológico de Almería \\
\hline Procedencia & Alcazaba de Almería \\
\hline Dimensiones & Alto: $18,5 \mathrm{~cm}$; Ancho: $6,5 \mathrm{~cm}$ \\
\hline Ciudad & Almería \\
\hline Cronología & Ss. XI-XV (Califal-Nazarí) \\
\hline Características & $\begin{array}{l}\text { Fragmento de tambor del que se conserva la parte media } \\
\text { del mismo. Se aprecia un adorno en la parte media más } \\
\text { grueso que el resto del tubo desde el que parten cada una } \\
\text { de las partes del instrumento. }\end{array}$ \\
\hline Materiales & Arcilla \\
\hline
\end{tabular}

\section{Datos organológicos}

\begin{tabular}{|l|l|}
\hline Tipo de instrumento & Membranófono \\
\hline $\begin{array}{l}\text { Clasificación } \\
\text { organológica }\end{array}$ & 211.211 .1 Unimembranófonos cilíndricos individuales \\
\hline
\end{tabular}




\begin{tabular}{|l|l|}
\hline Función & Lúdica o religiosa \\
\hline Fabricación & Alfares \\
\hline $\begin{array}{l}\text { Características } \\
\text { musicales }\end{array}$ & Membranófono de cuerpo tubular. \\
\hline
\end{tabular}

Datos arqueológicos

\begin{tabular}{|l|l|}
\hline Yacimiento & - \\
\hline $\begin{array}{l}\text { Responsable de la } \\
\text { excavación }\end{array}$ & - \\
\hline
\end{tabular}

Bibliografía

\begin{tabular}{|l|l}
\hline Documentación del Museo & Pieza con ficha de catalogación.
\end{tabular}

Inédito 


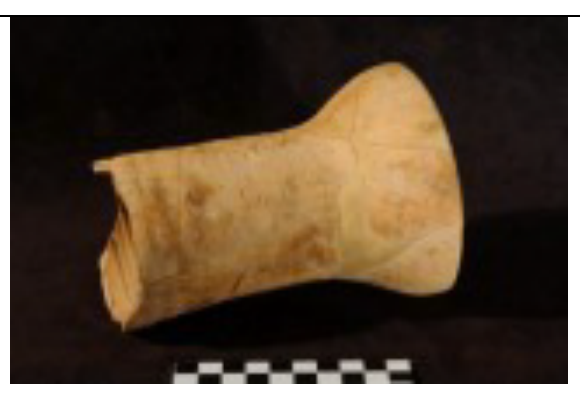

Datos generales

\begin{tabular}{|c|c|}
\hline Nombre & Tambor \\
\hline $\mathrm{N}^{0}$ de inventario & BEL-04/UE 274 \\
\hline Ubicación actual & Museo Arqueológico Jerez \\
\hline Procedencia & Plaza de Belén (Jerez de la Frontera) \\
\hline Dimensiones & Alto: $15,5 \mathrm{~cm}$; Ancho: $10,8 \mathrm{~cm}$ \\
\hline Ciudad & Cádiz \\
\hline Cronología & s. X (Califal) \\
\hline $\begin{array}{l}\text { Características } \\
\text { morfológicas }\end{array}$ & $\begin{array}{l}\text { Tambor de cerámica con pie cilíndrico y boca en forma de } \\
\text { copa. Parte de su cuerpo tubular se ha perdido. }\end{array}$ \\
\hline Materiales & Arcilla \\
\hline
\end{tabular}

\section{Datos organológicos}

\begin{tabular}{|l|l|}
\hline Tipo de instrumento & Membranófono \\
\hline $\begin{array}{l}\text { Clasificación } \\
\text { organológica }\end{array}$ & 211.26 Membranófonos en forma de copa \\
\hline Función & Lúdica o religiosa \\
\hline Fabricación & Alfares \\
\hline $\begin{array}{l}\text { Características } \\
\text { musicales }\end{array}$ & Unimembranófono de copa \\
\hline
\end{tabular}


Datos arqueológicos

\begin{tabular}{|l|l|}
\hline Yacimiento & Contexto doméstico. \\
\hline $\begin{array}{l}\text { Responsable de la } \\
\text { excavación }\end{array}$ & Domingo Martín Mochales \\
\hline
\end{tabular}

Bibliografía

\begin{tabular}{|l|l|}
\hline Documentación del Museo & Pieza con ficha de catalogación. \\
\hline Jiménez Pasalodos, Raquel y Alexandra Bill. "Los tambores de cerámica de al- \\
Andalus (ss. VIII-XIV): una aproximación desde la Arqueología Musical”. Nassarre, \\
(2012): 13-42; Bill Alexandra, Raquel Jiménez Pasalodos y Carlos García Benito. "A \\
classification of clay drums from al-Andalus (9th-14th Centuries AD)”. En \\
Proceedings of the 16th Symposium on Mediterranean Archaeology, 2012, 1103- \\
1104; García Benito, Carlos. "Arqueología Musical Prehistórica: aproximación a \\
través de la Arqueología Experimental aplicada a la Arqueo-Organología, de la \\
Arqueoacústica y de la Iconografía Musical Prehistórica". Tesis doctoral, Universidad \\
de Zaragoza, 2014.
\end{tabular}




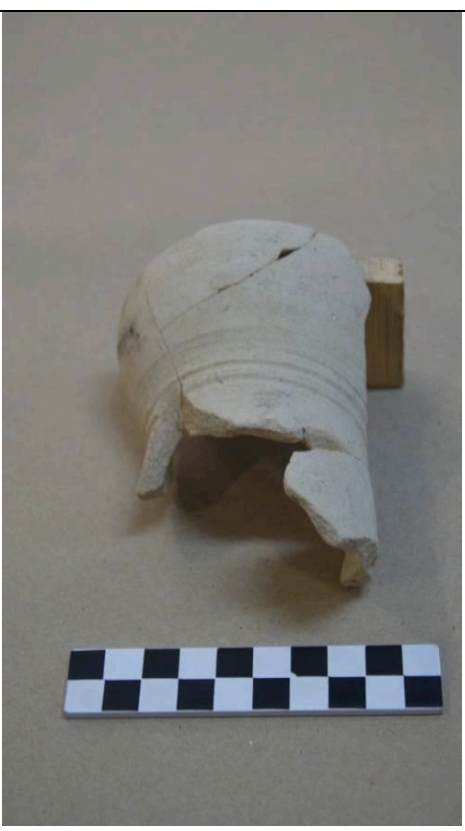

Datos generales

\begin{tabular}{|l|l|}
\hline Nombre & Tambor \\
\hline $\mathbf{N}^{\mathbf{0}}$ de inventario & JUS-39/94/3/1 \\
\hline Ubicación actual & Museo Arqueológico Jerez \\
\hline Procedencia & Calle Justicia, Jerez de la Frontera \\
\hline Dimensiones & Alto: $6,7 \mathrm{~cm}$; Diámetro máximo: $6,8 \mathrm{~cm}$ \\
\hline Ciudad & Cádiz \\
\hline Cronología & s. XII (Almohade) \\
\hline Características & $\begin{array}{l}\text { Fragmento de tambor del que se conserva parte de su boca } \\
\text { morfológicas }\end{array}$ \\
$\begin{array}{l}\text { inicio de la copa realizado mediante incisiones circulares } \\
\text { por el contorno del cuerpo. }\end{array}$ \\
\hline Materiales & Arcilla \\
\hline
\end{tabular}

\section{Datos organológicos}

\begin{tabular}{|l|l|}
\hline Tipo de instrumento & Membranófono \\
\hline $\begin{array}{l}\text { Clasificación } \\
\text { organológica }\end{array}$ & 211.26 Membranófonos en forma de copa \\
\hline
\end{tabular}




\begin{tabular}{|l|l|}
\hline Función & Lúdica o religiosa \\
\hline Fabricación & Alfares \\
\hline $\begin{array}{l}\text { Características } \\
\text { musicales }\end{array}$ & $\begin{array}{l}\text { Unimembranófono con forma tubular, su boca termina en } \\
\text { forma de copa. }\end{array}$ \\
\hline
\end{tabular}

Datos arqueológicos

\begin{tabular}{|l|l|}
\hline Yacimiento & Calle Justicia \\
\hline $\begin{array}{l}\text { Responsable de la } \\
\text { excavación }\end{array}$ & - \\
\hline
\end{tabular}

\section{Bibliografía}

\begin{tabular}{|l|l|}
\hline Documentación del Museo & Pieza con ficha de catalogación. \\
\hline Aguilar Moya, Laureano, Rosalía González Rodríguez y Francisco Barrionuevo \\
Contreras. "El asentamiento prealmohade de Jerez de la Frontera (Cádiz)". Spal, vol. \\
7, (1998): 166; Bill, Alexandra, Raquel Jiménez Pasalodos y Carlos García Benito. \\
“A classification of clay drums from al-Andalus (9th-14th Centuries AD)". En \\
Proceedings of the 16th Symposium on Mediterranean Archaeology, (2012): 1103- \\
1104; García Benito, Carlos. "Arqueología Musical Prehistórica: aproximación a \\
través de la Arqueología Experimental aplicada a la Arqueo-Organología, de la \\
Arqueoacústica y de la Iconografía Musical Prehistórica". Tesis doctoral, Universidad \\
de Zaragoza, 2014.
\end{tabular}




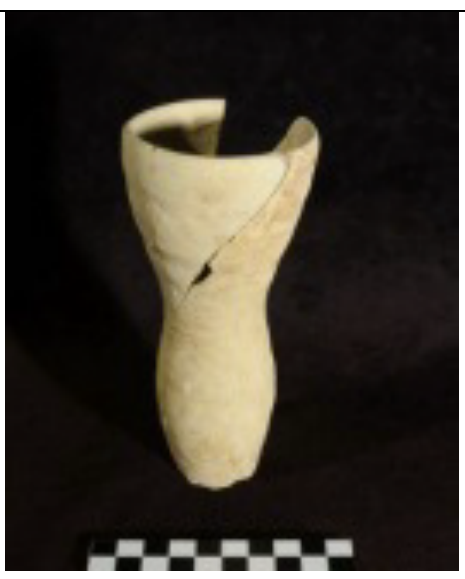

Datos generales

\begin{tabular}{|l|l|}
\hline Nombre & Tambor \\
\hline $\mathbf{N}^{\mathbf{0}}$ de inventario & $\mathrm{J} / 03 / \mathrm{E} 21 / 20$ \\
\hline Ubicación actual & Museo Arqueológico Jerez \\
\hline Procedencia & Calle Salas, 8 \\
\hline Dimensiones & Alto: $15 \mathrm{~cm}$; Diámetro boca: $3,6 \mathrm{~cm}$ \\
\hline Ciudad & Cádiz \\
\hline Cronología & ss. XII-XIII (Almohade) \\
\hline $\begin{array}{l}\text { Características } \\
\text { morfológicas }\end{array}$ & $\begin{array}{l}\text { Tambor con cuerpo tubular ligeramente abombado con } \\
\text { base e inicio de la copa más estrechos que el resto del } \\
\text { cuerpo. }\end{array}$ \\
\hline Materiales & Arcilla \\
\hline
\end{tabular}

\section{Datos organológicos}

\begin{tabular}{|l|l|}
\hline Tipo de instrumento & Membranófono \\
\hline $\begin{array}{l}\text { Clasificación } \\
\text { organológica }\end{array}$ & 211.26 Membranófonos en forma de copa \\
\hline Función & Lúdica o religiosa \\
\hline Fabricación & Alfares \\
\hline $\begin{array}{l}\text { Características } \\
\text { musicales }\end{array}$ & $\begin{array}{l}\text { No se conserva toda la boca del instrumento pero sí es } \\
\text { perceptible su forma de copa. }\end{array}$ \\
\hline
\end{tabular}




\section{Datos arqueológicos}

\begin{tabular}{|l|l|}
\hline Yacimiento & Calle Salas 8 (esquina con calle Justicia) \\
\hline $\begin{array}{l}\text { Responsable de la } \\
\text { excavación }\end{array}$ & Francisco Carrero Ramírez \\
\hline
\end{tabular}

\section{Bibliografía}

\begin{tabular}{|l|l|}
\hline Documentación del Museo & Pieza con ficha de catalogación. \\
\hline Jiménez Pasalodos, Raquel y Alexandra Bill. "Los tambores de cerámica de al- \\
Andalus (ss. VIII-XIV): una aproximación desde la Arqueología Musical”. Nassarre, \\
(2012): 13-42; Bill, Alexandra, Raquel Jiménez Pasalodos y Carlos García Benito. “A \\
classification of clay drums from al-Andalus (9th-14th Centuries AD)”. En \\
Proccedings of the 16th Symposium on Mediterranean Archaeology, (2012): 1103- \\
1104; García Benito, Carlos. "Arqueología Musical Prehistórica: aproximación a \\
través de la Arqueología Experimental aplicada a la Arqueo-Organología, de la \\
Arqueoacústica y de la Iconografía Musical Prehistórica". Tesis doctoral, Universidad \\
de Zaragoza, 2014.
\end{tabular}




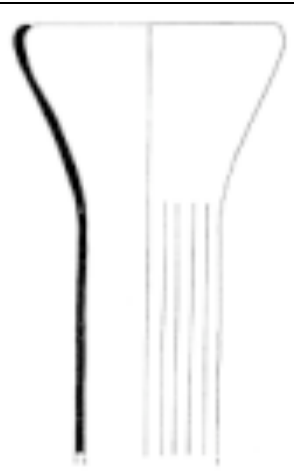

\section{Datos generales}

\begin{tabular}{|l|l|}
\hline Nombre & Tambor \\
\hline $\mathbf{N}^{\mathbf{0}}$ de inventario & - \\
\hline Ubicación actual & Museo Histórico de Villamartín \\
\hline Procedencia & Villamartín, Cádiz \\
\hline Dimensiones & Alto: $25 \mathrm{~cm}$; Diámetro: $11,1 \mathrm{~cm}$ \\
\hline Ciudad & Cádiz \\
\hline Cronología & ss. VIII-X (Emiral) \\
\hline $\begin{array}{l}\text { Características } \\
\text { morfológicas }\end{array}$ & $\begin{array}{l}\text { Unimembranófono de cerámica cilíndrico con forma de } \\
\text { copa. }\end{array}$ \\
\hline Materiales & Arcilla \\
\hline
\end{tabular}

\section{Datos organológicos}

\begin{tabular}{|l|l|}
\hline Tipo de instrumento & Membranófono \\
\hline $\begin{array}{l}\text { Clasificación } \\
\text { organológica }\end{array}$ & 211.26 Membranófonos en forma de copa \\
\hline Función & Lúdica o religiosa \\
\hline Fabricación & Alfares \\
\hline $\begin{array}{l}\text { Características } \\
\text { musicales }\end{array}$ & Unimembranófono con forma de copa. \\
\hline
\end{tabular}


Datos arqueológicos

\begin{tabular}{|l|l|}
\hline Yacimiento & Torrevieja \\
\hline $\begin{array}{l}\text { Responsable de la } \\
\text { excavación }\end{array}$ & José María Gutiérrez López \\
\hline
\end{tabular}

\section{Bibliografía}

\begin{tabular}{|l|l}
\hline Documentación del Museo & Pieza no inventariada. \\
\hline
\end{tabular}

Gutiérrez López, José María. "Intervención arqueológica de urgencia en el yacimiento de Torrevieja (Casco urbano de Villamartín, Cádiz)". Anuario Arqueológico de Andalucía. (1999): 122-141; Jiménez Pasalodos, Raquel y Alexandra Bill. "Los tambores de cerámica de al-Andalus (ss. VIII-XIV): una aproximación desde la Arqueología Musical”. Nassarre, (2012): 15; Bill, Alexandra, Raquel Jiménez Pasalodos y Carlos García Benito. "A classification of clay drums from al-Andalus (9th-14th Centuries AD)". En Proccedings of the 16th Symposium on Mediterranean Archaeology, (2012): 1103. 


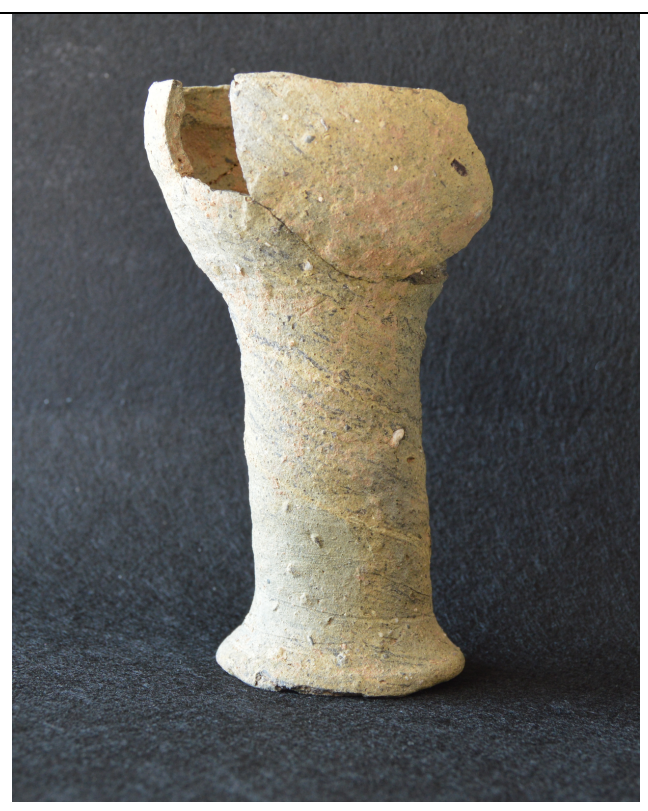

Datos generales

\begin{tabular}{|l|l|}
\hline Nombre & Tambor \\
\hline $\mathbf{N}^{\mathbf{0}}$ de inventario & B912 \\
\hline Ubicación actual & Museo Arqueológico y Etnológico de Córdoba \\
\hline Procedencia & Avenida de las Ollerías (Córdoba) \\
\hline Dimensiones & Alto: $22,3 \mathrm{~cm}$; Diámetro mayor: $11,8 \mathrm{~cm}$ \\
\hline Ciudad & Córdoba \\
\hline Cronología & ss. VIII-XII (Emiral-Califal) \\
\hline Características & $\begin{array}{l}\text { Tambor con pie plano cuerpo tubular y forma de copa. Se } \\
\text { encuentra la boca del mismo fracturada y reconstruida. No } \\
\text { cuenta con adornos o pintura. }\end{array}$ \\
\hline Materiales & Arcilla \\
\hline
\end{tabular}

Datos organológicos

\begin{tabular}{|l|l|}
\hline Tipo de instrumento & Membranófono \\
\hline $\begin{array}{l}\text { Clasificación } \\
\text { organológica }\end{array}$ & 211.26 Membranófonos en forma de copa \\
\hline Función & Lúdica o religiosa \\
\hline
\end{tabular}




\begin{tabular}{|l|l|}
\hline Fabricación & Alfares \\
\hline $\begin{array}{l}\text { Características } \\
\text { musicales }\end{array}$ & $\begin{array}{l}\text { Unimembranófono con forma de copa. Cuenta con un pie } \\
\text { plano. }\end{array}$ \\
\hline
\end{tabular}

Datos arqueológicos

\begin{tabular}{|l|l|}
\hline Yacimiento & Avenida Ollerías \\
\hline $\begin{array}{l}\text { Responsable de la } \\
\text { excavación }\end{array}$ & Antonio Molina Expósito y Agustín López Jiménez \\
\hline
\end{tabular}

\section{Bibliografía}

\begin{tabular}{|l|l|}
\hline Documentación del Museo & Pieza con ficha de catalogación. \\
\hline García Benito, Carlos. “Arqueología Musical Prehistórica: aproximación a través de \\
la Arqueología Experimental aplicada a la Arqueo-Organología, de la Arqueoacústica \\
y de la Iconografía Musical Prehistórica”. Tesis doctoral, Universidad de Zaragoza, \\
2014.
\end{tabular}




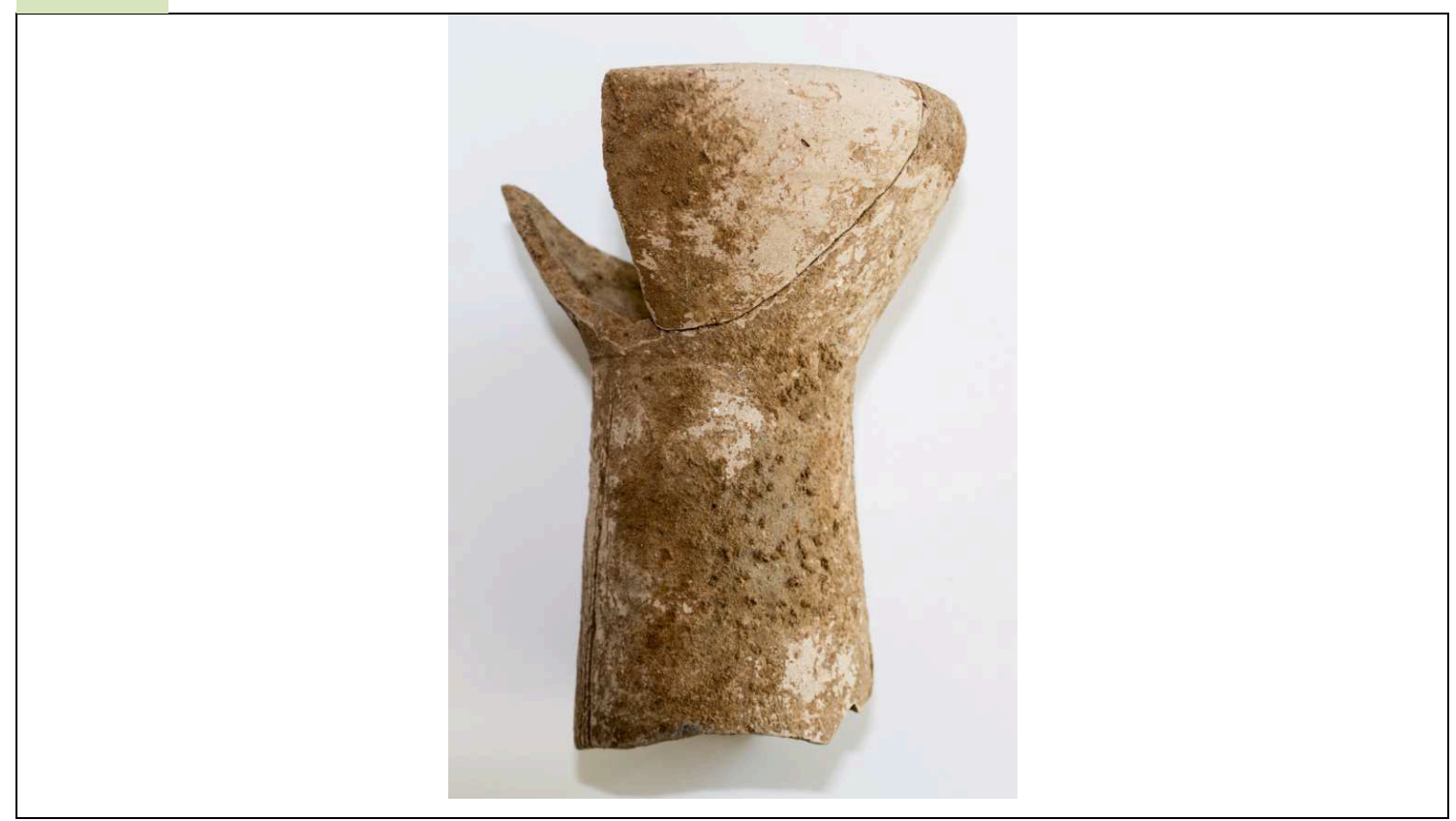

\section{Datos generales}

\begin{tabular}{|l|l|}
\hline Nombre & Tambor \\
\hline $\mathbf{N}^{\mathbf{0}}$ de inventario & - \\
\hline Ubicación actual & Museo Arqueológico y Etnológico de Córdoba \\
\hline Procedencia & Yacimiento de Cercadilla (Córdoba) \\
\hline Dimensiones & Alto: $12,8 \mathrm{~cm}$; Diámetro de la boca: $10,5 \mathrm{~cm}$ \\
\hline Ciudad & Córdoba \\
\hline Cronología & ss. VIII-XII (Emiral-Califal) \\
\hline $\begin{array}{l}\text { Características } \\
\text { morfológicas }\end{array}$ & Tambor con boca restaurada. \\
\hline Materiales & Arcilla \\
\hline
\end{tabular}

\section{Datos organológicos}

\begin{tabular}{|l|l|}
\hline Tipo de instrumento & Membranófono \\
\hline $\begin{array}{l}\text { Clasificación } \\
\text { organológica }\end{array}$ & 211.26 Membranófonos en forma de copa \\
\hline Función & Lúdica o religiosa \\
\hline Fabricación & Alfares \\
\hline
\end{tabular}




\begin{tabular}{|l|l|}
\hline $\begin{array}{l}\text { Características } \\
\text { musicales }\end{array}$ & Tambor con cuerpo tubular y boca en forma de copa. \\
\hline
\end{tabular}

Datos arqueológicos

\begin{tabular}{|l|l|}
\hline Yacimiento & Cercadilla \\
\hline $\begin{array}{l}\text { Responsable de la } \\
\text { excavación }\end{array}$ & - \\
\hline
\end{tabular}

\section{Bibliografía}

\begin{tabular}{|l|l|}
\hline Documentación del Museo & Pieza en estudio. \\
\hline Fuertes Santos, María del Camino. La cerámica califal del yacimiento de Cercadilla, \\
Córdoba. Sevilla: 2002, 142; González Vírseda, Marina y María del Camino Fuertes \\
Santos. "Nuevos materiales cerámicos emirales de Cercadilla (Córdoba): ensayo \\
tipológico". En Anales de arqueología cordobesa. Facultad de Filosofía y Letras, \\
(1994): 277-302.
\end{tabular}




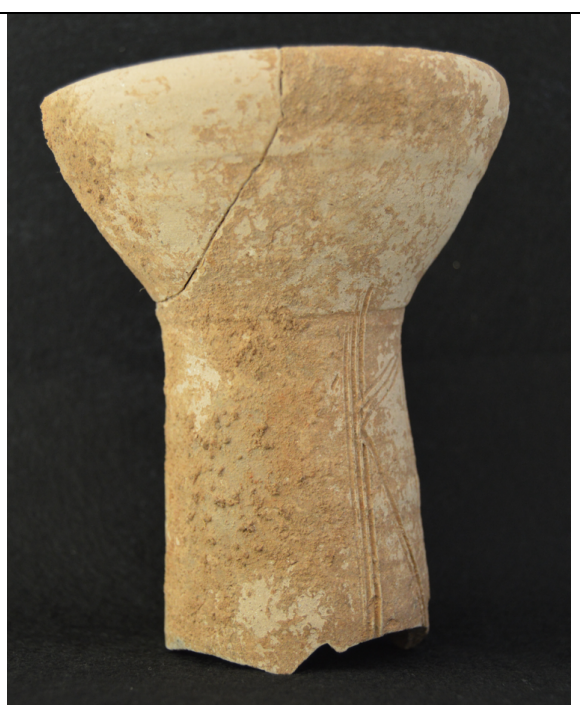

\section{Datos generales}

\begin{tabular}{|c|c|}
\hline Nombre & Tambor \\
\hline $\mathrm{N}^{0}$ de inventario & $18 / 2508$ \\
\hline Ubicación actual & Museo Arqueológico y Etnológico de Córdoba \\
\hline Procedencia & Yacimiento de Cercadilla (Córdoba) \\
\hline Dimensiones & Alto: $13,2 \mathrm{~cm}$; Ancho: $10,9 \mathrm{~cm}$ \\
\hline Ciudad & Córdoba \\
\hline Cronología & ss. X-XI (Califal) \\
\hline $\begin{array}{l}\text { Características } \\
\text { morfológicas }\end{array}$ & $\begin{array}{l}\text { Tambor con adornos realizados mediante incisiones en } \\
\text { parte de su cuerpo. Un fragmento de la boca del } \\
\text { instrumento está restaurada pero no se conserva entera. }\end{array}$ \\
\hline Materiales & Arcilla \\
\hline
\end{tabular}

\section{Datos organológicos}

\begin{tabular}{|l|l|}
\hline Tipo de instrumento & Membranófono \\
\hline $\begin{array}{l}\text { Clasificación } \\
\text { organológica }\end{array}$ & 211.26 Membranófonos en forma de copa \\
\hline Función & Lúdica o religiosa \\
\hline Fabricación & Alfares \\
\hline Características & Unimembranófono con cuerpo tubular y boca en forma de \\
\hline
\end{tabular}




\begin{tabular}{|l|l|}
\hline musicales & $\begin{array}{l}\text { copa. El filo del instrumento donde se tensaría la } \\
\text { membrana realiza como un amago de pliegue hacia el } \\
\text { interior del instrumento. }\end{array}$ \\
\hline
\end{tabular}

\section{Datos arqueológicos}

\begin{tabular}{|l|l|}
\hline Yacimiento & Cercadilla \\
\hline $\begin{array}{l}\text { Responsable de la } \\
\text { excavación }\end{array}$ & - \\
\hline
\end{tabular}

\section{Bibliografía}

\begin{tabular}{|l|l|}
\hline Documentación del Museo & Pieza inventariada. \\
\hline
\end{tabular}

Fuertes Santos, María del Camino. La cerámica califal del yacimiento de Cercadilla, Córdoba. Sevilla: 2002, 142; González Vírseda, Marina y María del Camino Fuertes Santos. "Nuevos materiales cerámicos emirales de Cercadilla (Córdoba): ensayo tipológico". En Anales de arqueología cordobesa. Facultad de Filosofía y Letras. (1994): 277-302; García Benito, Carlos. “Arqueología Musical Prehistórica: aproximación a través de la Arqueología Experimental aplicada a la ArqueoOrganología, de la Arqueoacústica y de la Iconografía Musical Prehistórica”. Tesis doctoral, Universidad de Zaragoza, 2014. 


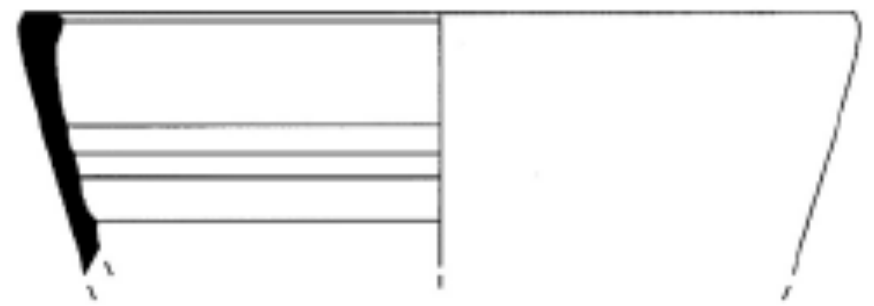

26.1.A.1.2.

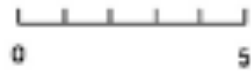

\section{Datos generales}

\begin{tabular}{|l|l|}
\hline Nombre & Tambor (fragmento) \\
\hline $\mathbf{N}^{\mathbf{0}}$ de inventario & - \\
\hline Ubicación actual & Museo Arqueológico y Etnológico de Córdoba \\
\hline Procedencia & Yacimiento de Cercadilla (Córdoba) \\
\hline Dimensiones & Alto: $5,4 \mathrm{~cm}$ \\
\hline Ciudad & Córdoba \\
\hline Cronología & s. IX (Emiral) \\
\hline Características & Fragmento de tambor con forma hemisférica \\
\hline Morfológicas & Arcilla \\
\hline
\end{tabular}

\section{Datos organológicos}

\begin{tabular}{|l|l|}
\hline Tipo de instrumento & Membranófono \\
\hline $\begin{array}{l}\text { Clasificación } \\
\text { organológica }\end{array}$ & 211.26 Membranófonos en forma de copa \\
\hline Función & Lúdica o religiosa \\
\hline Fabricación & Alfares \\
\hline $\begin{array}{l}\text { Características } \\
\text { musicales }\end{array}$ & Fragmento de boca de tambor en forma de copa. \\
\hline
\end{tabular}


Datos arqueológicos

\begin{tabular}{|l|l|}
\hline Yacimiento & Cercadilla \\
\hline $\begin{array}{l}\text { Responsable de la } \\
\text { excavación }\end{array}$ & María del Camino Fuentes Santos \\
\hline
\end{tabular}

Bibliografía

\begin{tabular}{|l|l|}
\hline Documentación del Museo & Pieza no inventariada. \\
\hline Fuertes Santos, María del Camino. La cerámica califal del yacimiento de Cercadilla, \\
Córdoba. Sevilla: 2002, 142; González Vírseda, Marina y María del Camino Fuertes \\
Santos. "Nuevos materiales cerámicos emirales de Cercadilla (Córdoba): ensayo \\
tipológico". En Anales de arqueología cordobesa. Facultad de Filosofía y Letras, \\
(1994): 277-302; García Benito, Carlos. “Arqueología Musical Prehistórica: \\
aproximación a través de la Arqueología Experimental aplicada a la Arqueo- \\
Organología, de la Arqueoacústica y de la Iconografía Musical Prehistórica”. Tesis \\
doctoral, Universidad de Zaragoza, 2014.
\end{tabular}




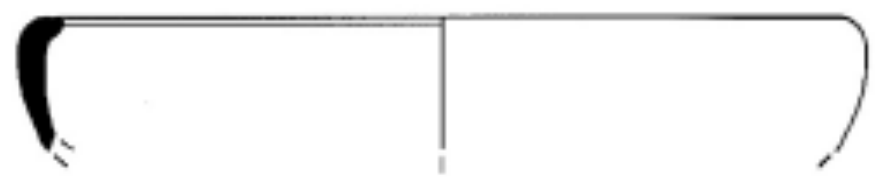

26.1.A.2.2.

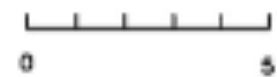

Datos generales

\begin{tabular}{|l|l|}
\hline Nombre & Tambor (fragmento) \\
\hline $\mathbf{N}^{\mathbf{0}}$ de inventario & - \\
\hline Ubicación actual & Museo Arqueológico y Etnológico de Córdoba \\
\hline Procedencia & Yacimiento de Cercadilla (Córdoba) \\
\hline Dimensiones & Alto: $3 \mathrm{~cm}$ \\
\hline Ciudad & Córdoba \\
\hline Cronología & s. IX (Emiral) \\
\hline $\begin{array}{l}\text { Características } \\
\text { morfológicas }\end{array}$ & Fragmento de tambor con copa redondeada. \\
\hline Materiales & Arcilla \\
\hline
\end{tabular}

\section{Datos organológicos}

\begin{tabular}{|l|l|}
\hline Tipo de instrumento & Membranófono \\
\hline $\begin{array}{l}\text { Clasificación } \\
\text { organológica }\end{array}$ & 211.26 Membranófonos en forma de copa \\
\hline Función & Lúdica o religiosa \\
\hline Fabricación & Alfares \\
\hline $\begin{array}{l}\text { Características } \\
\text { musicales }\end{array}$ & Fragmento de tambor con forma de copa. \\
\hline
\end{tabular}


Datos arqueológicos

\begin{tabular}{|l|l|}
\hline Yacimiento & Cercadilla \\
\hline $\begin{array}{l}\text { Responsable de la } \\
\text { excavación }\end{array}$ & María del Camino Fuentes Santos \\
\hline
\end{tabular}

\section{Bibliografía}

\begin{tabular}{|l|l|}
\hline Documentación del Museo & Pieza no inventariada. \\
\hline Fuertes Santos, María del Camino. La cerámica califal del yacimiento de Cercadilla, \\
Córdoba. Sevilla, (2002): 142; González Vírseda, Marina y María del Camino Fuertes \\
Santos. "Nuevos materiales cerámicos emirales de Cercadilla (Córdoba): ensayo \\
tipológico". En Anales de arqueología cordobesa. Facultad de Filosofía y Letras, \\
(1994): 277-302; García Benito, Carlos. “Arqueología Musical Prehistórica: \\
aproximación a través de la Arqueología Experimental aplicada a la Arqueo- \\
Organología, de la Arqueoacústica y de la Iconografía Musical Prehistórica". Tesis \\
doctoral, Universidad de Zaragoza, 2014.
\end{tabular}




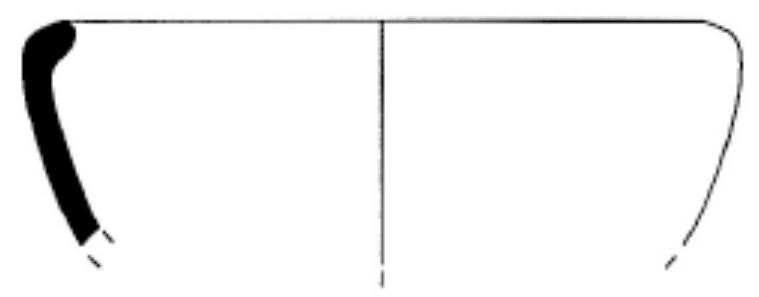

26.1.A.2.1.

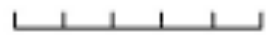

5

Datos generales

\begin{tabular}{|l|l|}
\hline Nombre & Tambor \\
\hline $\mathbf{N}^{\mathbf{0}}$ de inventario & - \\
\hline Ubicación actual & Museo Arqueológico y Etnológico de Córdoba \\
\hline Procedencia & Yacimiento de Cercadilla (Córdoba) \\
\hline Dimensiones & Alto: $5 \mathrm{~cm}$ \\
\hline Ciudad & Córdoba \\
\hline Cronología & ss. X-XI (Califal) \\
\hline $\begin{array}{l}\text { Características } \\
\text { morfológicas }\end{array}$ & Fragmento de tambor del que solo se conserva la copa. \\
\hline Materiales & Arcilla \\
\hline
\end{tabular}

\section{Datos organológicos}

\begin{tabular}{|l|l|}
\hline Tipo de instrumento & Membranófono \\
\hline $\begin{array}{l}\text { Clasificación } \\
\text { organológica }\end{array}$ & 211.26 Membranófonos en forma de copa \\
\hline Función & Lúdica o religiosa \\
\hline Fabricación & Alfares \\
\hline $\begin{array}{l}\text { Características } \\
\text { musicales }\end{array}$ & Fragmento de tambor en forma de copa. \\
\hline
\end{tabular}


Datos arqueológicos

\begin{tabular}{|l|l|}
\hline Yacimiento & Cercadilla \\
\hline $\begin{array}{l}\text { Responsable de la } \\
\text { excavación }\end{array}$ & - \\
\hline
\end{tabular}

\section{Bibliografía}

\begin{tabular}{|l|l|}
\hline Documentación del Museo & Pieza no inventariada. \\
\hline Fuertes Santos, María del Camino. La cerámica califal del yacimiento de Cercadilla, \\
Córdoba. Sevilla: 2002, 142; González Vírseda, Marina y María del Camino Fuertes \\
Santos. "Nuevos materiales cerámicos emirales de Cercadilla (Córdoba): ensayo \\
tipológico". En Anales de arqueología cordobesa. Facultad de Filosofía y Letras, \\
(1994): 277-302; García Benito, Carlos. “Arqueología Musical Prehistórica: \\
aproximación a través de la Arqueología Experimental aplicada a la Arqueo- \\
Organología, de la Arqueoacústica y de la Iconografía Musical Prehistórica". Tesis \\
doctoral, Universidad de Zaragoza, 2014.
\end{tabular}




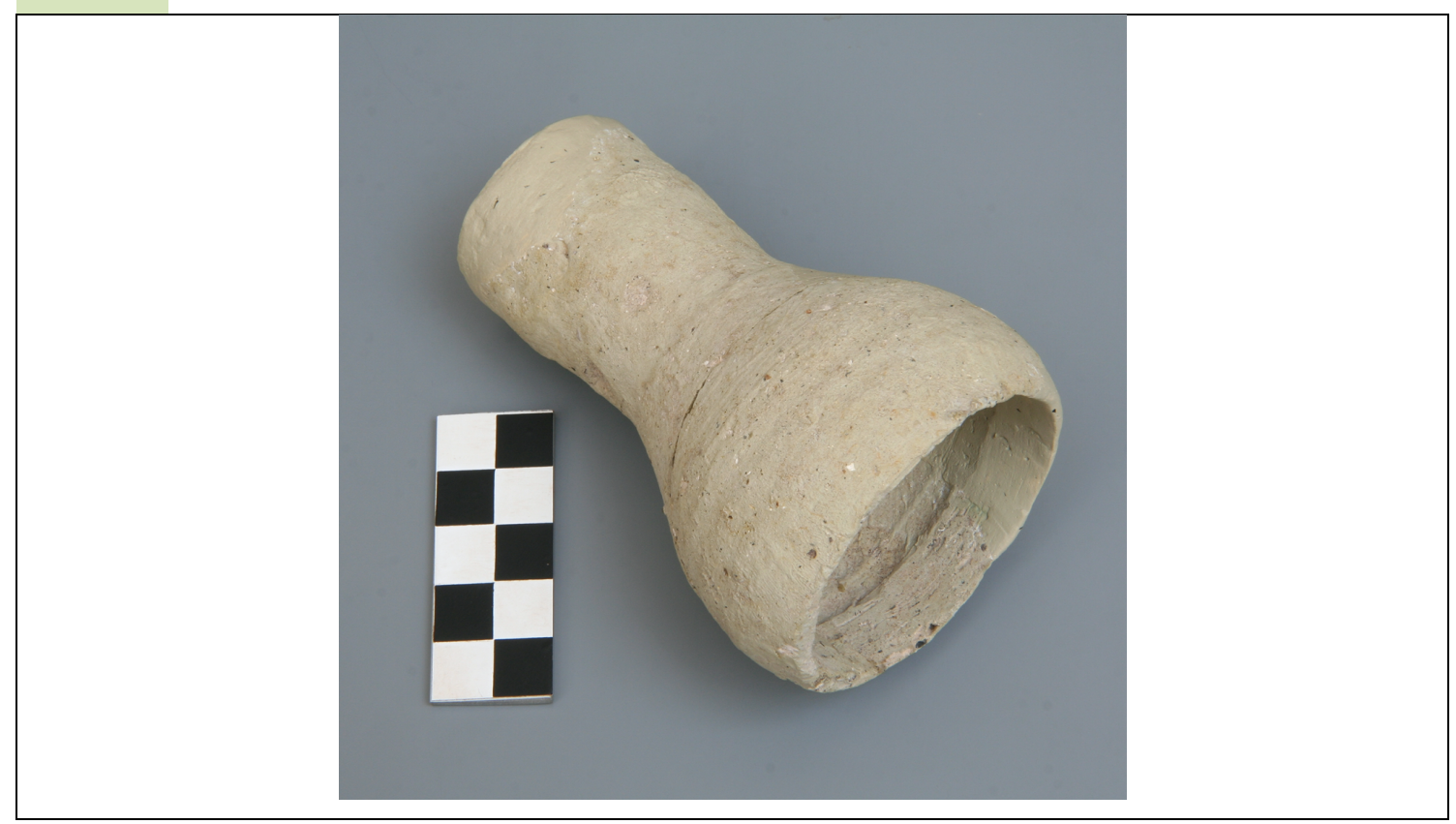

Datos generales

\begin{tabular}{|l|l|}
\hline Nombre & Tambor \\
\hline $\mathbf{N}^{\mathbf{0}}$ de inventario & - \\
\hline Ubicación actual & Museo Histórico Municipal de Priego \\
\hline Procedencia & Palenque Silo, 2 \\
\hline Dimensiones & - \\
\hline Ciudad & Córdoba \\
\hline Cronología & ss. XII-XIII (Almohade) \\
\hline $\begin{array}{l}\text { Características } \\
\text { morfológicas }\end{array}$ & $\begin{array}{l}\text { Tambor en muy buen estado de conservación tras su } \\
\text { restauración. }\end{array}$ \\
\hline Materiales & Arcilla \\
\hline
\end{tabular}

\section{Datos organológicos}

\begin{tabular}{|l|l|}
\hline Tipo de instrumento & Membranófono \\
\hline $\begin{array}{l}\text { Clasificación } \\
\text { organológica }\end{array}$ & 211.26 Membranófonos en forma de copa \\
\hline Función & Lúdica o religiosa \\
\hline
\end{tabular}




\begin{tabular}{|l|l|}
\hline Fabricación & Alfares \\
\hline $\begin{array}{l}\text { Características } \\
\text { musicales }\end{array}$ & Tamborcillo con cuerpo tubular y boca con forma de copa. \\
\hline
\end{tabular}

Datos arqueológicos

\begin{tabular}{|l|l|}
\hline Yacimiento & - \\
\hline $\begin{array}{l}\text { Responsable de la } \\
\text { excavación }\end{array}$ & Rafael Carmona Ávila \\
\hline
\end{tabular}

Bibliografía

\begin{tabular}{|l|l|}
\hline Documentación del Museo & Pieza en estudio. \\
\hline Inédito & \\
\hline
\end{tabular}




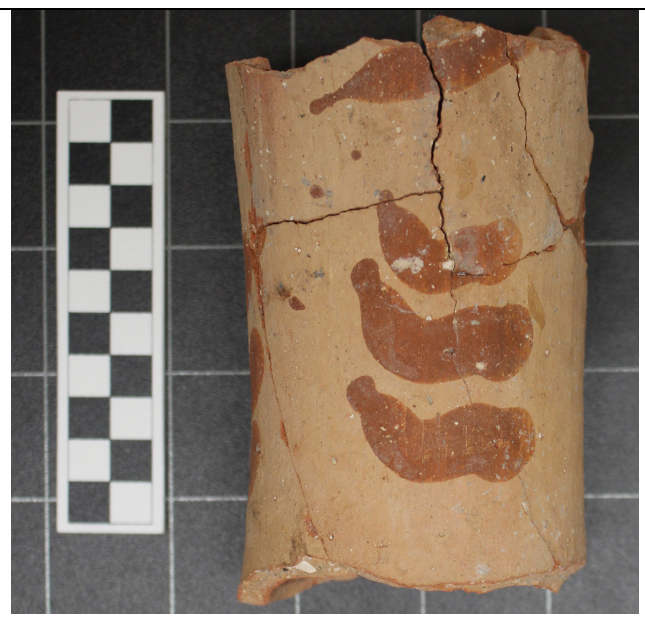

Datos generales

\begin{tabular}{|l|l|}
\hline Nombre & Tambor \\
\hline $\mathbf{N}^{\mathbf{0}}$ de inventario & - \\
\hline Ubicación actual & Museo Histórico Municipal de Priego \\
\hline Procedencia & Calle Real, 15 \\
\hline Dimensiones & - \\
\hline Ciudad & Córdoba \\
\hline Cronología & ss. XII-XIII (Almohade) \\
\hline $\begin{array}{l}\text { Características } \\
\text { morfológicas }\end{array}$ & $\begin{array}{l}\text { Fragmento pintado en rojo. Cuenta con adornos } \\
\text { anaranjados, ocre y gisáceos. }\end{array}$ \\
\hline Materiales & Arcilla \\
\hline
\end{tabular}

Datos organológicos

\begin{tabular}{|l|l|}
\hline Tipo de instrumento & Membranófono \\
\hline $\begin{array}{l}\text { Clasificación } \\
\text { organológica }\end{array}$ & 211.26 Membranófonos en forma de copa \\
\hline Función & Lúdica o religiosa \\
\hline Fabricación & Alfares \\
\hline $\begin{array}{l}\text { Características } \\
\text { musicales }\end{array}$ & $\begin{array}{l}\text { Al conservarse solo parte del cuerpo del instrumento solo } \\
\text { se puede decir de este su forma tubular. Lo que parece } \\
\text { dirigirse a la boca del instrumento parece ensancharse por }\end{array}$ \\
\hline
\end{tabular}


lo que podría tener forma de copa.

Datos arqueológicos

\begin{tabular}{|l|l|}
\hline Yacimiento & Calle Real \\
\hline $\begin{array}{l}\text { Responsable de la } \\
\text { excavación }\end{array}$ & Rafael Carmona Ávila \\
\hline
\end{tabular}

\section{Bibliografía}

\begin{tabular}{|l|l}
\hline Documentación del Museo & Pieza en estudio.
\end{tabular}

Inédito 


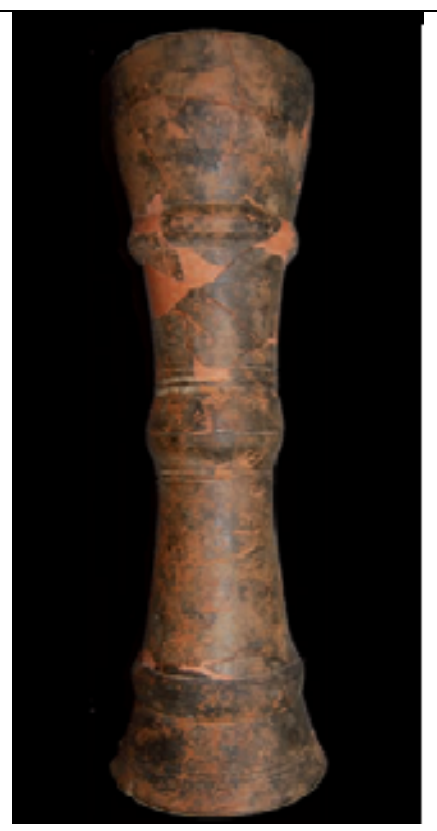

Datos generales

\begin{tabular}{|l|l|}
\hline Nombre & Tambor \\
\hline $\mathbf{N}^{\mathbf{0}}$ de inventario & C-85 20417-E \\
\hline Ubicación actual & Laboratorio de Arqueología de la Universidad de Granada \\
\hline Procedencia & Los Guájares \\
\hline Dimensiones & Altura: $32,2 \mathrm{~cm}$; Diámetro superior: 9,4 cm \\
\hline Ciudad & Granada \\
\hline Cronología & ss. XIV (Nazarí) \\
\hline $\begin{array}{l}\text { Características } \\
\text { morfológicas }\end{array}$ & Unimembranófono tubular con forma de reloj de arena. \\
\hline Materiales & Arcilla \\
\hline
\end{tabular}

Datos organológicos

\begin{tabular}{|l|l|}
\hline Tipo de instrumento & Membranófono \\
\hline $\begin{array}{l}\text { Clasificación } \\
\text { organológica }\end{array}$ & $\begin{array}{l}\text { 211.241.1 Unimembranófono individual en forma de reloj } \\
\text { de arena. }\end{array}$ \\
\hline Función & Lúdica o religiosa \\
\hline Fabricación & Alfares \\
\hline
\end{tabular}




\begin{tabular}{|l|l|}
\hline Características & $\begin{array}{l}\text { Este tambor cuenta con un cuerpo tubular que se estrecha } \\
\text { musicales }\end{array}$ \\
en el medio de la pieza y desde ese punto de forma \\
progresiva se va ampliando hacia la base y boca su \\
diámetro.
\end{tabular}

\section{Datos arqueológicos}

\begin{tabular}{|l|l|}
\hline Yacimiento & Castillejo de Los Guájares \\
\hline $\begin{array}{l}\text { Responsable de la } \\
\text { excavación }\end{array}$ & Antonio Malpica Cuello \\
\hline
\end{tabular}

\section{Bibliografía}

Malpica Cuello, Antonio, et al. "Excavación de El Castillejo (Los Guájares, Granada), 1985". Anuario Arqueológico de Andalucía, (1985): 436-446; Álvarez, Rosario y Guillermo Rosselló. "Hallazgo de tambores de la España islámica (siglos X al XIV)". Revista de Musicología, vol. 12, no 2 (1989): 411-421; Cortés García, Manuela. "Organología oriental en al-Andalus", Boletín de la Asociación Española de Orientalistas, no 26, (1990): 309; García Porras, Alberto. "La cerámica del poblado fortificado medieval de" El Castillejo"(Los Guájares, Granada)". Athos-Pérgamos. (2001): 330- 332 y 616; Jiménez Pasalodos, Raquel y Alexandra Bill. "Los tambores de cerámica de al-Andalus (ss. VIII-XIV): una aproximación desde la Arqueología Musical”. Nassarre. (2012): 13-42; Bill Alexandra, Raquel Jiménez Pasalodos y Carlos García Benito. "A classification of clay drums from al-Andalus (9th-14th Centuries AD)". En Proceedings of the 16th Symposium on Mediterranean Archaeology, (2012): 1103-1104. 


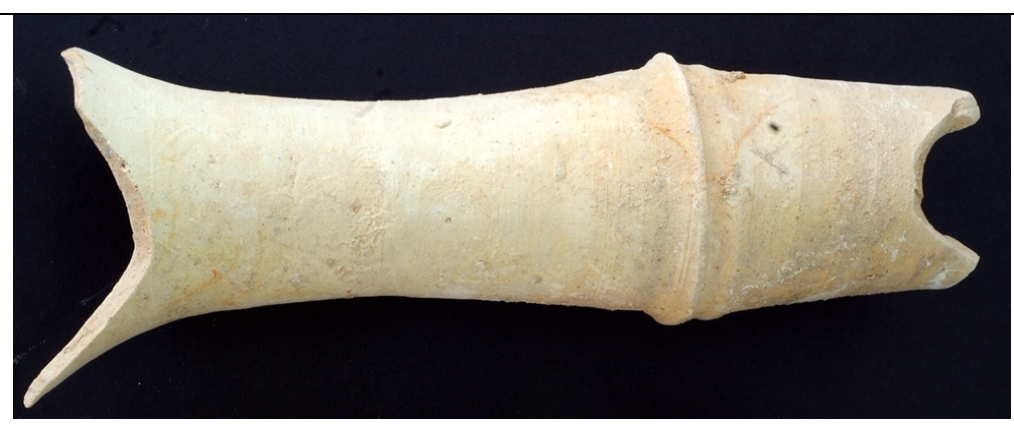

\section{Datos generales}

\begin{tabular}{|l|l|}
\hline Nombre & Tambor \\
\hline $\mathbf{N}^{\mathbf{0}}$ de inventario & - \\
\hline Ubicación actual & Particular \\
\hline Procedencia & Calle Dos Aceras \\
\hline Dimensiones & - \\
\hline Ciudad & Málaga \\
\hline Cronología & ss. XIV-XV (Nazarí) \\
\hline Características & $\begin{array}{l}\text { Instrumento similar al del Castillejo de los Guájares. } \\
\text { Cuenta con un adorno en mitad del cuerpo y a partir de ahí } \\
\text { se moldea el cuerpo de forma tubular con una pequeña } \\
\text { curvatura. }\end{array}$ \\
\hline Materiales & Arcilla \\
\hline
\end{tabular}

\section{Datos organológicos}

\begin{tabular}{|l|l|}
\hline Tipo de instrumento & Membranófono \\
\hline $\begin{array}{l}\text { Clasificación } \\
\text { organológica }\end{array}$ & 211.2 Membranófonos tubulares \\
\hline Función & Lúdica o religiosa \\
\hline Fabricación & Alfares \\
\hline $\begin{array}{l}\text { Características } \\
\text { musicales }\end{array}$ & $\begin{array}{l}\text { Al conservarse solo parte del instrumento solo deja intuir } \\
\text { la curvatura hacia la boca que parece probable terminar en }\end{array}$ \\
\hline
\end{tabular}


copa.

Datos arqueológicos

\begin{tabular}{|l|l}
\hline Yacimiento & - \\
\hline $\begin{array}{l}\text { Responsable de la } \\
\text { excavación }\end{array}$ & -
\end{tabular}

Bibliografía

Inédito 


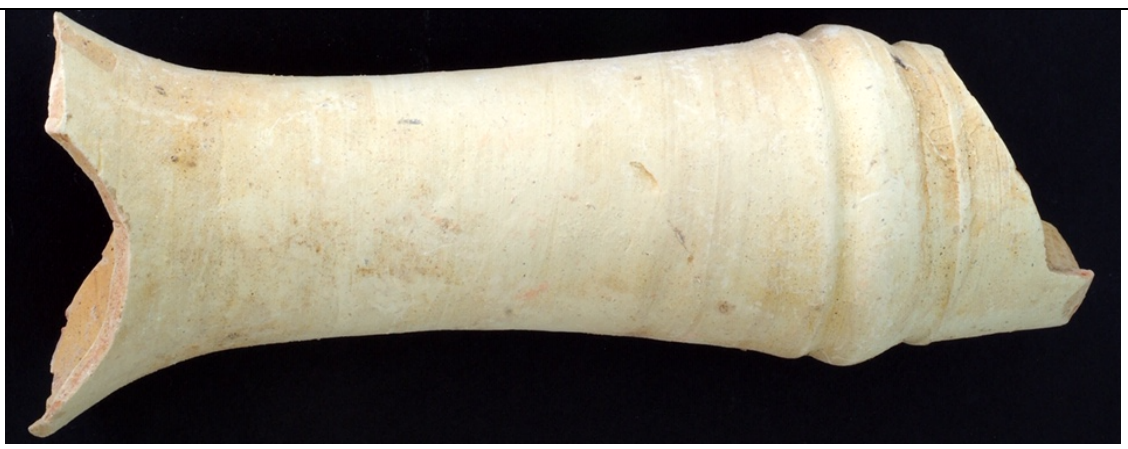

\begin{tabular}{|l|l|}
\hline Nombre & Tambor \\
\hline $\mathbf{N}^{\mathbf{0}}$ de inventario & - \\
\hline Ubicación actual & Particular \\
\hline Procedencia & Calle Dos Aceras \\
\hline Dimensiones & - \\
\hline Ciudad & Málaga \\
\hline Cronología & ss. XIV-XV (Nazarí) \\
\hline Características \\
morfológicas & $\begin{array}{l}\text { Instrumento similar al del Castillejo de los Guájares. } \\
\text { Cuenta con un adorno en mitad del cuerpo y a partir de ahí } \\
\text { se moldea el cuerpo de forma tubular con una pequeña } \\
\text { curvatura. }\end{array}$ \\
\hline Materiales & Arcilla \\
\hline
\end{tabular}

\section{Datos organológicos}

\begin{tabular}{|l|l|}
\hline Tipo de instrumento & Membranófono \\
\hline $\begin{array}{l}\text { Clasificación } \\
\text { organológica }\end{array}$ & 211.2 Membranófonos tubulares \\
\hline Función & Lúdica o religiosa \\
\hline Fabricación & Alfares \\
\hline $\begin{array}{l}\text { Características } \\
\text { musicales }\end{array}$ & $\begin{array}{l}\text { Al conservarse solo parte del instrumento solo deja intuir } \\
\text { la curvatura hacia la boca que parece probable terminar en } \\
\text { copa. }\end{array}$ \\
\hline
\end{tabular}




\section{Datos arqueológicos}

\begin{tabular}{|l|l|}
\hline Yacimiento & - \\
\hline $\begin{array}{l}\text { Responsable de la } \\
\text { excavación }\end{array}$ & - \\
\hline
\end{tabular}

\section{Bibliografía}

Inédito 


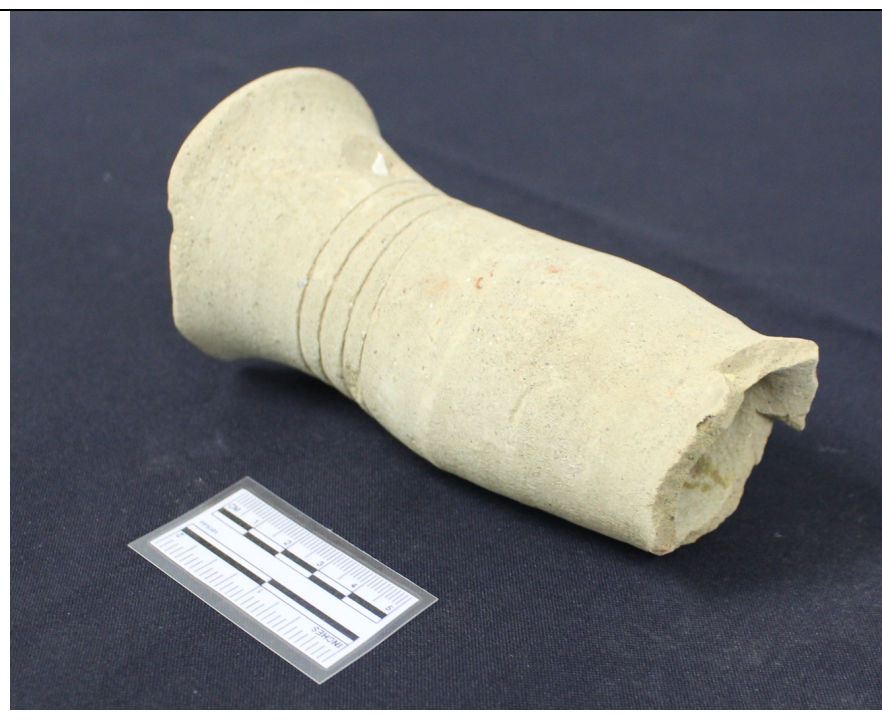

Datos generales

\begin{tabular}{|l|l|}
\hline Nombre & Tambor \\
\hline $\mathbf{N}^{\mathbf{0}}$ de inventario & $8516 / 194$ \\
\hline Ubicación actual & Museo de Málaga \\
\hline Procedencia & Calle Almacenes \\
\hline Dimensiones & Alto: $15,16 \mathrm{~cm}$; Ancho: $9,03 \mathrm{~cm}$ \\
\hline Ciudad & Málaga \\
\hline Cronología & ss. X-XI (Califal) \\
\hline $\begin{array}{l}\text { Características } \\
\text { morfológicas }\end{array}$ & $\begin{array}{l}\text { Base de un tambor con pie plano y adorno de tres } \\
\text { incisiones circulares alrededor del cuerpo del instrumento. }\end{array}$ \\
\hline Materiales & Arcilla \\
\hline
\end{tabular}

Datos organológicos

\begin{tabular}{|l|l|}
\hline Tipo de instrumento & Membranófono \\
\hline $\begin{array}{l}\text { Clasificación } \\
\text { organológica }\end{array}$ & 211.26 Membranófonos en forma de copa \\
\hline Función & Lúdica o religiosa \\
\hline Fabricación & Alfares \\
\hline $\begin{array}{l}\text { Características } \\
\text { musicales }\end{array}$ & $\begin{array}{l}\text { Unimembranófono con base tubular ligeramente } \\
\text { abombada. No se conserva la boca del instrumento por lo }\end{array}$ \\
\hline
\end{tabular}


que no puede saberse su forma exacta aunque posiblemente sea en forma de copa por semejanza con otras piezas y el dibujo en su base.

\section{Datos arqueológicos}

\begin{tabular}{|l|l|}
\hline Yacimiento & Excavación de urgencia Calle Almacenes \\
\hline $\begin{array}{l}\text { Responsable de la } \\
\text { excavación }\end{array}$ & José Suárez Padilla \\
\hline
\end{tabular}

\section{Bibliografía}

\section{Documentación del Museo \\ Pieza perdida en cajas hasta esta investigación.}

Soto Iborra, Antonio, Ildefonso Navarro Luego, Luis Efrén Fernández Rodríguez, José Suárez Padilla, José Antonio Santamaría García y José Manuel Sánchez Herrera. "Informe preliminar de la excavación arqueológica de urgencia en calle Almacenes, 6 (Málaga, Casco histórico)”. Anuario arqueológico de Andalucía, (1992): 465-475; Jiménez Pasalodos, Raquel y Alexandra Bill. "Los tambores de cerámica de alAndalus (ss. VIII-XIV): una aproximación desde la Arqueología Musical”. Nassarre, (2012): 13-42; Bill, Alexandra, Raquel Jiménez Pasalodos y Carlos García Benito. “A classification of clay drums from al-Andalus (9th-14th Centuries AD)". En Proccedings of the 16th Symposium on Mediterranean Archaeology, (2012): 11031104; García Benito, Carlos. “Arqueología Musical Prehistórica: aproximación a través de la Arqueología Experimental aplicada a la Arqueo-Organología, de la Arqueoacústica y de la Iconografía Musical Prehistórica”. Tesis doctoral, Universidad de Zaragoza, 2014. 


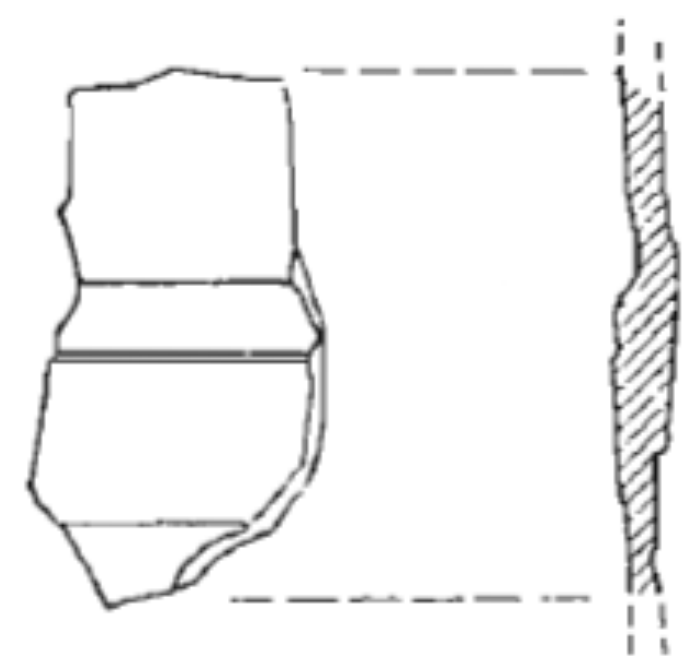

Datos generales

\begin{tabular}{|l|l|}
\hline Nombre & Tambor \\
\hline $\mathbf{N}^{\mathbf{0}}$ de inventario & $110 \mathrm{~b}$ \\
\hline Ubicación actual & Museo de Málaga ¿? \\
\hline Procedencia & Teatro Romano de Málaga \\
\hline Dimensiones & Alto: $11,3 \mathrm{~cm}$ \\
\hline Ciudad & Málaga \\
\hline Cronología & ss. XIII-XV (Nazarí) \\
\hline $\begin{array}{l}\text { Características } \\
\text { morfológicas }\end{array}$ & Fragmento de tambor con adorno. \\
\hline Materiales & Arcilla \\
\hline
\end{tabular}

\section{Datos organológicos}

\begin{tabular}{|l|l|}
\hline Tipo de instrumento & Membranófono \\
\hline $\begin{array}{l}\text { Clasificación } \\
\text { organológica }\end{array}$ & 211.26 Membranófonos en forma de copa \\
\hline Función & Lúdica o religiosa \\
\hline Fabricación & Alfares \\
\hline
\end{tabular}




\begin{tabular}{|l|l|}
\hline $\begin{array}{l}\text { Características } \\
\text { musicales }\end{array}$ & $\begin{array}{l}\text { Aunque es solo un fragmento lo que se conserva de este } \\
\text { tambor parece tener forma de copa. }\end{array}$ \\
\hline
\end{tabular}

\section{Datos arqueológicos}

\begin{tabular}{|l|l|}
\hline Yacimiento & Teatro Romano de Málaga \\
\hline $\begin{array}{l}\text { Responsable de la } \\
\text { excavación }\end{array}$ & Manuel Acién Almansa \\
\hline
\end{tabular}

\section{Bibliografía}

\begin{tabular}{|l|l|}
\hline Documentación del Museo & Pieza inventariada. Perdida. \\
\hline
\end{tabular}

Acién Almansa, Manuel. "La cerámica medieval del teatro romano de Málaga". Mainake, no 8-9, (1986): 230; Rosselló Bordoy, Guillermo, et al. "Instrumentos musicales en barro cocido: una pervivencia medieval". Música oral del Sur: revista internacional, no 2, (1996): 28-51; Jiménez Pasalodos, Raquel y Alexandra Bill. "Los tambores de cerámica de al-Andalus (ss. VIII-XIV): una aproximación desde la Arqueología Musical”. Nassarre, (2012): 13-42; García Benito, Carlos. “Arqueología Musical Prehistórica: aproximación a través de la Arqueología Experimental aplicada a la Arqueo-Organología, de la Arqueoacústica y de la Iconografía Musical Prehistórica”. Tesis doctoral, Universidad de Zaragoza, 2014. 


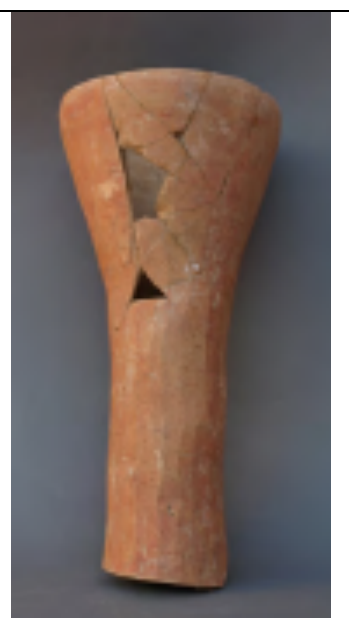

Datos generales

\begin{tabular}{|l|l|}
\hline Nombre & Tambor \\
\hline $\mathbf{N}^{\mathbf{0}}$ de inventario & REP22960 \\
\hline Ubicación actual & Museo Arqueológico de Sevilla \\
\hline Procedencia & Estacada de Faro, Puebla del Río \\
\hline Dimensiones & Alto: $24 \mathrm{~cm}$; Diámetro máximo: $11 \mathrm{~cm}$ \\
\hline Ciudad & Sevilla \\
\hline Cronología & ss. XII-XIII (Almohade) \\
\hline Características & $\begin{array}{l}\text { Tambor con cuerpo tubular y boca en forma de copa. Se } \\
\text { ha tenido que reconstruir la copa }\end{array}$ \\
\hline Materiales & Arcilla \\
\hline
\end{tabular}

Datos organológicos

\begin{tabular}{|l|l|}
\hline Tipo de instrumento & Membranófono \\
\hline $\begin{array}{l}\text { Clasificación } \\
\text { organológica }\end{array}$ & 211.26 Membranófonos en forma de copa \\
\hline Función & Lúdica o religiosa \\
\hline Fabricación & Alfares \\
\hline $\begin{array}{l}\text { Características } \\
\text { musicales }\end{array}$ & $\begin{array}{l}\text { Unimembranófono con cuerpo tubular y boca en forma de } \\
\text { copa. }\end{array}$ \\
\hline
\end{tabular}




\section{Datos arqueológicos}

\begin{tabular}{|l|l|}
\hline Yacimiento & Estacada de Afaro \\
\hline $\begin{array}{l}\text { Responsable de la } \\
\text { excavación }\end{array}$ & Juan de Mata Carriazo Arroquia \\
\hline
\end{tabular}

\section{Bibliografía}

\begin{tabular}{|l|l|}
\hline Documentación del Museo & Pieza con ficha de catalogación. \\
\hline de Mata Carriazo, Juan. Protohistoria de Sevilla. Vol. 1. Guadalquivir, 1980; Jiménez \\
Pasalodos, Raquel y Alexandra Bill. "Los tambores de cerámica de al-Andalus (ss. \\
VIII-XIV): una aproximación desde la Arqueología Musical”. Nassarre, (2012): 15; \\
Bill, Alexandra, Raquel Jiménez Pasalodos y Carlos García Benito. “A classification \\
of clay drums from al-Andalus (9th-14th Centuries AD)". En Proccedings of the 16th \\
Symposium on Mediterranean Archaeology, (2012): 1104.
\end{tabular}




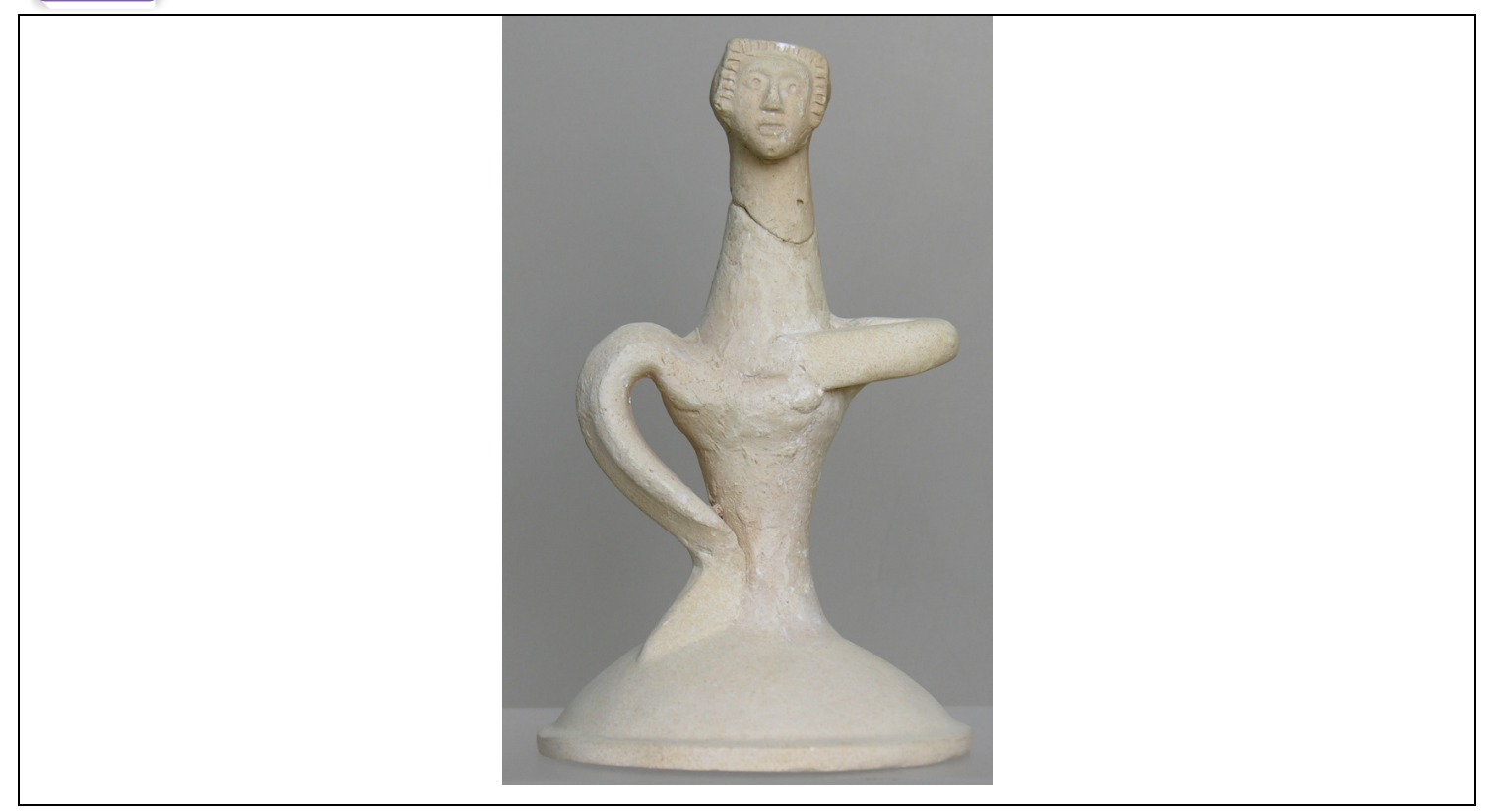

Datos generales

\begin{tabular}{|l|l|}
\hline Nombre & Campana \\
\hline $\mathbf{N}^{\mathbf{0}}$ de inventario & R1410 \\
\hline Ubicación actual & Museo de la Alhambra \\
\hline Procedencia & Alhambra, Granada \\
\hline Dimensiones & Altura: $15 \mathrm{~cm}$; Diámetro: $9 \mathrm{~cm}$ \\
\hline Ciudad & Granada \\
\hline Cronología & XV-XVI \\
\hline Características \\
morfológicas & $\begin{array}{l}\text { Figura acampanada con rostro femenino y dos asas a } \\
\text { modo de brazos de la figura. Esta pieza fue catalogada } \\
\text { como juguete originariamente aunque actualmente, por su } \\
\text { posibilidades sonoras y semejanzas con otras como la de } \\
\text { Jaén, se encuentra expuesta en el Museo de la Alhambra } \\
\text { como campana. }\end{array}$ \\
\hline Materiales & Arcilla \\
\hline
\end{tabular}

\section{Datos organológicos}

\begin{tabular}{|l|l|}
\hline Tipo de instrumento & Idiófono \\
\hline
\end{tabular}




\begin{tabular}{|l|l|}
\hline $\begin{array}{l}\text { Clasificación } \\
\text { organológica }\end{array}$ & $\begin{array}{l}111.242 .122 \text { Campanas individuales suspendidas con } \\
\text { percusión interna (con badajo) }\end{array}$ \\
\hline Función & Lúdica \\
\hline Fabricación & Alfares \\
\hline $\begin{array}{l}\text { Características } \\
\text { musicales }\end{array}$ & $\begin{array}{l}\text { La falda acampanada de la figura permite que un badajo } \\
\text { interior pudiera golpear esta parte de la pieza al estar } \\
\text { hueca. }\end{array}$ \\
\hline
\end{tabular}

Datos arqueológicos

\begin{tabular}{|l|l|}
\hline Yacimiento & Alhambra \\
\hline $\begin{array}{l}\text { Responsable de la } \\
\text { excavación }\end{array}$ & - \\
\hline
\end{tabular}

Bibliografía

\begin{tabular}{|l|l|}
\hline Documentación del Museo & Pieza con ficha de catalogación. \\
\hline
\end{tabular}

Rosselló Bordoy, Guillermo, Ana Navarro Ortega y Isabel Flores Escobosa. Del rito

al juego: juguetes y silbatos de cerámica desde el islam hasta la actualidad. Junta de Andalucía, 2006, 203. 


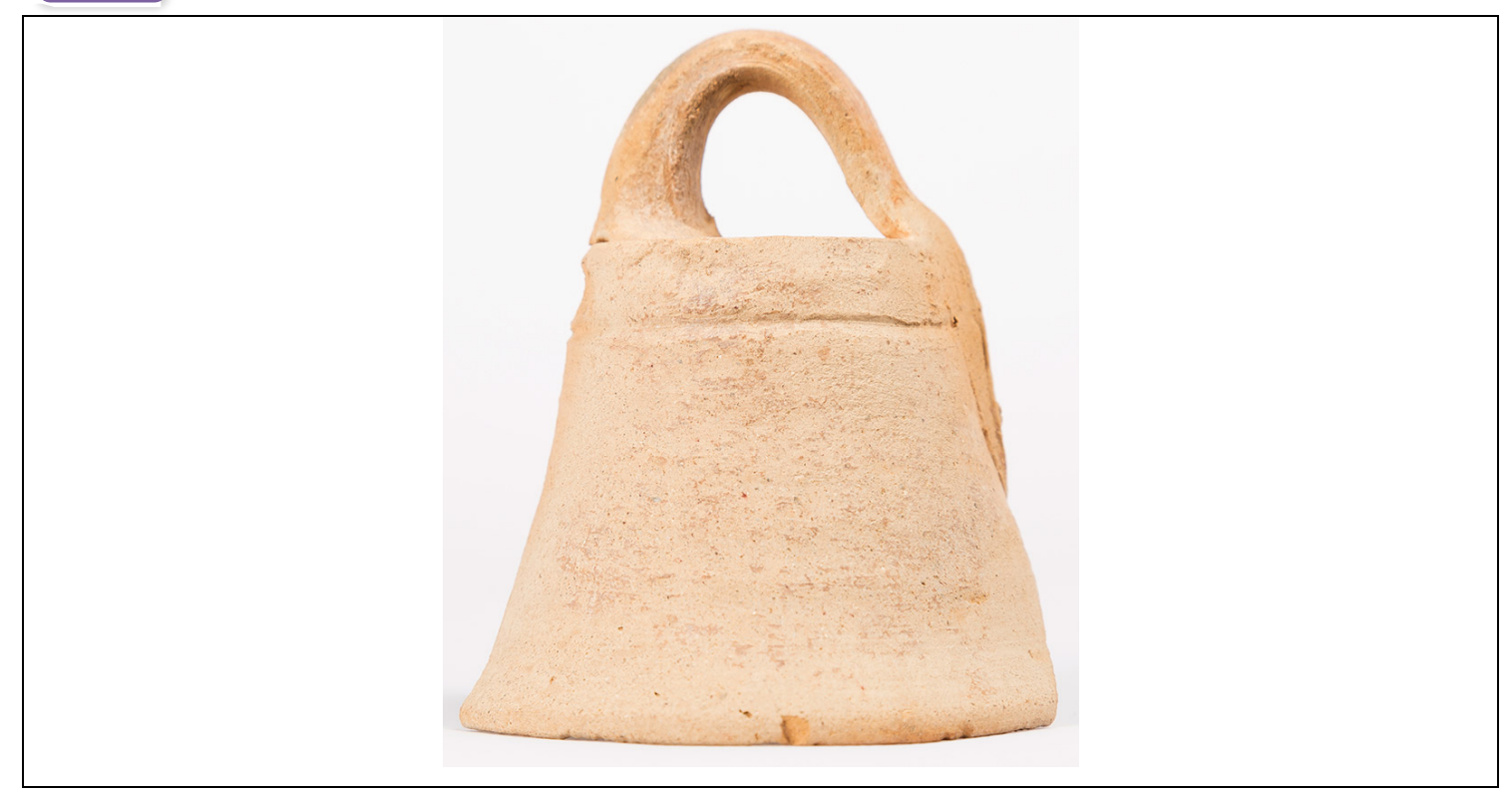

\section{Datos generales}

\begin{tabular}{|l|l|}
\hline Nombre & Campana \\
\hline $\mathbf{N}^{\mathbf{0}}$ de inventario & R104937 \\
\hline Ubicación actual & Museo de la Alhambra \\
\hline Procedencia & Alhambra, Granada \\
\hline Dimensiones & Altura: $7,8 \mathrm{~cm}$; Anchura: $4,6 \mathrm{~cm}$; Grosor: $4,4 \mathrm{~cm}$ \\
\hline Ciudad & Granada \\
\hline Cronología & Desconocida \\
\hline morfológicas & $\begin{array}{l}\text { Campana con forma cónica y asa curva. Ha perdido un } \\
\text { fragmento en uno de sus lados. Cuenta con una incisión } \\
\text { circular marcando el diámetro superior de la pieza a modo } \\
\text { de adorno. }\end{array}$ \\
\hline Materiales & Arcilla \\
\hline
\end{tabular}

\section{Datos organológicos}

\begin{tabular}{|c|c|}
\hline Tipo de instrumento & Idiófono \\
\hline $\begin{array}{l}\text { Clasificación } \\
\text { organológica }\end{array}$ & $\begin{array}{l}\text { 111.242.122 Campanas individuales suspendidas con } \\
\text { percusión interna (con badajo) }\end{array}$ \\
\hline Función & Lúdica o religiosa \\
\hline
\end{tabular}




\begin{tabular}{|l|l|}
\hline Fabricación & Alfares \\
\hline $\begin{array}{l}\text { Características } \\
\text { musicales }\end{array}$ & $\begin{array}{l}\text { Campana que contaba con un badajo interior que no se } \\
\text { conserva. }\end{array}$ \\
\hline
\end{tabular}

\section{Datos arqueológicos}

\begin{tabular}{|l|l|}
\hline Yacimiento & Alhambra \\
\hline $\begin{array}{l}\text { Responsable de la } \\
\text { excavación }\end{array}$ & - \\
\hline
\end{tabular}

\section{Bibliografía}

\begin{tabular}{|l|l|}
\hline Documentación del Museo & Pieza inventariada. \\
\hline Inédito & \\
\hline
\end{tabular}




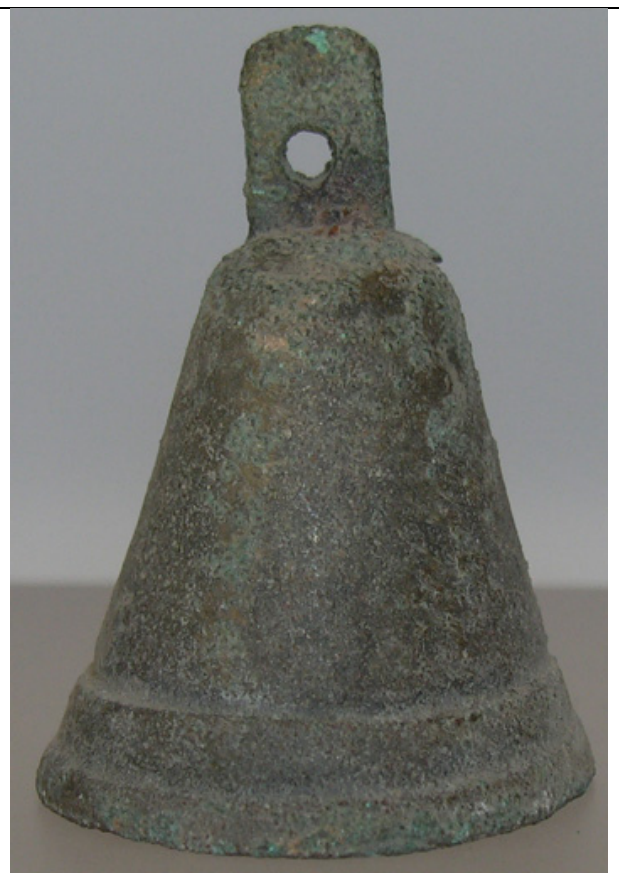

\section{Datos generales}

\begin{tabular}{|l|l|}
\hline Nombre & Campana \\
\hline $\mathbf{N}^{\mathbf{0}}$ de inventario & R10977 \\
\hline Ubicación actual & Museo de la Alhambra \\
\hline Procedencia & Alhambra, Granada \\
\hline Dimensiones & Altura: $5,2 \mathrm{~cm}$; Anchura: $4,3 \mathrm{~cm}$; Grosor: $3,7 \mathrm{~cm}$ \\
\hline Ciudad & Granada \\
\hline Cronología & Desconocida \\
\hline morfológicas & $\begin{array}{l}\text { Campana con dos refuerzos circulares en su base a modo } \\
\text { de adorno. Cuenta con un soporte a modo de asa con un } \\
\text { pequeño orificio. Por su apariencia parece posterior a la } \\
\text { época musulmana. }\end{array}$ \\
\hline Materiales & Bronce \\
\hline
\end{tabular}

\section{Datos organológicos}

\begin{tabular}{|l|ll|}
\hline Tipo de instrumento & Idiófono & \\
\hline Clasificación & 111.242 .122 & Campanas individuales suspendidas con \\
\hline
\end{tabular}




\begin{tabular}{|l|l|}
\hline organológica & percusión interna (con badajo) \\
\hline Función & Lúdica o religiosa \\
\hline Fabricación & Herrería \\
\hline $\begin{array}{l}\text { Características } \\
\text { musicales }\end{array}$ & $\begin{array}{l}\text { Campana con badajo interior sujeto a un soporte interno. } \\
\text { El badajo no se conserva. }\end{array}$ \\
\hline
\end{tabular}

\section{Datos arqueológicos}

\begin{tabular}{|l|l|}
\hline Yacimiento & Alhambra \\
\hline $\begin{array}{l}\text { Responsable de la } \\
\text { excavación }\end{array}$ & - \\
\hline
\end{tabular}

\section{Bibliografía}

\begin{tabular}{|l|l|}
\hline Documentación del Museo & Pieza inventariada. \\
\hline Inédito &
\end{tabular}




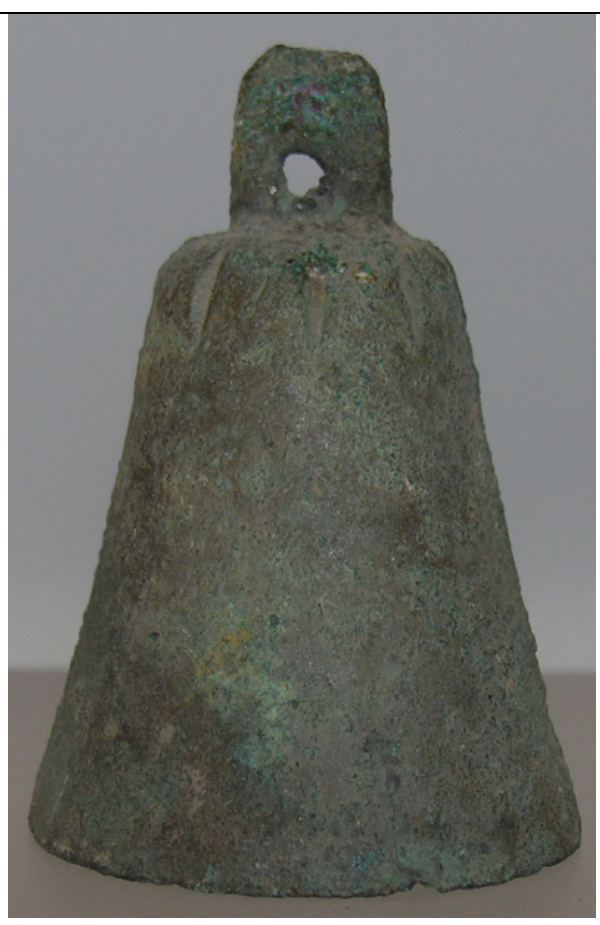

Datos generales

\begin{tabular}{|l|l|}
\hline Nombre & Campana \\
\hline $\mathbf{N}^{\mathbf{0}}$ de inventario & R10978 \\
\hline Ubicación actual & Museo de la Alhambra \\
\hline Procedencia & Alhambra, Granada \\
\hline Dimensiones & Altura: $6,4 \mathrm{~cm}$; Diámetro: $4,6 \mathrm{~cm}$ \\
\hline Ciudad & Granada \\
\hline Cronología & Desconocida \\
\hline Características & $\begin{array}{l}\text { Campana lisa con un soporte a modo de asa con un } \\
\text { pequeño orificio. }\end{array}$ \\
\hline Materiales & Bronce \\
\hline
\end{tabular}

Datos organológicos

\begin{tabular}{|l|l|}
\hline Tipo de instrumento & Idiófono \\
\hline $\begin{array}{l}\text { Clasificación } \\
\text { organológica }\end{array}$ & $\begin{array}{l}111.242 .122 \text { Campanas individuales suspendidas con } \\
\text { percusión interna (con badajo) }\end{array}$ \\
\hline Función & Lúdica o religiosa \\
\hline
\end{tabular}




\begin{tabular}{|l|l|}
\hline Fabricación & Herrería \\
\hline $\begin{array}{l}\text { Características } \\
\text { musicales }\end{array}$ & $\begin{array}{l}\text { Campana con badajo interior sujeto a un soporte interno. } \\
\text { El badajo no se conserva. }\end{array}$ \\
\hline
\end{tabular}

\section{Datos arqueológicos}

\begin{tabular}{|l|l|}
\hline Yacimiento & Alhambra \\
\hline $\begin{array}{l}\text { Responsable de la } \\
\text { excavación }\end{array}$ & - \\
\hline
\end{tabular}

\section{Bibliografía}

\begin{tabular}{|l|l|}
\hline Documentación del Museo & Pieza inventariada. \\
\hline Inédito & \\
\hline
\end{tabular}




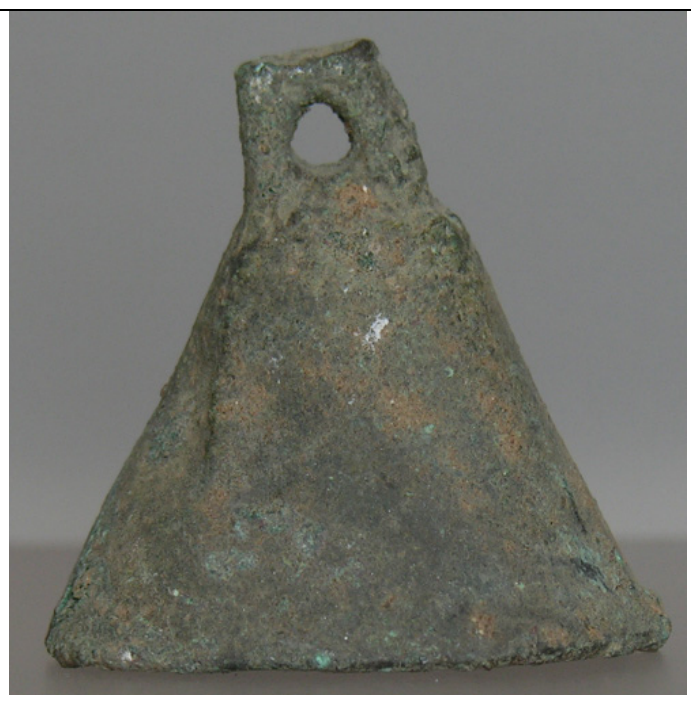

\section{Datos generales}

\begin{tabular}{|c|c|}
\hline Nombre & Campana \\
\hline $\mathrm{N}^{\mathrm{o}}$ de inventario & R10980 \\
\hline Ubicación actual & Museo de la Alhambra \\
\hline Procedencia & Alhambra \\
\hline Dimensiones & Altura $=3,7 \mathrm{~cm} ;$ Anchura $=3,7 \mathrm{~cm} ;$ Grosor $=2,7$ \\
\hline Ciudad & Granada \\
\hline Cronología & Desconocida \\
\hline $\begin{array}{l}\text { Características } \\
\text { morfológicas }\end{array}$ & $\begin{array}{l}\text { Campana con forma más triangular que las anteriores. } \\
\text { Cuenta con un soporte a modo de asa con un pequeño } \\
\text { orificio. }\end{array}$ \\
\hline Materiales & Bronce \\
\hline
\end{tabular}

Datos organológicos

\begin{tabular}{|l|l|}
\hline Tipo de instrumento & Idiófono \\
\hline $\begin{array}{l}\text { Clasificación } \\
\text { organológica }\end{array}$ & $\begin{array}{l}111.242 .122 \text { Campanas individuales suspendidas con } \\
\text { percusión interna (con badajo) }\end{array}$ \\
\hline Función & Lúdica o religiosa \\
\hline Fabricación & Herrería \\
\hline Características & Campana con badajo interior sujeto a un soporte interno. \\
\hline
\end{tabular}


Datos arqueológicos

\begin{tabular}{|l|l|}
\hline Yacimiento & Alhambra \\
\hline $\begin{array}{l}\text { Responsable de la } \\
\text { excavación }\end{array}$ & - \\
\hline
\end{tabular}

\section{Bibliografía}

Documentación del Museo

Pieza inventariada.

Inédito 


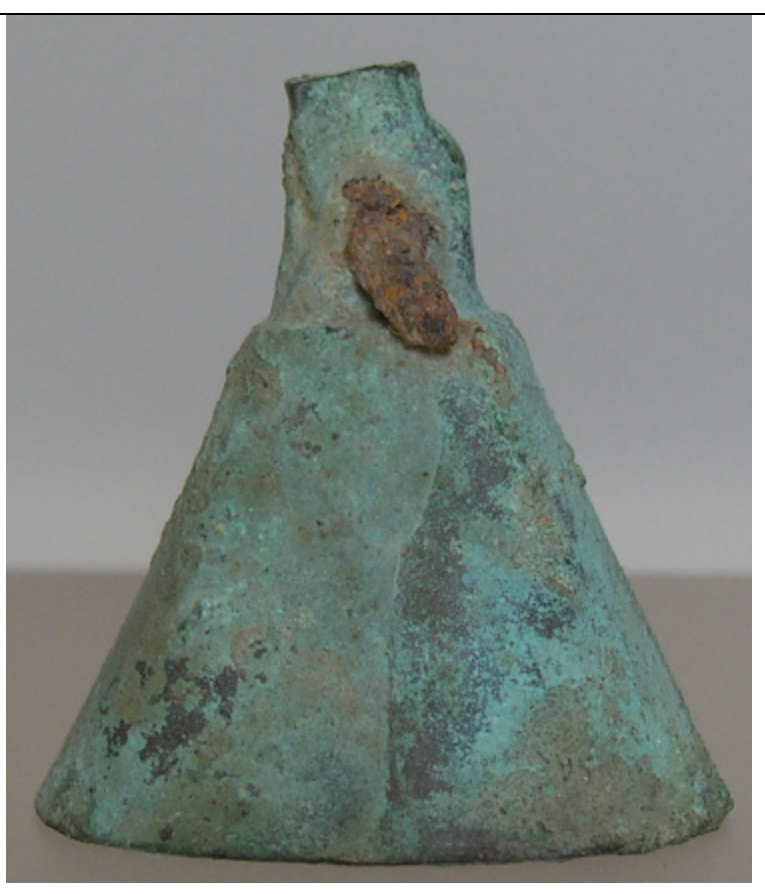

\section{Datos generales}

\begin{tabular}{|l|l|}
\hline Nombre & Campana \\
\hline $\mathbf{N}^{\mathbf{0}}$ de inventario & R10981 \\
\hline Ubicación actual & Museo de la Alhambra \\
\hline Procedencia & Alhambra, Granada \\
\hline Dimensiones & Altura: $4,3 \mathrm{~cm}$; Anchura: $4 \mathrm{~cm}$; Grosor: $2,8 \mathrm{~cm}$ \\
\hline Ciudad & Granada \\
\hline Cronología & Desconocida \\
\hline morfológicas & $\begin{array}{l}\text { Campana con forma más triangular que las anteriores. } \\
\text { Cuenta con un soporte a modo de asa con un pequeño } \\
\text { orificio obstruido por una pieza de metal que podría haber } \\
\text { funcionado como soporte. }\end{array}$ \\
\hline Materiales & Bronce \\
\hline
\end{tabular}

Datos organológicos

\begin{tabular}{|l|lll|}
\hline Tipo de instrumento & Idiófono & & \\
\hline Clasificación & 111.242 .122 & Campanas individuales suspendidas con \\
\hline
\end{tabular}




\begin{tabular}{|l|l|}
\hline organológica & percusión interna (con badajo) \\
\hline Función & Lúdica o religiosa \\
\hline Fabricación & Herrería \\
\hline $\begin{array}{l}\text { Características } \\
\text { musicales }\end{array}$ & $\begin{array}{l}\text { Campana con badajo interior sujeto a un soporte interno. } \\
\text { El badajo no se conserva. }\end{array}$ \\
\hline
\end{tabular}

\section{Datos arqueológicos}

\begin{tabular}{|l|l|}
\hline Yacimiento & Alhambra \\
\hline $\begin{array}{l}\text { Responsable de la } \\
\text { excavación }\end{array}$ & - \\
\hline
\end{tabular}

\section{Bibliografía}

\begin{tabular}{|l|l|}
\hline Documentación del Museo & Pieza inventariada. \\
\hline Inédito & \\
\hline
\end{tabular}




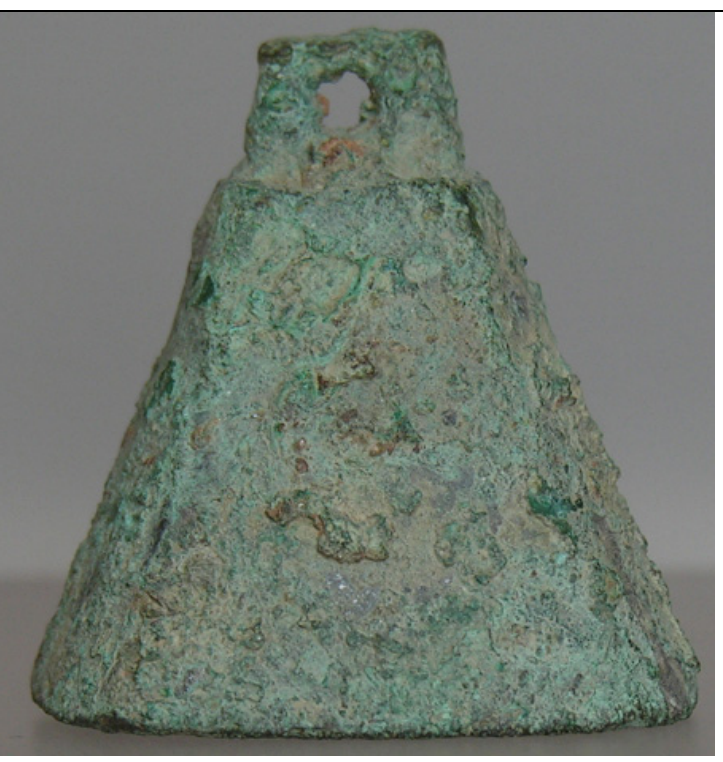

Datos generales

\begin{tabular}{|l|l|}
\hline Nombre & Campana \\
\hline $\mathbf{N}^{\mathbf{0}}$ de inventario & R10984 \\
\hline Ubicación actual & Museo de la Alhambra \\
\hline Procedencia & Alhambra, Granada \\
\hline Dimensiones & Altura: $3,5 \mathrm{~cm}$; Anchura: $3,4 \mathrm{~cm}$; Grosor: $2,5 \mathrm{~cm}$ \\
\hline Ciudad & Granada \\
\hline Cronología & Desconocida \\
\hline Características \\
morfológicas & $\begin{array}{l}\text { Campana con forma más triangular que las anteriores. } \\
\text { Cuenta con un soporte a modo de asa con un pequeño } \\
\text { orificio. Cuenta con pequeñas protuberancias en la } \\
\text { superficie de la pieza. }\end{array}$ \\
\hline Materiales & Bronce \\
\hline
\end{tabular}

Datos organológicos

\begin{tabular}{|l|l|}
\hline Tipo de instrumento & Idiófono \\
\hline $\begin{array}{l}\text { Clasificación } \\
\text { organológica }\end{array}$ & 111.242 .122 Campanas individuales suspendidas con \\
percusión interna (con badajo)
\end{tabular}




\begin{tabular}{|l|l|}
\hline Fabricación & Herrería \\
\hline $\begin{array}{l}\text { Características } \\
\text { musicales }\end{array}$ & $\begin{array}{l}\text { Campana con badajo interior sujeto a un soporte interno. } \\
\text { El badajo no se conserva. }\end{array}$ \\
\hline
\end{tabular}

\section{Datos arqueológicos}

\begin{tabular}{|l|l|}
\hline Yacimiento & Alhambra \\
\hline $\begin{array}{l}\text { Responsable de la } \\
\text { excavación }\end{array}$ & - \\
\hline
\end{tabular}

\section{Bibliografía}

\begin{tabular}{|l|l|}
\hline Documentación del Museo & Pieza inventariada. \\
\hline Inédito & \\
\hline
\end{tabular}




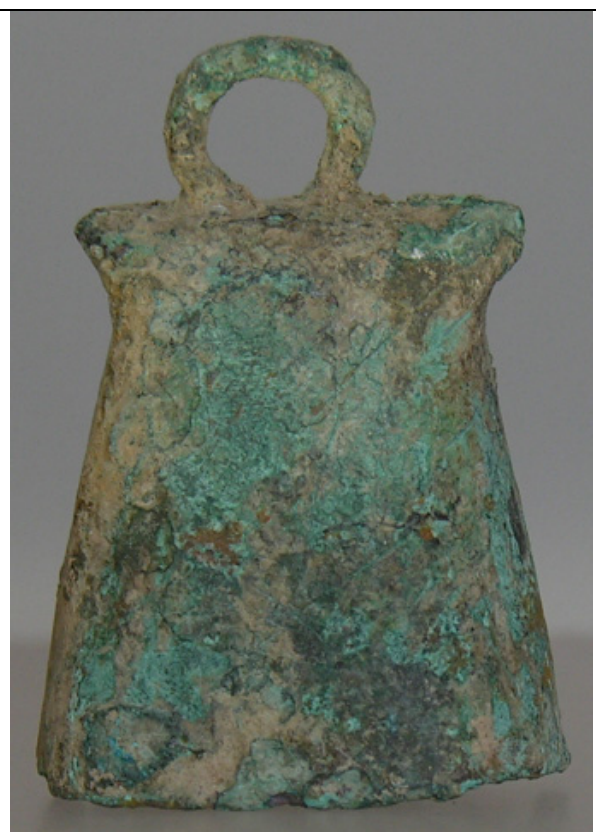

\section{Datos generales}

\begin{tabular}{|l|l|}
\hline Nombre & Campana \\
\hline $\mathbf{N}^{\mathbf{0}}$ de inventario & R10982 \\
\hline Ubicación actual & Museo de la Alhambra \\
\hline Procedencia & Alhambra, Granada \\
\hline Dimensiones & Altura: $3,6 \mathrm{~cm}$; Anchura: $2,5 \mathrm{~cm}$; Grosor: $1,6 \mathrm{~cm}$ \\
\hline Ciudad & Granada \\
\hline Cronología & Desconocida \\
\hline Características & $\begin{array}{l}\text { Campana de pequeño tamaño con asa superior y dos } \\
\text { pequeñas protuberancias a los lados. Tiene cuerpo y base } \\
\text { ovalada. }\end{array}$ \\
\hline Materiales & Bronce \\
\hline
\end{tabular}

\section{Datos organológicos}

\begin{tabular}{|l|l|}
\hline Tipo de instrumento & Idiófono \\
\hline $\begin{array}{l}\text { Clasificación } \\
\text { organológica }\end{array}$ & $\begin{array}{l}111.242 .122 \text { Campanas individuales suspendidas con } \\
\text { percusión interna (con badajo) }\end{array}$ \\
\hline Función & Lúdica \\
\hline
\end{tabular}




\begin{tabular}{|l|l|}
\hline Fabricación & Herrería \\
\hline $\begin{array}{l}\text { Características } \\
\text { musicales }\end{array}$ & Campana de pequeño tamaño con badajo. \\
\hline
\end{tabular}

\section{Datos arqueológicos}

\begin{tabular}{|l|l|}
\hline Yacimiento & Alhambra \\
\hline $\begin{array}{l}\text { Responsable de la } \\
\text { excavación }\end{array}$ & - \\
\hline
\end{tabular}

\section{Bibliografía}

\begin{tabular}{|l|l|}
\hline Documentación del Museo & Pieza inventariada. \\
\hline Inédito & \\
\hline
\end{tabular}




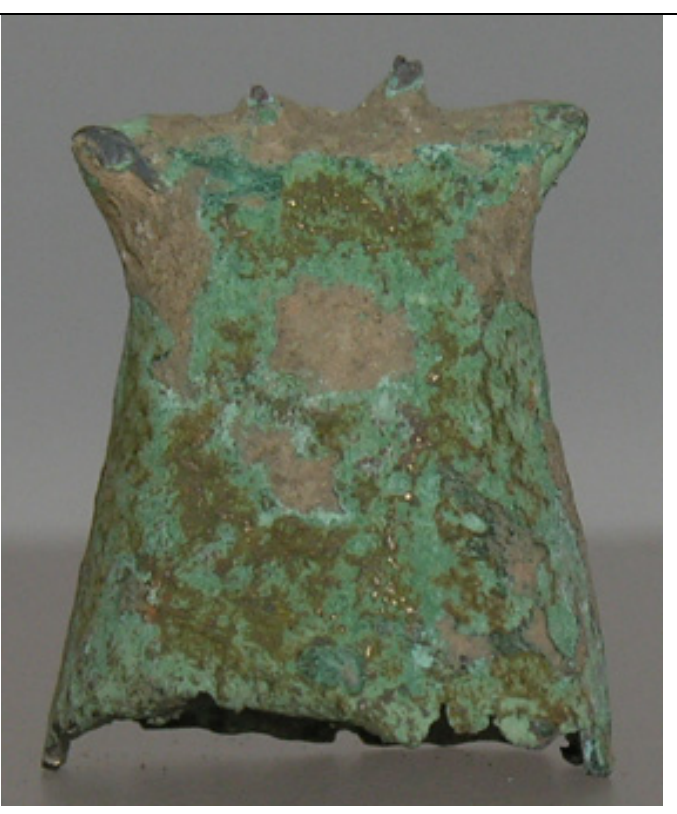

Datos generales

\begin{tabular}{|l|l|}
\hline Nombre & Campana \\
\hline $\mathbf{N}^{\mathbf{0}}$ de inventario & R10983 \\
\hline Ubicación actual & Museo de la Alhambra \\
\hline Procedencia & Alhambra, Granada \\
\hline Dimensiones & Altura: $2,5 \mathrm{~cm}$; Anchura: $1,9 \mathrm{~cm}$; Grosor: $1,4 \mathrm{~cm}$ \\
\hline Ciudad & Granada \\
\hline Cronología & Desconocida \\
\hline Características & $\begin{array}{l}\text { Campana de pequeño tamaño con restos de haber contado } \\
\text { con un asa superior. Tiene dos pequeñas protuberancias a } \\
\text { los lados y cuerpo y base ovalada. }\end{array}$ \\
\hline Materiales & Bronce \\
\hline
\end{tabular}

Datos organológicos

\begin{tabular}{|l|l|}
\hline Tipo de instrumento & Idiófono \\
\hline $\begin{array}{l}\text { Clasificación } \\
\text { organológica }\end{array}$ & $\begin{array}{l}111.242 .122 \text { Campanas individuales suspendidas con } \\
\text { percusión interna (con badajo) }\end{array}$ \\
\hline Función & Lúdica \\
\hline
\end{tabular}




\begin{tabular}{|l|l|}
\hline Fabricación & Herrería \\
\hline $\begin{array}{l}\text { Características } \\
\text { musicales }\end{array}$ & Campana de pequeño tamaño con badajo. \\
\hline
\end{tabular}

\section{Datos arqueológicos}

\begin{tabular}{|l|l|}
\hline Yacimiento & Alhambra \\
\hline $\begin{array}{l}\text { Responsable de la } \\
\text { excavación }\end{array}$ & - \\
\hline
\end{tabular}

\section{Bibliografía}

\begin{tabular}{|l|l|}
\hline Documentación del Museo & Pieza inventariada. \\
\hline Inédito &
\end{tabular}




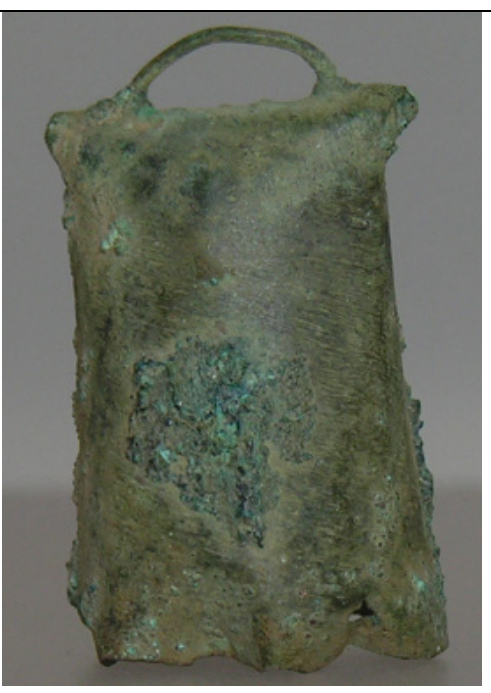

Datos generales

\begin{tabular}{|l|l|}
\hline Nombre & Campana \\
\hline $\mathbf{N}^{\mathbf{0}}$ de inventario & R10988 \\
\hline Ubicación actual & Museo de la Alhambra \\
\hline Procedencia & Alhambra, Granada \\
\hline Dimensiones & Altura: $2,9 \mathrm{~cm}$; Anchura: $1,7 \mathrm{~cm}$; Grosor: $1,6 \mathrm{~cm}$ \\
\hline Ciudad & Granada \\
\hline Cronología & Desconocida \\
\hline $\begin{array}{l}\text { Características } \\
\text { morfológicas }\end{array}$ & $\begin{array}{l}\text { Campana de pequeño tamaño con asa superior y dos } \\
\text { pequeñas protuberancias a los lados. Tiene cuerpo y base } \\
\text { ovalada. }\end{array}$ \\
\hline Materiales & Bronce \\
\hline
\end{tabular}

Datos organológicos

\begin{tabular}{|l|l|}
\hline Tipo de instrumento & Idiófono \\
\hline $\begin{array}{l}\text { Clasificación } \\
\text { organológica }\end{array}$ & $\begin{array}{l}111.242 .122 \text { Campanas individuales suspendidas con } \\
\text { percusión interna (con badajo) }\end{array}$ \\
\hline Función & Lúdica \\
\hline Fabricación & Herrería \\
\hline Características & Campana de pequeño tamaño con badajo. \\
\hline
\end{tabular}


musicales

Datos arqueológicos

\begin{tabular}{|l|l|}
\hline Yacimiento & Alhambra \\
\hline $\begin{array}{l}\text { Responsable de la } \\
\text { excavación }\end{array}$ & - \\
\hline
\end{tabular}

\section{Bibliografía}

Documentación del Museo

Pieza inventariada.

Inédito 


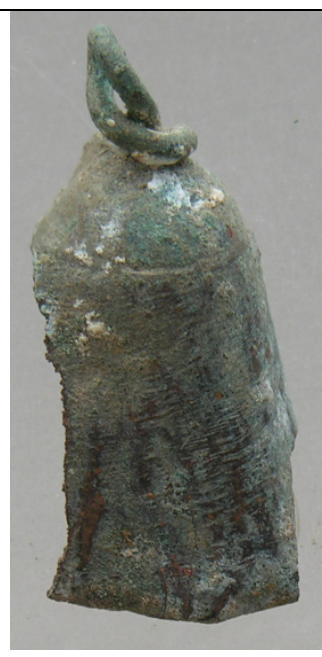

\section{Datos generales}

\begin{tabular}{|l|l|}
\hline Nombre & Campana \\
\hline $\mathbf{N}^{\mathbf{0}}$ de inventario & R10996 \\
\hline Ubicación actual & Museo de la Alhambra \\
\hline Procedencia & Alhambra, Granada \\
\hline Dimensiones & Altura: $3,5 \mathrm{~cm}$; Anchura: $1,8 \mathrm{~cm}$; Grosor: $1,4 \mathrm{~cm}$ \\
\hline Ciudad & Granada \\
\hline Cronología & Desconocida \\
\hline Características & $\begin{array}{l}\text { Fragmento de lo que pudo ser una campana. El asa del } \\
\text { morfológicas }\end{array}$ \\
\hline Materiales & Bronce \\
\hline
\end{tabular}

\section{Datos organológicos}

\begin{tabular}{|l|l|}
\hline Tipo de instrumento & Idiófono \\
\hline $\begin{array}{l}\text { Clasificación } \\
\text { organológica }\end{array}$ & $\begin{array}{l}111.242 .122 \text { Campanas individuales suspendidas con } \\
\text { percusión interna (con badajo) }\end{array}$ \\
\hline Función & Lúdica o religiosa \\
\hline Fabricación & Herrería \\
\hline $\begin{array}{l}\text { Características } \\
\text { musicales }\end{array}$ & Posible campana con badajo interior. \\
\hline
\end{tabular}




\section{Datos arqueológicos}

\begin{tabular}{|l|l|}
\hline Yacimiento & Alhambra \\
\hline $\begin{array}{l}\text { Responsable de la } \\
\text { excavación }\end{array}$ & - \\
\hline
\end{tabular}

\section{Bibliografía}

\section{Documentación del Museo}

Pieza inventariada.

Inédito 


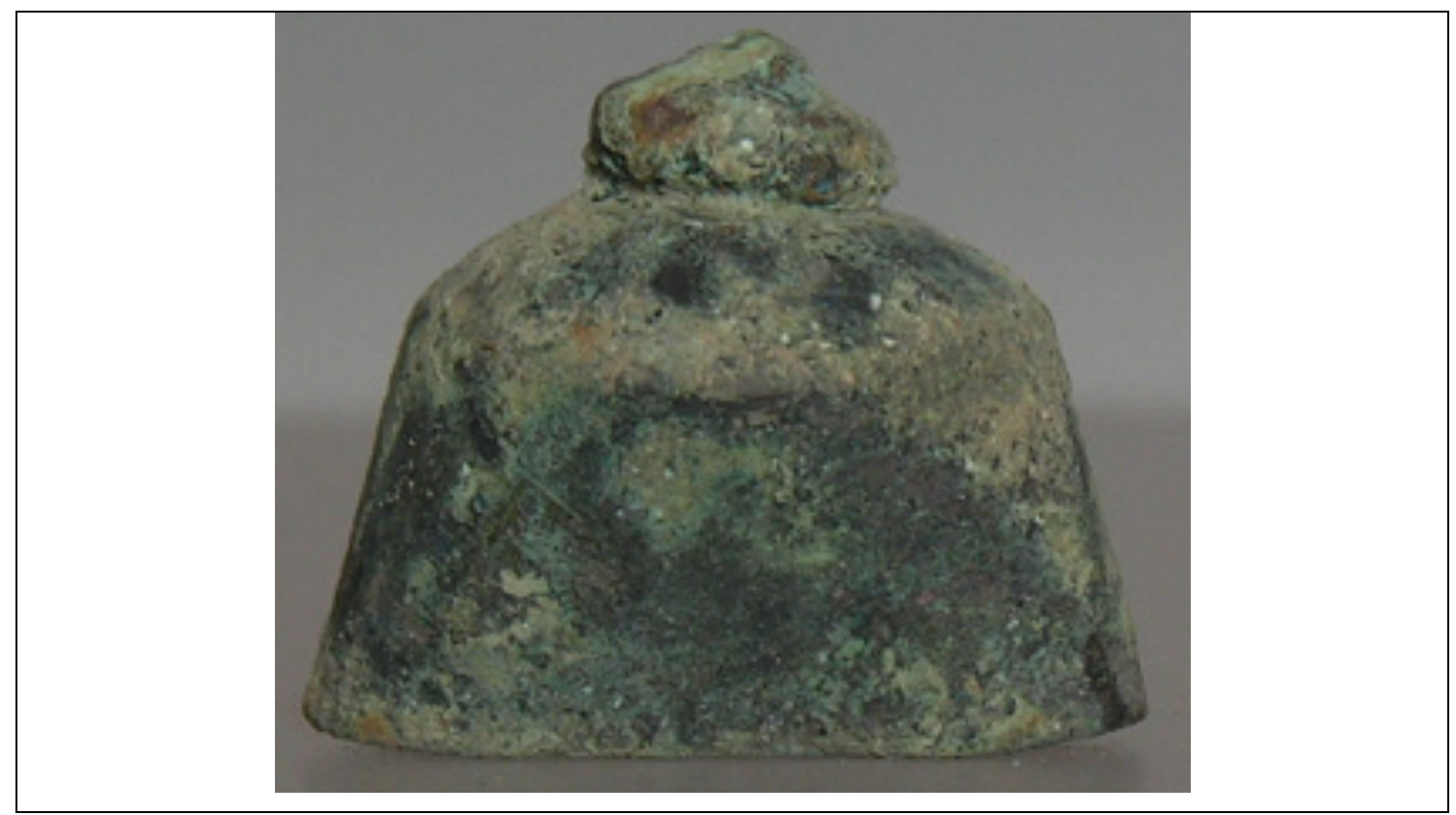

Datos generales

\begin{tabular}{|c|c|}
\hline Nombre & Cascabel \\
\hline $\mathrm{N}^{0}$ de inventario & R10998 \\
\hline Ubicación actual & Museo de la Alhambra \\
\hline Procedencia & Alhambra \\
\hline Dimensiones & - \\
\hline Ciudad & Granada \\
\hline Cronología & Desconocida \\
\hline $\begin{array}{l}\text { Características } \\
\text { morfológicas }\end{array}$ & $\begin{array}{l}\text { Pieza redonda con una soldadura en mitad de su cuerpo. } \\
\text { Cuenta con un asa redonda. }\end{array}$ \\
\hline Materiales & Bronce \\
\hline
\end{tabular}

\section{Datos organológicos}

\begin{tabular}{|l|l|}
\hline Tipo de instrumento & Idiófono \\
\hline $\begin{array}{l}\text { Clasificación } \\
\text { organológica }\end{array}$ & 112.1 Idiófonos sacudidos \\
\hline Función & Lúdica \\
\hline Fabricación & Herrería \\
\hline
\end{tabular}




\begin{tabular}{|l|l|}
\hline $\begin{array}{l}\text { Características } \\
\text { musicales }\end{array}$ & \\
\hline
\end{tabular}

Datos arqueológicos

\begin{tabular}{|l|l|}
\hline Yacimiento & \\
\hline Responsable de la & \\
excavación & \\
\hline
\end{tabular}

Bibliografía

\begin{tabular}{|l|l}
\hline Documentación del Museo & Pieza inventariada.
\end{tabular}

Inédito 


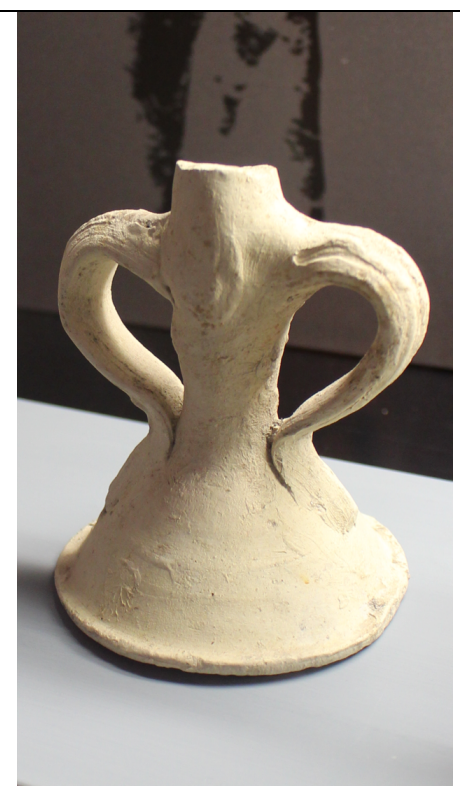

\section{Datos generales}

\begin{tabular}{|c|c|}
\hline Nombre & Campana \\
\hline $\mathrm{N}^{0}$ de inventario & A-4619 \\
\hline Ubicación actual & Museo Provincial de Jaén \\
\hline Procedencia & Calle Tinajeros \\
\hline Dimensiones & - \\
\hline Ciudad & Jaén \\
\hline Cronología & - \\
\hline $\begin{array}{l}\text { Características } \\
\text { morfológicas }\end{array}$ & $\begin{array}{l}\text { Campana que parece recrear a una figura femenina con los } \\
\text { brazos "en jarra". }\end{array}$ \\
\hline Materiales & Arcilla \\
\hline
\end{tabular}

\section{Datos organológicos}

\begin{tabular}{|l|l|}
\hline Tipo de instrumento & Idiófono \\
\hline $\begin{array}{l}\text { Clasificación } \\
\text { organológica }\end{array}$ & $\begin{array}{l}111.242 .122 \text { Campanas individuales suspendidas con } \\
\text { percusión interna (con badajo) }\end{array}$ \\
\hline Función & Lúdica \\
\hline Fabricación & Alfares \\
\hline Características & Campana que ha perdido su cabezal y por lo tanto no se \\
\hline
\end{tabular}


Datos arqueológicos

\begin{tabular}{|l|l|}
\hline Yacimiento & - \\
\hline $\begin{array}{l}\text { Responsable de la } \\
\text { excavación }\end{array}$ & - \\
\hline
\end{tabular}

\section{Bibliografía}

Documentación del Museo

Pieza con ficha de catalogación.

Inédito 


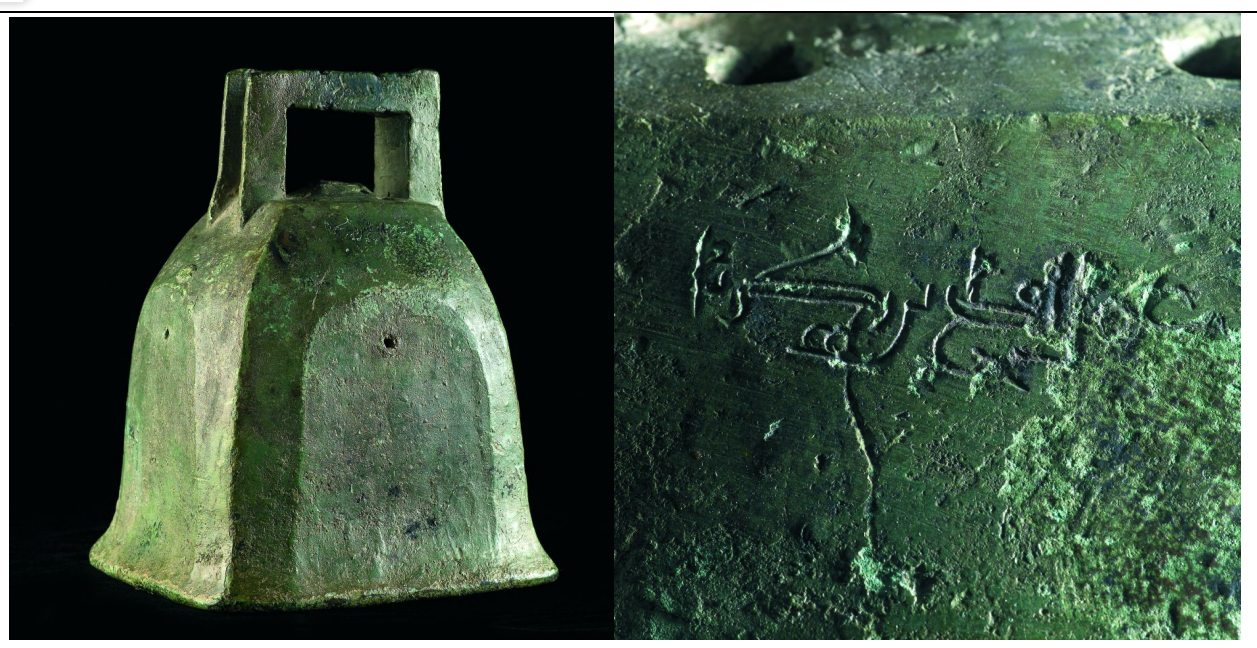

Datos generales

\begin{tabular}{|l|l|}
\hline Nombre & Campana \\
\hline $\mathbf{N}^{\mathbf{0}}$ de inventario & 2.901 \\
\hline Ubicación actual & Museo Provincial de Huelva \\
\hline Procedencia & Los Ronzones (Aljaraque) \\
\hline Dimensiones & Altura: $31,6 \mathrm{~cm}$; Ancho: $25,8 \mathrm{~cm}$ \\
\hline Ciudad & Huelva \\
\hline Cronología & s. XI (Califal-Mozárabe) \\
\hline Características & $\begin{array}{l}\text { Campana con estructura cuadrada de esquinas } \\
\text { modondeadas. Cuenta con dos asas de sujeción. Tiene una } \\
\text { inscripción cúfica: “Omar Ibn Zakaría”. }\end{array}$ \\
\hline Materiales & Bronce \\
\hline
\end{tabular}

Datos organológicos

\begin{tabular}{|l|l|}
\hline Tipo de instrumento & Idiófono \\
\hline $\begin{array}{l}\text { Clasificación } \\
\text { organológica }\end{array}$ & $\begin{array}{l}111.242 .122 \text { Campanas individuales suspendidas con } \\
\text { percusión interna (con badajo) }\end{array}$ \\
\hline Función & Lúdica \\
\hline Fabricación & Herrería \\
\hline $\begin{array}{l}\text { Características } \\
\text { musicales }\end{array}$ & Campana de bronce que ha perdido el badajo. \\
\hline
\end{tabular}




\section{Datos arqueológicos}

\begin{tabular}{|l|l|}
\hline Yacimiento & Ermita o iglesia rural, Los Ronzones, Aljaraque \\
\hline $\begin{array}{l}\text { Responsable } \\
\text { excavación }\end{array}$ & - \\
\hline
\end{tabular}

\section{Bibliografía}

\begin{tabular}{|l|l|}
\hline Documentación del Museo & Pieza con ficha de catalogación. \\
\hline Bedia García, Juana, José Beltrán Pizón y Miguel López Domínguez. "La campana \\
mozárabe del Museo Provincial de Huelva". Cuadernos del Suroeste, 3. Huelva: \\
(1992): 175-181.
\end{tabular}




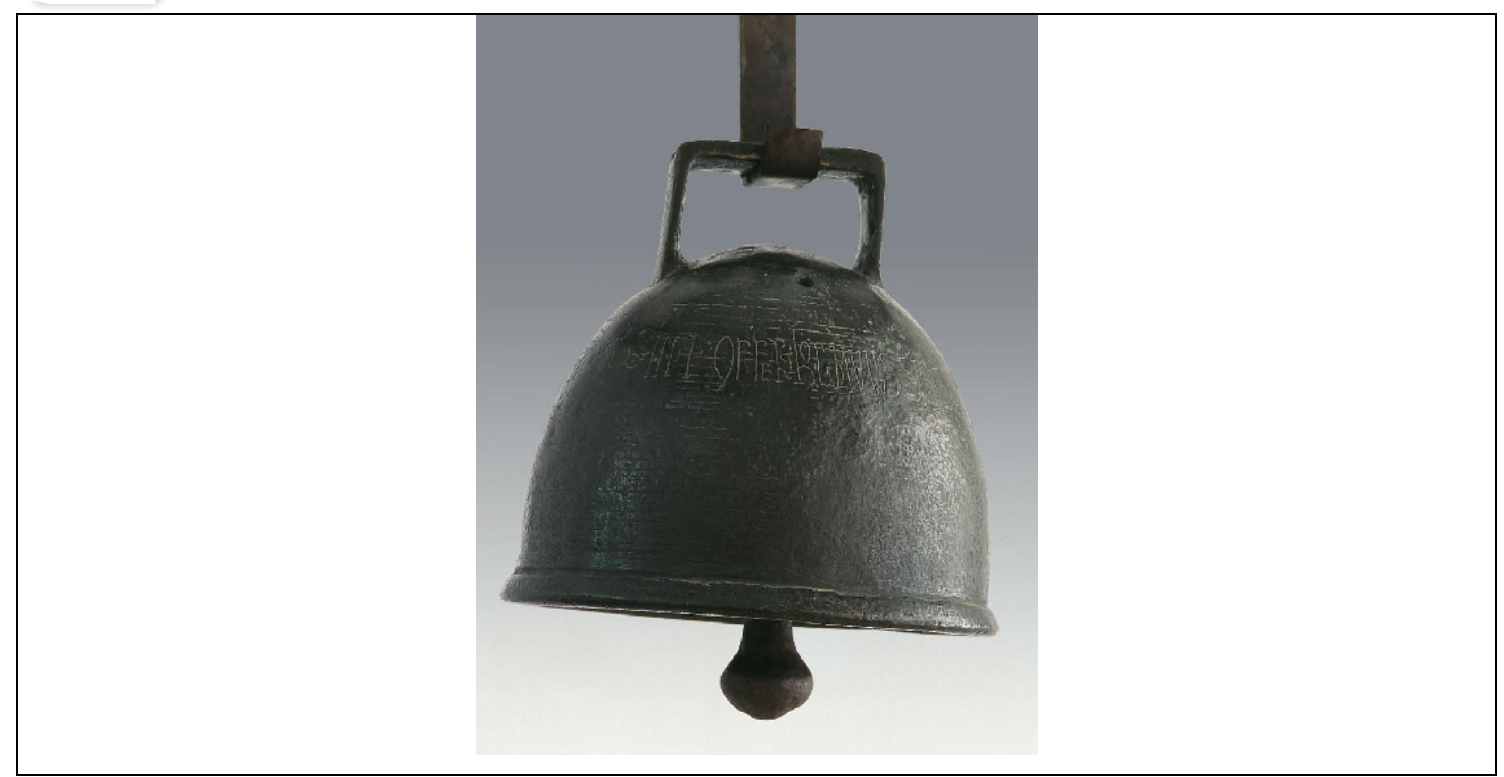

Datos generales

\begin{tabular}{|c|c|}
\hline Nombre & Campana \\
\hline $\mathrm{N}^{\mathrm{o}}$ de inventario & CE000430 \\
\hline Ubicación actual & Museo Arqueológico y Etnológico de Córdoba \\
\hline Procedencia & Penillanura Mariánica, Espiel, Córdoba \\
\hline Dimensiones & Altura: $19,5 \mathrm{~cm}$; Ancho: $19,5 \mathrm{~cm}$ \\
\hline Ciudad & Córdoba \\
\hline Cronología & s. X (Califal- Mozárabe) \\
\hline $\begin{array}{l}\text { Características } \\
\text { morfológicas }\end{array}$ & $\begin{array}{l}\text { Campana con forma semiovoidea con asa rectangular. } \\
\text { Cuenta con un reborde redondeado y marcas en su cuerpo } \\
\text { de círculos concéntricos. El badajo se sujeta a la campana } \\
\text { mediante una argolla soldada aunque esta pieza puede no } \\
\text { ser la originaria de esta campana. Cuenta con la siguiente } \\
\text { inscripción: "El abad Samson ofrece este regalo a la casa } \\
\text { (ermita) de S. Sebastián, mártir de Cristo, en el año de la } \\
\text { Era 993". Debido al estado de conservación de esta } \\
\text { inscripción se duda si la fecha exacta es la mencionada si } \\
\text { puede referirse a } 968 \text { o } 0930 \text {. }\end{array}$ \\
\hline Materiales & Bronce \\
\hline
\end{tabular}




\section{Datos organológicos}

\begin{tabular}{|l|l|}
\hline Tipo de instrumento & Idiófono \\
\hline $\begin{array}{l}\text { Clasificación } \\
\text { organológica }\end{array}$ & $\begin{array}{l}111.242 .122 \text { Campanas individuales suspendidas con } \\
\text { percusión interna (con badajo) }\end{array}$ \\
\hline Función & Lúdica \\
\hline Fabricación & Herrería \\
\hline $\begin{array}{l}\text { Características } \\
\text { musicales }\end{array}$ & Campana de bronce con badajo. \\
\hline
\end{tabular}

Datos arqueológicos

\begin{tabular}{|l|l|}
\hline Yacimiento & Penillanura Mariánica, Espiel, Córdoba \\
\hline $\begin{array}{l}\text { Responsable } \\
\text { excavación }\end{array}$ & - \\
\hline
\end{tabular}

\section{Bibliografía}

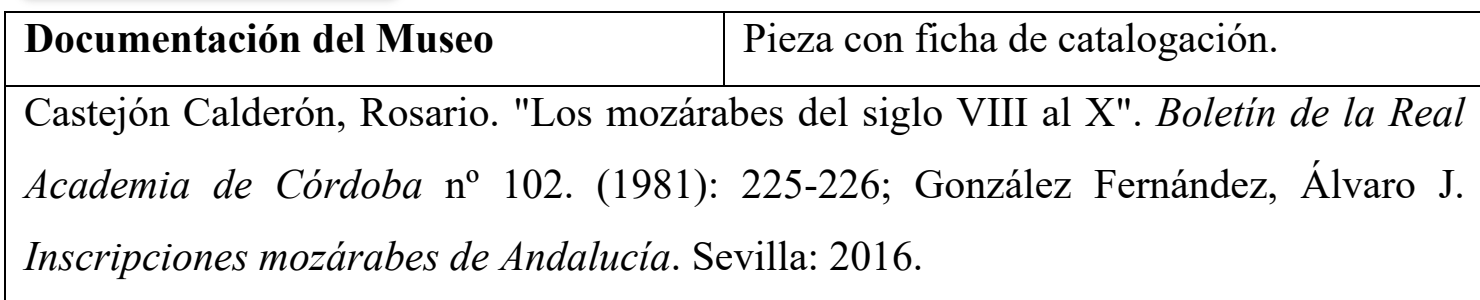




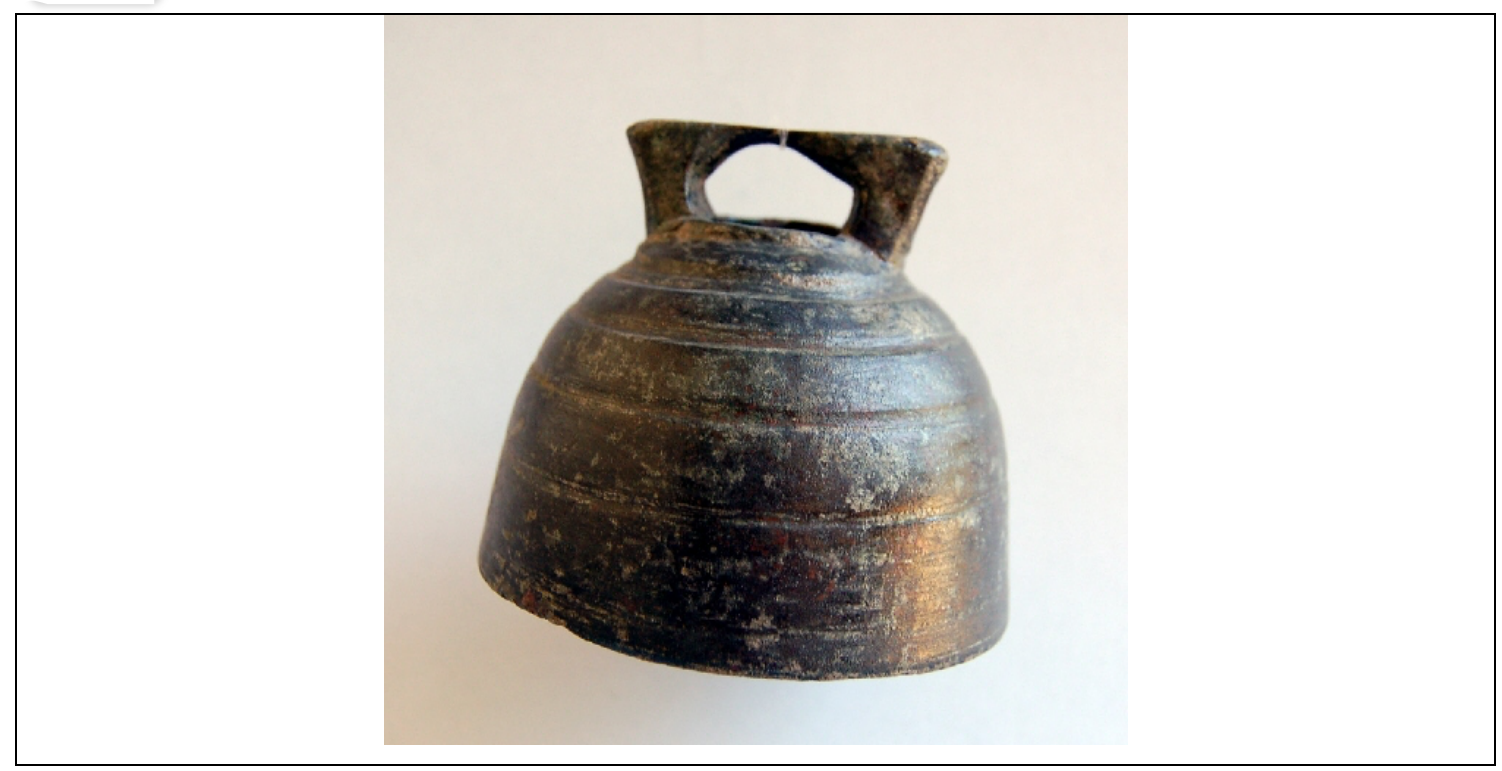

\section{Datos generales}

\begin{tabular}{|l|l|}
\hline Nombre & Campana \\
\hline $\mathbf{N}^{\mathbf{0}}$ de inventario & REP06396 \\
\hline Ubicación actual & Museo Arqueológico de Sevilla \\
\hline Procedencia & Vega del Guadalquivir, Sevilla \\
\hline Dimensiones & Altura: $8 \mathrm{~cm}$; Ancho: $8 \mathrm{~cm}$ \\
\hline Ciudad & Sevilla \\
\hline Cronología & s. X (Califal-Mozárabe) \\
\hline Características morfológicas & $\begin{array}{l}\text { Campana con forma semiesferoidal con anilla de } \\
\text { sujeción trapezoidal. La superficie se encuentra } \\
\text { adornada de estrías concéntricas parelelas. }\end{array}$ \\
\hline Materiales & Bronce \\
\hline
\end{tabular}

\section{Datos organológicos}

\begin{tabular}{|l|l|}
\hline Tipo de instrumento & Idiófono \\
\hline Clasificación organológica & $\begin{array}{l}111.242 .122 \text { Campanas individuales suspendidas } \\
\text { con percusión interna (con badajo) }\end{array}$ \\
\hline Función & Lúdica \\
\hline Fabricación & Herrería \\
\hline
\end{tabular}




\begin{tabular}{|l|l|}
\hline Características musicales & Campana de bronce que ha perdido el badajo. \\
\hline
\end{tabular}

\section{Datos arqueológicos}

\begin{tabular}{|l|l|}
\hline Yacimiento & Vega del Guadalquivir, Sevilla. \\
\hline Responsable excavación & - \\
\hline
\end{tabular}

\section{Bibliografía}

\begin{tabular}{|c|c|}
\hline Documentación del Museo & Pieza con ficha de catalogación. \\
\hline $\begin{array}{l}\text { Red Digital de Colecciones } \\
\text { http://ceres.mcu.es/pages/Main?idt=14957 }\end{array}$ & $\begin{array}{cccr}\text { de } & \text { Museos en } & \text { España: } \\
\text { \&inventary=REP06396\&table=FMUS\&m }\end{array}$ \\
\hline
\end{tabular}




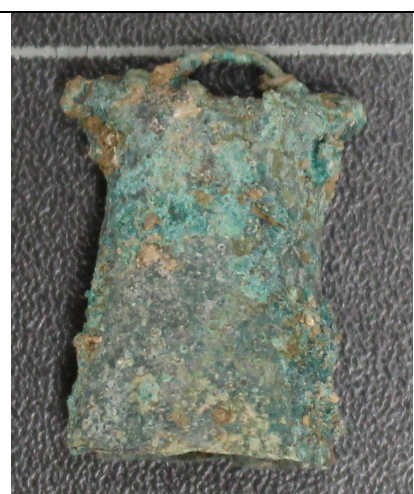

\section{Datos generales}

\begin{tabular}{|l|l|}
\hline Nombre & Campanita \\
\hline $\mathbf{N}^{\mathbf{0}}$ de inventario & - \\
\hline Ubicación actual & Museo Priego de Córdoba \\
\hline Procedencia & Calle Zurbarán \\
\hline Dimensiones & - \\
\hline Ciudad & Córdoba \\
\hline Cronología & ss.XII-XIII (Almohade) \\
\hline Características & $\begin{array}{l}\text { Campana de pequeño tamaño con asa superior y dos } \\
\text { pequeñas protuberancias a los lados. Tiene cuerpo y base } \\
\text { ovalada. }\end{array}$ \\
\hline Materiales & Bronce \\
\hline
\end{tabular}

Datos organológicos

\begin{tabular}{|l|l|}
\hline Tipo de instrumento & Idiófono \\
\hline $\begin{array}{l}\text { Clasificación } \\
\text { organológica }\end{array}$ & $\begin{array}{l}111.242 .122 \text { Campanas individuales suspendidas con } \\
\text { percusión interna (con badajo) }\end{array}$ \\
\hline Función & Lúdica \\
\hline Fabricación & Herrería \\
\hline $\begin{array}{l}\text { Características } \\
\text { musicales }\end{array}$ & $\begin{array}{l}\text { Campana de pequeño tamaño con badajo del cual queda } \\
\text { parte de la cuerda de sujeción. }\end{array}$ \\
\hline
\end{tabular}




\section{Datos arqueológicos}

\begin{tabular}{|l|l|}
\hline Yacimiento & Calle Zurbarán, UE-28/ Espacio 1/ UE2/ Codo Acceso \\
\hline $\begin{array}{l}\text { Responsable de la } \\
\text { excavación }\end{array}$ & Rafael Carmona Ávila \\
\hline
\end{tabular}

\section{Bibliografía}

Documentación del Museo

Pieza en estudio.

Inédito 


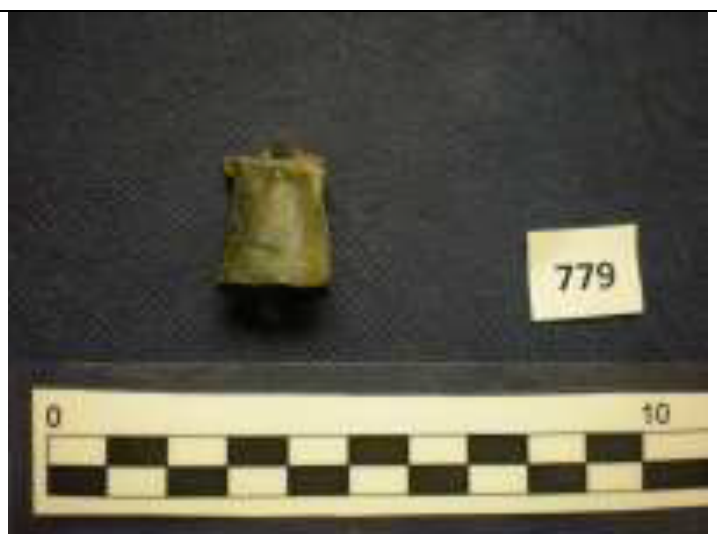

\section{Datos generales}

\begin{tabular}{|c|c|}
\hline Nombre & Campanita \\
\hline$N^{0}$ de inventario & 779 \\
\hline Ubicación actual & Museo Histórico Municipal de Teba \\
\hline Procedencia & Nina alta \\
\hline Dimensiones & Alto: $2,8 \mathrm{~cm}$; Ancho: $1,9 \mathrm{~cm}$ \\
\hline Ciudad & Málaga \\
\hline Cronología & ss. X-XIII (Califal-Almohade) \\
\hline $\begin{array}{l}\text { Características } \\
\text { morfológicas }\end{array}$ & $\begin{array}{l}\text { Campana de pequeño tamaño con asa superior y dos } \\
\text { pequeñas protuberancias a los lados. Tiene cuerpo y base } \\
\text { ovalada. }\end{array}$ \\
\hline Materiales & Bronce \\
\hline
\end{tabular}

\section{Datos organológicos}

\begin{tabular}{|l|l|}
\hline Tipo de instrumento & Idiófono \\
\hline $\begin{array}{l}\text { Clasificación } \\
\text { organológica }\end{array}$ & $\begin{array}{l}111.242 .122 \text { Campanas individuales suspendidas con } \\
\text { percusión interna (con badajo) }\end{array}$ \\
\hline Función & Lúdica \\
\hline Fabricación & Herrería \\
\hline $\begin{array}{l}\text { Características } \\
\text { musicales }\end{array}$ & Campana de pequeño tamaño con badajo. \\
\hline
\end{tabular}




\section{Datos arqueológicos}

\begin{tabular}{|l|l|}
\hline Yacimiento & Nina alta \\
\hline $\begin{array}{l}\text { Responsable de la } \\
\text { excavación }\end{array}$ & - \\
\hline
\end{tabular}

\section{Bibliografía}

Documentación del Museo

Pieza inventariada.

Inédito 


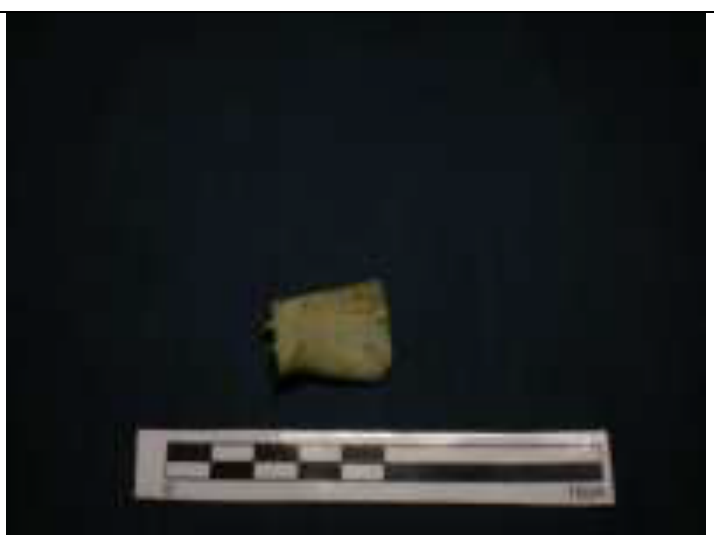

\section{Datos generales}

\begin{tabular}{|l|l|}
\hline Nombre & Campanita \\
\hline $\mathbf{N}^{\mathbf{0}}$ de inventario & 1901 \\
\hline Ubicación actual & Museo Histórico Municipal de Teba \\
\hline Procedencia & Nina alta \\
\hline Dimensiones & Alto: $2,8 \mathrm{~cm}$; Ancho: $2,4 \mathrm{~cm}$ \\
\hline Ciudad & Málaga \\
\hline Cronología & ss. VIII-XIII (Emiral-Almohade) \\
\hline Características & $\begin{array}{l}\text { Campana de pequeño tamaño con rastros de haber tenido } \\
\text { un asa superior y dos pequeñas protuberancias a los lados. } \\
\text { Tiene cuerpo y base ovalada. }\end{array}$ \\
\hline Materiales & Bronce \\
\hline
\end{tabular}

Datos organológicos

\begin{tabular}{|l|l|}
\hline Tipo de instrumento & Idiófono \\
\hline $\begin{array}{l}\text { Clasificación } \\
\text { organológica }\end{array}$ & $\begin{array}{l}111.242 .122 \text { Campanas individuales suspendidas con } \\
\text { percusión interna (con badajo) }\end{array}$ \\
\hline Función & Lúdica \\
\hline Fabricación & Herrería \\
\hline $\begin{array}{l}\text { Características } \\
\text { musicales }\end{array}$ & Campana de pequeño tamaño con badajo. \\
\hline
\end{tabular}




\section{Datos arqueológicos}

\begin{tabular}{|l|l|}
\hline Yacimiento & Nina alta \\
\hline $\begin{array}{l}\text { Responsable de la } \\
\text { excavación }\end{array}$ & - \\
\hline
\end{tabular}

\section{Bibliografía}

Documentación del Museo

Pieza inventariada.

Inédito 


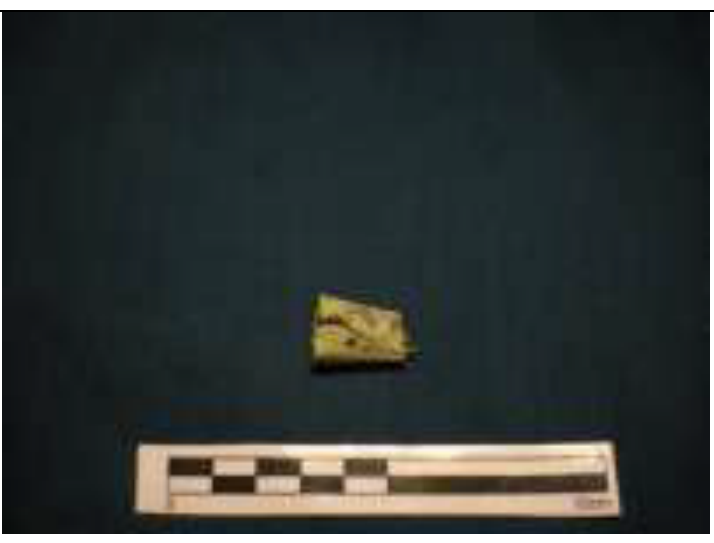

\section{Datos generales}

\begin{tabular}{|l|l|}
\hline Nombre & Campana \\
\hline $\mathbf{N}^{\mathbf{0}}$ de inventario & 1902 \\
\hline Ubicación actual & Museo Histórico Municipal de Teba \\
\hline Procedencia & Nina alta \\
\hline Dimensiones & Alto: $2,2 \mathrm{~cm}$; Ancho: $1,2 \mathrm{~cm}$ \\
\hline Ciudad & Málaga \\
\hline Cronología & ss. VIII-XIII (Emiral-Almohade) \\
\hline Características & $\begin{array}{l}\text { Campana de pequeño tamaño con rastros de haber tenido } \\
\text { morfológicas }\end{array}$ \\
Materiales & Tiene cuerpo y base ovalada. \\
\hline
\end{tabular}

Datos organológicos

\begin{tabular}{|l|l|}
\hline Tipo de instrumento & Idiófono \\
\hline $\begin{array}{l}\text { Clasificación } \\
\text { organológica }\end{array}$ & $\begin{array}{l}111.242 .122 \text { Campanas individuales suspendidas con } \\
\text { percusión interna (con badajo) }\end{array}$ \\
\hline Función & Lúdica \\
\hline Fabricación & Herrería \\
\hline $\begin{array}{l}\text { Características } \\
\text { musicales }\end{array}$ & Campana de pequeño tamaño con badajo. \\
\hline
\end{tabular}




\section{Datos arqueológicos}

\begin{tabular}{|l|l|}
\hline Yacimiento & Nina alta \\
\hline $\begin{array}{l}\text { Responsable de la } \\
\text { excavación }\end{array}$ & - \\
\hline
\end{tabular}

\section{Bibliografía}

Documentación del Museo

Pieza inventariada.

Inédito 


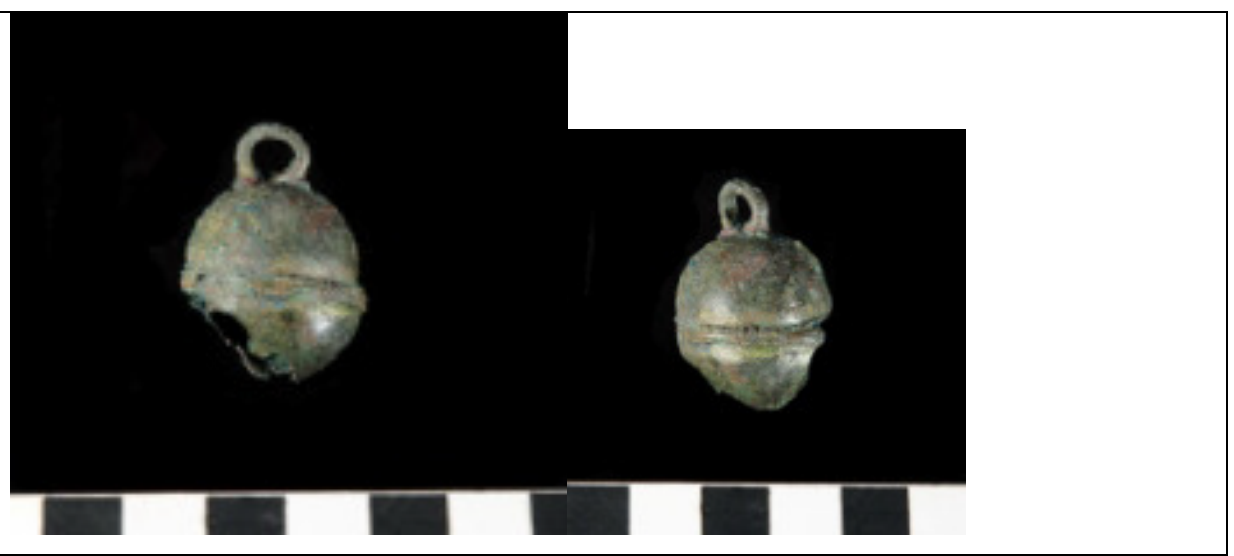

\section{Datos generales}

\begin{tabular}{|l|l|}
\hline Nombre & Cascabel \\
\hline $\mathbf{N}^{\mathbf{0}}$ de inventario & $816 / 00732-014$ \\
\hline Ubicación actual & Museo Arqueológico de Jerez \\
\hline Procedencia & Plaza Encarnación, 83 \\
\hline Dimensiones & Longitud: $3,5 \mathrm{~cm}$; Ancho: $3,6 \mathrm{~cm}$ \\
\hline Ciudad & Cádiz \\
\hline Cronología & ss. XII-XIII (Almohade) \\
\hline $\begin{array}{l}\text { Características } \\
\text { morfológicas }\end{array}$ & $\begin{array}{l}\text { Pieza redonda con una soldadura en mitad de su cuerpo. } \\
\text { Cuenta con un asa redonda. }\end{array}$ \\
\hline Materiales & Bronce \\
\hline
\end{tabular}

\section{Datos organológicos}

\begin{tabular}{|l|l|}
\hline Tipo de instrumento & Idiófono \\
\hline $\begin{array}{l}\text { Clasificación } \\
\text { organológica }\end{array}$ & 112.1 Idiófonos sacudidos \\
\hline Función & Lúdica \\
\hline Fabricación & Herrería \\
\hline $\begin{array}{l}\text { Características } \\
\text { musicales }\end{array}$ & $\begin{array}{l}\text { Cascabel que, a pesar de su estado de conservación, } \\
\text { parece contar con una pequeña abertura para la salida del } \\
\text { sonido. }\end{array}$ \\
\hline
\end{tabular}




\section{Datos arqueológicos}

\begin{tabular}{|l|l|}
\hline Yacimiento & Nina alta \\
\hline $\begin{array}{l}\text { Responsable de la } \\
\text { excavación }\end{array}$ & - \\
\hline
\end{tabular}

\section{Bibliografía}

Documentación del Museo

Pieza con ficha de catalogación.

Inédito 


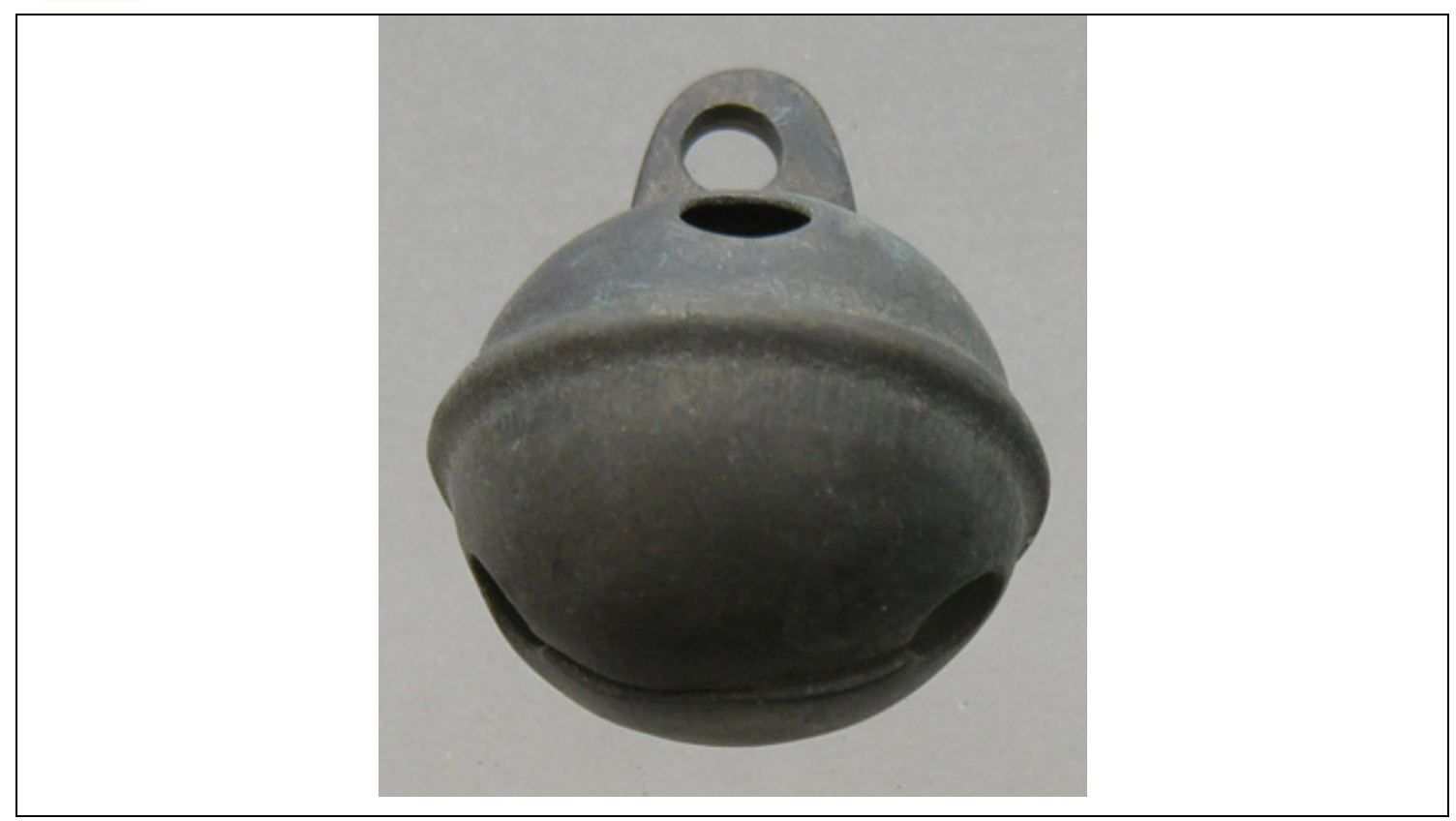

Datos generales

\begin{tabular}{|l|l|}
\hline Nombre & Cascabel \\
\hline $\mathbf{N}^{\mathbf{0}}$ de inventario & R10987 \\
\hline Ubicación actual & Museo de la Alhambra \\
\hline Procedencia & Alhambra, Granada \\
\hline Dimensiones & Altura: $2,2 \mathrm{~cm}$; Diámetro: $1,9 \mathrm{~cm}$ \\
\hline Ciudad & Granada \\
\hline Cronología & Desconocida \\
\hline morfológicas & $\begin{array}{l}\text { Pieza redonda con una soldadura en mitad de su cuerpo. } \\
\text { Cuenta con un asa redonda, dos agujeros en la parte } \\
\text { superior y una abertura que termina con orificios en la } \\
\text { parte posterior. Parece posterior a la época musulmana. }\end{array}$ \\
\hline Materiales & Bronce \\
\hline
\end{tabular}

Datos organológicos

\begin{tabular}{|l|l|}
\hline Tipo de instrumento & Idiófono \\
\hline $\begin{array}{l}\text { Clasificación } \\
\text { organológica }\end{array}$ & 112.1 Idiófonos sacudidos \\
\hline
\end{tabular}




\begin{tabular}{|l|l|}
\hline Función & Lúdica \\
\hline Fabricación & Herrería \\
\hline $\begin{array}{l}\text { Características } \\
\text { musicales }\end{array}$ & $\begin{array}{l}\text { Cascabel con pieza redonda interior y orificios de salida } \\
\text { del sonido. }\end{array}$ \\
\hline
\end{tabular}

Datos arqueológicos

\begin{tabular}{|l|l|}
\hline Yacimiento & Alhambra \\
\hline $\begin{array}{l}\text { Responsable de la } \\
\text { excavación }\end{array}$ & - \\
\hline
\end{tabular}

Bibliografía

\begin{tabular}{|l|l|}
\hline Documentación del Museo & Pieza inventariada. \\
\hline Inédito & \\
\hline
\end{tabular}




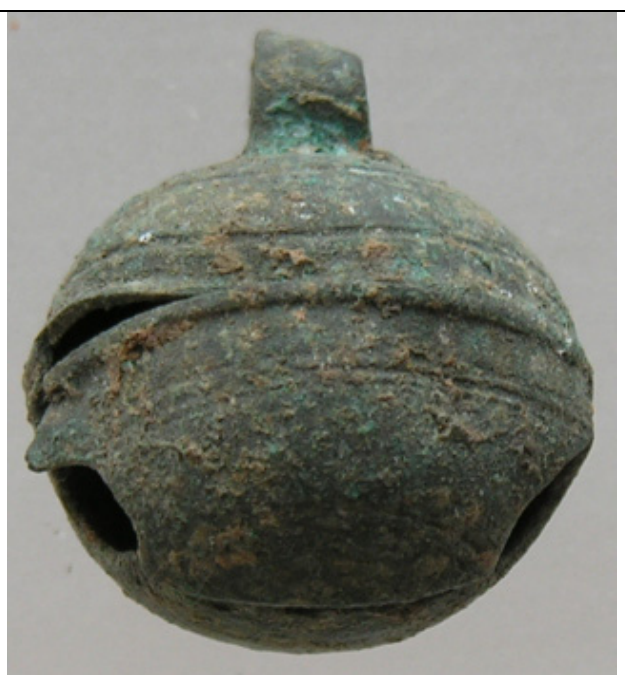

Datos generales

\begin{tabular}{|l|l|}
\hline Nombre & Cascabel \\
\hline $\mathbf{N}^{\mathbf{0}}$ de inventario & R10990 \\
\hline Ubicación actual & Museo de la Alhambra \\
\hline Procedencia & Alhambra, Granada \\
\hline Dimensiones & Altura: $2,2 \mathrm{~cm}$; Diámetro: $2 \mathrm{~cm}$ \\
\hline Ciudad & Granada \\
\hline Cronología & Desconocida \\
\hline Características & $\begin{array}{l}\text { Pieza redonda con una soldadura en mitad de su cuerpo. } \\
\text { morfológicas }\end{array}$ \\
\hline Materiales & la parte media a modo de adorno. \\
\hline
\end{tabular}

Datos organológicos

\begin{tabular}{|l|l|}
\hline Tipo de instrumento & Idiófono \\
\hline $\begin{array}{l}\text { Clasificación } \\
\text { organológica }\end{array}$ & 112.1 Idiófonos sacudidos \\
\hline Función & Lúdica \\
\hline Fabricación & Herrería \\
\hline Características & Cascabel con pieza redonda interior y orificios de salida \\
\hline
\end{tabular}


Datos arqueológicos

\begin{tabular}{|l|l|}
\hline Yacimiento & Alhambra \\
\hline $\begin{array}{l}\text { Responsable de la } \\
\text { excavación }\end{array}$ & - \\
\hline
\end{tabular}

\section{Bibliografía}

Documentación del Museo

Pieza inventariada.

Inédito 


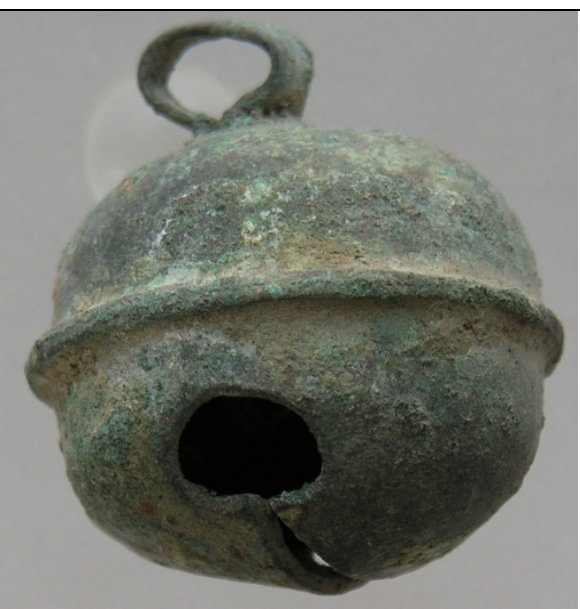

\section{Datos generales}

\begin{tabular}{|l|l|}
\hline Nombre & Cascabel \\
\hline $\mathbf{N}^{\mathbf{0}}$ de inventario & R10991 \\
\hline Ubicación actual & Museo de la Alhambra \\
\hline Procedencia & Alhambra, Granada \\
\hline Dimensiones & Altura: $3,3 \mathrm{~cm}$; Diámetro: $3 \mathrm{~cm}$ \\
\hline Ciudad & Granada \\
\hline Cronología & Desconocida \\
\hline Características & $\begin{array}{l}\text { Pieza redonda con una soldadura en mitad de su cuerpo. } \\
\text { morfológicas }\end{array}$ \\
\hline Materiales & Bronce \\
\hline
\end{tabular}

\section{Datos organológicos}

\begin{tabular}{|l|l|}
\hline Tipo de instrumento & Idiófono \\
\hline $\begin{array}{l}\text { Clasificación } \\
\text { organológica }\end{array}$ & 112.1 Idiófonos sacudidos \\
\hline Función & Lúdica \\
\hline Fabricación & Herrería \\
\hline $\begin{array}{l}\text { Características } \\
\text { musicales }\end{array}$ & $\begin{array}{l}\text { Cascabel con pieza redonda interior y orificios de salida } \\
\text { del sonido. }\end{array}$ \\
\hline
\end{tabular}




\section{Datos arqueológicos}

\begin{tabular}{|l|l|}
\hline Yacimiento & Alhambra \\
\hline $\begin{array}{l}\text { Responsable de la } \\
\text { excavación }\end{array}$ & - \\
\hline
\end{tabular}

\section{Bibliografía}

Documentación del Museo

Pieza inventariada.

Inédito 


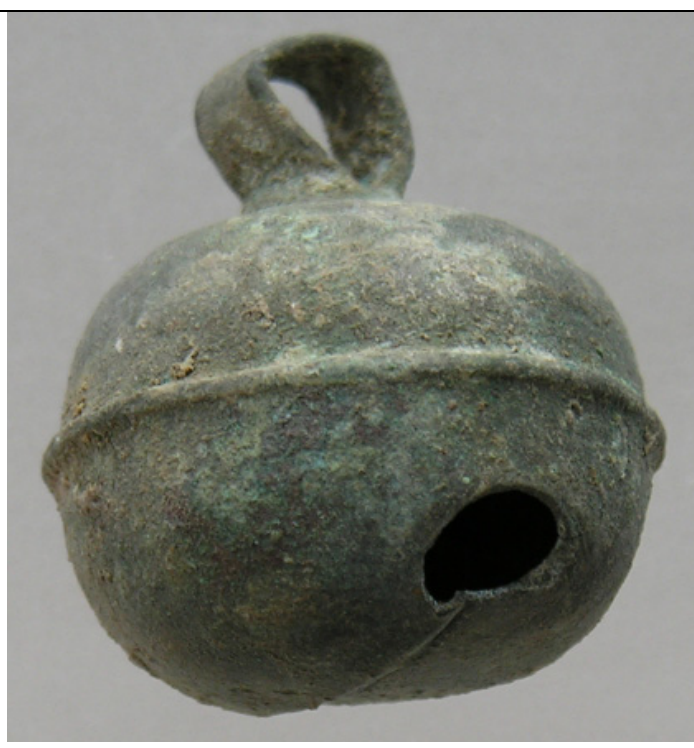

\section{Datos generales}

\begin{tabular}{|l|l|}
\hline Nombre & Cascabel \\
\hline $\mathbf{N}^{\mathbf{0}}$ de inventario & R10993 \\
\hline Ubicación actual & Museo de la Alhambra \\
\hline Procedencia & Alhambra, Granada \\
\hline Dimensiones & Altura: $2,7 \mathrm{~cm}$; Diámetro: $2,6 \mathrm{~cm}$ \\
\hline Ciudad & Granada \\
\hline Cronología & Desconocida \\
\hline Características & Pieza redonda con una soldadura en mitad de su cuerpo. \\
morfológicas & Cuenta con un asa redonda. \\
\hline Materiales & Bronce \\
\hline
\end{tabular}

Datos organológicos

\begin{tabular}{|l|l|}
\hline Tipo de instrumento & Idiófono \\
\hline $\begin{array}{l}\text { Clasificación } \\
\text { organológica }\end{array}$ & 112.1 Idiófonos sacudidos \\
\hline Función & Lúdica \\
\hline Fabricación & Herrería \\
\hline Características & Cascabel con pieza redonda interior y orificios de salida \\
\hline
\end{tabular}


Datos arqueológicos

\begin{tabular}{|l|l|}
\hline Yacimiento & Alhambra \\
\hline $\begin{array}{l}\text { Responsable de la } \\
\text { excavación }\end{array}$ & - \\
\hline
\end{tabular}

\section{Bibliografía}

Documentación del Museo

Pieza inventariada.

Inédito 


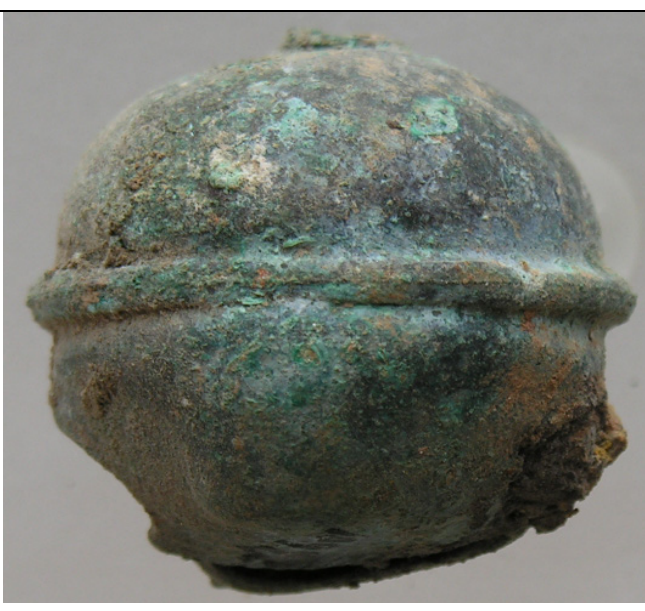

Datos generales

\begin{tabular}{|l|l|}
\hline Nombre & Cascabel \\
\hline $\mathbf{N}^{\mathbf{0}}$ de inventario & R10997 \\
\hline Ubicación actual & Museo de la Alhambra \\
\hline Procedencia & Alhambra, Granada \\
\hline Dimensiones & Altura: $3 \mathrm{~cm}$; Diámetro: $3,3 \mathrm{~cm}$ \\
\hline Ciudad & Granada \\
\hline Cronología & Desconocida \\
\hline Características & $\begin{array}{l}\text { Pieza redonda con una soldadura en mitad de su cuerpo. } \\
\text { morfológicas }\end{array}$ \\
\hline Materiales & Bronce \\
\hline
\end{tabular}

Datos organológicos

\begin{tabular}{|l|l|}
\hline Tipo de instrumento & Idiófono \\
\hline $\begin{array}{l}\text { Clasificación } \\
\text { organológica }\end{array}$ & 112.1 Idiófonos sacudidos \\
\hline Función & Lúdica \\
\hline Fabricación & Herrería \\
\hline $\begin{array}{l}\text { Características } \\
\text { musicales }\end{array}$ & $\begin{array}{l}\text { Cascabel con pieza redonda interior y orificios de salida } \\
\text { del sonido. }\end{array}$ \\
\hline
\end{tabular}




\section{Datos arqueológicos}

\begin{tabular}{|l|l|}
\hline Yacimiento & Alhambra \\
\hline $\begin{array}{l}\text { Responsable de la } \\
\text { excavación }\end{array}$ & - \\
\hline
\end{tabular}

\section{Bibliografía}

Documentación del Museo

Pieza inventariada.

Inédito 


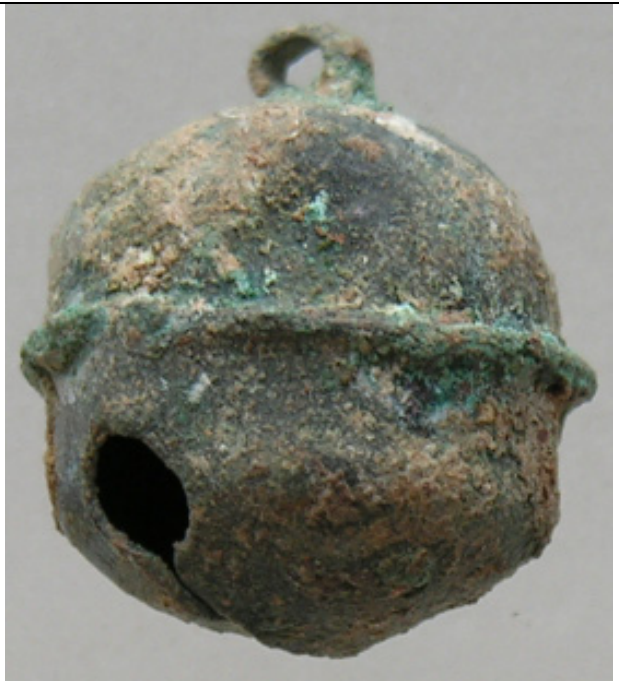

\section{Datos generales}

\begin{tabular}{|l|l|}
\hline Nombre & Cascabel \\
\hline $\mathbf{N}^{\mathbf{0}}$ de inventario & R11002 \\
\hline Ubicación actual & Museo de la Alhambra \\
\hline Procedencia & Alhambra, Granada \\
\hline Dimensiones & Altura: $1,9 \mathrm{~cm}$; Diámetro: $1,8 \mathrm{~cm}$ \\
\hline Ciudad & Granada \\
\hline Cronología & Desconocida \\
\hline Características & $\begin{array}{l}\text { Pieza redonda con una soldadura en mitad de su cuerpo. } \\
\text { Cuenta con un asa redonda. }\end{array}$ \\
\hline Materiales & Bronce \\
\hline
\end{tabular}

\section{Datos organológicos}

\begin{tabular}{|l|l|}
\hline Tipo de instrumento & Idiófono \\
\hline $\begin{array}{l}\text { Clasificación } \\
\text { organológica }\end{array}$ & 112.1 Idiófonos sacudidos \\
\hline Función & Lúdica \\
\hline Fabricación & Herrería \\
\hline Características & Cascabel con pieza redonda interior y orificios de salida \\
\hline
\end{tabular}


Datos arqueológicos

\begin{tabular}{|l|l|}
\hline Yacimiento & Alhambra \\
\hline $\begin{array}{l}\text { Responsable de la } \\
\text { excavación }\end{array}$ & - \\
\hline
\end{tabular}

\section{Bibliografía}

Documentación del Museo

Pieza inventariada.

Inédito 


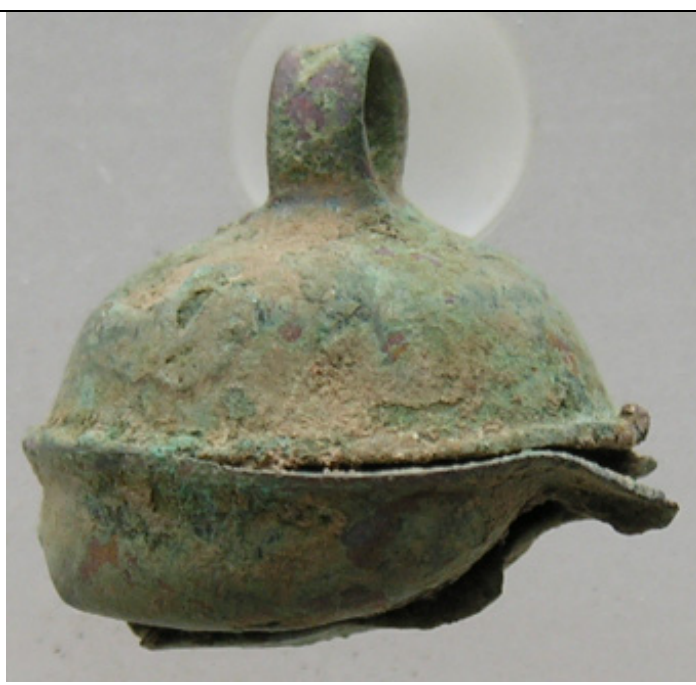

\section{Datos generales}

\begin{tabular}{|c|c|}
\hline Nombre & Cascabel \\
\hline $\mathrm{N}^{0}$ de inventario & R11003 \\
\hline Ubicación actual & Museo de la Alhambra \\
\hline Procedencia & Alhambra, Granada \\
\hline Dimensiones & Altura: 1,9 cm; Diámetro: $2,1 \mathrm{~cm}$ \\
\hline Ciudad & Granada \\
\hline Cronología & Desconocida \\
\hline $\begin{array}{l}\text { Características } \\
\text { morfológicas }\end{array}$ & $\begin{array}{l}\text { Pieza parcialmente achatada por su estado de } \\
\text { conservación. Cuenta con una soldadura en mitad de su } \\
\text { cuerpo y un asa redonda. }\end{array}$ \\
\hline Materiales & Bronce \\
\hline
\end{tabular}

\section{Datos organológicos}

\begin{tabular}{|l|l|}
\hline Tipo de instrumento & Idiófono \\
\hline $\begin{array}{l}\text { Clasificación } \\
\text { organológica }\end{array}$ & 112.1 Idiófonos sacudidos \\
\hline Función & Lúdica \\
\hline Fabricación & Herrería \\
\hline Características & Cascabel con pieza redonda interior y orificios de salida \\
\hline
\end{tabular}


Datos arqueológicos

\begin{tabular}{|l|l|}
\hline Yacimiento & Alhambra \\
\hline $\begin{array}{l}\text { Responsable de la } \\
\text { excavación }\end{array}$ & - \\
\hline
\end{tabular}

\section{Bibliografía}

Documentación del Museo

Pieza inventariada.

Inédito 


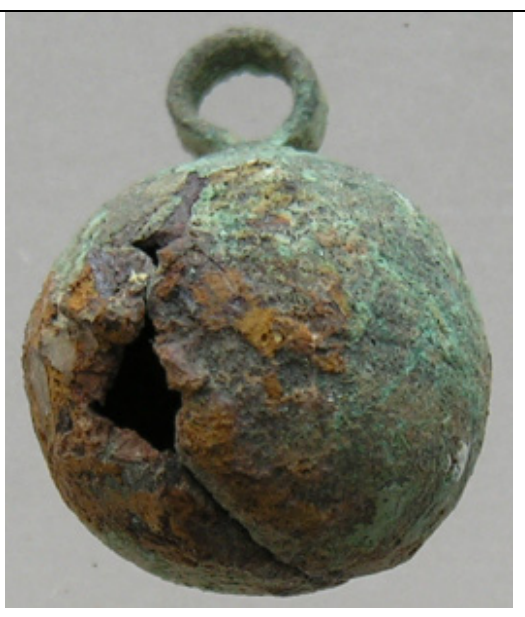

Datos generales

\begin{tabular}{|l|l|}
\hline Nombre & Cascabel \\
\hline $\mathbf{N}^{\mathbf{0}}$ de inventario & R11005 \\
\hline Ubicación actual & Museo de la Alhambra \\
\hline Procedencia & Alhambra, Granada \\
\hline Dimensiones & Altura: $2,1 \mathrm{~cm}$; Diámetro: $1,7 \mathrm{~cm}$ \\
\hline Ciudad & Granada \\
\hline Cronología & Desconocida \\
\hline Características & $\begin{array}{l}\text { Pieza redonda con una soldadura en mitad de su cuerpo. } \\
\text { Cuenta con un asa redonda. }\end{array}$ \\
\hline Materiales & Bronce \\
\hline
\end{tabular}

Datos organológicos

\begin{tabular}{|l|l|}
\hline Tipo de instrumento & Idiófono \\
\hline $\begin{array}{l}\text { Clasificación } \\
\text { organológica }\end{array}$ & 112.1 Idiófonos sacudidos \\
\hline Función & Lúdica \\
\hline Fabricación & Herrería \\
\hline $\begin{array}{l}\text { Características } \\
\text { musicales }\end{array}$ & $\begin{array}{l}\text { Cascabel con pieza redonda interior y orificios de salida } \\
\text { del sonido. }\end{array}$ \\
\hline
\end{tabular}




\section{Datos arqueológicos}

\begin{tabular}{|l|l|}
\hline Yacimiento & Alhambra \\
\hline $\begin{array}{l}\text { Responsable de la } \\
\text { excavación }\end{array}$ & - \\
\hline
\end{tabular}

\section{Bibliografía}

Documentación del Museo

Pieza inventariada.

Inédito 


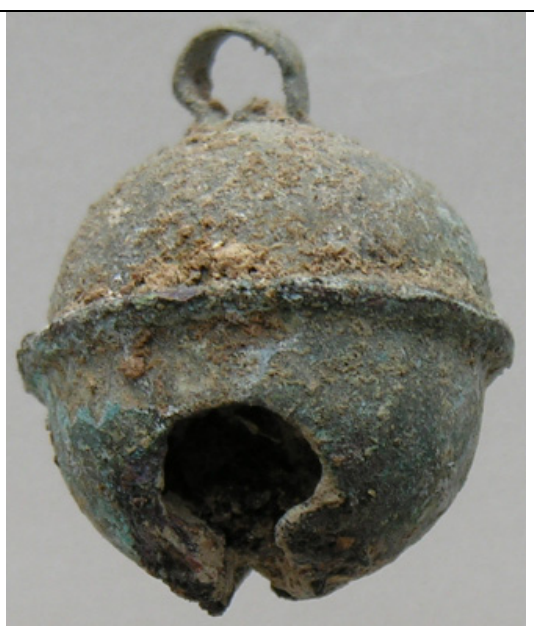

Datos generales

\begin{tabular}{|l|l|}
\hline Nombre & Cascabel \\
\hline $\mathbf{N}^{\mathbf{0}}$ de inventario & R11006 \\
\hline Ubicación actual & Museo de la Alhambra \\
\hline Procedencia & Alhambra, Granada \\
\hline Dimensiones & Altura: $2,6 \mathrm{~cm}$; Diámetro: $2,1 \mathrm{~cm}$ \\
\hline Ciudad & Granada \\
\hline Cronología & Desconocida \\
\hline Características & $\begin{array}{l}\text { Pieza redonda con una soldadura en mitad de su cuerpo. } \\
\text { Cuenta con un asa redonda. }\end{array}$ \\
\hline Materiales & Bronce \\
\hline
\end{tabular}

\section{Datos organológicos}

\begin{tabular}{|l|l|}
\hline Tipo de instrumento & Idiófono \\
\hline $\begin{array}{l}\text { Clasificación } \\
\text { organológica }\end{array}$ & 112.1 Idiófonos sacudidos \\
\hline Función & Lúdica \\
\hline Fabricación & Herrería \\
\hline $\begin{array}{l}\text { Características } \\
\text { musicales }\end{array}$ & $\begin{array}{l}\text { Cascabel con pieza redonda interior y orificios de salida } \\
\text { del sonido. }\end{array}$ \\
\hline
\end{tabular}




\section{Datos arqueológicos}

\begin{tabular}{|l|l|}
\hline Yacimiento & Alhambra \\
\hline $\begin{array}{l}\text { Responsable de la } \\
\text { excavación }\end{array}$ & - \\
\hline
\end{tabular}

\section{Bibliografía}

Documentación del Museo

Pieza inventariada.

Inédito 


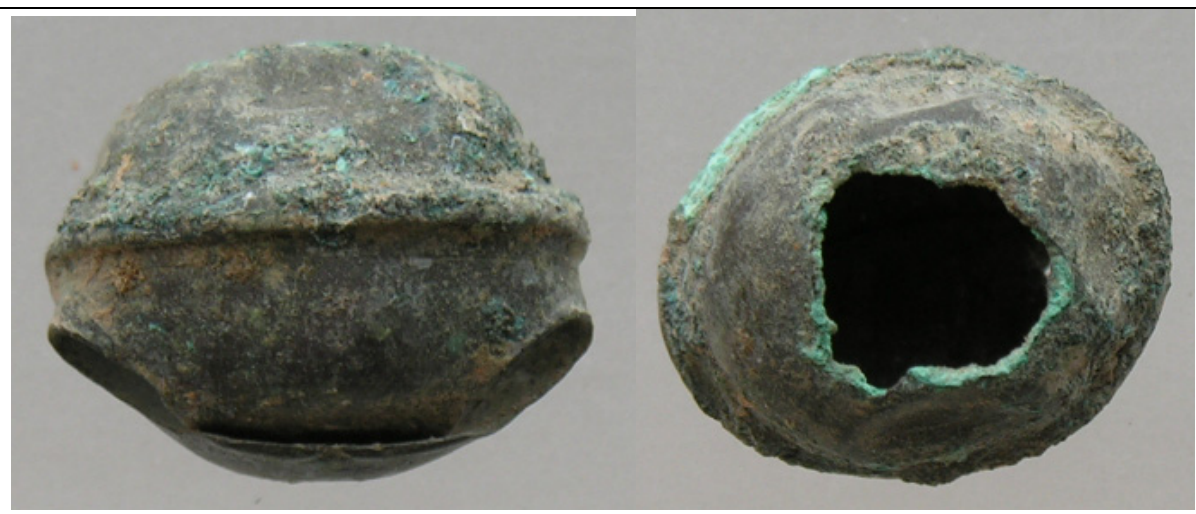

\section{Datos generales}

\begin{tabular}{|l|l|}
\hline Nombre & Cascabel \\
\hline $\mathbf{N}^{\mathbf{0}}$ de inventario & R1 1008 \\
\hline Ubicación actual & Museo de la Alhambra \\
\hline Procedencia & Alhambra, Granada \\
\hline Dimensiones & Altura: $1,6 \mathrm{~cm}$; Diámetro: $2 \mathrm{~cm}$ \\
\hline Ciudad & Granada \\
\hline Cronología & Desconocida \\
\hline Características & $\begin{array}{l}\text { Pieza redonda con una soldadura en mitad de su cuerpo. } \\
\text { morfológicas }\end{array}$ \\
Materiales & conservación se encuentra ligeramente achatada. \\
\hline
\end{tabular}

\section{Datos organológicos}

\begin{tabular}{|l|l|}
\hline Tipo de instrumento & Idiófono \\
\hline $\begin{array}{l}\text { Clasificación } \\
\text { organológica }\end{array}$ & 112.1 Idiófonos sacudidos \\
\hline Función & Lúdica \\
\hline Fabricación & Herrería \\
\hline $\begin{array}{l}\text { Características } \\
\text { musicales }\end{array}$ & $\begin{array}{l}\text { Cascabel con pieza redonda interior y orificios de salida } \\
\text { del sonido. }\end{array}$ \\
\hline
\end{tabular}




\section{Datos arqueológicos}

\begin{tabular}{|l|l|}
\hline Yacimiento & Alhambra \\
\hline $\begin{array}{l}\text { Responsable de la } \\
\text { excavación }\end{array}$ & - \\
\hline
\end{tabular}

\section{Bibliografía}

Documentación del Museo

Pieza inventariada.

Inédito 


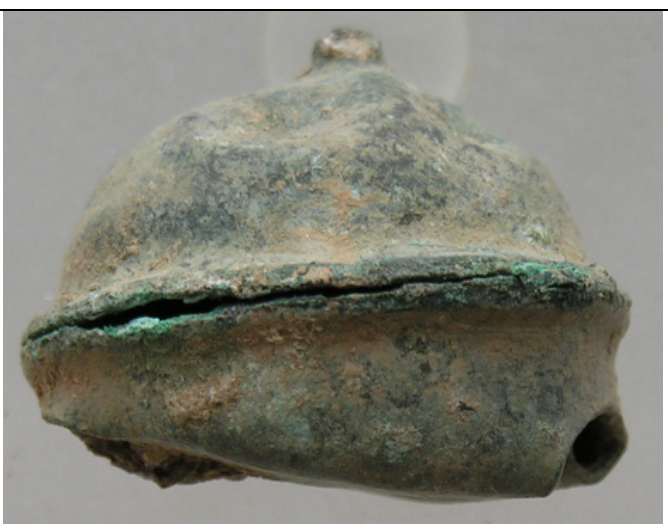

\section{Datos generales}

\begin{tabular}{|l|l|}
\hline Nombre & Cascabel \\
\hline $\mathbf{N}^{\mathbf{0}}$ de inventario & R11009 \\
\hline Ubicación actual & Museo de la Alhambra \\
\hline Procedencia & Alhambra, Granada \\
\hline Dimensiones & Altura: $2,4 \mathrm{~cm}$; Diámetro: $2,8 \mathrm{~cm}$ \\
\hline Ciudad & Granada \\
\hline Cronología & Desconocida \\
\hline Características & $\begin{array}{l}\text { Pieza redonda con una soldadura en mitad de su cuerpo. } \\
\text { morfológicas }\end{array}$ \\
\hline Materiales & está aplastada y la superior golpeada. \\
\hline
\end{tabular}

Datos organológicos

\begin{tabular}{|l|l|}
\hline Tipo de instrumento & Idiófono \\
\hline $\begin{array}{l}\text { Clasificación } \\
\text { organológica }\end{array}$ & 112.1 Idiófonos sacudidos \\
\hline Función & Lúdica \\
\hline Fabricación & Herrería \\
\hline $\begin{array}{l}\text { Características } \\
\text { musicales }\end{array}$ & $\begin{array}{l}\text { Cascabel con pieza redonda interior y orificios de salida } \\
\text { del sonido. }\end{array}$ \\
\hline
\end{tabular}




\section{Datos arqueológicos}

\begin{tabular}{|l|l|}
\hline Yacimiento & Alhambra \\
\hline $\begin{array}{l}\text { Responsable de la } \\
\text { excavación }\end{array}$ & - \\
\hline
\end{tabular}

\section{Bibliografía}

Documentación del Museo

Pieza inventariada.

Inédito 


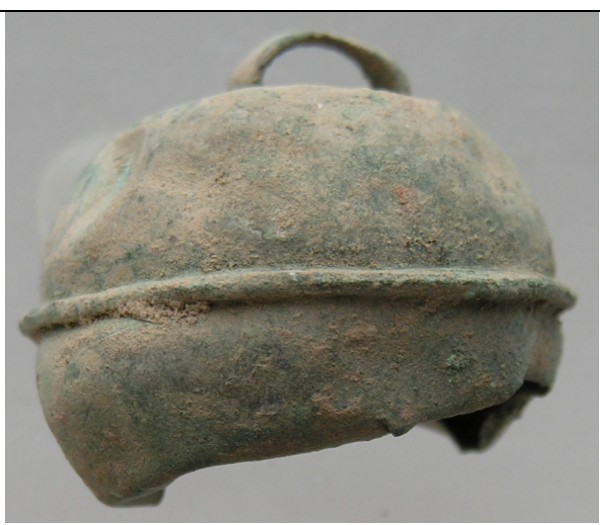

\section{Datos generales}

\begin{tabular}{|c|c|}
\hline Nombre & Cascabel \\
\hline $\mathrm{N}^{\mathrm{o}}$ de inventario & R11010 \\
\hline Ubicación actual & Museo de la Alhambra \\
\hline Procedencia & Alhambra, Granada \\
\hline Dimensiones & Altura: $2,8 \mathrm{~cm}$; Diámetro: $3,8 \mathrm{~cm}$ \\
\hline Ciudad & Granada \\
\hline Cronología & Desconocida \\
\hline $\begin{array}{l}\text { Características } \\
\text { morfológicas }\end{array}$ & $\begin{array}{l}\text { Pieza redonda con una soldadura en mitad de su cuerpo. } \\
\text { Cuenta con un asa redonda. Ha perdido parte de la parte } \\
\text { inferior. }\end{array}$ \\
\hline Materiales & Bronce \\
\hline
\end{tabular}

\section{Datos organológicos}

\begin{tabular}{|l|l|}
\hline Tipo de instrumento & Idiófono \\
\hline $\begin{array}{l}\text { Clasificación } \\
\text { organológica }\end{array}$ & 112.1 Idiófonos sacudidos \\
\hline Función & Lúdica \\
\hline Fabricación & Herrería \\
\hline $\begin{array}{l}\text { Características } \\
\text { musicales }\end{array}$ & $\begin{array}{l}\text { Cascabel con pieza redonda interior y orificios de salida } \\
\text { del sonido. }\end{array}$ \\
\hline
\end{tabular}




\section{Datos arqueológicos}

\begin{tabular}{|l|l|}
\hline Yacimiento & Alhambra \\
\hline $\begin{array}{l}\text { Responsable de la } \\
\text { excavación }\end{array}$ & - \\
\hline
\end{tabular}

\section{Bibliografía}

Documentación del Museo

Pieza inventariada.

Inédito 


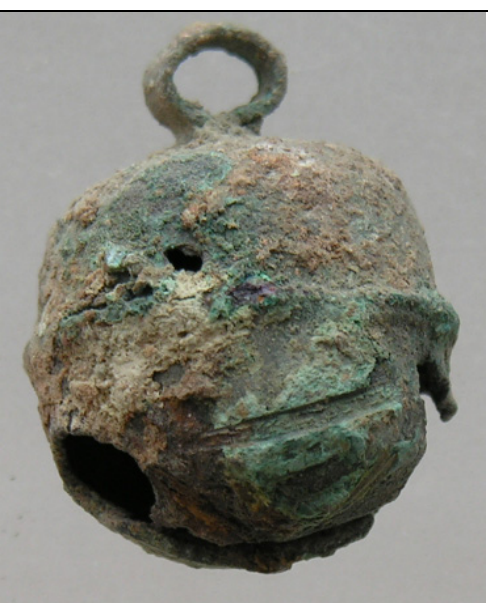

Datos generales

\begin{tabular}{|c|c|}
\hline Nombre & Cascabel \\
\hline $\mathrm{N}^{0}$ de inventario & R11011 \\
\hline Ubicación actual & Museo de la Alhambra \\
\hline Procedencia & Alhambra, Granada \\
\hline Dimensiones & Altura: $2,8 \mathrm{~cm}$; Diámetro: $2,1 \mathrm{~cm}$ \\
\hline Ciudad & Granada \\
\hline Cronología & Desconocida \\
\hline $\begin{array}{l}\text { Características } \\
\text { morfológicas }\end{array}$ & $\begin{array}{l}\text { Pieza redonda con una soldadura en mitad de su cuerpo. } \\
\text { Cuenta con un asa redonda. }\end{array}$ \\
\hline Materiales & Bronce \\
\hline
\end{tabular}

\section{Datos organológicos}

\begin{tabular}{|l|l|}
\hline Tipo de instrumento & Idiófono \\
\hline $\begin{array}{l}\text { Clasificación } \\
\text { organológica }\end{array}$ & 112.1 Idiófonos sacudidos \\
\hline Función & Lúdica \\
\hline Fabricación & Herrería \\
\hline $\begin{array}{l}\text { Características } \\
\text { musicales }\end{array}$ & $\begin{array}{l}\text { Cascabel con pieza redonda interior y orificios de salida } \\
\text { del sonido. }\end{array}$ \\
\hline
\end{tabular}




\section{Datos arqueológicos}

\begin{tabular}{|l|l|}
\hline Yacimiento & Alhambra \\
\hline $\begin{array}{l}\text { Responsable de la } \\
\text { excavación }\end{array}$ & - \\
\hline
\end{tabular}

\section{Bibliografía}

Documentación del Museo

Pieza inventariada.

Inédito 


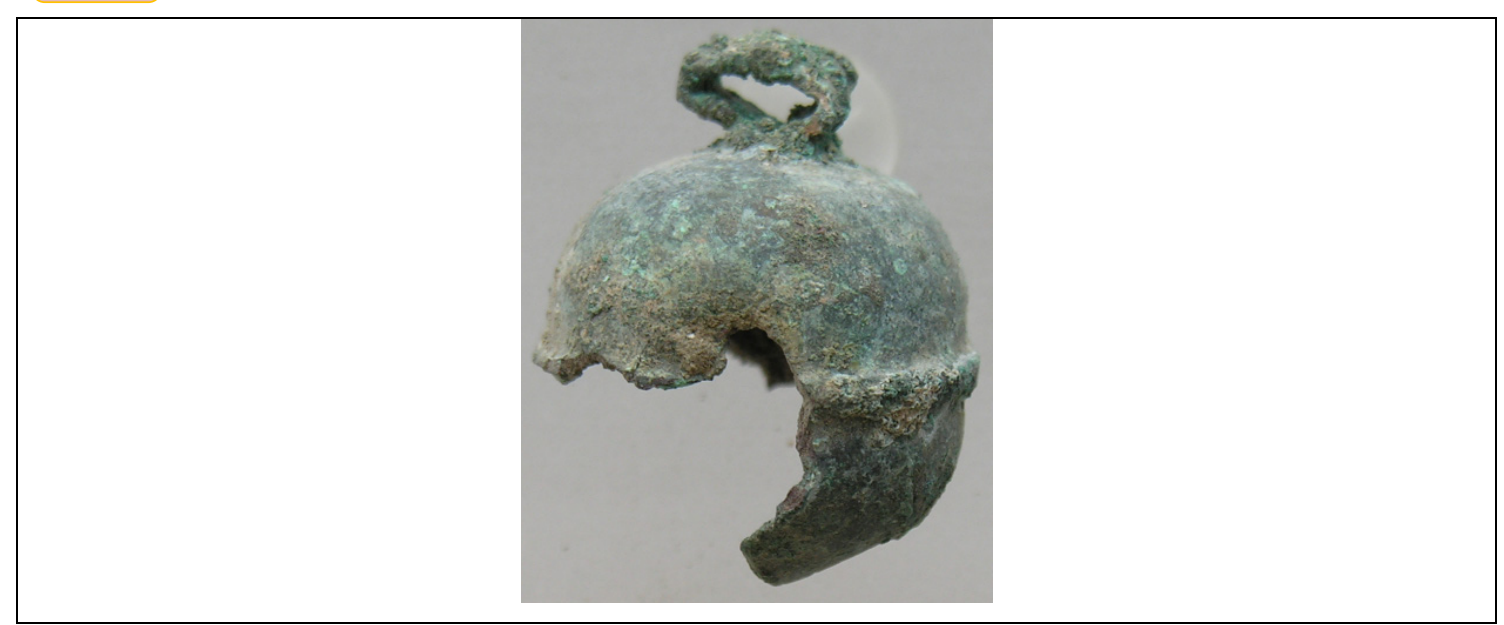

\section{Datos generales}

\begin{tabular}{|l|l|}
\hline Nombre & Cascabel \\
\hline $\mathbf{N}^{\mathbf{0}}$ de inventario & R11012 \\
\hline Ubicación actual & Museo de la Alhambra \\
\hline Procedencia & Alhambra, Granada \\
\hline Dimensiones & Altura: $3 \mathrm{~cm}$; Diámetro: $2,6 \mathrm{~cm}$ \\
\hline Ciudad & Granada \\
\hline Cronología & Desconocida \\
\hline Características & $\begin{array}{l}\text { Fragmento redondo con una soldadura en mitad de su } \\
\text { cuerpo. Cuenta con un asa redonda. }\end{array}$ \\
\hline Materiales & Bronce \\
\hline
\end{tabular}

\section{Datos organológicos}

\begin{tabular}{|l|l|}
\hline Tipo de instrumento & Idiófono \\
\hline $\begin{array}{l}\text { Clasificación } \\
\text { organológica }\end{array}$ & 112.1 Idiófonos sacudidos \\
\hline Función & Lúdica \\
\hline Fabricación & Herrería \\
\hline $\begin{array}{l}\text { Características } \\
\text { musicales }\end{array}$ & Fragmento de cascabel. \\
\hline
\end{tabular}




\section{Datos arqueológicos}

\begin{tabular}{|l|l|}
\hline Yacimiento & Alhambra \\
\hline $\begin{array}{l}\text { Responsable de la } \\
\text { excavación }\end{array}$ & - \\
\hline
\end{tabular}

\section{Bibliografía}

Documentación del Museo

Pieza inventariada.

Inédito 


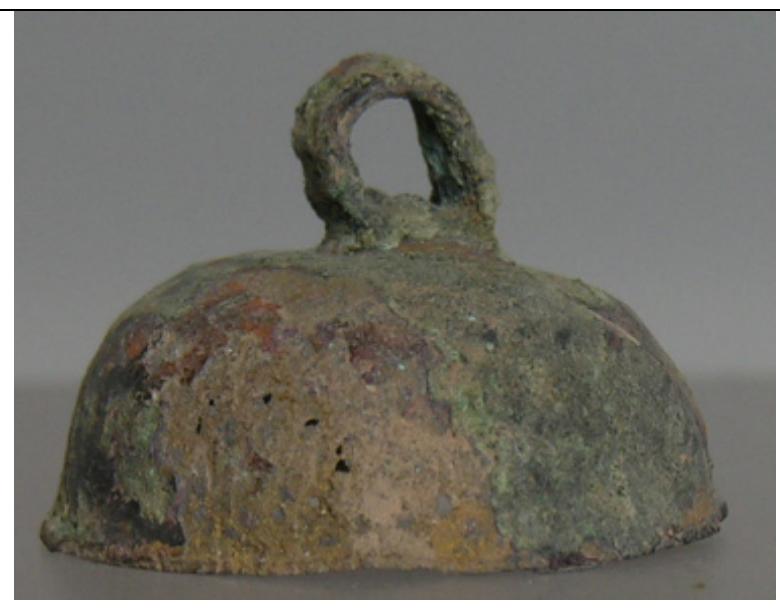

\section{Datos generales}

\begin{tabular}{|l|l|}
\hline Nombre & Cascabel \\
\hline $\mathbf{N}^{\mathbf{0}}$ de inventario & R11013 \\
\hline Ubicación actual & Museo de la Alhambra \\
\hline Procedencia & Alhambra, Granada \\
\hline Dimensiones & Altura: $1,9 \mathrm{~cm}$; Diámetro: $2,8 \mathrm{~cm}$ \\
\hline Ciudad & Granada \\
\hline Cronología & Desconocida \\
\hline $\begin{array}{l}\text { Características } \\
\text { morfológicas }\end{array}$ & $\begin{array}{l}\text { Parte superior de lo que pudo ser un cascabel con asa } \\
\text { redonda. }\end{array}$ \\
\hline Materiales & Bronce \\
\hline
\end{tabular}

\section{Datos organológicos}

\begin{tabular}{|l|l|}
\hline Tipo de instrumento & Idiófono \\
\hline $\begin{array}{l}\text { Clasificación } \\
\text { organológica }\end{array}$ & 112.1 Idiófonos sacudidos \\
\hline Función & Lúdica \\
\hline Fabricación & Herrería \\
\hline $\begin{array}{l}\text { Características } \\
\text { musicales }\end{array}$ & Fragmento de un posible cascabel. \\
\hline
\end{tabular}




\section{Datos arqueológicos}

\begin{tabular}{|l|l|}
\hline Yacimiento & Alhambra \\
\hline $\begin{array}{l}\text { Responsable de la } \\
\text { excavación }\end{array}$ & - \\
\hline
\end{tabular}

\section{Bibliografía}

Documentación del Museo

Pieza inventariada.

Inédito 


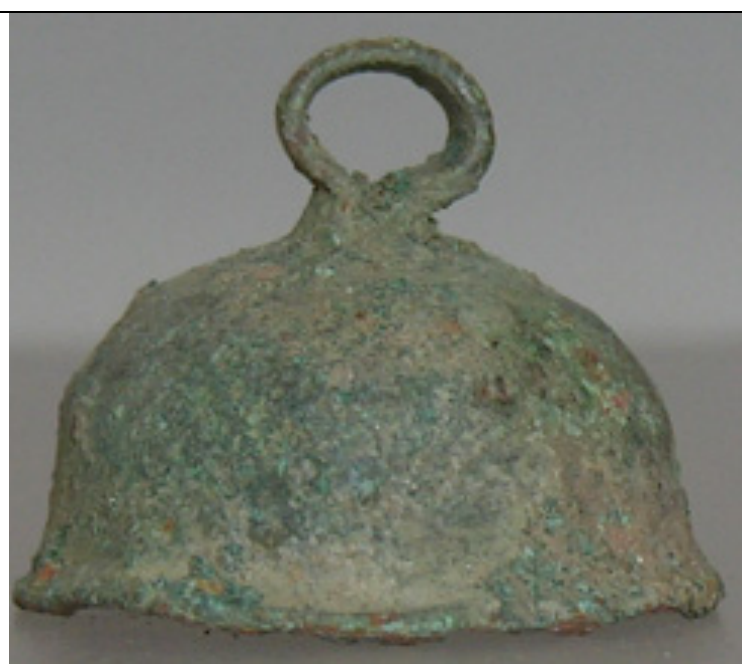

Datos generales

\begin{tabular}{|l|l|}
\hline Nombre & Cascabel \\
\hline $\mathbf{N}^{\mathbf{0}}$ de inventario & R11014 \\
\hline Ubicación actual & Museo de la Alhambra \\
\hline Procedencia & Alhambra, Granada \\
\hline Dimensiones & Altura: $1,5 \mathrm{~cm}$; Diámetro: $2 \mathrm{~cm}$ \\
\hline Ciudad & Granada \\
\hline Cronología & Desconocida \\
\hline $\begin{array}{l}\text { Características } \\
\text { morfológicas }\end{array}$ & $\begin{array}{l}\text { Parte superior de lo que pudo ser un cascabel con asa } \\
\text { redonda. }\end{array}$ \\
\hline Materiales & Bronce \\
\hline
\end{tabular}

Datos organológicos

\begin{tabular}{|l|l|}
\hline Tipo de instrumento & Idiófono \\
\hline $\begin{array}{l}\text { Clasificación } \\
\text { organológica }\end{array}$ & 112.1 Idiófonos sacudidos \\
\hline Función & Lúdica \\
\hline Fabricación & Herrería \\
\hline $\begin{array}{l}\text { Características } \\
\text { musicales }\end{array}$ & Fragmento de un posible cascabel. \\
\hline
\end{tabular}




\section{Datos arqueológicos}

\begin{tabular}{|l|l|}
\hline Yacimiento & Alhambra \\
\hline $\begin{array}{l}\text { Responsable de la } \\
\text { excavación }\end{array}$ & - \\
\hline
\end{tabular}

\section{Bibliografía}

Documentación del Museo

Pieza inventariada.

Inédito 


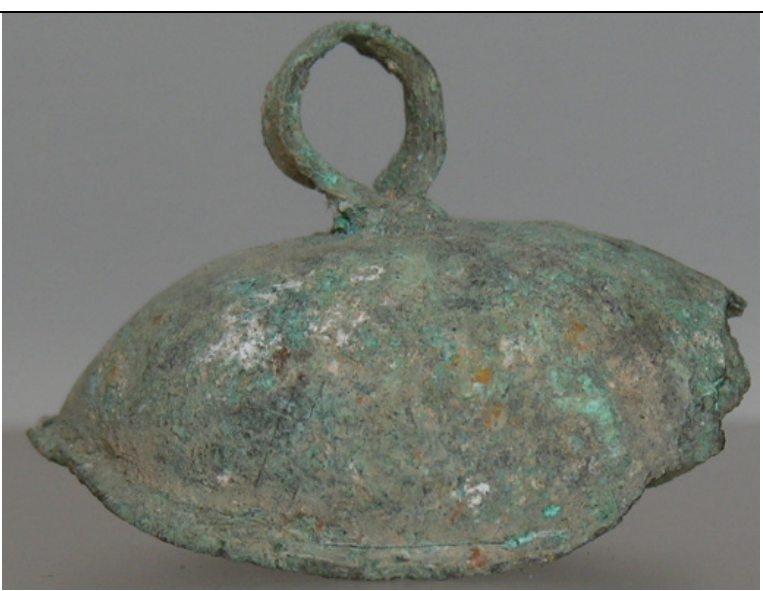

\section{Datos generales}

\begin{tabular}{|l|l|}
\hline Nombre & Cascabel \\
\hline $\mathbf{N}^{\mathbf{0}}$ de inventario & R1 1015 \\
\hline Ubicación actual & Museo de la Alhambra \\
\hline Procedencia & Alhambra, Granada \\
\hline Dimensiones & Altura: $3 \mathrm{~cm}$; Anchura: $4 \mathrm{~cm}$; Grosor: 2,7 cm \\
\hline Ciudad & Granada \\
\hline Cronología & Desconocida \\
\hline Características & $\begin{array}{l}\text { Parte superior de lo que pudo ser un cascabel con asa } \\
\text { modondógicas }\end{array}$ \\
\hline Materiales & Bronce \\
\hline
\end{tabular}

\section{Datos organológicos}

\begin{tabular}{|l|l|}
\hline Tipo de instrumento & Idiófono \\
\hline $\begin{array}{l}\text { Clasificación } \\
\text { organológica }\end{array}$ & 112.1 Idiófonos sacudidos \\
\hline Función & Lúdica \\
\hline Fabricación & Herrería \\
\hline $\begin{array}{l}\text { Características } \\
\text { musicales }\end{array}$ & Fragmento de un posible cascabel. \\
\hline
\end{tabular}

\section{Datos arqueológicos}




\begin{tabular}{|l|l|}
\hline Yacimiento & Alhambra \\
\hline $\begin{array}{l}\text { Responsable de la } \\
\text { excavación }\end{array}$ & - \\
\hline
\end{tabular}

Bibliografía

\begin{tabular}{|l|l}
\hline Documentación del Museo & Pieza inventariada. \\
\hline
\end{tabular}

Inédito 


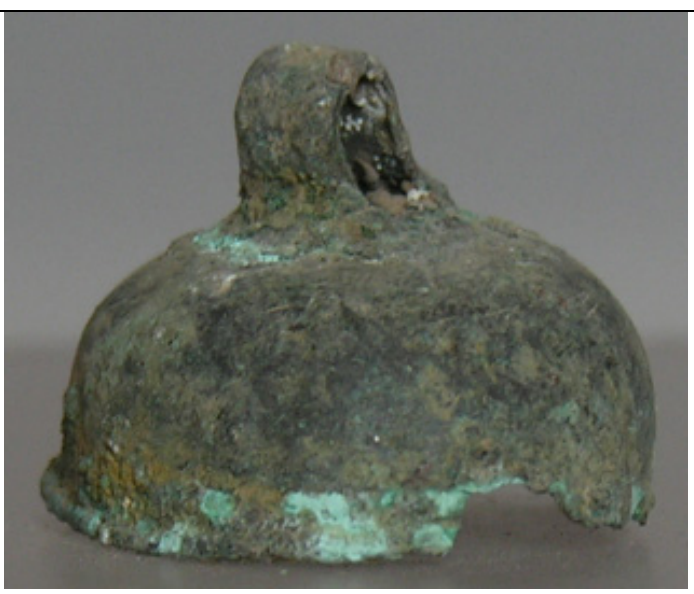

Datos generales

\begin{tabular}{|l|l|}
\hline Nombre & Cascabel \\
\hline $\mathbf{N}^{\mathbf{0}}$ de inventario & R11016 \\
\hline Ubicación actual & Museo de la Alhambra \\
\hline Procedencia & Alhambra, Granada \\
\hline Dimensiones & Altura: $1,8 \mathrm{~cm}$; Anchura: $2,8 \mathrm{~cm}$; Grosor: $2,2 \mathrm{~cm}$ \\
\hline Ciudad & Granada \\
\hline Cronología & Desconocida \\
\hline Características & $\begin{array}{l}\text { Parte superior de lo que pudo ser un cascabel con asa } \\
\text { redonda. }\end{array}$ \\
\hline Morfológicas & Bronce \\
\hline
\end{tabular}

Datos organológicos

\begin{tabular}{|l|l|}
\hline Tipo de instrumento & Idiófono \\
\hline $\begin{array}{l}\text { Clasificación } \\
\text { organológica }\end{array}$ & 112.1 Idiófonos sacudidos \\
\hline Función & Lúdica \\
\hline Fabricación & Herrería \\
\hline $\begin{array}{l}\text { Características } \\
\text { musicales }\end{array}$ & Fragmento de un posible cascabel. \\
\hline
\end{tabular}

Datos arqueológicos 


\begin{tabular}{|l|l|}
\hline Yacimiento & Alhambra \\
\hline $\begin{array}{l}\text { Responsable de la } \\
\text { excavación }\end{array}$ & - \\
\hline
\end{tabular}

Bibliografía

\begin{tabular}{|l|l}
\hline Documentación del Museo & Pieza inventariada. \\
\hline
\end{tabular}

Inédito 


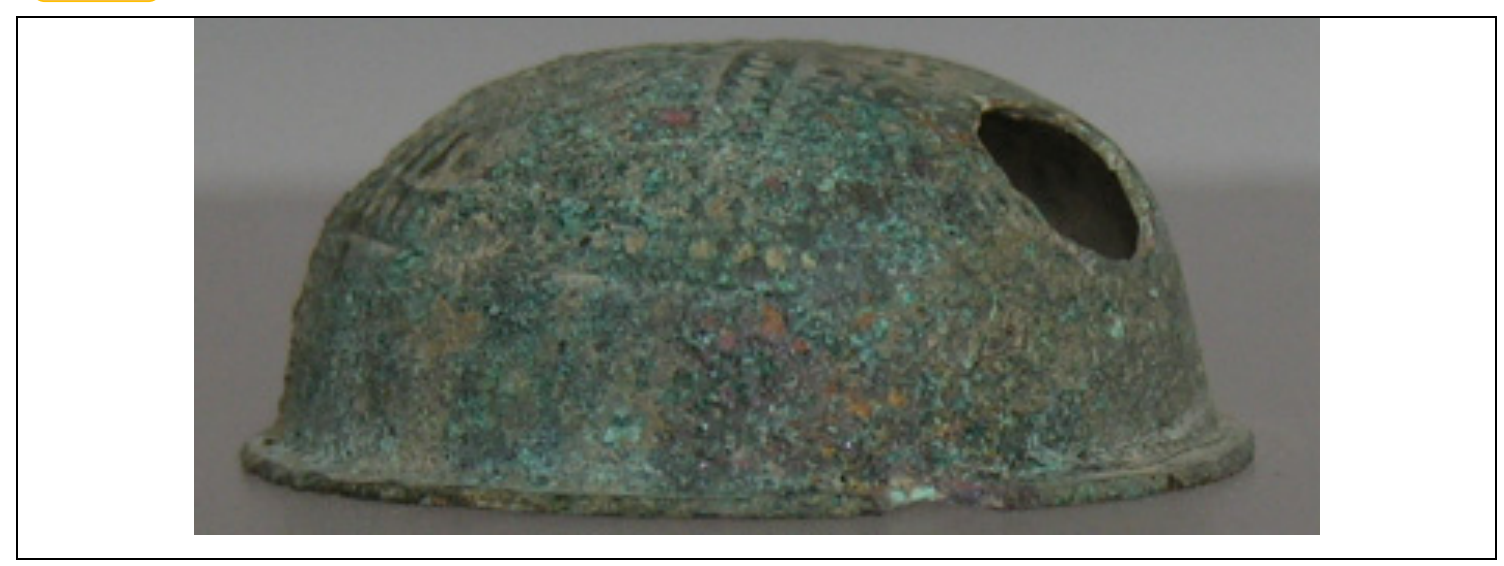

\section{Datos generales}

\begin{tabular}{|l|l|}
\hline Nombre & Cascabel \\
\hline $\mathbf{N}^{\mathbf{0}}$ de inventario & R11019 \\
\hline Ubicación actual & Museo de la Alhambra \\
\hline Procedencia & Alhambra, Granada \\
\hline Dimensiones & Altura: $1,1 \mathrm{~cm}$; Diámetro: $2,6 \mathrm{~cm}$ \\
\hline Ciudad & Granada \\
\hline Cronología & Desconocida \\
\hline $\begin{array}{l}\text { Características } \\
\text { morfológicas }\end{array}$ & $\begin{array}{l}\text { Parte inferior de lo que pudo ser un cascabel con dos } \\
\text { orificios. }\end{array}$ \\
\hline Materiales & Bronce \\
\hline
\end{tabular}

Datos organológicos

\begin{tabular}{|l|l|}
\hline Tipo de instrumento & Idiófono \\
\hline $\begin{array}{l}\text { Clasificación } \\
\text { organológica }\end{array}$ & 112.1 Idiófonos sacudidos \\
\hline Función & Lúdica \\
\hline Fabricación & Herrería \\
\hline $\begin{array}{l}\text { Características } \\
\text { musicales }\end{array}$ & Fragmento de un posible cascabel. \\
\hline
\end{tabular}

\section{Datos arqueológicos}




\begin{tabular}{|l|l|}
\hline Yacimiento & Alhambra \\
\hline $\begin{array}{l}\text { Responsable de la } \\
\text { excavación }\end{array}$ & - \\
\hline
\end{tabular}

Bibliografía

\begin{tabular}{|l|l}
\hline Documentación del Museo & Pieza inventariada.
\end{tabular}

Inédito 


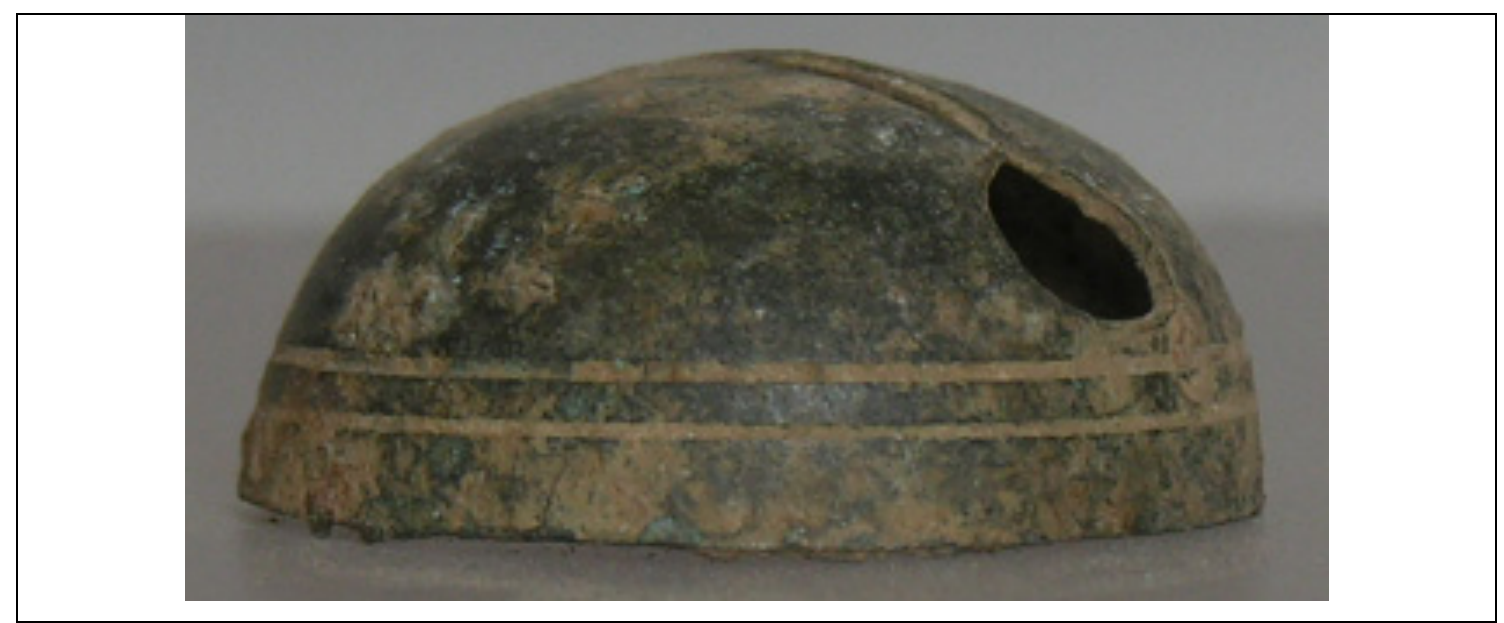

\section{Datos generales}

\begin{tabular}{|l|l|}
\hline Nombre & Cascabel \\
\hline $\mathbf{N}^{\mathbf{0}}$ de inventario & R1 1020 \\
\hline Ubicación actual & Museo de la Alhambra \\
\hline Procedencia & Alhambra, Granada \\
\hline Dimensiones & Altura: $1,1 \mathrm{~cm}$; Diámetro: $2,5 \mathrm{~cm}$ \\
\hline Ciudad & Granada \\
\hline Cronología & Desconocida \\
\hline Características & $\begin{array}{l}\text { Parte inferior de lo que pudo ser un cascabel abertura y } \\
\text { morfológicas }\end{array}$ \\
circulares.
\end{tabular}

Datos organológicos

\begin{tabular}{|l|l|}
\hline Tipo de instrumento & Idiófono \\
\hline $\begin{array}{l}\text { Clasificación } \\
\text { organológica }\end{array}$ & 112.1 Idiófonos sacudidos \\
\hline Función & Lúdica \\
\hline Fabricación & Herrería \\
\hline $\begin{array}{l}\text { Características } \\
\text { musicales }\end{array}$ & Fragmento de lo que pudo ser un cascabel. \\
\hline
\end{tabular}




\section{Datos arqueológicos}

\begin{tabular}{|l|l|}
\hline Yacimiento & Alhambra \\
\hline $\begin{array}{l}\text { Responsable de la } \\
\text { excavación }\end{array}$ & - \\
\hline
\end{tabular}

\section{Bibliografía}

Documentación del Museo

Pieza inventariada.

Inédito 


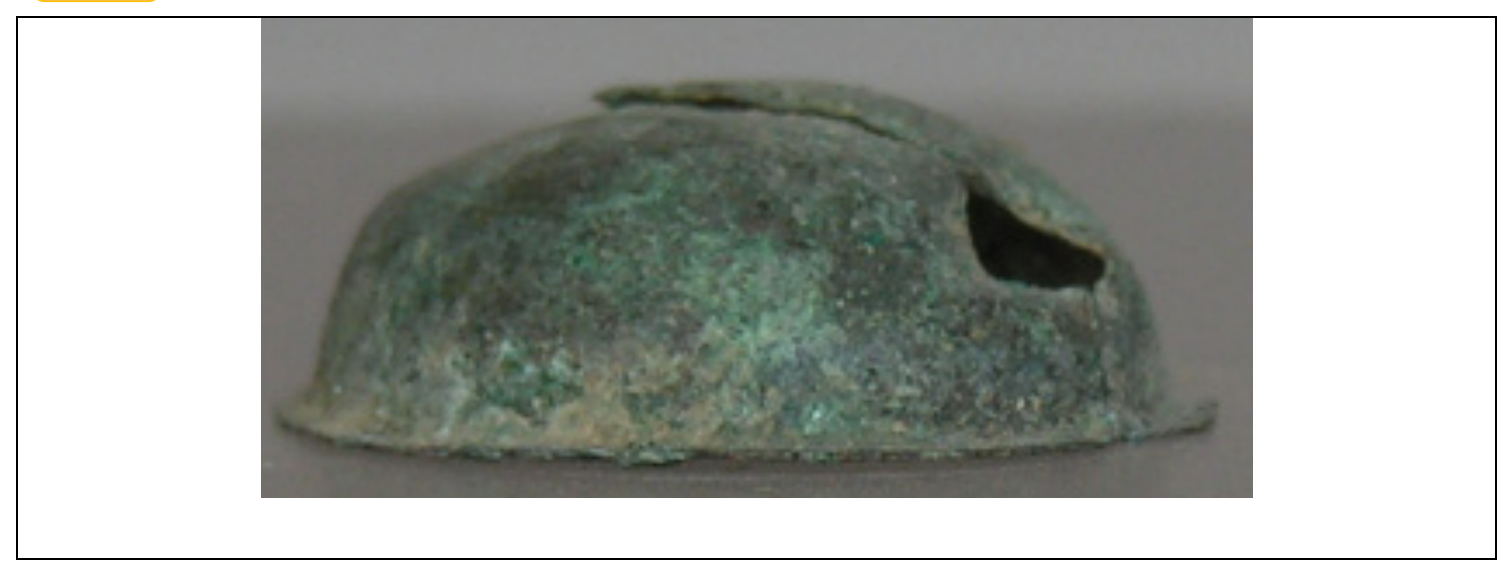

\section{Datos generales}

\begin{tabular}{|l|l|}
\hline Nombre & Cascabel \\
\hline $\mathbf{N}^{\mathbf{0}}$ de inventario & R11018 \\
\hline Ubicación actual & Museo de la Alhambra \\
\hline Procedencia & Alhambra, Granada \\
\hline Dimensiones & Altura: $0,8 \mathrm{~cm}$; Diámetro: $2,1 \mathrm{~cm}$ \\
\hline Ciudad & Granada \\
\hline Cronología & Desconocida \\
\hline Características & Parte inferior de lo que pudo ser un cascabel abertura y \\
morfológicas & agujeros de salida del sonido. \\
\hline Materiales & Bronce \\
\hline
\end{tabular}

\section{Datos organológicos}

\begin{tabular}{|l|l|}
\hline Tipo de instrumento & Idiófono \\
\hline $\begin{array}{l}\text { Clasificación } \\
\text { organológica }\end{array}$ & 112.1 Idiófonos sacudidos \\
\hline Función & Lúdica \\
\hline Fabricación & Herrería \\
\hline $\begin{array}{l}\text { Características } \\
\text { musicales }\end{array}$ & Fragmento de lo que pudo ser un cascabel. \\
\hline
\end{tabular}

\section{Datos arqueológicos}




\begin{tabular}{|l|l|}
\hline Yacimiento & Alhambra \\
\hline $\begin{array}{l}\text { Responsable de la } \\
\text { excavación }\end{array}$ & - \\
\hline
\end{tabular}

Bibliografía

\begin{tabular}{|l|l}
\hline Documentación del Museo & Pieza inventariada.
\end{tabular}

Inédito 


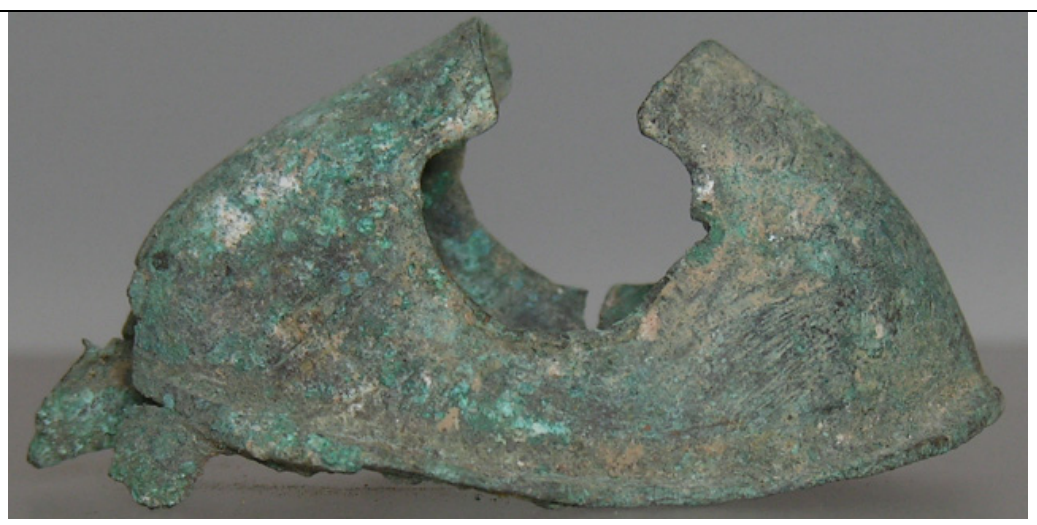

\section{Datos generales}

\begin{tabular}{|c|c|}
\hline Nombre & Cascabel \\
\hline $\mathrm{N}^{0}$ de inventario & R11017 \\
\hline Ubicación actual & Museo de la Alhambra \\
\hline Procedencia & Alhambra, Granada \\
\hline Dimensiones & Altura: 2,4 cm; Anchura: 5,1 cm; Grosor: 2,3 cm \\
\hline Ciudad & Granada \\
\hline Cronología & Desconocida \\
\hline $\begin{array}{l}\text { Características } \\
\text { morfológicas }\end{array}$ & $\begin{array}{l}\text { Parte inferior de lo que pudo ser un cascabel abertura y } \\
\text { agujeros de salida del sonido muy abiertos por su delicado } \\
\text { estado de conservación. }\end{array}$ \\
\hline Materiales & Bronce \\
\hline
\end{tabular}

\section{Datos organológicos}

\begin{tabular}{|l|l|}
\hline Tipo de instrumento & Idiófono \\
\hline $\begin{array}{l}\text { Clasificación } \\
\text { organológica }\end{array}$ & 112.1 Idiófonos sacudidos \\
\hline Función & Lúdica \\
\hline Fabricación & Herrería \\
\hline $\begin{array}{l}\text { Características } \\
\text { musicales }\end{array}$ & Fragmento de lo que pudo ser un cascabel. \\
\hline
\end{tabular}




\section{Datos arqueológicos}

\begin{tabular}{|l|l|}
\hline Yacimiento & Alhambra \\
\hline $\begin{array}{l}\text { Responsable de la } \\
\text { excavación }\end{array}$ & - \\
\hline
\end{tabular}

\section{Bibliografía}

Documentación del Museo

Pieza inventariada.

Inédito 


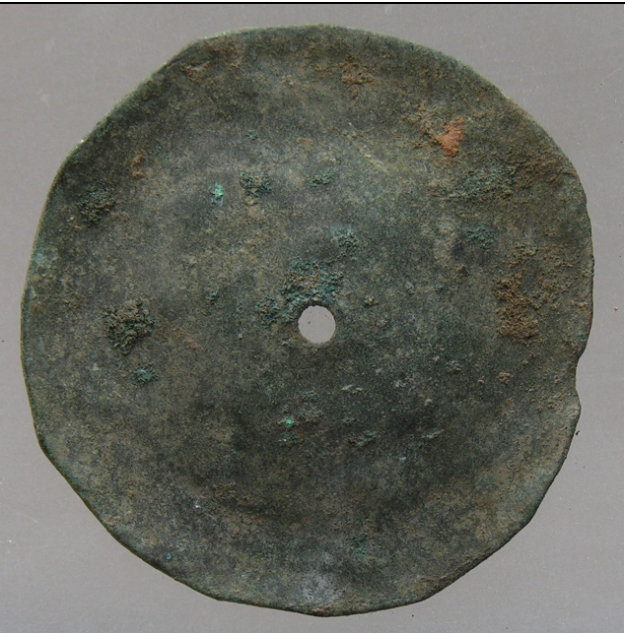

\section{Datos generales}

\begin{tabular}{|l|l|}
\hline Nombre & Platillo (címbalo) \\
\hline $\mathbf{N}^{\circ}$ de inventario & R10985 \\
\hline Ubicación actual & Museo de la Alhambra \\
\hline Procedencia & Alhambra, Granada \\
\hline Dimensiones & - \\
\hline Ciudad & Granada \\
\hline Cronología & Desconocida \\
\hline Características & Pieza de metal ligeramente curva en su parte media con un \\
morfológicas & agujero en el centro de la circunferencia. \\
\hline Materiales & Bronce \\
\hline
\end{tabular}

\section{Datos organológicos}

\begin{tabular}{|l|l|}
\hline Tipo de instrumento & Idiófono \\
\hline $\begin{array}{l}\text { Clasificación } \\
\text { organológica }\end{array}$ & 111.142 Platillos (Címbalos) \\
\hline Función & Lúdica \\
\hline Fabricación & Herrería \\
\hline
\end{tabular}




\begin{tabular}{|l|l|}
\hline $\begin{array}{l}\text { Características } \\
\text { musicales }\end{array}$ & Crótalo plano con pequeña cavidad en la parte media. \\
\hline
\end{tabular}

Datos arqueológicos

\begin{tabular}{|l|l|}
\hline Yacimiento & Alhambra \\
\hline $\begin{array}{l}\text { Responsable de la } \\
\text { excavación }\end{array}$ & - \\
\hline
\end{tabular}

Bibliografía

\begin{tabular}{|l|l|}
\hline Documentación del Museo & Pieza inventariada. \\
\hline Inédito & \\
\hline
\end{tabular}




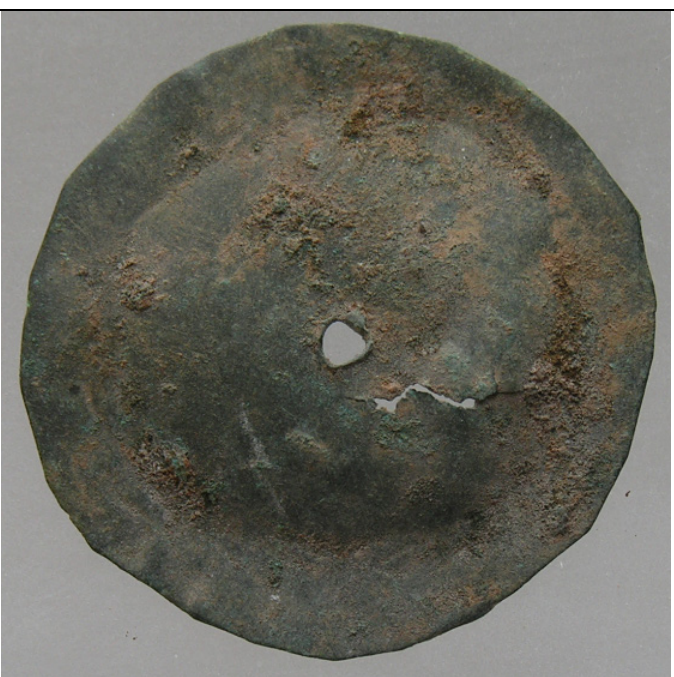

\section{Datos generales}

\begin{tabular}{|l|l|}
\hline Nombre & Platillo (címbalo) \\
\hline $\mathbf{N}^{\mathbf{0}}$ de inventario & R10986 \\
\hline Ubicación actual & Museo de la Alhambra \\
\hline Procedencia & Alhambra, Granada \\
\hline Dimensiones & - \\
\hline Ciudad & Granada \\
\hline Cronología & Desconocida \\
\hline Características & Pieza de metal ligeramente curva en su parte media con un \\
morfológicas & agujero en el centro de la circunferencia. \\
\hline Materiales & Bronce \\
\hline
\end{tabular}

Datos organológicos

\begin{tabular}{|l|l|}
\hline Tipo de instrumento & Idiófono \\
\hline $\begin{array}{l}\text { Clasificación } \\
\text { organológica }\end{array}$ & 111.142 Platillos (Címbalos) \\
\hline Función & Lúdica \\
\hline Fabricación & Herrería \\
\hline Características & Crótalo plano con pequeña cavidad en la parte media. \\
\hline
\end{tabular}


musicales

Datos arqueológicos

\begin{tabular}{|l|l|}
\hline Yacimiento & Alhambra \\
\hline $\begin{array}{l}\text { Responsable de la } \\
\text { excavación }\end{array}$ & - \\
\hline
\end{tabular}

Bibliografía

Documentación del Museo

Pieza inventariada.

Inédito 


\section{Glosario de términos musicales}

\begin{tabular}{|c|c|}
\hline 'artaba: & Laúd de mango corto. \\
\hline 'asaf: & Tambor unimembranófono. \\
\hline 'ayr: & Tambor cilíndrico. \\
\hline 'azf: & Aerófono. \\
\hline 'ud: & Laúd. \\
\hline abu qarun: & Cuerno de grandes dimensiones. \\
\hline ahjal (singular: hijl): & $\begin{array}{l}\text { Anillos o tobilleras de metal para acompañar el baile de las } \\
\text { mujeres. }\end{array}$ \\
\hline ajras (singular: jaras): & Campana. \\
\hline algaitha: & Aerófono de lengüeta doble. \\
\hline aqwal: & Especie de tambor. \\
\hline artaba: & Variante del laúd de origen persa. \\
\hline awtar: & Cuerdas. \\
\hline balag (balag-di): & Tambor del cantor. \\
\hline barbat: & Laúd de mango corto. \\
\hline buk: & Cuerno. \\
\hline buq: & Albogue medieval. Relacionado con escenas militares. \\
\hline dabdaba: & Membranófono de sonido intenso. \\
\hline daff (duff): & Adufe, pandero. \\
\hline daffata: & Tambor. \\
\hline dirridj: & Laúd de mango corto. \\
\hline dirriy: & Especie de monocordio de dos o tres cuerdas. \\
\hline duff murabba: & Pandero rectangular. \\
\hline durraj: & Posible nombre de la darbuka en la época. \\
\hline girbal: & Tipo de adufe (pandero). \\
\hline hamm: & Cuarta cuerda del laúd. \\
\hline hayarat: & Sonajas. \\
\hline hayra'a: & Crótalos. \\
\hline hayra'a: & Relacionado normalmente con crótalos o castañuelas. \\
\hline iran: & Flauta de doble lengüeta. \\
\hline jalajil (singular: & Campanas. \\
\hline
\end{tabular}




\begin{tabular}{|c|c|}
\hline kabar: & Atabal tipo darbuka de barro o cerámica. \\
\hline kanun: & Cítara. \\
\hline karriy: & Flauta de caña. \\
\hline $\begin{array}{l}\text { kasat (kas o kasa en } \\
\text { singular): }\end{array}$ & Crótalos con forma de cuenco. \\
\hline kassaba: & Atabal tipo darbuka de madera. \\
\hline kaytar: & Cordófono. \\
\hline $\begin{array}{l}\text { khalakhil o kalakil (en } \\
\text { singular khalkhal): }\end{array}$ & $\begin{array}{l}\text { Anillos o tobilleras de metal para acompañar el baile de las } \\
\text { mujeres. }\end{array}$ \\
\hline kinnara: & Tipo de adufe (pandero). \\
\hline kiran: & Laúd de mango corto. \\
\hline kitara (kithara): & Cítara. \\
\hline $\begin{array}{l}k u^{\prime} u s \quad(\text { en singular } \\
\left.k a^{\prime} s\right)\end{array}$ & Crótalos. \\
\hline kuba: & Posible bimembranófono con forma de reloj de arena. \\
\hline kus: & Tipo de tambor. \\
\hline kussab: & Aerófono tipo clarinete de doble lengüeta. \\
\hline ma'azif: & Arpa o lira. \\
\hline masafiq: & Palmeo. \\
\hline matlat: & Tercera cuerda del laúd, negra. \\
\hline matnà: & Segunda cuerda del laúd, roja. \\
\hline$m i{ }^{\prime} z a f:$ & $\begin{array}{l}\text { Familia de las arpas y cítaras cuyo origen se remonta al } \\
\text { periodo mesopotámico y faraónico. }\end{array}$ \\
\hline$m i i^{\prime} z a f a:$ & Cítara. \\
\hline mizhar: & Laúd de mango corto. \\
\hline mizmar: & Aerófono de lengüeta doble. \\
\hline nai: & Flauta de caña o hueso. \\
\hline $\begin{array}{l}\text { naqqara } \quad \text { (plural } \\
\text { naqqarat): }\end{array}$ & $\begin{array}{l}\text { Timbal percutido con baquetas enlazado a escenarios } \\
\text { militares. }\end{array}$ \\
\hline $\begin{array}{l}\text { naqus (en plural } \\
\text { nawaqis): }\end{array}$ & $\begin{array}{l}\text { Placas de madera o metal usadas como un gong por los } \\
\text { cristianos en tierras de habla árabe. }\end{array}$ \\
\hline nura: & Flauta triple. \\
\hline
\end{tabular}




\begin{tabular}{|c|c|}
\hline $\begin{array}{l}\text { qalaqil (singular: } \\
\text { qalqal): }\end{array}$ & $\begin{array}{l}\text { Cascabeles usados, junto a campanas, como parte de la } \\
\text { vestimenta de mulos y camellos con la intención de } \\
\text { intimidar al enemigo. }\end{array}$ \\
\hline qanun: & Cítara. \\
\hline qitar: & Tipo de guitarra. \\
\hline qussaba: & Aerófono de lengüeta doble. \\
\hline rabab al-sha'ir: & $\begin{array}{l}\text { Considerado el "violín" del poeta, de una sola cuerda y con } \\
\text { caja de resonancia. }\end{array}$ \\
\hline rabab y rubab: & Posiblemente de origen persa, instrumento cercano al laúd. \\
\hline rebab $(r a b a b):$ & Rabel. \\
\hline rebab al-mughanni: & $\begin{array}{l}\text { Considerado el "violín" del cantante, éste cuenta con dos } \\
\text { cuerdas de crin y una caja de resonancia hecha con la } \\
\text { cáscara de un coco abierta sobre la que se tensa una } \\
\text { membrana de cuero. }\end{array}$ \\
\hline riqq: & Tipo de pandero. \\
\hline ruta: & Rota. \\
\hline $\begin{array}{l}\text { sabbaba (shabbaba, } \\
\text { axabeba): }\end{array}$ & Silbato. \\
\hline $\begin{array}{l}\text { saffara } \quad \text { (saffarah, } \\
\text { safara): }\end{array}$ & Silbato. \\
\hline saffarrat al-ra'i: & Silbato del pastor. Pudo acompañar a la danza. \\
\hline safir-i bulbul: & "Silbido" que se utiliza en el sama. \\
\hline safir: & Silbato compuesto por dos piezas de hueso. \\
\hline sany (sunny): & Crótalos. Instrumentista que se especializaba en ellos. \\
\hline sayyida: & Señora. \\
\hline sinj: & Crótalos planos. \\
\hline sofar al-ray: & Silbato pastoril. \\
\hline sunuj (singular: sanj): & Crótalos con forma de placa. \\
\hline suqra: & Flauta barítona. \\
\hline tabir: & $\begin{array}{l}\text { Nombre genérico de procedencia persa para referirse al } \\
\text { tambor. }\end{array}$ \\
\hline tabl: & $\begin{array}{l}\text { Nombre genérico referido al atabal o tambor. Tamborcillo } \\
\text { cilíndrico. }\end{array}$ \\
\hline
\end{tabular}




\begin{tabular}{l|l} 
tanbur: & Cordófono tipo laúd. \\
\hline tar: & Pandero con seis pares de crótalos. \\
\hline tasfiq: & Palmeo. \\
\hline tinbar: & Laúd de mango corto. \\
\hline tunbur al-bagdadi: & Laúd de mango corto de la Escuela de Bagdad. \\
\hline tunbur al-jurasani: & Laúd de mango corto de la Escuela de Jurasán. \\
\hline tunbur: & Laúd de mango corto. \\
\hline urtuba: & Laúd de mango corto. \\
\hline ya-ra': & Flauta pastoril. \\
\hline yank: & Arpa. \\
\hline yara: & Flauta corta pastoril o popular. \\
\hline zamkhara: & Especie de clarinete con lengüeta doble. \\
\hline zammara: & Flauta pastoril con lengüeta doble relacionada con la música \\
popular.
\end{tabular}




\section{Índice de términos}

'artaba.

$74,85,87,91,521$

'asaf. $85,90,521$

'ayr $85,90,521$

'azf....... $85,91,521$

'ud .25, 26, 30, 35, 40, 43, 72, 74, 76, 82, 85, 86, 87, 88, 89, 90, 91, 93, 117, 118, 119 , $120,121,123,125,126,127,140,142,218,239,521$

A

abu qarun . $82,91,173,521$

abu-qarun. 89

adufe. 82, 87, 88, 89, 90, 91, 94, 103, 105, 119, 125, 129, 192, 196, 256, 257, 521, 522 ahjal 206, 521

ajras 204, 521

albogue..43, 74, 82, 87, 89, 91, 102, 103, 118, 119, 135, 248, 249, 250, 252, 253, 256, 257

Albogue 121,521

algaitha 134,521

aqwal $82,89,91,196,521$

artaba 74,521

awtar $72,83,85,90,521$

axabeba $91,157,173,175,523$

\section{B}

balag 190, 521

balag-di 190, 521

barbat $.40,46,72,74,77,85,86,87,88,90,91,124,521$

buk $.74,521$

buq. $40,43,74,82,85,87,89,91,135,173,174,521$ 
Campanas....57, 204, 432, 433, 435, 437, 439, 441, 443, 445, 447, 449, 451, 455, 457, 460, 461, 463, 465, 467, 469, 521

Cascabeles $.57,206,523$

Cítara 522,523

Crótalos $201,521,522,523$

D

dabdaba $.82,89,521$ daff $41,46,74,82,87,91,196,521$ daffata $.74,87,521$ darbuka. $42,43,74,87,90,91,135,190,193,195,196,197,199,521,522$ dirridj $.74,521$ dirriy $74,87,91,521$ duff $. .40,43,74,76,82,85,88,89,90,125,128,129,130,175,192,257,521$ durraj 195,521

\section{G}

girbal $.85,90,521$

\section{H}

hadib 76,88

hamaq al-barabir 82,89

hamaqi 82,89

hamm $.78,81,521$

hayarat. $.72,86,521$ hayra'a $74,87,91,201,521$

hijl 206, 521

\section{I}

iran $74,87,91,173,174,521$

jalajil $43,204,205,521$ 
jaras

204, 205, 521

jayal.

82,89

juljul

204, 521

K

$k a$ 's $.202,522$

kabar $.74,85,87,90,91,190,196,522$

kalakil. .206, 522

kanira 82,89

kanun

$.77,88,522$

karriy. $.82,83,89,91,173,174,522$

kas 202,522

kasa 202, 522

kasat 202, 522

kassaba. $74,87,91,196,522$

kaytar $85,91,522$

khalakhil. .206, 522

kinnara . $.85,90,522$

kiran $.72,74,85,86,87,90,91,522$

kitara $76,88,522$

kitarat 72,86

kithara $.82,89,522$

$k u^{\prime} u s$ 202,522

kuba $.74,85,87,90,91,135,189,196,213,522$

kus $.85,90,522$ kussab $74,87,522$

M

ma'azif... $76,88,125,522$

masafiq. $85,90,522$

matlat $.79,80,522$

matnà $. .78,79,80,522$

mi'zaf. $40,74,85,87,90,522$ mi'zafa $.73,86,91,522$ 
mizhar $46,72,74,85,86,90,93,522$ mizmar.20, 43, 73, 74, 75, 76, 77, 85, 86, 87, 88, 91, 92, 133, 171, 173, 174, 175, 177, 522

mizmar al-djarab .87 munis $82,83,89$

$\mathbf{N}$

nai $40,41,43,73,74,86,87,91,92,152,155,158,171,172,173,522$

Naqqara 130,220

Naqqarat 130 naqus 206, 522

nawaqis 206, 522

nawruz. $.91,157$

nayruz..... 91,157 nura $82,89,91,173,175,522$

\section{$\mathbf{P}$}

Pandero $121,521,524$

\section{Q}

qadib $76,85,88$

Qadib.

qalaqil 206, 523

qalqal .206, 523

qanun $.41,43,82,87,89,91,141,143,523$

qitar. $76,82,88,89,523$ qussaba $85,91,523$

\section{$\mathbf{R}$}

rabab $.41,43,46,77,82,85,87,88,89,90,91,93,94,126,523$ rebab $40,77,119,125,126,127,140,142,523$ reclamo $115,121,123,152,212,282$ riqq $.43,128,523$ ruta $82,89,91,523$ 
sabbaba $43,85,91,523$

safaqis 85,91

saffara $85,91,155,156,158,176,523$

saffarrat al-ra'i 157,523

safir $156,157,523$

safir-i bulbul. 156,523

sahin 85,91

sandj .87

sandj djini o sini .87

sanj $190,202,523$

sany $43,85,91,203,523$

shahrud 87

shaqra 82,89

silbato..91, 115, 120, 152, 155, 156, 157, 158, 159, 163, 167, 168, 169, 174, 180, 284 , $288,292,298,303,304,310,313,317,319,321,323,325,338,339,344,346$, $350,353,358,359,362,366,368,371,373,376,377,378,384,386$ $\operatorname{sinj}$ 202,523

sizan 85,91

sofar al-ray. 157,523

sunuj $202,203,523$

suqra $82,89,91,173,176,523$ surnay $87,155,176,190,524$

\section{$\mathbf{T}$}

tabir 189,523

tabl $.41,43,74,76,85,87,88,90,91,125,135,189,196,523$ tanbur $46,189,524$ tar...... $43,112,120,121,128,191,524$

tasfiq 524

tinbar $.74,87,91,524$

tunbur $.43,74,75,76,77,85,87,88,90,91,92,524$

tunbur al-bagdadi 88,524 
tunbur jurasani. 88

$\mathbf{U}$

urghun ...... 87

urtuba $.74,87,524$

$\mathbf{Y}$

yank $.91,92,524$ yara $.74,82,83,89,91,176,524$ $y a-r a^{\prime}$ $.74,87,91,173,176,524$

\section{$\mathbf{Z}$}

zamkhara $.74,87,524$ zammara. $.43,74,76,87,88,91,173,176,177,524$

zulami $.82,89,524$ 


\section{Índice de imágenes}

Figura 1. Arqueta danzantes Museo Victoria \& Albert (extraída de la web del museo).

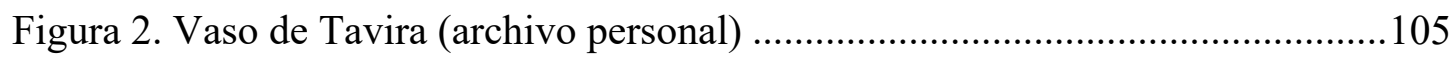

Figura 3. Detalle de Naqqarat del manuscrito Maqamat al Hariri............................109

Figura 4. Detalle mural del Partal (extraída del artículo de Torres Balbás) ...............109

Figura 5. Detalle del mural del Partal de Isidoro Marín 1921-1922 (cedida por la

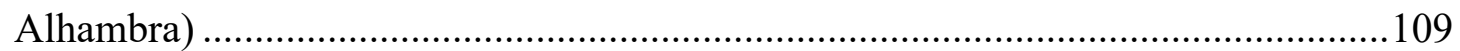

Figura 6. Detalle mural del Partal de Manuel López Vázquez. .................................110

Figura 7. Detalle mural del Partal de Antonio Fernández Puertas.............................110

Figura 8. Detalle del mural del Partal de Isidoro Marín. .............................................111

Figura 9. Detalle del mural del Partal de Antonio Fernández Puertas.......................111

Figura 10. Detalle del mural del Partal de Manuel López Vázquez. ..........................111

Figura 11. Detalle Pandero del mural del Partal, Isidoro Marín.................................112

Figura 12. Detalle posible cordófono mural del Partal, Isidoro Marín......................112

Figura 13. Detalle del mural del Partal de Isidoro Marín. ..........................................113

Figura 14. Detalle del mural del Parta de Antonio Fernández Puertas......................113

Figura 15. Detalle del mural del Partal de Manuel López Vázquez. .........................113

Figura 16. Gliptografía danzante en Granada XVI................................................113

Figura 17. Detalle de la Capa de Fermo por Laura Ciampini....................................115

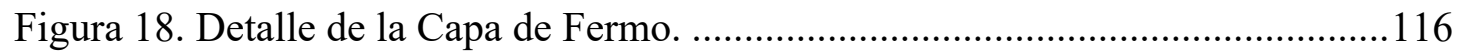

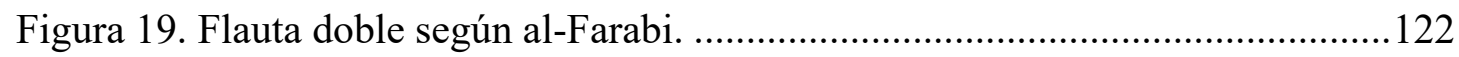

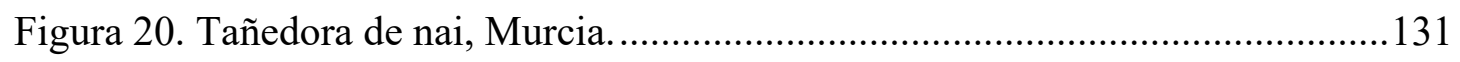

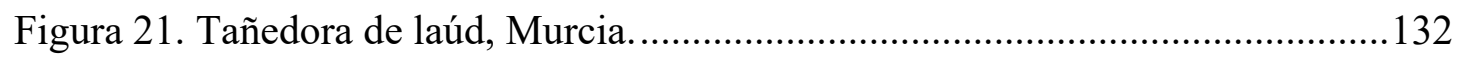

Figura 22. Vaso con escena festiva (aerófono), Murcia. ..........................................133

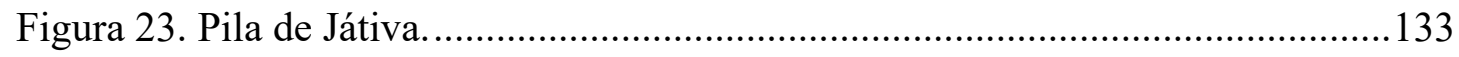

Figura 24. Detalle de bimembranófono Pila de Játiva ..............................................134

Figura 25. Recreación de bimembranófono de la Pila de Játiva de Jota Martínez....134

Figura 26. Almohada de Berenguela de Castilla. ...................................................137

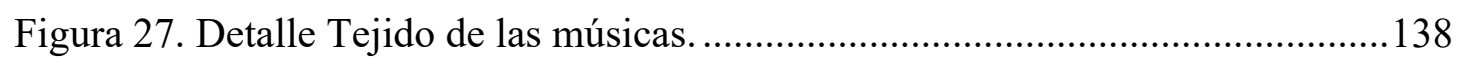

Figura 28. Miniatura de la Cantiga de Alfonso X.................................................139

Figura 29. Miniatura del Libro de ajedrez y dados, Lámina 15, folio $31 \mathrm{v}^{\mathrm{o}}$...............140

Figura 30. Miniaturas de Libro de ajedrez y dados, Lámina 14, Folio 22 R ${ }^{\mathrm{o}}$.............141

Figura 31. Miniaturas de Libro de ajedrez y dados. Lámina 13, Folio 18 R ${ }^{\circ}$...........141 
Figura 32. Ataifor fatimí Alhambra (pandero).

Figura 33. Ataifor fatimí Alhambra (laúd). ............................................................ 143

Figura 34. Ataifor fatimí Alhambra (danzante). ....................................................... 144

Figura 35. Ataifor fatimí Freer Gallery of Arts de Nueva York (danzante)..............145

Figura 36. Friso fatimí Alhambra- El Cairo (danzante)..............................................145

Figura 37. Friso fatimí Alhambra- El Cairo (arpista). ...............................................146

Figura 38. Imágenes fatimíes artículo Basilio Pavón. ...............................................146

Figura 39. Ataifor del Benaki Museum de Grecia (laudista)...................................147

Figura 40. Estatuilla del Musée d'art islamique, Doha, Catar (pandero). ..................147

Figura 41. Silbatos del Anuario Arqueológico de Andalucía 2004 ..........................167

Figura 42. Pieza catalogada como silbato en el Museo Arqueológico de Ciudad Real.

Figura 43. Proceso de construcción de recreación de piezas arqueológicas catalogadas como flautas.

Figura 44. Pieza catalogada como flauta en el Museo del Puerto de Santa María,

Cádiz.

Figura 46. Piezas del Museo Arqueológico de Jerez.

Figura 45. Mango de abanico del Museo Arqueológico de Jerez de la Frontera.

Imagen extraída del TFM de Carmen Salvador. 183

Figura 47. Pieza catalogada como flauta en el Museo Arqueológico de Sevilla.......184

Figura 48. Recreación de la pieza del museo de Sevilla.

Figura 49. Pieza catalogada como posible flauta en el Museo de Estepona y recreación de la pieza en caña.

Figura 50. Fragmento del Museo de Estepona......................................................... 185

Figura 51. Pieza catalogada como flauta en el Museo Arqueológico de Sevilla.......185

Figura 52. Recreación de la pieza catalogada como flauta en el Museo Arqueológico

de Sevilla.

Figura 53. Pieza catalogada como flauta en el Museo Arqueológico de Sevilla.

Imagen extraída del TFM de Carmen Salvador.

Figura 54. Pieza catalogada como flauta en el Museo Arqueológico de Sevilla.

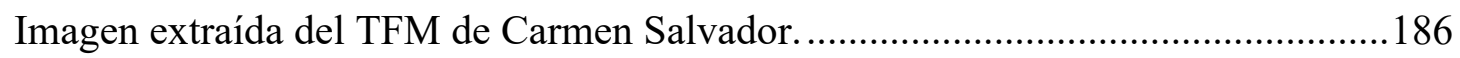

Figura 55. Pieza catalogada como flauta en el Museo de Montemayor. ...................187

Figura 56. Piezas expuestas como flautas en el Museo Arqueológico de Tetuán. ....188

Figura 57. Dibujos de membranófonos del artículo de Francisco de Asís. 
Figura 58. Pieza catalogada como crótalo del Museo de Zaragoza. Imagen cedida por

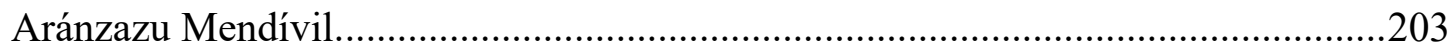
Figura 59. Campana. Museo de Zaragoza. Imagen realizada por J. Garrido. NIG: 50983 